\title{
Catalytic, Asymmetric Dearomative Synthesis of Complex Cyclohexanes via a Highly Regio- and Stereoselective Arene Cyclopropanation using $\alpha$-Cyanodiazoacetates
}

\author{
Kendrick L. Smith, Cody L. Padgett, William D. Mackay, Jeffrey S. Johnson* \\ Department of Chemistry, University of North Carolina at Chapel Hill, Chapel Hill, North Carolina 27599-3290, United \\ States \\ jsi@unc.edu
}

\section{Contents}

General Information 2

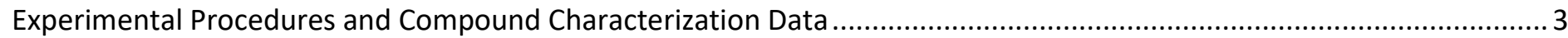

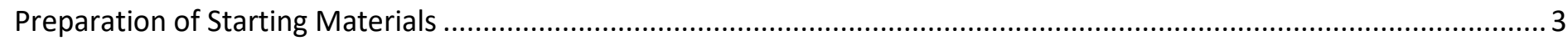

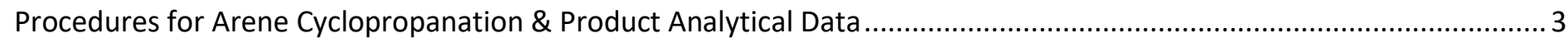

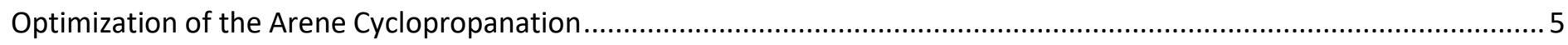

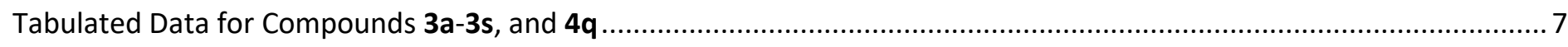

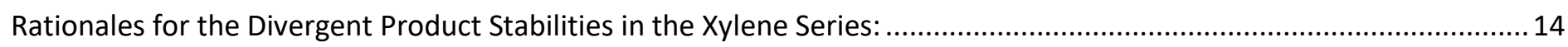

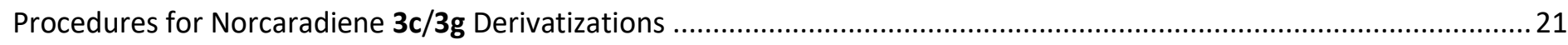

Benzene Dearomatization, Desymmetrization and Further Functionalizations...........................................................26

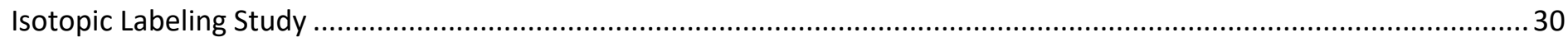

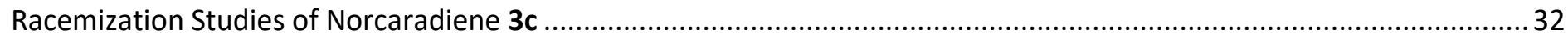

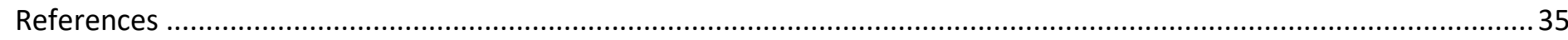

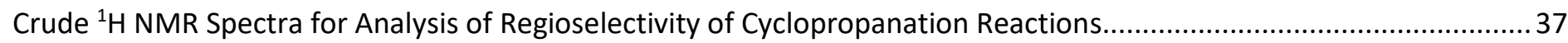

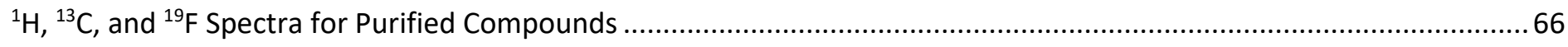

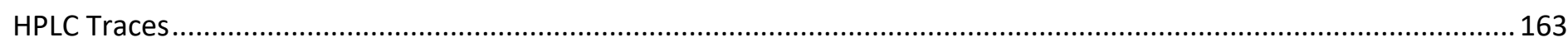

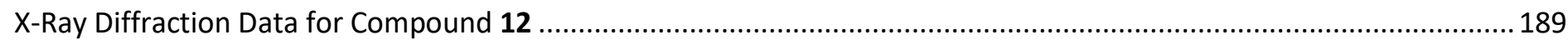

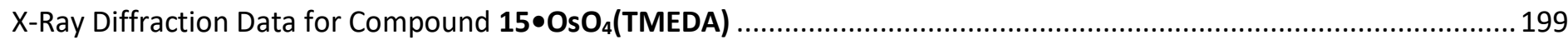


General Methods: Unless otherwise stated, all reactions were carried out open to air. Thin layer chromatography (TLC) was performed on Sorbent Technologies $0.20 \mathrm{~mm}$ Silica Gel TLC plates. Visualization was accomplished using UV light and either $\mathrm{KMnO}_{4}$ solution or cerium ammonium molybdate (CAM) stain. Flash chromatography was performed under positive air pressure using Siliaflash-P60 silica gel $(40-63 \mu \mathrm{m})$ purchased from Silicycle. Yields, regioisomeric ratios, diastereomeric ratios and enantiomeric ratios are reported for a specific experiment and as a result may differ slightly from those reported in the in-text figures, which represent averages of at least two experimental trials.

Instrumentation and Data Acquisition: Proton $\left({ }^{1} \mathrm{H}\right)$, carbon $\left({ }^{13} \mathrm{C}\right)$, and fluorine $\left({ }^{19} \mathrm{~F}\right)$ magnetic resonance spectra were obtained on Bruker Avance 400 MHz, Bruker NEO Avance 400 MHz, Bruker Avance III 500 MHz, Bruker NEO Avance 600 $\mathrm{MHz}$, or a Bruker Avance III 600 instruments, using solvent resonances and/or hexafluorobenzene for internal chemical shift calibration ( ${ }^{1} \mathrm{H}$ NMR: $\mathrm{CDCl}_{3}$ at $\delta=7.26 \mathrm{ppm}, d^{7}$-DMF at $\delta=8.03,2.92,2.75 \mathrm{ppm} ;{ }^{13} \mathrm{C} \mathrm{NMR:} \mathrm{CDCl}_{3}$ at $\delta=77.0 \mathrm{ppm}, d^{7}-$ DMF at $\delta=8.03,2.92,2.75 \mathrm{ppm}, \mathrm{d}^{2}-\mathrm{CD}_{2} \mathrm{Cl}_{2}$ at $\delta=54.00 \mathrm{ppm} ;{ }^{19} \mathrm{~F} N \mathrm{NMR}: \mathrm{C}_{6} \mathrm{~F}_{6}$ at $\left.\delta=-164.90 \mathrm{ppm}\right)$. Mass spectra were obtained using a Thermo Scientific Q Exactive HF-X mass spectrometer with electrospray introduction and external calibration. Infrared (IR) spectra were obtained using a Jasco 460 Plus Fourier transform infrared spectrometer. Optical rotations were measured at room temperature using a $2 \mathrm{~mL}$ cell with a $1 \mathrm{dm}$ path length on a Jasco P-1010 polarimeter. Melting points were obtained using a Thomas Hoover Uni-Melt 6LO6-K melting point apparatus.

High pressure liquid chromatography was performed using a Perkin Elmer Flexar HPLC system equipped with a Perkin Elmer PDA detector. Daicel Chiralpak IA (received: August 2014), Chiralpak IB (received: August 2014), Chiralpak IC (received: August 2014), Chiralpak ID (received: August 2014), and Chiralpak OJ-H (received: November 2018) were available for use in separations.

Data Reporting: The following format is used for the presentation of ${ }^{1} \mathrm{H}$ NMR spectroscopic data: magnet strength, analysis solvent, chemical shift (ppm), multiplicity ( $s=$ singlet, $b r s=$ broad singlet, app $s=$ apparent singlet, $d=d o u b l e t$, $\mathrm{bd}=$ broad doublet, $\mathrm{t}=$ triplet, app $\mathrm{t}=$ apparent triplet, $\mathrm{q}=$ quartet, $\mathrm{app} \mathrm{q}=$ apparent quartet, $\mathrm{dd}=$ doublet of doublets, $\mathrm{td}=$ triplet of doublets, app $\mathrm{td}=$ apparent triplet of doublets, $\mathrm{ddd}=$ doublet of doublet of doublets, $\mathrm{ddt}=$ doublet of doublet of triplets, app ddt = apparent doublet of doublet of triplets, dddd = doublet of doublet of doublet of doublets, $\mathrm{m}=$ multiplet), $J$-coupling constants $(\mathrm{Hz})$, and integration.

Equipment: Transformations requiring syringe pump addition were performed using a New Era NE-300 Just Infusion ${ }^{\mathrm{TM}}$ single channel syringe pump. Transformations requiring extended cooling were performed in a methanol bath maintained by a Techno Sigma UCR $150 \mathrm{~N}$ cooling reactor [referred to as "UC reactor"].

Materials: Unless otherwise stated, technical grade solvents were used as received. Anhydrous tetrahydrofuran (THF), diethyl ether $\left(\mathrm{Et}_{2} \mathrm{O}\right)$, methylene chloride $\left(\mathrm{CH}_{2} \mathrm{Cl}_{2}\right)$, toluene ( $\left.\mathrm{PhMe}\right)$, and triethylamine (TEA, $\mathrm{NEt}_{3}$ ) were obtained by passage of the respective solvents through a neutral alumina column under nitrogen. Solvent ratios are reported as volume ratios.

Triethylamine-deactivated silica gel (TEA-deactivated silica) was prepared by stirring a suspension of $200 \mathrm{~g}$ of silica gel in 3:1 hexanes:triethylamine $(2 \mathrm{~L})$ for $4 \mathrm{~h}$. The suspension was filtered and the silica gel filter cake was washed with hexanes $(2 \mathrm{~L})$. The silica gel was dried first by passing air over the silica for $24 \mathrm{~h}$ then further under high vacuum.

HPLC grade solvents were used for both sample preparation and analysis eluent.

Trifluoromethanesulfonic anhydride (Oakwood), perfluorobutanesulfonyl fluoride (Oakwood), ethyl cyanoacetate (Sigma), $t$-butyl cyanoacetate ( $\mathrm{TCl}$ Chemical) and sodium azide (Sigma, Oakwood) were obtained from commercial sources. Catalysts $\mathrm{Rh}_{2}(\mathrm{esp})_{2}$ (Sigma), $\mathrm{Rh}_{2}[(\mathrm{~S})-\mathrm{PTTL}]_{4}$ (TCl Chemical), $\mathrm{Rh}_{2}[(\mathrm{~S})-\mathrm{PTAD}]_{4}(\mathrm{Strem}), \mathrm{Rh}_{2}[(\mathrm{~S})-\mathrm{BTPCP}]_{4}(\mathrm{Strem})$, and $\mathrm{Rh}_{2}[(S) \text {-DOSP }]_{4}$ (Sigma) were obtained from commercial sources. Catalysts $\mathrm{Rh}_{2}$ (OPiv) ${ }_{4}{ }^{1 \mathrm{aa}}$, and $\mathrm{Rh}_{2}[(S)-\mathrm{TFPTTL}]_{4}{ }^{1 \mathrm{~b}}$ were prepared according to literature procedures. $(1 S, 2 S)-(+)-\left[1,2\right.$-cyclohexanediamino- $N, N^{\prime}$-bis(3,5-di-t-

butylsalicylidene)]manganese(III) chloride [“(S,S)-Jacobsen catalyst"] was obtained from commercial sources (Strem). 4Phenyl-1,2,4-triazoline-3,5-dione (PTAD) was acquired from commercial sources (TCI Chemical). 
Commercially available arenes were used without further purification. (Benzyloxy)(tert-butyl)dimethylsilane ${ }^{2 a}$, (benzhydryloxy)(tert-butyl)dimethylsilane ${ }^{2 b}$, (3-phenylpropoxy)(tert-butyl)dimethylsilane ${ }^{2 c}, N$-benzyl-4-

methylbenzenesulfonamide ${ }^{2 \mathrm{~d}}$, (Z)-2-fluoro- $N$-hydroxybenzimidoyl chloride ${ }^{2 \mathrm{e}}$ and $\mathrm{N}$-(2,5-dioxo-2,5-dihydro-1H-pyrrol-1$\mathrm{yl}$ )-4-(trifluoromethyl)benzamide ${ }^{2 f}$ were prepared according to literature procedures.

\section{Experimental Procedures and Compound Characterization Data}

SAFETY NOTICE: Organic azides (triflyl azide, nonaflyl azide, azidotrimethylsilane), inorganic azides (sodium azide) and diazo compounds are known for their potential to produce an explosion when exposed to heat or shock. ${ }^{3}$ Although we have not experienced an incident to date, great care should be used when handling these reagents. All new azides prepared have $\mathrm{C} / \mathrm{N}$ ratios larger than 3:1.

\section{Preparation of Starting Materials}

Ethyl cyanodiazoacetate was prepared using triflyl azide according to a previously reported procedure..$^{4 a}$ Likewise, $t$ butyl cyanodiazoacetate could also be prepared using triflyl azide. However, we observed significant variance in output diazo compounds from batch to batch, likely stemming from varying concentrations of the azide solution as well as insufficient mixing of the biphasic reaction medium. These variances precluded reliable scale-up to produce larger quantities of the azide. An alternative synthesis of $t$-butyl cyanodiazoacetate using conditions reported by Suárez ${ }^{4 b}$ employing perfluorobutanesulfonyl azide is described below:

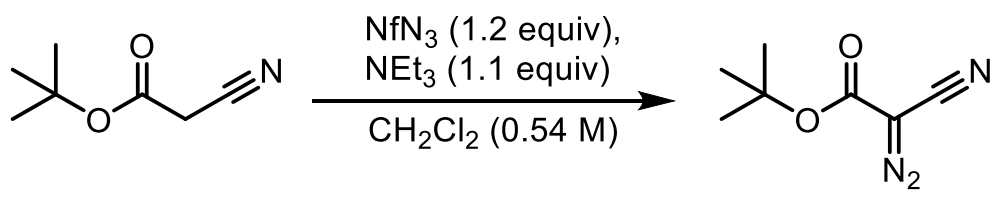

$1 \mathrm{~b}$

tert-butyl cyanodiazoacetate (1b): To a flame-dried round bottom flask that was allowed to cool under nitrogen flow, tert-butyl cyanoacetate $(4.788 \mathrm{~g}, 33.9 \mathrm{mmol})$ and perfluorobutanesulfonyl azide $(13.235 \mathrm{~g}, 40.7 \mathrm{mmol}, 1.2$ equiv) were added then diluted with anhydrous methylene chloride $(62 \mathrm{~mL}, 0.54 \mathrm{M})$. The vessel was submerged in a water bath (15$20^{\circ} \mathrm{C}$ ) and anhydrous triethylamine $(5.2 \mathrm{~mL}, 37.31 \mathrm{mmol}, 1.1$ equiv) was added dropwise over the course of $5 \mathrm{~min}$, causing the solution to turn a bright gold color. The reaction was stirred under nitrogen at ambient temperature with monitoring by TLC (90:10 hexanes:ethyl acetate). Once TLC analysis showed complete consumption of the starting material (10 $\mathrm{min}$ ) the reaction was quenched by adding saturated aqueous sodium bicarbonate ( $4 \mathrm{~mL}$ bicarbonate solution/mmol of azide) and mixing thoroughly. The layers were separated after partitioning and the organic phase was washed with saturated aqueous sodium bicarbonate $(2 \mathrm{x})$ and brine. The organic phase was dried over anhydrous sodium sulfate, filtered, and concentrated in vacuo. The pure diazoacetate was obtained after purification by column chromatography (silica gel; $\mathrm{CHCl}_{3}$ ) as a reddish-orange oil ( $5.501 \mathrm{~g}, 97 \%$ yield) which was confirmed by spectral comparison to the same compound prepared by reported methods.

\section{Procedures for Arene Cyclopropanation \& Product Analytical Data}

General Procedure A: $\mathbf{R h}\left(\right.$ II) Asymmetric Buchner Reaction for liquid arenes: A vial was charged with $\operatorname{Rh}_{2}[(S)$ PTTL] EtOAc ( $0.25 \mathrm{~mol} \%$ ) and arene (10-60 equiv; see below). A solution of the diazo compound (1.00 equiv) in DCE ( $300 \mu \mathrm{L} / 0.1 \mathrm{mmol}$ of diazo) was added slowly to the reaction vial. The reaction was stirred until effervescence stopped (ca. $5 \mathrm{~min}$ ), where then the reaction was concentrated directly under reduced pressure. The crude residue was purified by flash chromatography on silica gel. ${ }^{i}$

General Procedure B: Rh(II) Asymmetric Buchner Reaction for solid arenes: A vial was charged with $\mathrm{Rh}_{2}[(S)$ PTTL] EtOAc ( $0.25 \mathrm{~mol} \%)$ and arene (10 equiv) followed by the addition of $\mathrm{CH}_{2} \mathrm{Cl}_{2}(200 \mu \mathrm{L} / 1.0 \mathrm{mmol}$ arene) A solution

'Substrate-specific modifications to the general procedure are noted individually in the tabulated data. 
of the diazo compound ( 1.00 equiv) in DCE ( $300 \mu \mathrm{L} / 0.1 \mathrm{mmol}$ of diazo) was added slowly to the reaction vial. The reaction was stirred until effervescence stopped (ca. $5 \mathrm{~min}$ ), where then the reaction was concentrated directly under reduced pressure. The crude residue was purified by flash chromatography on silica using the appropriate condition.

General Procedure C: Large Scale Rh (II) Asymmetric Buchner Reaction for liquid arenes: A flask was charged with $\mathrm{Rh}_{2}[(S)-\mathrm{PTTL}] \bullet$ EtOAc $(0.25 \mathrm{~mol} \%)$ and arene (10-60 equiv; see below) open to air and was chilled in a water bath (temperature of bath $=12-13 \stackrel{\circ}{\circ}$ ). A solution of the diazo compound ( 1.00 equiv) in DCE $(0.3 \mathrm{~mL} / 0.1 \mathrm{mmol}$ of diazo) was added via syringe pump over $30 \mathrm{~min}$. The bath temperature increased to $16 \circ \mathrm{C}$ by the end of the addition. The reaction was stirred until effervescence ceased where then the entire volume was concentrated in vacuo. The crude residue was purified by flash chromatography on silica using the appropriate condition. 


\section{Optimization of the Arene Cyclopropanation}

Unless otherwise annotated, the reactions were performed according to General Procedure A. All optimization reactions were performed on $0.1 \mathrm{mmol}$ scale of the corresponding diazo compound. Yields shown were determined by quantitative ${ }^{1} \mathrm{H}$ NMR analysis on the crude reaction mixture using 1,3,5-mesitylene as an internal standard, which was added after the reaction was completed, immediately prior to NMR sample preparation. The use of "-_ indicates that the entry was not filled due to inexistence (i.e. not using an additive in the reaction) or due to inapplicability (i.e. measuring er for a racemic reaction). The use " $\mathrm{n} / \mathrm{d}$ " indicates that the given measurement was not determined.

\begin{tabular}{|c|c|c|c|c|c|c|c|c|}
\hline \multirow[b]{2}{*}{$\begin{array}{l}E \\
\text { identity }\end{array}$} & \multirow[b]{2}{*}{$\begin{array}{l}\text { Toluene } \\
\text { (X equiv) } \\
\end{array}$} & $\prod_{N_{2}}^{C N}+$ & $\nabla$ & $\begin{array}{c}\begin{array}{c}\text { catalyst, } \\
\text { additive }\end{array} \\
\begin{array}{c}\text { co-solvent, } \\
\mathrm{x}^{\circ} \mathrm{C}\end{array}\end{array}$ & ${ }^{\mathrm{Me}} Y$ & - $\mathrm{CN}$ & \multirow[b]{2}{*}{ rr } & \multirow[b]{2}{*}{ er } \\
\hline & & $\begin{array}{l}\text { Catalyst } \\
\text { (mol \%) }\end{array}$ & $\mathrm{T}\left({ }^{\circ} \mathrm{C}\right)$ & $\begin{array}{l}\text { Co-solvent } \\
(\mu \mathrm{L} / 0.1 \mathrm{mmol})\end{array}$ & $\begin{array}{l}\text { Additive } \\
\text { (mol \%) }\end{array}$ & $\begin{array}{l}\text { Yield } \\
\text { (\%) }\end{array}$ & & \\
\hline $\mathrm{CO}_{2} \mathrm{Bn}$ & $1882^{a}$ & $\begin{array}{l}\mathrm{Rh}_{2} \text { (OPiv) } \\
(1 \mathrm{~mol} \%)\end{array}$ & 25 & - & - & 84 & $9.0: 1.0$ & - \\
\hline $\mathrm{CO}_{2} \mathrm{Bn}$ & $941^{a}$ & $\begin{array}{l}\mathrm{Rh}_{2} \text { (OPiv) }{ }_{4} \\
(1 \mathrm{~mol} \%)\end{array}$ & 25 & - & - & 63 & 7.1:1.0 & - \\
\hline $\mathrm{CO}_{2} \mathrm{Bn}$ & $470^{\mathrm{a}}$ & $\begin{array}{l}\mathrm{Rh}_{2} \text { (OPiv) }{ }_{4} \\
(1 \mathrm{~mol} \%)\end{array}$ & 25 & - & - & 70 & 7.0:1.0 & - \\
\hline $\mathrm{CO}_{2} \mathrm{Bn}$ & $188^{\mathrm{a}}$ & $\begin{array}{l}\mathrm{Rh}_{2}(\mathrm{OPiv})_{4} \\
(1 \mathrm{~mol} \%)\end{array}$ & 25 & - & - & 56 & 7.1:1.0 & - \\
\hline $\mathrm{CO}_{2} \mathrm{Bn}$ & $188^{b}$ & $\begin{array}{l}\mathrm{Rh}_{2}(\mathrm{OPiv})_{4} \\
(1 \mathrm{~mol} \%)\end{array}$ & 25 & $\mathrm{CH}_{2} \mathrm{Cl}_{2}(3000)$ & - & 59 & 7.1:1.0 & - \\
\hline $\mathrm{CO}_{2} \mathrm{Bn}$ & $188^{b}$ & $\begin{array}{l}\mathrm{Rh}_{2} \text { (OPiv) }{ }_{4} \\
(1 \mathrm{~mol} \%)\end{array}$ & 25 & $\mathrm{CH}_{2} \mathrm{Cl}_{2}(3000)$ & - & 55 & 7.7:1.0 & - \\
\hline $\mathrm{CO}_{2} \mathrm{Et}$ & $188^{b}$ & $\begin{array}{l}\mathrm{Rh}_{2}(\mathrm{OPiv})_{4} \\
(1 \mathrm{~mol} \%)\end{array}$ & 25 & $\mathrm{CH}_{2} \mathrm{Cl}_{2}(3000)$ & - & 39 & $8.3: 1.0$ & - \\
\hline $\mathrm{CO}_{2} \mathrm{Et}$ & 40 & $\begin{array}{l}\mathrm{Rh}_{2}(\mathrm{esp})_{2} \\
(1 \mathrm{~mol} \%)\end{array}$ & 25 & $\mathrm{CH}_{2} \mathrm{Cl}_{2}(200)$ & - & 45 & 10.0:1.0 & - \\
\hline $\mathrm{CO}_{2} \mathrm{Et}$ & 20 & $\begin{array}{l}\mathrm{Rh}_{2} \text { (esp) } \\
(1 \mathrm{~mol} \%)\end{array}$ & 25 & $\mathrm{CH}_{2} \mathrm{Cl}_{2}(200)$ & - & 57 & 10.0:1.0 & - \\
\hline $\mathrm{CO}_{2} \mathrm{Et}$ & 20 & $\begin{array}{l}\mathrm{Rh}_{2}(\mathrm{esp})_{2} \\
(1 \mathrm{~mol} \%)\end{array}$ & 0 & $\mathrm{CH}_{2} \mathrm{Cl}_{2}(200)$ & - & 60 & 11.0:1.0 & - \\
\hline $\mathrm{CO}_{2} \mathrm{Bn}$ & 20 & $\begin{array}{l}\mathrm{Rh}_{2}(\mathrm{esp})_{2} \\
(1 \mathrm{~mol} \%)\end{array}$ & 0 & $\mathrm{CH}_{2} \mathrm{Cl}_{2}$ (200) & - & 54 & $8.3: 1.0$ & - \\
\hline $\mathrm{CO}_{2}{ }^{t} \mathrm{Bu}$ & 20 & $\begin{array}{l}\mathrm{Rh}_{2}(\mathrm{esp})_{2} \\
(1 \mathrm{~mol} \%)\end{array}$ & 0 & $\mathrm{CH}_{2} \mathrm{Cl}_{2}(200)$ & - & 43 & $9.6: 1.0$ & - \\
\hline $\mathrm{CO}_{2} \mathrm{Et}$ & 20 & $\begin{array}{c}\mathrm{Rh}_{2}[(S)-\mathrm{DOSP}]_{4} \\
\quad(1 \mathrm{~mol} \%)\end{array}$ & 25 & $\mathrm{CH}_{2} \mathrm{Cl}_{2}(300)$ & - & 55 & $6.3: 1.0$ & $69: 31$ \\
\hline $\mathrm{CO}_{2} \mathrm{Et}$ & 20 & $\begin{array}{c}\mathrm{Rh}_{2}[(S)-\mathrm{PTTL}]_{4} \\
(1 \mathrm{~mol} \%)\end{array}$ & 25 & $\mathrm{CH}_{2} \mathrm{Cl}_{2}(300)$ & - & 63 & 11.1:1.0 & $83: 17$ \\
\hline $\mathrm{CO}_{2} \mathrm{Et}$ & 20 & $\begin{array}{l}\mathrm{Rh}_{2}[(\mathrm{~S})-\mathrm{PTTL}]_{4} \\
\quad(1 \mathrm{~mol} \%)\end{array}$ & 0 & $\mathrm{CH}_{2} \mathrm{Cl}_{2}$ (300) & - & 59 & $12.5: 1.0$ & $84.5: 15.5$ \\
\hline $\mathrm{CO}_{2} \mathrm{Et}$ & 20 & $\begin{array}{c}\mathrm{Rh}_{2}[(S)-\mathrm{PTAD}]_{4} \\
(1 \mathrm{~mol} \%)\end{array}$ & 0 & $\mathrm{CH}_{2} \mathrm{Cl}_{2}(300)$ & - & 57.5 & $12.7: 1.0$ & $74: 26$ \\
\hline
\end{tabular}




\begin{tabular}{|c|c|c|c|c|c|c|c|c|}
\hline $\begin{array}{l}E \\
\text { identity }\end{array}$ & $\begin{array}{l}\text { Toluene } \\
\text { ( } \mathrm{X} \text { equiv) } \\
\end{array}$ & $\begin{array}{l}\text { Catalyst } \\
\text { (mol \%) } \\
\end{array}$ & $\mathrm{T}\left({ }^{\circ} \mathrm{C}\right)$ & $\begin{array}{l}\text { Co-solvent } \\
(\mu \mathrm{L} / 0.1 \mathrm{mmol})\end{array}$ & $\begin{array}{l}\text { Additive } \\
\text { (mol \%) }\end{array}$ & $\begin{array}{l}\text { Yield } \\
(\%) \\
\end{array}$ & rr & er \\
\hline $\mathrm{CO}_{2} \mathrm{Et}$ & 20 & $\begin{array}{c}\mathrm{Rh}_{2}[(S)-\mathrm{BTPCP}]_{4} \\
(1 \mathrm{~mol} \%)\end{array}$ & 0 & $\mathrm{CH}_{2} \mathrm{Cl}_{2}(300)$ & - & 55.5 & 8.0:1.0 & $66: 34$ \\
\hline $\mathrm{CO}_{2} \mathrm{Et}$ & 20 & $\begin{array}{l}\mathrm{Rh}_{2}[(\mathrm{~S})-\mathrm{PTTL}]_{4} \\
\quad(1 \mathrm{~mol} \%)\end{array}$ & -10 & $\mathrm{CH}_{2} \mathrm{Cl}_{2}(300)$ & - & 55 & 14.9:1.0 & $80.5: 19.5$ \\
\hline $\mathrm{CO}_{2} \mathrm{Et}$ & 20 & $\begin{array}{l}\mathrm{Rh}_{2}[(S)-\mathrm{PTTL}]_{4} \\
\quad(1 \mathrm{~mol} \%)\end{array}$ & -40 & $\mathrm{CH}_{2} \mathrm{Cl}_{2}(300)$ & - & 54.5 & $14.3: 1.0$ & $77: 23$ \\
\hline $\mathrm{CO}_{2} \mathrm{Et}$ & 20 & $\begin{array}{c}\mathrm{Rh}_{2}[(S)-\mathrm{PTTL}]_{4} \\
(1 \mathrm{~mol} \%)\end{array}$ & 50 & $\mathrm{CH}_{2} \mathrm{Cl}_{2}(300)$ & - & 65 & 9.7:1.0 & $83: 17$ \\
\hline $\mathrm{CO}_{2} \mathrm{Bn}$ & 20 & $\begin{array}{l}\mathrm{Rh}_{2}[(S)-\mathrm{PTTL}]_{4} \\
\quad(1 \mathrm{~mol} \%)\end{array}$ & 0 & $\mathrm{CH}_{2} \mathrm{Cl}_{2}(300)$ & - & 72 & 7.6:1.0 & $85: 15$ \\
\hline $\mathrm{CO}_{2}^{t} \mathrm{Bu}$ & 20 & $\begin{array}{c}\mathrm{Rh}_{2}[(S)-\mathrm{PTTL}]_{4} \\
(1 \mathrm{~mol} \%)\end{array}$ & 0 & $\mathrm{CH}_{2} \mathrm{Cl}_{2}(300)$ & - & 58 & 16.1:1.0 & $94.5: 5.5$ \\
\hline $\mathrm{CO}_{2}{ }^{t} \mathrm{Bu}$ & 10 & $\begin{array}{c}\mathrm{Rh}_{2}[(S)-\mathrm{PTTL}]_{4} \\
\quad(1 \mathrm{~mol} \%)\end{array}$ & 0 & $\mathrm{CH}_{2} \mathrm{Cl}_{2}(300)$ & - & 53.5 & 16.7:1.0 & $94: 6$ \\
\hline $\mathrm{CO}_{2}{ }^{t} \mathrm{Bu}$ & 10 & $\begin{array}{c}\mathrm{Rh}_{2}[(S)-\mathrm{PTTL}]_{4} \\
\quad(1 \mathrm{~mol} \%)\end{array}$ & 25 & $\mathrm{CH}_{2} \mathrm{Cl}_{2}(300)$ & - & 62 & $14: 1.0$ & $94: 6$ \\
\hline $\mathrm{CO}_{2}{ }^{t} \mathrm{Bu}$ & 10 & $\begin{array}{l}\mathrm{Rh}_{2}[(\mathrm{~S})-\mathrm{PTTL}]_{4} \\
\quad(1 \mathrm{~mol} \%)\end{array}$ & 50 & $\mathrm{CH}_{2} \mathrm{Cl}_{2}(300)$ & - & 61.5 & 13.1:1.0 & $93: 7$ \\
\hline $\mathrm{CO}_{2}{ }^{t} \mathrm{Bu}$ & 10 & $\begin{array}{l}\mathrm{Rh}_{2}[(\mathrm{~S})-\mathrm{PTTL}]_{4} \\
\quad(1 \mathrm{~mol} \%)\end{array}$ & $0^{c}$ & $\mathrm{CH}_{2} \mathrm{Cl}_{2}(300)$ & - & 58 & $16.5: 1.0$ & $94.5: 5.5$ \\
\hline $\mathrm{CO}_{2}{ }^{t} \mathrm{Bu}$ & 10 & $\begin{array}{l}\mathrm{Rh}_{2}[(S)-\mathrm{PTTL}]_{4} \\
\quad(1 \mathrm{~mol} \%)\end{array}$ & $25^{c}$ & $\mathrm{CH}_{2} \mathrm{Cl}_{2}(300)$ & - & 59 & $14: 1.0$ & $94: 6$ \\
\hline $\mathrm{CO}_{2}{ }^{t} \mathrm{Bu}$ & 10 & $\begin{array}{l}\mathrm{Rh}_{2}[(\mathrm{~S})-\mathrm{PTTL}]_{4} \\
\quad(1 \mathrm{~mol} \%)\end{array}$ & 25 & 1,2-DCE (300) & - & 62.5 & $15.7: 1.0$ & $94.5: 5.5$ \\
\hline $\mathrm{CO}_{2}{ }^{t} \mathrm{Bu}$ & 10 & $\begin{array}{l}\mathrm{Rh}_{2}[(S)-\mathrm{PTTL}]_{4} \\
\quad(1 \mathrm{~mol} \%)\end{array}$ & 25 & $\mathrm{CHCl}_{3}(300)$ & - & 52 & $15.5: 1.0$ & $94: 6$ \\
\hline $\mathrm{CO}_{2}{ }^{t} \mathrm{Bu}$ & 10 & $\begin{array}{c}\mathrm{Rh}_{2}[(S)-\mathrm{PTTL}]_{4} \\
(1 \mathrm{~mol} \%)\end{array}$ & 25 & MeCN (300) & - & 0 & $\mathrm{n} / \mathrm{d}$ & $\mathrm{n} / \mathrm{d}$ \\
\hline $\mathrm{CO}_{2}{ }^{t} \mathrm{Bu}$ & 10 & $\begin{array}{l}\mathrm{Rh}_{2}[(S)-\mathrm{PTTL}]_{4} \\
\quad(1 \mathrm{~mol} \%)\end{array}$ & 25 & EtOAc (300) & - & 45 & $17.5: 1.0$ & $94: 6$ \\
\hline $\mathrm{CO}_{2}{ }^{t} \mathrm{Bu}$ & 10 & $\begin{array}{c}\mathrm{Rh}_{2}[(S)-\mathrm{PTTL}]_{4} \\
(1 \mathrm{~mol} \%)\end{array}$ & 25 & Hexanes (300) & - & 49 & $20: 1.0$ & $94.5: 5.5$ \\
\hline $\mathrm{CO}_{2}{ }^{t} \mathrm{Bu}$ & 10 & $\begin{array}{c}\mathrm{Rh}_{2}[(S)-\mathrm{PTTL}]_{4} \\
(0.25 \mathrm{~mol} \%)\end{array}$ & 25 & 1,2-DCE (300) & - & 66 & $14.5: 1.0$ & $94: 6$ \\
\hline $\mathrm{CO}_{2}{ }^{t} \mathrm{Bu}$ & 10 & $\begin{array}{c}\mathrm{Rh}_{2}[(S)-\mathrm{TFPTTL}]_{4} \\
(1 \mathrm{~mol} \%)\end{array}$ & 25 & 1,2-DCE (300) & - & 57 & $11: 1$ & $84: 16$ \\
\hline $\mathrm{CO}_{2}{ }^{t} \mathrm{Bu}$ & 10 & $\begin{array}{c}\mathrm{Rh}_{2}[(S)-\mathrm{PTTL}]_{4} \\
(1 \mathrm{~mol} \%)\end{array}$ & 25 & 1,2-DCE (300) & $\begin{array}{l}\text { pyridine } \\
(1.1 \mathrm{~mol} \%)^{d}\end{array}$ & 0 & $\mathrm{n} / \mathrm{d}$ & $n / d$ \\
\hline $\mathrm{CO}_{2}{ }^{t} \mathrm{Bu}$ & 10 & $\begin{array}{c}\mathrm{Rh}_{2}[(S)-\mathrm{PTTL}]_{4} \\
(1 \mathrm{~mol} \%)\end{array}$ & 25 & 1,2-DCE (300) & $\begin{array}{l}\mathrm{PPh}_{3} \\
(1.1 \mathrm{~mol} \%)^{\mathrm{d}}\end{array}$ & 21 & 11.0:1.0 & $n / d$ \\
\hline
\end{tabular}

${ }^{\mathrm{a}}$ Diazo, in solution of toluene, added to solution of catalyst in $100 \mu \mathrm{L}$ of toluene over $1 \mathrm{~h} .{ }^{\mathrm{b}}$ Diazo, in solution of toluene, added to solution of catalyst in $\mathrm{CH}_{2} \mathrm{Cl}_{2}$ co-solvent. ${ }^{\mathrm{C}}$ Diazo added as solution in co-solvent over $90 \mathrm{~min}$. ${ }^{\mathrm{d} C}$ Catalyst and additive were pre-complexed prior to addition of diazo solution in co-solvent. 


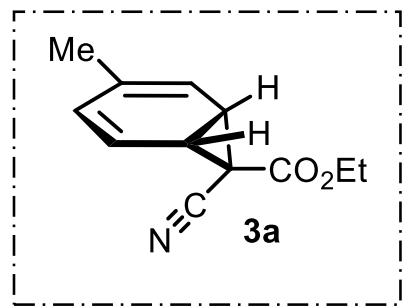

ethyl (1S,6R,7S)-7-cyano-3-methylbicyclo[4.1.0]hepta-2,4-diene-7-carboxylate (3a): The title compound was prepared according to General Procedure A using 10 equiv of toluene and $0.2 \mathrm{mmol}$ of diazo $1 \mathrm{a}$. The product was purified from the crude mixture by flash chromatography on TEA-deactivated silica (100\% hexanes $\rightarrow 10 \%$ MTBE:hexanes) to afford $3 \mathrm{a}$ in $23.1 \mathrm{mg}$ as a clear, colorless oili [56\% yield, 11.0:1.0 rr, 83:17 er]. The regioselectivity was determined from the crude ${ }^{1} \mathrm{H}$ NMR spectrum by integrating and comparing relative values for the olefin resonances of the major $(\delta 6.30)$ and minor $(\delta 6.39)$ regioisomers.

Analytical data for 3a: ${ }^{1} \mathrm{H}$ NMR $\left(600 \mathrm{MHz}, \mathrm{CDCl}_{3}\right): \delta 6.29$ (dd J=9.5, $\left.1.3 \mathrm{~Hz}, 1 \mathrm{H}\right), 6.20(\mathrm{dd}, J=9.4,4.5 \mathrm{~Hz}, 1 \mathrm{H}), 5.92(\mathrm{~m}$, $1 \mathrm{H}), 4.30(\mathrm{q}, J=7.1 \mathrm{~Hz}, 2 \mathrm{H}), 3.18(\mathrm{~m}, 2 \mathrm{H}), 1.97(\mathrm{~d}, J=1.3,2 \mathrm{H}), 1.35(\mathrm{t}, J=7.1,3 \mathrm{H}) ;{ }^{13} \mathrm{C} \mathrm{NMR}\left(101 \mathrm{MHz}, \mathrm{CDCl}_{3}\right): 170.2$ 136.1, 131.2, 122.2, 117.1, 112.8, 63.0, 39.4, 38.0, 21.6, 14.2, 13.2; IR (thin film, KBr, cm ${ }^{-1}$ ) 3429, 2982, 2938, 2920, 2241, 1725, 1650, 1450, 1421, 1368, 1292, 1245, 1131, 1113, 1027, 988, 847, 781, 751, 641, 573; HRMS (ESI-): Calculated for [C $\left.{ }_{12} \mathrm{H}_{12} \mathrm{NO}_{2}\right]^{-}$([M-H]): 202.08735, Found: 202.08622; HPLC (95:5 hexanes:'PrOH, Daicel CHIRALPAK IC): 83:17 er, $t_{R}$ $($ major $)=15.9 \mathrm{~min}, t_{R}(\operatorname{minor})=25.7 \mathrm{~min} ;[\alpha]_{\mathrm{D}}:-10.1\left(\mathrm{c}=0.01, \mathrm{CHCl}_{3}\right) ; \mathrm{TLC}(90: 10$ hexanes:MTBE$): R_{\mathrm{f}}=0.18$.

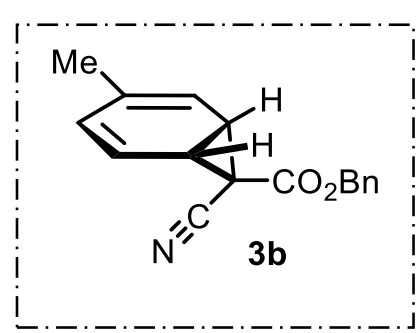

benzyl (1S,6R,7S)-7-cyano-3-methylbicyclo[4.1.0]hepta-2,4-diene-7-carboxylate (3b): The title compound was prepared according to General Procedure A using 10 equiv of toluene and $0.2 \mathrm{mmol}$ of diazo $\mathbf{1 b}$. The product was purified from the crude mixture by flash chromatography on TEA-deactivated silica gel (100\% hexanes $\rightarrow 10 \%$ MTBE:hexanes) to afford $\mathbf{3 b}$ in $15.4 \mathrm{mg}$ as a colorless oiliii [29\% yield, 7.0:1.0 rr, 76:24 er]. The regioselectivity was determined from the crude ${ }^{1} \mathrm{H}$ NMR spectrum by integrating and comparing relative values for the olefin resonances of the major $(\delta 6.23)$ and minor regioisomers $(\delta 6.09)$.

Analytical data for 3b: ${ }^{1} \mathbf{H}$ NMR $\left(600 \mathrm{MHz}, \mathrm{CDCl}_{3}\right): \delta 7.45-7.33(\mathrm{~m}, 5 \mathrm{H}), 6.30(\mathrm{~d}, J=9.5 \mathrm{~Hz}, 1 \mathrm{H}), 6.19(\mathrm{dd}, J=9.5,4.6 \mathrm{~Hz}$, $1 \mathrm{H}), 5.92(\mathrm{~m}, 1 \mathrm{H}), 5.27(\mathrm{~m}, 1 \mathrm{H}), 3.22(\mathrm{~m}, 2 \mathrm{H}), 1.97(\mathrm{~s}, 3 \mathrm{H}) ;{ }^{13} \mathrm{C} \mathrm{NMR}\left(151 \mathrm{MHz}, \mathrm{CDCl}_{3}\right):$ 170.1, 136.3, 134.9, 131.4, 128.6, $128.5,128.3,122.2,117.0,112.6,68.3,39.6,38.2,21.6,13.3$ IR (thin film, KBr, cm${ }^{-1}$ ) 3034, 2954, 2919, 2852, 2240, 1725, 1499, 1452, 1379, 1284, 1235, 1130, 1026, 984, 909, 807, 748, 698, 572; HRMS (ESI-): Calculated for $\left[\mathrm{C}_{17} \mathrm{H}_{15} \mathrm{NO}_{2}\right]^{-}([\mathrm{M}-$ H]): 264.1030, Found: 264.1021; HPLC (95:5 hexanes:'PrOH, Daicel CHIRALPAK IC): 76:24 er, $t_{R}$ (major) $=24.6 \mathrm{~min}, t_{R}$ (minor) $=18.0 \min ;[\alpha]_{\mathrm{D}}:-9.81\left(\mathrm{c}=0.011, \mathrm{CHCl}_{3}\right) ; \operatorname{TLC}(90: 10$ hexanes:MTBE$): R_{\mathrm{f}}=0.18$.

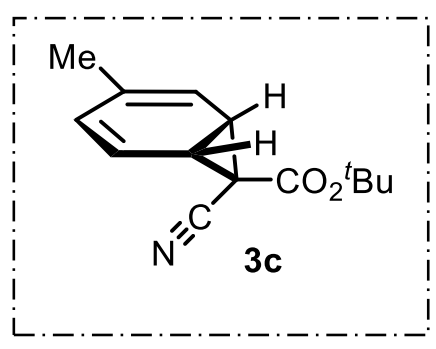

tert-butyl (1S,6R,7S)-7-cyano-3-methylbicyclo[4.1.0]hepta-2,4-diene-7-carboxylate (3c): Small-scale reaction: The title compound was prepared according to General Procedure $\mathbf{A}$ using 10 equiv of toluene and $0.2 \mathrm{mmol}$ of diazo 1c. The product was purified from the crude mixture by flash chromatography on silica geliv (100\% hexanes $\rightarrow 5 \%$ EtOAc:hexanes) to afford $3 \mathrm{c}$ in $30.4 \mathrm{mg}$ as a colorless oil [66\% yield, 14.5:1.0 rr, 94:6 er]. The regioselectivity was determined from the crude ${ }^{1} \mathrm{H}$ NMR spectrum by integrating and comparing relative values for the olefin resonances of the major $(\delta 6.31)$ and minor $(\delta 6.37)$ regioisomers.

\footnotetext{
ii Product 3a exhibited appreciable configurational instability as a pure oil. A significant decrease in enantiopurity was observed after storing for $48 \mathrm{~h}$. Similarly, 3a exhibited increased sensitivity to acidic impurities in deuterated chloroform. Concentration of $\mathrm{CDCl}_{3}$ solutions of $3 a$ lead to product decomposition via rearomatization.

iii Product 3b exhibited significant instability as a pure oil.

${ }^{\text {iv }}$ Alternatively, synthetically pure samples of $3 \mathrm{c}$ can be obtained by filtration through a silica gel $(20 \mathrm{~g} / 1 \mathrm{mmol})$ pad by initially rinsing the pad with hexanes ( $10 \mathrm{~mL} / 1 \mathrm{mmol}$ split into two equal volume washes) to remove residual arene followed by product elution with $10 \% \mathrm{MTBE} /$ Hexanes ( $30 \mathrm{~mL} / 1 \mathrm{mmol}$ split into three equal volume washes).
} 
Large-scale Reaction: The title compound was prepared according General Procedure $\mathbf{C}$ using $5 \mathrm{mmol}$ of diazo $1 \mathrm{c}$. The product was purified by flash chromatography on silica ( $100 \%$ hexanes $\rightarrow 5 \%$ EtOAc/hexanes) to afford $3 \mathrm{c}$ as a colorless oil that solidified to a semi-solid upon standing in 1.5839 $\mathrm{g}$ [68\%, 13.0:1.0 rr, 92:8 er].

Analytical data for 3c: ${ }^{1} \mathrm{H}$ NMR $\left(500 \mathrm{MHz}, \mathrm{CDCl}_{3}\right): \delta 6.27(\mathrm{~d}, J=9.5 \mathrm{~Hz}, 1 \mathrm{H}), 6.18(\mathrm{dt}, J=9.5,3.5 \mathrm{~Hz}, 1 \mathrm{H}), 5.91(\mathrm{~m}, 1 \mathrm{H})$, 3.14-3.02 (m, 2H), 1.95 (s, 3H), 1.52 (s, 9H); $\left.{ }^{13} \mathrm{C} \mathrm{NMR} \mathrm{(101} \mathrm{MHz,} \mathrm{CDCl}_{3}\right): 168.9,135.8,131.1,122.3,117.2,113.0,83.9$, 38.9, 37.5, 28.0, 21.6, 13.7; IR (thin film, KBr, cm${ }^{-1}$ ) 3046, 2978, 2935, 2240, 1719, 1455, 1370, 1300, 1255, 1159, 987, 837, 778, 751, 719, 574; HRMS (ESI+): Calculated for $\left[\mathrm{C}_{14} \mathrm{H}_{18} \mathrm{NO}_{2}\right]^{+}([\mathrm{M}+\mathrm{H}]):$ 232.1332, Found: 232.1344; HPLC (95:5 hexanes: ${ }^{P}$ PrOH, Daicel CHIRALPAK IC): 94:6 er, $t_{R}$ (major) $=8.5 \mathrm{~min}, t_{R}$ (minor) $=10.5 \mathrm{~min} ;[\alpha]_{\mathrm{D}}:-27.3\left(\mathrm{c}=0.01, \mathrm{CHCl}_{3}\right)$; $\operatorname{TLC}\left(90: 10\right.$ hexanes:EtOAc): $R_{\mathrm{f}}=0.24$.

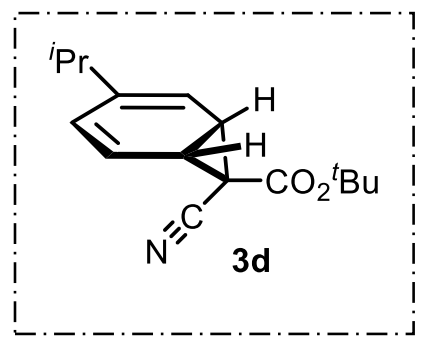

tert-butyl (1S,6R,7S)-7-cyano-3-isopropylbicyclo[4.1.0]hepta-2,4-diene-7-carboxylate (3d): The title compound was prepared according to General Procedure A using 10 equiv of cumene and $0.2 \mathrm{mmol}$ of diazo $1 \mathrm{c}$. The product was purified from the crude mixture by flash chromatography on silica gel (100\% hexanes $\rightarrow 5 \%$ MTBE:hexanes) to afford $\mathbf{3 d}$ in $35.0 \mathrm{mg}$ as a clear, colorless oil [67\% yield, 11.0:1.0 rr, 90:10 er]. The regioselectivity was determined from the crude ${ }^{1} \mathrm{H}$ NMR spectrum by integration of the olefin resonances for the major $(\delta$ $6.25)$ and minor ( $\delta 6.09)$ regioisomers.

Analytical data for 3d: ${ }^{1} \mathrm{H} \mathrm{NMR}\left(600 \mathrm{MHz}, \mathrm{CDCl}_{3}\right): \delta 6.35(\mathrm{~d}, J=9.6 \mathrm{~Hz}, 1 \mathrm{H}), 6.19(\mathrm{~m}, 1 \mathrm{H}), 5.91(\mathrm{~m}, 1 \mathrm{H}), 3.10(\mathrm{~m}, 2 \mathrm{H}), 2.45$ (hept, $J=6.8 \mathrm{~Hz}, 1 \mathrm{H}), 1.52(\mathrm{~s}, 9 \mathrm{H}), 1.11(\mathrm{~d}, J=6.8 \mathrm{~Hz}, 3 \mathrm{H}), 1.09(\mathrm{~d}, J=6.8 \mathrm{~Hz}, 3 \mathrm{H}) ;{ }^{13} \mathrm{C} \mathrm{NMR}(151 \mathrm{MHz}, \mathrm{CDCl}): \delta 169.0$, $146.3,129.1,122.4,114.6,112.9,83.9,38.4,37.8,33.7,28.0,27.2,21.5,13.6$; IR (thin film, KBr, cm ${ }^{-1}$ ) 2965, 2933, 2360, 2240, 1720, 1647, 1458, 1424, 1393, 1370, 1302, 1255, 1159, 1044, 984, 837, 816, 782, 720, 664, 620, 583, 555; HRMS (ESI-): Calculated for [ $\left.\mathrm{C}_{16} \mathrm{H}_{21} \mathrm{NO}_{2}\right]^{-}([\mathrm{M}-\mathrm{H}])$ : 258.1499, Found: 258.1484; HPLC (95:5 hexanes: 'PrOH, Daicel CHIRALPAK IC): $90: 10 \mathrm{er}, t_{R}($ major $)=6.9 \mathrm{~min}, t_{R}($ minor $)=8.5 \mathrm{~min} ;[\alpha]_{\mathrm{D}}:-24.2\left(\mathrm{c}=0.014, \mathrm{CHCl}_{3}\right) ; \operatorname{TLC}(90: 10$ hexanes:MTBE$): R_{\mathrm{f}}=0.40$.

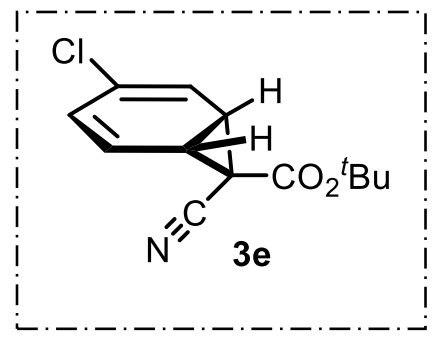

tert-butyl (1R,6R,7S)-3-chloro-7-cyanobicyclo[4.1.0]hepta-2,4-diene-7-carboxylate (3e): The title compound was prepared according to General Procedure A using 60 equiv of chlorobenzene and $0.2 \mathrm{mmol}$ of $\mathbf{1 c}$. The product was purified from the crude mixture by flash chromatography on silica gel (100\% hexanes $\rightarrow 5 \%$ EtOAc:hexanes) to afford $\mathbf{3 e}$ as a colorless oil in $21 \mathrm{mg}$ [42\% yield, 19.0:1.0 rr, 96:4 er]. The regioselectivity was determined from the crude ${ }^{1} \mathrm{H}$ NMR spectrum by integrating and comparing values for the olefin resonances of the major $(\delta 6.39-6.36)$ and minor $(\delta 6.46-6.44)$ regioisomers .

Analytical data for $3 \mathrm{e}:{ }^{1} \mathrm{H}$ NMR $\left(600 \mathrm{MHz}, \mathrm{CDCl}_{3}\right): \delta 6.38(\mathrm{dd}, J=9.7,1.6 \mathrm{~Hz}, 1 \mathrm{H}), 6.28(\mathrm{dd}, J=9.8,5.4 \mathrm{~Hz}, 1 \mathrm{H}), 6.25(\mathrm{~d}, J=$ $5.9 \mathrm{~Hz}, 1 \mathrm{H}), 3.15$ (ddd, $J=8.5,5.9,1 \mathrm{~Hz}, 1 \mathrm{H}), 3.10$ (dd, $J=8.4,5.4 \mathrm{~Hz}, 1 \mathrm{H}), 1.53(\mathrm{~s}, 9 \mathrm{H}) ;{ }^{13} \mathrm{C} \mathrm{NMR}\left(151 \mathrm{MHz}, \mathrm{CDCl}_{3}\right) \delta$ 168.0, 132.7, 130.1, 125.0, 118.6, 112.5, 84.9, 39.2, 37.1, 28.1, 13.9. IR (thin film, KBr, cm${ }^{-1}$ ); HRMS (ESI+): Calculated for $\left[\mathrm{C}_{13} \mathrm{H}_{14}{ }^{35} \mathrm{CINO}_{2} \mathrm{Na}\right]^{+}$([M+Na]): 274.0606, Found: 274.0599; HPLC (95:5 hexanes:'PrOH, Daicel CHIRALPAK IC): $94: 6$ er, $t_{R}$ (major) $=8.1 \mathrm{~min}, t_{R}$ (minor) $=9.5 ;[\alpha]_{\mathrm{D}}:-33\left(\mathrm{c}=0.0105, \mathrm{CHCl}_{3}\right) ; \operatorname{TLC}\left(70: 30\right.$ hexanes:EtOAc): $R_{\mathrm{f}}=0.67$.

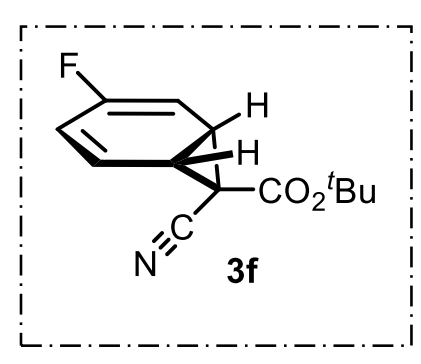

tert-butyl (1R,6R,7S)-7-cyano-3-fluorobicyclo[4.1.0]hepta-2,4-diene-7-carboxylate (3f): The title compound was prepared according to General Procedure A using 60 equiv of fluorobenzene and $0.2 \mathrm{mmol}$ of diazo $1 \mathrm{c}$. The product was purified from the crude mixture by flash chromatography on silica gel ( $100 \%$ hexanes $\rightarrow 5 \%$ EtOAc:Hexanes) to afford $\mathbf{3 f}$ as an off-white amorphous solid in $20 \mathrm{mg}$ [43\% yield, $>20: 1.0 \mathrm{rr}, 96: 4 \mathrm{er}$ ]. No minor regioisomers were by detected by ${ }^{1} \mathrm{H}$ NMR or chiral HPLC.

Analytical data for $3 f:{ }^{1} \mathrm{H}$ NMR $\left(600 \mathrm{MHz}, \mathrm{CDCl}_{3}\right): \delta 6.37-6.32(\mathrm{~m}, 2 \mathrm{H}), 5.72(\mathrm{dd}, J=10.1,6.1$ $\mathrm{Hz}, 1 \mathrm{H}), 3.19-3.15(\mathrm{~m}, 1 \mathrm{H}), 3.13-3.10(\mathrm{~m}, 1 \mathrm{H}), 1.53(\mathrm{~s}, 9 \mathrm{H}) ;{ }^{13} \mathrm{C} \mathrm{NMR}(151 \mathrm{MHz}, \mathrm{CDCl}): \delta 168.2,160.7,159.0,126.9$, $126.8,123.7,123.4,112.6,99.8,99.7,84.7,38.7,38.1,28.1,13.9,13.9 ;{ }^{19} \mathrm{~F} \mathrm{NMR}\left(376 \mathrm{MHz}, \mathrm{CDCl}_{3}\right):-113.79--114.07$ 
(m); IR (thin film, KBr, cm ${ }^{-1}$ ) 2981, 2935, 2360, 2243, 1722, 1660, 1424, 1371, 1299, 1257, 1204, 1154, 839, 764, 717; HRMS (ESI-): Calculated for [ $\left.\mathrm{C}_{13} \mathrm{H}_{14} \mathrm{FNO}_{2}\right]^{-}([\mathrm{M}-\mathrm{H}])$ : 234.0936, Found: 234.0945; HPLC (95:5 hexanes 'PrOH, Daicel CHIRALPAK IC): $96: 4 \mathrm{er}, t_{R}$ (major) $=8.5 \mathrm{~min}, t_{R}$ (minor) $=9.8 \mathrm{~min} ;[\alpha]_{\mathrm{D}}:-27.2\left(\mathrm{c}=0.012, \mathrm{CHCl}_{3}\right) ; \operatorname{TLC}(70: 30$ hexanes:EtOAc): $R_{\mathrm{f}}=0.63$.

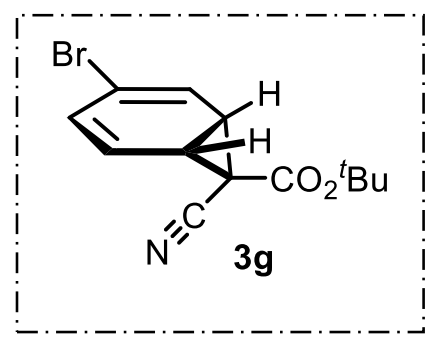

tert-butyl (1R,6R,7S)-3-bromo-7-cyanobicyclo[4.1.0]hepta-2,4-diene-7-carboxylate (3g): The title compound was prepared according to General Procedure A using 60 equiv of bromobenzene and $0.2 \mathrm{mmol}$ of diazo $1 \mathrm{c}$ with the following modification. Once effervescence ceased ( $10 \mathrm{~min})$, the unreacted bromobenzene was removed by heating the crude reaction solution at $70{ }^{\circ} \mathrm{C}$ under vacuum ( $<0.1$ torr). The product was purified from the crude residue by flash chromatography on silica gel ( $100 \%$ hexanes $\rightarrow 5 \%$

EtOAc:hexanes) to afford $\mathbf{3 g}$ as a colorless oil that yellows on standing in $25 \mathrm{mg}$ [ $42 \%$ yield, 13.3:1.0 rr, 94.5:5.5 er]. The regioselectivity was determined from the crude ${ }^{1} \mathrm{H}$ NMR spectrum by integrating and comparing values for the olefin resonances of the major ( $\delta 6.50-6.47)$ and minor $(\delta 6.69-6.67)$ regioisomers.

Analytical data for 3g: ${ }^{1} \mathrm{H}$ NMR $\left(600 \mathrm{MHz}, \mathrm{CDCl}_{3}\right): \delta 6.51-6.45(\mathrm{~m}, 2 \mathrm{H}), 6.22-6.17(\mathrm{~m}, 1 \mathrm{H}), 3.17-3.05(\mathrm{~m}, 2 \mathrm{H}), 1.53(\mathrm{~s}, 9 \mathrm{H})$; ${ }^{13} \mathrm{C} \mathrm{NMR}\left(151 \mathrm{MHz}, \mathrm{CDCl}_{3}\right): \delta 167.9,131.9,124.7,122.4,121.0,112.4,84.9,40.4,37.1,28.1,13.7$; IR (thin film, $\mathrm{cm}^{-1}$ ) 3428, 2981, 2934, 2245, 1724, 1618, 1557, 1408, 1371, 1302, 1258, 1157, 1013, 983, 960, 913, 836, 815, 798, 732, 647, 570; HRMS (ESI-): Calculated for $\left[\mathrm{C}_{13} \mathrm{H}_{14}{ }^{79} \mathrm{BrNO}_{2}\right]^{-}([\mathrm{M}-\mathrm{H}]): 294.0152$, Found: 294.0152; HPLC (95:5 hexanes:'PrOH, Daicel CHIRALPAK IC): $94.5: 5.5 \mathrm{er}, t_{R}$ (major) $=8.9 \mathrm{~min}, t_{R}$ (minor) $=10.2 \mathrm{~min} ;[\alpha]_{\mathrm{D}}:-56.4\left(\mathrm{c}=0.012, \mathrm{CHCl}_{3}\right) ; \operatorname{TLC}(70: 30$ hexanes:EtOAc): $R_{\mathrm{f}}=0.70$.

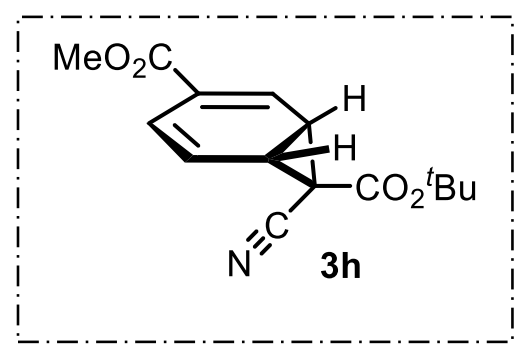

\section{7-(tert-butyl) 3-methyl (1S,6R,7S)-7-cyanobicyclo[4.1.0]hepta-2,4-diene-3,7- dicarboxylate (3h): The title compound was prepared according to General Procedure A using $0.4 \mathrm{mmol}$ of diazo 1c, with a modified work-up to remove the unreacted methyl benzoate ( 60 equiv of arene). ${ }^{\vee}$ Once effervescence ceased $(20 \mathrm{~min}$ ) the reaction solution was transferred to a $500 \mathrm{~mL}$ round bottom flask using minimal $\mathrm{CH}_{2} \mathrm{Cl}_{2}$. The vessel was charged with water $(125 \mathrm{~mL})$ and a large magnetic stirring bar before concentrating the mixture to dryness using a rotary evaporator $\left(45^{\circ} \mathrm{C}\right.$ bath} temp). The residue left behind was taken up into $\mathrm{CH}_{2} \mathrm{Cl}_{2}$, washed with brine, dried over anhydrous $\mathrm{Na}_{2} \mathrm{SO}_{4}$, filtered, and concentrated in vacuo. The product was purified from the crude mixture by flash chromatography on silica gel $(100 \%$ hexanes $\rightarrow 10 \%$ EtOAc:hexanes) to afford $3 \mathrm{~h}$ as a colorless oil in $18 \mathrm{mg}$ [16\% yield, 4.6:1.0 $\mathrm{rr}$ (crude), 5.6:1.0 rr (chromatographed), 96:4 er]. The regioselectivity was determined from the ${ }^{1} \mathrm{H}$ NMR spectra by integrating and comparing values for the olefin resonances of the major $(\delta 6.55)$ and minor $(\delta 6.94)$ regioisomers.

Analytical data for $3 \mathrm{~h}::^{1} \mathrm{H}$ NMR $\left(600 \mathrm{MHz}, \mathrm{CDCl}_{3}\right): \delta 7.38(\mathrm{dt}, J=6.2,1.1 \mathrm{~Hz}, 1 \mathrm{H}), 6.58-6.51(\mathrm{~m}, 2 \mathrm{H}), 3.84(\mathrm{~s}, 3 \mathrm{H}), 3.67(\mathrm{~d}$, $J=8.7 \mathrm{~Hz}, 1 \mathrm{H}), 3.21(\mathrm{dd}, J=8.7,5.3 \mathrm{~Hz}, 1 \mathrm{H}), 1.54(\mathrm{~s}, 9 \mathrm{H}) ;{ }^{13} \mathrm{C} \mathrm{NMR}\left(151 \mathrm{MHz}, \mathrm{CDCl}_{3}\right): \delta$ 168.0, 166.2, 133.4, 128.8, 126.8, 124.0, 112.4, 84.9, 52.5, 38.1, 36.6, 28.1, 12.9; IR (thin film, KBr, cm ${ }^{-1}$ ) 2981, 2244, 1722, 1558, 1439, 1371, 1306, 1255, 1158, 1089, 839, 758; HRMS (ESI+): Calculated for $\left[\mathrm{C}_{15} \mathrm{H}_{17} \mathrm{NO}_{4} \mathrm{Na}\right]^{+}([\mathrm{M}+\mathrm{Na}]):$ 298.1050, Found: 298.1050; HPLC (90:10 hexanes:'PrOH, Daicel CHIRALPAK IC): 96:4 er, $t_{R}($ major $)=17.0 \mathrm{~min}, t_{R}(\operatorname{minor})=14.3 \mathrm{~min} ;[\alpha]_{\mathrm{D}}:-160.1\left(\mathrm{c}=0.009, \mathrm{CHCl}_{3}\right)$; $\operatorname{TLC}\left(70: 30\right.$ hexanes:EtOAc): $R_{\mathrm{f}}=0.54$.

\footnotetext{
${ }^{\vee}$ The reaction of this substrate is sensitive to scale, addition rate, and stirring rate (this example: $0.40 \mathrm{mmol}, 30 \mathrm{~s},>800 \mathrm{rpm}$ in a 20 $\mathrm{mL}$ scintillation vial).
} 


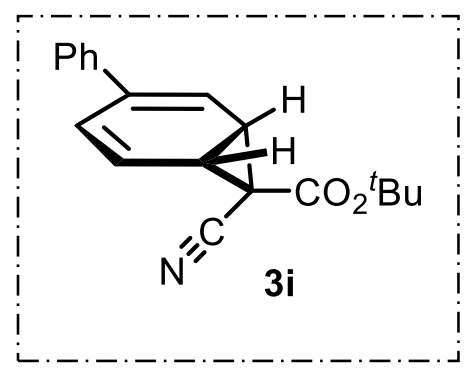

tert-butyl (1S,6R,7S)-7-cyano-3-phenylbicyclo[4.1.0]hepta-2,4-diene-7-carboxylate (3i): The title compound was prepared according to General Procedure B using $0.2 \mathrm{mmol}$ of diazo 1c. The product was purified from the crude mixture by flash chromatography on silica gel (100\% hexanes $\rightarrow 15 \%$ MTBE:hexanes) to afford $3 \mathbf{i}$ in $21.8 \mathrm{mg}$ as a colorless oil [37\% yield, 18.0:1.0 rr, 91:9 er]. The regioselectivity was determined from the crude ${ }^{1} \mathrm{H}$ NMR spectrum by integrating and comparing values for the olefin resonances of the major ( $\delta 6.80)$ and minor $(\delta 6.61)$ regioisomers.

Analytical data for 3i: ${ }^{1} \mathbf{H}$ NMR $\left(500 \mathrm{MHz}, \mathrm{CDCl}_{3}\right): \delta 7.45(\mathrm{~d}, J=8.0 \mathrm{~Hz}, 2 \mathrm{H}), 7.39(\mathrm{~d}, J=8.0 \mathrm{~Hz}, 2 \mathrm{H}), 7.35(\mathrm{~m}, 1 \mathrm{H}), 6.79(\mathrm{~d}, J$ $=9.6 \mathrm{~Hz}, 1 \mathrm{H}), 6.41(\mathrm{dd}, J=9.6,5.1 \mathrm{~Hz}, 1 \mathrm{H}), 6.38(\mathrm{~d}, J=5.7 \mathrm{~Hz}, 1 \mathrm{H}), 3.32(\mathrm{dd}, J=8.4,5.7 \mathrm{~Hz}, 1 \mathrm{H}), 3.25(\mathrm{dd}, J=8.4,5.2 \mathrm{~Hz}$, 1H), 1.58 (s, 9H); $\left.{ }^{13} \mathrm{C} \mathrm{NMR} \mathrm{(101} \mathrm{MHz,} \mathrm{CDCl} 3\right): \delta 168.6,139.7,139.6,128.9,128.6,128.0,126.3,123.3,118.6,112.8,84.2$, 39.1, 38.2, 28.0, 14.1; IR (thin film, KBr, cm ${ }^{-1}$ ) 3448, 2981, 2931, 2242, 1731, 1477, 1449, 1395, 1371, 1299, 1255, 1151, 1063, 1032, 970, 837, 758, 699, 667, 633; HRMS (ESI+): Calculated for $\left[\mathrm{C}_{19} \mathrm{H}_{20} \mathrm{NO}_{2}\right]^{+}([\mathrm{M}+\mathrm{H}]):$ 294.1488, Found: 294.1502; HPLC (95:5 Hexanes:'PrOH, Daicel CHIRALPAK IC): 91:9 er, $t_{R}$ (major) = $11.8 \mathrm{~min}, t_{R}$ (minor) = $13.8 \mathrm{~min} ;[\alpha]_{\mathrm{D}}:-75$ (c= $\left.0.0124, \mathrm{CHCl}_{3}\right) ; \operatorname{TLC}\left(90: 10\right.$ hexanes:EtOAC): $R_{\mathrm{f}}=0.19$.

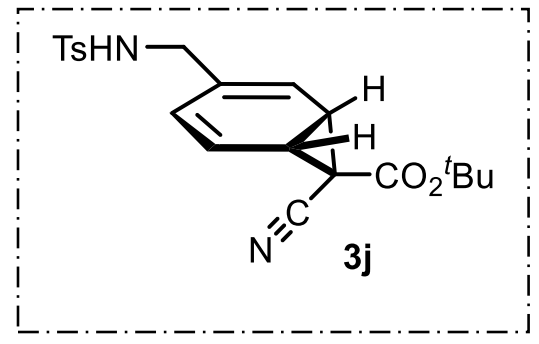

tert-butyl (1S,6R,7S)-7-cyano-3-(((4methylphenyl)sulfonamido)methyl)bicyclo[4.1.0]hepta-2,4-diene-7-carboxylate (3j): The title compound was prepared according to General Procedure B using 0.2 $\mathrm{mmol}$ of diazo $\mathbf{1 c}$. The product was purified from the crude mixture by flash chromatography on silica gel ( $10 \% \rightarrow 40 \%$ MTBE:hexanes) to afford $\mathbf{3} \mathbf{j}$ in $34.8 \mathrm{mg}$ as a white, amorphous semisolid [43\% yield, >20:1.0 rr, 91:9 er]. The regioselectivity was determined from the crude ${ }^{1} \mathrm{H}$ NMR spectrum by integrating and comparing values for the olefin resonances of the major $(\delta 6.27)$ and minor $(\delta 6.34)$ regioisomers.

Analytical data for $3 \mathrm{~h}:{ }^{1} \mathrm{H} \mathrm{NMR}\left(600 \mathrm{MHz}, \mathrm{CDCl}_{3}\right): \delta 7.74(\mathrm{~d}, J=7.9 \mathrm{~Hz}, 2 \mathrm{H}), 7.31(\mathrm{~d}, J=7.9 \mathrm{~Hz}, 2 \mathrm{H}) 6.26(\mathrm{~d}, J=9.6 \mathrm{~Hz}, 1 \mathrm{H})$, $6.21(\mathrm{dd}, J=9.6,5.2 \mathrm{~Hz}, 1 \mathrm{H}), 6.04(\mathrm{~d}, J=5.2 \mathrm{~Hz}, 1 \mathrm{H}), 4.71(\mathrm{~d}, J=6.0 \mathrm{~Hz}, 1 \mathrm{H}), 3.72(\mathrm{dd}, J=14.1,6.0 \mathrm{~Hz}, 1 \mathrm{H}), 3.68(\mathrm{dd}, J=$ 14.1, $6.0 \mathrm{~Hz}, 1 \mathrm{H}), 3.08(\mathrm{dd}, J=8.3,5.3 \mathrm{~Hz}, 1 \mathrm{H}), 3.05(\mathrm{dd}, J=8.3,5.3 \mathrm{~Hz}, 1 \mathrm{H}), 2.43(\mathrm{~s}, 3 \mathrm{H}), 1.51(\mathrm{~s}, 9 \mathrm{H}) ;{ }^{13} \mathrm{C} \mathrm{NMR}(151 \mathrm{MHz}$, $\left.\mathrm{CDCl}_{3}\right): \delta 168.3,143.6,136.7,135.2,129.8,127.6,127.2,123.6,119.8,119.8,112.7,84.4,47.0,37.7,37.6,27.9,26.5$, 13.7; IR (thin film, KBr, cm ${ }^{-1}$ ): 3282(b), 2980, 2932, 2243, 1718, 1589, 1456, 1419, 1371, 1326, 1304, 1257, 1159, 1093, 985, 836, 814, 756, 718, 663, 550; HRMS (ESI-): Calculated for $\left[\mathrm{C}_{21} \mathrm{H}_{23} \mathrm{~N}_{2} \mathrm{O}_{4} \mathrm{~S}\right]^{-}([\mathrm{M}-\mathrm{H}])$ : 399.1384 , Found: $399.1368 ; \mathrm{HPLC}$ (80:20 hexanes: ${ }^{\prime} P r O H$, Daicel CHIRALPAK IA): $91: 9 \mathrm{er}, t_{R}($ major $)=9.1 \mathrm{~min}, t_{R}(\mathrm{minor})=8.2 \mathrm{~min} ;[\alpha]_{\mathrm{D}}:-8.0$ (c=0.011, $\left.\mathrm{CHCl}_{3}\right) ; \operatorname{TLC}\left(70: 30\right.$ hexanes:EtOAC): $R_{\mathrm{f}}=0.35$.

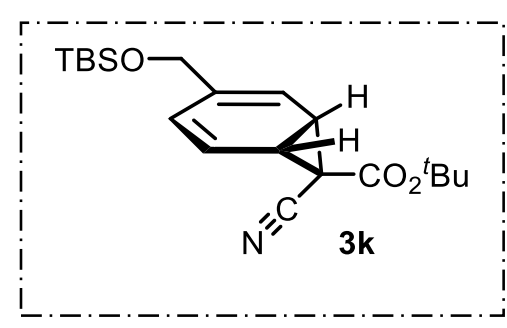

tert-butyl (1S,6R,7S)-3-((tert-butyldimethylsilyl)oxy)methyl)-7cyanobicyclo[4.1.0]hepta-2,4-diene-7-carboxylate (3k): The title compound was prepared according to General Procedure A using 10 equiv. of arene and $0.2 \mathrm{mmol}$ of diazo 1c. The product was purified from the crude mixture by flash chromatography on TEA-deactivated silica gel (100\% hexanes $\rightarrow 5 \%$ MTBE:hexanes) to afford $\mathbf{3 k}$ in $36.6 \mathrm{mg}$ as a clear, colorless oil [ $46 \%$ yield, 13:1.0 rr, 92:8 er]. Due to poor resolution of the minor regioisomer apart from the baseline in the spectrum of the crude reaction mixture, the regioselectivity was determined from the purified ${ }^{1} \mathrm{H}$ NMR spectrum by integrating and comparing values for the olefin resonances of the major ( $\delta 6.34)$ and minor $(\delta 6.43)$ regioisomers.

Analytical data for 3k: ${ }^{1} \mathrm{H}$ NMR $\left(500 \mathrm{MHz}, \mathrm{CDCl}_{3}\right): \delta 6.3(\mathrm{~d}, J=9.4 \mathrm{~Hz}, 1 \mathrm{H}), 6.22(\mathrm{dd}, J=9.4,5.1 \mathrm{~Hz}, 1 \mathrm{H}), 6.15(\mathrm{~d}, J=5.3 \mathrm{~Hz}$, $1 \mathrm{H}), 4.33(\mathrm{~d}, J=14.3 \mathrm{~Hz}, 1 \mathrm{H}), 4.28(\mathrm{~d}, J=14.3 \mathrm{~Hz}, 1 \mathrm{H}), 3.15(\mathrm{dd}, J=8.4,5.3 \mathrm{~Hz}, 1 \mathrm{H}), 3.11(\mathrm{dd}, J=8.4,5.1 \mathrm{~Hz}, 1 \mathrm{H}), 1.53(\mathrm{~s}$, 9H), 0.92 (s, 9H), 0.09 (as, 6H); ${ }^{13} \mathrm{C} \mathrm{NMR}\left(126 \mathrm{MHz}, \mathrm{CDCl}_{3}\right): \delta 168.8,139.3,126.9,122.5,115.7,112.9,84.0,64.2,38.2$, 38.1, 27.9, 25.8, 18.3, 13.6, -5.3, -5.5; IR (thin film, KBr, cm${ }^{-1}$ ): 2955, 2930, 2885, 2857, 2241, 1721, 1422, 1370, 1301, 1256, 1159, 1121, 1093, 985, 837, 778, 720, 670; HRMS (ESI-): Calculated for $\left[\mathrm{C}_{20} \mathrm{H}_{30} \mathrm{NO}_{3} \mathrm{Si}^{-}\right]^{-}([\mathrm{M}-\mathrm{H}]): 360.2000$, Found: 
360.1988; HPLC (95:5 hexanes: $:$ PrOH, Daicel CHIRALPAK IC): 92:8 er, $t_{R}$ (major) $=4.3 \mathrm{~min}, t_{R}($ minor $)=5.5 \mathrm{~min} ;[\alpha]_{\mathrm{D}}:-29.9$ (c $\left.=0.01, \mathrm{CHCl}_{3}\right) ; \operatorname{TLC}\left(90: 10\right.$ hexanes:MTBE): $R_{\mathrm{f}}=0.33$.

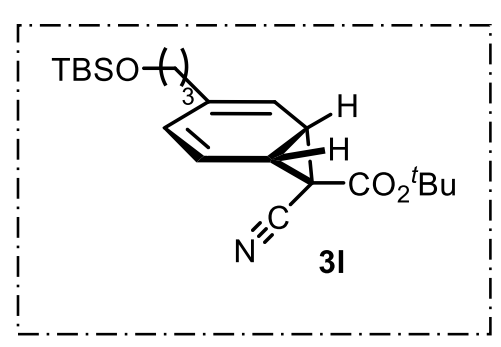

tert-butyl (1S,6R,7S)-3-(3-((tert-butyldimethylsilyl)oxy)propyl)-7-

cyanobicyclo[4.1.0]hepta-2,4-diene-7-carboxylate (3I): The title compound was prepared according to General Procedure A using 10 equiv. of arene and $0.2 \mathrm{mmol}$ of diazo 1c. The product was purified from the crude mixture by flash chromatography on silica gel (100\% hexanes $\rightarrow 2.5 \%$ MTBE:hexanes) to afford 31 in $52.1 \mathrm{mg}$ as a colorless oil [66\% yield, 10:1.0 rr, 91:9 er]. Due to poor resolution of the minor regioisomer apart from the baseline in the spectrum of the crude reaction mixture, the regioselectivity was determined from the purified ${ }^{1} \mathrm{H}$ NMR spectrum by integrating and comparing values for the olefin resonances of the major ( $\delta 6.33)$ and minor $(\delta 6.39)$ regioisomers.

Analytical data for $3 \mathrm{ll}:{ }^{1} \mathrm{H}$ NMR $\left(500 \mathrm{MHz}, \mathrm{CDCl}_{3}\right): \delta 6.30(\mathrm{~d}, J=9.5 \mathrm{~Hz}, 1 \mathrm{H}), 6.19$ (dd, J = 9.5, $\left.3.4 \mathrm{~Hz}, 1 \mathrm{H}\right), 5.91$ (d, $J=3.4$ $\mathrm{Hz}, 1 \mathrm{H}), 3.63(\mathrm{~m}, 2 \mathrm{H}), 3.10(\mathrm{~m}, 2 \mathrm{H}), 2.32(\mathrm{dd}, J=14.3,7.4 \mathrm{~Hz}, 1 \mathrm{H}), 2.26(\mathrm{dd}, J=14.3,7.4 \mathrm{~Hz}, 1 \mathrm{H}), 1.68(\mathrm{~m}, 2 \mathrm{H}), 1.52(\mathrm{~s}$, 9H), 0.89 (s, 9H), 0.04 (as, 6H); $\left.{ }^{13} \mathrm{C} \mathrm{NMR} \mathrm{(126MHz,} \mathrm{CDCl}\right): \delta 168.9,140.1,130.4,127.4,117.0,113.0,83.9,62.1,38.7$, 37.7, 32.1, 27.9, 25.9, 18.2, 13.5, -5.3; IR (thin film, KBr, cm ${ }^{-1}$ ): 2953, 2930, 2857, 2241, 1720, 1472, 1394, 1370, 1300, 1255, 1159, 1101, 984, 836, 776, 720, 660; HRMS (ESI-): Calculated for $\left[\mathrm{C}_{22} \mathrm{H}_{34} \mathrm{NO}_{3} \mathrm{Si}^{-}([\mathrm{M}-\mathrm{H}]): 388.2313\right.$, Found: 388.2300; HPLC (98:2 hexanes:'PrOH, Daicel CHIRALPAK IC): 91:9 er, $t_{R}$ (major) = $5.5 \mathrm{~min}, t_{R}$ (minor) $=7.2 \mathrm{~min} ;[\alpha]_{\mathrm{D}}:-25.2$ (c =0.01, $\left.\mathrm{CHCl}_{3}\right) ;$ TLC (90:10 hexanes:MTBE): $R_{\mathrm{f}}=0.37$.

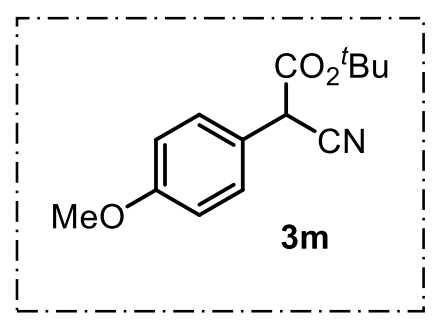

tert-butyl 2-cyano-2-(4-methoxyphenyl)acetate $(3 \mathrm{~m})$ : The title compound was prepared according to General Procedure A using 10 equiv. of anisole $0.2 \mathrm{mmol}$ of diazo $1 \mathrm{c}$. The product was purified from the crude mixture by flash chromatography on silica gel $(100 \%$ hexanes $\rightarrow 5 \%$ EtOAc:hexanes) to afford $3 \mathrm{~m}$ as a colorless oil in $34 \mathrm{mg}$ [69\% yield, $>20: 1.0$ rr]. No minor regioisomers were detected.

Analytical data for $3 \mathrm{m:}{ }^{1} \mathrm{H}$ NMR $\left(600 \mathrm{MHz}, \mathrm{CDCl}_{3}\right): \delta 7.35(\mathrm{~d}, J=8.6 \mathrm{~Hz}, 2 \mathrm{H}), 6.92(\mathrm{~d}, J=8.7$ $\mathrm{Hz}, 2 \mathrm{H}), 4.55$ (s, 1H), 3.82 (s, 3H), $1.44(\mathrm{~s}, 9 \mathrm{H}) ;{ }^{13} \mathrm{C} \mathrm{NMR}\left(151 \mathrm{MHz}, \mathrm{CDCl}_{3}\right): \delta 164.3,160.1,129.1,122.5,116.4,114.7$, 84.5, 55.5, 44.2, 27.8; IR (thin film, KBr, cm ${ }^{-1}$ ): 3853, 3750, 3649, 2979, 2251, 1734, 1615, 1507, 1457, 1253, 1148, 1032, 948, 834, 527; HRMS (ESI+): Calculated for $\left[\mathrm{C}_{14} \mathrm{H}_{17} \mathrm{NO}_{3}\right]^{+}([\mathrm{M}+\mathrm{H}]): 270.1101$, Found: $270.1100 ;$ TLC (70:30 hexanes:EtOAc): $R_{\mathrm{f}}=0.62$.

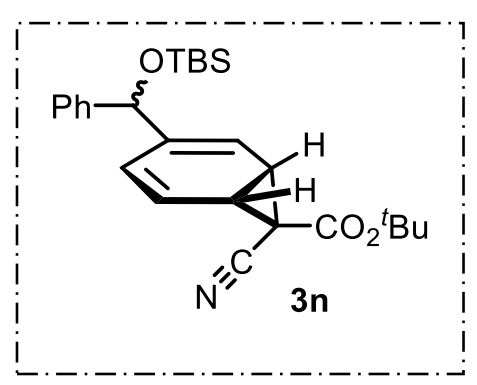

tert-butyl (1S,6R,7S)-3-(((tert-butyldimethylsilyl)oxy)(phenyl)methyl)-7cyanobicyclo[4.1.0] hepta-2,4-diene-7-carboxylate (3n): The title compound was prepared according to General Procedure A using 10 equiv of arene $0.2 \mathrm{mmol}$ of diazo 1c. The product was purified from the crude mixture by flash chromatography on silica gel (100\% hexanes $\rightarrow 5 \%$ MTBE:hexanes $\rightarrow 10 \%$ MTBE:hexanes) to afford $\mathbf{3 n}$ in $57.4 \mathrm{mg}$ as a clear, colorless oil [66\% yield, 7.5:1.0 dr, 11:1.0 $\mathrm{rr}_{\text {major }}$, 94:6 er]. Due to poor resolution of the minor regioisomer apart from the baseline in the spectrum of the crude reaction mixture, the regioselectivity was reported using the integrations in the ${ }^{1} \mathrm{H} N \mathrm{NMR}$ spectrum of the pure compound by integrating and comparing values for the olefin resonances of the major $(\delta 6.37)$ and minor ( $\delta 6.42$ ) regioisomers. The diastereoselectivity was determined from the crude ${ }^{1} \mathrm{H}$ NMR spectrum by comparative integration of the methine resonances for major $(\delta 5.35)$ and minor $(\delta 5.44)$ as well as the olefin resonances for major $(\delta$ 6.37) and minor ( $\delta 6.33)$.

Analytical data for $3 \mathrm{n}:{ }^{1} \mathrm{H}$ NMR $\left(500 \mathrm{MHz}, \mathrm{CDCl}_{3}\right): \delta 7.38(\mathrm{~m}, 2 \mathrm{H}), 7.30(\mathrm{dd}, J=8.3,6.8 \mathrm{~Hz}, 2 \mathrm{H}), 7.24(\mathrm{~m}, 1 \mathrm{H}), 6.34(\mathrm{~d}, J=$ $5.6 \mathrm{~Hz}, 1 \mathrm{H}), 6.21(\mathrm{~d}, J=5.6 \mathrm{~Hz}, 1 \mathrm{H}), 6.11(\mathrm{dd}, J=9.6,5.3 \mathrm{~Hz}, 1 \mathrm{H}), 5.32(\mathrm{~s}, 1 \mathrm{H}), 3.15(\mathrm{dd}, J=8.5,5.6 \mathrm{~Hz}, 1 \mathrm{H}), 3.05(\mathrm{dd}, J=$ 8.5, $5.3 \mathrm{~Hz}, 1 \mathrm{H}), 1.53(\mathrm{~s}, 9 \mathrm{H}), 0.91(\mathrm{~s}, 9 \mathrm{H}), 0.07(\mathrm{~s}, 3 \mathrm{H}),-0.03(\mathrm{~s}, 3 \mathrm{H}) ;{ }^{13} \mathrm{C} \mathrm{NMR}\left(126 \mathrm{MHz}, \mathrm{CDCl}_{3}\right): \delta 168.8,142.5,142.3$, $128.1,127.6,127.4,127.2,126.8,116.3,112.9,84.0,75.8,38.0,37.6,27.9,25.8,18.2,13.3,-4.9,-5.0$; IR (thin film, KBr, 
$\mathrm{cm}^{-1}$ ): 3870, 3749, 3734, 3648, 3565, 2955, 2930, 2885, 2857, 2241, 1713, 1652, 1558, 1456, 1370, 1302, 1256, 1159, 1088, 1067, 985, 836, 772, 700, 677; HRMS (ESI-): Calculated for [ $\left.\mathrm{C}_{26} \mathrm{H}_{34} \mathrm{NO}_{3} \mathrm{Si}\right]^{-}$([M-H]): 436.2313, Found: 436.2299; HPLC (99:1 hexanes:'PrOH, Daicel CHIRALPAK IC): 99:1 er, $t_{R}$ (major) $=8.5 \mathrm{~min}, t_{R}$ (minor) $=14.5 \mathrm{~min} ;[\alpha]_{\mathrm{D}}:-57.6$ (c $=$ $\left.0.013, \mathrm{CHCl}_{3}\right) ;$ TLC (90:10 hexanes:MTBE): $R_{\mathrm{f}}=0.37$.

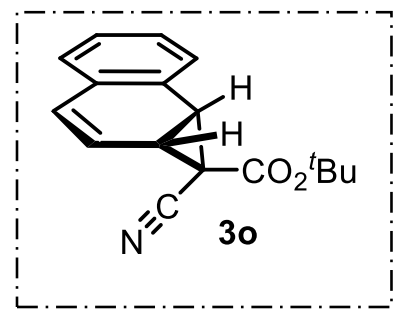

tert-butyl (1S,1aR,7bR)-1-cyano-1a,7b-dihydro-1H-cyclopropa[a]naphthalene-1-carboxylate (3o): The title compound was prepared according to General Procedure B using $0.2 \mathrm{mmol}$ of diazo 1c. The product was purified from the crude mixture by flash chromatography on silica gel (100\% hexanes $\rightarrow 10 \%$ EtOAc:hexanes) to afford 30 in $25.4 \mathrm{mg}$ as a white solid [ $47 \%$ yield, $>20: 1.0 \mathrm{rr}, 94: 6 \mathrm{er}]$.

Analytical data for $30:{ }^{1} \mathrm{H}$ NMR $\left(500 \mathrm{MHz}, \mathrm{CDCl}_{3}\right): \delta 7.49(\mathrm{~m}, 1 \mathrm{H}), 7.34(\mathrm{~m}, 2 \mathrm{H}), 7.29(\mathrm{~m}, 1 \mathrm{H})$, $6.84(\mathrm{~d}, J=9.6 \mathrm{~Hz}, 1 \mathrm{H}), 6.23(\mathrm{dd}, J=9.6,5.3 \mathrm{~Hz}, 1 \mathrm{H}), 3.61(\mathrm{~d}, J=8.6 \mathrm{~Hz}, 1 \mathrm{H}), 3.18(\mathrm{dd}, J=8.6,5.3 \mathrm{~Hz}, 1 \mathrm{H}), 1.55(\mathrm{~s}, 9 \mathrm{H}) ;{ }^{13} \mathrm{C}$ NMR (126 MHz, CDCl$): ~ \delta 168.1,131.7,130.7,129.9,128.6,128.6,128.5,127.6,120.1,113.5,84.3,38.0,35.5,28.0,16.7$; IR (thin film, KBr, cm${ }^{-1}$ ): 2979, 2240, 1717, 1540, 1456, 1371, 1298, 1255, 1155, 1124, 986, 839, 795, 778, 719, 594; HRMS (ESI-): Calculated for [ $\left.\mathrm{C}_{17} \mathrm{H}_{16} \mathrm{NO}_{2}\right]^{-}([\mathrm{M}-\mathrm{H}])$ : 266.1186, Found: 266.1176; HPLC (90:10 hexanes:'PrOH, Daicel CHIRALPAK IC): $94: 6 \mathrm{er}, t_{R}$ (major) $=8.0 \mathrm{~min}, t_{R}$ (minor) $=14.6 \mathrm{~min} ;[\alpha]_{\mathrm{D}}:-132.2\left(\mathrm{c}=0.01, \mathrm{CHCl}_{3}\right) ; \operatorname{TLC}(90: 10$ hexanes:MTBE): $R_{\mathrm{f}}=0.26 ; \mathrm{mp} 112-114{ }^{\circ} \mathrm{C}$.

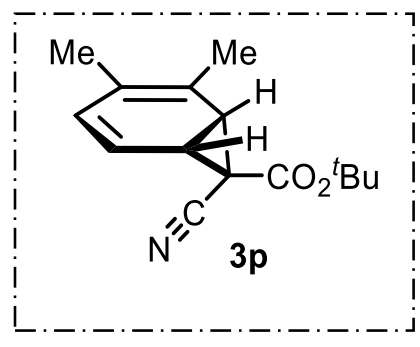

tert-butyl (1R,6R,7S)-7-cyano-2,3-dimethylbicyclo[4.1.0]hepta-2,4-diene-7-carboxylate (3p): The title compound was prepared according to General Procedure A using 10 equiv of arene and $0.2 \mathrm{mmol}$ of diazo $1 \mathrm{c}$. The product was purified from the crude mixture by flash chromatography on silica gel (100\% hexanes $\rightarrow 5 \%$ EtOAc:hexanes) to afford $3 p$ in $26.8 \mathrm{mg}$ as a colorless oil [ $55 \%$ yield, 14.0:1.0 rr, 95:5 er]. The regioselectivity was determined by integration of the major and minor regioisomeric olefin resonances at $(\delta 6.28)$ and $(\delta 5.98)$ respectively.

Analytical data for 3p: ${ }^{1} \mathrm{H}$ NMR $\left(400 \mathrm{MHz}, \mathrm{CDCl}_{3}\right): 6.24$ (d, $\left.J=9.4 \mathrm{~Hz}, 1 \mathrm{H}\right), 6.01$ (dd, $\left.J=9.4,5.4 \mathrm{~Hz}, 1 \mathrm{H}\right), 3.08$ (dd, $J=8.7$, $5.4 \mathrm{~Hz}, 1 \mathrm{H}), 2.96(\mathrm{~d}, J=8.7 \mathrm{~Hz}, 1 \mathrm{H}), 1.99(\mathrm{~s}, 3 \mathrm{H}), 1.91(\mathrm{~s}, 3 \mathrm{H}), 1.53(\mathrm{~s}, 9 \mathrm{H}) ;{ }^{13} \mathrm{C} \mathrm{NMR}\left(101 \mathrm{MHz}, \mathrm{CDCl}_{3}\right): \delta 169.2,132.8$, $129.3,125.0,118.8,113.1,83.8,42.7,38.8,28.0,19.4,18.5,13.4$; IR (thin film, KBr, cm${ }^{-1}$ ) 2980, 2932, 2240, 1718, 1477, 1456, 1421, 1394, 1370, 1301, 1256, 1159, 1140, 983, 896, 840, 803, 773, 729, 642, 605, 563, 530; HRMS (ESI+):

Calculated for $\left[\mathrm{C}_{15} \mathrm{H}_{20} \mathrm{NO}_{2}\right]^{+}([\mathrm{M}+\mathrm{H}]): 246.1502$, Found: 246.15022; HPLC (95:5 hexanes:'PrOH, Daicel CHIRALPAK IC): $95: 5$ er, $t_{R}$ (major) $=7.4 \mathrm{~min}, t_{R}($ minor $)=8.9 \mathrm{~min} ;[\alpha]_{\mathrm{D}}:-149.5\left(\mathrm{c}=0.013, \mathrm{CHCl}_{3}\right) ;$ TLC $(90: 10$ hexanes:MTBE$): R_{\mathrm{f}}=0.37$.

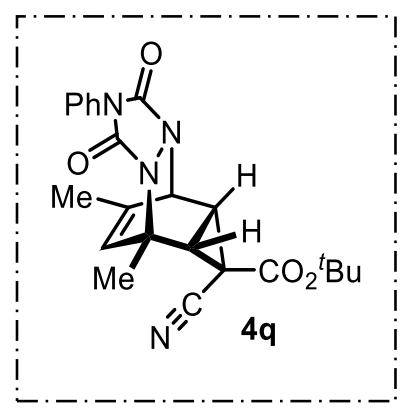

tert-butyl (5S,5aR,6R,6aS,7S)-6-cyano-5,9-dimethyl-1,3-dioxo-2-phenyl-2,3,5a,6,6a,7-hexa hydro-1H,5H-5,7-ethenocyclopropa[d][1,2,4]triazolo[1,2-a]pyridazine-6-carboxylate (4q): The title compound was prepared according to General Procedure A using 10 equiv of arene and $0.2 \mathrm{mmol}$ of diazo $1 \mathrm{c}$ with the following modification for post-reaction isolation. The crude reaction residue was dissolved in diethyl ether $(1 \mathrm{~mL}$ ) where then PTAD (3 equiv.) was added directly to the solution with stirring for $30 \mathrm{~min}$. The entire reaction volume was dryloaded onto Celite and transferred to a silica gel column where gradient elution using $10 \rightarrow$ $40 \% \mathrm{MTBE} /$ hexanes afforded product $\mathbf{4 q}$ in $38.3 \mathrm{mg}$ as a white solid [43\% yield, $>20: 1.0 \mathrm{rr}$, 79:21 er]. No other regioisomers were observed in the crude ${ }^{1} \mathrm{H}$ NMR spectrum.

Analytical data for 4q: ${ }^{1} \mathrm{H}$ NMR $\left(500 \mathrm{MHz}, \mathrm{CDCl}_{3}\right): \delta 7.45$ (dd, $\left.J=8.7,7.3 \mathrm{~Hz}, 2 \mathrm{H}\right), 7.40(\mathrm{~d}, J=7.3 \mathrm{~Hz}, 2 \mathrm{H}), 7.36(\mathrm{dd}, J=8.7$, $7.3 \mathrm{~Hz}, 1 \mathrm{H}$ ), $5.83(\mathrm{dd}, J=1.8,1.1 \mathrm{~Hz}, 1 \mathrm{H}), 5.19(\mathrm{dd}, J=5.0,1.8 \mathrm{~Hz}, 1 \mathrm{H}), 2.58(\mathrm{dd}, J=8.6,5.0 \mathrm{~Hz}, 1 \mathrm{H}), 2.41(\mathrm{~d}, J=8.6 \mathrm{~Hz}$, $1 \mathrm{H}), 2.15(\mathrm{~s}, 3 \mathrm{H}), 2.00(\mathrm{~d}, J=1.1 \mathrm{~Hz}, 3 \mathrm{H}), 1.51(\mathrm{~s}, 9 \mathrm{H}) ;{ }^{13} \mathrm{C} \mathrm{NMR}\left(126 \mathrm{MHz}, \mathrm{CDCl}_{3}\right): \delta 163.9,155.4,155.3,136.8,131.0$, $129.1,128.4,127.3,125.5,113.9,85.4,62.1,54.8,32.6,27.7,26.0,23.4,21.9,20.2$; IR (thin film, $\mathrm{KBr}, \mathrm{cm}^{-1}$ ): 2980, 2935, 2237, 1722, 1716, 1683, 1646, 1540, 1506, 1456, 1403, 1322, 1292, 1232, 1155, 1051, 1022, 838, 758, 705, 645, 533; HRMS (ESI-): Calculated for $\left[\mathrm{C}_{23} \mathrm{H}_{25} \mathrm{~N}_{4} \mathrm{O}_{5}\right]^{-}([\mathrm{M}+\mathrm{OH}])$ : 437.1830, Found: 437.1828 ; HPLC (40:60 hexanes: $\mathrm{CH}_{2} \mathrm{Cl}_{2}$, Daicel 
CHIRALPAK IA): 79:21 er, $t_{R}$ (major) $=4.6 \mathrm{~min}, t_{R}($ minor $)=3.9 \mathrm{~min} ;[\alpha]_{\mathrm{D}}:-23.9\left(\mathrm{c}=0.01, \mathrm{CHCl}_{3}\right) ;$ TLC $(70: 30$ hexanes:EtOAC): $R_{\mathrm{f}}=0.5 ; \mathrm{mp} 140{ }^{\circ} \mathrm{C}$ (decomposition).

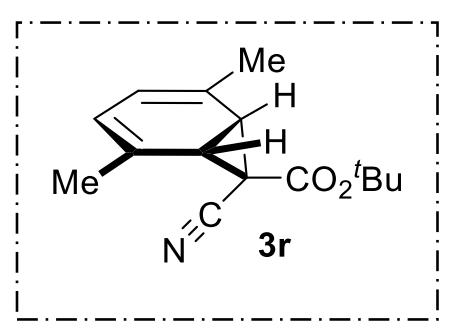

tert-butyl 7-cyano-2,5-dimethylbicyclo[4.1.0]hepta-2,4-diene-7-carboxylate (3r): The title compound was prepared according to General Procedure A using 10 equiv of arene and $0.2 \mathrm{mmol}$ of diazo 1c. The product was purified from the crude mixture by flash chromatography on silica gel (100\% hexanes $\rightarrow 5 \%$ EtOAc:hexanes) to afford $3 r$ in $5.8 \mathrm{mg}$ as a colorless oil [11\% yield, >20:1.0 $\mathrm{rr}^{\mathrm{vi}}$ ].

Analytical data for $3 \mathrm{r}:{ }^{1} \mathrm{H}$ NMR $\left(600 \mathrm{MHz}, \mathrm{CDCl}_{3}\right): \delta 6.07(\mathrm{~m}, 2 \mathrm{H}), 2.93(\mathrm{~s}, 2 \mathrm{H}), 2.02(\mathrm{~s}, 6 \mathrm{H})$, 1.54 (s, 9H); ${ }^{13} \mathrm{C}$ NMR (151 MHz, CDCl $)$ : $\delta 169.3,128.6,123.2,113.0,84.1,41.9,28.0,22.6,12.8$; IR (thin film, $\mathrm{KBr}, \mathrm{cm}^{-1}$ ): 2979, 2932, 2241, 1715, 1654, 1453, 1395, 1320, 1296, 1258, 1159, 986, 840, 788, 720, 639; HRMS (ESI-): Calculated for $\left[\mathrm{C}_{15} \mathrm{H}_{18} \mathrm{NO}_{2}\right]^{+}([\mathrm{M}-\mathrm{H}]): 244.1343$, Found: 244.1325; TLC (90:10 hexanes:MTBE): $R_{\mathrm{f}}=0.37$.

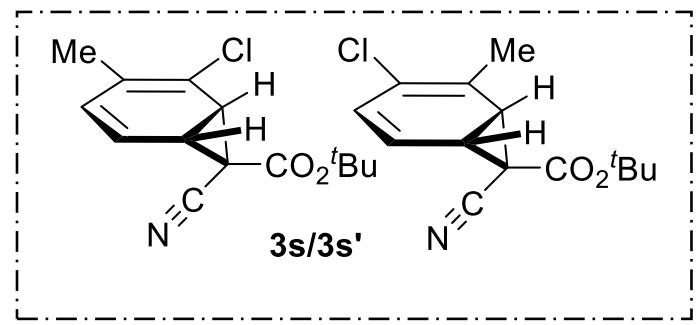

tert-butyl (1S,6R,7S)-2-chloro-7-cyano-3-methylbicyclo[4.1.0]hepta-2,4-
diene-7-carboxylate (3s) \& tert-butyl (1S,6R,7S)-3-chloro-7-cyano-2-
methylbicyclo[4.1.0]hepta-2,4-diene-7-carboxylate (3s'): The title
compound was prepared according to General Procedure A using 10 equiv
of arene and 0.2 mmol of diazo $1 \mathrm{c}$. The product was purified from the
crude mixture by flash chromatography on silica gel (100\% hexanes $\rightarrow$
$10 \%$ EtOAc:hexanes) to afford a mixture of regioisomers $3 \mathrm{~s} / 3 \mathrm{~s}^{\prime}$ in $36.6 \mathrm{mg}$ as a colorless oil [68\% yield, 1.0:1.0 $\mathrm{rr}_{3 \mathrm{~s} / 3 \mathrm{~s}^{\prime}}, 92: 8 \mathrm{er}_{3 \mathrm{~s}}, 94: 6 \mathrm{er}_{3 \mathrm{~s}^{\prime}}$ ]. The regioselectivity was determined from the crude ${ }^{1} \mathrm{H}$ NMR spectrum by integrating and comparing values for the methyl resonances $(\delta 2.03)$ and $(\delta 2.14)$.

Analytical data for 3s/3s': ${ }^{1} \mathrm{H}$ NMR $\left(500 \mathrm{MHz}, \mathrm{CDCl}_{3}\right): \delta 6.36(\mathrm{~d}, J=9.2 \mathrm{~Hz}, 1 \mathrm{H}), 6.28(\mathrm{~d}, J=9.3 \mathrm{~Hz}, 1 \mathrm{H}), 6.10(\mathrm{~m}, 2 \mathrm{H}), 3.24$ (d, $9.3 \mathrm{~Hz}, 1 \mathrm{H}), 3.10(\mathrm{dd}, \mathrm{J}=9.2,5.4 \mathrm{~Hz}, 1 \mathrm{H}), 3.04(\mathrm{~m}, 2 \mathrm{H}), 2.14(\mathrm{~s}, 3 \mathrm{H}), 2.02(\mathrm{~s}, 3 \mathrm{H}), 1.53(\mathrm{~s}, 18 \mathrm{H}) ;{ }^{13} \mathrm{C} \mathrm{NMR}(126 \mathrm{MHz}$, $\mathrm{CDCl}_{3}$ ): $\delta 168.1,167.8,131.7,130.7,127.8,126.4,124.4,121.2,120.3,112.4,112.2,84.6,84.5,42.0,41.7,39.0,37.4$, 27.9, 20.0, 19.0, 13.4, 13.0 ; IR (thin film, KBr, cm${ }^{-1}$ ): 2981, 2934, 2242, 2136, 1723, 1630, 1559, 1477, 1456, 1395, 1371, 1299, 1257, 1159, 1033, 983, 881, 838, 764, 722, 638, 607, 555, 528; HRMS (ESI-): Calculated for $\left[\mathrm{C}_{14} \mathrm{H}_{15} \mathrm{NO}_{2}{ }^{35} \mathrm{Cl}\right]^{-}([\mathrm{M}-\mathrm{H}])$ : 264.0796, Found: 264.0784; Calculated for $\left.\left[\mathrm{C}_{14} \mathrm{H}_{15} \mathrm{NO}_{2}{ }^{37} \mathrm{Cl}\right]\right]^{-}$([M-H]): 266.0758, Found: 266.0755; HPLC (95:5 hexanes:'PrOH, Daicel CHIRALPAK IC): $92: 8 \mathrm{er}_{3 \mathrm{~s}}, t_{R}($ major $)=5.4 \mathrm{~min}, t_{R}(\mathrm{minor})=6.6 \mathrm{~min} ; 92: 8 \mathrm{er}_{3 \mathrm{~s}^{\prime}}, t_{R}$ (major) $=7.1 \mathrm{~min}$, $t_{R}($ minor $)=9.0 \min [\alpha]_{\mathrm{D}}:-43.2\left(\mathrm{c}=0.012, \mathrm{CHCl}_{3}\right) ; \operatorname{TLC}(90: 10$ hexanes:MTBE$): R_{\mathrm{f}}=0.33$.

\footnotetext{
vi Due to a regioconvergent isomerization (vide infra) during chromatography, the regioisomeric ratio is reported on the product after column chromatography.
} 
Rationales for the Divergent Product Stabilities in the Xylene Series:

During the course of our investigation, we observed variable product stabilities amongst the norcaradienes resulting from cyclopropanation of the xylene series using the general procedures. Separately, cyclopropanation of $p$-xylene gave a mixture of regioisomers which funneled to a single regioisomer, $3 r$, during chromatography.

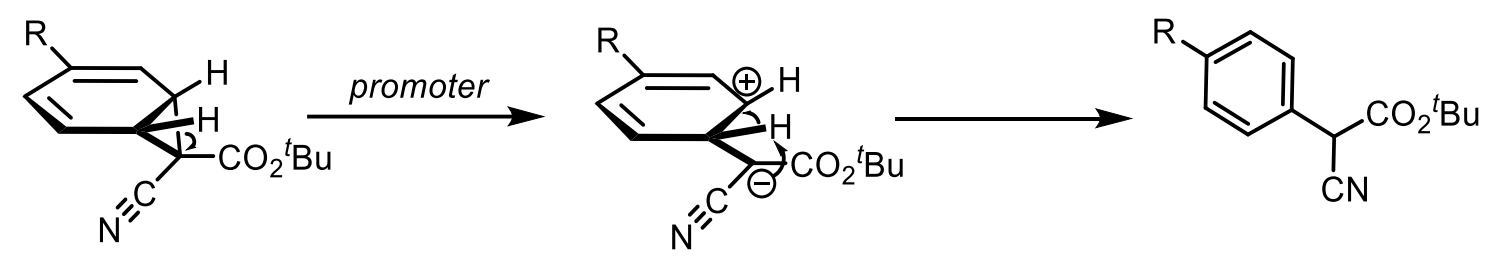

The susceptibility of norcaradienes to rearomatization, especially under Lewis and/or Brønsted acidic conditions, has been reported in numerous systems to likely occur via prototropic shift of the zwitterionic structure following $\mathrm{C} 6-\mathrm{C} 7$ heterolysis. ${ }^{5}$ The stability of the resulting cyclohexa-2,4-dien-1-ylium ion contributes to the product instability; the increased stability of the cation amplifies rearomatization.

- The $o$-xylene NCD 3p was well-behaved, allowing for the use of conventional chromatographic techniques for its purification and isolation.

\section{$\underline{m-x y l e n e:}$}
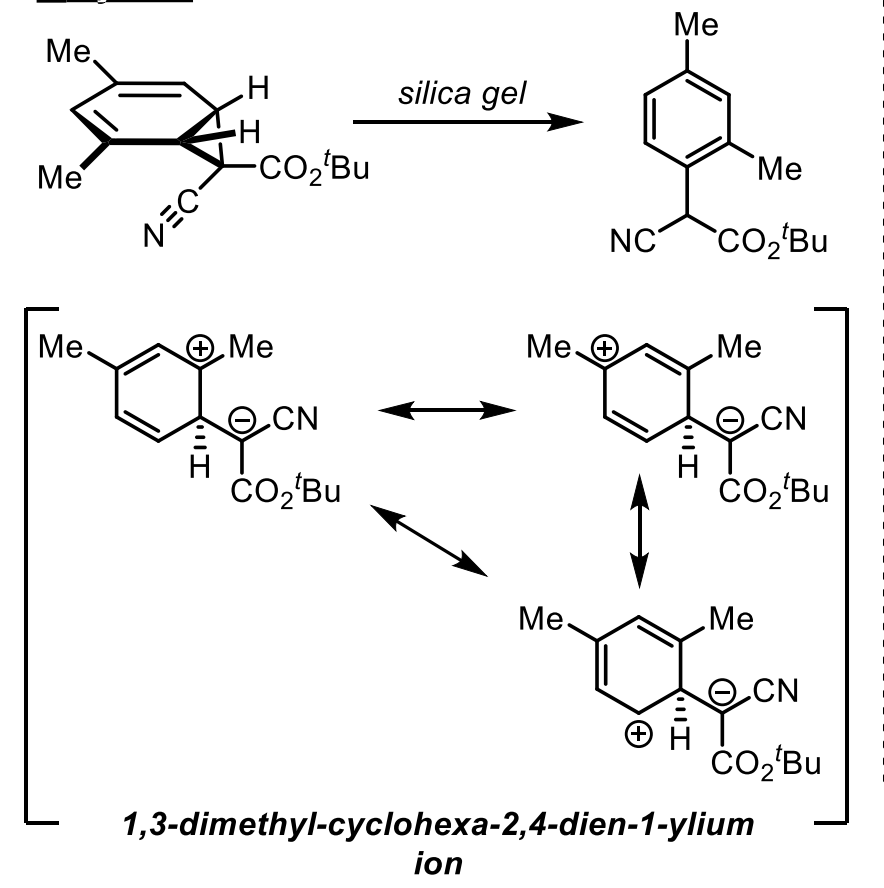
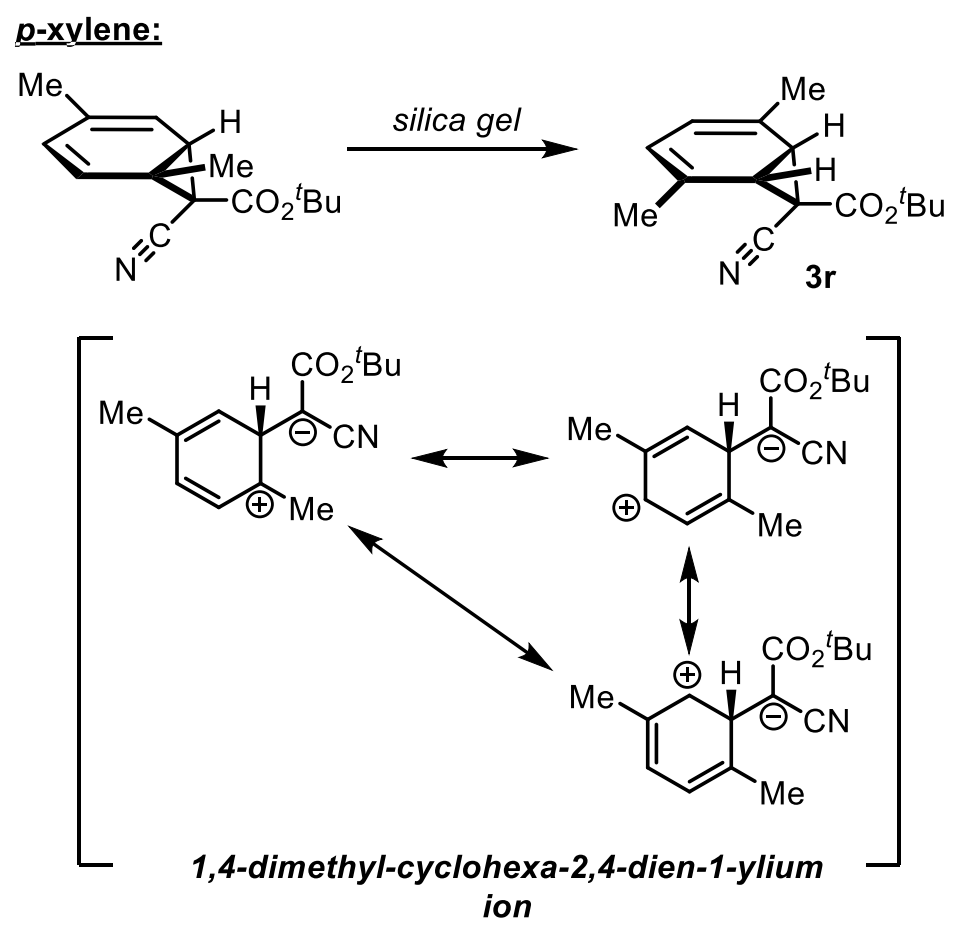

- For the $m$-xylene NCD, cyclopropanation occurs regioselectively at C3-C4, which was identified in the crude spectrum. The substitution pattern of the NCD orients the methyl groups such that a highly stabilized 1,3dimethyl-cyclohexa-2,4-dien-1-ylium ion forms after C6-C7 heterolysis. The ion stability allows for relatively weak acidic promoters to cleave the $\mathrm{C} 6-\mathrm{C} 7 \sigma$-bond, leading to rearomatization. To demonstrate the sensitivity of the norcaradiene, a solution of the crude mixture in $\mathrm{CDCl}_{3}$ was stirred for 10 minutes with various stationary phases [silica gel, neutral alumina, Florisil] and the amount of rearomatization was tracked. In all cases, appreciable rearomatization was observed. This prompted the isolation of the norcaradiene as its PTAD cycloadduct $\mathbf{4 q}$ for analysis and enantiopurity assessment.

${ }^{1} \mathrm{H}$ NMR of $\boldsymbol{m}$-xylene rearomatization product $\left(400 \mathrm{MHz}, \mathrm{CDCl}_{3}\right): \delta 7.32(\mathrm{~d}, J=7.8 \mathrm{~Hz}, 1 \mathrm{H}), 7.06(\mathrm{~d}, J=7.8 \mathrm{~Hz}, 1 \mathrm{H})$, $7.04(\mathrm{~s}, 1 \mathrm{H}), 4.74(\mathrm{~s}, 1 \mathrm{H}), 2.35(\mathrm{~s}, 3 \mathrm{H}), 2.32(\mathrm{~s}, 3 \mathrm{H}), 1.46(\mathrm{~s}, 9 \mathrm{H})$. 
- For the $p$-xylene NCD, cyclopropanation occurs with poor regioselectivity as identified in the crude spectrum. However, the NCD undergoes a regioconvergent walk-type rearrangement ${ }^{6}$ to a single regioisomer, NCD $3 r$. The substitution pattern presents a less stable 1,4-dimethyl-cyclohexa-2,4-dien-1-ylium ion. The ion stability contributes to NCD shuffling to the meso 3r, but however is not enough to sensitize the system to rearomatization. 


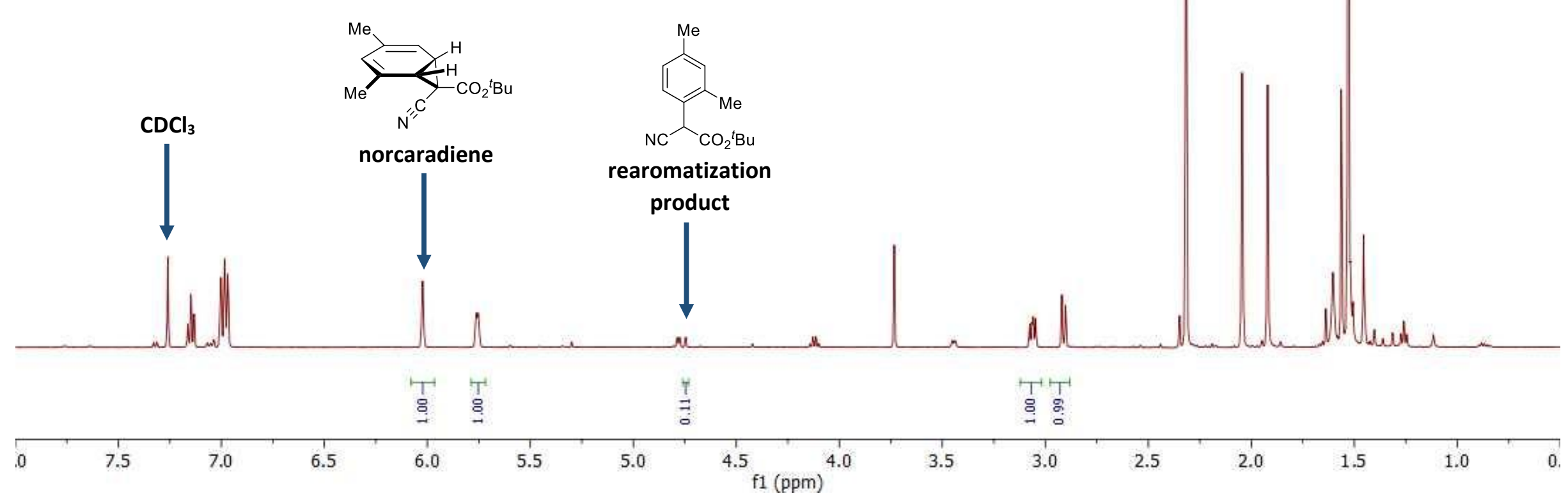


$\underline{{ }^{1} \mathrm{H} \mathrm{NMR}\left(\mathrm{CDCl}_{3}, 500 \mathrm{MHz}\right) \text { of silica treated meta-xylene crude mixture }}$

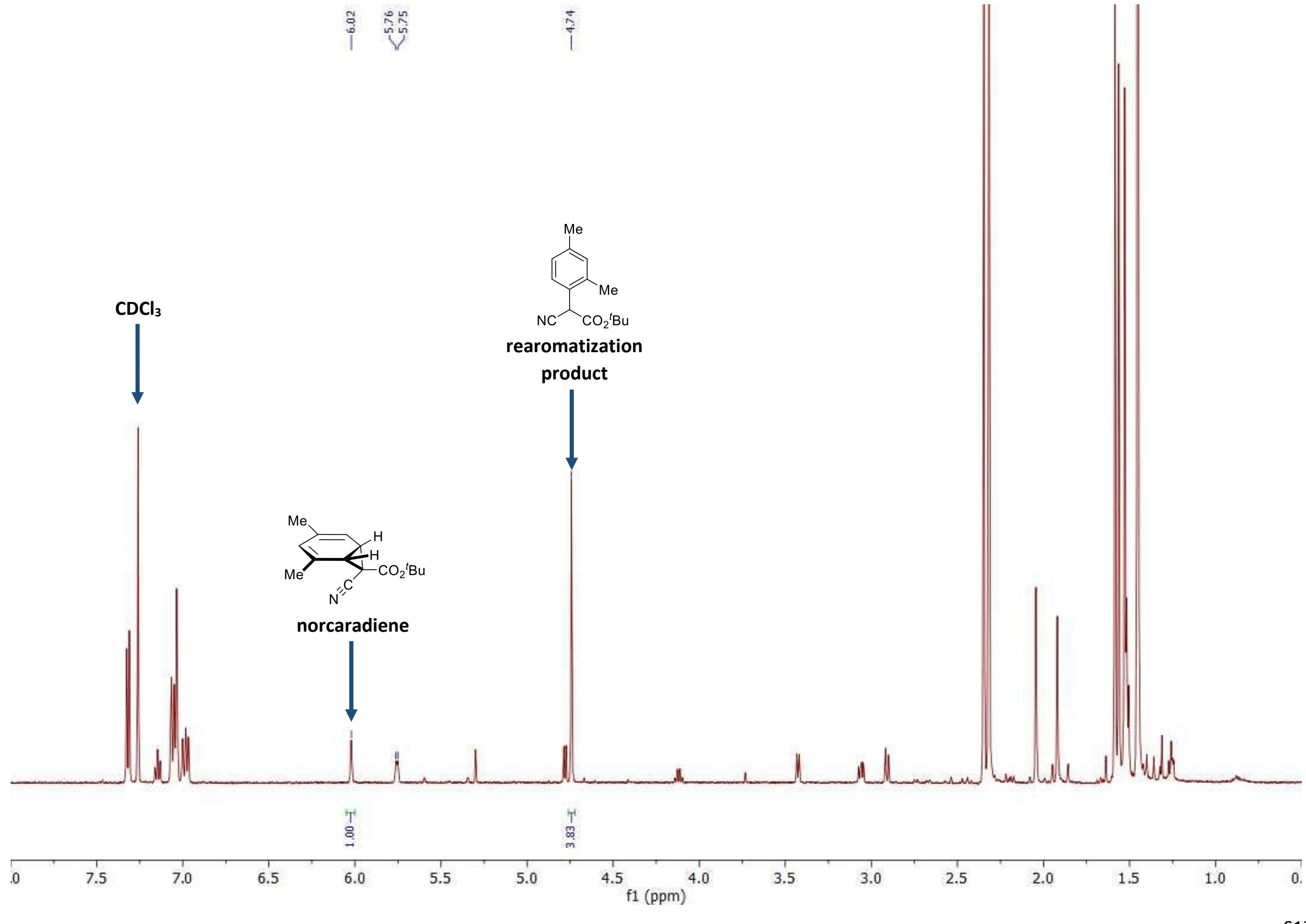




\section{${ }^{1} \mathrm{H}$ NMR $\left(\mathrm{CDCl}_{3}, 500 \mathrm{MHz}\right)$ of alumina treated meta-xylene crude mixture}

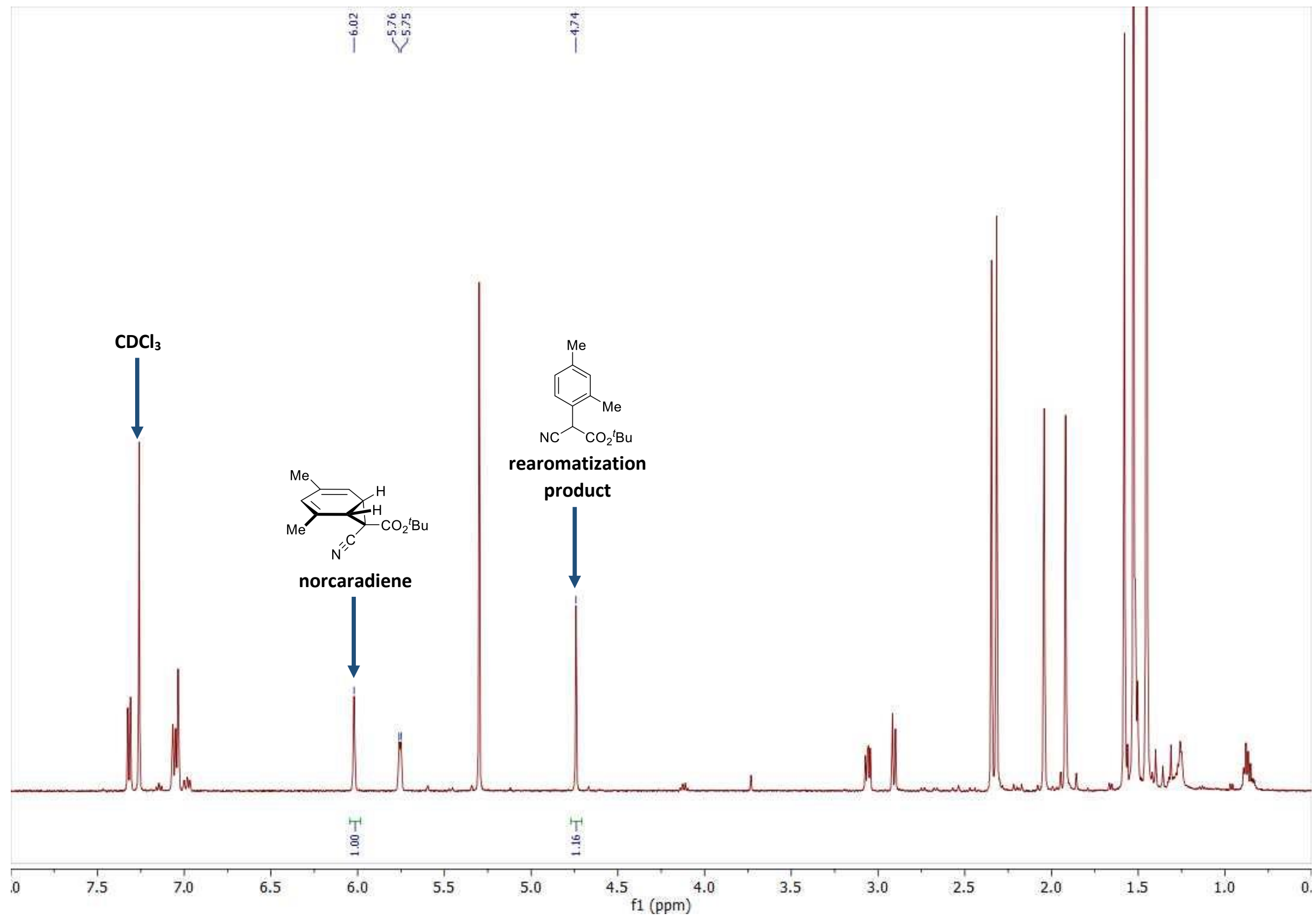




\section{${ }^{1} \mathrm{H} \mathrm{NMR}\left(\mathrm{CDCl}_{3}, 500 \mathrm{MHz}\right)$ of florisil treated meta-xylene crude mixture}

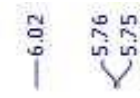

ن

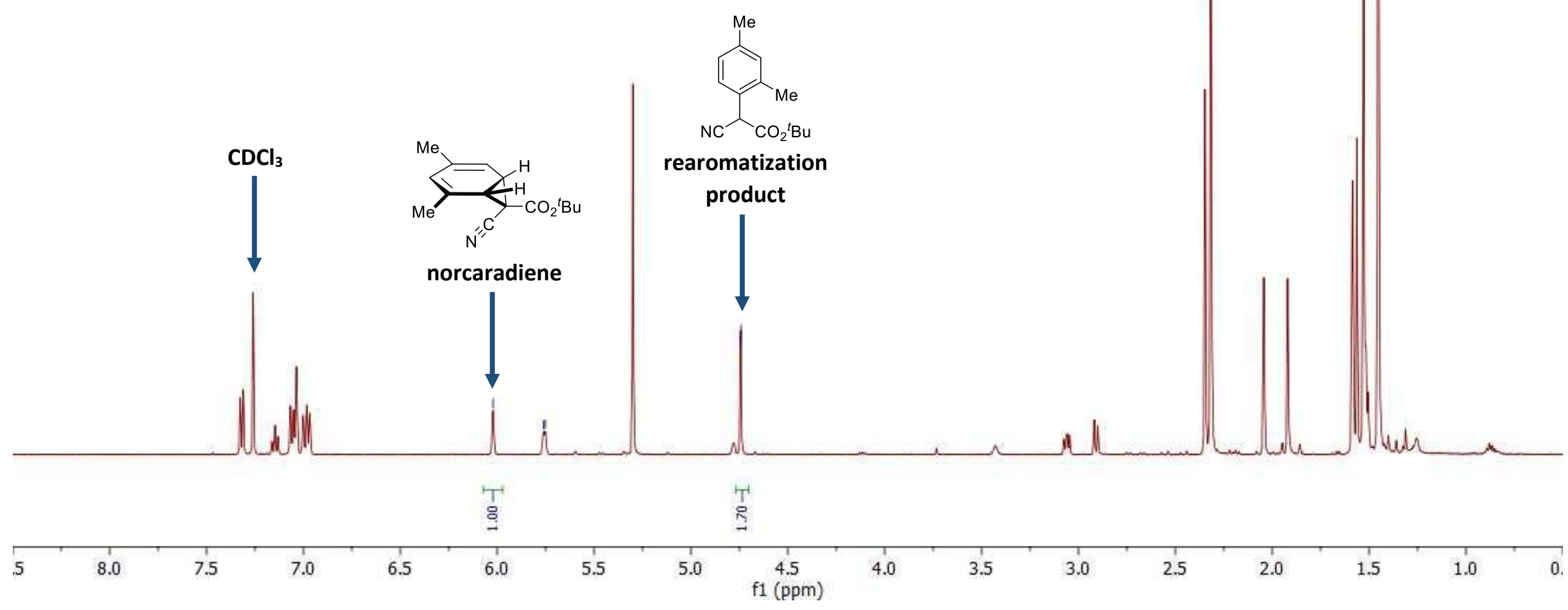


$\underline{{ }^{1} \mathrm{H} \mathrm{NMR}\left(\mathrm{CDCl}_{3}, 400 \mathrm{MHz}\right) \text { of meta-xylene rearomatization product }}$
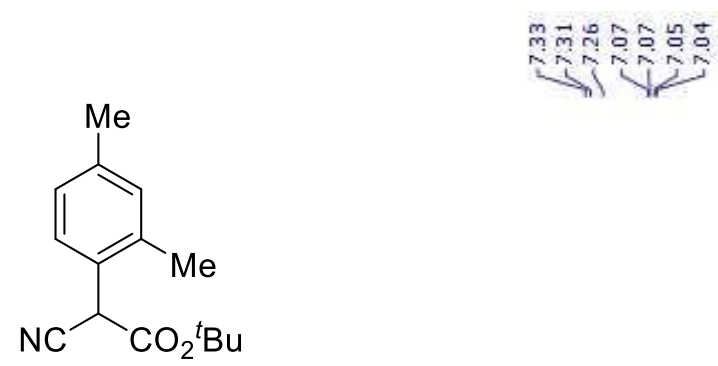

$\mathrm{NC} \quad \mathrm{CO}_{2}{ }^{t} \mathrm{Bu}$

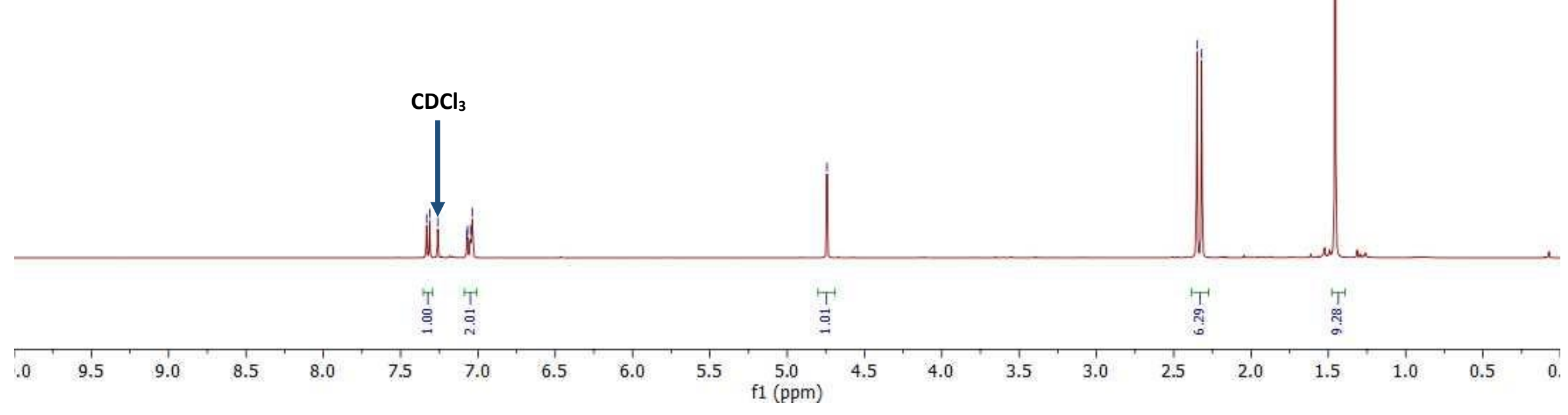



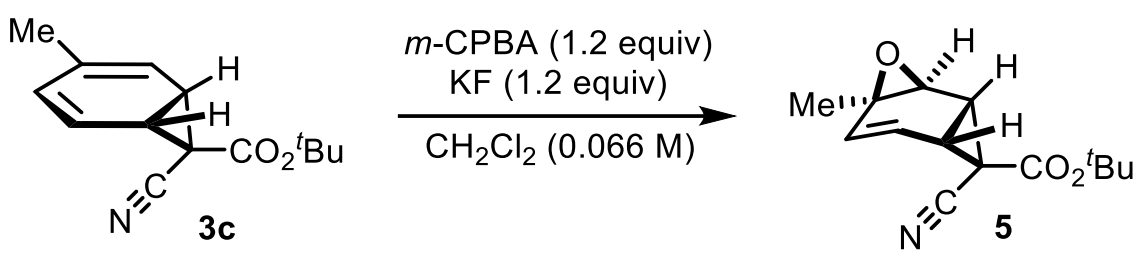

tert-butyl (1S,2S,4R,7R,8S)-8-cyano-4-methyl-3-oxatricyclo[5.1.0.0 $0^{2,4}$ ]oct-5-ene-8-carboxylate (5): A dram vial was charged with $\mathrm{m}$-CPBA (22 $\mathrm{mg}, 0.088 \mathrm{mmol}, 1.2$ equiv, $70 \mathrm{wt} \%$ ), finely crushed potassium fluoride $(5 \mathrm{mg}, 0.088 \mathrm{mmol}, 1.2$ equiv), and $\mathrm{CH}_{2} \mathrm{Cl}_{2}(400 \mu \mathrm{L})$. The resulting mixture was stirred rapidly while open to the atmosphere for 20 min before adding $3 \mathrm{c}(17.0 \mathrm{mg}, 0.073 \mathrm{mmol})$ as a solution in $\mathrm{CH}_{2} \mathrm{Cl}_{2}(700 \mu \mathrm{L}, 0.1 \mathrm{M}$ wrt $3 \mathrm{c})$. The vial was sealed with a screw cap and the reaction mixture was stirred at ambient temperature until TLC analysis showed complete consumption of the norcaradiene $(21 \mathrm{~h})$. The crude reaction mixture was diluted with an equal part of $\mathrm{CH}_{2} \mathrm{Cl}_{2}$ then washed with saturated aqueous thiosulfate solution followed by brine. The organic layer was isolated, dried over anhydrous sodium sulfate, filtered, and concentrated in vacuo. Purification of the crude mixture by flash chromatography on silica gel ( $5 \rightarrow 10 \%$ EtOAc:hexanes) furnished 5 as a white solid in $13 \mathrm{mg}$ [72\% yield, >20:1 dr, 87:13 er]. No minor diastereomer was observed.

Analytical data for 5: ${ }^{1} \mathrm{H}$ NMR $\left(500 \mathrm{MHz}, \mathrm{CDCl}_{3}\right): \delta 5.98(\mathrm{~d}, J=9.8 \mathrm{~Hz}, 1 \mathrm{H}), 5.92(\mathrm{dd}, J=9.8,4.8 \mathrm{~Hz}, 1 \mathrm{H}), 3.46(\mathrm{~d}, J=2.0 \mathrm{~Hz}$, $1 \mathrm{H}), 2.79(\mathrm{dd}, J=8.8,2.1 \mathrm{~Hz}, 1 \mathrm{H}), 2.33(\mathrm{dd}, J=8.8,4.8 \mathrm{~Hz}, 1 \mathrm{H}), 1.51(\mathrm{~s}, 9 \mathrm{H}), 1.43(\mathrm{~s}, 3 \mathrm{H}) ;{ }^{13} \mathrm{C} \mathrm{NMR}\left(151 \mathrm{MHz}, \mathrm{CDCl}_{3}\right): \delta$ $164.9,132.0,124.2,114.8,84.8,57.7,53.7,31.3,29.7,28.7,28.0,21.5$; IR (thin film, KBr, cm${ }^{-1}$ ): 2981, 2933, 2360, 2341, $2244,1728,1456,1395,1371,1303,1255,1150,1055,884,840,785,640 ; \mathrm{HRMS}(\mathrm{ESI}+)$ : Calculated for $\left[\mathrm{C}_{14} \mathrm{H}_{18} \mathrm{NO}_{3}\right]^{+}$ ([M+H]): 246.1136, Found: 246.1148; HPLC (95:5 hexanes:'PrOH, Daicel CHIRALPAK IC): 87:13 er, $t_{R}$ (major) $=11.9 \mathrm{~min}$, $t_{R}$ (minor) $=9.7 \mathrm{~min} ;[\alpha]_{\mathrm{D}}:-130\left(\mathrm{c}=0.013, \mathrm{CHCl}_{3}\right) ; \operatorname{TLC}\left(70: 30\right.$ hexanes:EtOAC): $R_{\mathrm{f}}=0.58 ; \mathrm{mp} 78-80{ }^{\circ} \mathrm{C}$.
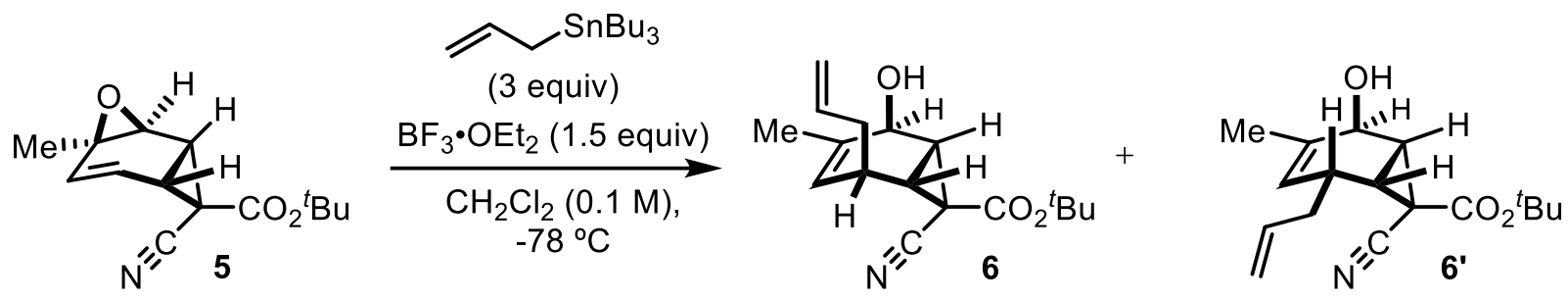

tert-butyl (1S,2S,5S,6R,7S)-5-allyl-7-cyano-2-hydroxy-3-methyl bicyclo[4.1.0]hept-3-ene-7-carboxylate (6) \& tert-butyl $(1 S, 2 S, 5 R, 6 R, 7 S)$-5-allyl-7-cyano-2-hydroxy-3-methylbicyclo[4.1.0] hept-3-ene-7-carboxylate (6'): A dram vial containing a magnetic stir bar was flame-dried, sealed with a PTFE-lined screw cap, then left to cool under nitrogen flow. The vial was charged with norcaradiene oxide $5(25 \mathrm{mg}, 0.10 \mathrm{mmol})$ which was then purged with nitrogen for several minutes before leaving under positive pressure. Anhydrous $\mathrm{CH}_{2} \mathrm{Cl}_{2}(1 \mathrm{~mL}, 0.1 \mathrm{M})$ and allyltributylstannane $(93 \mu \mathrm{L}, 0.30$ $\mathrm{mmol}$ ) were added to the vial and the colorless solution that forms on stirring was cooled to $-78{ }^{\circ} \mathrm{C}$ using a dry ice/acetone bath. $\mathrm{BF}_{3} \cdot \mathrm{OEt}_{2}(19 \mu \mathrm{L}, 0.15 \mathrm{mmol})$ was added dropwise and the resulting faint yellow reaction solution was left stirring at $-78^{\circ} \mathrm{C}$ until TLC analysis showed complete consumption of the starting material $(1 \mathrm{~h})$. The reaction was quenched with an equal part of saturated aqueous bicarbonate solution while still at $-78{ }^{\circ} \mathrm{C}$. Afterward, the vessel was pulled from the cooling bath, the layers were mixed thoroughly and the mixture then left to warm to ambient temperature. The mixture was diluted with additional $\mathrm{CH}_{2} \mathrm{Cl}_{2} /$ saturated aqueous bicarbonate solution, mixed again, and left to partition. The aqueous layer was isolated, extracted with $\mathrm{CH}_{2} \mathrm{Cl}_{2}(2 \mathrm{x})$ and the organic layers then combined, washed with brine, dried over anhydrous sodium sulfate, filtered, and concentrated in vacuo. The diastereomers were separated by flash chromatography on silica gel $(0 \rightarrow 15 \%$ EtOAc:hexanes, hold at $12.5 \%$ to elute the syn diastereomer 
then ramp to $15 \%$ to elute the anti diastereomer). Both isomers co-elute with tin by-product-pure $69.0 \mathrm{mg}$ [31\% yield] and $\mathbf{6}^{\prime} 8.0 \mathrm{mg}$ [28\% yield] were obtained by taking up each chromatographed sample into acetonitrile and washing with hexanes $(5 x)$. The relative stereochemistry was determined by analysis of the ${ }^{3}{ }_{\mathrm{H}-\mathrm{H}}$ couplings between methine protons.

Analytical data for 6: ${ }^{1} \mathrm{H}$ NMR $\left(600 \mathrm{MHz}, \mathrm{CDCl}_{3}\right): \delta 5.87-5.75(\mathrm{~m}, 1 \mathrm{H}), 5.41(\mathrm{dt}, J=4.7,1.3 \mathrm{~Hz}, 1 \mathrm{H}), 5.17(\mathrm{~d}, J=10.1 \mathrm{~Hz}$, $1 \mathrm{H}), 5.12(\mathrm{dd}, J=17.1,1.6 \mathrm{~Hz}, 1 \mathrm{H}), 4.19(\mathrm{~d}, J=5.2 \mathrm{~Hz}, 1 \mathrm{H}), 2.73(\mathrm{~d}, J=5.8 \mathrm{~Hz}, 1 \mathrm{H}), 2.44-2.38(\mathrm{~m}, 1 \mathrm{H}), 2.36(\mathrm{~d}, J=9.0 \mathrm{~Hz}$, $1 \mathrm{H}), 2.32-2.27(\mathrm{~m}, 1 \mathrm{H}), 2.06(\mathrm{~d}, J=9.0 \mathrm{~Hz}, 1 \mathrm{H}), 1.82(\mathrm{~s}, 3 \mathrm{H}), 1.68(\mathrm{br} \mathrm{s}, 1 \mathrm{H}), 1.50(\mathrm{~s}, 9 \mathrm{H}) ;{ }^{13} \mathrm{C} \mathrm{NMR}\left(151 \mathrm{MHz}, \mathrm{CDCl}_{3}\right): \delta$ 166.5, 135.1, 133.2, 125.6, 118.7, 115.2, 84.2, 64.5, 40.0, 34.8, 32.6, 31.4, 28.0, 21.6, 21.2; IR (thin film, KBr cm${ }^{-1}$ ): 3853 , $3750,3649,3446,2979,1731,1653,1558,1541,1457,1371,1301,1256,1154,1013,841$; HRMS (ESI-): Calculated for $\left[\mathrm{C}_{17} \mathrm{H}_{22} \mathrm{NO}_{3}\right]^{-}([\mathrm{M}-\mathrm{H}]): 288.1610$, Found: 288.1614; $[\alpha]_{\mathrm{D}}:+5.9$ (c $\left.=0.005, \mathrm{CHCl}_{3}\right) ;$ TLC (70:30 hexanes:EtOAc): $R_{\mathrm{f}}=0.40$.

Analytical data for 6': ${ }^{1} \mathrm{H}$ NMR $\left(600 \mathrm{MHz}, \mathrm{CDCl}_{3}\right): \delta 5.87-5.79(\mathrm{~m}, 1 \mathrm{H}), 5.37-5.35(\mathrm{~m}, 1 \mathrm{H}), 5.16(\mathrm{dd}, J=17.0,1.6 \mathrm{~Hz}, 1 \mathrm{H})$, 5.12-5.09 (m, 1H), $4.25(\mathrm{~s}, 1 \mathrm{H}), 2.91-2.76(\mathrm{~m}, 1 \mathrm{H}), 2.46(\mathrm{dd}, J=9.0,1.3 \mathrm{~Hz}, 1 \mathrm{H}), 2.42-2.31(\mathrm{~m}, 2 \mathrm{H}), 2.21$ (ddd, $J=9.0,5.5$, $1.1 \mathrm{~Hz}, 1 \mathrm{H}), 1.85-1.83(\mathrm{~m}, 3 \mathrm{H}), 1.81-1.71(\mathrm{~m}, 1 \mathrm{H}), 1.49(\mathrm{~s}, 9 \mathrm{H}) ;{ }^{13} \mathrm{C}$ NMR $\left(151 \mathrm{MHz}, \mathrm{CDCl}_{3}\right): \delta 166.6,135.4,133.3,125.8$, $117.9,115.8,84.0,64.9,37.9,34.8,33.1,31.8,28.0,21.4,19.5$; IR (thin film, $\mathrm{cm}^{-1}$ ): 3583, 3750, 3649, 2980, 1732, 1684, 1653, 1558, 1541, 1474, 1457, 1372, 1301, 1253, 1159, 841; HRMS (ESI-): Calculated for $\left[\mathrm{C}_{17} \mathrm{H}_{22} \mathrm{NO}_{3}\right]^{-}([\mathrm{M}-\mathrm{H}]): 288.1605$, Found: $288.1616 ;[\alpha]_{\mathrm{D}}:-30\left(\mathrm{c}=0.0045, \mathrm{CHCl}_{3}\right) ; \operatorname{TLC}\left(70: 30\right.$ hexanes:EtOAC): $R_{\mathrm{f}}=0.30$.
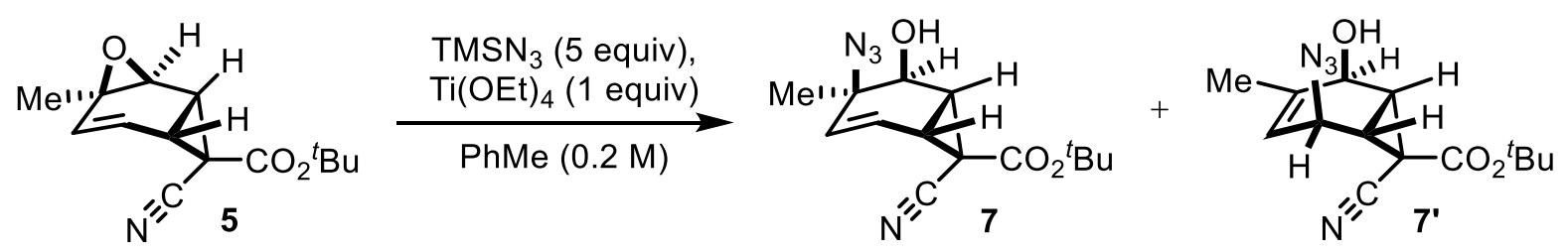

tert-butyl (1R,4R,5S,6S,7S)-4-azido-7-cyano-5-hydroxy-4-methyl bicyclo[4.1.0]hept-2-ene-7-carboxylate (7) \& tertbutyl (1S,2S,5S,6R,7S)-5-azido-7-cyano-2-hydroxy-3-methylbicyclo [4.1.0] hept-3-ene-7-carboxylate (7'): A dram vial containing a magnetic stir bar was flame-dried, sealed with a PTFE-lined screw cap, then left to cool under nitrogen flow. The vial was charged with norcaradiene oxide $5(25 \mathrm{mg}, 0.10 \mathrm{mmol})$ which was then purged with nitrogen for several minutes before leaving under positive pressure. The epoxide was taken up into anhydrous toluene (500 $\mu \mathrm{L}, 0.2 \mathrm{M})$ and to the stirring solution was added, in order, azidotrimethylsilane (66 $\mu \mathrm{L}, 0.50 \mathrm{mmol})$ and titanium(IV) ethoxide ( $21 \mu \mathrm{L}$, $0.10 \mathrm{mmol}$ ). The gold-colored solution was stirred at ambient temperature under nitrogen until TLC analysis showed complete consumption of the starting material $(3 \mathrm{~h})$. The reaction mixture was then loaded directly onto a plug of silica gel, eluted with diethyl ether, and concentrated in vacuo. Purification of the crude mixture by flash chromatography on silica gel (column 1: $5 \rightarrow$ 10\% EtOAc:hexanes; column 2: $\mathrm{CHCl}_{3}$ ) furnished a 1.85:1.0 mixture of allylic azides $\left(\mathbf{7}+\mathbf{7}^{\prime}\right)$ as a colorless oil in $20 \mathrm{mg}$ [ $69 \%$ yield, $18.1: 1.0 \mathrm{dr}(7)$ ]. The diastereomeric ratio for 7 was assigned by comparison of olefinic resonances (major: $\delta 6.20$, minor: $\delta 6.00$ ) in the ${ }^{1} \mathrm{H}$ NMR spectrum of the purified azide mixture. No minor diastereomer of $\mathbf{7}^{\prime}$ was observed. ${ }^{1} \mathrm{H} /{ }^{13} \mathrm{C}$ NMR signals were assigned with the aid of COSY/HSQC experiments. The relative stereochemistry of $\mathbf{7}$ was determined by observation of a nOe (see purified spectra below) between the methyl group ( $\delta$ 1.48) and adjacent methine proton $(\delta 3.63)$. Values for ${ }^{3} \mathrm{~J}_{\mathrm{H}-\mathrm{H}}$ couplings between methine protons of the minor isomer support the assignment of $\mathbf{7}^{\prime}$ as the syn-1,4-azido alcohol. ${ }^{\text {vii }}$

Analytical data for $7 \& 7^{\prime}:{ }^{1} \mathrm{H}$ NMR (600 MHz, CDCl 3$): 7-\delta 6.18$ (dd, $\left.J=9.4,3.0, \mathrm{~Hz}, 1 \mathrm{H}\right), 5.97(\mathrm{~d}, J=9.4,1 \mathrm{H}), 3.63(\mathrm{dd}, J=$ 9.8, 3.6 Hz, 1H), $2.62(\mathrm{~d}, J=10.3 \mathrm{~Hz}, 1 \mathrm{H}), 2.54(\mathrm{dd}, J=8.9,3.0 \mathrm{~Hz}, 1 \mathrm{H}), 2.22(\mathrm{dd}, J=8.8,3.6 \mathrm{~Hz}, 1 \mathrm{H}), 1.51(\mathrm{~s}, 9 \mathrm{H}), 1.48(\mathrm{~s}$, $3 \mathrm{H}), 7^{\prime}-\delta 5.61(\mathrm{dt}, J=5.1,1.5 \mathrm{~Hz}, 1 \mathrm{H}), 4.29(\mathrm{~s}, 1 \mathrm{H}), 4.12(\mathrm{~d}, J=4.4 \mathrm{~Hz}, 1 \mathrm{H}), 2.48(\mathrm{~d}, J=8.6 \mathrm{~Hz}, 1 \mathrm{H}), 2.38(\mathrm{dd}, J=8.7,1.2$ $\mathrm{Hz}, 1 \mathrm{H}), 1.94(\mathrm{~s}, 3 \mathrm{H}), 1.63(\mathrm{~s}, 1 \mathrm{H}), 1.50(\mathrm{~s}, 9 \mathrm{H}) ;{ }^{13} \mathrm{C} \mathrm{NMR}\left(151 \mathrm{MHz}, \mathrm{CDCl}_{3}\right): 7-\delta 164.8,135.4,126.4,114.8,84.8,71.8$,

\footnotetext{
vii The allylic azides are separable by column chromatography, however, each isomer equilibrated to the 1.8:1.0 mixture during solvent removal.
} 
61.9, 33.5, 29.6, 28.0, 22.8, 7'- $-165.2,139.6,118.7,114.2,85.0,63.7,52.6,32.9,29.4,28.0,21.3,20.7$; IR (thin film, $\left.\mathrm{KBr}, \mathrm{cm}^{-1}\right): 3853,3649,3481,2981,2245,2107,1731,1653,1558,1541,1507,1457,1396,1371,1303,1255,1159$, 1094, 1071, 839, 732; HRMS (ESI-): Calculated for $\left[\mathrm{C}_{14} \mathrm{H}_{17} \mathrm{~N}_{4} \mathrm{O}_{3}\right]^{-}\left([\mathrm{M}-\mathrm{H}]^{-}\right): 289.1306$, Found: $289.1316 ;[\alpha]_{\mathrm{D}}:+156(\mathrm{c}=$ $\left.0.0095, \mathrm{CHCl}_{3}\right)$; TLC (70:30 hexanes:EtOAc): $R_{\mathrm{f}}=0.48$.
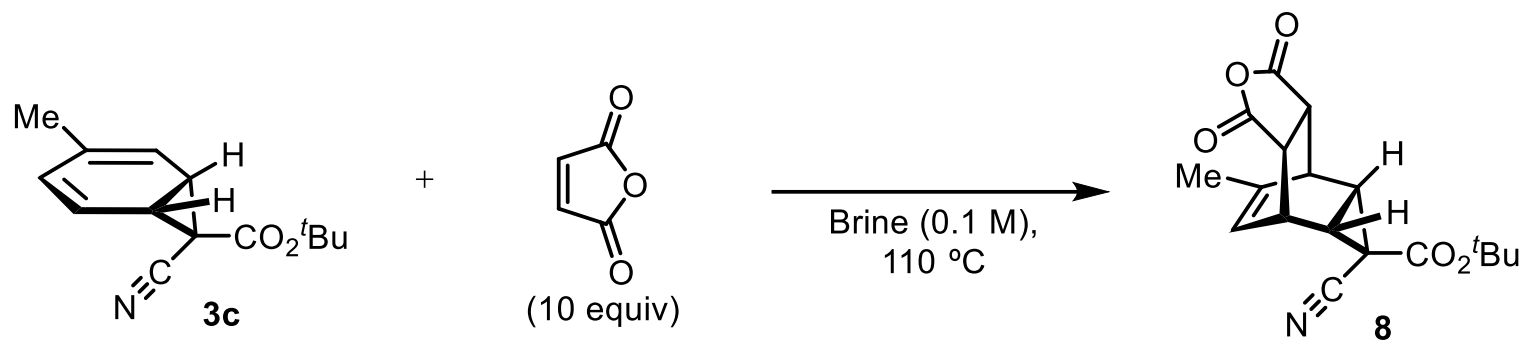

tert-butyl (3aS,4S,4aR,5S,5aS,6R,6aR)-5-cyano-7-methyl-1,3-dioxo-3,3a,4,4a,5,5a,6,6a-octahydro-1H-4,6ethenocyclopropa[f]isobenzofuran-5-carboxylate (8): A microwave reaction tube was charged with norcaradiene 3c (23.5 $\mathrm{mg}, 0.101 \mathrm{mmol})$ and freshly ground maleic anhydride $(100.1 \mathrm{mg}, \mathrm{mmol}, 10$ equiv). The vial was sparged with argon followed by the addition of brine $(1 \mathrm{~mL})$. The suspension was subjected to microwave heating $\left(200 \mathrm{~W}, 110^{\circ} \mathrm{C}\right)$ for $10 \mathrm{~min}$. After cooling to ambient temperature, the reaction mixture was extracted with methylene chloride. ${ }^{\text {viii }}$ The combined organic extracts were dried over anhydrous sodium sulfate, filtered, and the filtrate was concentrated in vacuo. The crude residue was purified by flash chromatography on silica (30\% MTBE/hexanes), furnishing 8 in 13.4 mg as a white solid [40\% yield, >20:1 dr, 88:12 er].

Analytical data for 8: ${ }^{1} \mathrm{H}$ NMR $\left(600 \mathrm{MHz}, \mathrm{CDCl}_{3}\right): \delta 5.79(\mathrm{~m}, 1 \mathrm{H}), 3.78(\mathrm{~m}, 1 \mathrm{H}), 3.61(\mathrm{~m}, 1 \mathrm{H}), 3.37(\mathrm{dd}, J=8.5,3.6 \mathrm{~Hz}, 1 \mathrm{H})$, $3.28(\mathrm{dd}, J=8.5,3.4 \mathrm{~Hz}, 1 \mathrm{H}), 2.27-2.15(\mathrm{~m}, 2 \mathrm{H}), 1.87(\mathrm{~d}, J=1.7 \mathrm{~Hz}, 3 \mathrm{H}), 1.49(\mathrm{~s}, 9 \mathrm{H}) ;^{13} \mathrm{C} \mathrm{NMR}\left(151 \mathrm{MHz}, \mathrm{CD}_{2} \mathrm{Cl}_{2}\right): \delta 170.9$, 170.5, 165.2, 140.6, 124.4, 114.9, 84.5, 45.6, 45.4, 32.5, 32.9, 31.6, 29.5, 27.6, 22.1; IR (thin film, KBr, $\mathrm{cm}^{-1}$ ): 3452, 2965, 2932, 2238, 1639, 1556, 1417, 1252, 1098, 1019, 799; HRMS (ESI-): Calculated for $\left[\mathrm{C}_{18} \mathrm{H}_{19} \mathrm{NO}_{5}{ }^{35} \mathrm{Cl}\right]^{-}\left(\left[\mathrm{M}+{ }^{35} \mathrm{Cl}\right]\right): 364.0957$, Found: 364.09574; Calculated for $\left[\mathrm{C}_{18} \mathrm{H}_{19} \mathrm{NO}_{5}{ }^{37} \mathrm{Cl}\right]-\left(\left[\mathrm{M}+{ }^{37} \mathrm{Cl}\right]\right)$ : 366.0918, Found: 366.0924; HPLC (55:45 hexanes: $\mathrm{CH}_{2} \mathrm{Cl}_{2}$, Daicel CHIRALPAK IA): 88:12 er, $t_{R}$ (major) $=5.3 \mathrm{~min}, t_{R}$ (minor) $=5.1 \mathrm{~min} ;[\alpha]_{\mathrm{D}}:-19$ (c=0.010, $\left.\mathrm{CHCl}_{3}\right) ; \mathrm{TLC}(40: 60$ hexanes:EtOAC): $R_{\mathrm{f}}=0.62 ; \mathrm{mp} 190^{\circ} \mathrm{C}$ (decomposition).
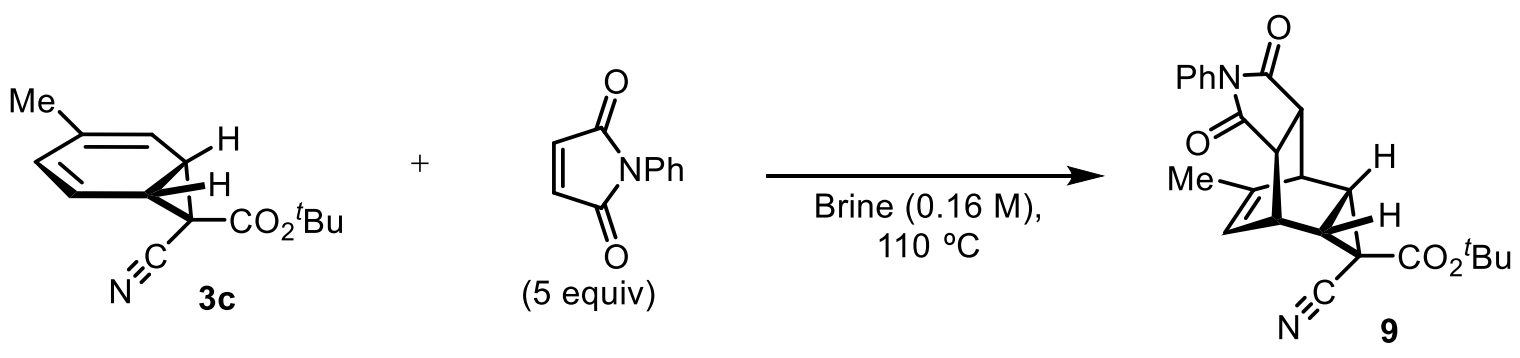

tert-butyl (3aS,4S,4aR,5S,5aS,6R,6aR)-5-cyano-7-methyl-1,3-dioxo-2-phenyl-1,2,3,3a,4,4a, 5,5a,6,6a-decahydro-4,6ethenocyclopropa[f]isoindole-5-carboxylate (9): A microwave reaction tube was charged with norcaradiene 3c (37.0 $\mathrm{mg}, 0.160 \mathrm{mmol}$ ) and $\mathrm{N}$-phenyl maleimide ( $138.7 \mathrm{mg}, 0.800 \mathrm{mmol}, 5$ equiv). The vial was sparged with argon followed by the addition of brine $(1 \mathrm{~mL})$. The suspension was subjected to microwave heating $\left(200 \mathrm{~W}, 110^{\circ} \mathrm{C}\right)$ for $10 \mathrm{~min}$. After cooling to ambient temperature, the yellow reaction mixture was extracted with methylene chloride. The combined organic extracts were dried over anhydrous sodium sulfate, filtered, and the filtrate was concentrated in vacuo. The crude residue was purified by flash chromatography on silica (25 $\rightarrow 40 \%$ MTBE/hexanes) furnishing 9 in 56.9 mg as a white solid [88\% yield, >20:1 dr, 83:17 er].

\footnotetext{
viii Care must be taken to minimize water content during extraction in order to minimize the amount of unwanted anhydride hydrolysis. Similarly, excessively wet NMR solvent will cause hydrolysis upon concentration.
} 
Analytical data for 9: ${ }^{1} \mathrm{H}$ NMR $\left(500 \mathrm{MHz}, \mathrm{CDCl}_{3}\right): \delta 7.46$ (at, $\left.J=8,1 \mathrm{~Hz}, 2 \mathrm{H}\right), 7.40$ (at, $\left.J=8.1,7.4 \mathrm{~Hz}, 1 \mathrm{H}\right), 7.11(\mathrm{~d}, J=7.4 \mathrm{~Hz}$, $2 \mathrm{H}), 5.76(\mathrm{dd}, J=6.6,1.8 \mathrm{~Hz}), 3.81(\mathrm{~m}, 1 \mathrm{H}), 3.65(\mathrm{~m}, 1 \mathrm{H}), 3.24(\mathrm{dd}, J=7.8,3.5 \mathrm{~Hz}, 1 \mathrm{H}), 3.17(\mathrm{dd}, J=7.8,3.2 \mathrm{~Hz}, 1 \mathrm{H}), 1.88$ (d, $J=1.8 \mathrm{~Hz}, 3 \mathrm{H}), 1.50(\mathrm{~s}, 9 \mathrm{H}) ;{ }^{13} \mathrm{C}$ NMR $\left(126 \mathrm{MHz}, \mathrm{CDCl}_{3}\right): \delta 175.9,175.5,165.4,139.6,131.4,129.2,128.9,126.3,123.6$, 115.2, 84.5, 44.8, 44.3, 37.6, 33.0, 32.2, 30.2, 27.8, 22.0, 21.5; IR (thin film, KBr, cm ${ }^{-1}$ ): 3460, 2925, 2234, 1713, 1498, 1381, 1292, 1252, 1157, 983, 838, 807, 754, 694, 633; HRMS (ESI+): Calculated for $\left[\mathrm{C}_{24} \mathrm{H}_{24} \mathrm{~N}_{2} \mathrm{O}_{4} \mathrm{Na}\right]^{+}([\mathrm{M}+\mathrm{Na}]): 427.1660$, Found: 427.1643; HPLC (25:75 hexanes: $\mathrm{CH}_{2} \mathrm{Cl}_{2}$, Daicel CHIRALPAK IC): 83:17 er, $t_{R}$ (major) $=5.6$ min, $t_{R}$ (minor) $=7.3 \mathrm{~min}$; $[\alpha]_{\mathrm{D}}:-55\left(\mathrm{c}=0.015, \mathrm{CHCl}_{3}\right) ; \mathrm{TLC}\left(70: 30\right.$ hexanes:EtOAC): $R_{\mathrm{f}}=0.31 ; \mathrm{mp} 171-172{ }^{\circ} \mathrm{C}$.
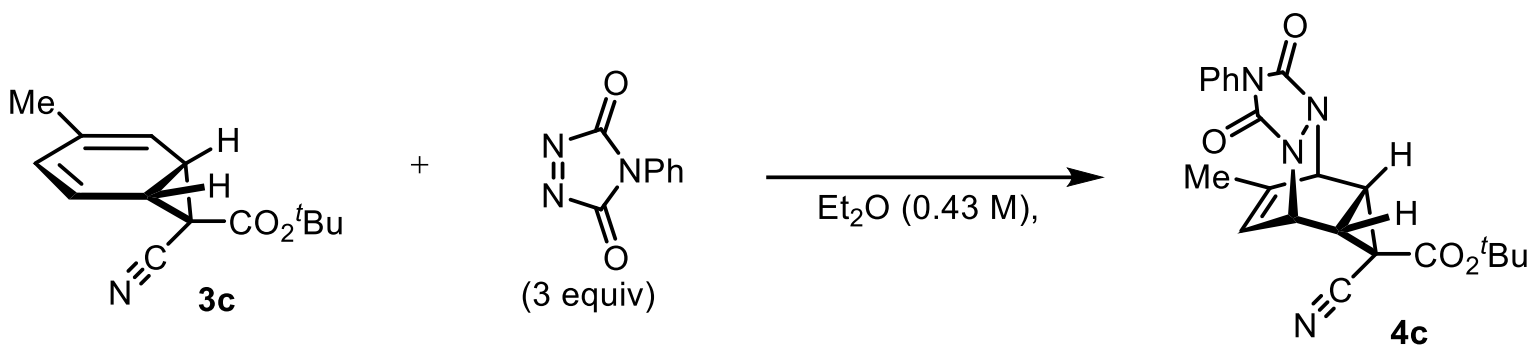

tert-butyl (5S,5aR,6S,6aS,7S)-6-cyano-9-methyl-1,3-dioxo-2-phenyl-2,3,5a,6,6a,7-hexa hydro-1H,5H-5,7ethenocyclopropa[d][1,2,4]triazolo[1,2-a]pyridazine-6-carboxylate (4c): To a 1-dram vial with stir flea was charged 3c $(50.0 \mathrm{mg}, 0.216 \mathrm{mmol})$ and diethyl ether $(500 \mu \mathrm{L})$ open to air. PTAD (113.4 mg, $0.647 \mathrm{mmol}, 3$ equiv.) was added to the vial with stirring, causing immediate precipitation of a white solid. The reaction was stirred at ambient temperature for $30 \mathrm{~min}$ where then the entire reaction mixture was diluted with methylene chloride $(2 \mathrm{~mL})$ and dry-loaded onto Celite, packed onto a silica column, then eluted with $40 \% \mathrm{MTBE} /$ hexanes. The product urazole $4 \mathrm{c}$ was obtained in $85.8 \mathrm{mg}$ as a white solid [97\% yield, >20:1 dr, 91:9 er]. A single crystal was obtained for X-ray diffraction by vapor diffusion using benzene (solvent) and pentane (anti-solvent).

Analytical data for $4 \mathrm{c}:{ }^{1} \mathrm{H}$ NMR $\left(600 \mathrm{MHz}, \mathrm{CDCl}_{3}\right): \delta 7.45(\mathrm{~m}, 2 \mathrm{H}), 7.42(\mathrm{~d}, J=8.4 \mathrm{~Hz}, 2 \mathrm{H}), 7.38(\mathrm{~m}, 1 \mathrm{H}), 5.98(\mathrm{~m}, 1 \mathrm{H}), 5.37$ $(\mathrm{m}, 1 \mathrm{H}), 5.21(\mathrm{~m}, 1 \mathrm{H}), 2.61(\mathrm{dd}, J=8.7,4.6 \mathrm{~Hz}, 1 \mathrm{H}), 2.58(\mathrm{dd}, J=8.7,4.0 \mathrm{~Hz}, 1 \mathrm{H}), 2.00(\mathrm{~s}, 3 \mathrm{H}), 1.51(\mathrm{~s}, 9 \mathrm{H}) ;{ }^{13} \mathrm{C} \mathrm{NMR}(126$ $\left.\mathrm{MHz}, \mathrm{CDCl}_{3}\right): \delta 163.8,156.6,156.6,138.6,130.9,129.1,128.5,125.3,121.2,114.0,85.4,55.5,52.0,27.7,26.4,24.4$, 23.9, 20.6; IR (thin film, KBr, cm${ }^{-1}$ ): 3470, 2981, 2240, 1775, 1716, 1502, 1457, 1403, 1292, 1237, 1155, 1052, 1022, 838, 757, 705, 646; HRMS (ESI+): Calculated for $\left[\mathrm{C}_{22} \mathrm{H}_{22} \mathrm{~N}_{4} \mathrm{O}_{4} \mathrm{Na}\right]^{+}([\mathrm{M}+\mathrm{Na}])$ : 429.1534, Found: 429.1546; HPLC (20:80 hexanes; $\mathrm{CH}_{2} \mathrm{Cl}_{2}$, Daicel CHIRALPAK IC): 93:7 er, $t_{R}$ (major) $=8.4 \mathrm{~min}, t_{R}$ (minor) $=9.5 \mathrm{~min} ;[\alpha]_{\mathrm{D}}:-32$ (c $\left.=0.010, \mathrm{CHCl}_{3}\right) ; \mathrm{TLC}(70: 30$ hexanes:EtOAC): $R_{\mathrm{f}}=0.46 ; \mathrm{mp} 160-163^{\circ} \mathrm{C}$ (decomposition).
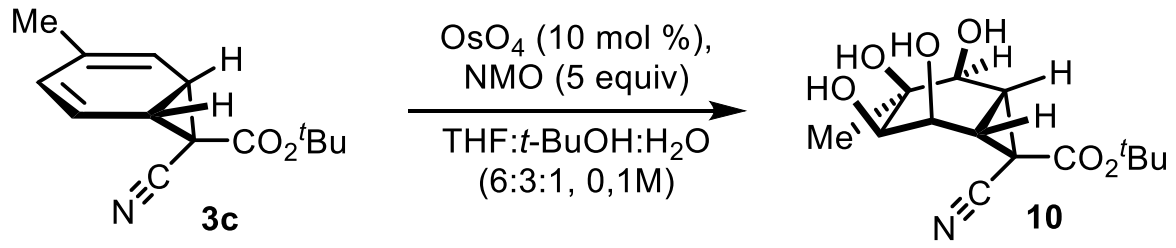

tert-butyl (1S,2S,3S,4R,5R,6R,7S)-7-cyano-2,3,4,5-tetrahydroxy-3-methylbicyclo[4.1.0] heptane-7-carboxylate (10): Norcaradiene $3 c$ (12 mg, $0.05 \mathrm{mmol})$ was dissolved in 6:3:1 THF:t-BuOH: $\mathrm{H}_{2} \mathrm{O}(500 \mu \mathrm{L}, 0.1 \mathrm{M})$ in a 1-dram vial with stir flea. $\mathrm{N}$-Methyl morpholine $\mathrm{N}$-oxide ( $30 \mathrm{mg}, 5$ equiv.) was added followed by $\mathrm{OsO}_{4}(1.3 \mathrm{mg}, 10 \mathrm{~mol} \%$, transferred using $50 \mu \mathrm{L}$ of THF). The reaction was stirred at ambient temperature until TLC indicated full conversion ( $2 \mathrm{~h}$ ). Solid sodium sulfite $(50 \mathrm{mg})$ and water $(300 \mu \mathrm{L})$ was added to the pot and the biphase was stirred vigorously for 30 min to neutralize excess osmium. The biphase was transferred to a separatory funnel where the layers were separated and the aqueous phase was extracted with ethyl acetate. The combined organic phases were washed with saturated sodium thiosulfate and brine. The organic phase was dried over $\mathrm{MgSO}_{4}$, filtered, and the filtrate was concentrated in vacuo. The crude residue 
was purified by flash chromatography on silica gel (80\% EtOAc:hexanes $\left.{ }^{i x}\right)$. The product tetraol 10 was obtained in 11.2 mg as a sticky, clear, off-white oil [75\% yield].

Analytical data for $10:{ }^{1} \mathrm{H}$ NMR $\left(500 \mathrm{MHz}, \mathrm{CDCl}_{3}\right): \delta 4.21$ (dd, $\left.J=8.9,4.4 \mathrm{~Hz}, 1 \mathrm{H}\right), 3.78(J=8.9 \mathrm{~Hz}, 1 \mathrm{H}), 3.65(\mathrm{~d}, J=7.2 \mathrm{~Hz}$, $1 \mathrm{H}$ ), 3.50 (dd, J=8.0, $5.2 \mathrm{~Hz}, 1 \mathrm{H}$, broad), 3.21-3.10 (broad, $2 \mathrm{H}$ ), 3.05 (d, J = 7.2 Hz, 1H), 2.54 (d, J=9.6 Hz, $1 \mathrm{H}$ ), 2.09 (d, J= $9.6 \mathrm{~Hz}, 1 \mathrm{H}), 1.51(\mathrm{~s}, 9 \mathrm{H}), 1.39(\mathrm{~s}, 3 \mathrm{H}) ;{ }^{13} \mathrm{C}$ NMR $\left(126 \mathrm{MHz}, \mathrm{CDCl}_{3}\right): \delta 165.0,115.5,84.9,75.6,70.7,69.6,65.8,34.1,32.8$, 27.8, 22.4, 21.1; IR (thin film, KBr, cm${ }^{-1}$ ): 3392, 2981, 2935, 2240, 1728, 1457, 1371, 1301, 1255, 1155, 1074, 1041, 963, 838, 813, 729; HRMS (ESI-): Calculated for $\left[\mathrm{C}_{14} \mathrm{H}_{20} \mathrm{NO}_{6}\right]^{-}([\mathrm{M}-\mathrm{H}]): 298.1296$, Found: 298.1294; $[\alpha]_{\mathrm{D}}:+95$ (c $=0.013$, $\left.\mathrm{CHCl}_{3}\right) ; \operatorname{TLC}\left(40: 60\right.$ hexanes:EtOAc): $R_{\mathrm{f}}=0.09$.
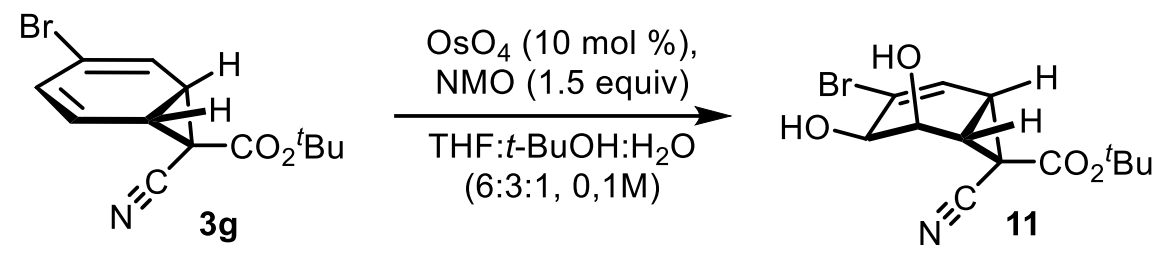

tert-butyl (1R,4R,5R,6R,7R)-3-bromo-7-cyano-4,5-dihydroxybicyclo[4.1.0]hept-2-ene-7-carboxylate (11): Compound 3g (29.8 mg, $0.10 \mathrm{mmol}$ ) was dissolved in 6:3:1 THF:t-BuOH: $\mathrm{H}_{2} \mathrm{O}(1 \mathrm{~mL}, 0.1 \mathrm{M})$ in a 1-dram vial with stir flea. $N$-methyl morphline $\mathrm{N}$-oxide (17 mg, 1.5 equiv.) was added followed by $\mathrm{OsO}_{4}(2.5 \mathrm{mg}, 10 \mathrm{~mol} \%$, transferred using $50 \mu \mathrm{L} \mathrm{of} \mathrm{THF).}$ The reaction was stirred at ambient temperature for $16 \mathrm{~h}$. Solid sodium sulfite $(100 \mathrm{mg})$ and water $(1 \mathrm{~mL})$ was added to the pot and the biphase was stirred vigorously for $30 \mathrm{~min}$ to neutralize excess osmium. The biphase was transferred to a separatory funnel where the layers were separated and the aqueous phase was extracted with ethyl acetate. The combined organic phases were washed with saturated sodium thiosulfate and brine. The organic phase was dried over $\mathrm{MgSO}_{4}$, filtered, and the filtrate was concentrated in vacuo. The crude residue was purified by flash chromatography on silica $\left(15 \% \rightarrow 35 \%\right.$ MTBE:hexanes $\left.{ }^{\text {viii }}\right)$. The product diol 11 was obtained in $23.3 \mathrm{mg}$ as a clear, colorless oil [70\% yield].

Analytical data for $11:{ }^{1} \mathrm{H}$ NMR $\left(600 \mathrm{MHz}, \mathrm{CDCl}_{3}\right): \delta 6.42(\mathrm{~d}, J=4.4 \mathrm{~Hz}, 1 \mathrm{H}), 4.36(\mathrm{t}, J=4.7 \mathrm{~Hz}, 1 \mathrm{H}), 4.28$ (ddd, $J=6.5,4.7$, $3.0 \mathrm{~Hz}, 1 \mathrm{H}), 3.02(\mathrm{~d}, J=5.4 \mathrm{~Hz}, 1 \mathrm{H}), 2.78(\mathrm{~m}, 1 \mathrm{H}), 2.54(\mathrm{dd}, J=8.7,4.4 \mathrm{~Hz}, 1 \mathrm{H}), 2.40(\mathrm{dd}, J=8.7,3.0 \mathrm{~Hz}, 1 \mathrm{H}), 1.51(\mathrm{~s}, 9 \mathrm{H})$; ${ }^{13} \mathrm{C}$ NMR $\left(151 \mathrm{MHz}, \mathrm{CDCl}_{3}\right): \delta 164.3,128.3,124.6,114.9,84.9,70.2,65.7,30.9,30.2,29.4,27.8$; IR (thin film, $\mathrm{KBr}, \mathrm{cm}^{-1}$ ) 3530(b), 3341(b), 2977, 2930, 2246, 1722, 1628, 1457, 1395, 1302, 1260, 1150, 1082, 1028, 971, 908, 837, 731, 647; HRMS (ESI-): Calculated for $\left[\mathrm{C}_{13} \mathrm{H}_{16} \mathrm{NO}_{4}{ }^{79} \mathrm{Br}^{35} \mathrm{Cl}\right]^{-}\left(\left[\mathrm{M}\left({ }^{79} \mathrm{Br}\right)+{ }^{35} \mathrm{Cl}\right]\right)$ : 363.9956, Found: 363.9956; Calculated for $\left[\mathrm{C}_{13} \mathrm{H}_{16} \mathrm{NO}_{4}{ }^{79} \mathrm{Br}^{37} \mathrm{Cl}\right] /\left[\mathrm{C}_{13} \mathrm{H}_{16} \mathrm{NO}_{4}{ }^{81} \mathrm{Br}^{35} \mathrm{Cl}\right]^{-}\left(\left[\mathrm{M}\left({ }^{79} \mathrm{Br}\right)+{ }^{37} \mathrm{Cl} / \mathrm{M}\left({ }^{81} \mathrm{Br}\right)+{ }^{35} \mathrm{Cl}\right]\right): 365.991817 / 365.993621$, Found: 365.99315; Calculated for $\left[\mathrm{C}_{13} \mathrm{H}_{16} \mathrm{NO}_{4}{ }^{81} \mathrm{Br}^{37} \mathrm{Cl}\right]^{-}\left(\left[\mathrm{M}\left({ }^{81} \mathrm{Br}\right)+{ }^{37} \mathrm{Cl}\right]\right)$ : 367.9897, Found: 367.9903 ; With CID - Calculated for $\left[\mathrm{C}_{13} \mathrm{H}_{15} \mathrm{NO}_{4}{ }^{79} \mathrm{Br}\right]^{-}$ ([M( $\left.\left.\left.{ }^{79} \mathrm{Br}\right)-\mathrm{H}\right]\right): 328.01899$, Found: 328.01871; Calculated for $\left[\mathrm{C}_{13} \mathrm{H}_{15} \mathrm{NO}_{4}{ }^{81} \mathrm{Br}\right]^{-}\left(\left[\mathrm{M}\left({ }^{81} \mathrm{Br}\right)-\mathrm{H}\right]\right): 330.016947$, Found: 330.01670; $[\alpha]_{\mathrm{D}}:+47$ ( $\left.\mathrm{c}=0.010, \mathrm{CHCl}_{3}\right) ;$ TLC (70:30 hexanes:EtOAC): $R_{\mathrm{f}}=0.60$.

\footnotetext{
${ }^{i x}$ Acetone/hexanes as a chromatography eluent mixture can lead to formation of variable amounts of acetonide. Similarly, acetone must be carefully excluded from transfer vessels to avoid undesirable acetonide formation.

${ }^{x}$ The mass spectrum was obtained in acetonitrile with added chloroform to promote formation of the chloride adduct. ${ }^{7}$ Collisioninduced dissociation lead to full disappearance of the $[\mathrm{M}+\mathrm{Cl}]$ peaks to completely favor a complex $[2 \mathrm{M}+\mathrm{Cl}-\mathrm{X}]$ mass splitting pattern with slight population of the molecular ion peak.
} 


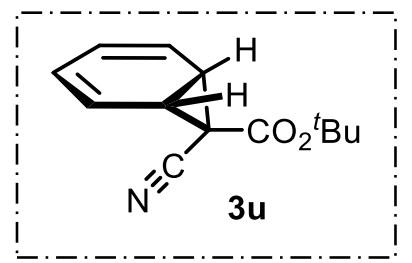

tert-butyl 7-cyanobicyclo[4.1.0]hepta-2,4-diene-7-carboxylate (3u): The title compound was prepared according to General Procedure A using 40 equiv. of benzene and $0.2 \mathrm{mmol}$ of diazo 1c. ${ }^{\text {ii }}$ The product was purified from the crude mixture by flash chromatography on silica gel (100\% hexanes $\rightarrow 10 \%$ EtOAc:hexanes) to afford $3 \mathbf{u}$ in $26.0 \mathrm{mg}$ as a white solid [59\% yield].

Large-scale Reaction: The title compound was prepared according General Procedure $\mathbf{C}$ using $10 \mathrm{mmol}$ of diazo $\mathbf{1 b}$. The product was purified by flash chromatography on silica (100\% hexanes $\rightarrow 10 \%$ EtOAc/hexanes) to afford $3 \mathbf{u}$ as a white solid in $1.261 \mathrm{~g}[58 \%$ yield].

Analytical data for 3u: ${ }^{1} \mathrm{H}$ NMR $\left(500 \mathrm{MHz}, \mathrm{CDCl}_{3}\right): \delta 6.40(\mathrm{~m}, 2 \mathrm{H}), 6.21(\mathrm{~m}, 2 \mathrm{H}), 3.15(\mathrm{~m}, 2 \mathrm{H}), 1.53(\mathrm{~s}, 9 \mathrm{H}) ;{ }^{13} \mathrm{C}$ NMR $(101$ $\mathrm{MHz}_{\mathrm{CDCl}}$ ): $\delta 168.8,127.1,122.2,112.7,84.2,39.1,27.9,12.8$; IR (thin film, KBr, $\mathrm{cm}^{-1}$ ) 3052, 2980, 2934, 2742, 1720, $1478,1457,1427,1395,1370,1301,1255,1159,1044,986,836,796,741,639,549$; HRMS (ESI+): Calculated for $\left[\mathrm{C}_{13} \mathrm{H}_{16} \mathrm{NO}_{2}\right]^{+}([\mathrm{M}+\mathrm{H}]): 218.11755$, Found: $218.11858 ; \mathrm{TLC}\left(90: 10\right.$ hexanes:MTBE): $R_{\mathrm{f}}=0.22 ; \mathrm{mp}$ 67-69 ${ }^{\circ} \mathrm{C}$.

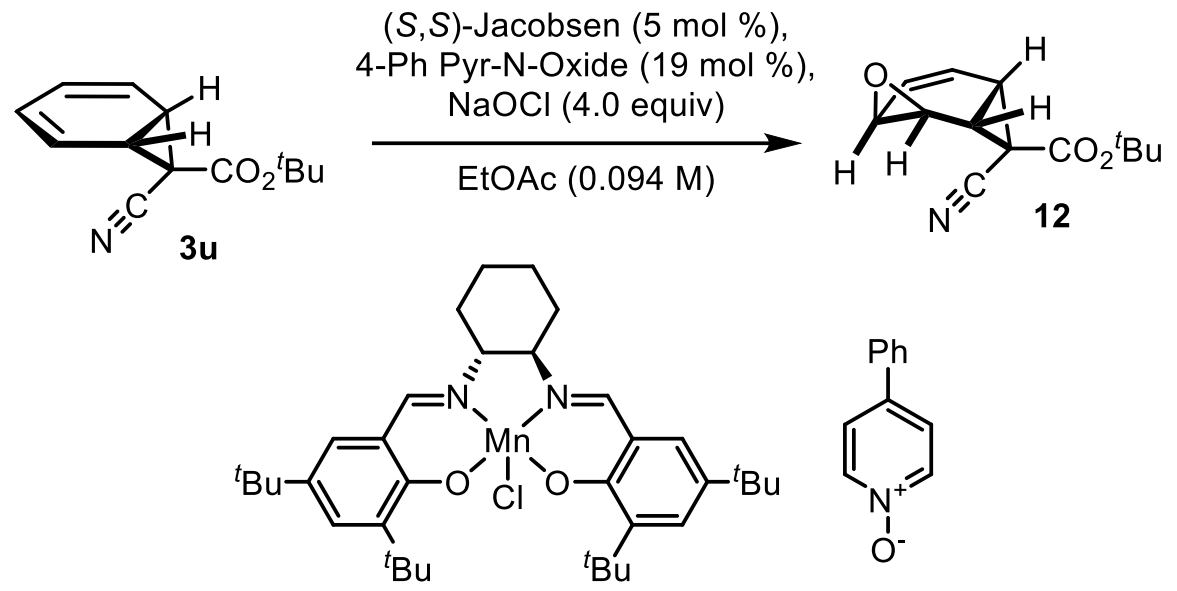

(S,S)-Jacobsen 4-Ph Pyr-N-Oxide

tert-butyl (1S,2S,4R,7R,8S)-8-cyano-3-oxatricyclo[5.1.0.02,4]oct-5-ene-8-carboxylate (12): Norcaradiene $3 \mathrm{u}$ (250 mg, $1.15 \mathrm{mmol}$ ), 4-phenyl pyridine $\mathrm{N}$-Oxide $(38.2 \mathrm{mg}, 0.223 \mathrm{mmol}, 19 \mathrm{~mol} \%)$, and (S,S)-Jacobsen catalyst (36.5 mg, 0.058 $\mathrm{mmol}, 5 \mathrm{~mol} \%)$ were taken up in ethyl acetate $(10 \mathrm{~mL}, 0.094 \mathrm{M})$ in a round bottom flask under nitrogen atmosphere and the vessel was cooled to $-5{ }^{\circ} \mathrm{C}$ in a UC reactor. Aqueous sodium hypochlorite [ $13 \%$ by weight] $(2.2 \mathrm{~mL}, 4.60 \mathrm{mmol}, 4.0$ equiv.) was added dropwise to the pot and the brown reaction mixture was stirred vigorously for $15 \mathrm{~h}$ at $-5^{\circ} \mathrm{C}$. The reaction medium was transferred to a separatory funnel where the layers were separated. The aqueous phase was extracted with ethyl acetate $(3 \times 10 \mathrm{~mL})$. The combined organic phase was washed with water $(2 \times 20 \mathrm{ml})$, then brine $(1 \mathrm{x}$ $40 \mathrm{ml}$ ). The organic phase was separated and dried over sodium sulfate followed by removal of the drying agent and concentration of the solution in vacuo. The crude brown residue was submitted to flash chromatography on silica gel (20\% EtOAc:hexanes) which afforded the desired norcaradiene oxide as an off-white solid [180.4 mg, 66\% yield]. The

\footnotetext{
${ }^{\mathrm{xi}}$ Upon inspection of the crude ${ }^{1} \mathrm{H}$ NMR spectrum of the reaction following concentration, the desired norcaradiene was observed as a 6.5:1.0 mixture of product to the compound resulting from over-cyclopropanation. The tricyclic over-cyclopropanation side product can be readily removed via flash chromatography. Employing fewer equivalents of benzene resulted in an increase in side product formation.
} 
enantiopurity of the sample can be increased by crystallization of the racemate from hot MTBE:hexanes. The recrystallization was stopped once the enantiomeric ratio of $\mathbf{1 2}$ in solution reached >99:1 by HPLC assay.

Analytical data for 12: ${ }^{1} \mathrm{H}$ NMR $\left(500 \mathrm{MHz}, \mathrm{CDCl}_{3}\right): \delta 6.18$ (dd, $\left.J=9.7,3.8 \mathrm{~Hz}, 1 \mathrm{H}\right), 6.02(\mathrm{dd}, J=9.7,5.0 \mathrm{~Hz}, 1 \mathrm{H}), 3.70(\mathrm{~m}$, $1 \mathrm{H}), 3.18(\mathrm{~m}, 1 \mathrm{H}), 2.77(\mathrm{dd}, J=9.2,3.8 \mathrm{~Hz}, 1 \mathrm{H}), 2.32(\mathrm{dd}, J=9.2,5.0 \mathrm{~Hz}, 1 \mathrm{H}), 1.52(\mathrm{~s}, 9 \mathrm{H}) ;{ }^{13} \mathrm{C} \mathrm{NMR}\left(151 \mathrm{MHz}, \mathrm{CDCl}_{3}\right): \delta$ 164.6, 127.4, 126.0, 114.7, 84.8, 51.5, 46.7, 29.9, 29.6, 28.5, 27.8; IR (thin film, KBr, cm${ }^{-1}$ ) 3446(b), 2981, 2244, 1730, 1698, 1652, 1558, 1540, 1507, 1456, 1396, 1371, 1299, 1259, 1150, 980, 839, 805, 732, 648; HRMS (ESI+): Calculated for $\left[\mathrm{C}_{13} \mathrm{H}_{15} \mathrm{NO}_{3} \mathrm{Na}\right]^{+}([\mathrm{M}+\mathrm{Na}]): 256.0944$, Found: 256.0952; HPLC (95:5 hexanes:'PrOH, Daicel CHIRALPAK IC): $84: 16$ er, $t_{R}$ $($ major $)=12.9 \mathrm{~min}, t_{R}($ minor $)=16.9 \mathrm{~min} ;[\alpha]_{\mathrm{D}}:+88.4\left(\mathrm{c}=0.011, \mathrm{CHCl}_{3}\right) ; \mathrm{TLC}(70: 30$ hexanes:EtOAC$): R_{\mathrm{f}}=0.58 ; \mathrm{mp} 112-$ $113^{\circ} \mathrm{C}$.
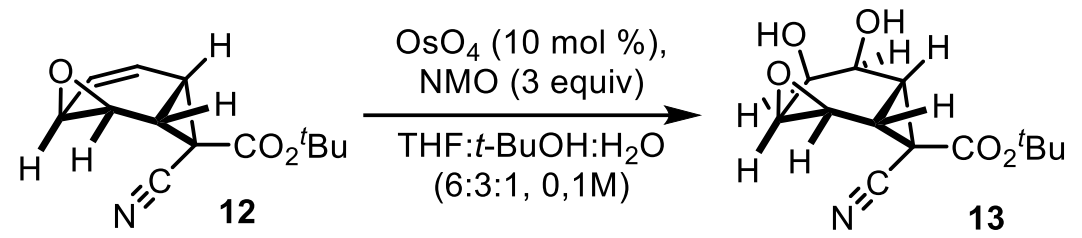

tert-butyl (1S,2S,4R,5R,6R,7R,8S)-8-cyano-5,6-dihydroxy-3-oxatricyclo[5.1.0.02,4]octane-8-carboxylate (13): Osmium tetroxide [1.4 mg, $10 \mathrm{~mol} \%$ ] was added to a stirring solution of cyclohexene 12 (13.0 $\mathrm{mg}, 0.055 \mathrm{mmol})$ and $N$-methyl morpholine $\mathrm{N}$-Oxide (19.6 mg, 3 equiv.) in 6:3:1 THF:t-BuOH:water $(500 \mu \mathrm{L}, 0.1 \mathrm{M})$. The reaction was stirred at ambient temperature for $12 \mathrm{~h}$. When the reaction was complete by TLC, sodium sulfite $(50 \mathrm{mg}, 100 \mathrm{mg}$ ) was added followed by water $(300 \mu \mathrm{L})$. The biphase was stirred for $30 \mathrm{~min}$ to neutralize residual osmium tetroxide. The biphase was separated and the aqueous phase was extracted with $\mathrm{CH}_{2} \mathrm{Cl}_{2}$. The combined organic phase was washed with sodium thiosulfate, water, then brine. The organic phase was dried over sodium sulfate and then was concentrated in vacuo after removal of drying agent. The crude residue was purified by flash chromatography on silica (60\% EtOAc:hexanes) to afford diol 13 as a white solid [13.9 $\mathrm{mg}, 95 \%$ yield,].

Analytical data for $13:{ }^{1} \mathrm{H}$ NMR $\left(500 \mathrm{MHz}, \mathrm{CDCl}_{3}\right): \delta 4.40(\mathrm{~m}, 1 \mathrm{H}), 4.26(\mathrm{~m}, 1 \mathrm{H}), 3.74(\mathrm{~m}, 1 \mathrm{H}), 3.50(\mathrm{~m}, 1 \mathrm{H}), 3.09(\mathrm{bd}, J=$ $9.7 \mathrm{~Hz}, 1 \mathrm{H}), 2.58$ (bs, $1 \mathrm{H}), 2.55$ (dd, $J=8.7,2.7 \mathrm{~Hz}, 1 \mathrm{H}), 2.41$ (ddd, $J=8.7,3.3,1.6 \mathrm{~Hz}, 1 \mathrm{H}), 1.52(\mathrm{~s}, 9 \mathrm{H}) ;{ }^{13} \mathrm{C} \mathrm{NMR}(126$ $\mathrm{MHz}, \mathrm{CDCl}_{3}$ ): $\delta$ 164.0, 116.0, 85.4, 65.4, 64.2, 57.1, 51.9, 33.8, 27.8, 26.4, 24.1; IR (thin film, KBr, $\mathrm{cm}^{-1}$ ) 3444, 2981, 1927, 2854, 2244, 1730, 1651, 1457, 1396, 1371, 1293, 1256, 1153, 1081, 983, 870, 838, 731; HRMS (ESI+): Calculated for $\left[\mathrm{C}_{13} \mathrm{H}_{17} \mathrm{NO}_{5} \mathrm{Na}\right]^{+}([\mathrm{M}+\mathrm{Na}]): 290.0999$, Found: 290.1009; $[\alpha]_{\mathrm{D}}:+63\left(\mathrm{c}=0.012, \mathrm{CHCl}_{3}\right) ; \operatorname{TLC}\left(40: 60\right.$ hexanes:EtOAc): $R_{\mathrm{f}}=0.29$; mp $123-124^{\circ} \mathrm{C}$.

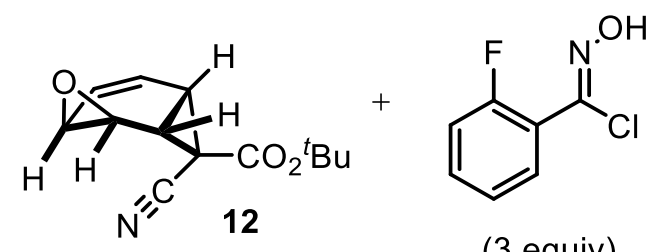

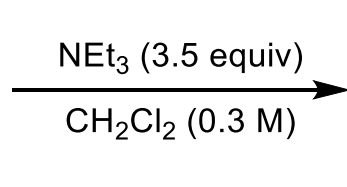

(3 equiv)

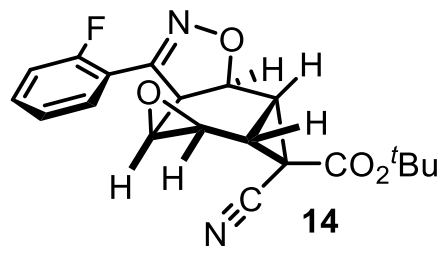

tert-butyl (4aS,4bS,5aR)-5-cyano-3-(2-fluorophenyl)-3a,3b,4a,4b,5a,5b-hexahydro-5Hcyclopropa[3,4]oxireno[2',3':5,6]benzo[1,2-d]isoxazole-5-carboxylate (14) : A solution of cyclohexene 12 (35 mg, 0.15 $\mathrm{mmol}$ ) and triethylamine ( $75 \mu \mathrm{L}, 0.525 \mathrm{mmol}, 3.5$ equiv) in methylene chloride (500 $\mu \mathrm{L}, 0.3 \mathrm{M}$ with respect to 12) was prepared in a flame-dried, nitrogen purged round bottom flask with stirbar. A solution of (Z)-2-fluoro- $N$ hydroxybenzimidoyl chloride ( $78 \mathrm{mg}, 3$ equiv.) in methylene chloride $(500 \mu \mathrm{L})$ was added to the reaction by syringe pump over $14 \mathrm{~h}$. After completion of the addition, the reaction was stirred for an additional $1 \mathrm{~h}$. The reaction was 
quenched by addition of water $(3 \mathrm{~mL})$ and the biphase was transferred to a separatory funnel. The layers were separated and the aqueous phase was extracted with methylene chloride. The combined organic phase was washed with $1 \mathrm{M} \mathrm{HCl}$, saturated sodium bicarbonate, water, then brine. The organic phase was dried over $\mathrm{MgSO}_{4}$ and then filtered. The filtrate was concentrated in vacuo. The crude residue was purified by flash chromatography on silica ( $100 \%$ hexanes $\rightarrow 15 \%$ EtOAc/hexanes) to afford 2-isoxazoline 14 as a beige semisolid [39.1 $\mathrm{mg}, 70.5 \%$ yield,]. The regiochemical assignment of the 2-isoxazoline was determined by observation of a correlation between the resonances at $\delta 4.37 \mathrm{ppm}$ and $\delta 3.38 \mathrm{ppm}$ in the COSY spectrum of 14. The diastereoselectivity of the cycloaddition was confirmed by separate selective 1D-NOESY experiments: a) Irradiation of the methine $\mathrm{C}-\mathrm{H}$ at $\delta 4.37$ lead to observable nOe enhancements at both resonances at $\delta 5.01 \mathrm{ppm}$ and $\delta 3.38 \mathrm{ppm}$, and b) Irradiation of the methine C-H at $\delta 5.01 \mathrm{ppm}$ lead to observable nOe enhancements at both resonances at $\delta 4.37 \mathrm{ppm}$ and $\delta 2.57 \mathrm{ppm}$. Furthermore, a strong correlation was observed at $\delta 4.37 \mathrm{ppm}$ in the 1D-COSY experiment with irradiation of the methine at $\delta$ 5.01. A much weaker correlation was observed under the same irradiation parameter with the resonance at $\delta 2.57$, which represents the cyclopropyl methine. The combined 1D-COSY data indicates that there is a weaker coupling between the cyclopropyl methine and the methine of the 2-isoxazoline, assigning a trans relationship between the two protons.

Analytical data for $14:{ }^{1} \mathrm{H}$ NMR $\left(400 \mathrm{MHz}, \mathrm{CDCl}_{3}\right): \delta 7.95(\mathrm{dd}, J=7.6,1.8 \mathrm{~Hz}, 1 \mathrm{H}), 7.44(\mathrm{~m}, 1 \mathrm{H}), 7.23(\mathrm{~m}, 1 \mathrm{H}), 7.15(\mathrm{~m}, 1 \mathrm{H})$, $5.01(\mathrm{dd}, J=10.5,1.4 \mathrm{~Hz}, 1 \mathrm{H}), 4.37(\mathrm{ddd}, J=10.5,3.4,2.1 \mathrm{~Hz}, 1 \mathrm{H}), 3.64(\mathrm{~m}, 1 \mathrm{H}), 3.38(\mathrm{~m}, 1 \mathrm{H}), 2.71(\mathrm{dd}, J=9.0,2.1 \mathrm{~Hz}$, $1 \mathrm{H}), 2.57(\mathrm{~d}, J=9.0 \mathrm{~Hz}, 1 \mathrm{H}), 1.53(\mathrm{~s}, 9 \mathrm{H}) ;{ }^{13} \mathrm{C} \mathrm{NMR}\left(151 \mathrm{MHz}, \mathrm{CDCl}_{3}\right): \delta 163.9,161.0 / 159.3(\mathrm{~d}, J=251.3 \mathrm{~Hz}), 153.3(\mathrm{~d}, J=$ $2.7 \mathrm{~Hz}), 132.5(\mathrm{~d}, J=8.7 \mathrm{~Hz}), 129.9(\mathrm{~d}, J=2.9 \mathrm{~Hz}), 125.0(\mathrm{~d}, J=3.3 \mathrm{~Hz}), 116.5$ (d, J = 22.3 Hz), $116.1(\mathrm{~d}, J=11.4 \mathrm{~Hz}), 115.3$, 85.3, 74.0, 49.2 (d, $J=5.4 \mathrm{~Hz}$ ), 48.6, 45.7 (d, $J=3.2 \mathrm{~Hz}), 28.8,27.8,27.0,23.1 ;{ }^{19} \mathbf{F ~ N M R}\left(564 \mathrm{MHz}, \mathrm{CDCl}_{3}\right): \delta 117.2$; IR (thin film, $\mathrm{KBr}, \mathrm{cm}^{-1}$ ) 3443, 2982, 2933, 2245, 1731, 1599, 1487, 1455, 1371, 1345, 1298, 1257, 1149, 1057, 939, 894, 864, 837, 754, 664, 621; HRMS (ESI+): Calculated for $\left[\mathrm{C}_{20} \mathrm{H}_{20} \mathrm{~N}_{2} \mathrm{O}_{4} \mathrm{~F}\right]^{+}([\mathrm{M}+\mathrm{H}]): 371.141255$, Found: $371.13967 ;[\alpha]_{\mathrm{D}}:+41(\mathrm{c}=0.012$, $\left.\mathrm{CHCl}_{3}\right) ; \mathrm{TLC}\left(70: 30\right.$ hexanes:EtOAc): $R_{\mathrm{f}}=0.54$.
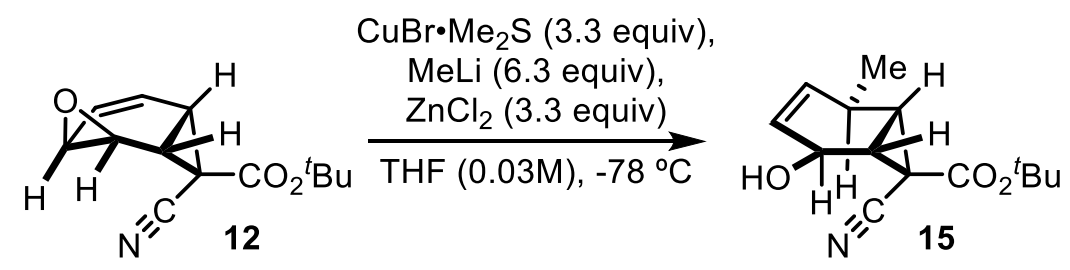

tert-butyl (1R,2S,5R,6S,7R)-7-cyano-2-hydroxy-5-methylbicyclo[4.1.0]hept-3-ene-7-carboxylate (15): Copper (I) bromide $\bullet$ dimethyl sulfide ( $155 \mathrm{mg}, 0.753 \mathrm{mmol}, 3.3$ equiv) was added to a flame-dried round bottom flask under positive nitrogen flow. Anhydrous THF $(4.0 \mathrm{~mL})$ was added to the solid and the suspension was cooled to $-78^{\circ} \mathrm{C}$. A $1.6 \mathrm{M}$ solution of methyllithium in diethyl ether $\left(900 \mu \mathrm{L}, 1.44 \mathrm{mmol}, 6.3\right.$ equiv to epoxide; 1.91 equiv to $\left.\mathrm{CuBr} \bullet \mathrm{Me}_{2} \mathrm{~S}\right)$ was added to the suspension, causing dissolution of the copper salt. The brown solution was stirred at $-78{ }^{\circ} \mathrm{C}$ for 30 min during which time the solution became clear with a pale blue hue. A solution of zinc (II) chloride (103 $\mathrm{mg}, 0.753 \mathrm{mmol}, 3.3$ equiv) in anhydrous THF $(2.0 \mathrm{~mL})$ was added dropwise over a minute to the cuprate solution, causing an initial color change to deep orange to a final intense yellow color of the solution. The pot was stirred for an additional $10 \mathrm{~min}$ at -78 ${ }^{\circ} \mathrm{C}$ before norcaradiene oxide $12(53.2 \mathrm{mg}, 0.228 \mathrm{mmol})$ in anhydrous THF (1.6 mL) was added dropwise. The solution was stirred for $30 \mathrm{~min}$ at $-78^{\circ} \mathrm{C}$. The cooling bath was removed and the reaction allowed to warm to ambient temperature with stirring over $5 \mathrm{~h}$. The reaction was cooled in an ice bath and then quenched with the addition of saturated ammonium chloride $(4 \mathrm{~mL})$, followed by saturated ammonium hydroxide $(1 \mathrm{~mL})$. The biphase was transferred to a separatory funnel where the layers were separated and the blue aqueous phase was extracted with ethyl acetate. The combined organic extracts were washed with saturated ammonium chloride then brine. The organic phase was dried over sodium sulfate then decanted away from the drying agent and concentrated in vacuo to give a colorless residue. Analysis of the ${ }^{1} \mathrm{H} N \mathrm{NMR}$ spectrum of the crude residue indicated a 5.7:1.0 mixture of the $\mathrm{S}_{\mathrm{N}} 2^{\prime}: \mathrm{S}_{\mathrm{N}} 2$ products, with $>20: 1 \mathrm{dr}$ for the $\mathrm{S}_{\mathrm{N}} 2^{\prime}$ and 1:1 dr for the $\mathrm{S}_{\mathrm{N}} 2$ products respectively. The $\mathrm{S}_{\mathrm{N}} 2^{\prime}$ alcohol product was purified by flash 
chromatography on silica (slow gradient from 5\% MTBE/hexanes $\rightarrow$ 15\% MTBE/hexanes $\rightarrow 35 \% \mathrm{MTBE} /$ hexanes), affording alcohol 15 as a white semisolid [31.8 $\mathrm{mg}, 56 \%$ yield].

Analytical data for 15: ${ }^{1} \mathrm{H}$ NMR $\left(600 \mathrm{MHz}, \mathrm{CDCl}_{3}\right): \delta 5.76(\operatorname{app~m}, 2 \mathrm{H}), 4.43(\mathrm{~s}, 1 \mathrm{H}), 2.61(\mathrm{~m}, 1 \mathrm{H}), 2.22(\mathrm{~d}, J=9.1 \mathrm{~Hz}, 1 \mathrm{H})$, $2.02(\mathrm{~d}, J=9.1 \mathrm{~Hz}, 1 \mathrm{H}), 1.79(\mathrm{~s}, 1 \mathrm{H}), 1.50(\mathrm{~s}, 9 \mathrm{H}), 1.32$ (d, $J=7.3 \mathrm{~Hz}, 3 \mathrm{H}) \mathrm{ppm} ;{ }^{13} \mathrm{C}\left(151 \mathrm{MHz}, \mathrm{CDCl}_{3}\right)$ 166.3, 133.2, 124.4, 115.0, 84.1, 60.5, 33.2, 32.9, 27.9, 26.7, 22.3, 22.1 ppm; IR (thin film, KBr, cm ${ }^{-1}$ ) 3430, 3032, 2978, 2933, 2877, 2241, 1726, 1458, 1395, 1371, 1299, 1250, 1156, 1093, 1024, 980, 911, 879, 809, 730, 647, 628, 531; HMRS (ESI+): Calculated for $\left[\mathrm{C}_{14} \mathrm{H}_{19} \mathrm{NO}_{3} \mathrm{Na}\right]^{+}\left([\mathrm{M}+\mathrm{Na}]^{+}\right): 272.12628$, Found: 272.1255 ; TLC (30:70 MTBE:hexanes): $R_{\mathrm{f}}=0.19$.
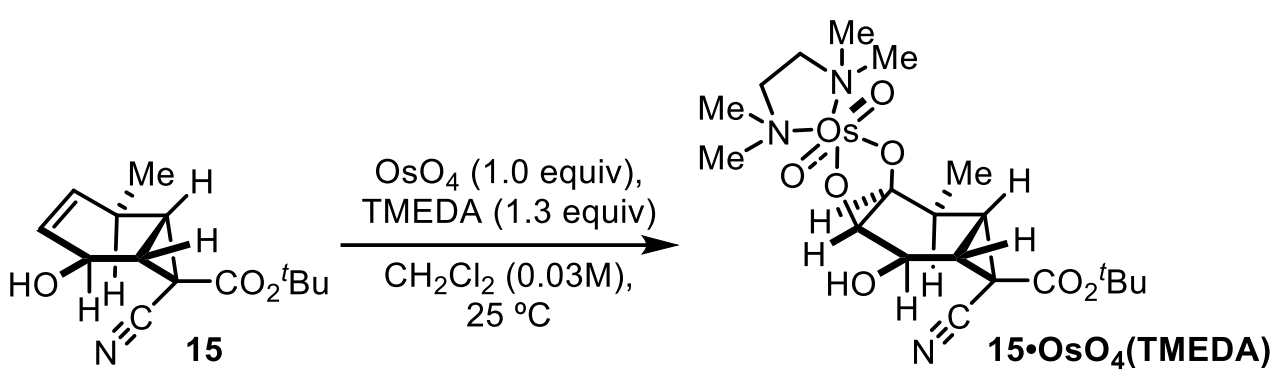

15•OsO ${ }_{4}$ (TMEDA) : Allylic alcohol $15(12.6 \mathrm{mg}, 0.0505 \mathrm{mmol})$ and $N, N, N^{\prime}, N^{\prime}$-tetramethylethylenediamine $(10 \mu \mathrm{L}, 0.067$ mmol, 1.3 equiv) were added to an open 1-dram vial with stir flea and then dissolved in methylene chloride ( $1 \mathrm{~mL}$, $0.051 \mathrm{M}$ with respect to alcohol). The vial was sealed with a septum and the atmosphere was exchanged with nitrogen. The solution was cooled to $-78{ }^{\circ} \mathrm{C}$. Osmium tetroxide $(12.8 \mathrm{mg}, 0.0505 \mathrm{mmol}, 1.0$ equiv) was dissolved in $500 \mu \mathrm{L}$ of methylene chloride and then added dropwise, by syringe, to the pot. The cooling bath was removed and the dark brown reaction was allowed to warm to ambient temperature with stirring for $15 \mathrm{~min}$. The septum was removed and the solvent was allowed to evaporate in the open fume hood. The black residue was purified by flash chromatography on silica $\left(100 \% \mathrm{CH}_{2} \mathrm{Cl}_{2}->10 \% \mathrm{MeOH} / \mathrm{CH}_{2} \mathrm{Cl}_{2}\right.$ ) to give a brown oil. Diethyl ether was added to promote solidification of the oil and then the suspension was concentrated in vacuo. Product osmate ester $15 \bullet \mathrm{OsO}_{4}(\mathrm{TMEDA})$ was isolated as a brown solid ( $24.8 \mathrm{mg}, 83 \%$ yield). X-ray quality crystals were obtained by room temperature vapor diffusion of pentanes into a $\mathrm{CDCl}_{3}$ solution of $\mathbf{1 5} \bullet^{-\mathrm{OsO}_{4}}$ (TMEDA) $(20 \mathrm{mg})$ that had been filtered through a $13 \mathrm{~mm}$ diameter syringe filter $(0.45 \mu \mathrm{m}$ PTFE membrane).

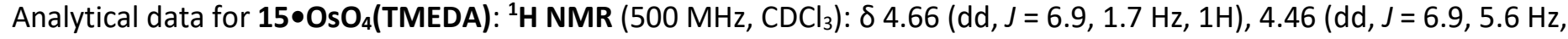
$1 \mathrm{H}), 3.85(\mathrm{dt}, J=9.0,5.6 \mathrm{~Hz}, 1 \mathrm{H}), 3.68(\mathrm{~d}, J=9.0 \mathrm{~Hz}, 1 \mathrm{H}), 3.20-3.01(\operatorname{app~m}, 4 \mathrm{H}), 2.89(\operatorname{app~s}, 6 \mathrm{H}), 2.88(\mathrm{~s}, 3 \mathrm{H}), 2.86(\mathrm{~s}$, $3 \mathrm{H}), 2.04(\mathrm{dd}, J=9.1,5.6 \mathrm{~Hz}, 1 \mathrm{H}), 1.79(\mathrm{app} \mathrm{m}, 2 \mathrm{H}), 1.47(\mathrm{~s}, 9 \mathrm{H}), 1.36(\mathrm{~d}, J=6.3 \mathrm{~Hz}, 3 \mathrm{H}) \mathrm{ppm} ;{ }^{13} \mathrm{C}\left(121 \mathrm{MHz}, \mathrm{CDCl}_{3}\right) \delta$ $166.7,115.9,92.7,86.7,83.3,66.8,64.5,63.9,52.5,52.1,51.43,51.41,36.4,34.1,31.4,27.9,26.1,17.0$ ppm; IR (thin film, KBr, cm ${ }^{-1}$ ) 3438(b), 3231(b), 2979, 2929, 2871, 2236, 1722, 1475, 1457, 1394, 1370, 1299, 1253, 1159, 1071, 1015, $976,959,910,880,838,798,731,647,617,556 ; \mathrm{TLC}\left(10: 90 \mathrm{MeOH}: \mathrm{CH}_{2} \mathrm{Cl}_{2}\right) R_{\mathrm{f}}=0.6 ; \mathrm{mp} 163^{\circ} \mathrm{C}$ (decomp).

HRMS (ESI+) Monomer: Calculated for $\left[\mathrm{C}_{20} \mathrm{H}_{36} \mathrm{~N}_{3} \mathrm{O}_{7}{ }^{192} \mathrm{Os}\right]^{+}\left(\left[\mathrm{M}\left({ }^{192} \mathrm{Os}\right)+\mathrm{H}\right]^{+}\right): 622.21625$, Found: 622.2153; Calculated for $\left[\mathrm{C}_{20} \mathrm{H}_{36} \mathrm{~N}_{3} \mathrm{O}_{7}{ }^{190} \mathrm{Os}\right]^{+}\left(\left[\mathrm{M}\left({ }^{190} \mathrm{Os}\right)+\mathrm{H}\right]^{+}\right): 620.213212$, Found: 620.2176; Calculated for $\left[\mathrm{C}_{20} \mathrm{H}_{36} \mathrm{~N}_{3} \mathrm{O}_{7}{ }^{189} \mathrm{Os}\right]^{+}\left(\left[\mathrm{M}\left({ }^{189} \mathrm{Os}\right)+\mathrm{H}\right]^{+}\right)$: 619.212907, Found: 619.2123; Calculated for $\left[\mathrm{C}_{20} \mathrm{H}_{36} \mathrm{~N}_{3} \mathrm{O}_{7}{ }^{188} \mathrm{Os}\right]^{+}\left(\left[\mathrm{M}\left({ }^{188} \mathrm{Os}\right)+\mathrm{H}\right]^{+}\right)$: 618.210633, Found: 618.20980; Calculated for $\left[\mathrm{C}_{20} \mathrm{H}_{36} \mathrm{~N}_{3} \mathrm{O}_{7}{ }^{187} \mathrm{Os}\right]^{+}\left(\left[\mathrm{M}\left({ }^{187} \mathrm{Os}\right)+\mathrm{H}\right]^{+}\right): 617.210511$, Found: 617.2095; Calculated for $\left[\mathrm{C}_{20} \mathrm{H}_{36} \mathrm{~N}_{3} \mathrm{O}_{7}{ }^{186} \mathrm{Os}\right]^{+}$ $\left(\left[\mathrm{M}\left({ }^{186} \mathrm{Os}\right)+\mathrm{H}\right]\right)^{+}:$616.208615, Found: 616.20750;

Dimer (+H): Calculated for $\left[\mathrm{C}_{40} \mathrm{H}_{71} \mathrm{~N}_{6} \mathrm{O}_{14}{ }^{192} \mathrm{Os}_{2}\right]^{+}\left(\left[2 \mathrm{M}\left({ }^{192} \mathrm{Os}\right)+\mathrm{H}\right]^{+}\right)$: 1243.425221 , Found: 1243.4257 ; Calculated for $\left[\mathrm{C}_{40} \mathrm{H}_{71} \mathrm{~N}_{6} \mathrm{O}_{14}{ }^{192} \mathrm{Os}^{190} \mathrm{Os}\right]^{+}\left(\left[2 \mathrm{M}\left({ }^{192} \mathrm{Os},{ }^{190} \mathrm{Os}\right)+\mathrm{H}\right]^{+}\right): 1241.422184$, Found: 1241.42240 ; Calculated for $\left[\mathrm{C}_{40} \mathrm{H}_{71} \mathrm{~N}_{6} \mathrm{O}_{14}{ }^{190} \mathrm{Os}_{2}\right]^{+}$ $\left(\left[2 \mathrm{M}\left({ }^{190} \mathrm{Os}\right)+\mathrm{H}\right]^{+}\right) /\left[\mathrm{C}_{40} \mathrm{H}_{71} \mathrm{~N}_{6} \mathrm{O}_{14}{ }^{190} \mathrm{Os}^{188} \mathrm{Os}\right]^{+}\left(\left[2 \mathrm{M}\left({ }^{190} \mathrm{Os},{ }^{188} \mathrm{Os}\right)+\mathrm{H}\right]^{+}\right)$: 1239.419148, 1239.419605: Found: 1239.41960;

Dimer (+Na): Calculated for $\left[\mathrm{C}_{40} \mathrm{H}_{70} \mathrm{~N}_{6} \mathrm{O}_{14}{ }^{192} \mathrm{Os}_{2} \mathrm{Na}\right]^{+}\left(\left[2 \mathrm{M}\left({ }^{192} \mathrm{Os}\right)+\mathrm{Na}\right]^{+}\right)$: 1266.415021 , Found: 1266.40800 ; Calculated for $\left[\mathrm{C}_{40} \mathrm{H}_{70} \mathrm{~N}_{6} \mathrm{O}_{14}{ }^{192} \mathrm{Os}^{189} \mathrm{OsNa}\right]^{+}\left(\left[2 \mathrm{M}\left({ }^{192} \mathrm{Os},{ }^{189} \mathrm{Os}\right)+\mathrm{Na}\right]^{+}\right)$: 1263.411679, Found: 1263.40380; Calculated for 
$\left[\mathrm{C}_{40} \mathrm{H}_{70} \mathrm{~N}_{6} \mathrm{O}_{14}{ }^{190} \mathrm{Os}^{189} \mathrm{OsNa}\right]^{+}\left(\left[2 \mathrm{M}\left({ }^{190} \mathrm{Os}^{189} \mathrm{Os}\right)+\mathrm{Na}\right]^{+}\right): 1261.408642$, Found: 1261.40110 ; Calculated for $\left[\mathrm{C}_{40} \mathrm{H}_{70} \mathrm{~N}_{6} \mathrm{O}_{14}{ }^{189} \mathrm{Os}{ }_{2} \mathrm{Na}\right]^{+}\left(\left[2 \mathrm{M}\left({ }^{189} \mathrm{Os}\right)+\mathrm{Na}\right]^{+}\right) /\left[\mathrm{C}_{40} \mathrm{H}_{70} \mathrm{~N}_{6} \mathrm{O}_{14}{ }^{190} \mathrm{Os}^{188} \mathrm{OsNa}\right]^{+}\left(\left[2 \mathrm{M}\left({ }^{190} \mathrm{Os}^{188} \mathrm{Os}\right)+\mathrm{Na}\right]^{+}\right): 1260.408337$, 1260.406369, Found: 1260.40090; Calculated for $\left[\mathrm{C}_{40} \mathrm{H}_{70} \mathrm{~N}_{6} \mathrm{O}_{14}{ }^{190} \mathrm{Os}^{187} \mathrm{OsNa}\right]^{+}\left(\left[2 \mathrm{M}\left({ }^{190} \mathrm{Os},{ }^{187} \mathrm{Os}\right)+\mathrm{Na}\right]^{+}\right) /$ $\left[\mathrm{C}_{40} \mathrm{H}_{70} \mathrm{~N}_{6} \mathrm{O}_{14}{ }^{189} \mathrm{Os}^{188} \mathrm{OsNa}\right]^{+}\left(\left[2 \mathrm{M}\left({ }^{189} \mathrm{Os},{ }^{188} \mathrm{Os}\right)+\mathrm{Na}\right]^{+}\right): 1259.406247,1259.406064$, Found: $1259.39890 ;$ $\left[\mathrm{C}_{40} \mathrm{H}_{70} \mathrm{~N}_{6} \mathrm{O}_{14}{ }^{189} \mathrm{Os}^{187} \mathrm{OsNa}\right]^{+}\left(\left[2 \mathrm{M}\left({ }^{189} \mathrm{Os},{ }^{187} \mathrm{Os}\right)+\mathrm{Na}\right]^{+}\right): /\left[\mathrm{C}_{40} \mathrm{H}_{70} \mathrm{~N}_{6} \mathrm{O}_{14}{ }^{188} \mathrm{Os}_{2} \mathrm{Na}\right]^{+}\left(\left[2 \mathrm{M}\left({ }^{188} \mathrm{Os}\right)+\mathrm{Na}\right]^{+}\right): 1258.405942$, 1258.403790, Found: 1258.39790.
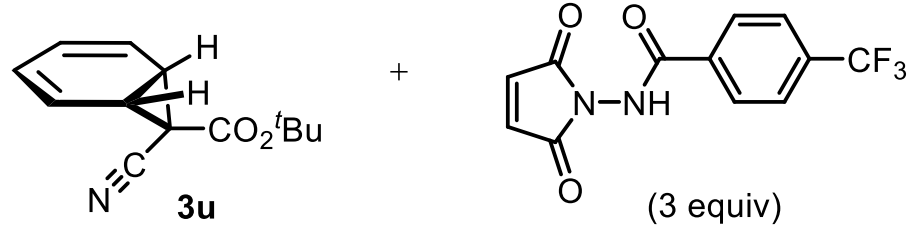
Brine $(0.13 \mathrm{M})$, $110{ }^{\circ} \mathrm{C}$

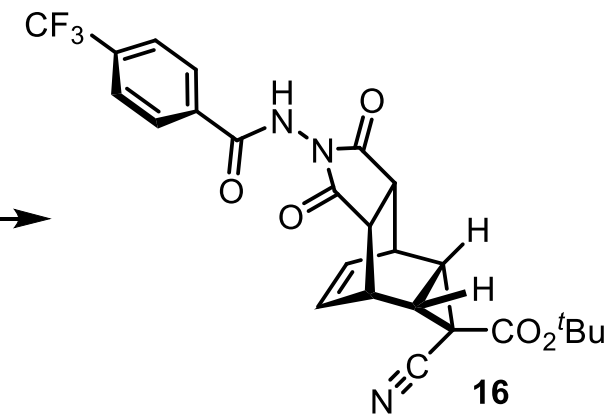

tert-butyl (3aR,4aR,5aS,6aS)-5-cyano-1,3-dioxo-2-(4-(trifluoromethyl) benzamido)-1,2,3,3a,4,4a,5,5a,6,6a-decahydro4,6-ethenocyclopropa [f] iso indole-5-carboxylate (16) : Norcaradiene $\mathbf{3 u}(45 \mathrm{mg}, 0.20 \mathrm{mmol})$ and $\mathrm{N}$-(2,5-dioxo-2,5dihydro-1H-pyrrol-1-yl)-4-(trifluoromethyl)benzamide ( $177 \mathrm{mg}, 0.6 \mathrm{mmol}, 3$ equiv.) were placed into a microwave reactor tube and sparged with argon. Brine $(1.5 \mathrm{~mL})$ was added and the suspension was subjected to microwave heating $\left(200 \mathrm{~W}, 110^{\circ} \mathrm{C}\right)$ for $10 \mathrm{~min}$. After cooling, DMF $(5 \mathrm{~mL})$ was added to provide a homogeneous solution which was directly concentrated in vacuo. Residual DMF was azeotropically removed using heptane until a solid residue was obtained, where the residual sodium chloride salt was removed by filtration of the initial binary solution. The yellow, crude residue was washed with diethyl ether to remove excess maleimide until a white solid was obtained, identified to be pure 16 [94 $\mathrm{mg}, 89 \%$ yield].

Analytical data for 16: ${ }^{1} \mathrm{H}$ NMR (400 MHz, d7-DMF): $\delta 11.61$ (bs, $\left.1 \mathrm{H}\right), 8.27$ (d, J=8.1 Hz, 2H), $7.99(\mathrm{~d}, J=8.2 \mathrm{~Hz}, 2 \mathrm{H}), 6.13$ (appt, $J=4.1 \mathrm{~Hz}, 2 \mathrm{H}$ ), 3.86 (bs, 2H), $3.54(\mathrm{~m}, 2 \mathrm{H}), 2.55(\mathrm{~m}, 2 \mathrm{H}), 1.47$ (s, 9H) ppm; ${ }^{13} \mathrm{C}$ NMR (151 MHz, d $\left.\mathrm{d}_{7}-\mathrm{DMF}\right): \delta 174.7$, $166.6,164.9,132.0,129.9,127.0,125.2$ (q, $J=272 \mathrm{~Hz}$ ), 117.5, 84.6, 44.1, 43.6, 33.8, 33.6, 32.3, 28.1, 22.1 ppm; ${ }^{19} \mathrm{~F} \mathrm{NMR}$ (564 MHz, d7-DMF): $\delta$-63.6 ppm; IR (thin film, KBr, cm ${ }^{-1}$ ) 3415, 2095, 1730, 1644, 1372, 1325, 1304, 1264, 1208, 1163, 1124, 529, 516; HRMS (ESI-): Calculated for $\left[\mathrm{C}_{25} \mathrm{H}_{21} \mathrm{~N}_{3} \mathrm{O}_{5} \mathrm{~F}_{3}\right]^{-}([\mathrm{M}-\mathrm{H}]): 500.1439$, Found: 500.1437; $\mathbf{m p} 219-221^{\circ} \mathrm{C}$.

\section{Isotopic Labeling Study}

Mono-deuterated toluene $\mathbf{2} \mathbf{v}$ was prepared according to precedent. ${ }^{8}$ Norcaradiene $\mathbf{3} \mathbf{v} / \mathbf{3} \mathbf{v}$ ' was obtained according to General Procedure A, using 10 equiv of $2 \mathbf{v}$. The $k_{H} / k_{D}$ was determined by the regioisomeric ratio measured in the ${ }^{2} \mathrm{H}$ NMR spectrum of the crude reaction mixture upon concentration in $\mathrm{CCl}_{4}$. For characterization, the crude mixture was purified by flash chromatography on silica (95:5 Hexanes:MTBE) to obtain a mixture of $\mathbf{3 v} \mathbf{3} \mathbf{3} \mathbf{v}$ ' as a clear, colorless oil.

Analytical data for 3v/3v': ${ }^{1} \mathrm{H}$ NMR $\left(500 \mathrm{MHz}, \mathrm{CDCl}_{3}\right): \delta 6.27(\mathrm{~m}, 1 \mathrm{H}), 6.18(\mathrm{dd}, J=9.6,5.3 \mathrm{~Hz}, 1 \mathrm{H})$ xii $, 5.91(\mathrm{~m}, 1 \mathrm{H}), 3.08(\mathrm{~m}$, 2H), $1.96(\mathrm{~m}, 3 \mathrm{H}), 1.52(\mathrm{~m}, 9 \mathrm{H}) ;{ }^{2} \mathrm{H} \mathrm{NMR}^{\mathrm{xiii}}\left(500 \mathrm{MHz}, \mathrm{CCl}_{4}\right): \delta 6.32(\mathrm{~s}, 1 \mathrm{H}), 3.10(\mathrm{~s}, 1 \mathrm{H}) ;{ }^{13} \mathrm{C} \mathrm{NMR}\left(126 \mathrm{MHz}, \mathrm{CDCl}_{3}\right): \delta$

\footnotetext{
xii Specific resonance is for the $\mathrm{sp}^{3} \mathrm{C}-\mathrm{D}$ compound.

xiii Ratio observed in ${ }^{2} \mathrm{H}$ of the purified sample differs due to chromatographic separation of the two isomers, leading to partial enrichment.
} 
168.9, 135.8, 131.1, 130.9, 122.3, 117.2, 117.1, 113.1, 83.9, 38.9, 37.4, 37.4, 28.0, 21.6, 13.6, 13.6; HRMS (ESI-): Calculated for $\left[\mathrm{C}_{14} \mathrm{H}_{15} \mathrm{NO}_{2}^{2} \mathrm{H}\right]^{-2}([\mathrm{M}-\mathrm{H}]): 231.1248$, Found: 231.1255 .

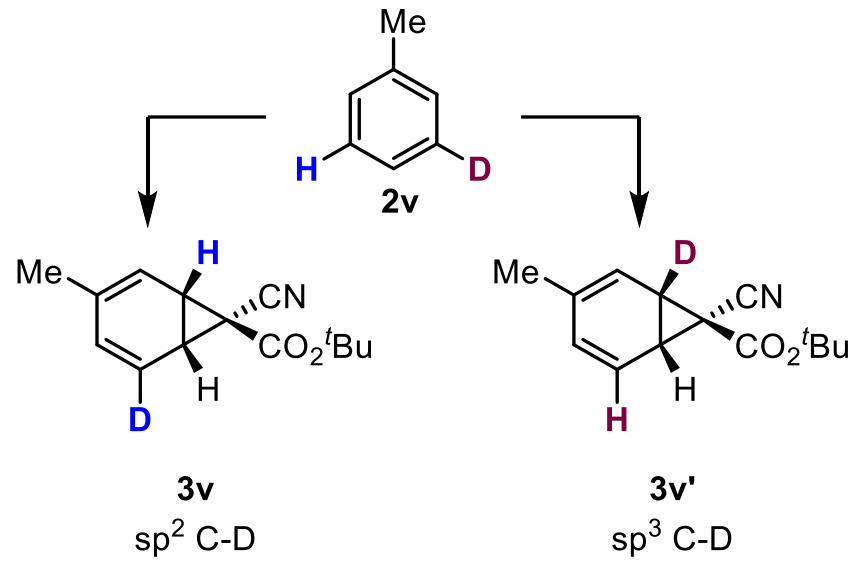

\begin{tabular}{|l|l|l|l|}
\hline Entry & Integral $\mathrm{sp}^{2} \mathrm{C}-\mathrm{D}$ 3v & Integral $\mathrm{sp}^{3} \mathrm{C}-\mathrm{D}$ 3v' & $\mathrm{k}_{\mathrm{h}} / \mathrm{k}_{\mathrm{D}}$ \\
\hline 1 & 1.00 & 0.96 & 1.04 \\
\hline 2 & 1.00 & 0.92 & 1.08 \\
\hline 3 & 1.00 & 0.96 & 1.04 \\
\hline 4 & 1.00 & 0.98 & 1.02 \\
\hline
\end{tabular}




\section{Racemization Studies of Norcaradiene 3c}

Procedure: Two solutions were separately prepared using a common, freshly prepared stock solution of norcaradiene 3c $\left(100 \mathrm{mg} 3 \mathrm{c}\right.$ in $2.08 \mathrm{~mL}$ of $\mathrm{CDCl}_{3}$ ). An initial assay of the enantiomeric ratio of $3 \mathrm{c}$ was obtained immediately after solution preparation.

- A control solution of norcaradiene $3 \mathrm{c}$ was prepared from the $500 \mu \mathrm{L}$ of the $3 \mathrm{c}$ stock solution by diluting with $\mathrm{CDCl}_{3}$ to a total volume of $600 \mu \mathrm{L}(24.0 \mathrm{mg} \mathrm{3c}, 0.104 \mathrm{mmol} ; 600 \mu \mathrm{L} \mathrm{CDCl}, 0.17 \mathrm{M})$ at room temperature in a 1dram vial containing a stir flea.

- A test solution of norcaradiene $3 \mathrm{c}$ was prepared by combining $500 \mu \mathrm{L}$ of the $\mathbf{3 c}$ stock solution (24.0 mg of 3c, $0.104 \mathrm{mmol})$ and $100 \mu \mathrm{L}$ of hexafluoroisopropanol $\left(1: 5 \mathrm{CDCl}_{3}:\left(\mathrm{CF}_{3}\right)_{2} \mathrm{CHOH}, 600 \mu \mathrm{L}, 0.17 \mathrm{M}\right)$ at room temperature in a 1-dram vial containing a stir flea.

The solutions were stirred at ambient temperature. The enantiomeric ratios of the samples were assayed by chiral HPLC (95:5 hexanes:'PrOH; Daicel CHIRALPAK IC). HPLC samples were prepared by concentration of $50 \mu \mathrm{L}$ of the respective solution in vacuo, followed by standard preparation using 90:10 hexanes: ${ }^{\mathrm{P} O \mathrm{OH}}$ as diluent.

\section{- $\quad$ Trace of Stock Solution at $\mathrm{t}=\mathbf{0}$}

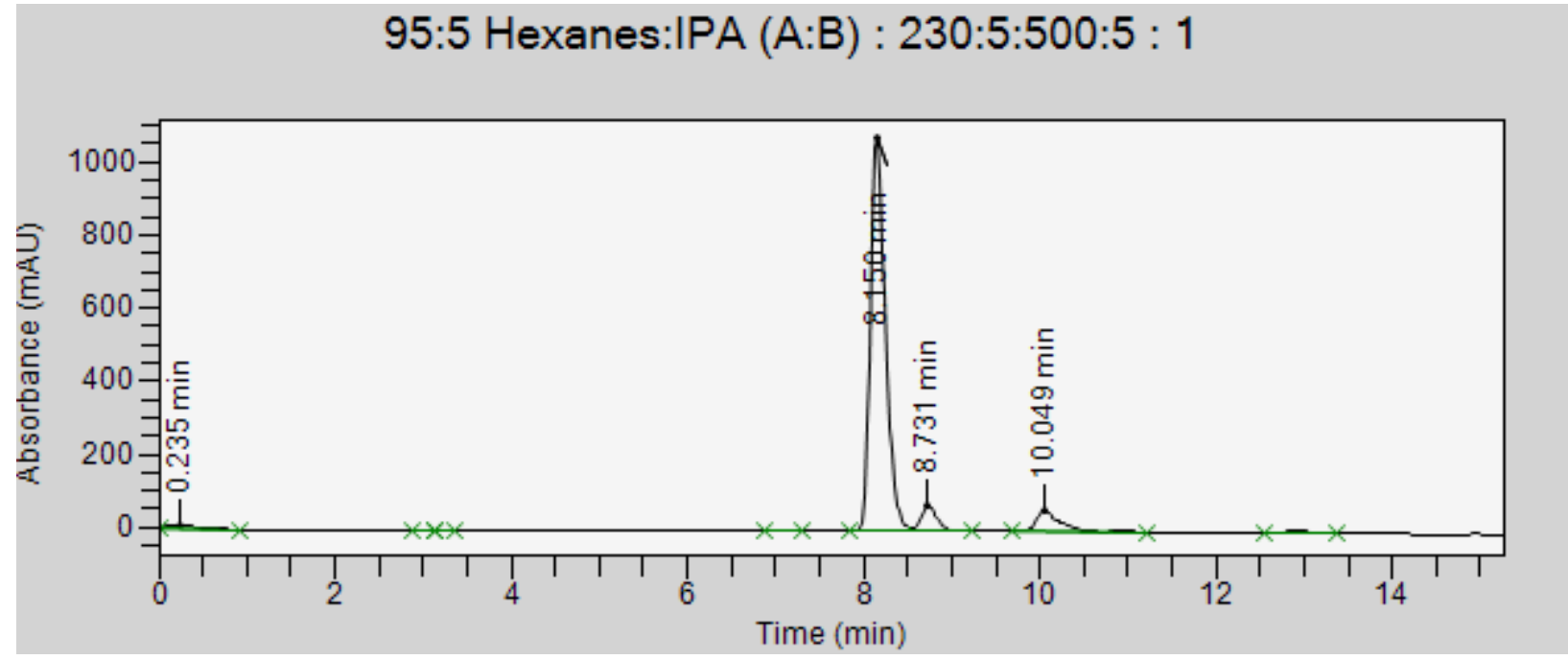

\begin{tabular}{lll}
\hline \hline $\begin{array}{l}\text { Retention Time } \\
(\mathrm{min})\end{array}$ & $\begin{array}{l}\text { Area } \\
(\mathrm{mAU} \bullet \min )\end{array}$ & Area \% \\
\hline \hline 8.150 & 12486694.21 & 91.9 \\
10.049 & 1103199.66 & 8.1
\end{tabular}


- Trace of control solution at $\mathrm{t}=\mathbf{5 0 0} \mathrm{min}$

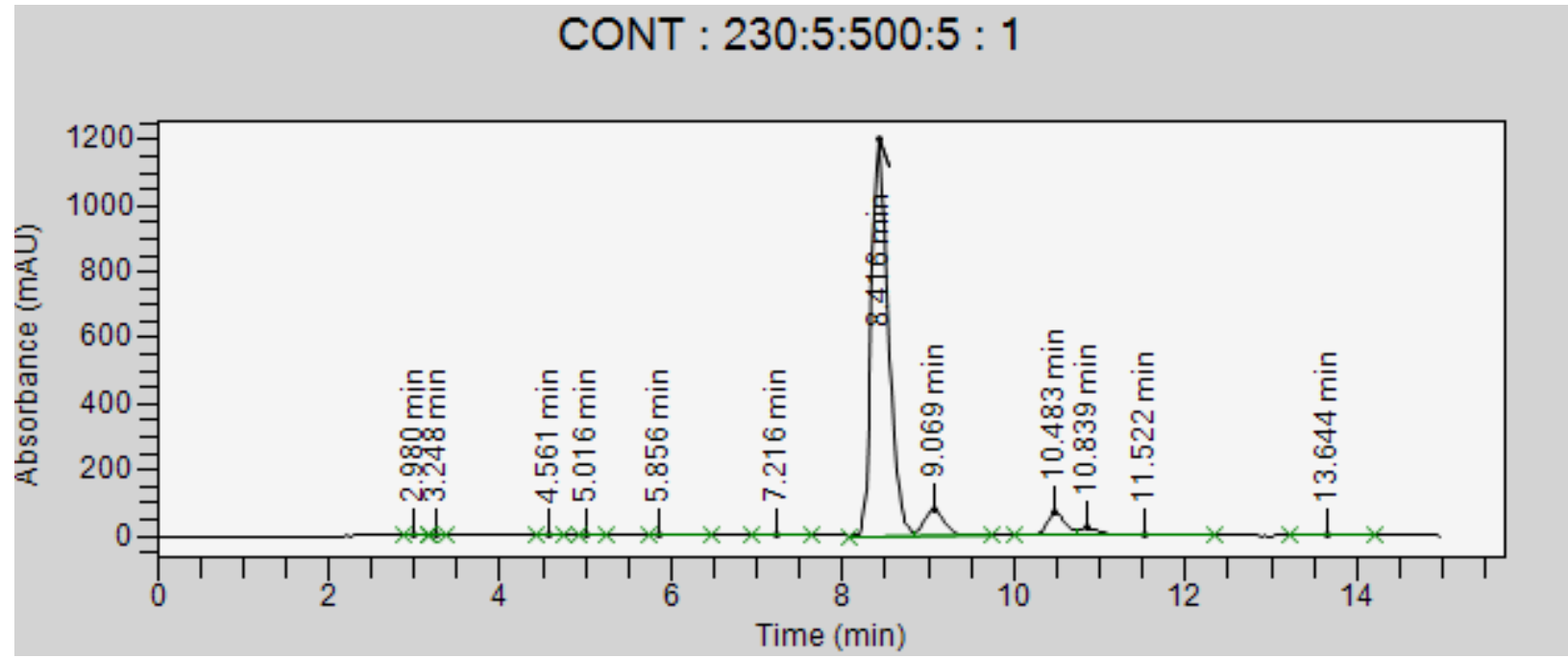

\begin{tabular}{lll}
\hline $\begin{array}{l}\text { Retention Time } \\
(\mathrm{min})\end{array}$ & $\begin{array}{l}\text { Area } \\
(\mathrm{mAU} \bullet \min )\end{array}$ & Area \% \\
\hline \hline 8.416 & 18403605.79 & 92.3 \\
10.483 & 1517097.46 & 7.7
\end{tabular}

- Trace of 5:1 $\mathrm{CDCl}_{3}:\left(\mathrm{CF}_{3}\right) \mathrm{CHOH}$ solution at $\mathrm{t}=120 \mathrm{~min}$

BUCH_SHORTRUN_COL3_95_5_2H : 215:5:500:5 : 1

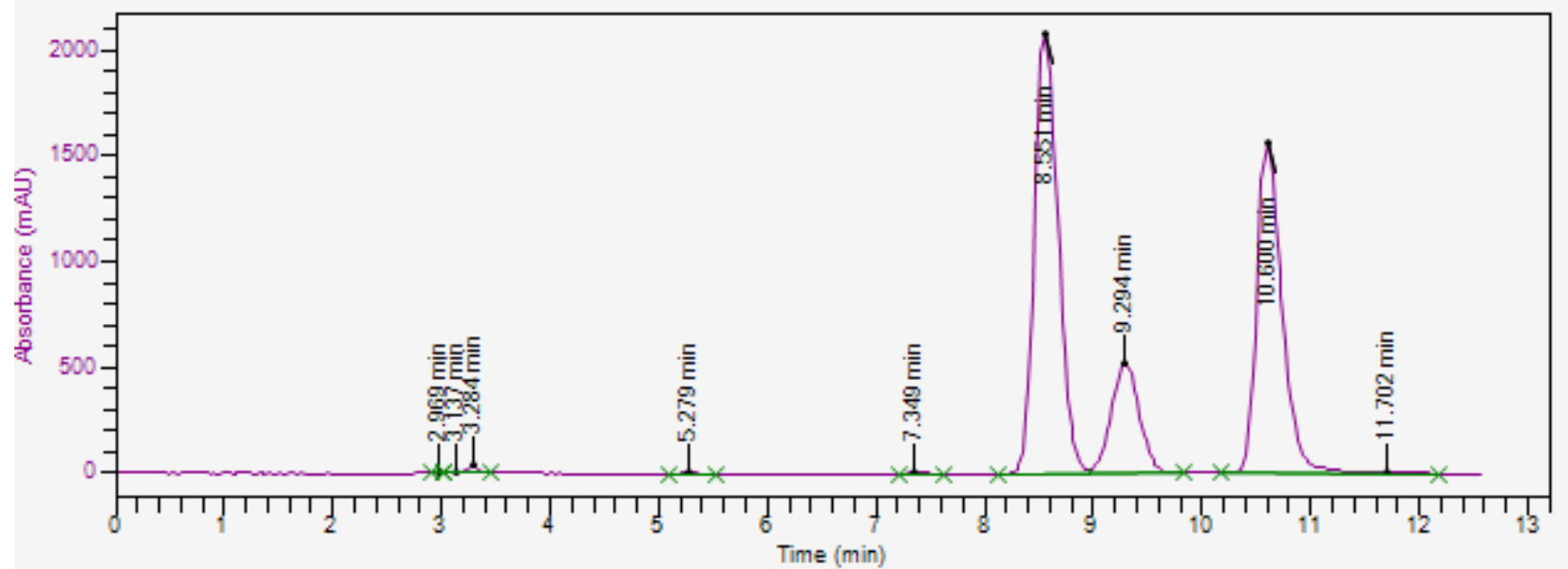

\begin{tabular}{lll}
\hline \hline $\begin{array}{l}\text { Retention Time } \\
(\mathrm{min})\end{array}$ & $\begin{array}{l}\text { Area } \\
(\mathrm{mAU} \bullet \min )\end{array}$ & Area \% \\
\hline \hline 8.551 & 31644504.71 & 51.2 \\
10.600 & 30139694.88 & 48.8
\end{tabular}

Mechanism of Racemization: 
A potential mechanism to describe the racemization is a ring-opening/ring-closure process that is facilitated by the highly ionizing hexafluoroisopropyl alcohol. This type of C-C bond scission argument has been used to describe the enantioerosion observed by Doyle and Moody independently in intramolecular Buchner adducts of electron-rich cycloheptatrienes. ${ }^{9}$ Although the methyl group is a significantly weaker donor [hyperconjugative effects] compared to the heteroatom donors [lone pair donation] seen in the Doyle and Moody cases, the enhanced stability of the cyanoacetate enolate would provide enough activation for $\mathrm{C}-\mathrm{C}$ bond heterolysis.

\section{Norcaradiene $\underline{3 c}$ Racemization:}
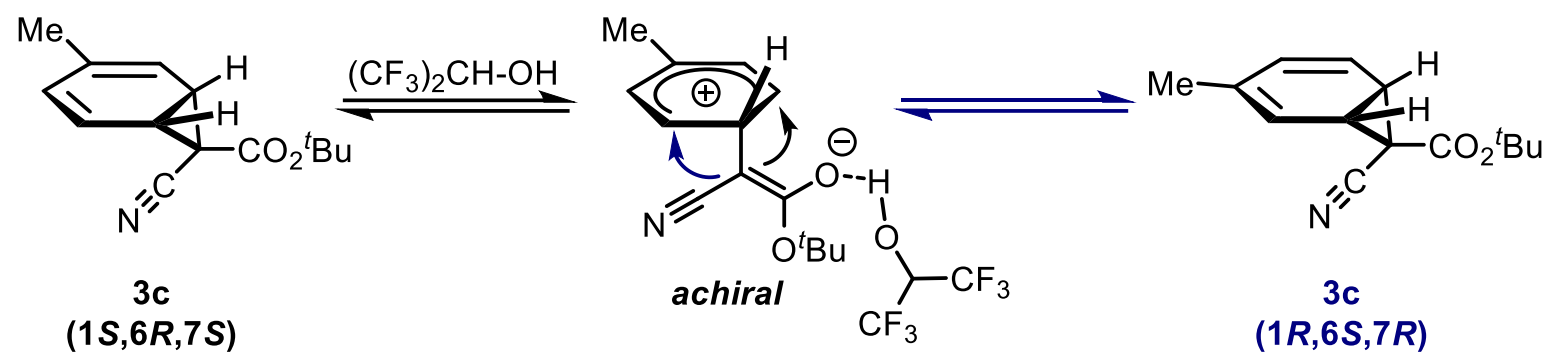
1. (a) Panish, R.; Selvaraj, R.; Fox, J. M. Rh(II)-Catalyzed Reactions of Diazoesters with Organozinc Reagents. Org. Lett. 2015, 17, 3978. (b) Tsutsui, H.; Yamaguchi, Y.; Kitagaki, S.; Nakamura, S.; Anada, M.; Hashimoto, S. Dirhodium(II) Tetrakis[ $N$-tetrafluorophthaloyl-(S)-tert-leucinate]: An Exceptionally Effective Rh(II) Catalyst for Enantiotopically Selective Aromatic C-H Insertions of Diazo Ketoesters. Tetrahedron: Asymmetry 2003, 14, 817.

2. (a) Brook, M.; Balduzzi, S.; Mohamed, M.; Gottardo, C. The Photolytic and Hydrolytic Lability of Sisyl

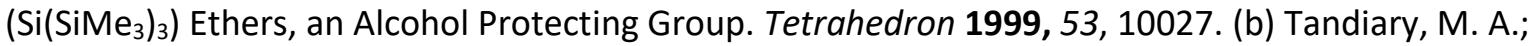
Asano, M.; Hattori, T.; Takehira, S.; Masui, Y.; Onaka, M. Unprecedented Alkylation of Silicon Enolates with Alcohols via Carbenium Ion Formations Catalyzed by Tin Hydroxide-Embedded Montmorillonite. Tetrahedron Letters 2017, 58, 1925. (c) Sun, Q-A.; Lu, Z-H.; Pu, X-Q.; Hu, H-L.; Zhang, J-H.; Yang, X-J. Deoxyalkoxyamination of Alcohols for the Synthesis of $\mathrm{N}$-Alkoxy- $\mathrm{N}$-alkylbenzenesulfonamides. Eur. J. Org. Chem. 2018, 3920. (d) Clavier, H.; Lepronier, A.; Bengobesse-Mintsa, N.; Gatineau, D.; Pellissier, H.; Giordano, L.; Tenaglia, A.; Buono, G. Palladium-Mediated [2+1] Cycloaddition of Norbornene Derivatives with Ynamides. Adv. Synth. Catal. 2013, 355, 403. (e) Bartlett, S. L.; Sohtome, Y.; Hashizume, D.; White, P. S.; Sawamura, M.; Johnson, J. S.; Sodeoka, M. Catalytic Enantioselective [3+2] Cycloaddition of $\alpha$-Keto Ester Enolates and Nitrile Oxides. J. Am. Chem. Soc. 2017, 139, 8661. (f) Siga Technologies, Inc.; Methods of Preparing Tecovirimat. WO2014/28545, February 20, 2014.

3. (a) Bräse, S.; Gil, C.; Knepper, K.; Zimmermann, V. Organic Azides: An Exploding Diversity of a Unique Class of Compounds. Angew. Chem. Int. Ed. 2005, 44, 5188. (b) Archibald, T. Strategies for Safely Handling Industrial Azide Reactions: The Three Traps. Managing Hazardous Reactions and Compounds in Process Chemistry (c) Cavender, C. J.; Shiner, V. J. Trifluoromethanesulfonyl Azide. Its Reaction with Alkyl Amines to Form Alkyl Azides. J. Org. Chem. 1972, 37, 3567. (d) Fischer, N.; Goddard-Borger, E. D; Greiner, R.; Klapötke, T. M.; Skelton, B. W.; Stierstorfer, J. Sensitivities of Some Imidazole-1-Sulfonyl Azide Salts. J. Org. Chem. 2012, 77, 1760. (e) Green, S. P.; Wheelhouse, K. M.; Payne, A. D.; Hallet, J. P. Miller, P. M.; Bull, J. A. Thermal Stability and Explosive Hazard Assessment of Diazo Compounds and Diazo Transfer Reagents. Org. Process Res. Dev. 2020, 24, 67.

4. (a) Cui, X.; Xu, X.; Lu, H.; Zhu, S.; Wojtas, L.; Zhang, X. P. Enantioselective Cyclopropenation of Alkynes with Acceptor/Acceptor-Substituted Diazo Reagents via Co(II)-Based Metalloradical Catalysis. J. Am. Chem. Soc. 2011, 133, 3304. (b) Chiara, J. L.; Suárez, J. R. Synthesis of $\alpha$-Diazo Carbonyl Compounds with the Shelf-Stable Diazo Transfer Reagent Nonafluorobutanesulfonyl Azide. Adv. Synth. Catal. 2011, 353, 575.

5. (a) Kennedy, M.; McKervey, M. A.; Maguire, A. R.; Tuladhar, S. M.; Twohig, M. F. The Intramolecular Buchner Reaction of Aryl Diazoketones. Substituent Effects and Scope in Synthesis. J. Chem. Soc., Perkin Trans. 1 1990, 1047. (b) Sugimura, T.; Kagawa, M.; Ohuchi, N.; Hagiya, K.; Okuyama, T. Preparation of Methoxy-Substituted Optically Active 7-Alkoxycarbonylcycloheptatrienes and Their Acid-Promoted Rearrangements. Bull. Chem. Soc. Jpn. 2005, 78, 671. (c) Betz, W.; Daub, J.; Rapp, K. M. Substituenteneffekte Pericyclischer Reaktionen 1); Synthesen und Reaktionen von 7-monosubstituierten Cycloheptatrienen und Norcaradienen. Justis Liebigs Ann. Chem. 1974, 2089.

6. (a) Klaerner, F. G.; Brassel, B. Stereochemistry of the Thermal Walk Rearrangement of Optically Active 2,7-dimethyl-7-methoxymethyl-1,3,5-cycloheptatriene: 1,5-Carbon Migration with Inversion, No OneCenter Epimerization at C-7. J. Am. Chem. Soc. 1980, 102, 2469. (b) Kless, A.; Nendel, M.; Wilsey, S.; Houk, K. N. Origin of the Preference for the Orbital Symmetry Forbidden Stereochemistry of the 1,5Sigmatropic Shift of Substituted Norcaradienes. J. Am. Chem. Soc. 1999, 121, 4524. 
7. (a) Zhu, J.; Cole, R. B. Formation and Decompositions of Chloride Adduct lons, $[\mathrm{M}+\mathrm{Cl}]^{-}$, in Negative lon Electrospray Ionization Mass Spectrometry. Journal of the American Society for Mass Spectrometry 2000, 11, 932. (b) Wan, E. C. H.; Yu, J. Z. Analysis of Sugars and Sugar Polyols in Atmospheric Aerosols by Chloride Attachment in Liquid Chromatography/Negative Ion Electrospray Mass Spectrometry. Environ. Sci. Technol. 2007, 41, 2459. (c) Boutegrabet, L.; Kanawati, B.; Gebefügi, I.; Peyron, D.; Cayot, P.;

Gougeon, R. D.; Schmitt-Kopplin, P. Attachment of Chloride Anion to Sugars: Mechanistic Investigation and Discovery of a New Dopant for Efficient Sugar Ionization/Detection in Mass Spectrometers. Chem. Eur. J. 2012, 18, 13059.

8. Meić, Z.; Vikić-topić, D.; Güsten, H. Unusual Deuterium Isotope Effects in ${ }^{13} \mathrm{C}$ NMR Spectra of transStilbene. Organic Magnetic Resonance 1984, 22, 237.

9. (a) Xu, X.; Wang, X.; Zavalij, P. Y.; Doyle, M. P. Straightforward Access to the [3.2.2]Nonatriene Structural Framework via Intramolecular Cyclopropenation/Buchner Reaction/Cope Rearrangement Cascade. Org. Lett., 2015, 17, 790. (b) Moody, C. J.; Miah, S.; Slawin, A. M. Z.; Mansfield, D. J.; Richards, I. C. Stereocontrol in the Intramolecular Buchner Reaction of Diazoamides and Diazoesters. J. Chem. Soc., Perkin Trans. 1. 1998, 17, 4067. 
Crude ${ }^{1}$ H NMR Spectra for Analysis of Regioselectivity of Cyclopropanation Reactions

\section{Compound 3a}

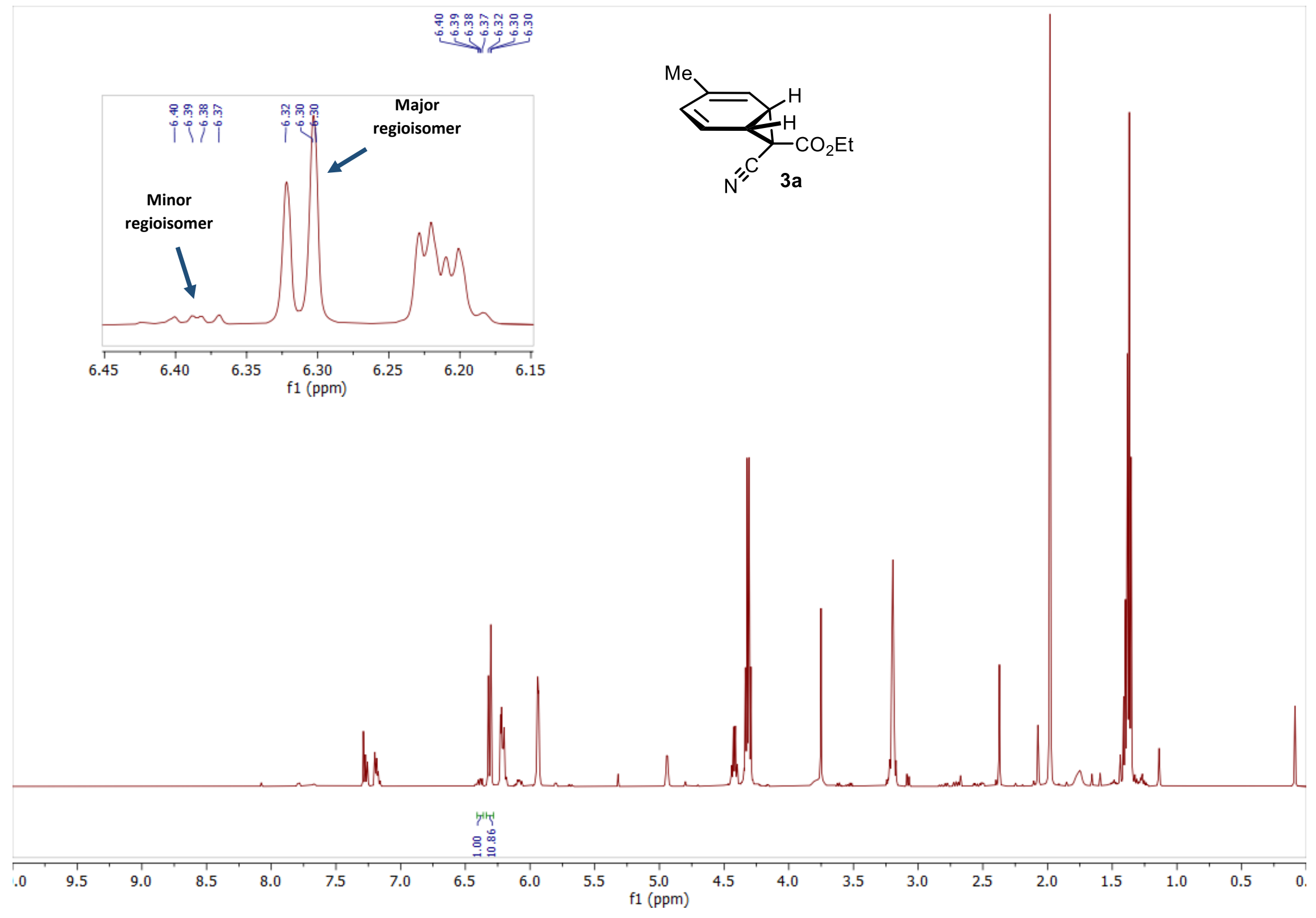




\section{Compound 3b}

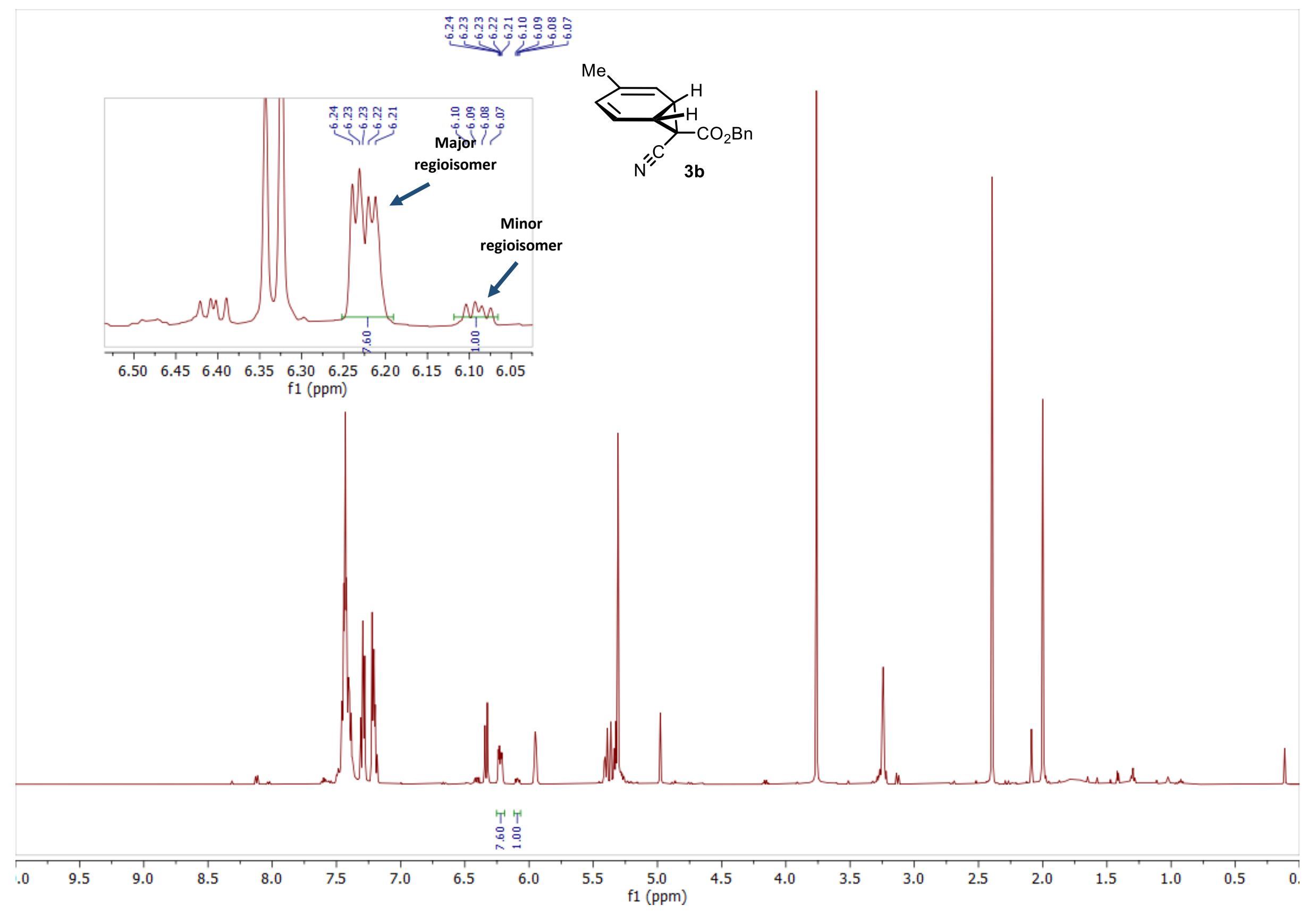




\section{Compound 3c}

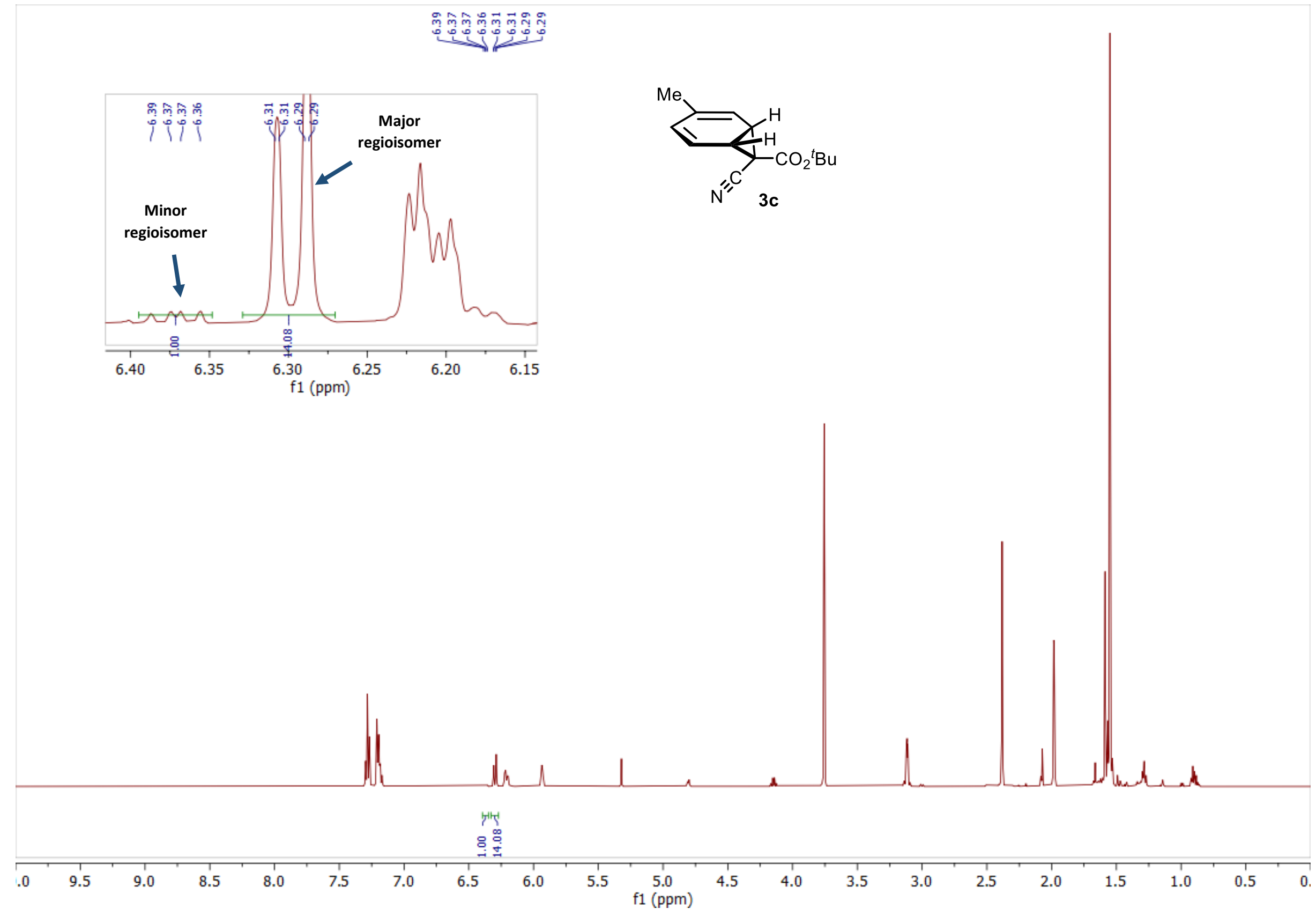




\section{Compound 3d}

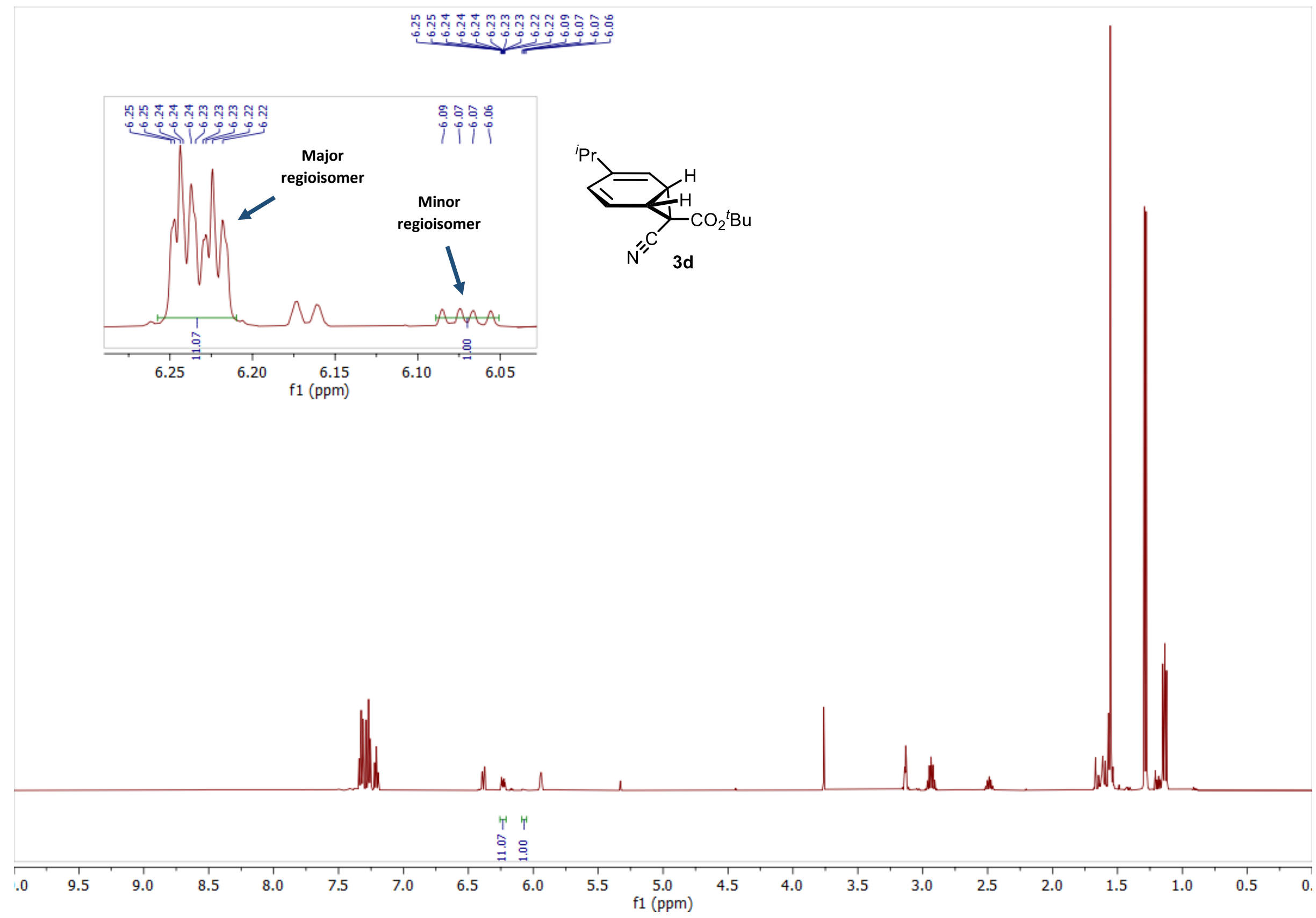


Compound $\mathbf{3 e}$ (contains phenanthrene)

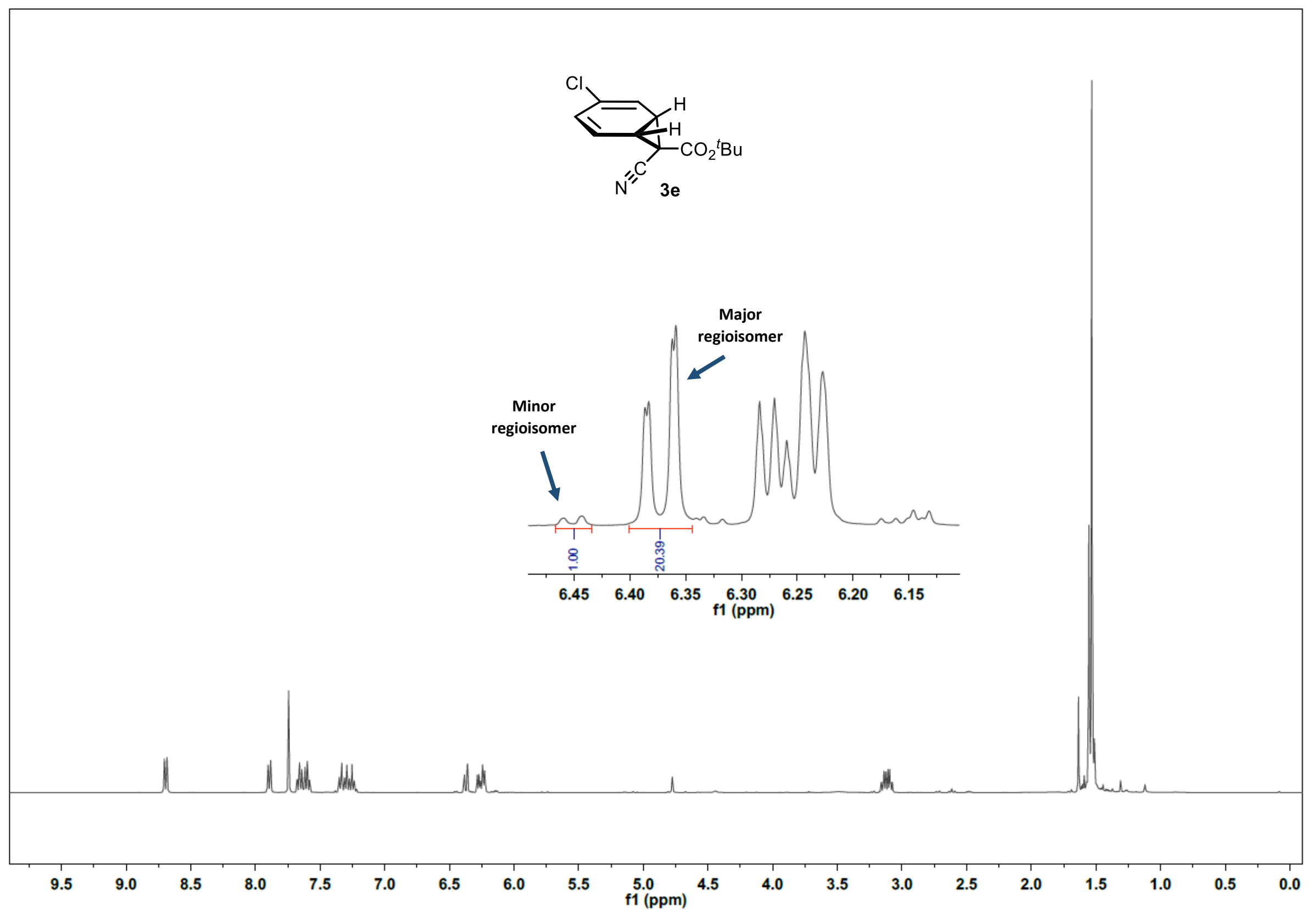


Compound $\mathbf{3 f}$ (contains phenanthrene)

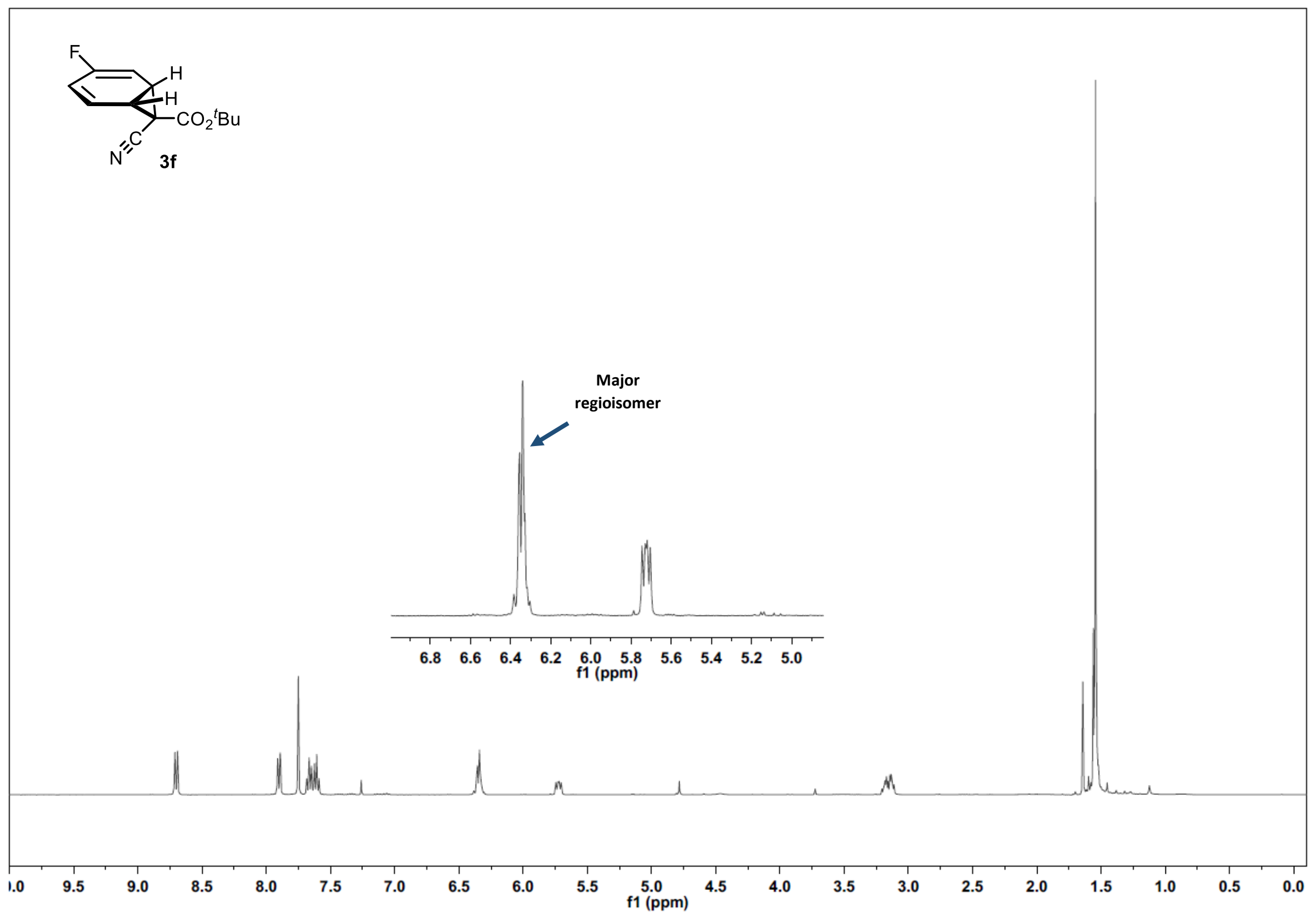




\section{Compound 3g}

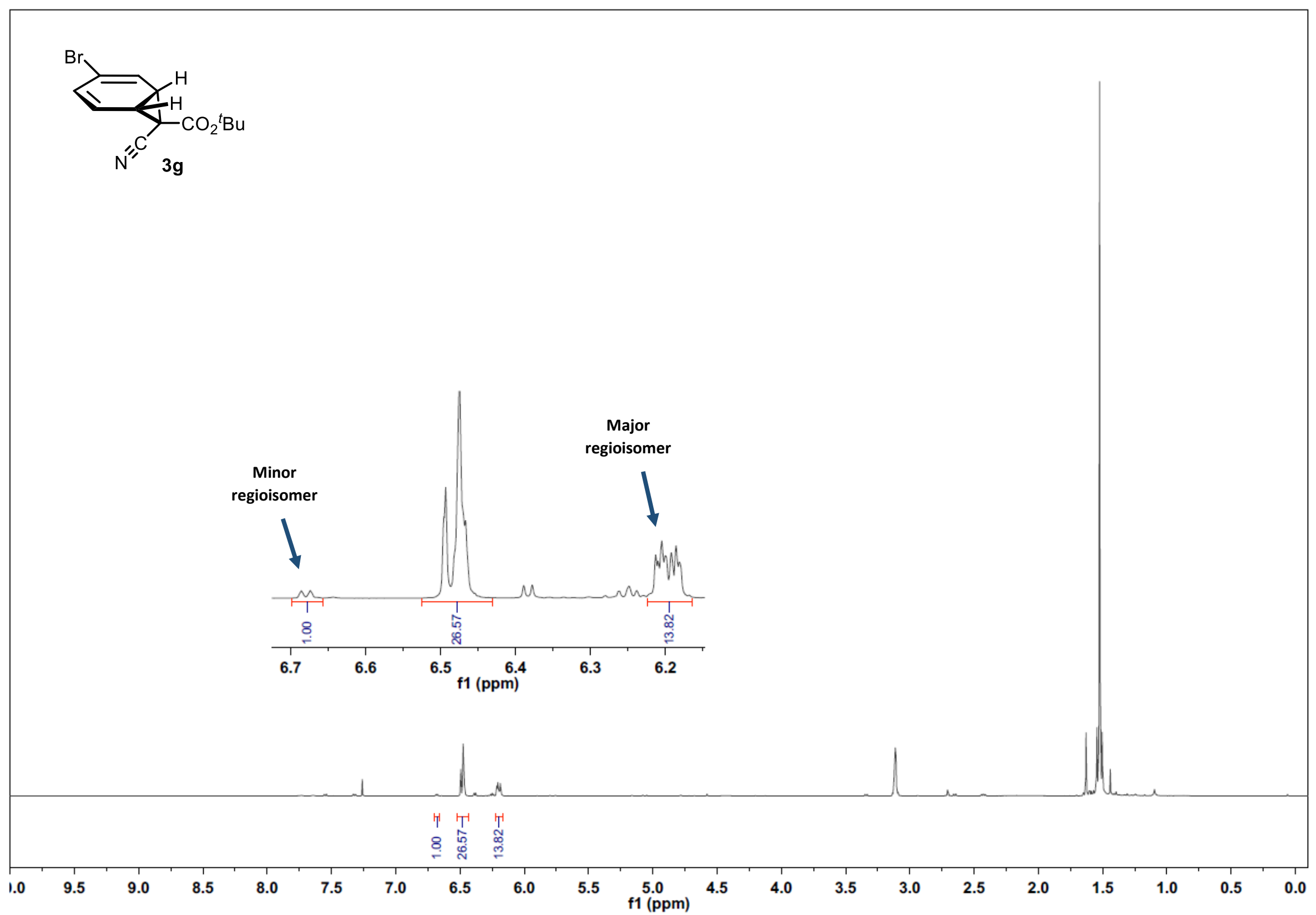




\section{Compound 3h}

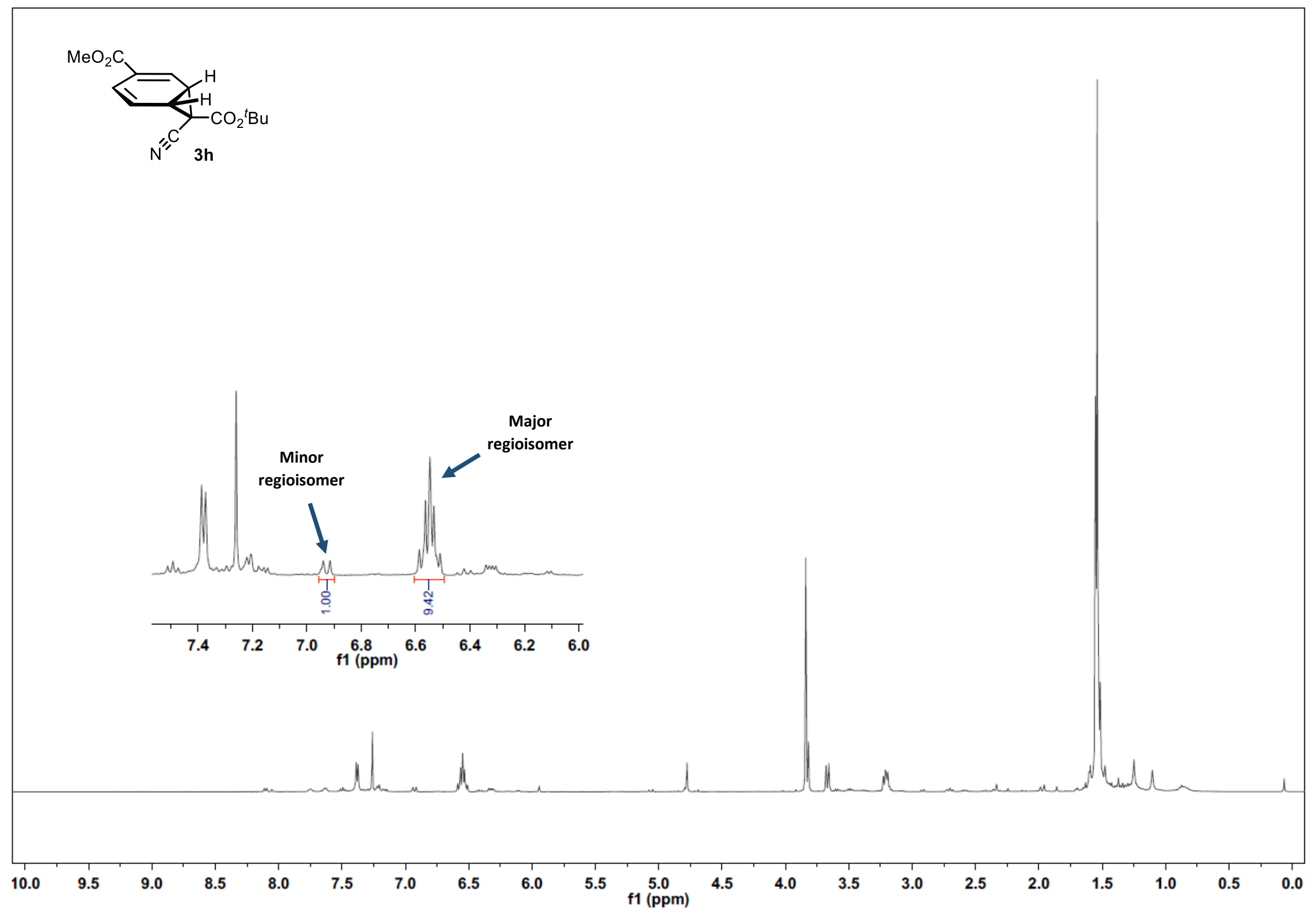


Compound $\mathbf{3 i}$
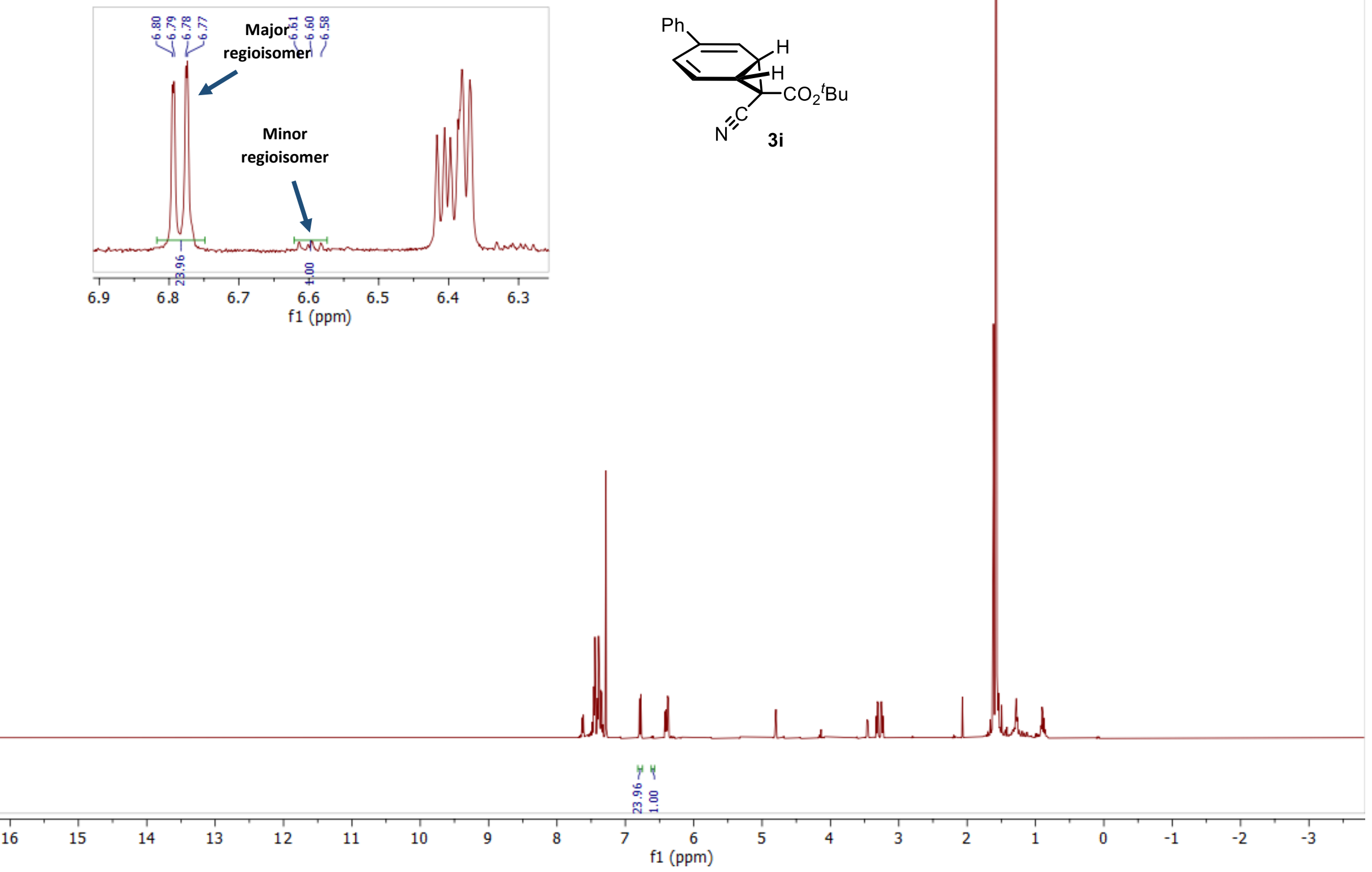
Compound $\mathbf{3 j}$

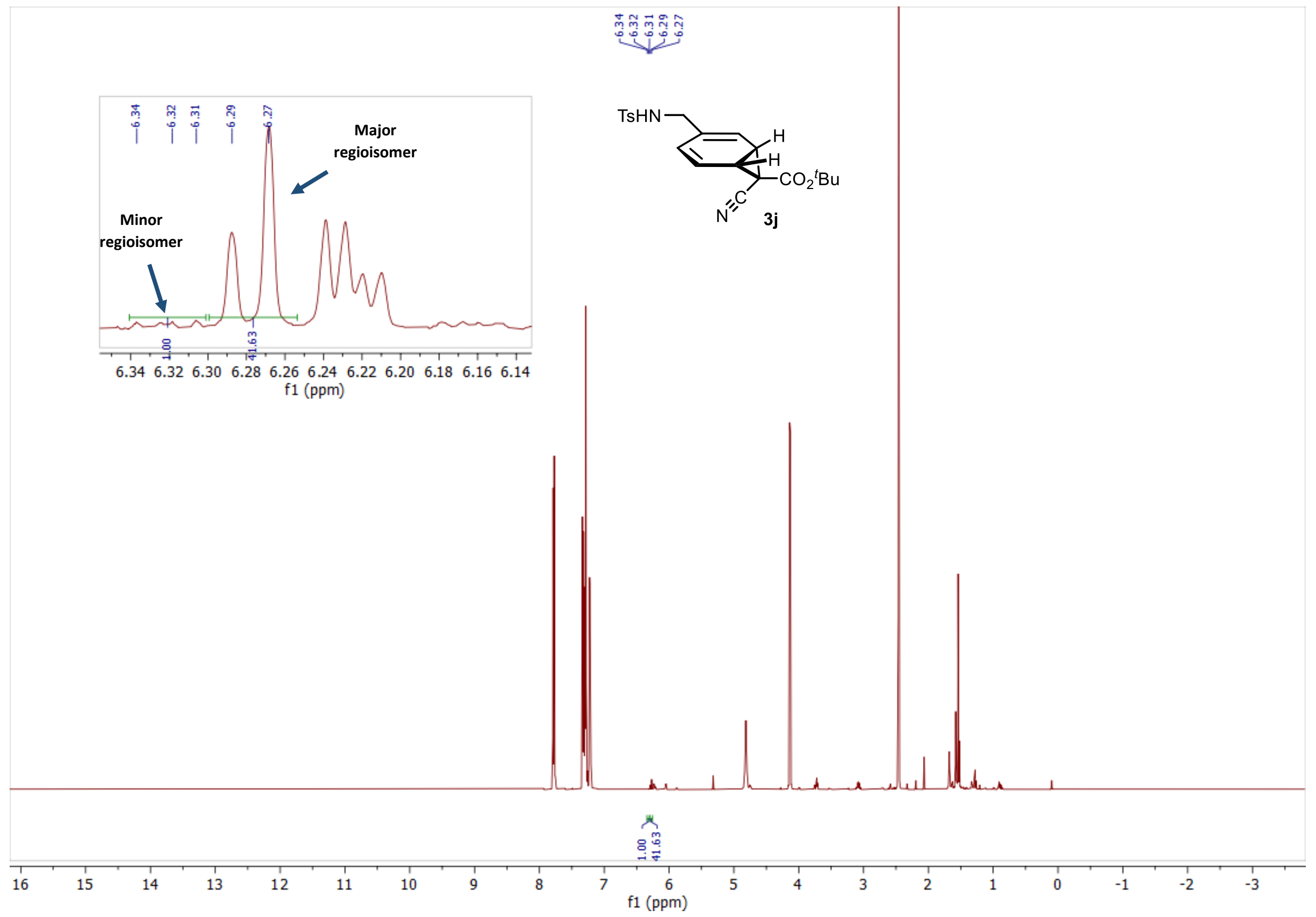




\section{Compound 3k}

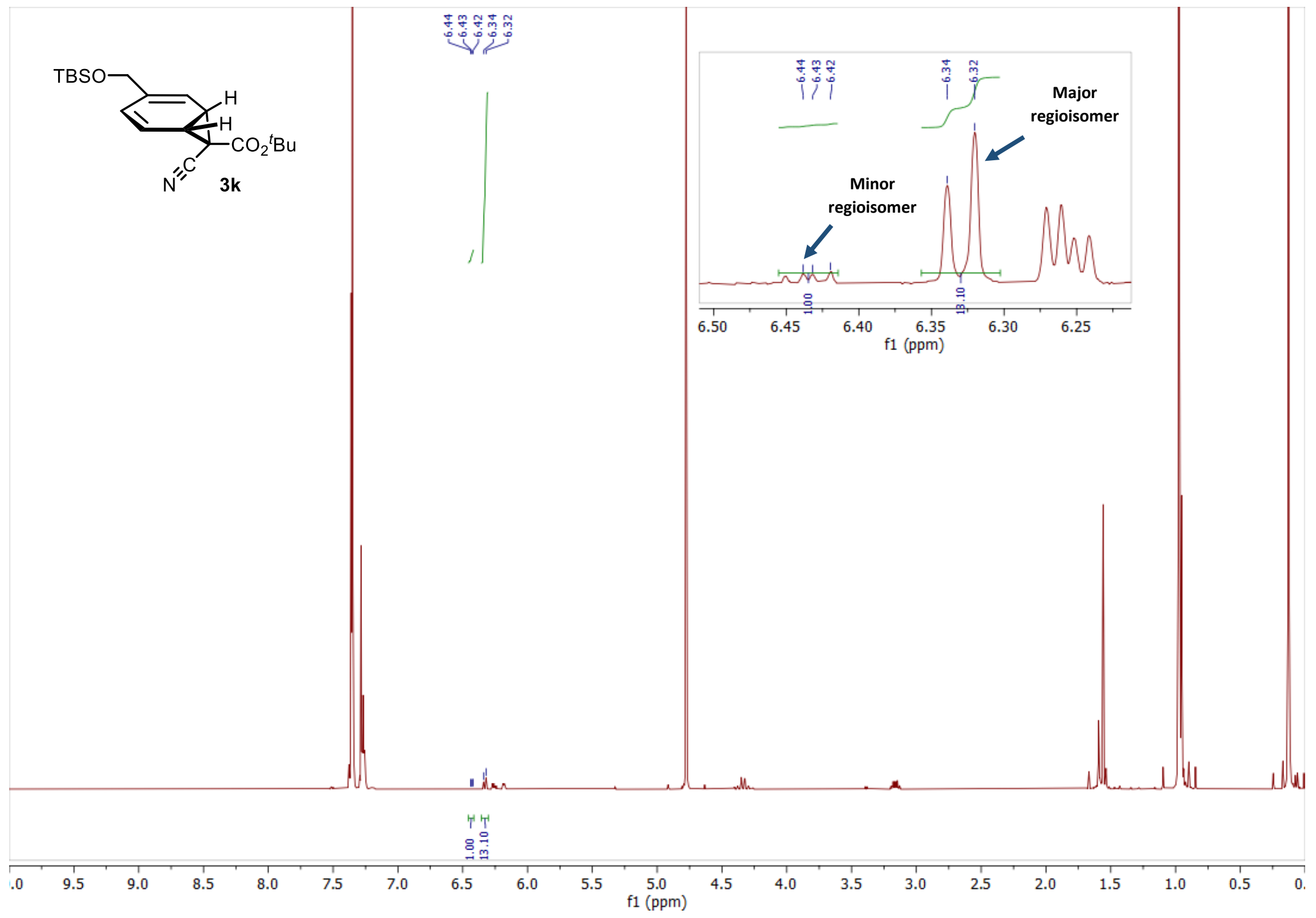


Compound $\mathbf{3}$ I

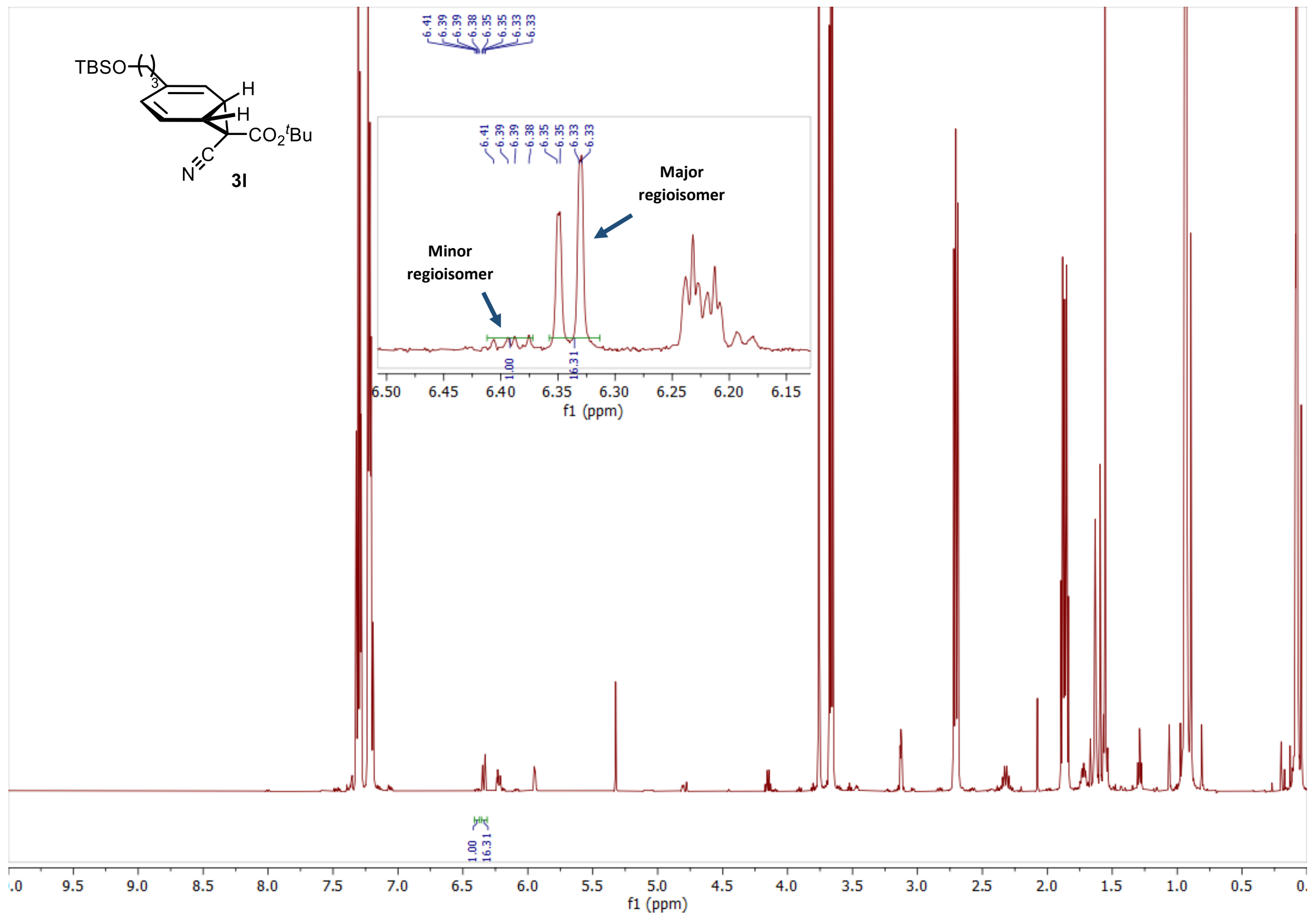




\section{Compound 3n}

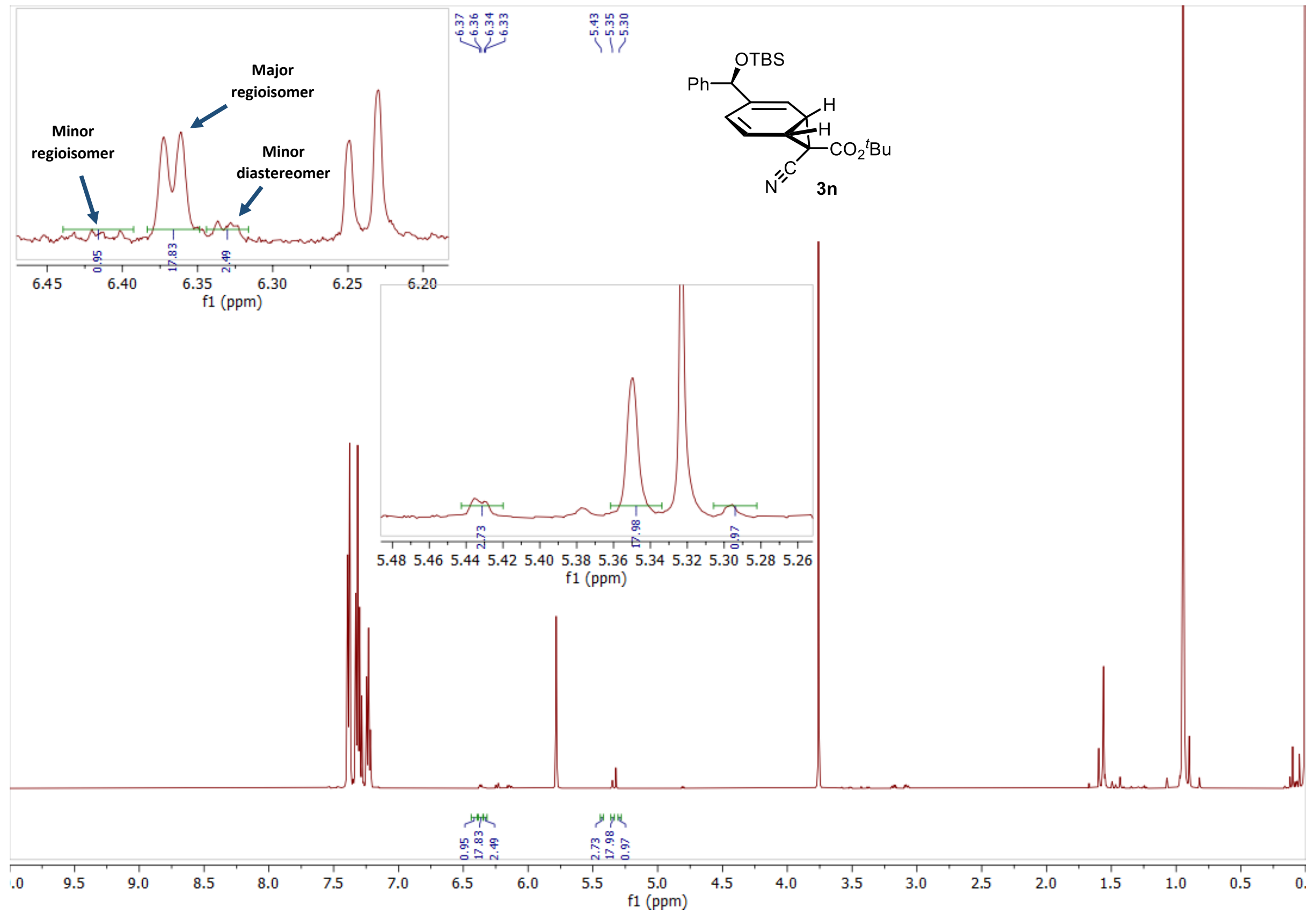


Compound 30
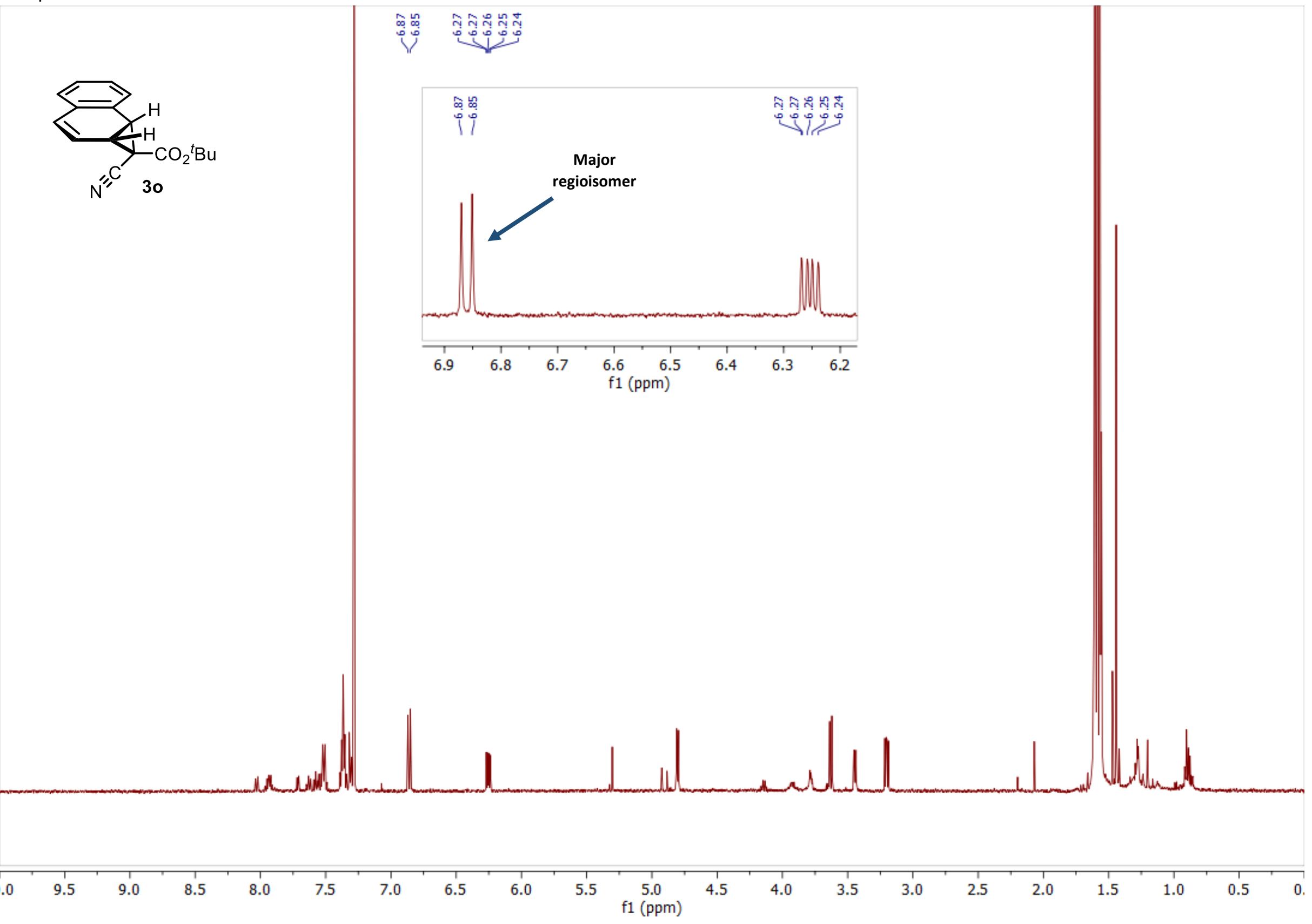
Compound 3p

หูำ
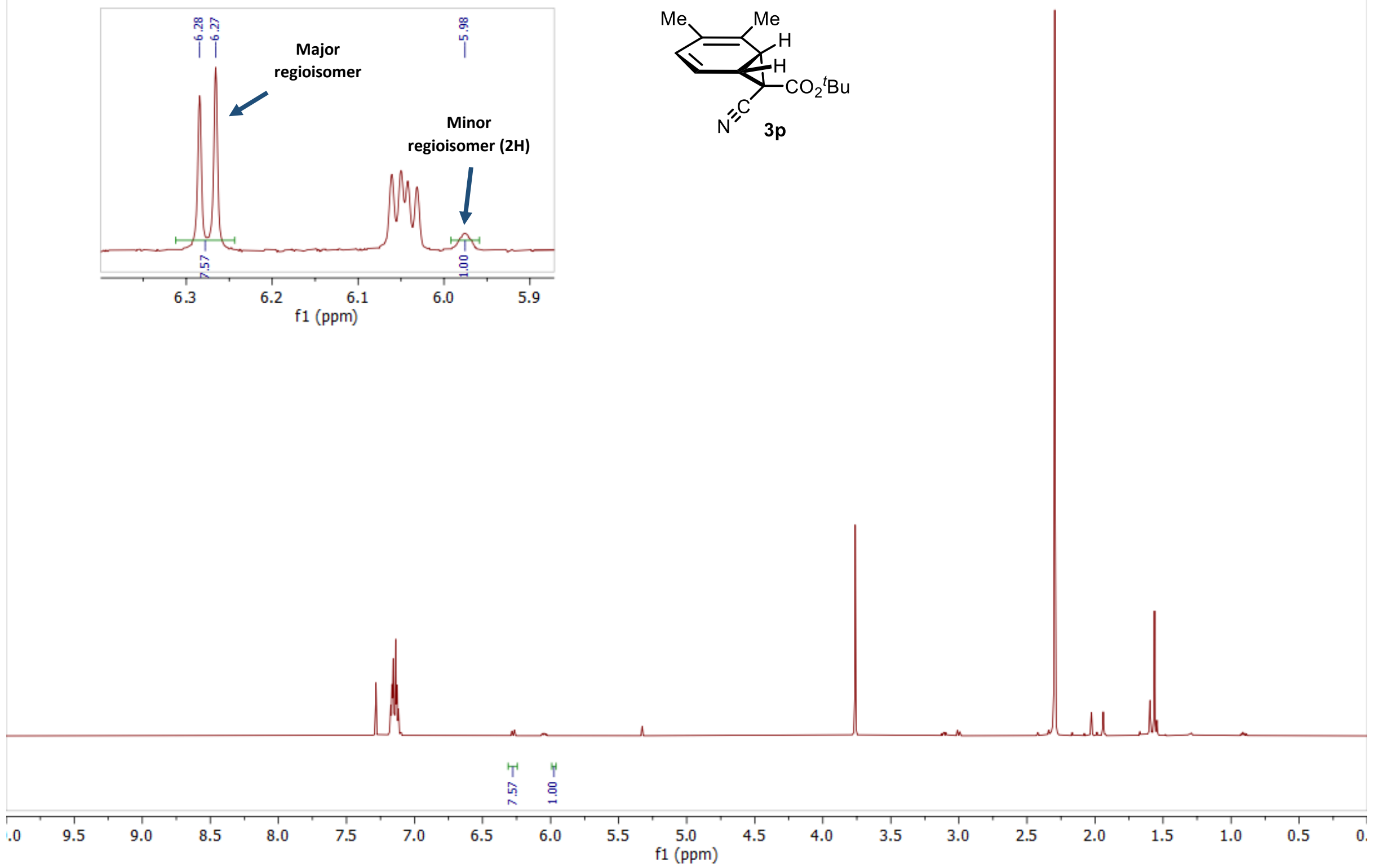
Compound norcaradiene $\mathbf{3 q}$ [(not isolated en route to $\mathbf{4 q})$ before PTAD cycloaddition]
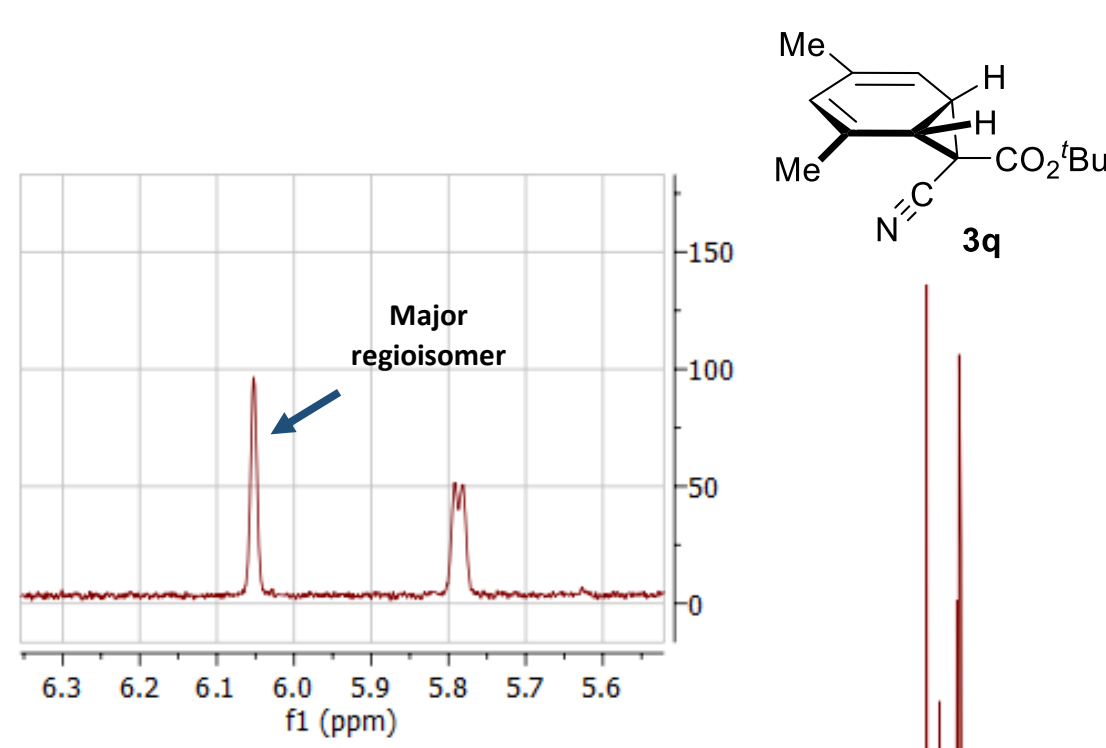

$3 q$
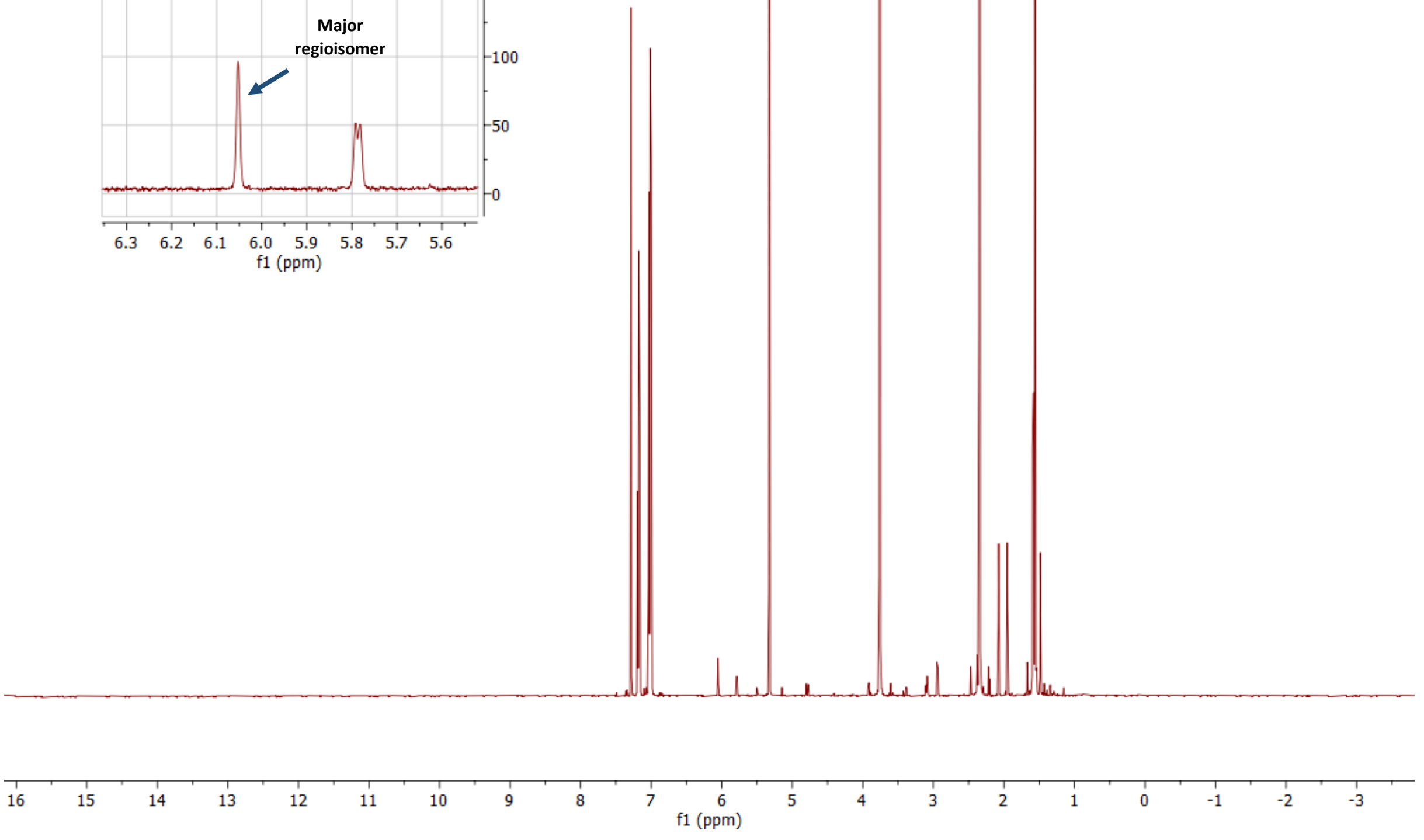
Compound $\mathbf{4 q}$ (PTAD cycloaddition with $\mathbf{3 q}$ crude mixture)
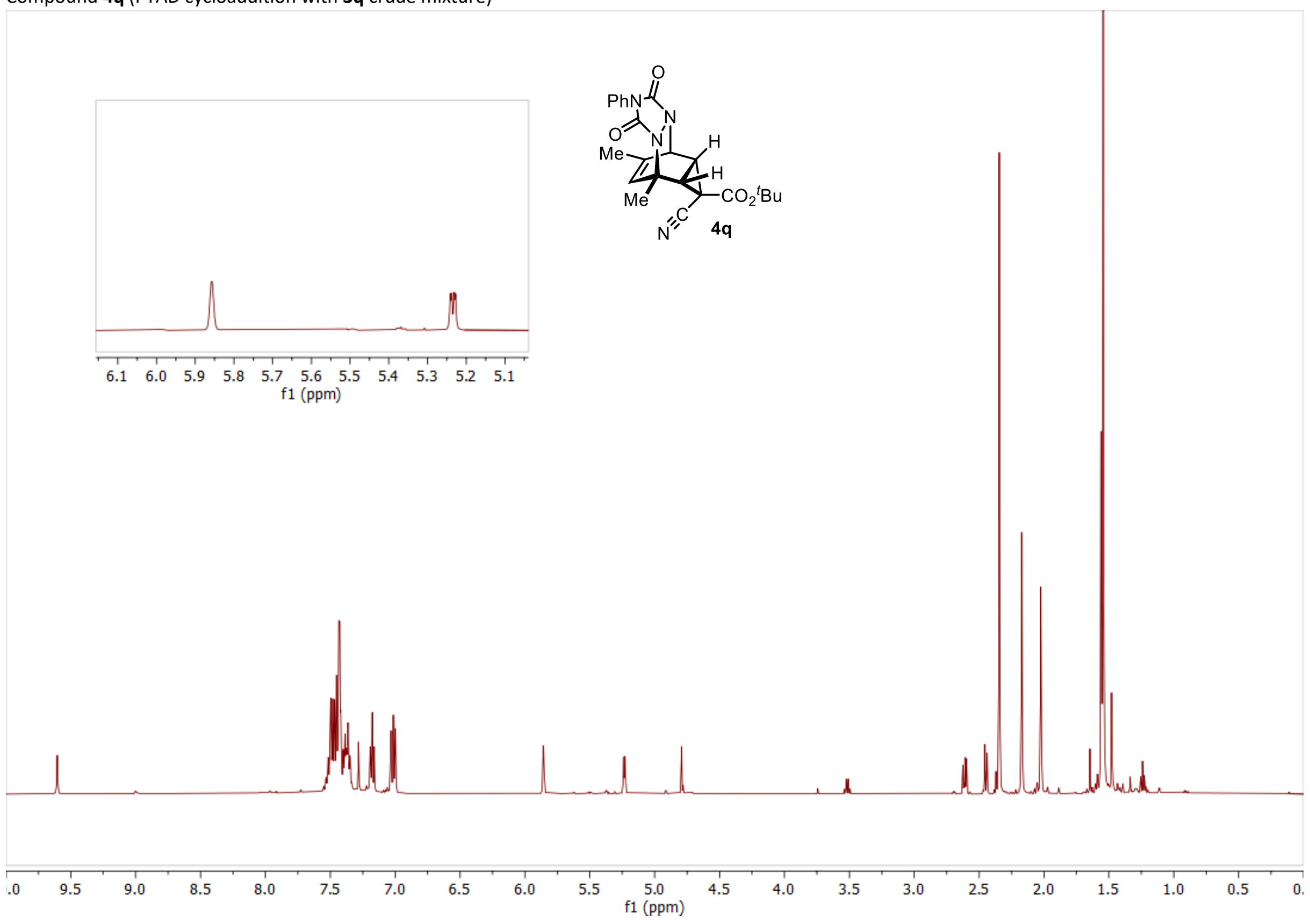

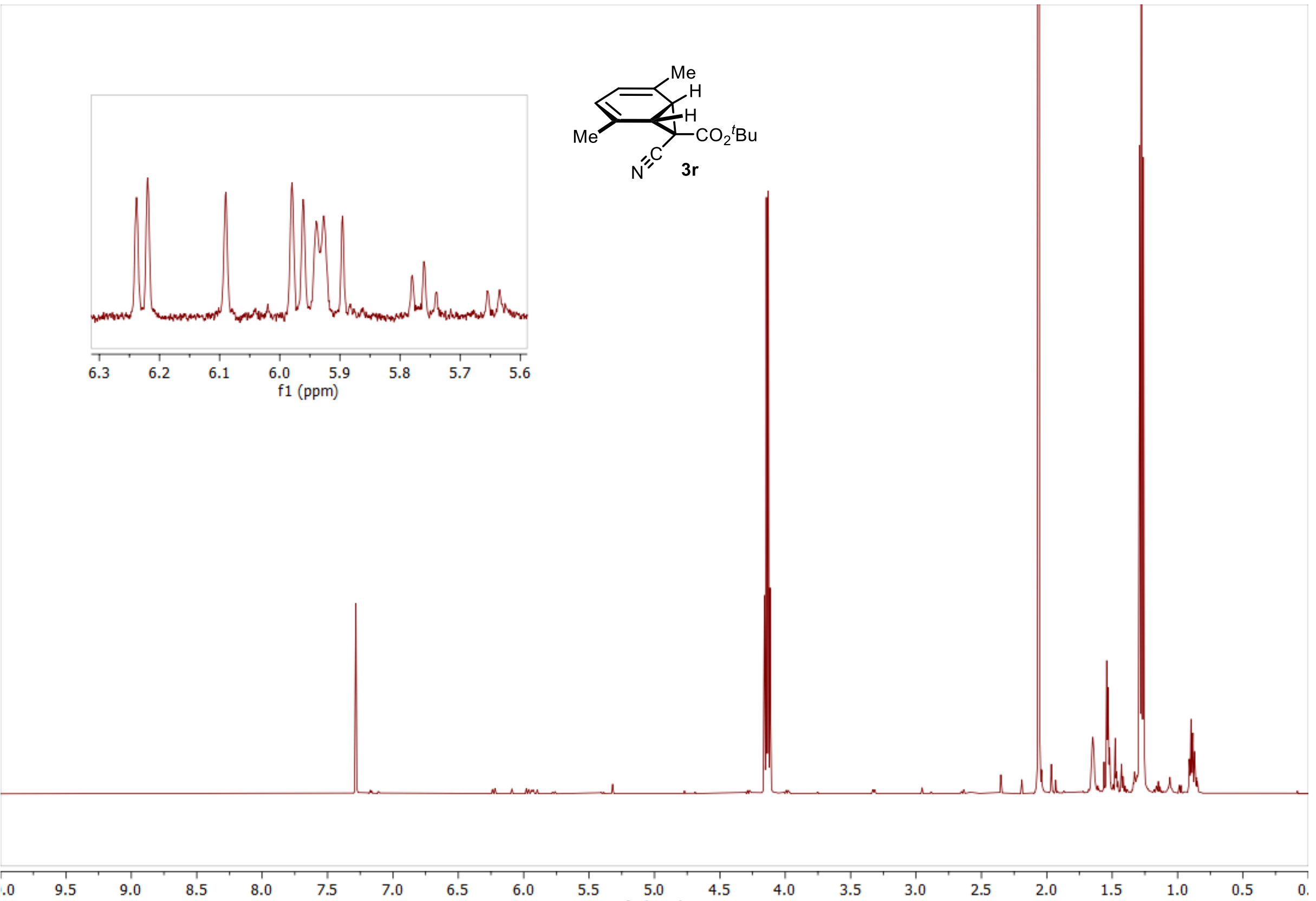


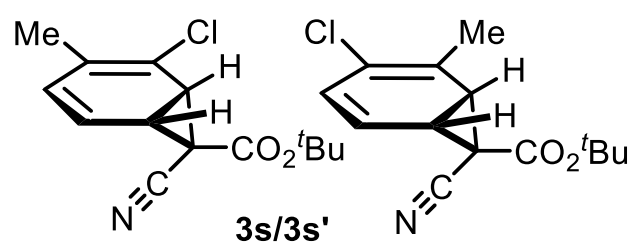

$$
\text { Ulun }
$$

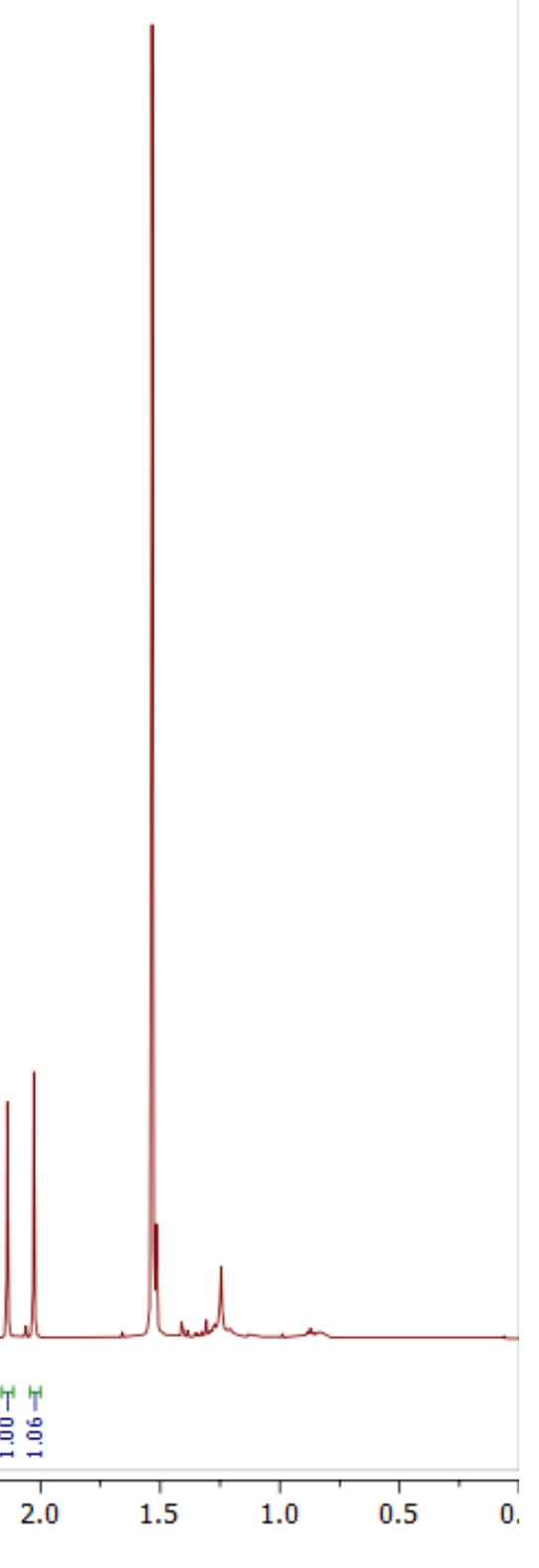


Compound 8
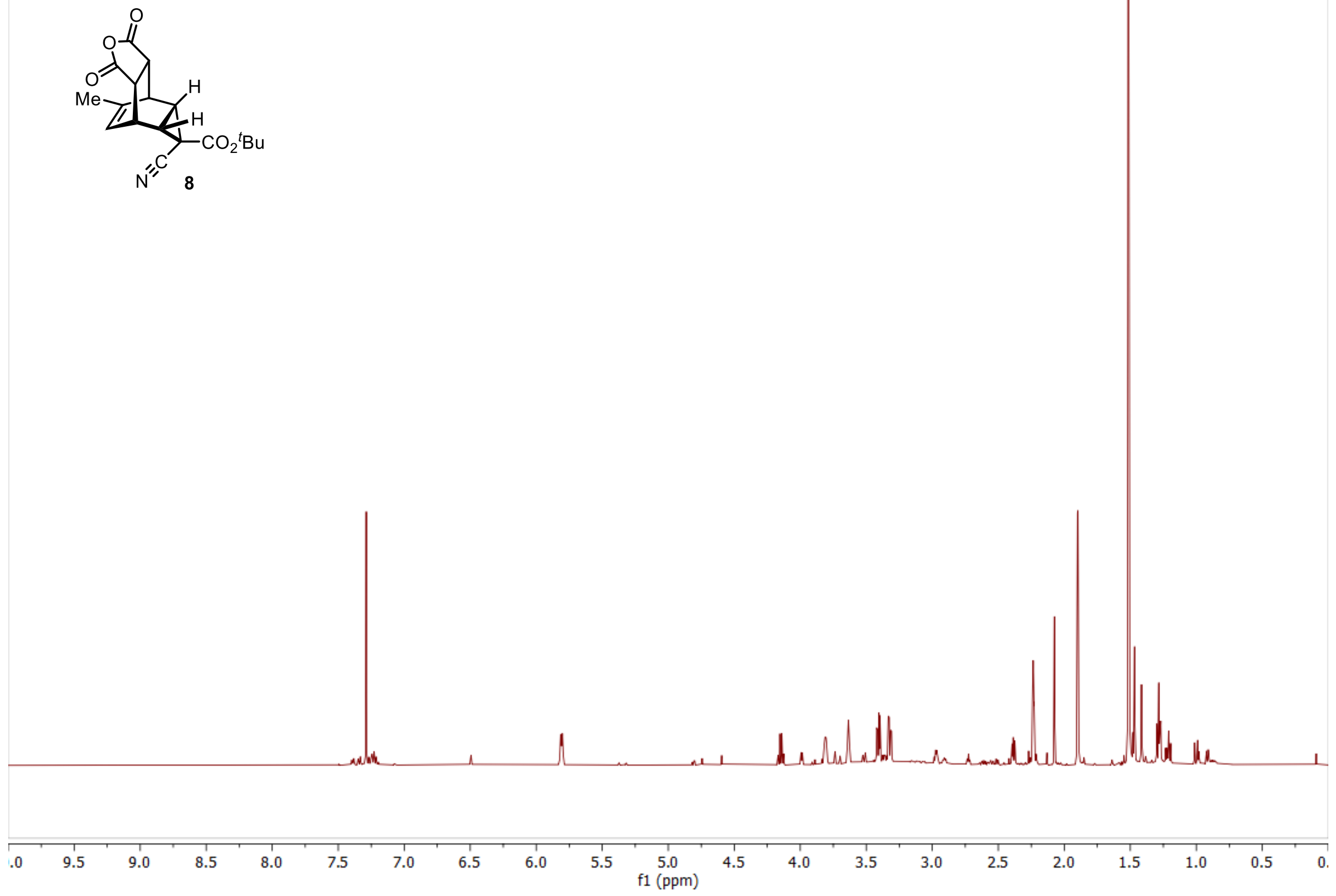
Compound 9
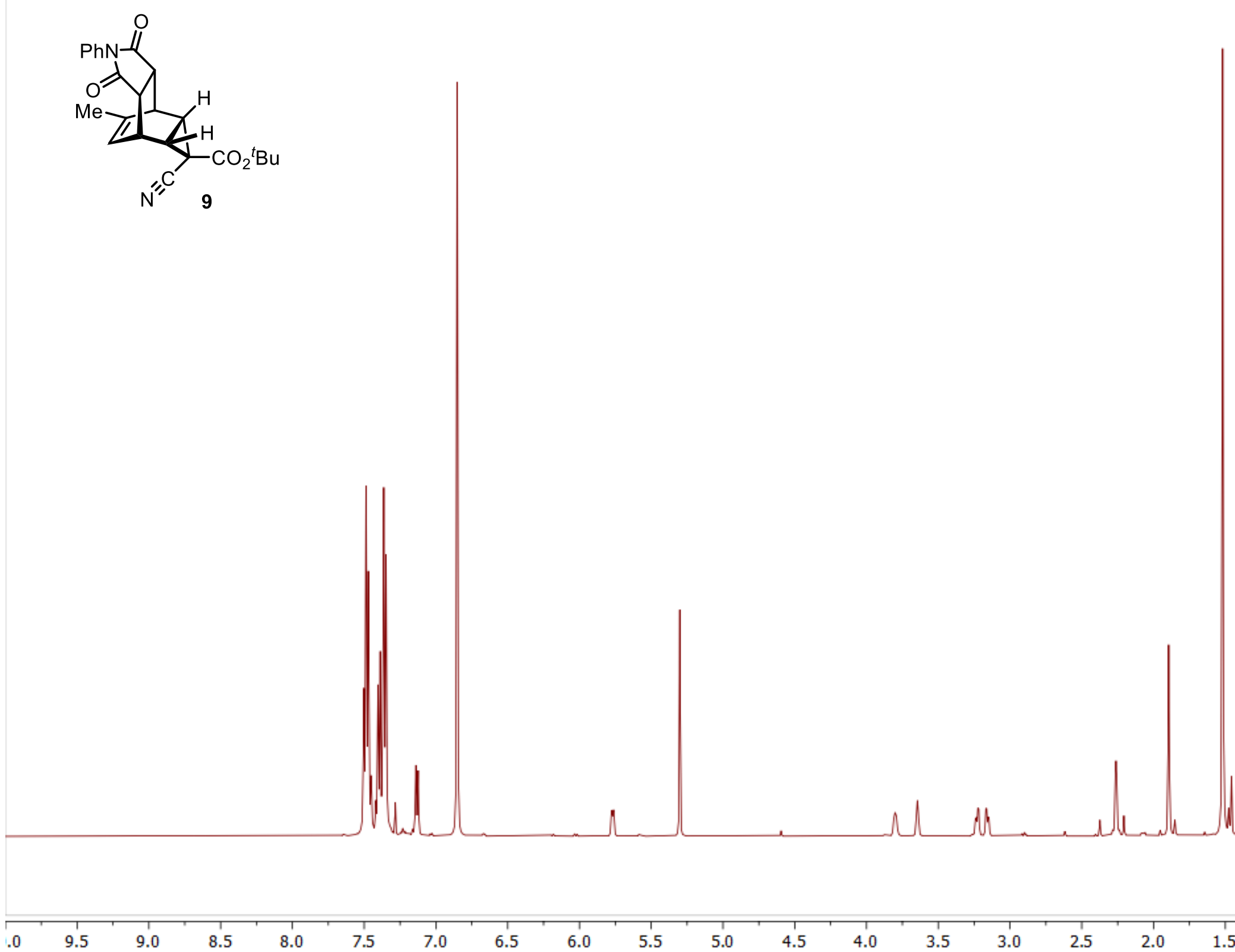

9.5

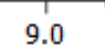

8.5
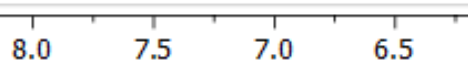

6.0
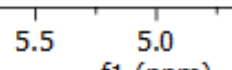
f1 (ppm) 
Compound 4c

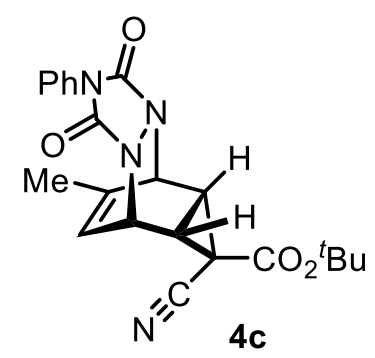

$4 c$

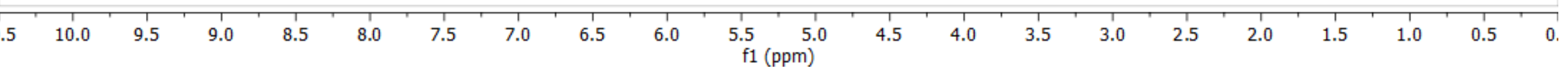



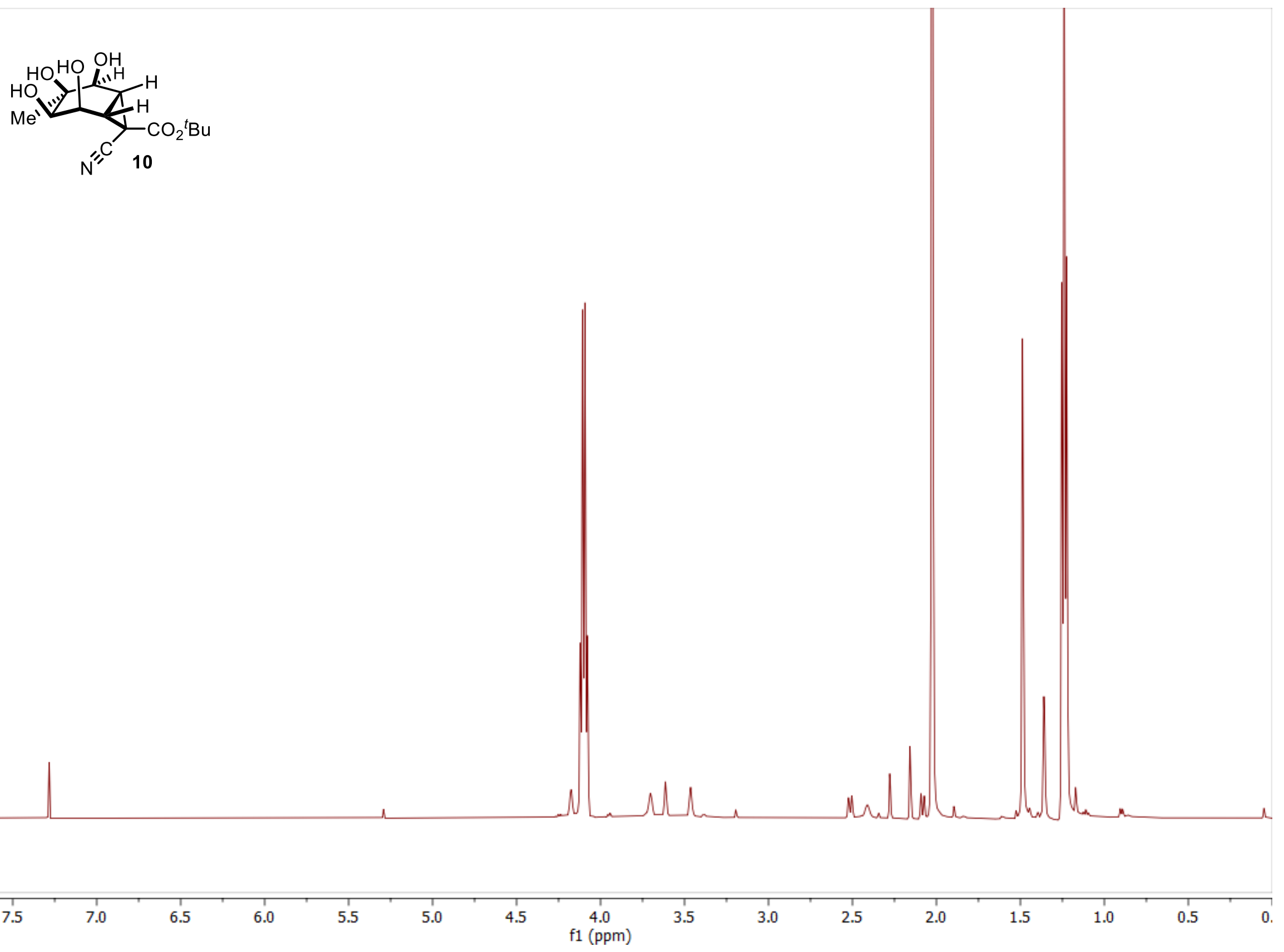

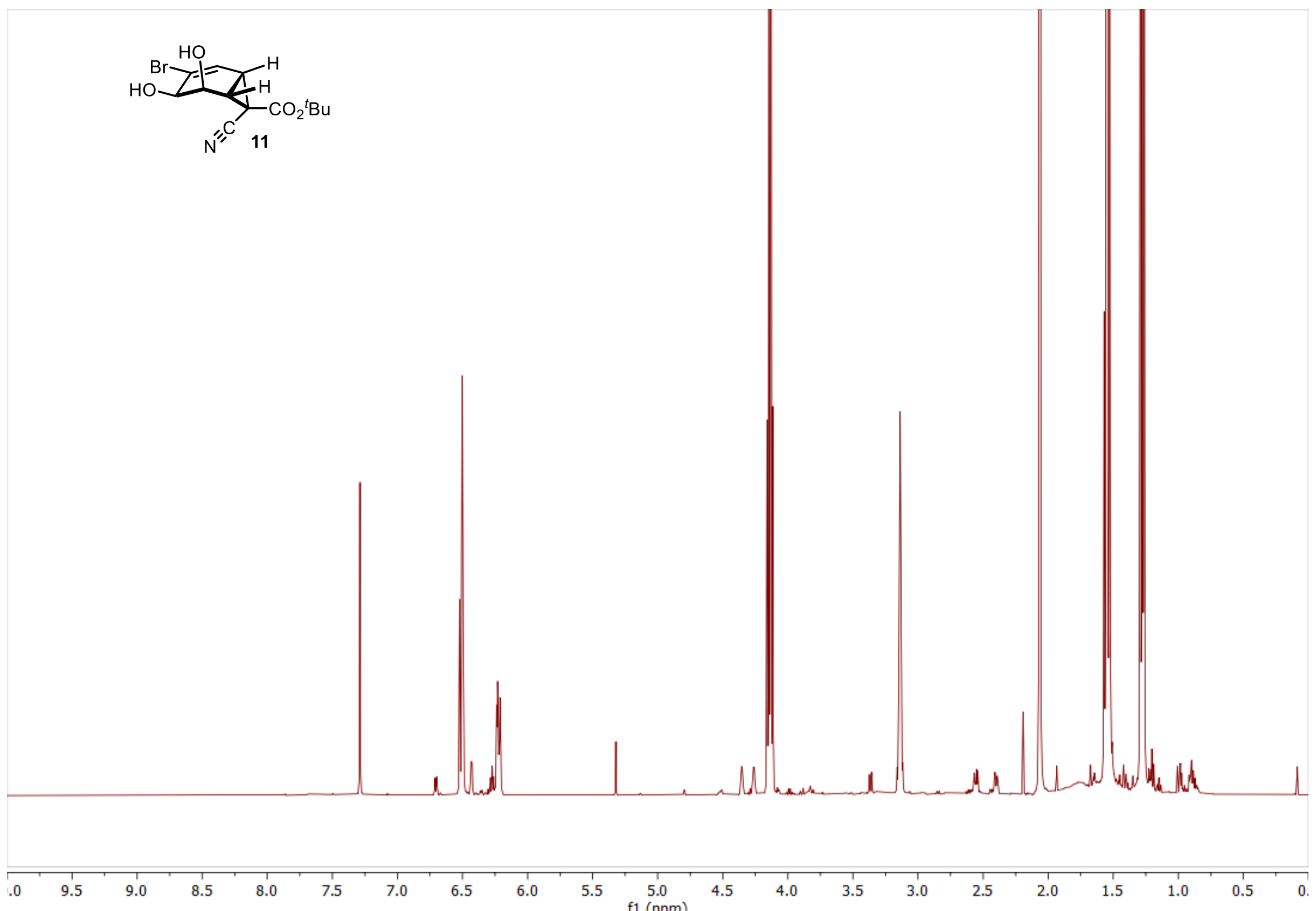

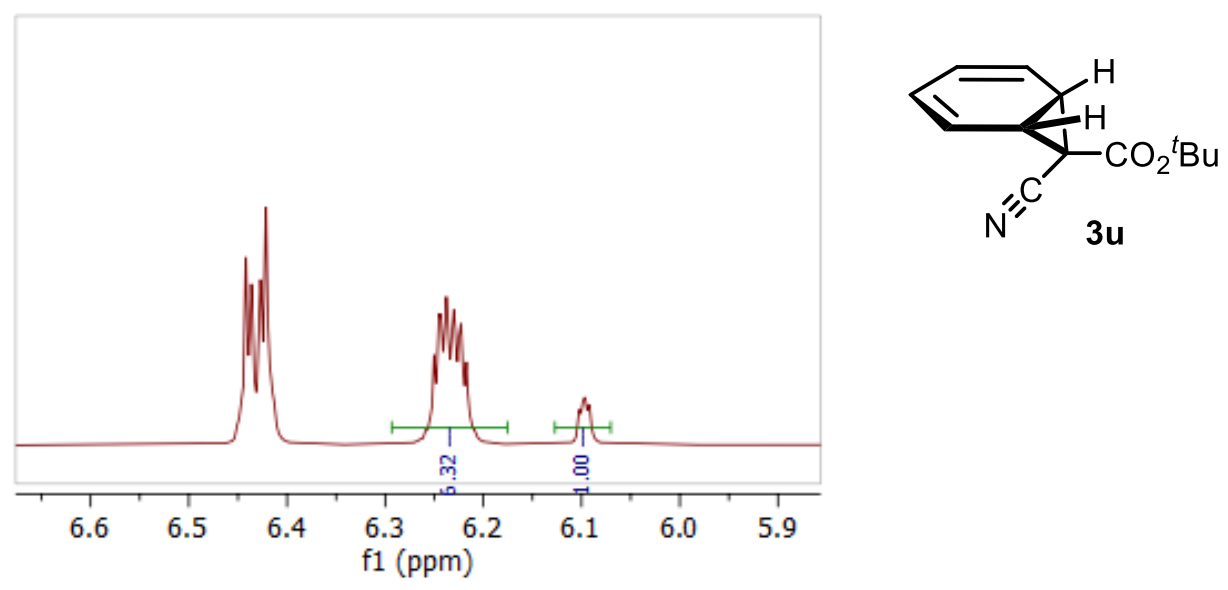

$$
3 u
$$

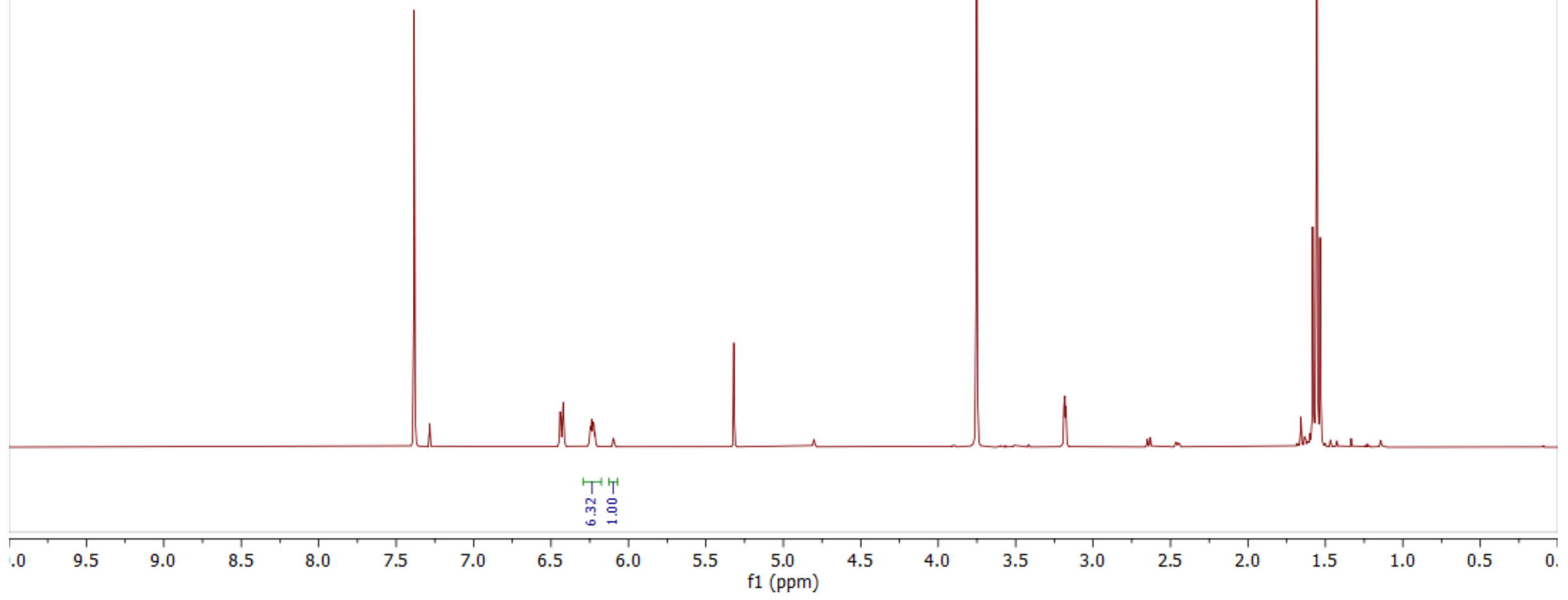


Compound 12
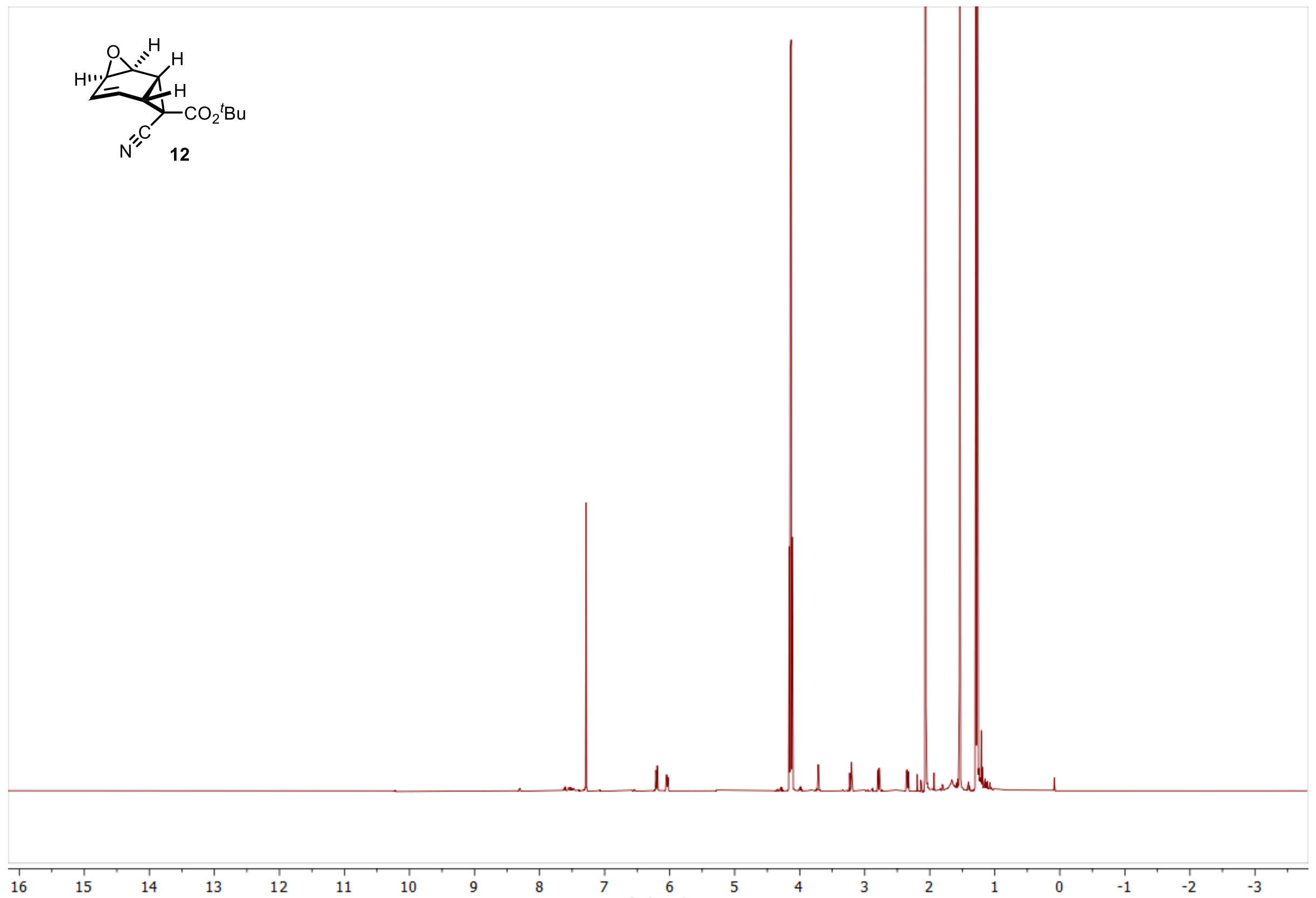

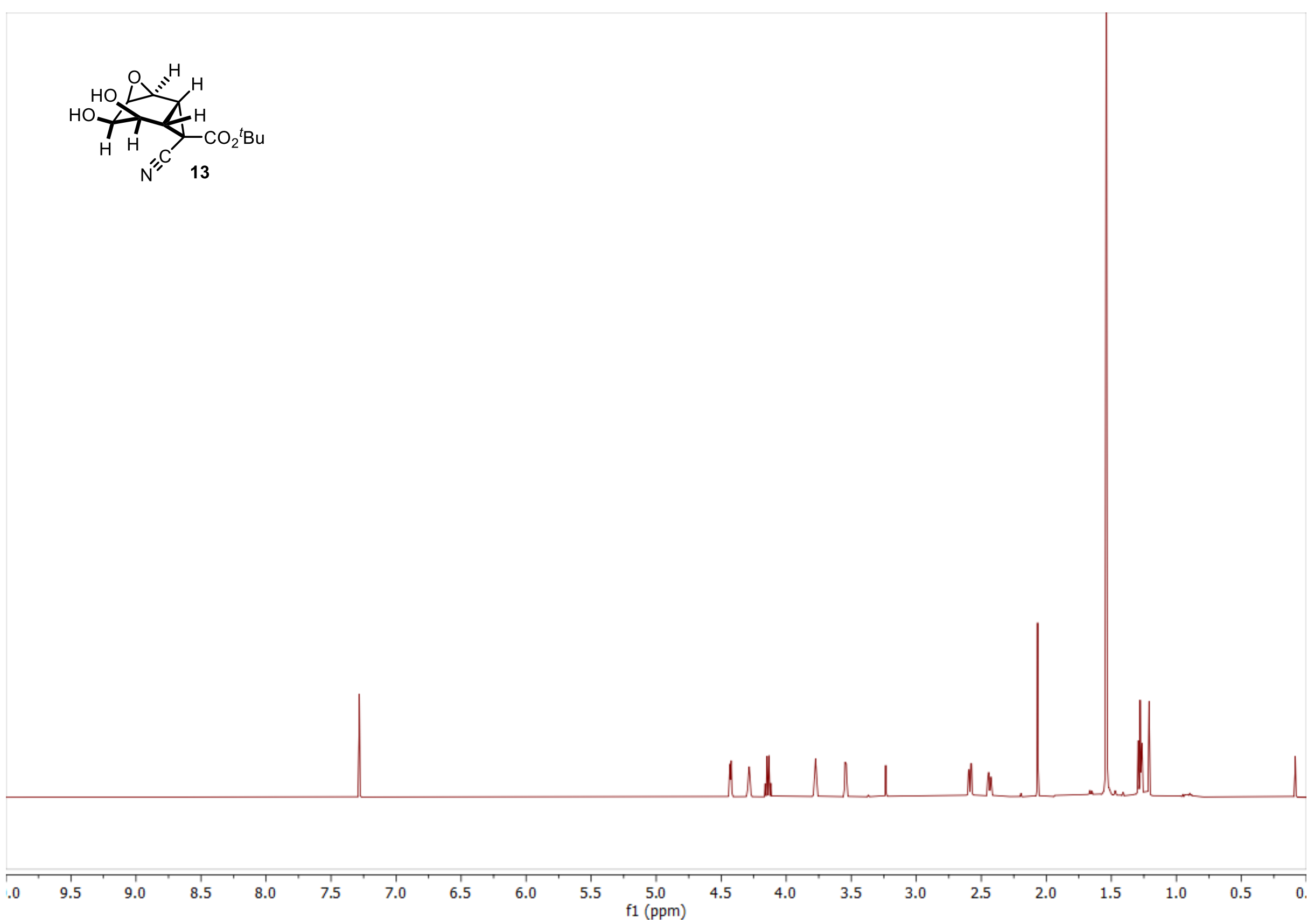


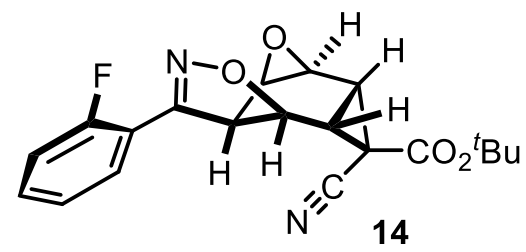

and N M N w

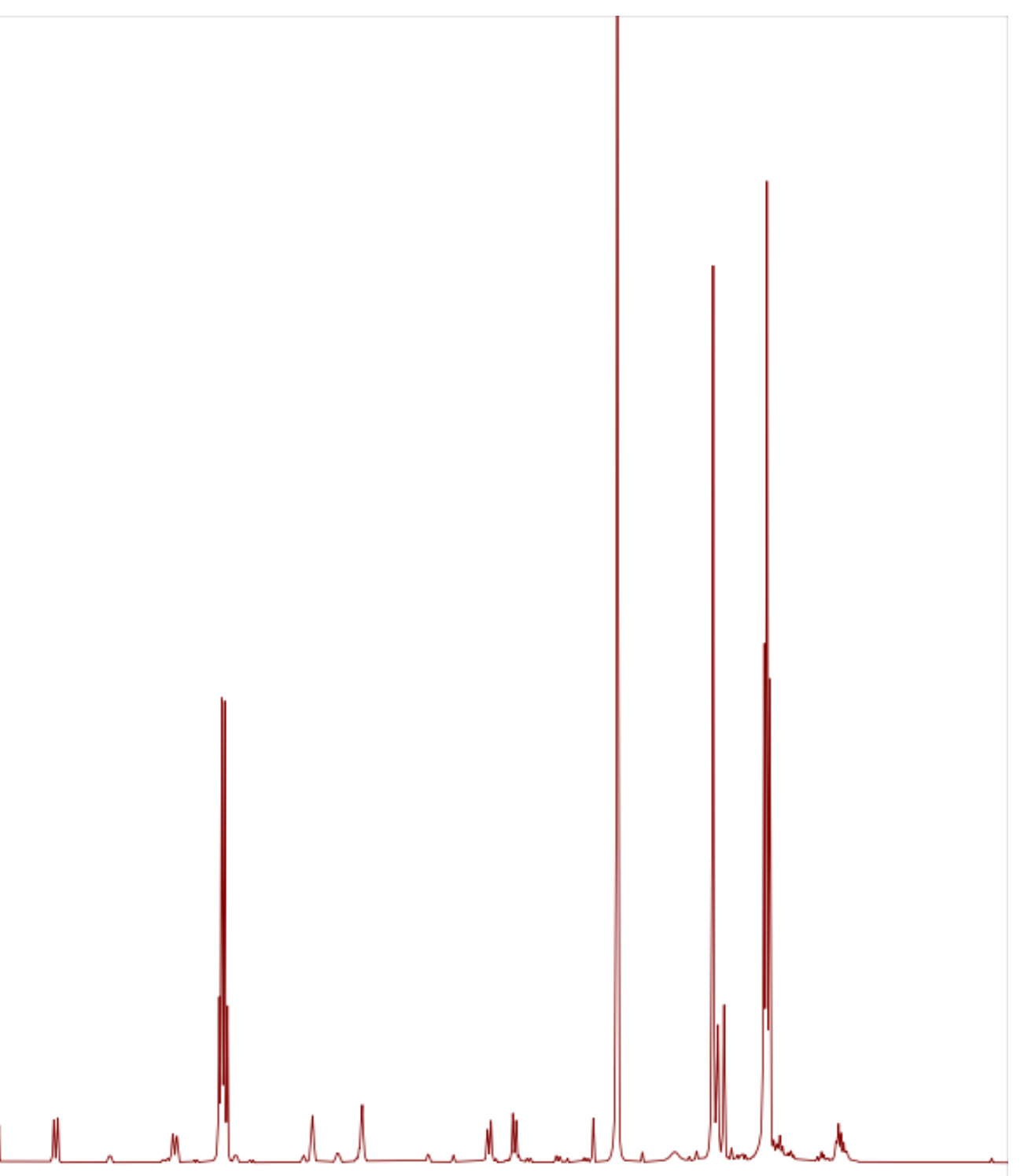

$9.5 \quad 9.0$

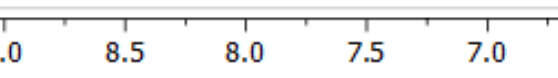

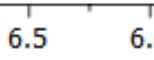

$6.0 \quad 5$

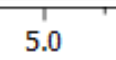

f1 (ppm) 


\section{Compound 15}

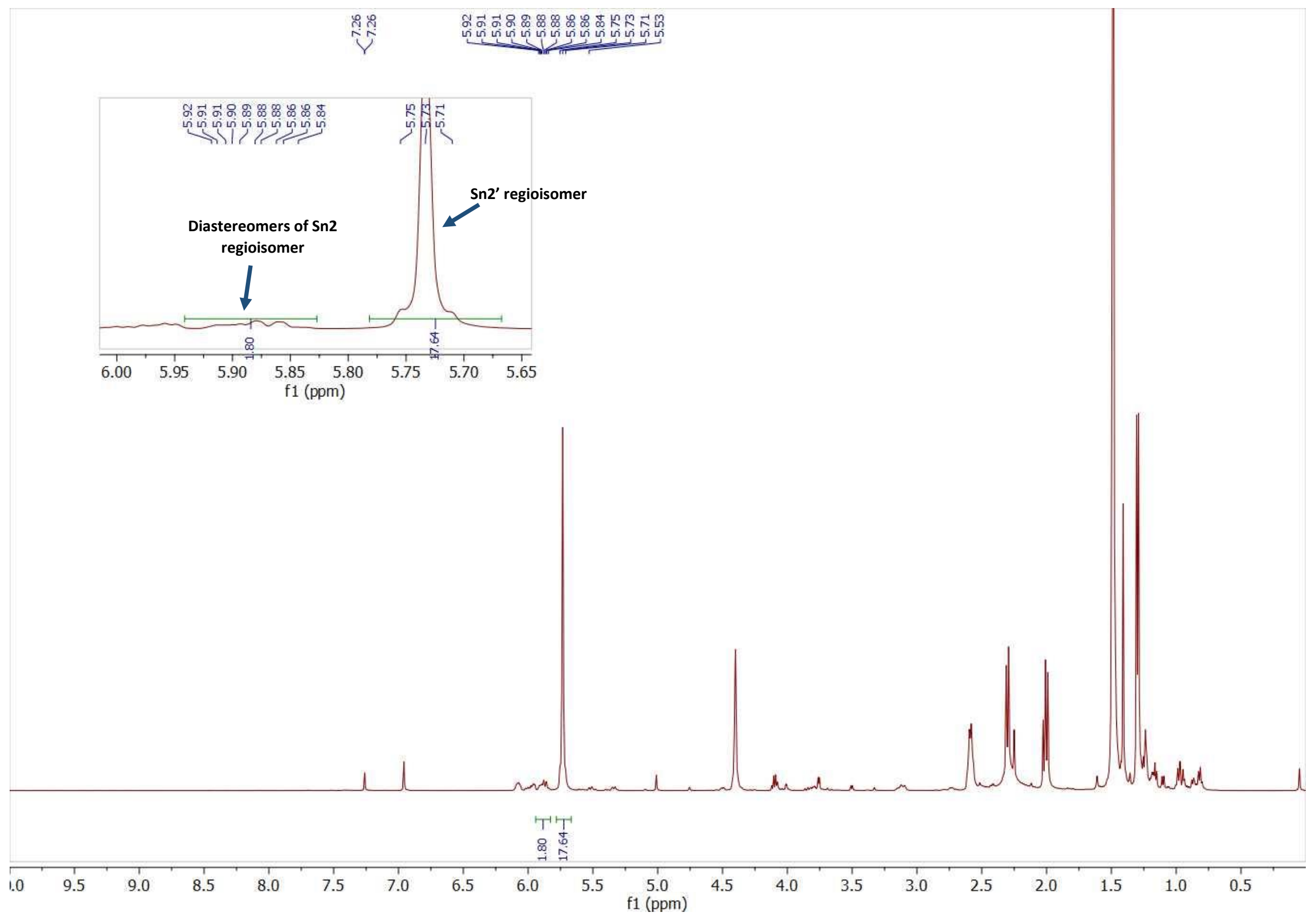


${ }^{1} \mathrm{H},{ }^{13} \mathrm{C}$, and ${ }^{19} \mathrm{~F}$ Spectra for Purified Compounds

tert-butylcyanodiazoacetate $\mathbf{1 b}\left(\mathrm{CDCl}_{3}, 500 \mathrm{MHz}\right)$

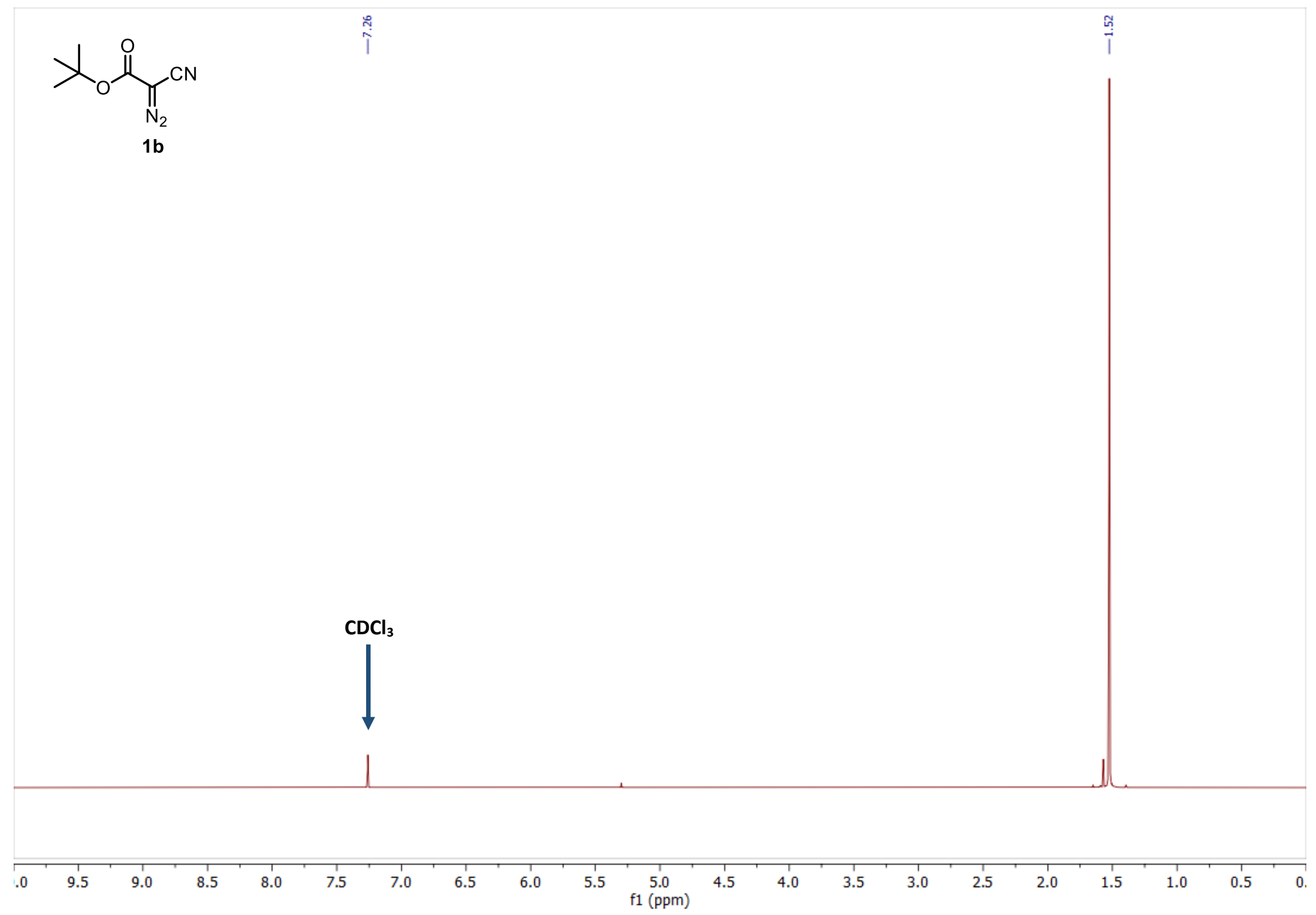


Compound 3a $\left({ }^{1} \mathrm{H}, 600 \mathrm{MHz}, \mathrm{CDCl}_{3}\right.$, full view)

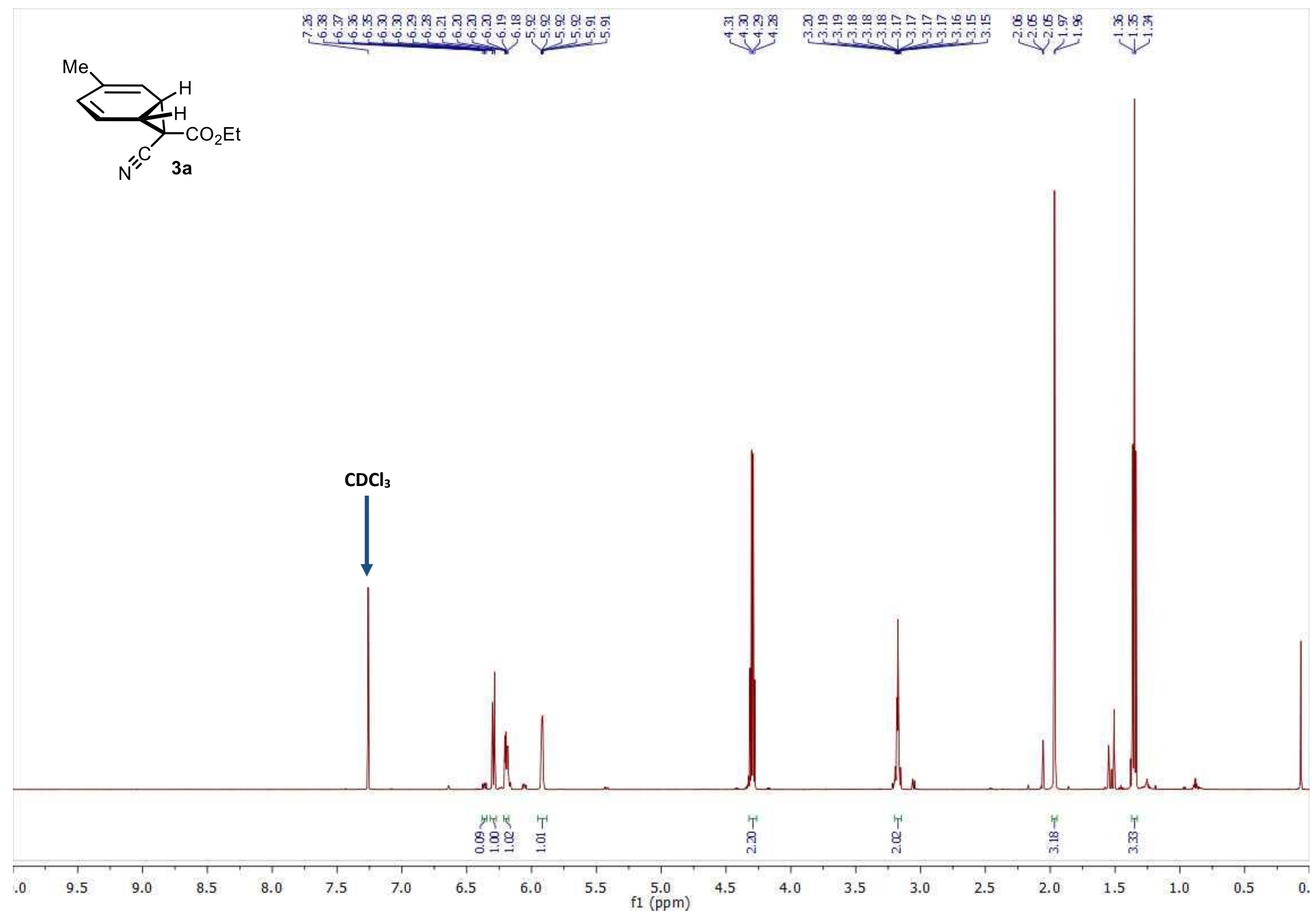


Compound 3a ( ${ }^{1} \mathrm{H}, 600 \mathrm{M} \mathrm{Hz}, \mathrm{CDCl}_{3}$, expanded view)

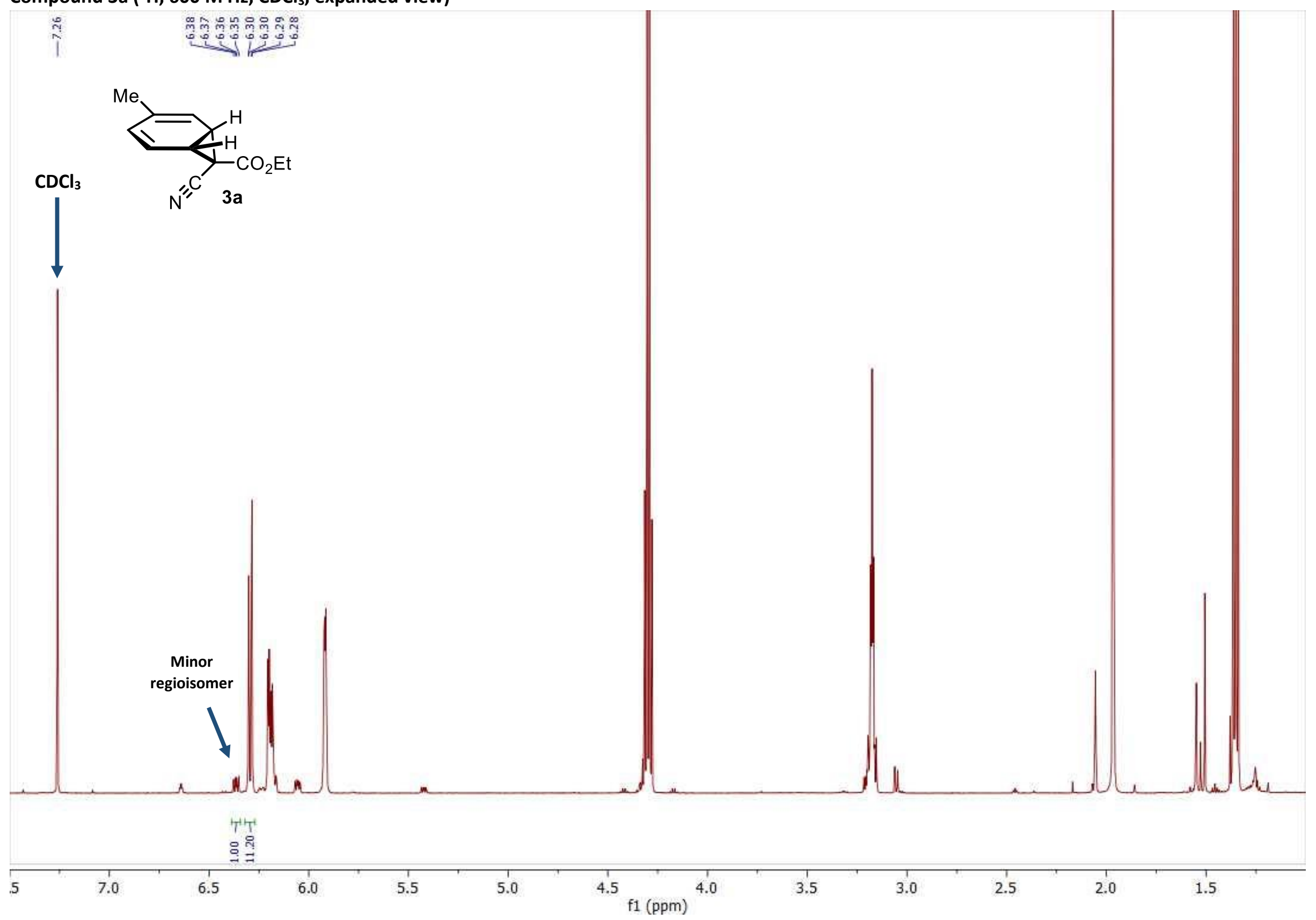


Compound 3a $\left({ }^{13} \mathrm{C}, 101 \mathrm{MHz}, \mathrm{CDCl}_{3}\right)$
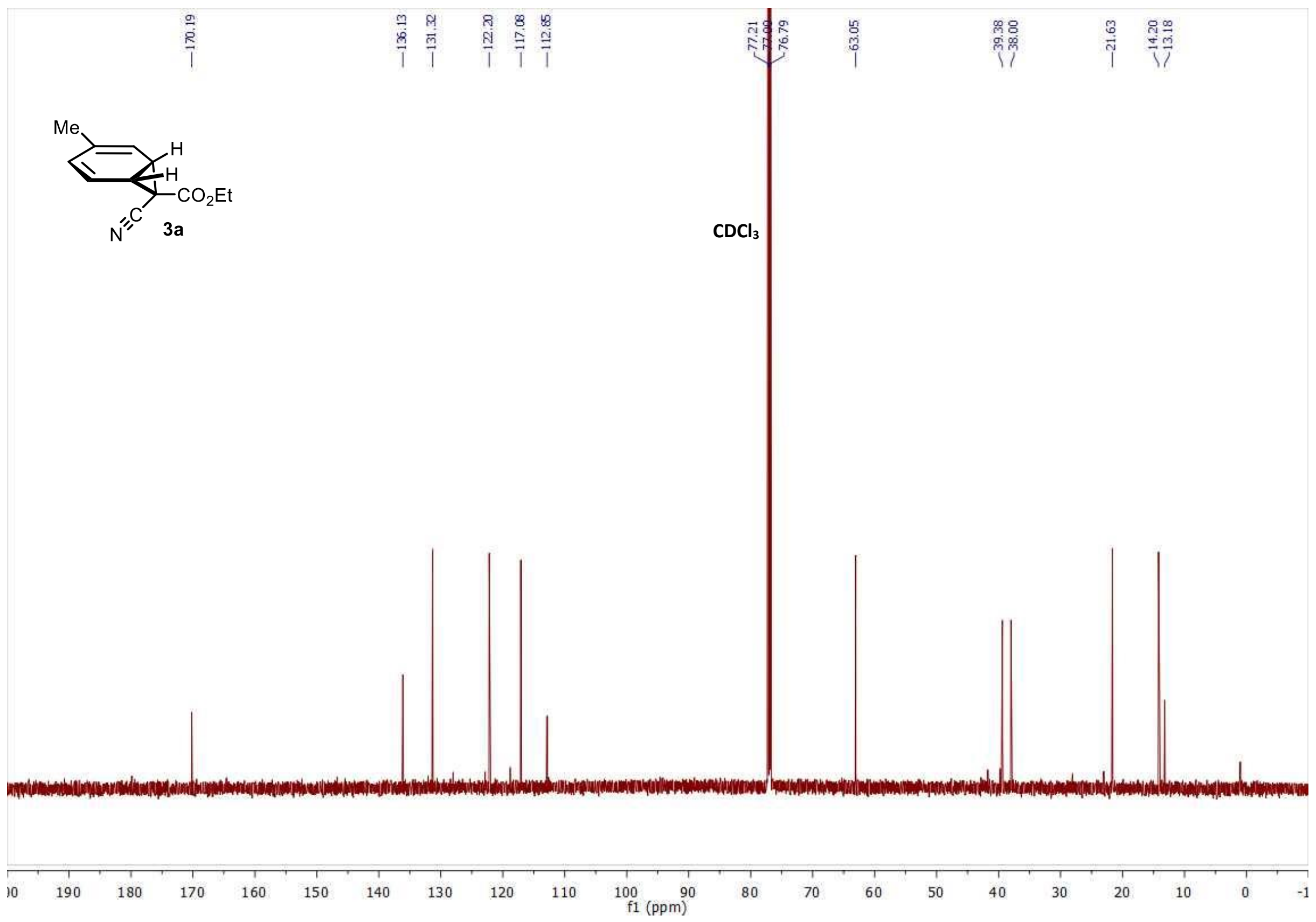
Compound $3 \mathrm{~b}\left({ }^{1} \mathrm{H}, 600 \mathrm{MHz}, \mathrm{CDCl}_{3}\right.$, standard view)

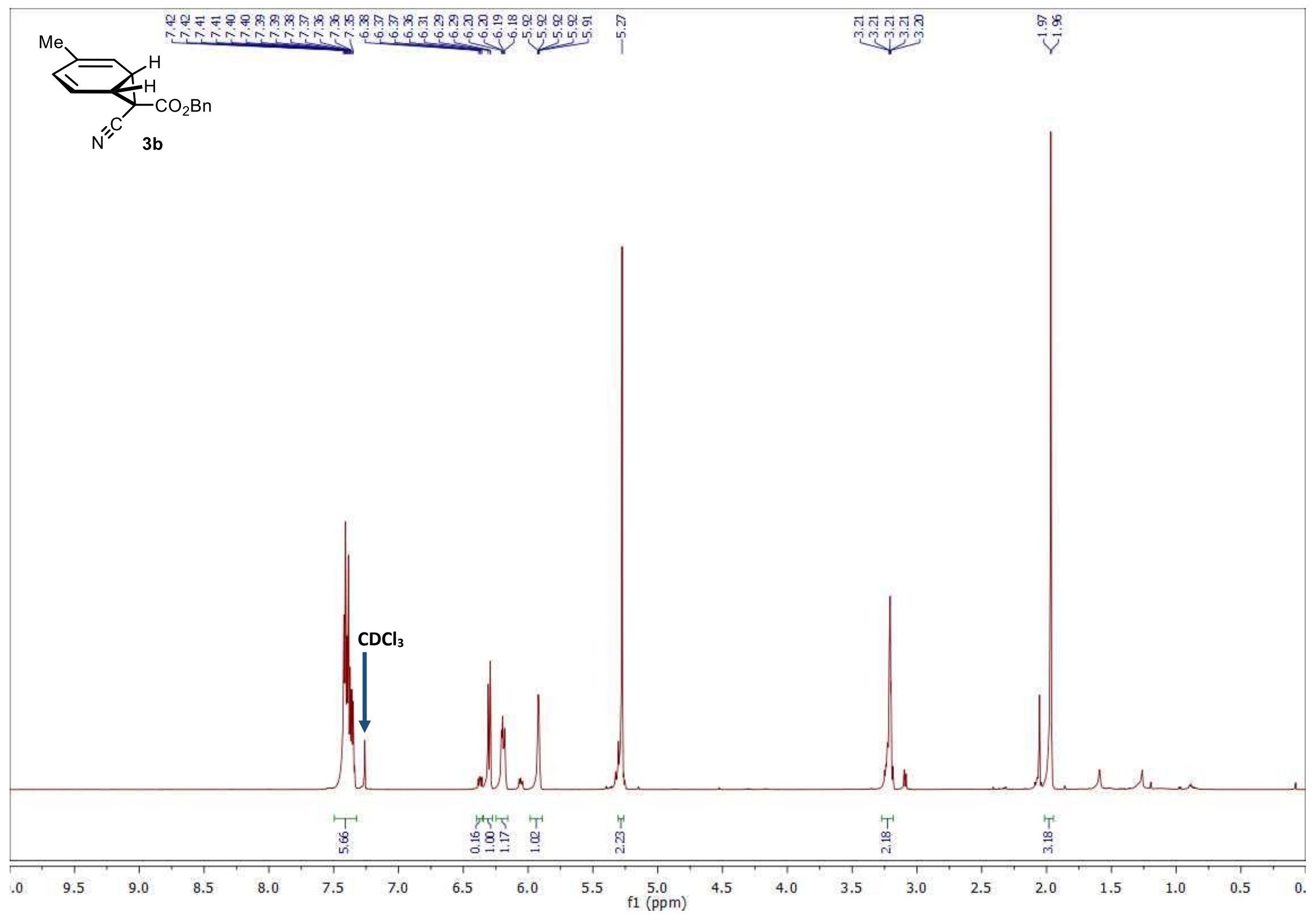


Compound 3b ( ${ }^{1} \mathrm{H}, 600 \mathrm{MHz}, \mathrm{CDCl}_{3}$, expanded view)

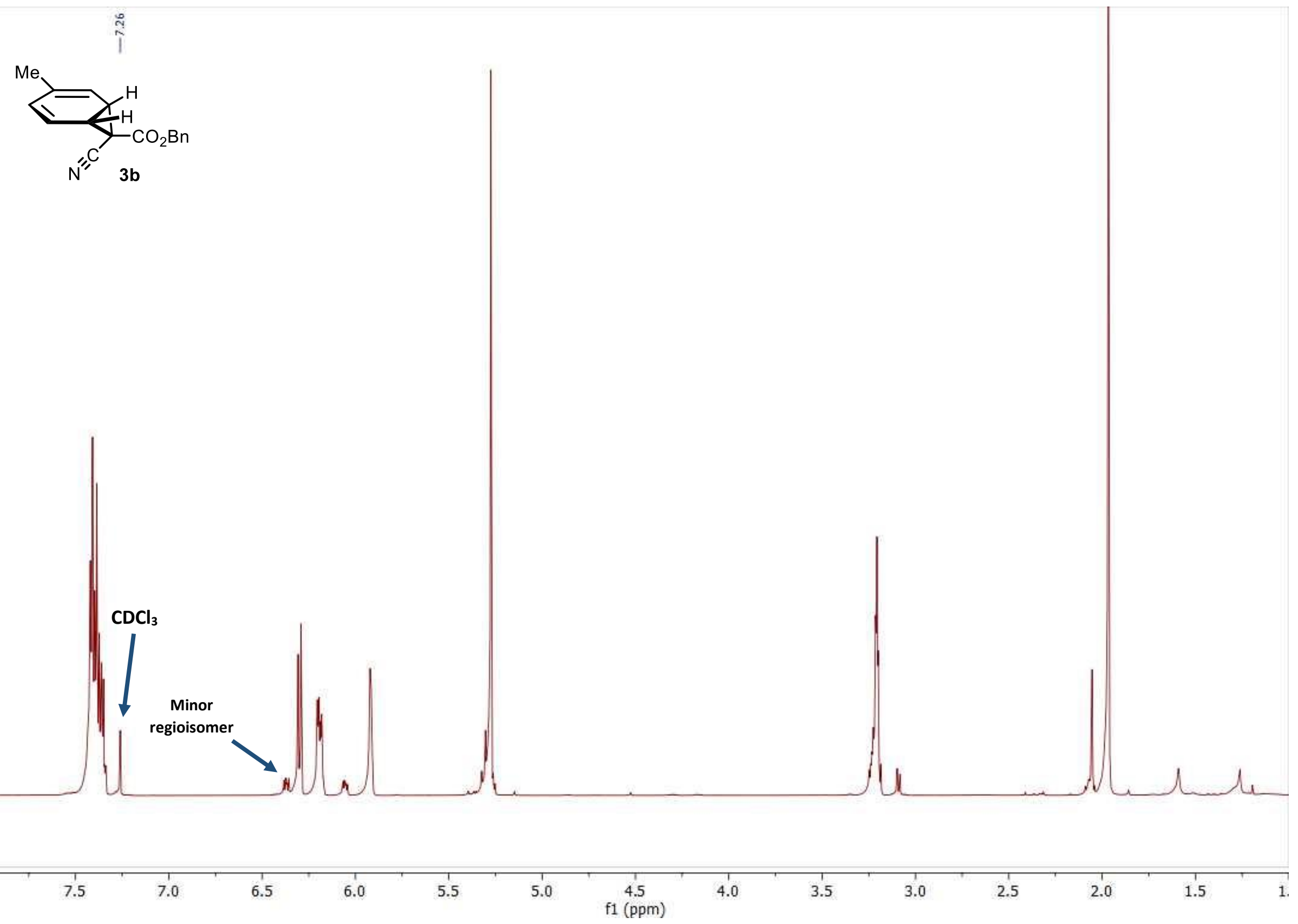


Compound $3 \mathrm{~b}\left({ }^{13} \mathrm{C}, 151 \mathrm{MHz}, \mathrm{CDCl}_{3}\right)$

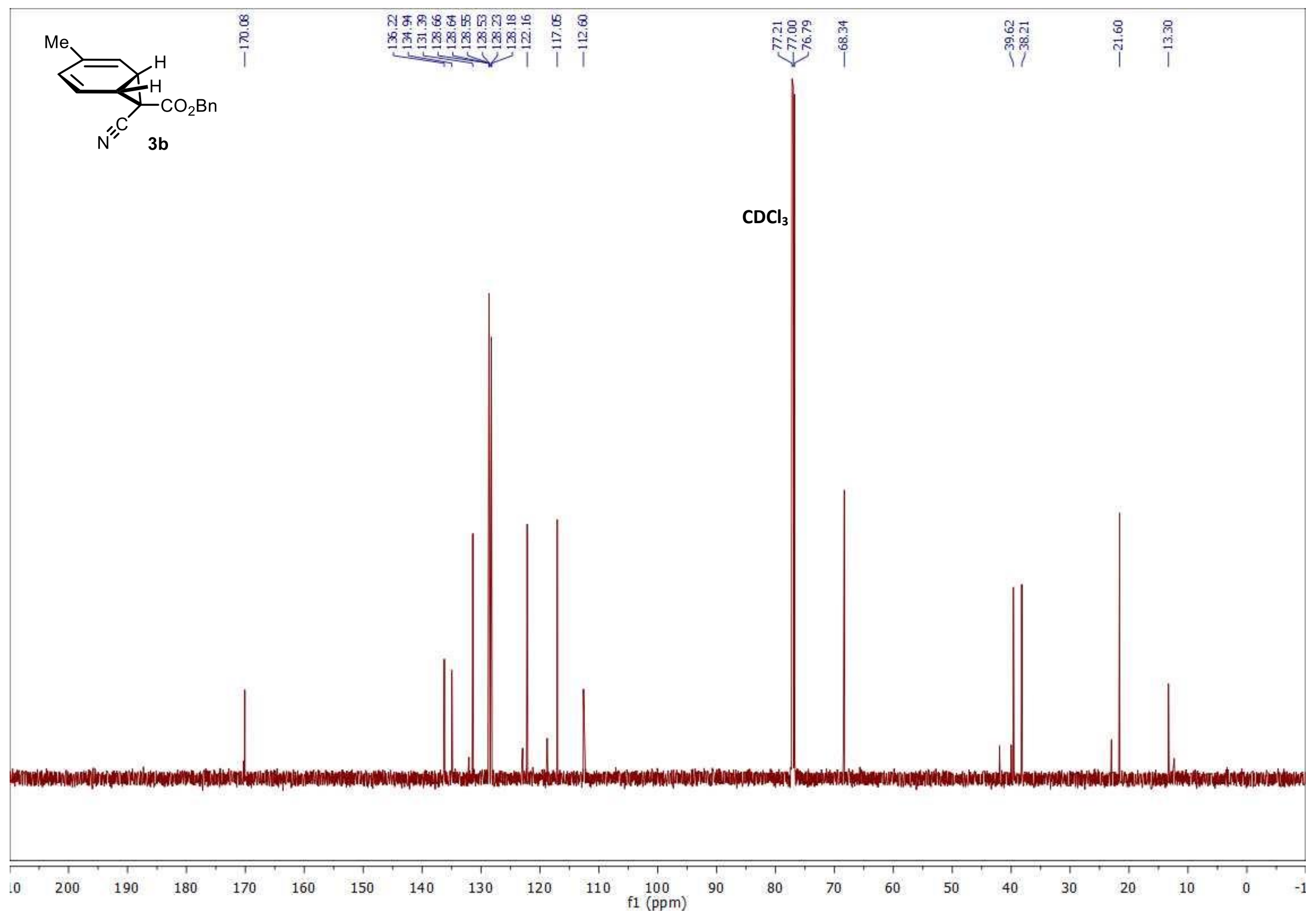


Compound 3c ( ${ }^{1} \mathrm{H}, 500 \mathrm{MHz}, \mathrm{CDCl}_{3}$, standard view)

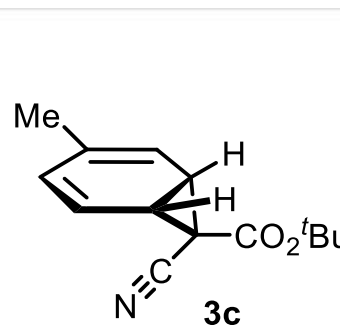

1.

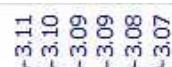

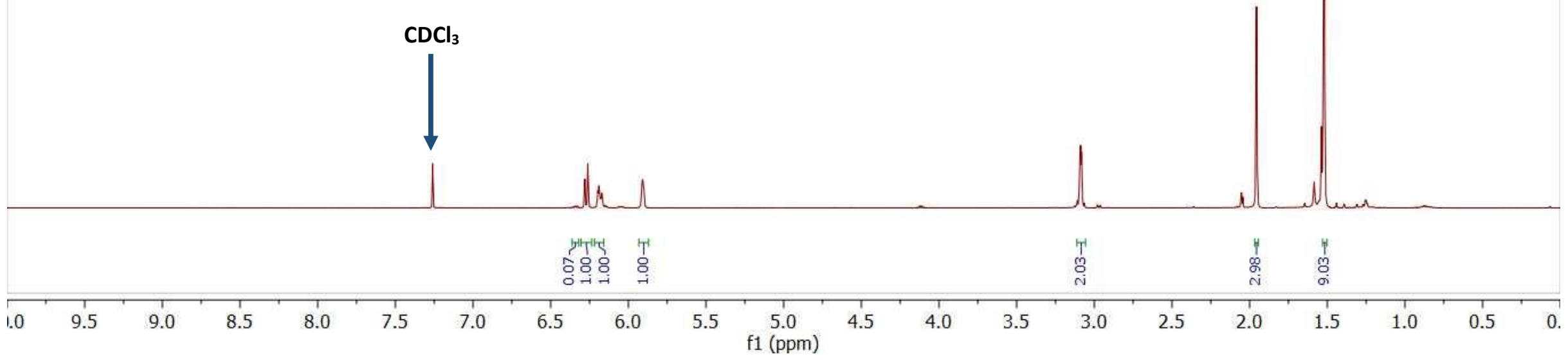


Compound $3 \mathrm{C}\left({ }^{1} \mathrm{H}, 500 \mathrm{MHz}, \mathrm{CDCl}_{3}\right.$, expanded view)
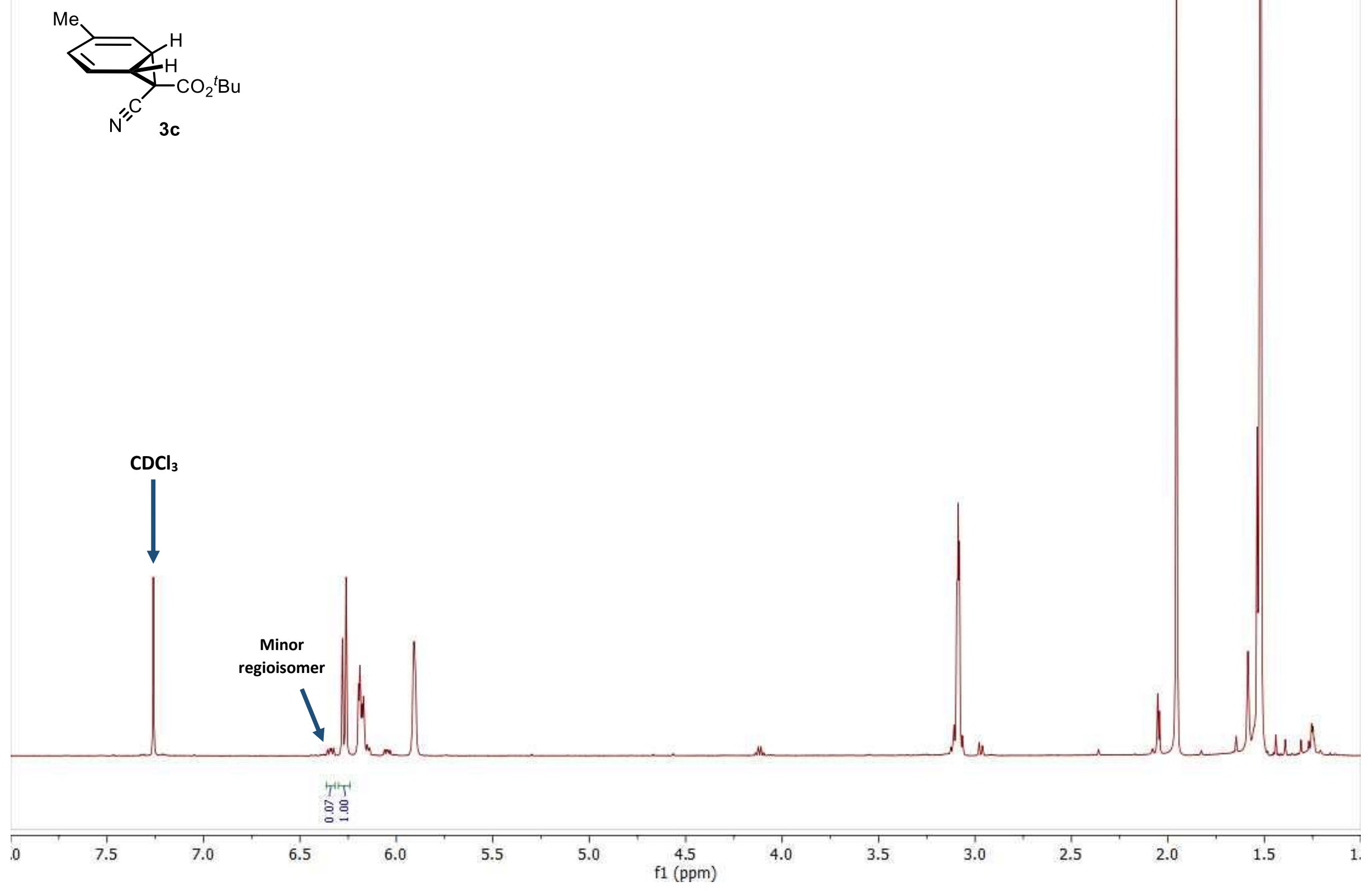
Compound $3 \mathrm{c}\left({ }^{13} \mathrm{C}, 101 \mathrm{MHz}, \mathrm{CDCl}_{3}\right)$

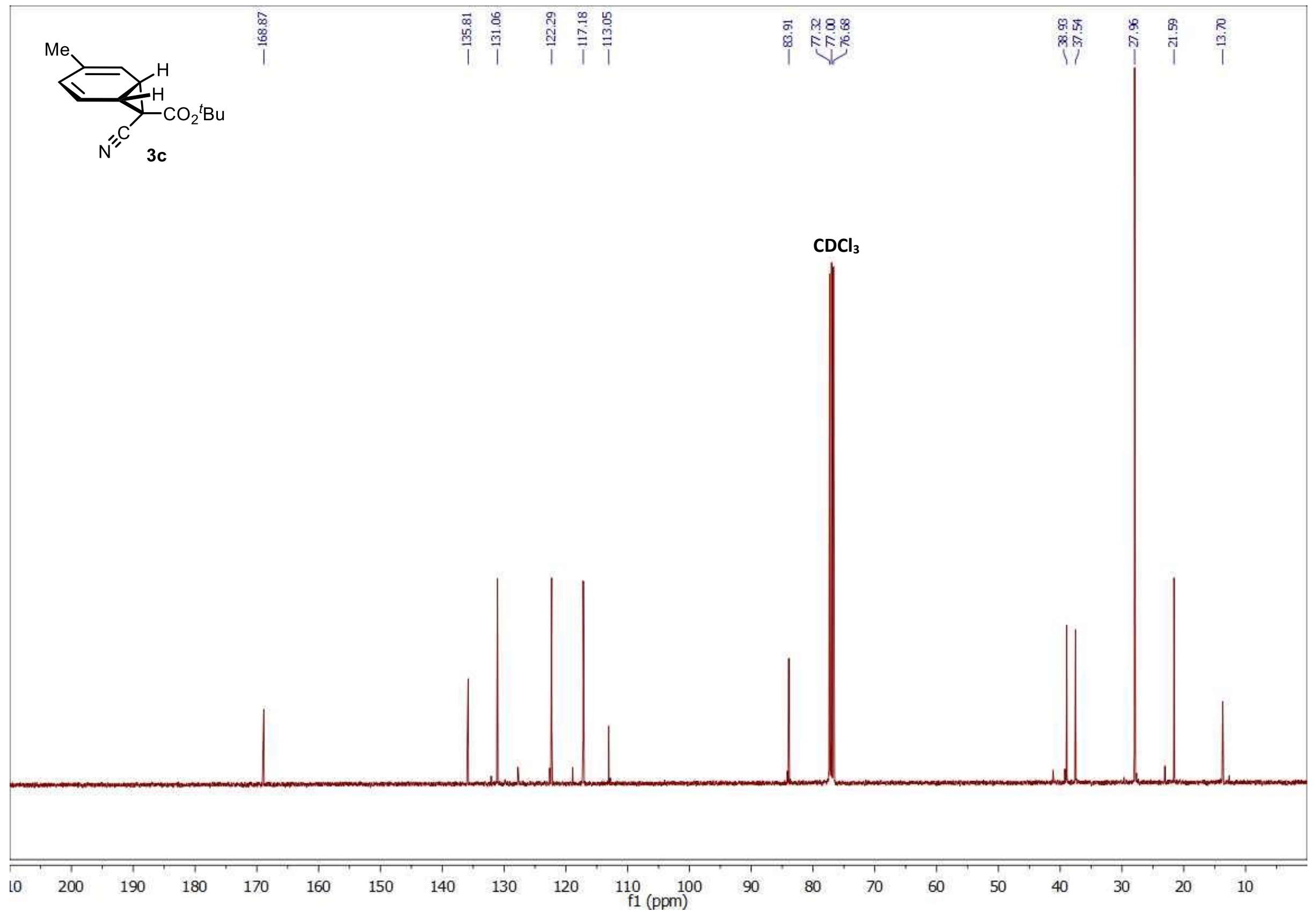


Compound $3 \mathrm{~d}\left({ }^{1} \mathrm{H}, 600 \mathrm{MHz}, \mathrm{CDCl}_{3}\right.$, standard view)

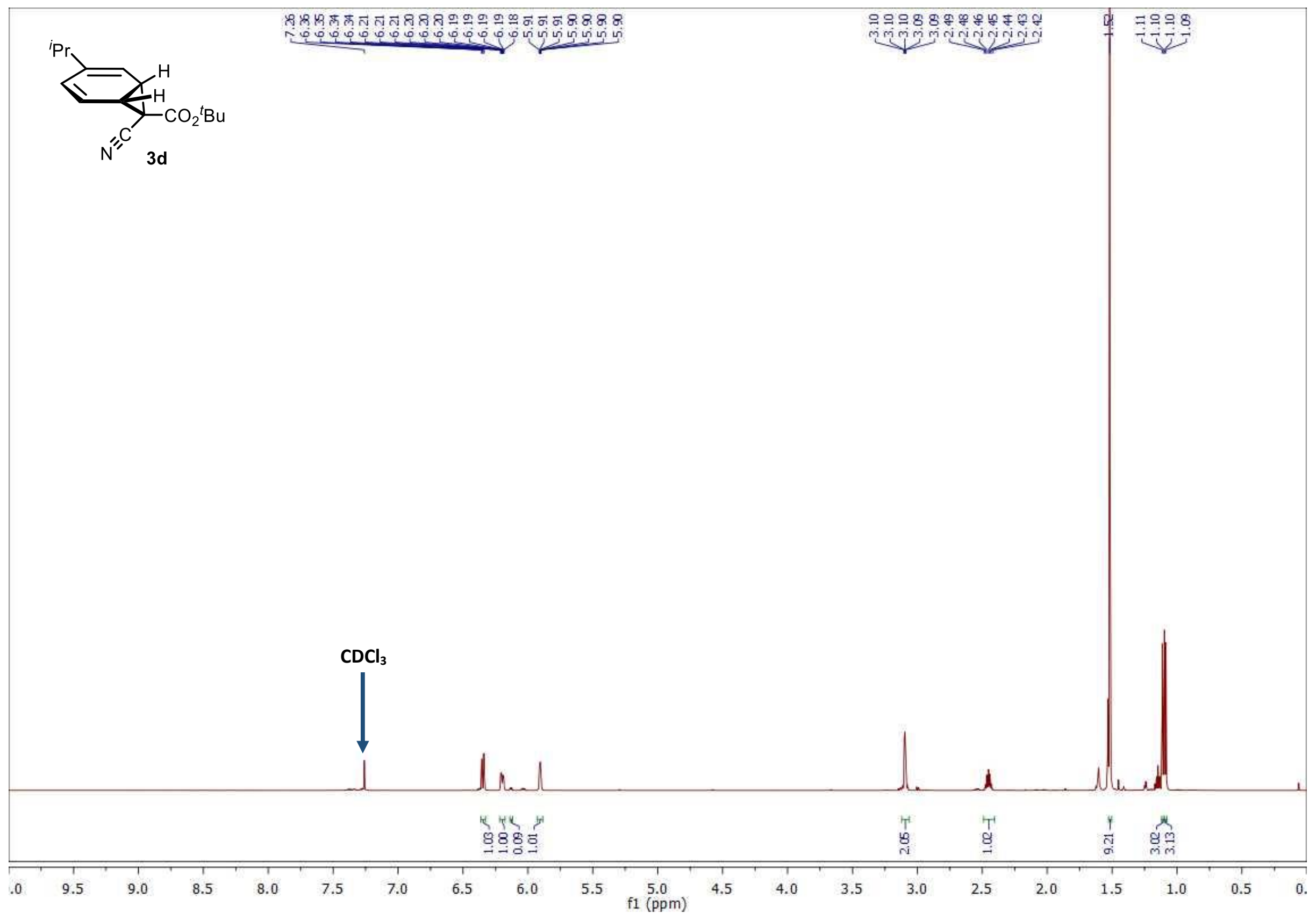


Compound 3d ( ${ }^{1} \mathrm{H}, 600 \mathrm{MHz}, \mathrm{CDCl}_{3}$, expanded view)
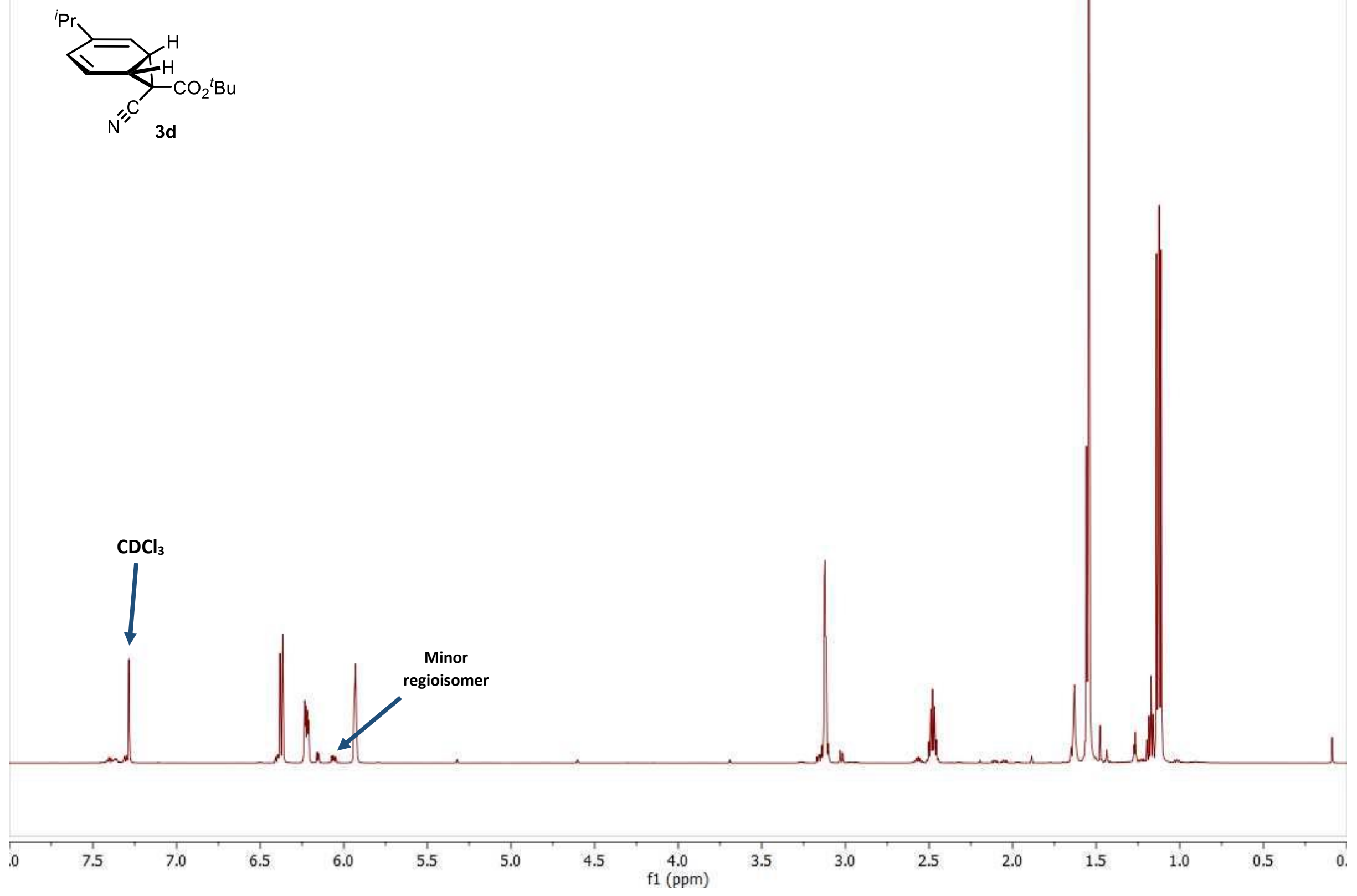
Compound $3 \mathrm{~d}\left({ }^{13} \mathrm{C}, 151 \mathrm{MHz}, \mathrm{CDCl}_{3}\right)$

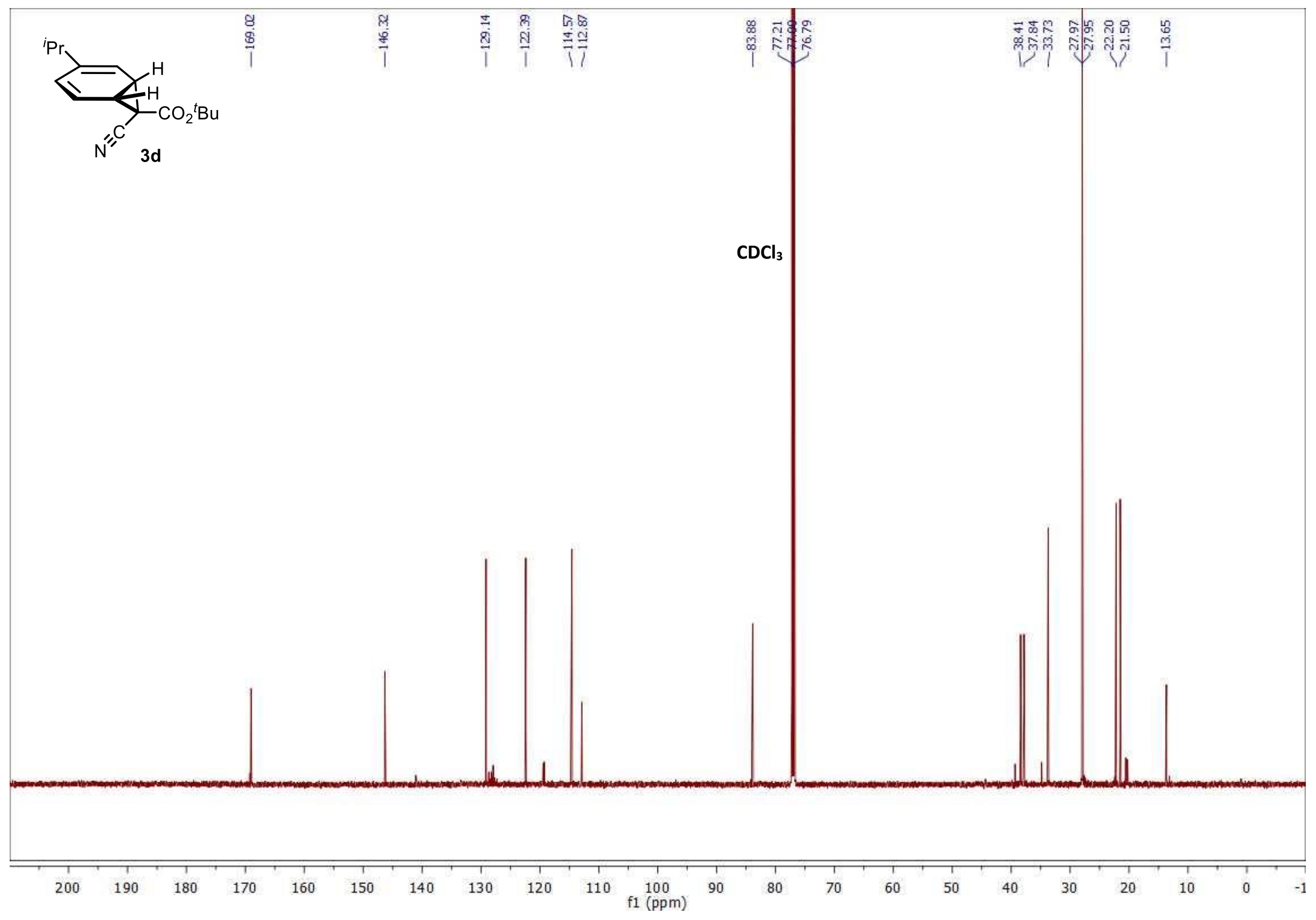


Compound $3 \mathrm{e}\left({ }^{1} \mathrm{H}, 600 \mathrm{MHz}, \mathrm{CDCl}_{3}\right.$, standard view)

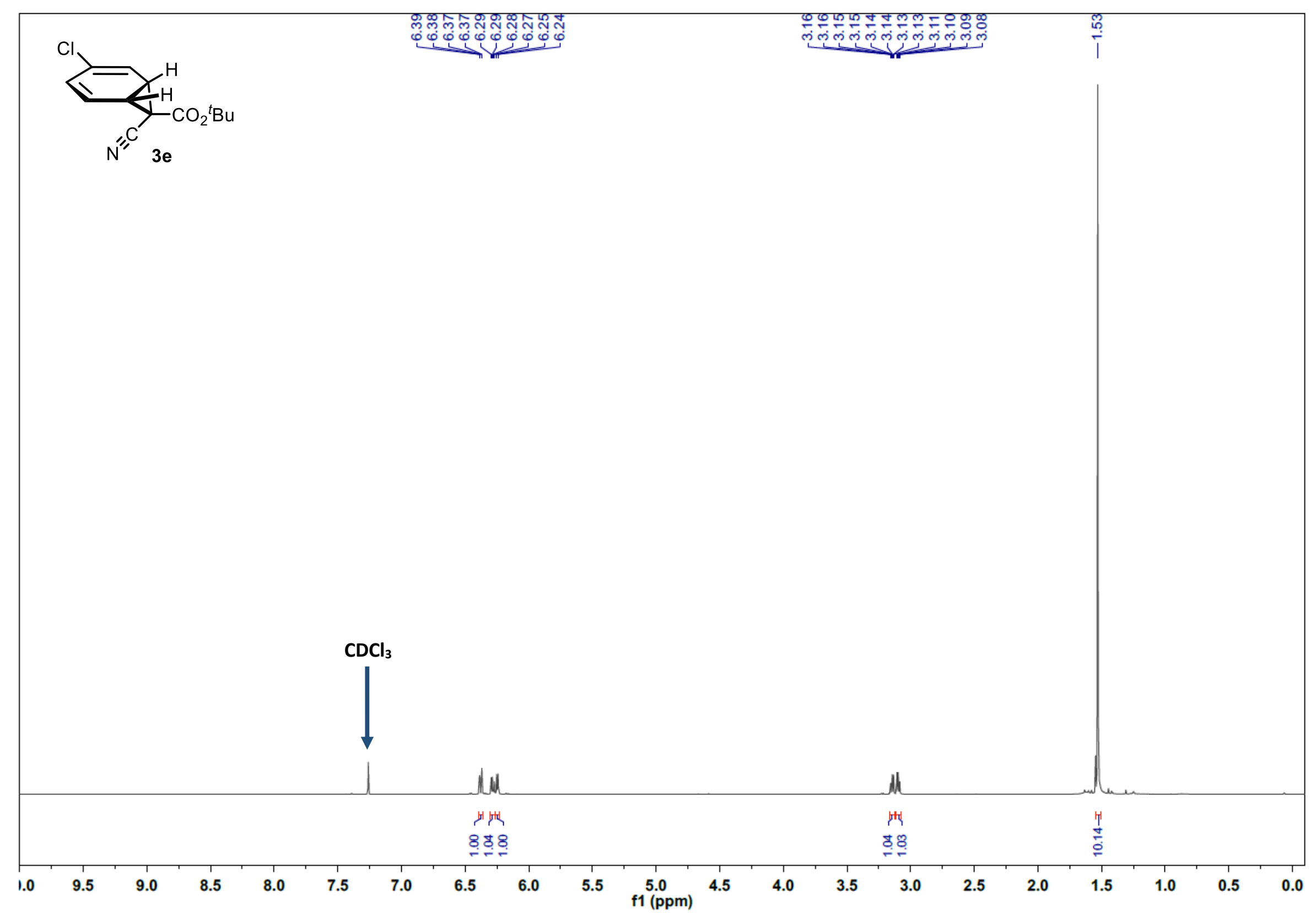


Compound $3 e\left({ }^{1} \mathrm{H}, 600 \mathrm{MHz}, \mathrm{CDCl}_{3}\right.$, expanded view)
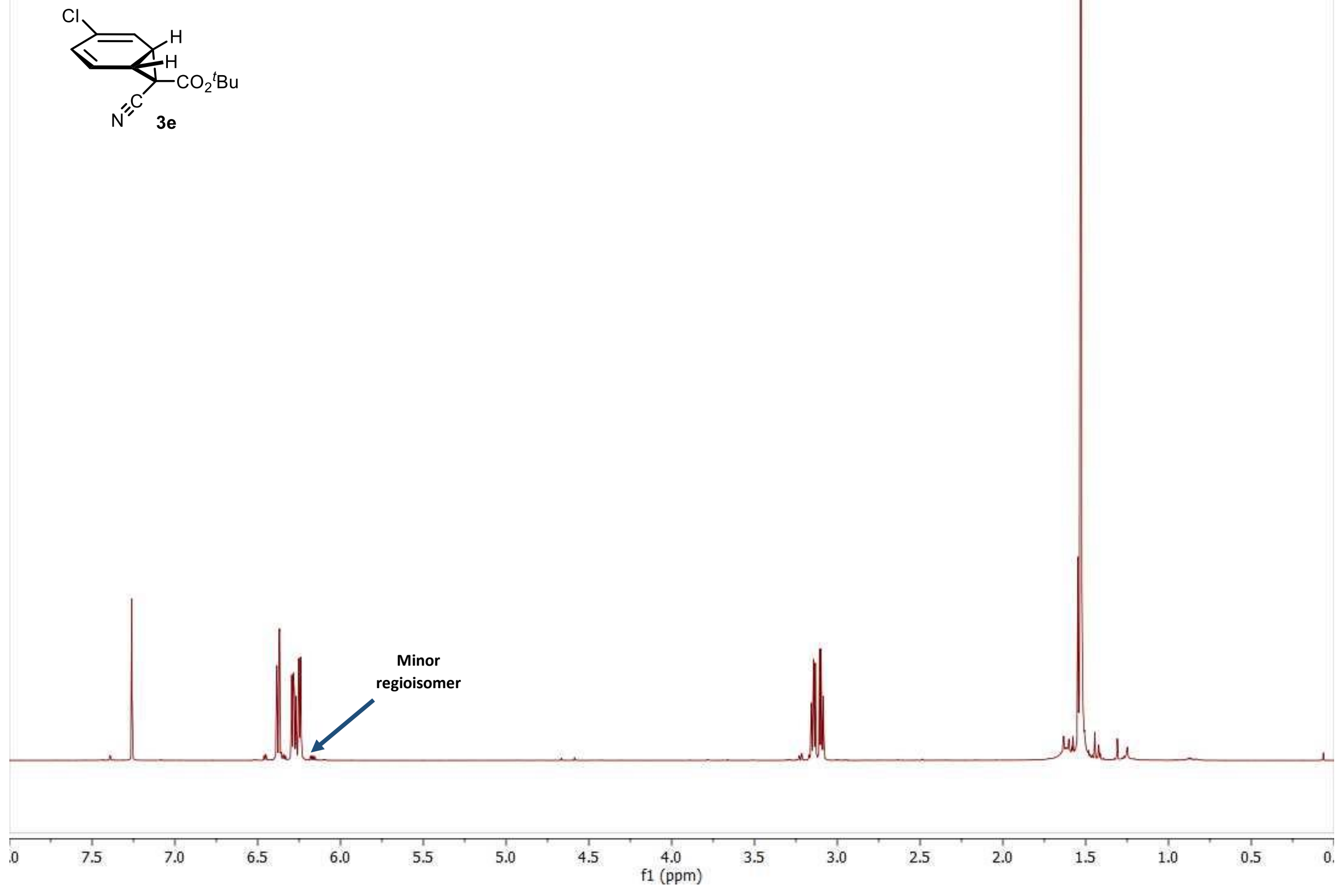
Compound $3 e\left({ }^{13} \mathrm{C}, 151 \mathrm{MHz}, \mathrm{CDCl}_{3}\right)$

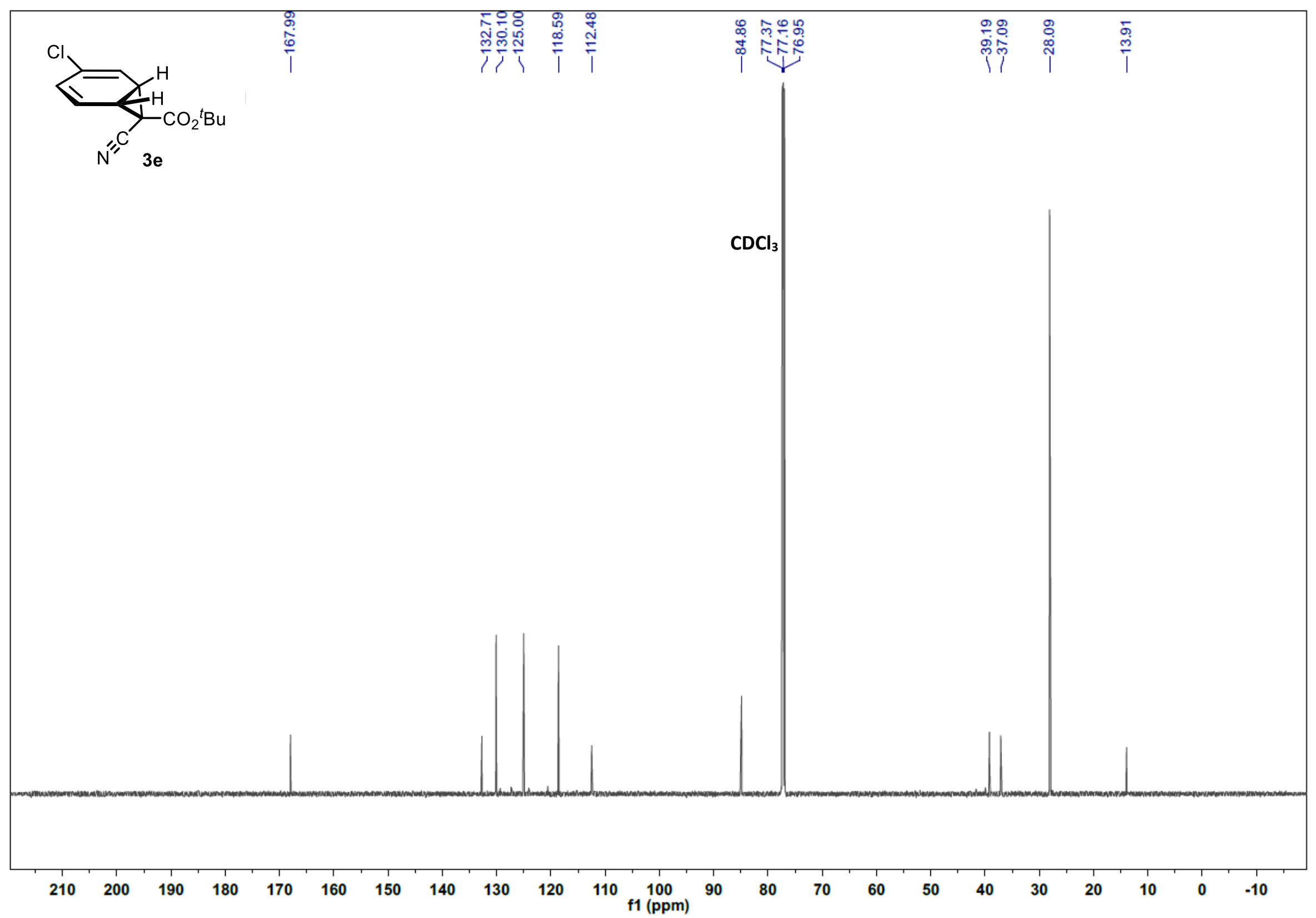


Compound $3 f\left({ }^{1} \mathrm{H}, 600 \mathrm{MHz}, \mathrm{CDCl}_{3}\right.$, standard view)

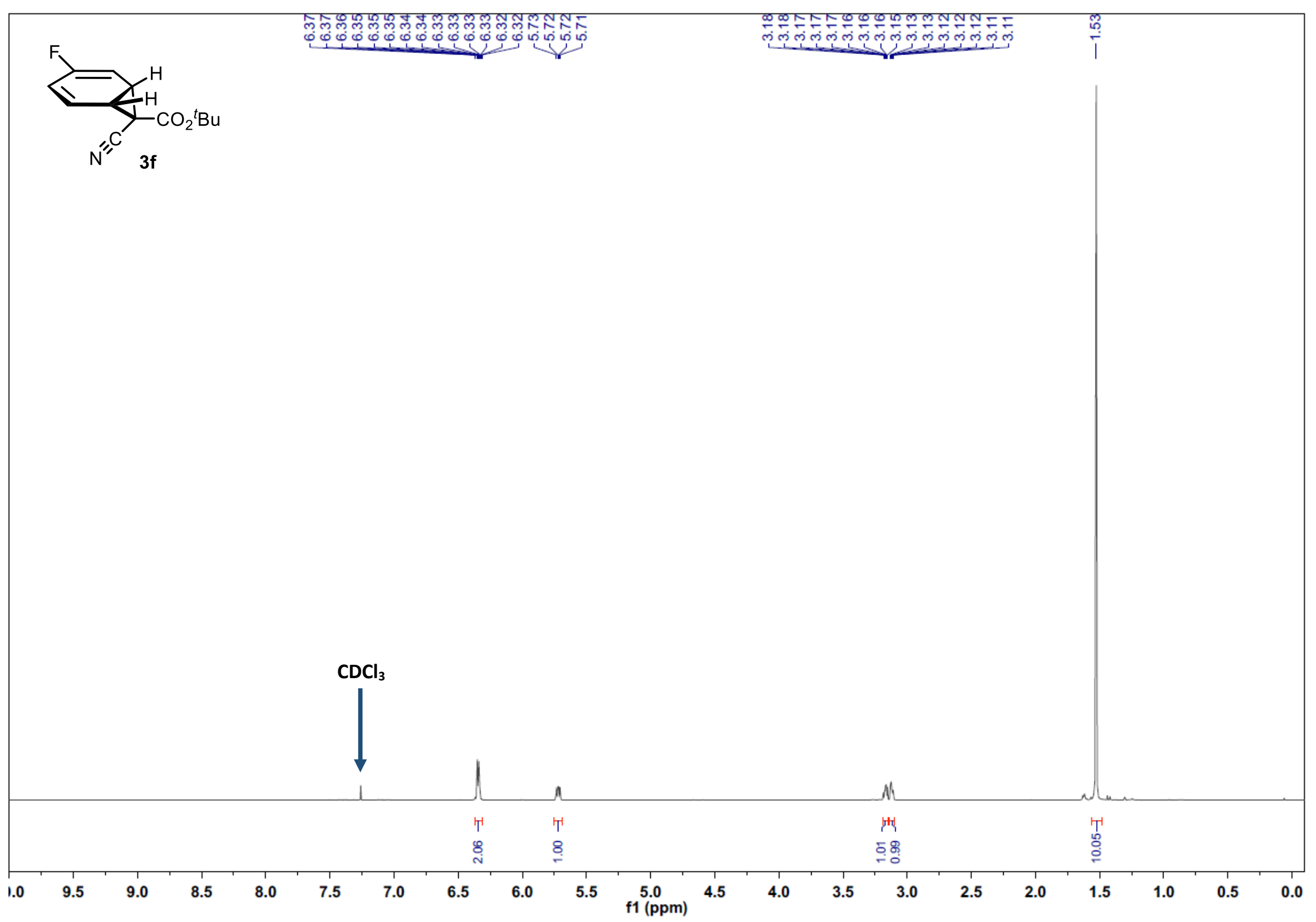


Compound $3 f\left({ }^{1} \mathrm{H}, 600 \mathrm{MHz}, \mathrm{CDCl}_{3}\right.$, expanded view)
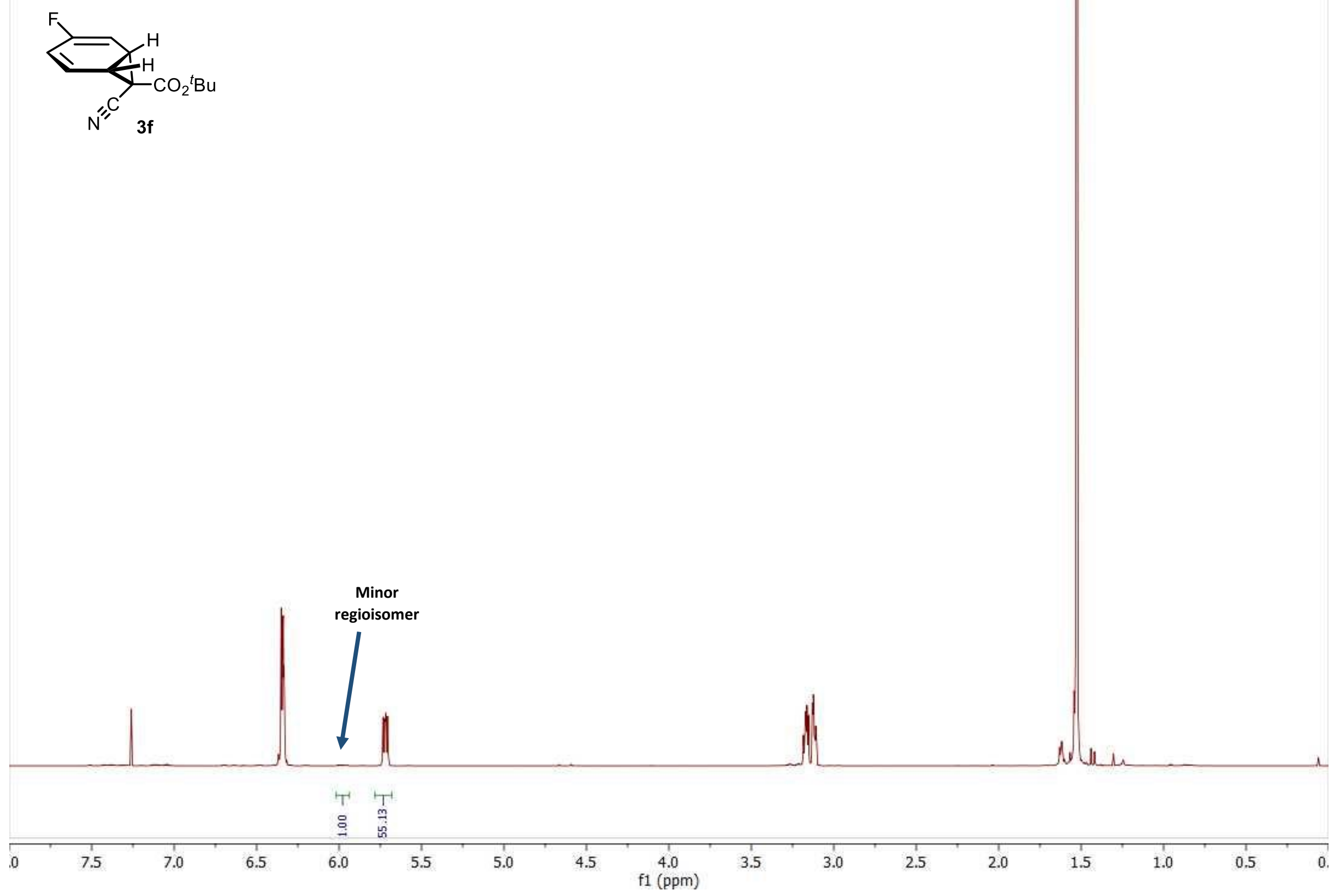
Compound $3 \mathrm{f}\left({ }^{13} \mathrm{C}, 151 \mathrm{MHz}, \mathrm{CDCl}_{3}\right)$

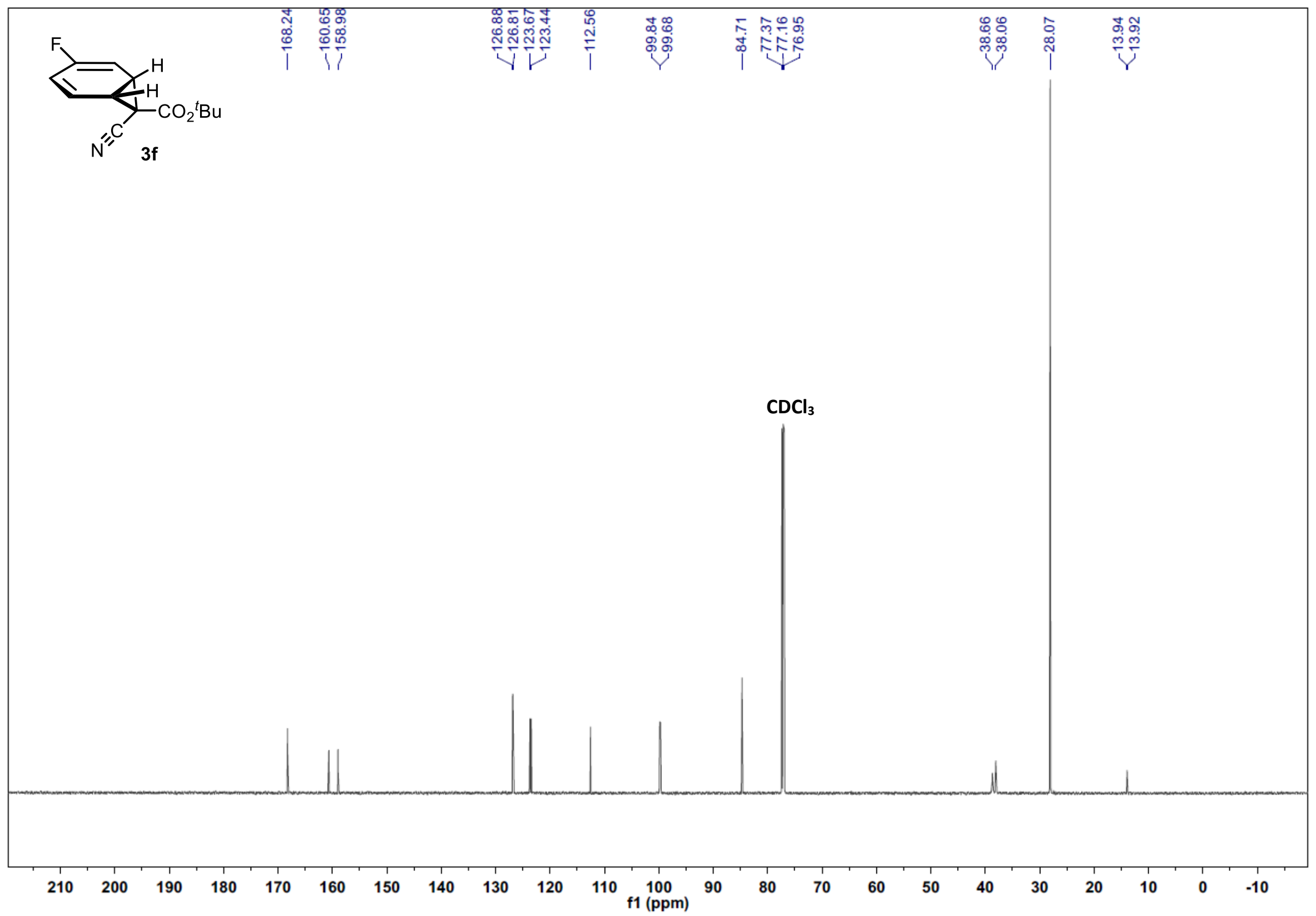


Compound $3 f\left({ }^{19} \mathrm{~F}, 376 \mathrm{MHz}, \mathrm{CDCl}_{3}\right)$

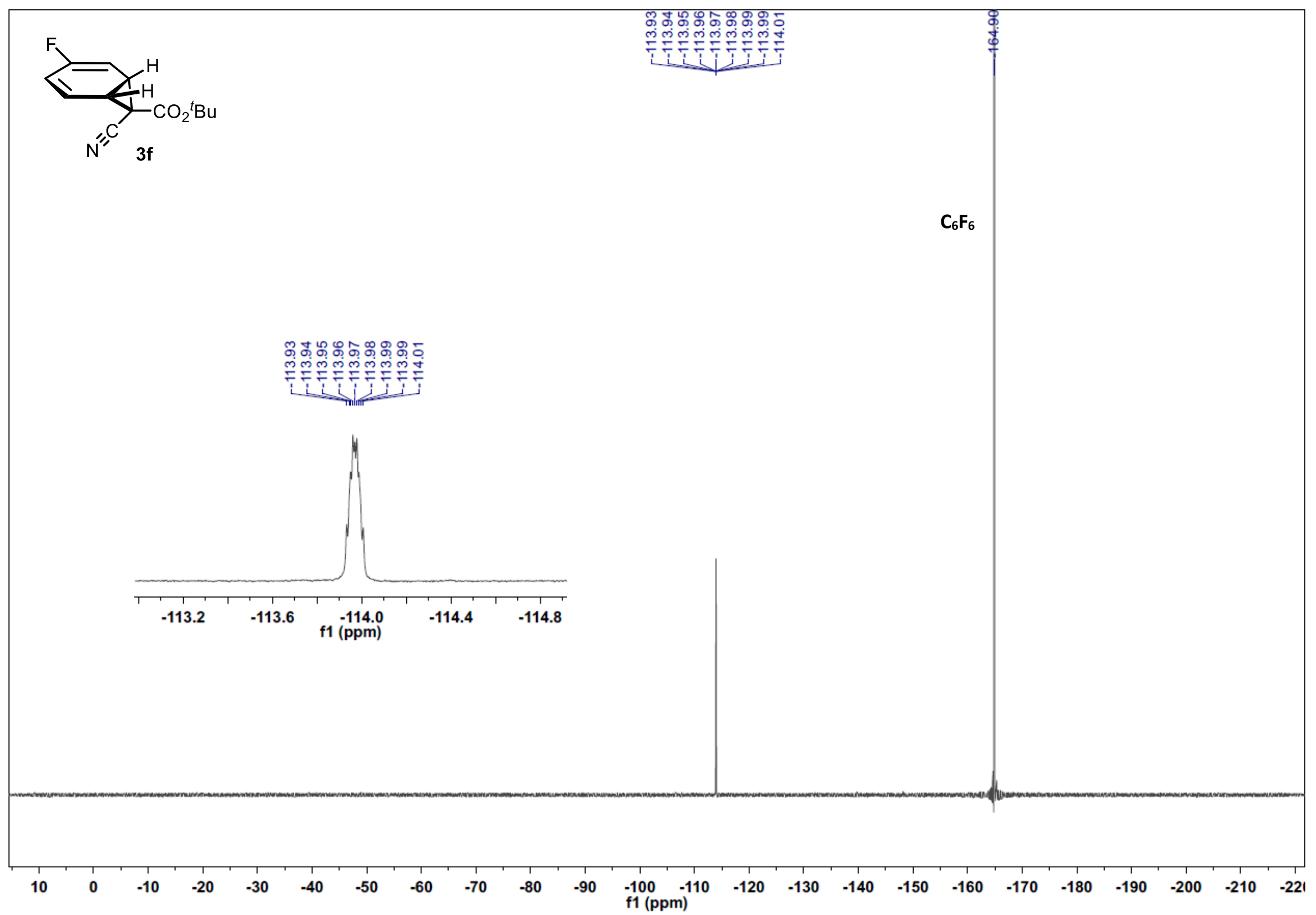


Compound 3g $\left({ }^{1} \mathrm{H}, 600 \mathrm{MHz}, \mathrm{CDCl}_{3}\right.$, standard view)

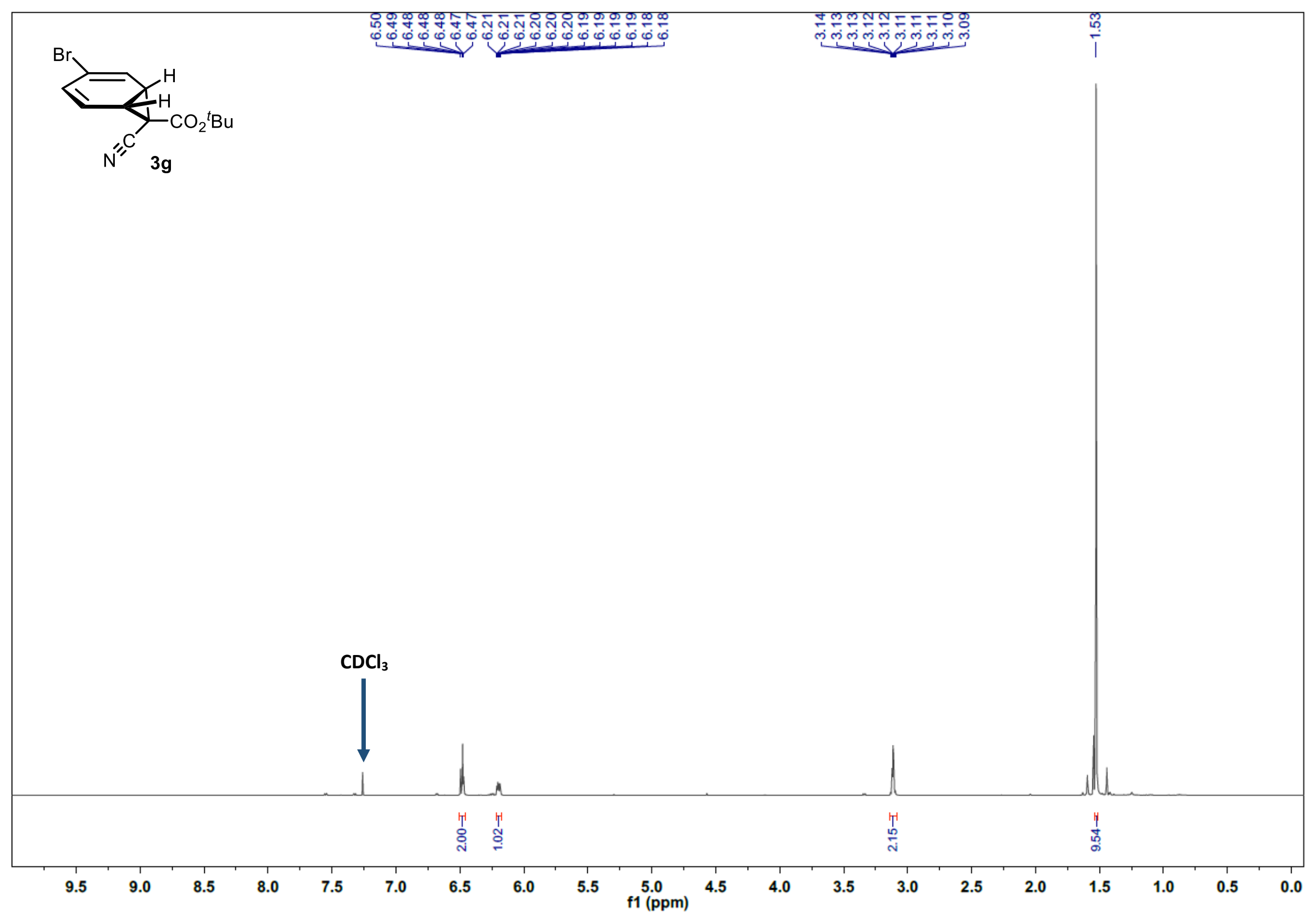


Compound $3 \mathrm{~g}\left({ }^{1} \mathrm{H}, 600 \mathrm{MHz}, \mathrm{CDCl}_{3}\right.$, expanded view)

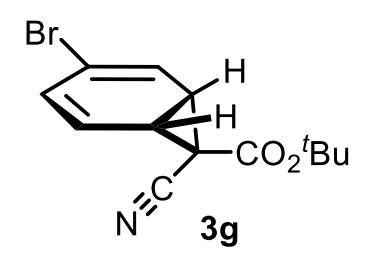

Minor

regioisomer

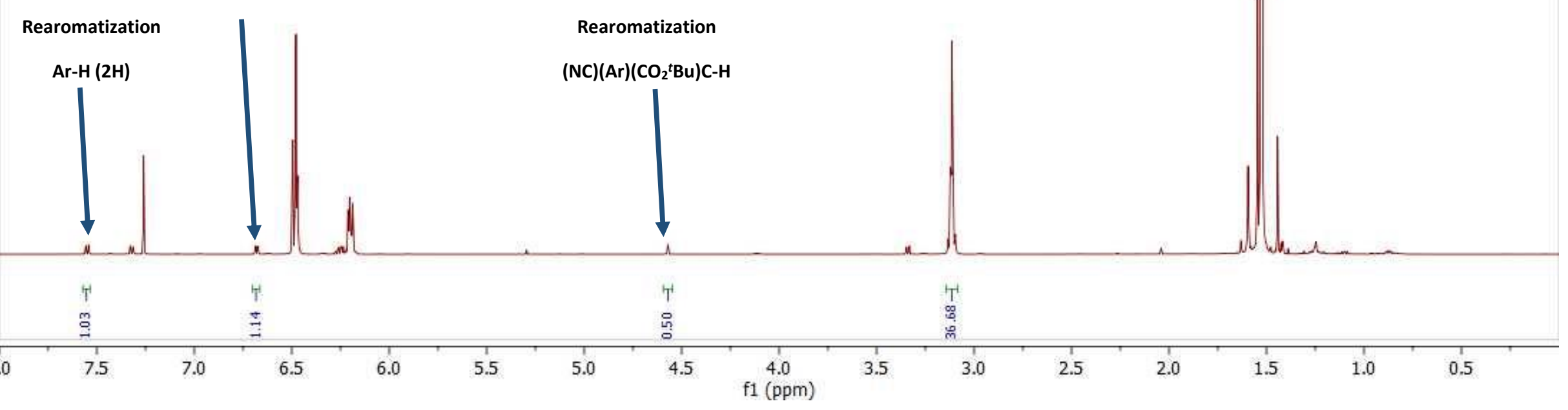


Compound $3 \mathrm{~g}\left({ }^{13} \mathrm{C}, 151 \mathrm{MHz}, \mathrm{CDCl}_{3}\right)$

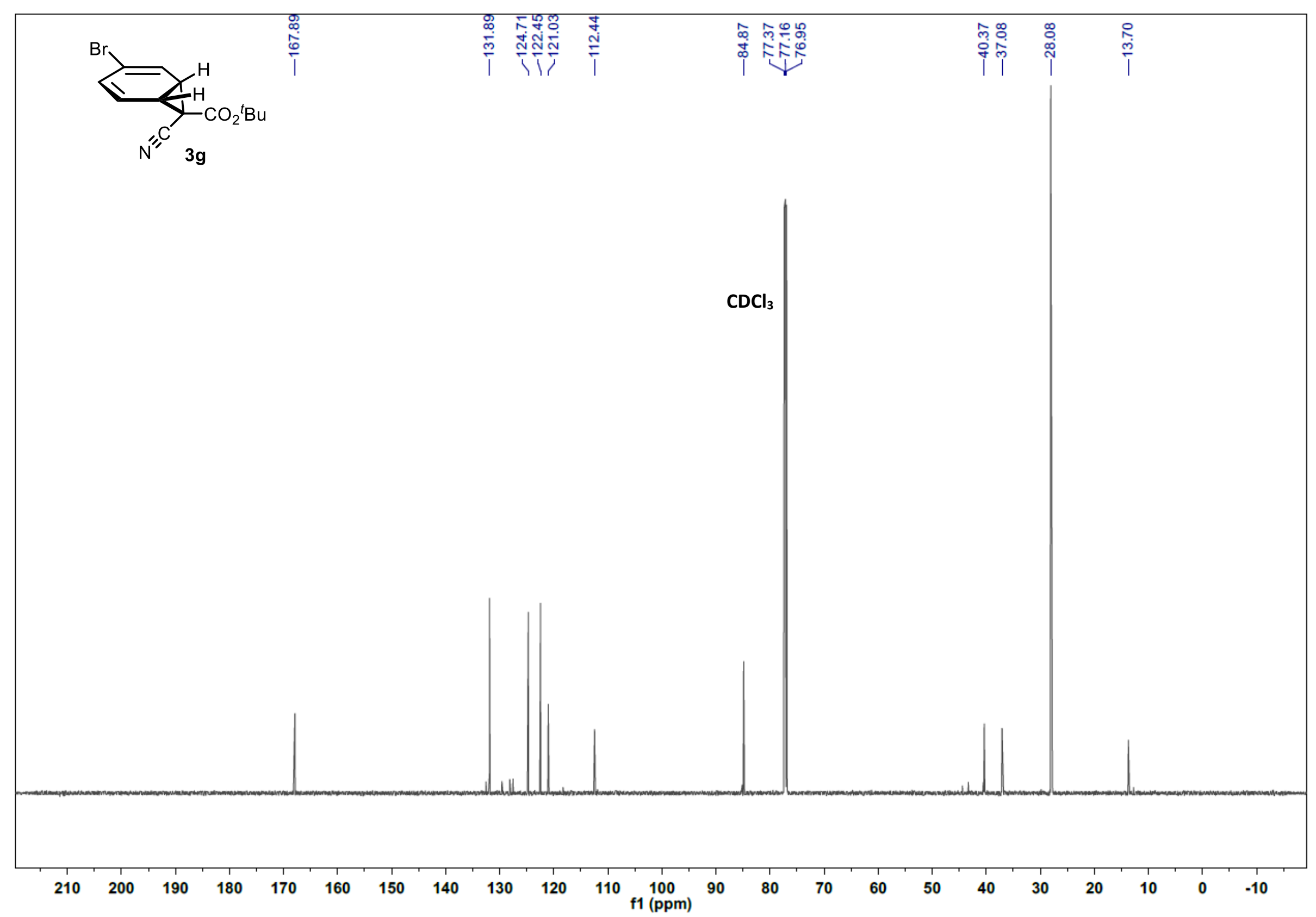


Compound $3 \mathrm{~h}\left({ }^{1} \mathrm{H}, 600 \mathrm{MHz}, \mathrm{CDCl}_{3}\right)$

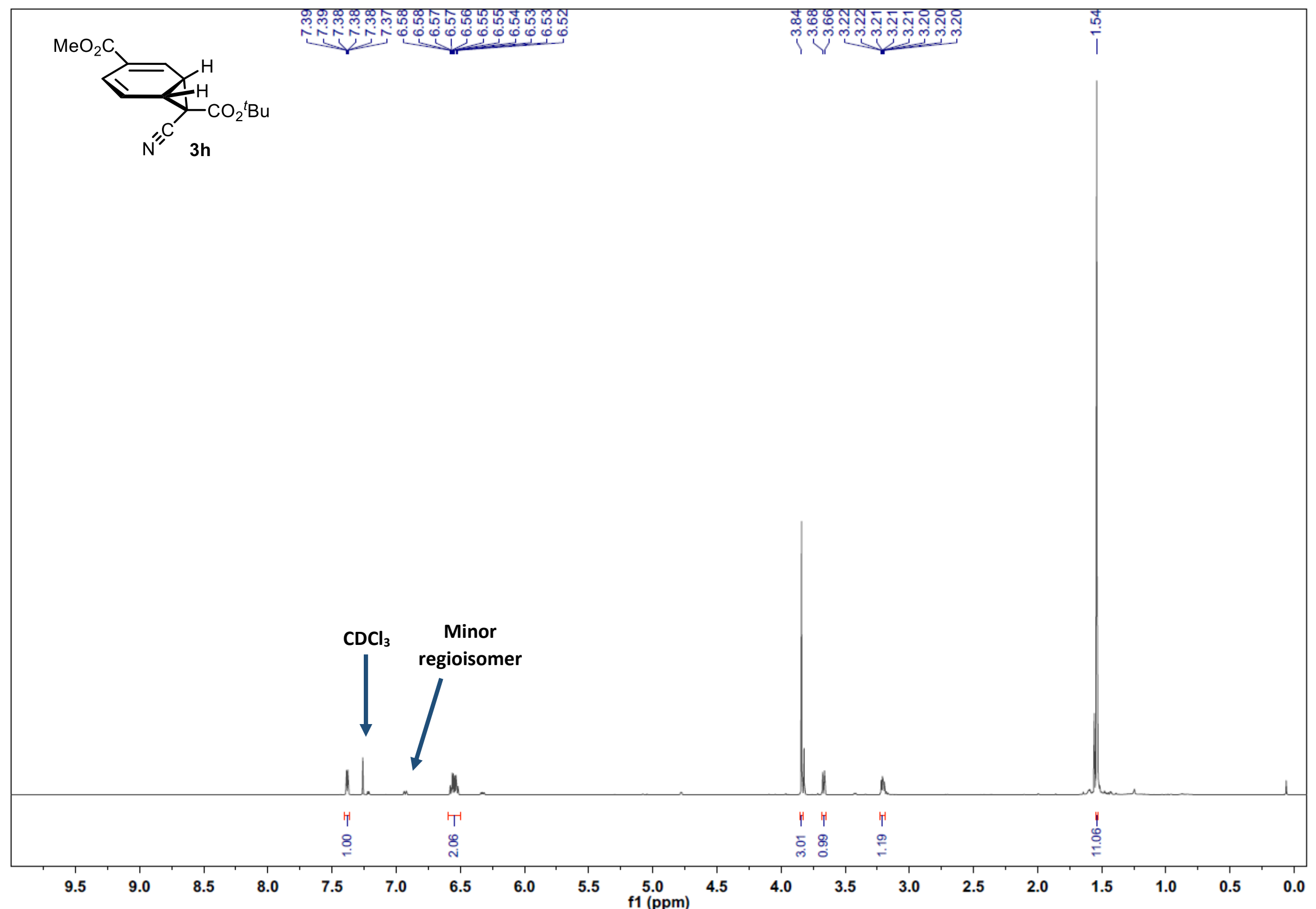


Compound $3 \mathrm{~h}\left({ }^{13} \mathrm{C}, 151 \mathrm{MHz}, \mathrm{CDCl}_{3}\right)$

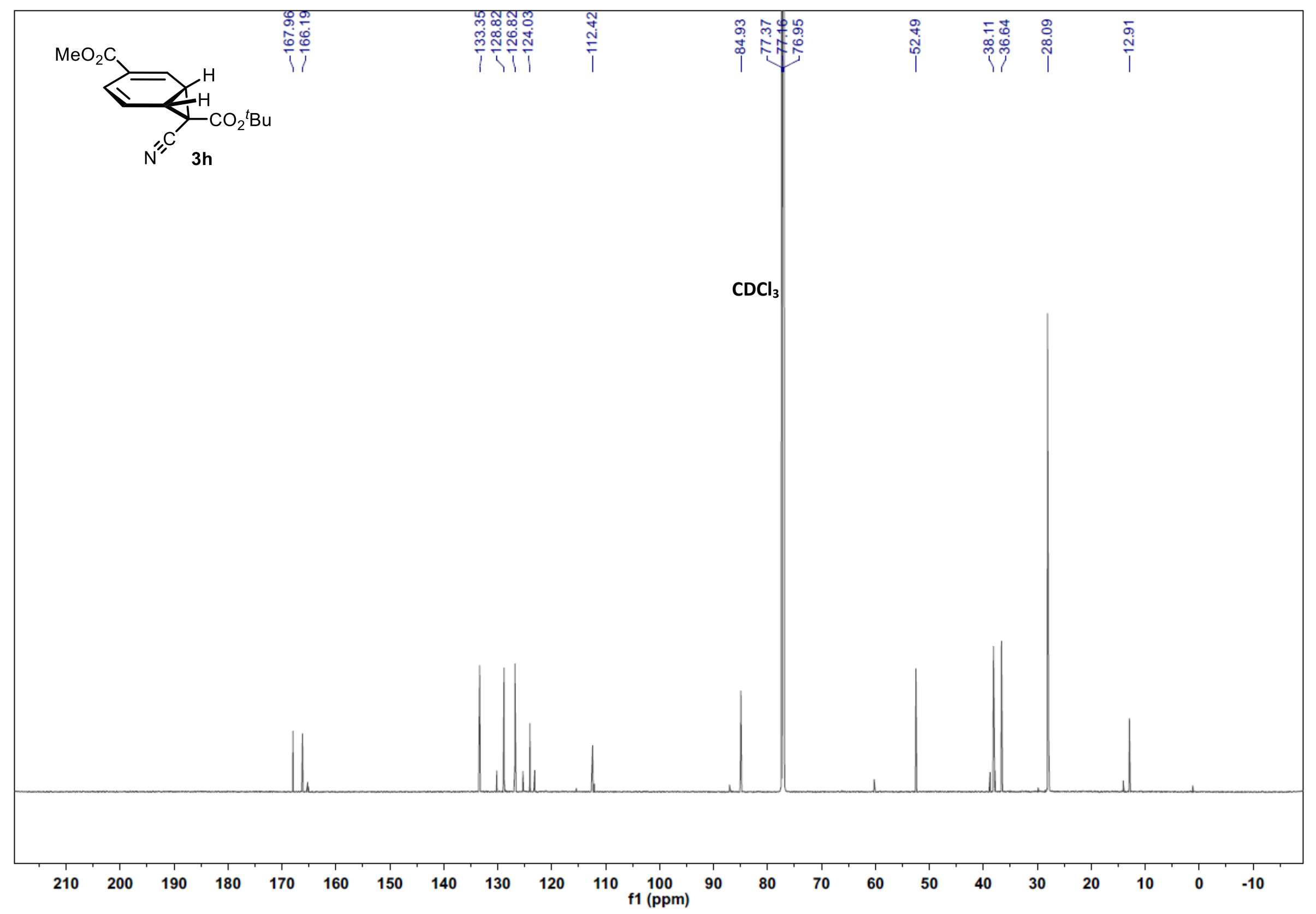


Compound 3i ( ${ }^{1} \mathrm{H}, 500 \mathrm{MHz}, \mathrm{CDCl}_{3}$, standard view)

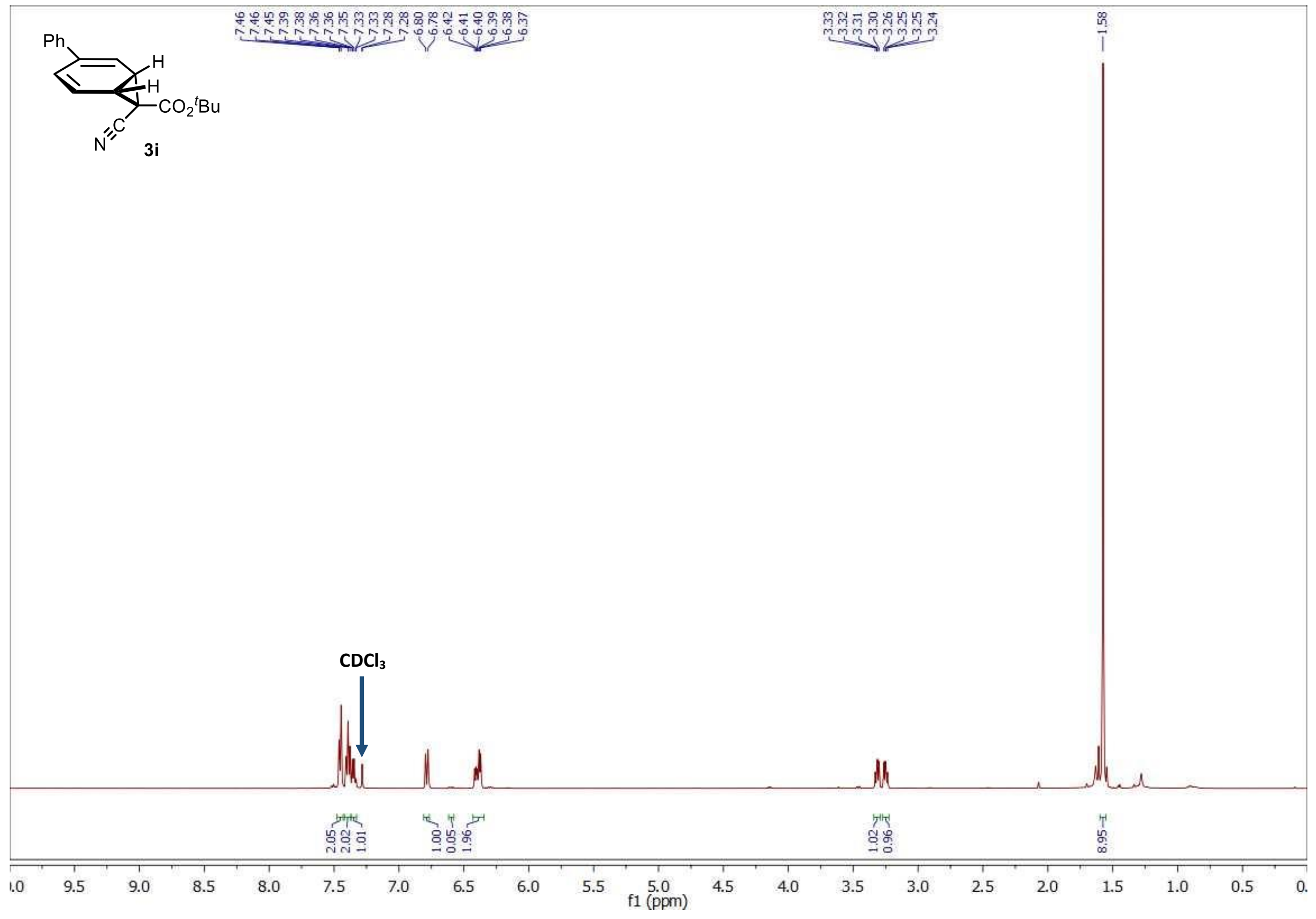


Compound 3i ( ${ }^{1} \mathrm{H}, 500 \mathrm{MHz}, \mathrm{CDCl}_{3}$, expanded view)
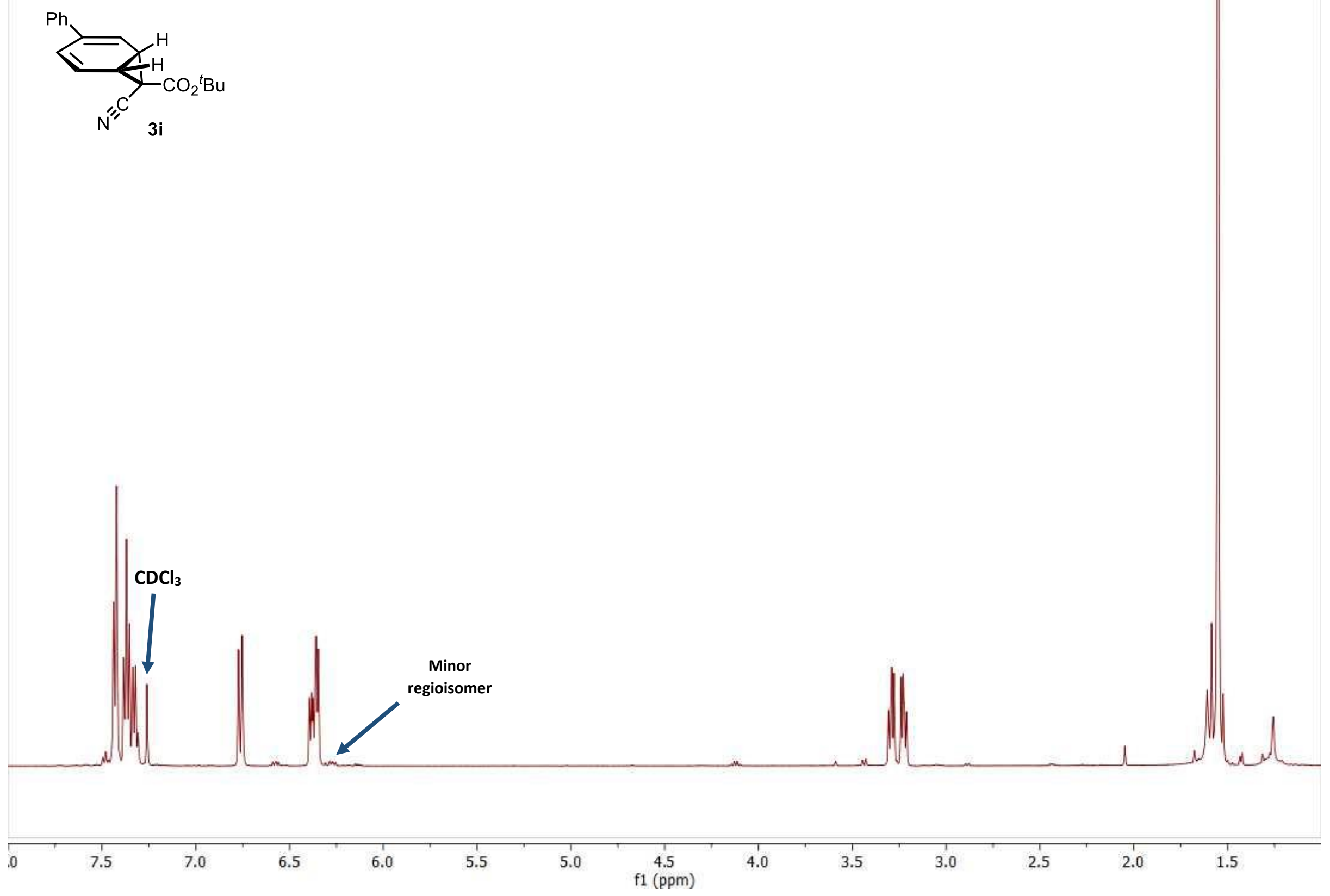
Compound $3 \mathrm{i}\left({ }^{13} \mathrm{C}, 101 \mathrm{MHz}, \mathrm{CDCl}_{3}\right)$

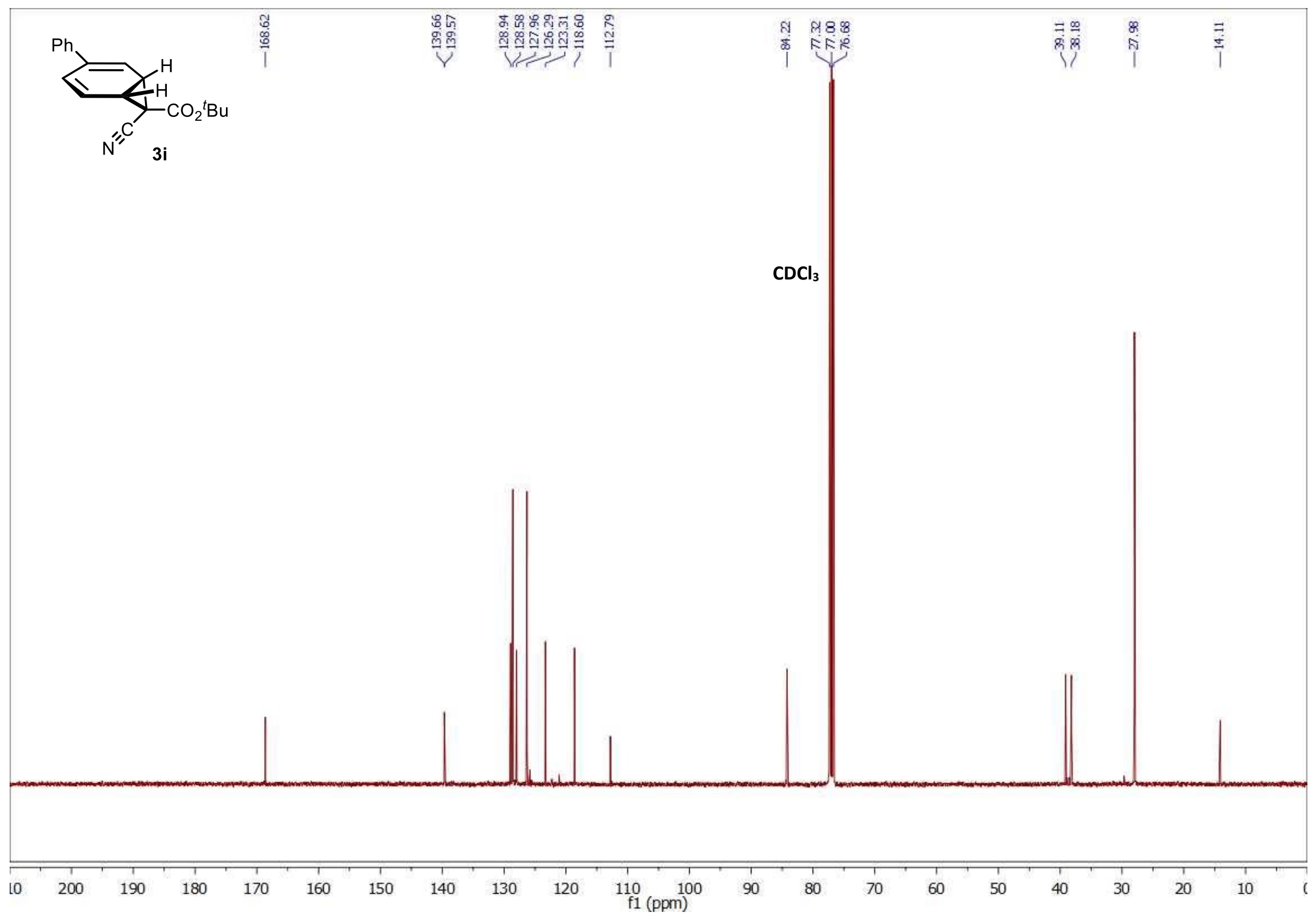


Compound 3j $\left({ }^{1} \mathrm{H}, 600 \mathrm{MHz}, \mathrm{CDCl}_{3}\right.$, standard view)

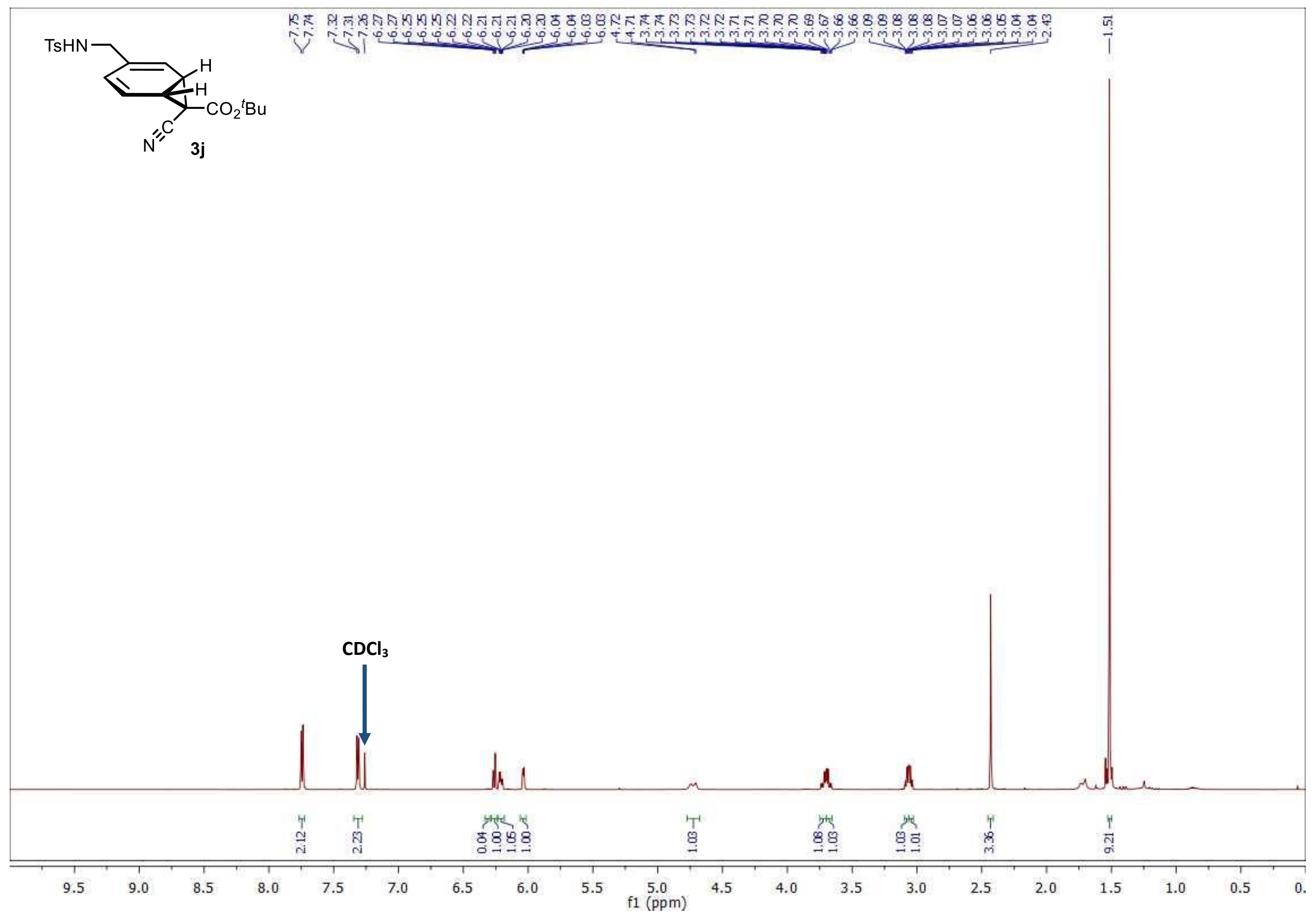


Compound $3 \mathrm{j}\left({ }^{1} \mathrm{H}, 600 \mathrm{MHz}, \mathrm{CDCl}_{3}\right.$, expanded view)
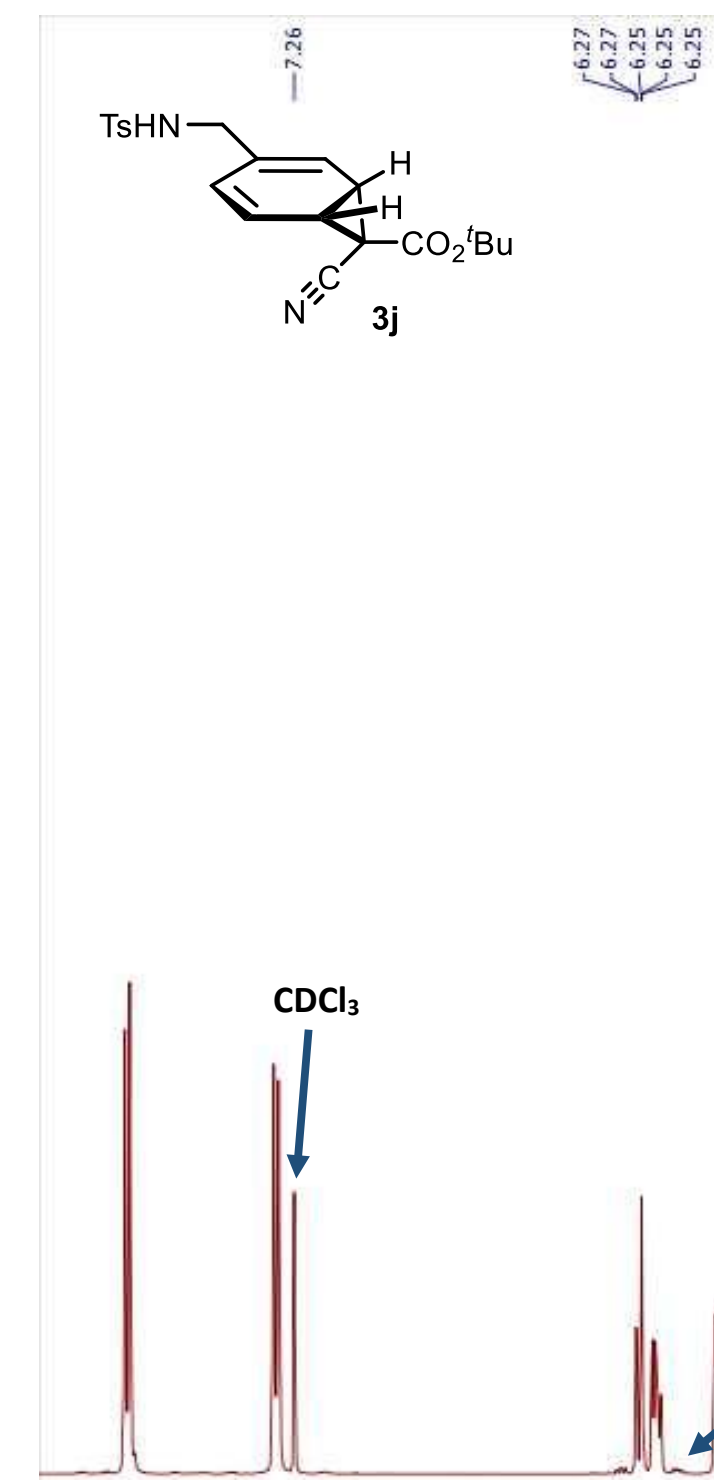

Minor regioisomer
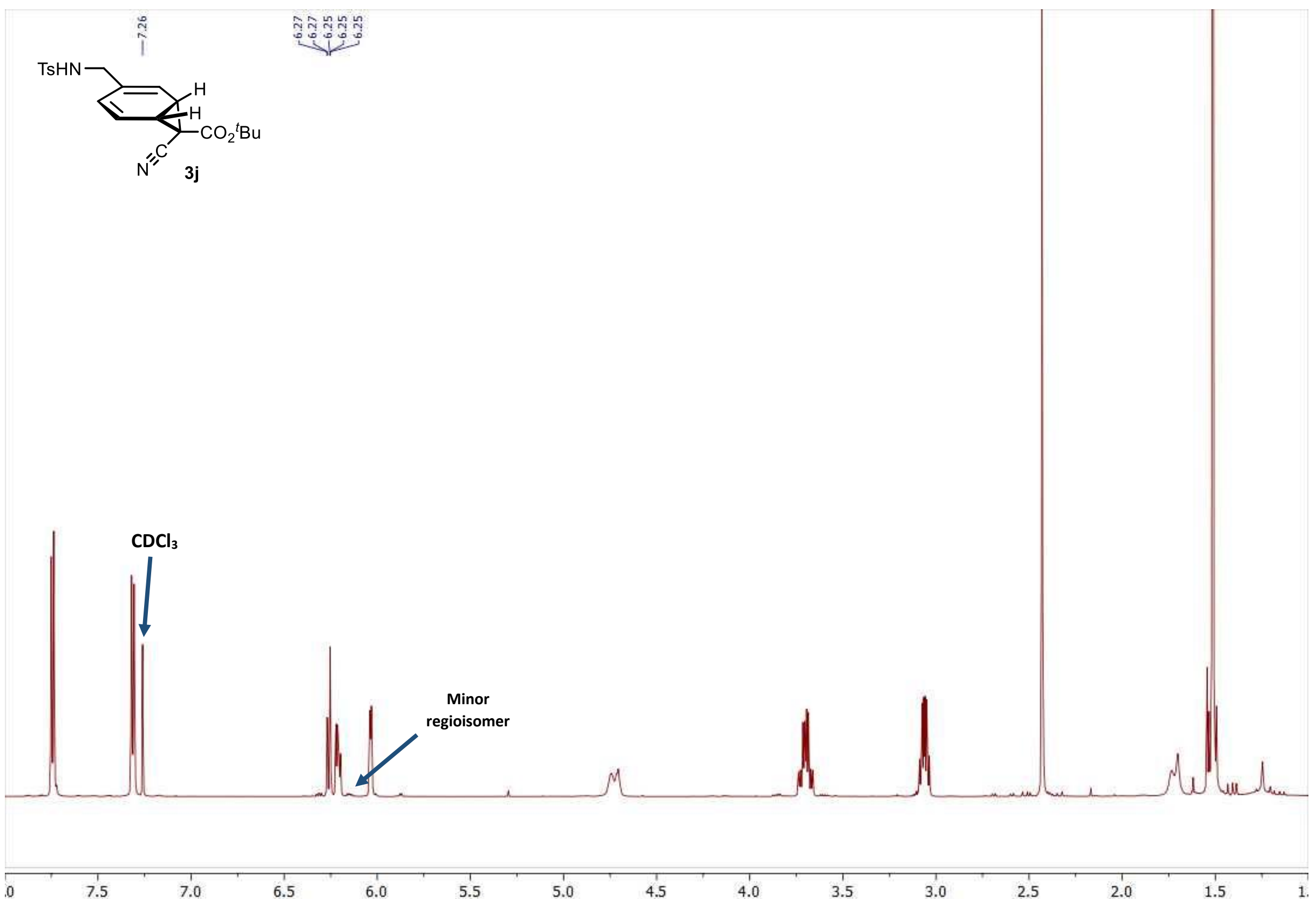

6.5

6.0

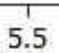

5.0

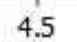
$\mathrm{f1}$ (ppm) 
Compound $3 \mathrm{j}\left({ }^{13} \mathrm{C}, 151 \mathrm{MHz}, \mathrm{CDCl}_{3}\right)$

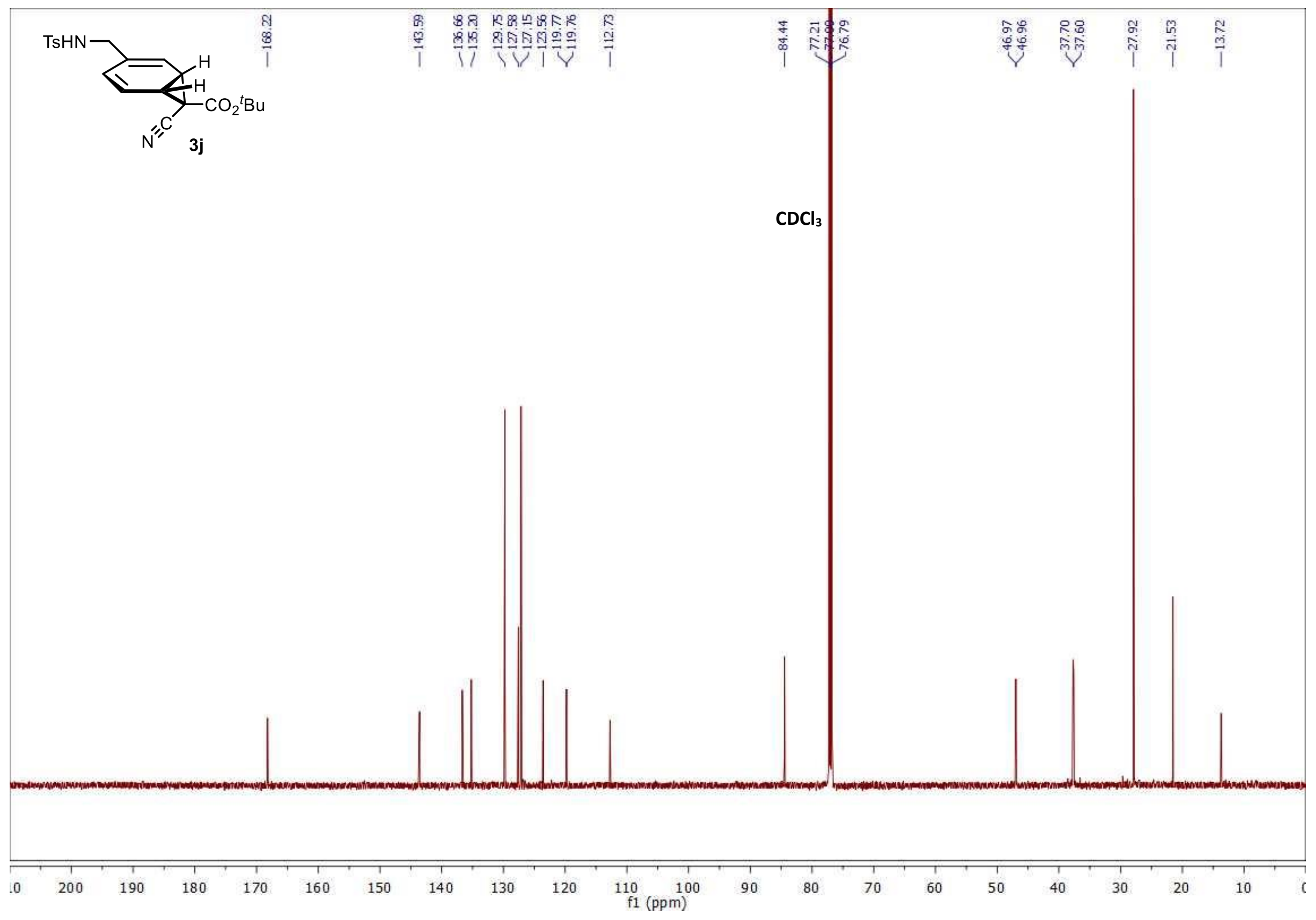


Compound $3 \mathrm{k}\left({ }^{1} \mathrm{H}, 500 \mathrm{MHz}, \mathrm{CDCl}_{3}\right.$, standard view)

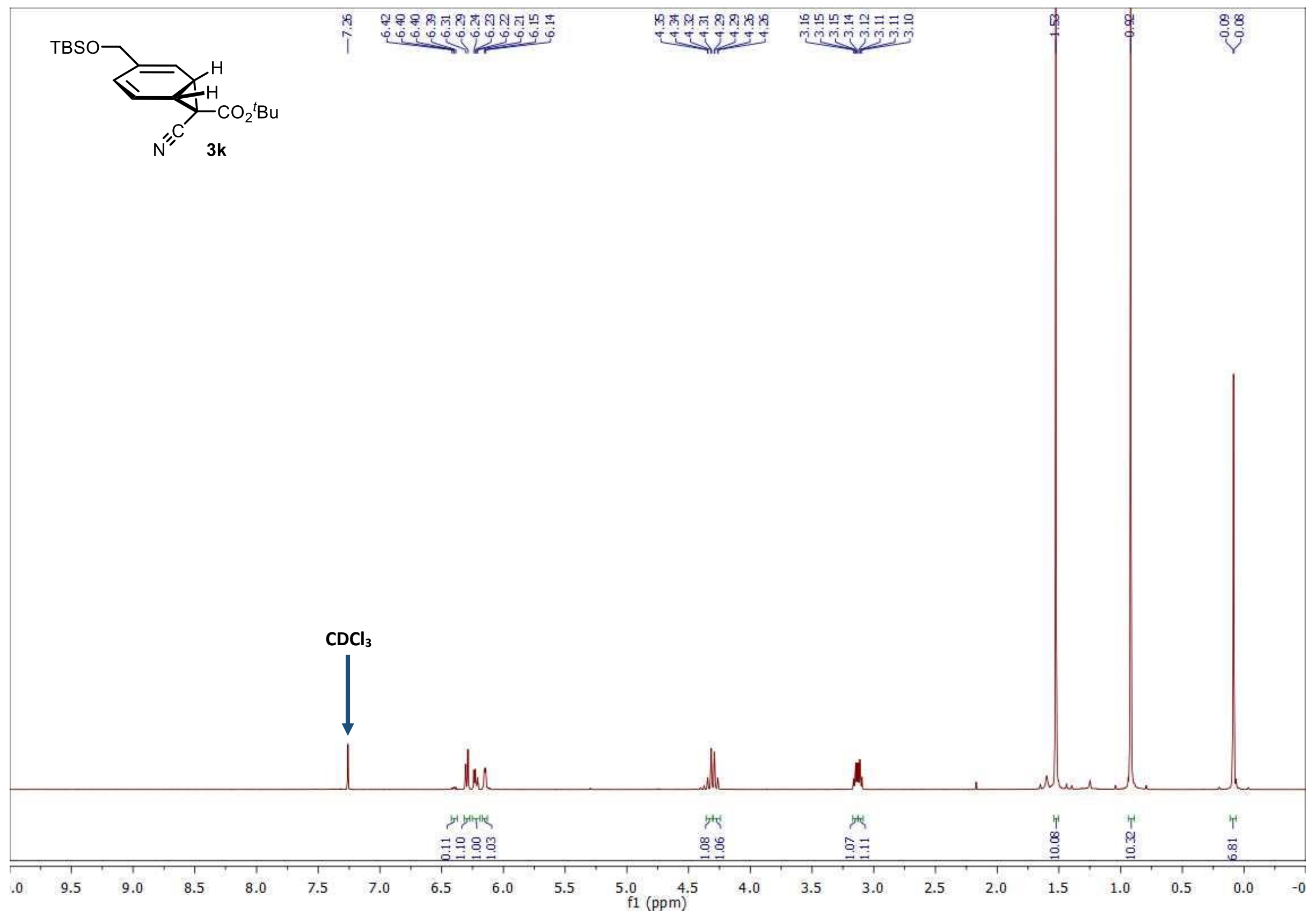




\section{Compound 3k ( ${ }^{1} \mathrm{H}, 500 \mathrm{MHz}, \mathrm{CDCl}_{3}$, expanded view)}
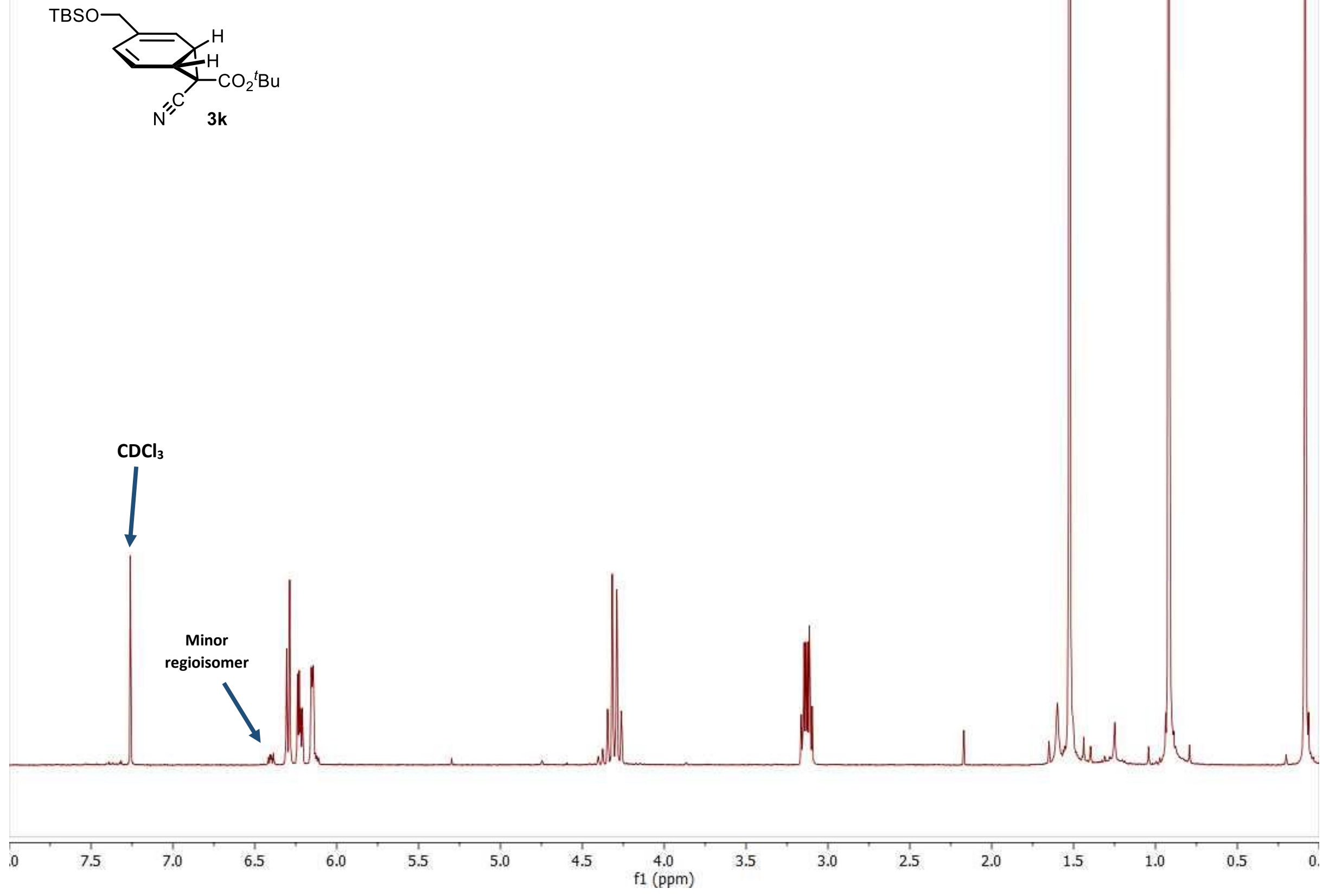
Compound 3k $\left({ }^{13} \mathrm{C}, 126 \mathrm{MHz}, \mathrm{CDCl}_{3}\right)$

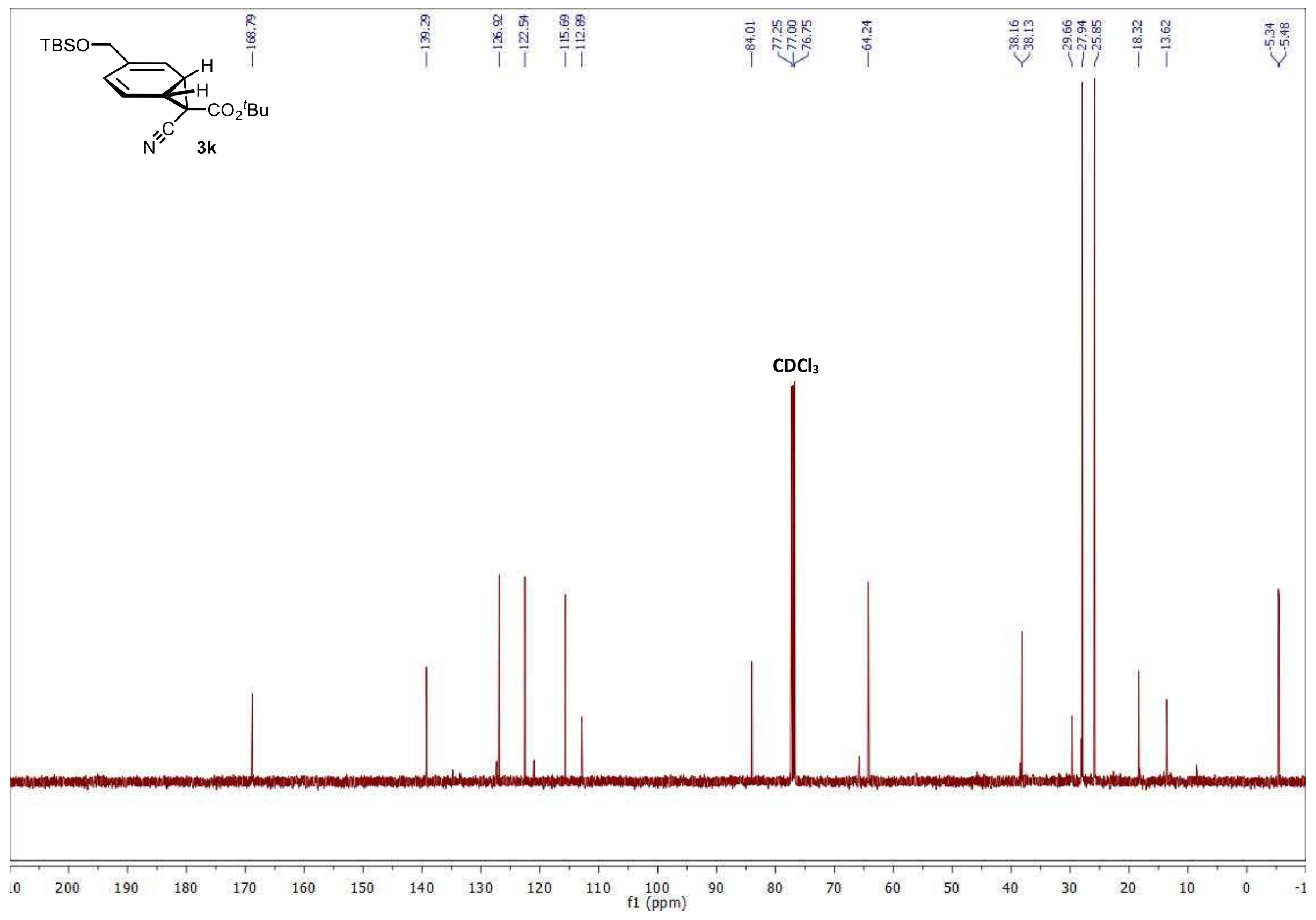


Compound $31\left({ }^{1} \mathrm{H}, 500 \mathrm{MHz}, \mathrm{CDCl}_{3}\right.$, standard view)

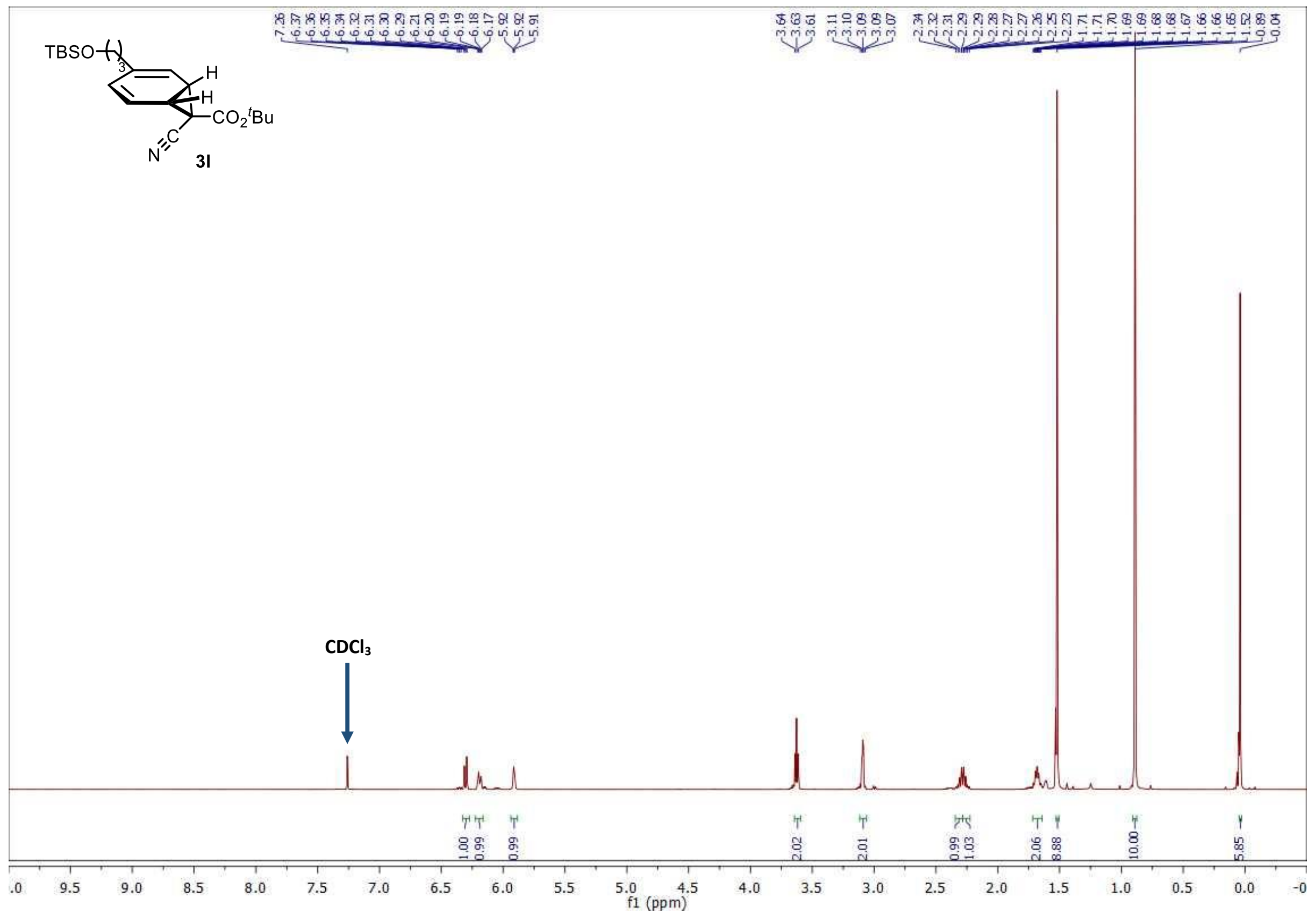


Compound $3 \mathrm{I}\left({ }^{1} \mathrm{H}, 500 \mathrm{MHz}, \mathrm{CDCl}_{3}\right.$, expanded view)
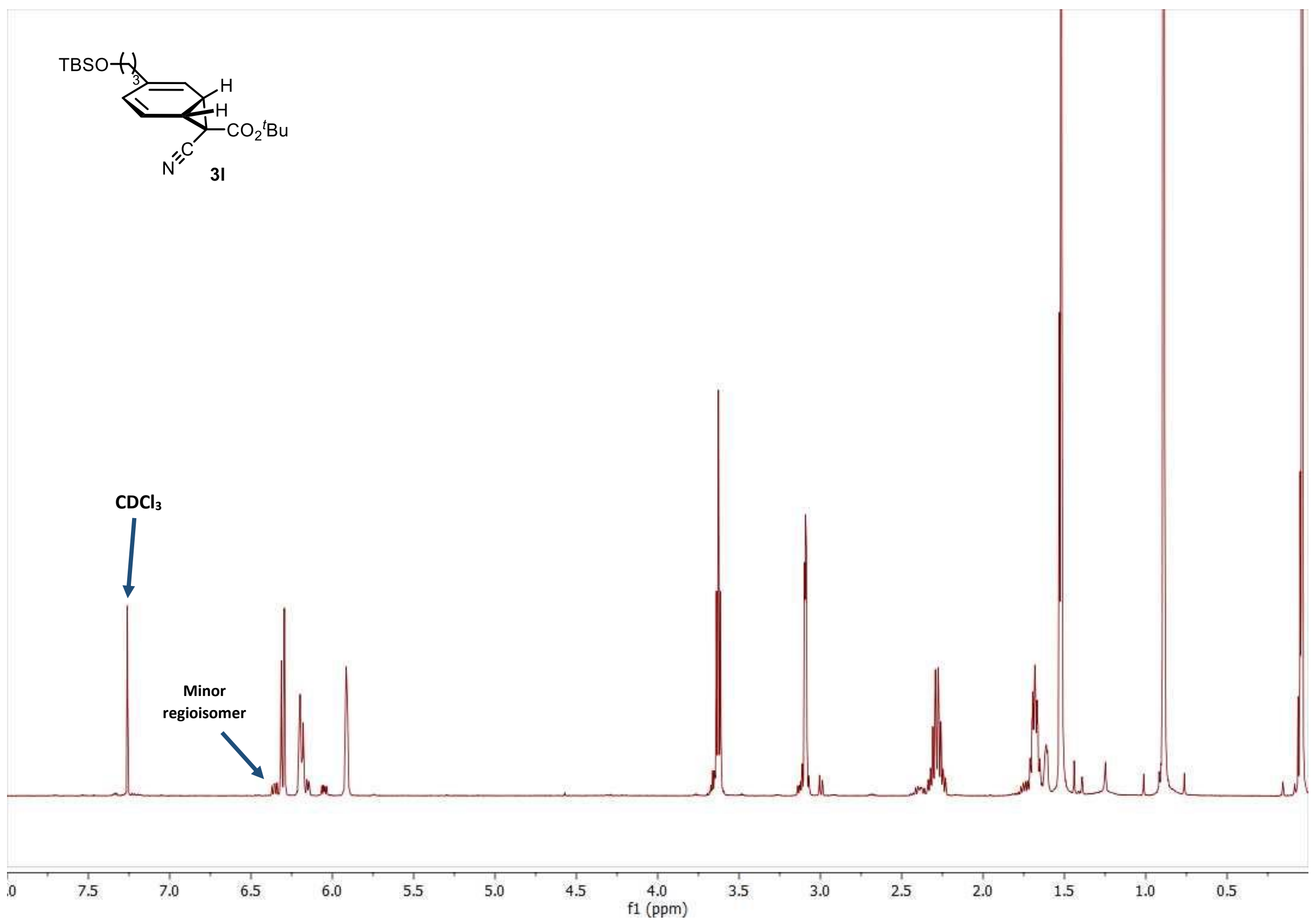
Compound $3 \mathrm{I}\left({ }^{13} \mathrm{C}, 126 \mathrm{MHz}, \mathrm{CDCl}_{3}\right)$

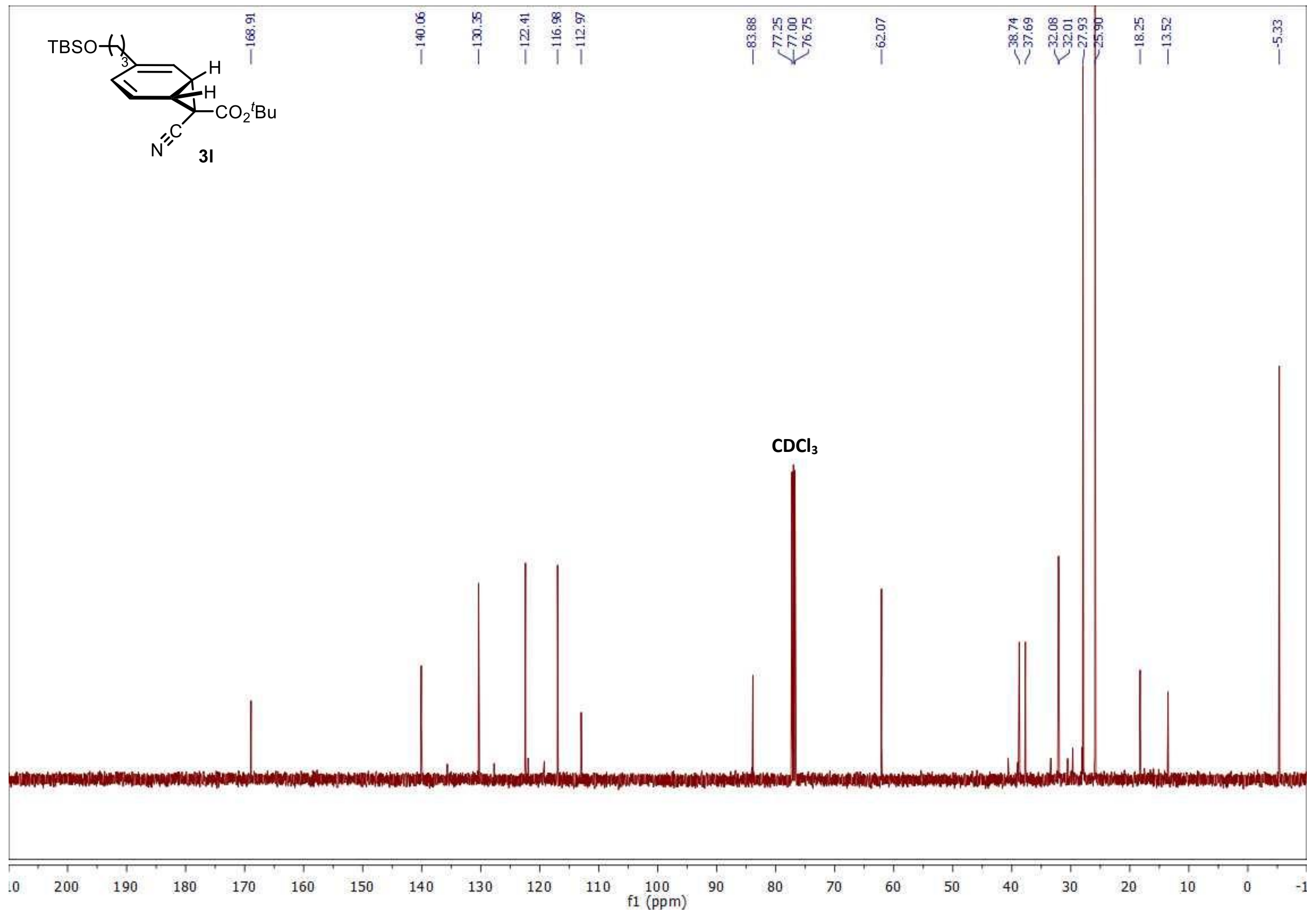


Compound $3 \mathrm{~m}\left({ }^{1} \mathrm{H}, 600 \mathrm{MHz}, \mathrm{CDCl}_{3}\right)$

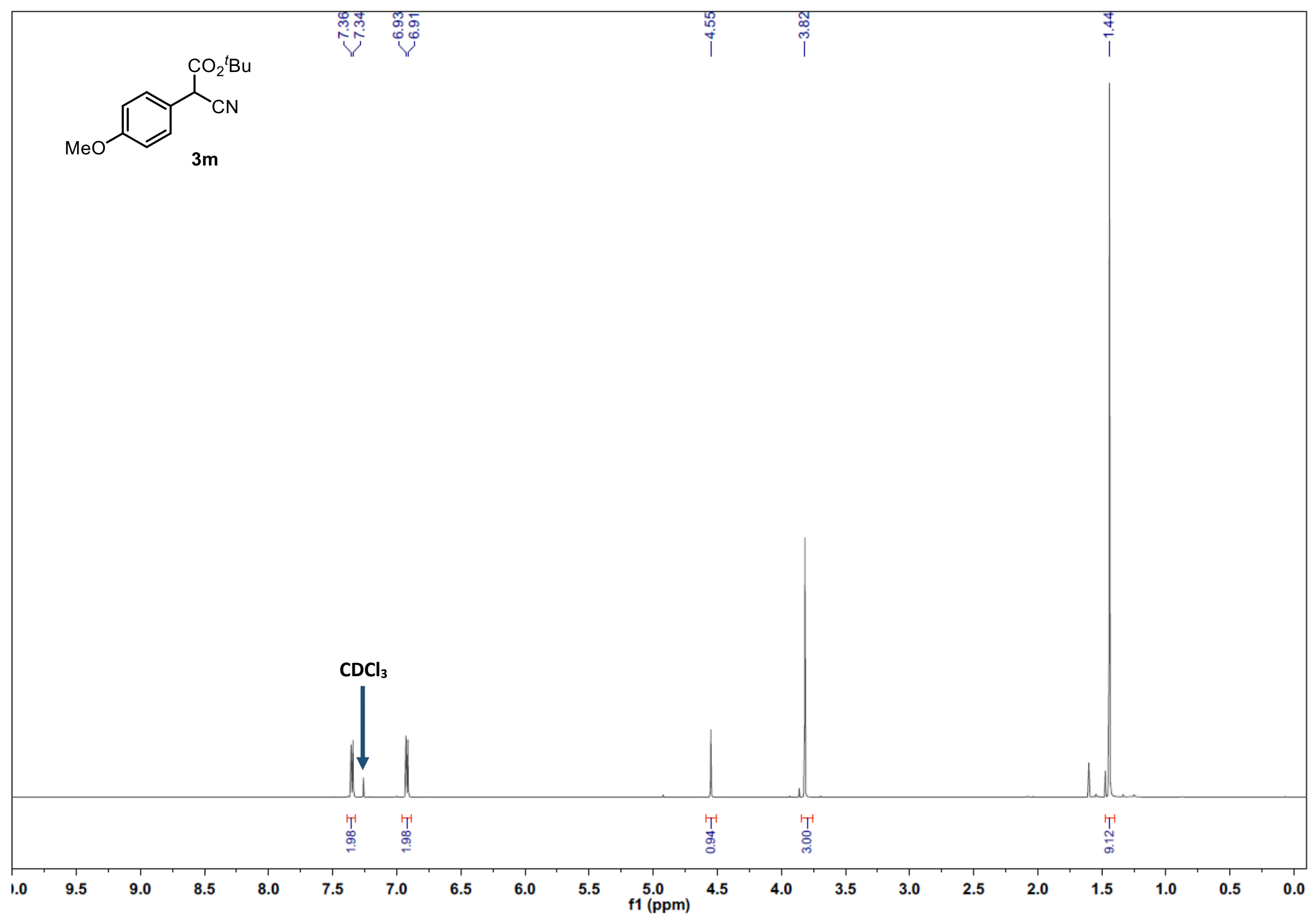


Compound $3 \mathrm{~m}\left({ }^{13} \mathrm{C}, 151 \mathrm{MHz}, \mathrm{CDCl}_{3}\right)$

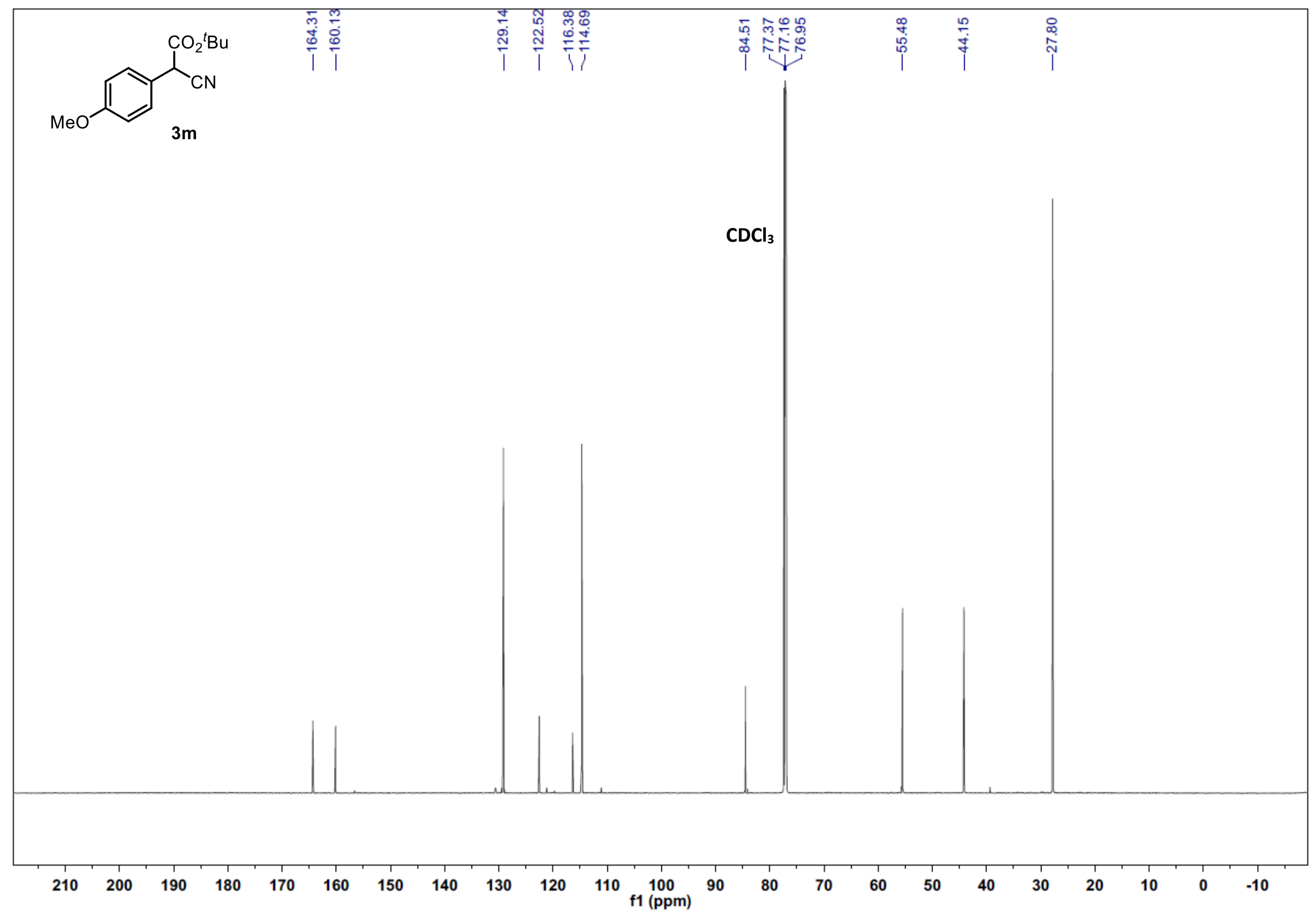


Compound $3 \mathrm{n}\left({ }^{1} \mathrm{H}, 500 \mathrm{MHz}, \mathrm{CDCl}_{3}\right.$, standard view)

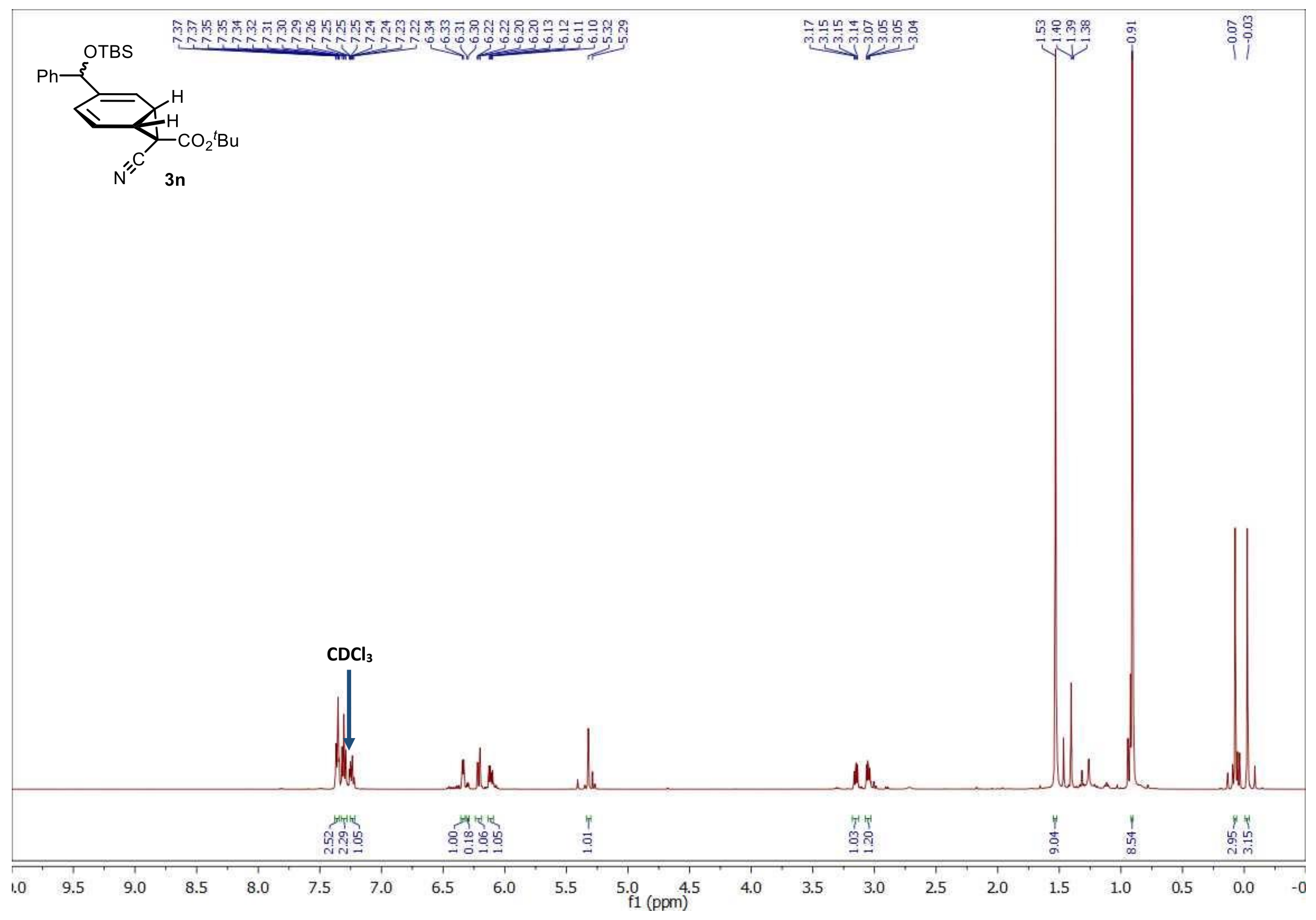


Compound $3 \mathrm{n}\left({ }^{1} \mathrm{H}, 500 \mathrm{MHz}, \mathrm{CDCl}_{3}\right.$, expanded view)
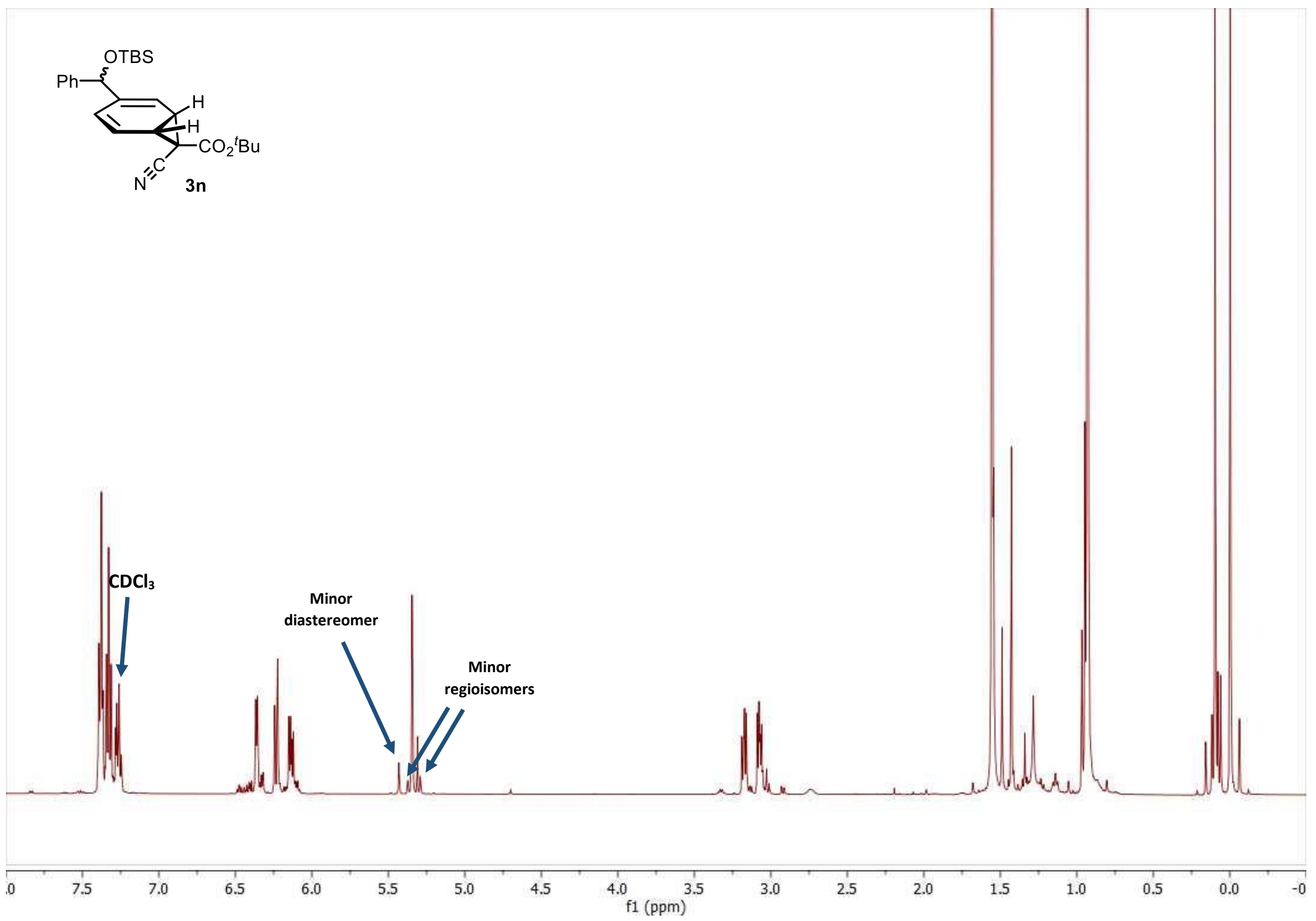
Compound 3n ( $\left.{ }^{1} \mathrm{H}-\mathrm{COSY}, 500 \mathrm{MHz}, \mathrm{CDCl}_{3}\right)$

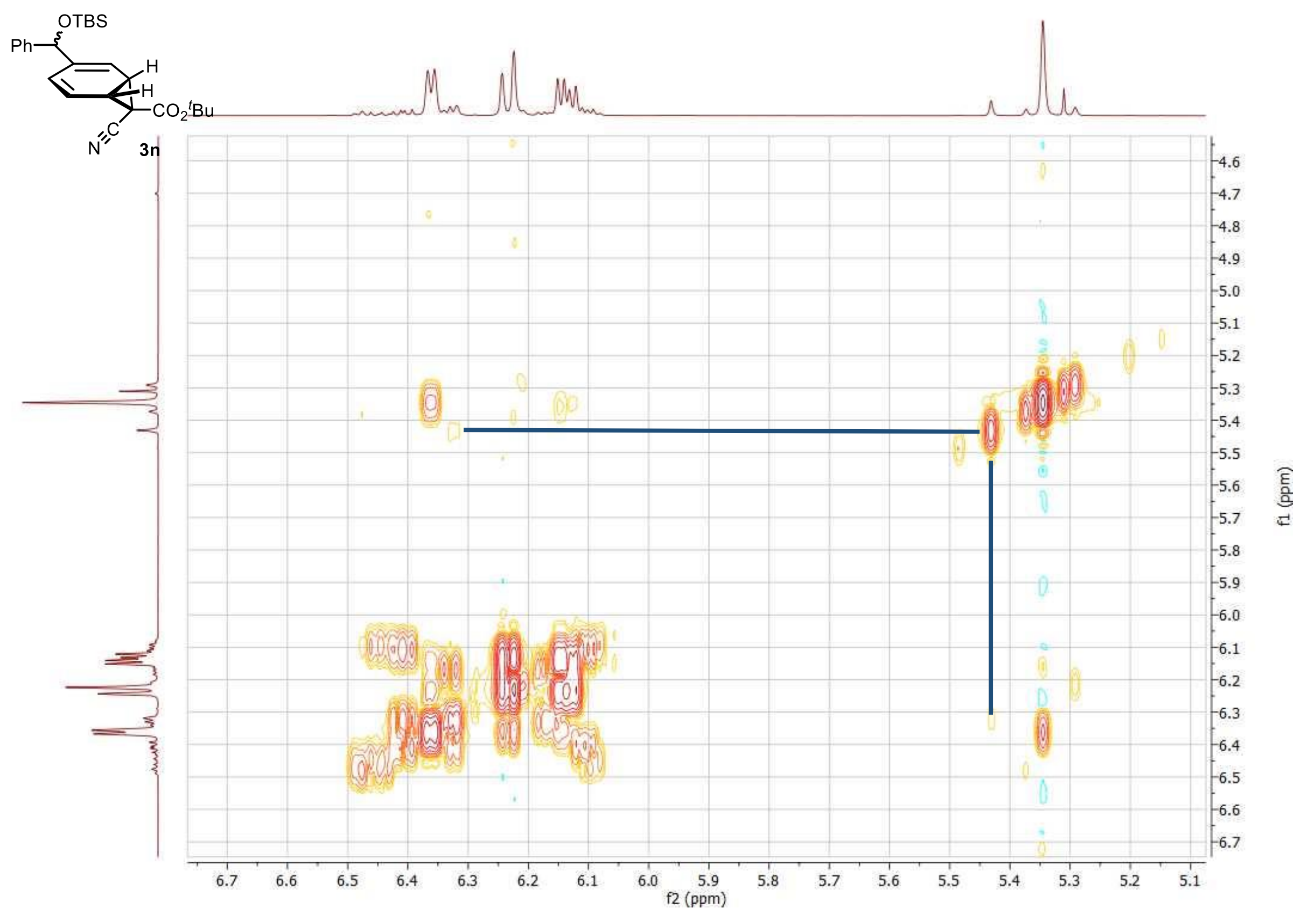


Compound $3 \mathrm{n}\left({ }^{13} \mathrm{C}, 126 \mathrm{MHz}, \mathrm{CDCl}_{3}\right)$

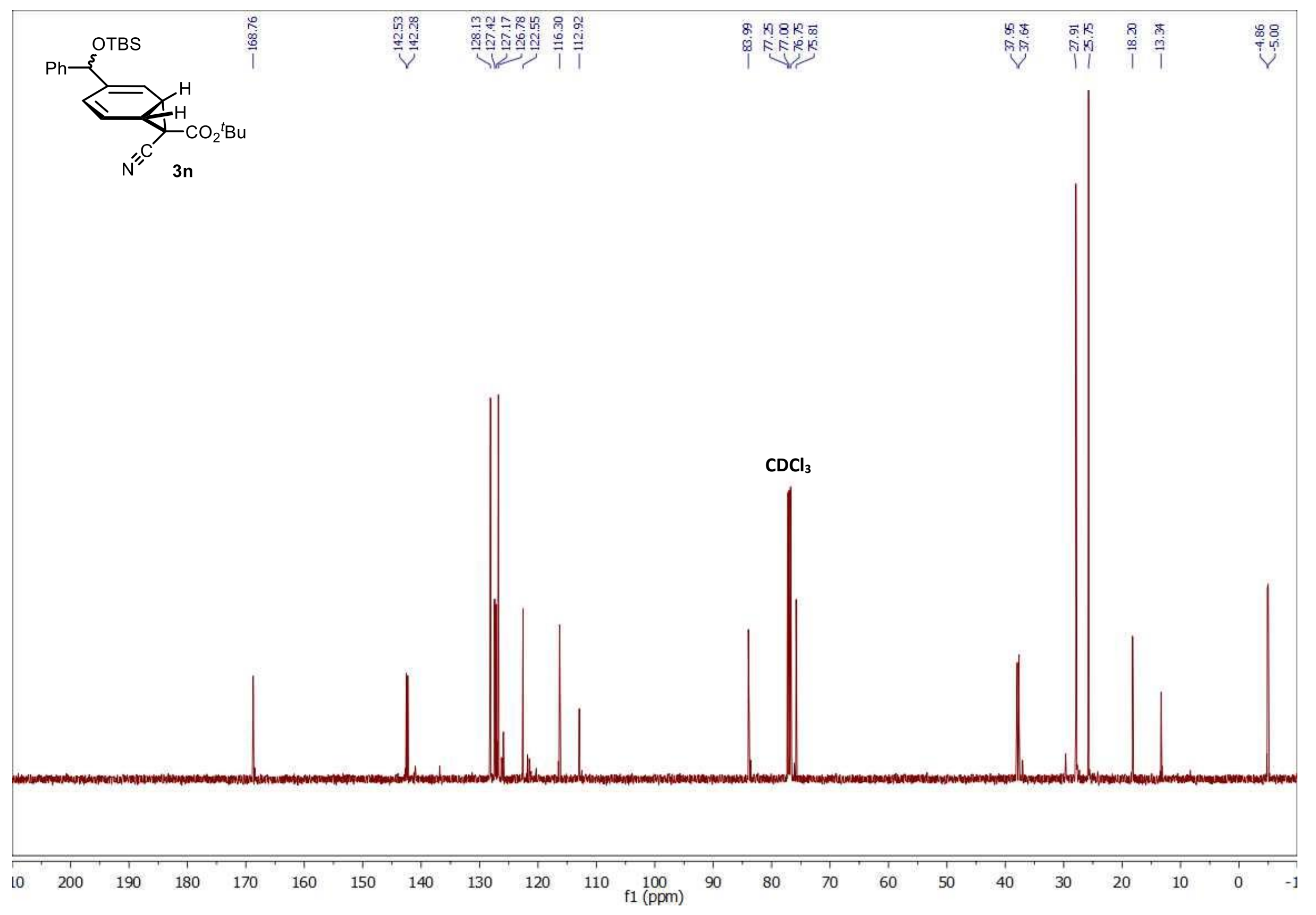


Compound 3n ( ${ }^{1} \mathrm{H}, 500 \mathrm{MHz}, \mathrm{CDCl}_{3}$, sample for HPLC)

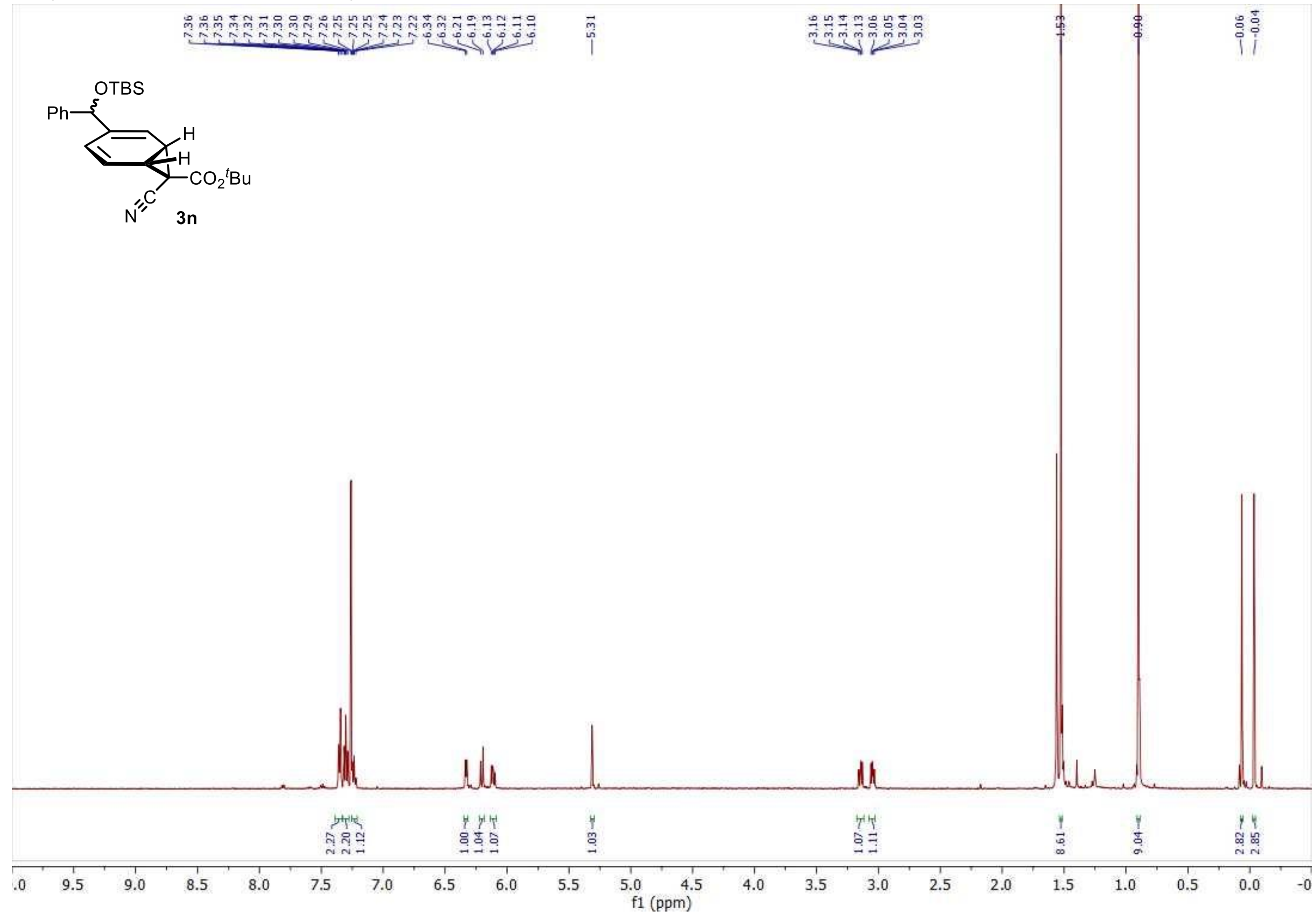


Compound $30\left({ }^{1} \mathrm{H}, 500 \mathrm{MHz}, \mathrm{CDCl}_{3}\right.$, standard view)

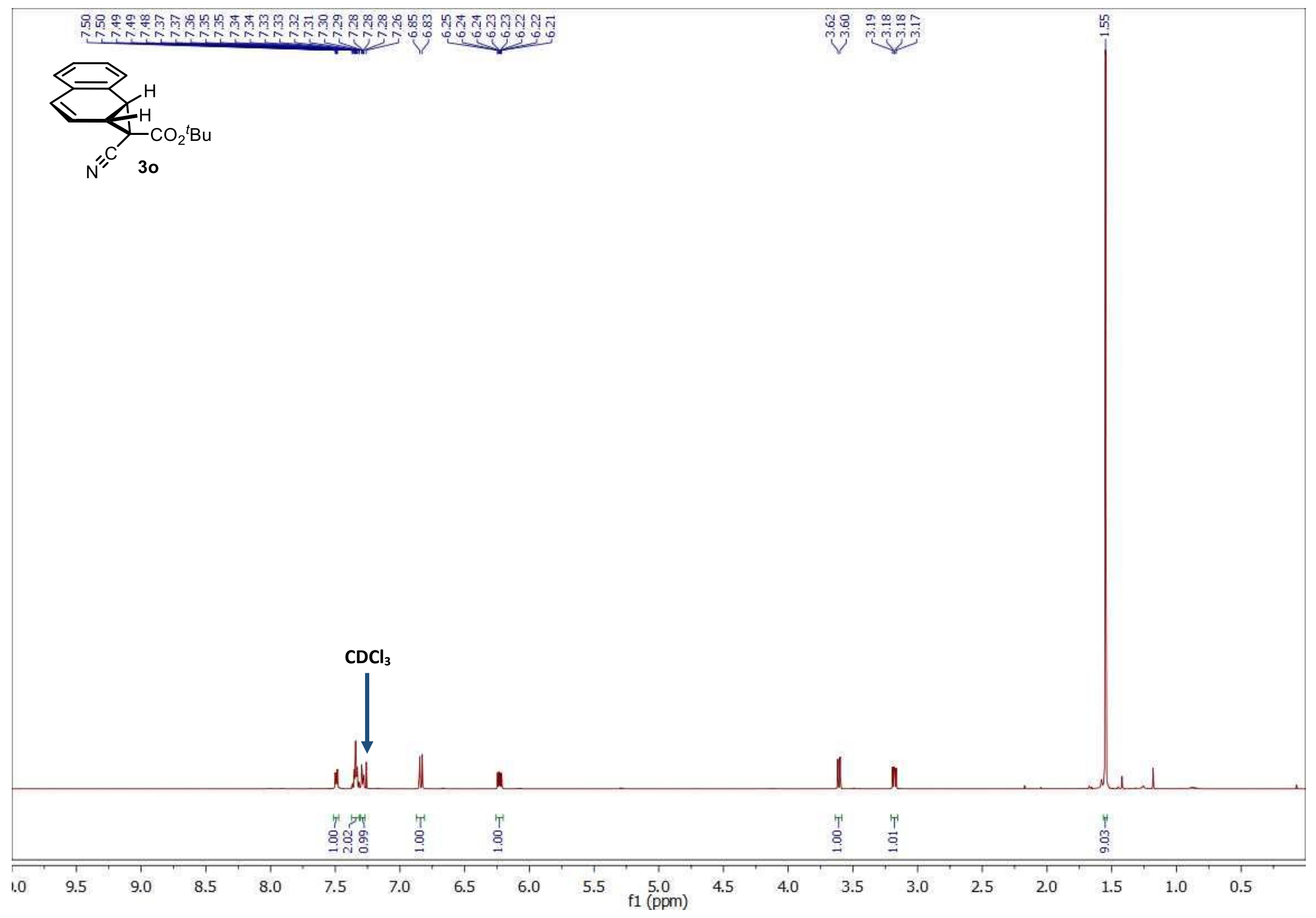


Compound $30\left({ }^{1} \mathrm{H}, 500 \mathrm{MHz}, \mathrm{CDCl}_{3}\right.$, expanded view)
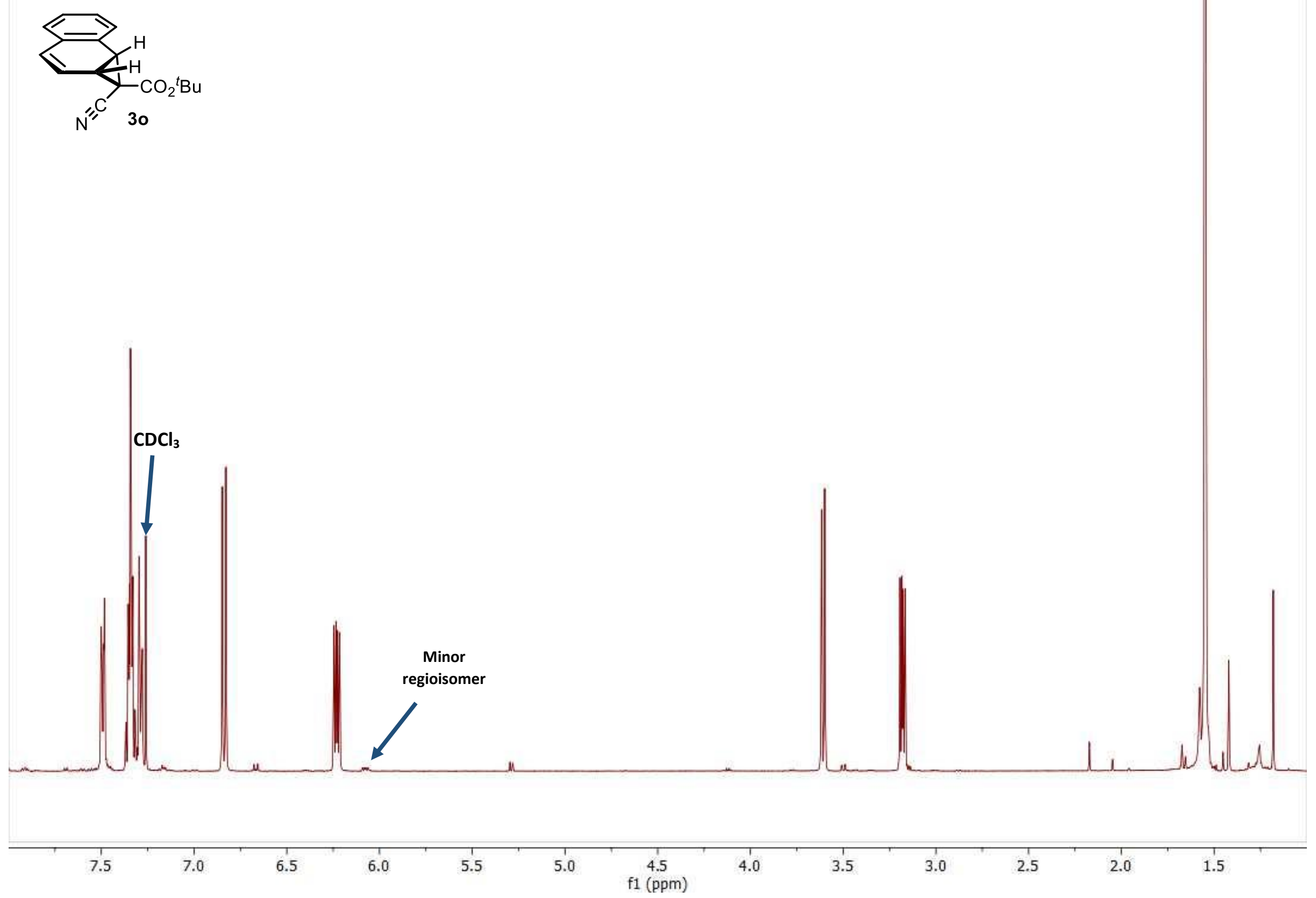
Compound $30\left({ }^{13} \mathrm{C}, 126 \mathrm{MHz}, \mathrm{CDCl}_{3}\right)$

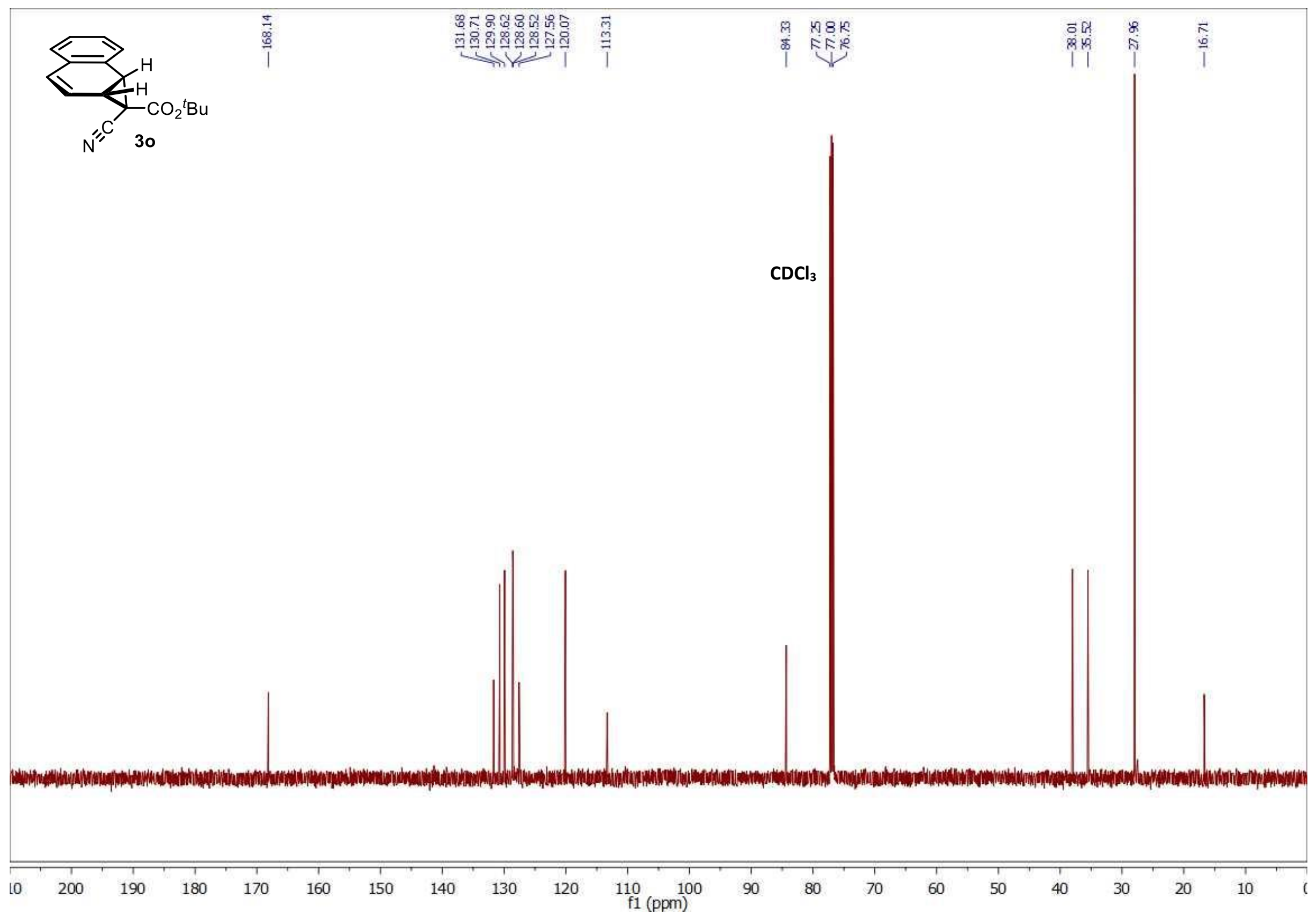


Compound $3 p\left({ }^{1} \mathrm{H}, 400 \mathrm{MHz}, \mathrm{CDCl}_{3}\right.$, standard view)

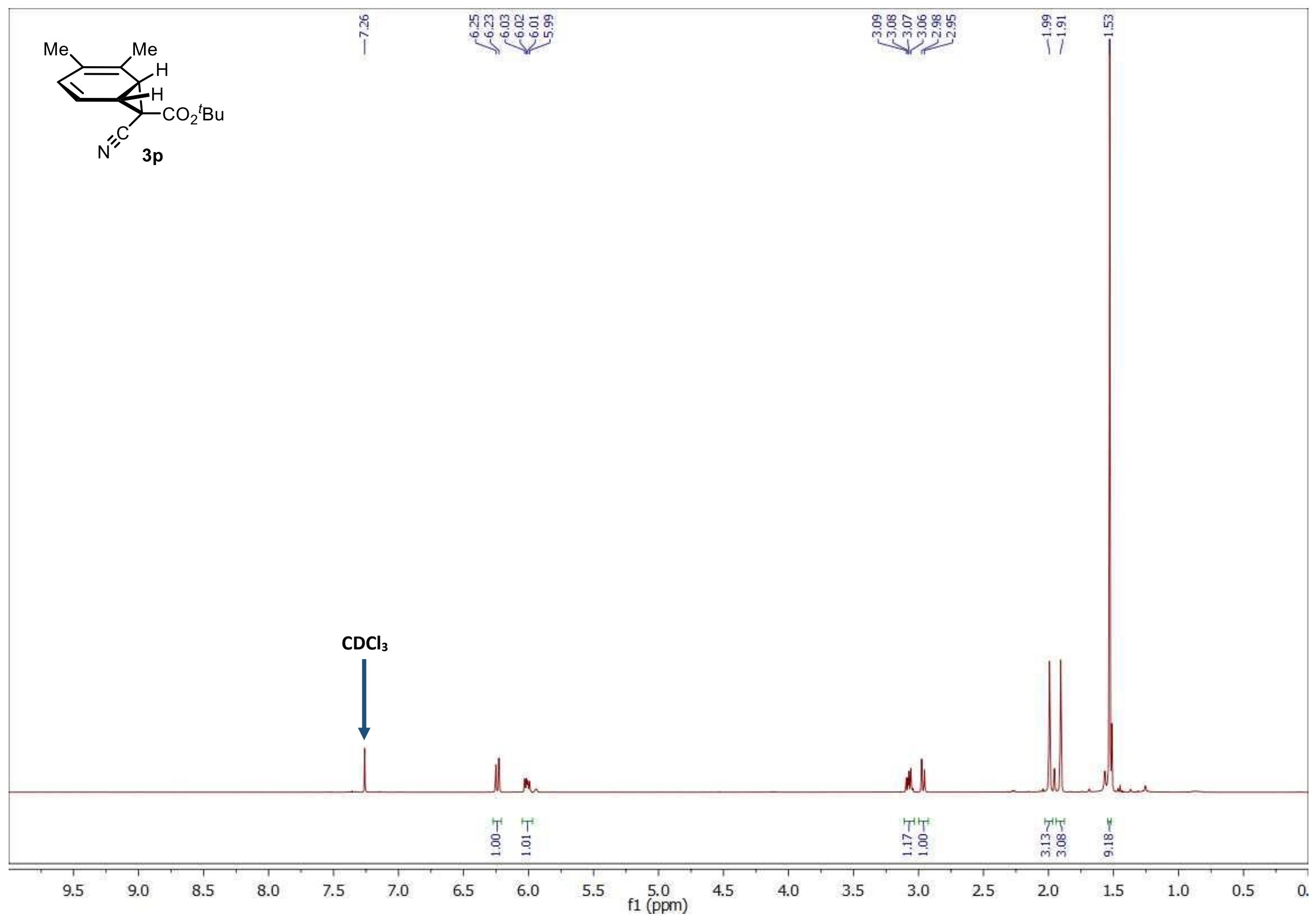


Compound 3p ( ${ }^{1} \mathrm{H}, 400 \mathrm{MHz}, \mathrm{CDCl}_{3}$, expanded view)
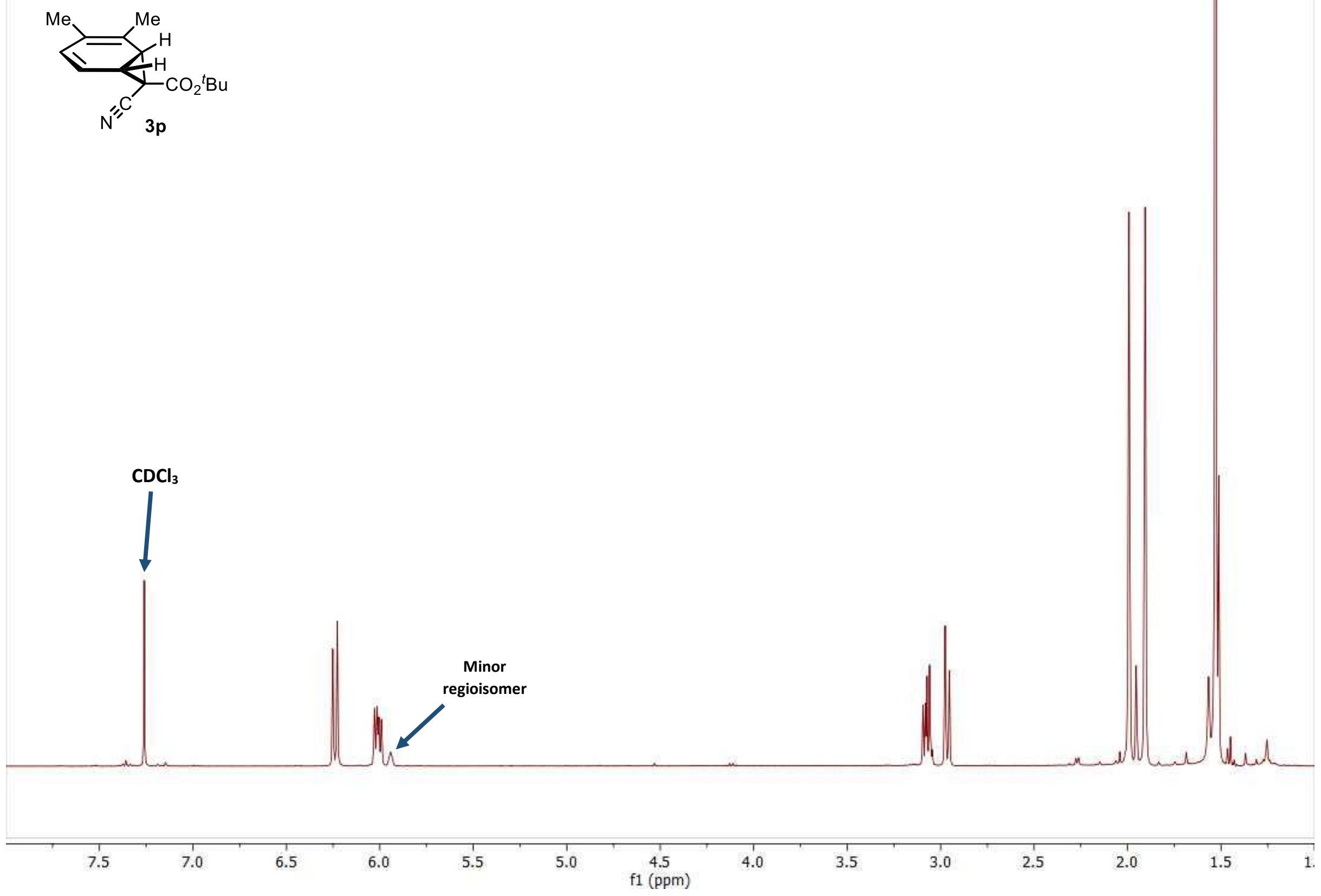
Compound 3p $\left({ }^{13} \mathrm{C}, 101 \mathrm{MHz}, \mathrm{CDCl}_{3}\right)$

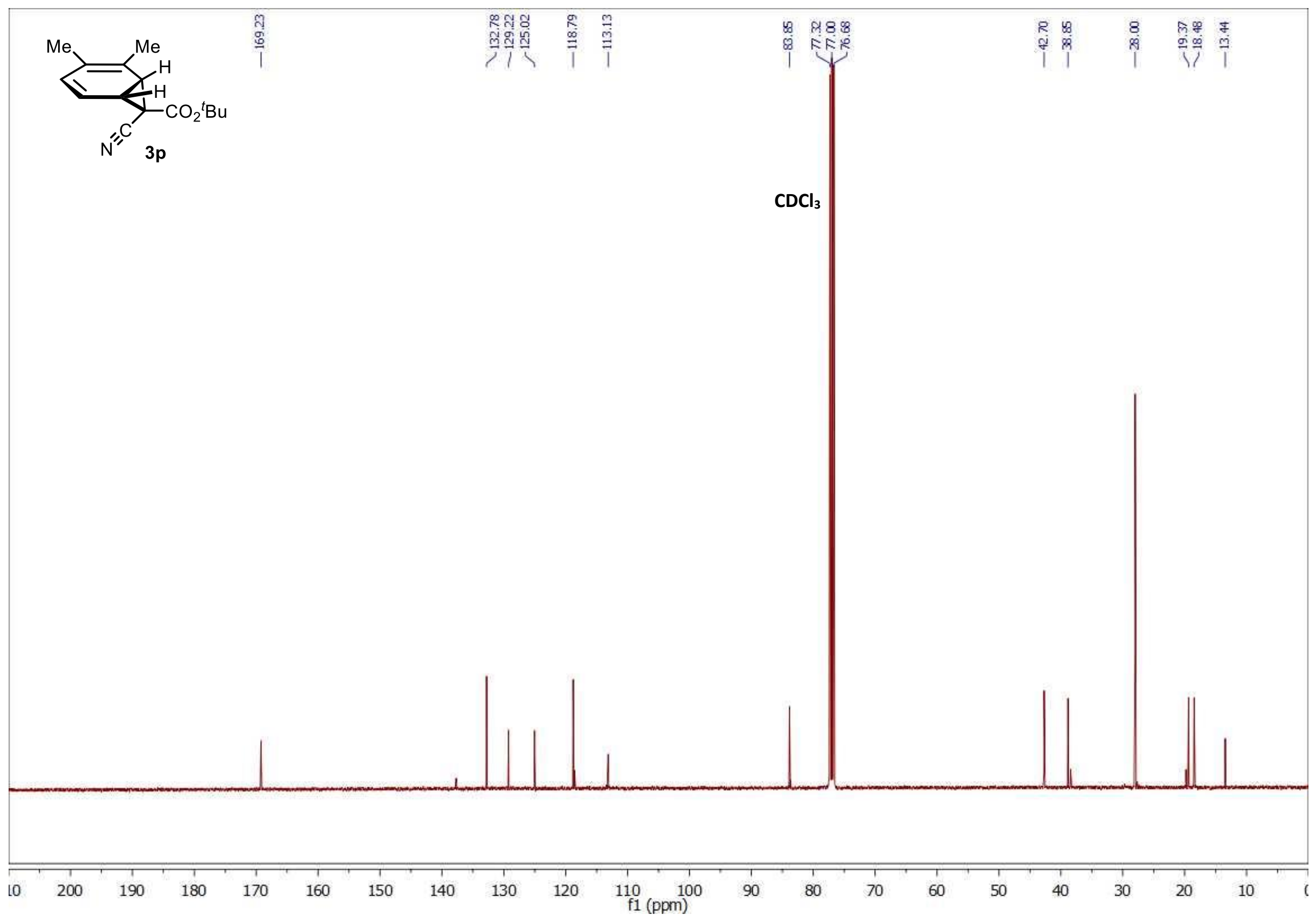


Compound $4 \mathrm{q}\left({ }^{1} \mathrm{H}, 500 \mathrm{MHz}, \mathrm{CDCl}_{3}\right)$

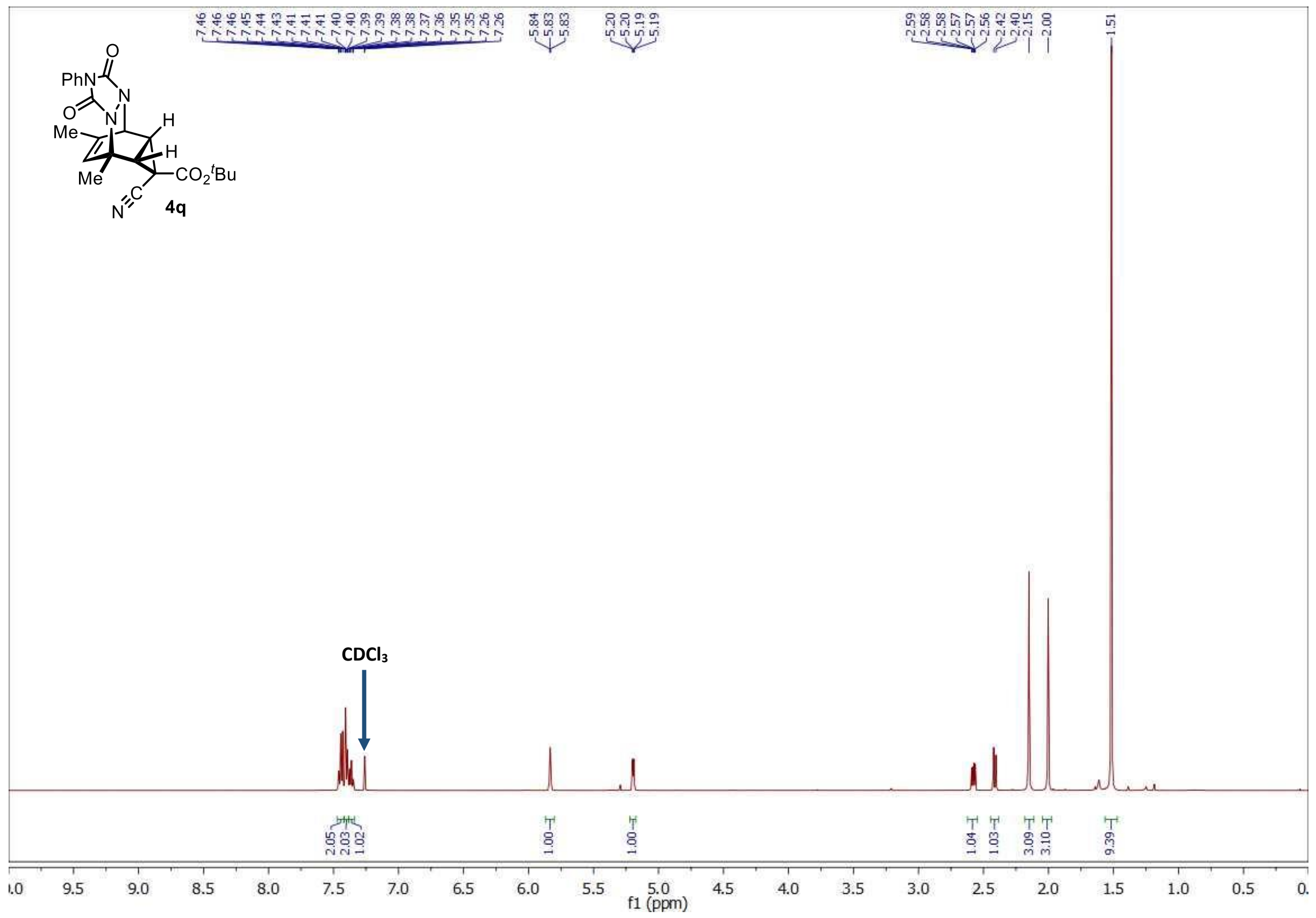


Compound $4 \mathrm{q}\left({ }^{13} \mathrm{C}, 126 \mathrm{MHz}, \mathrm{CDCl}_{3}\right)$

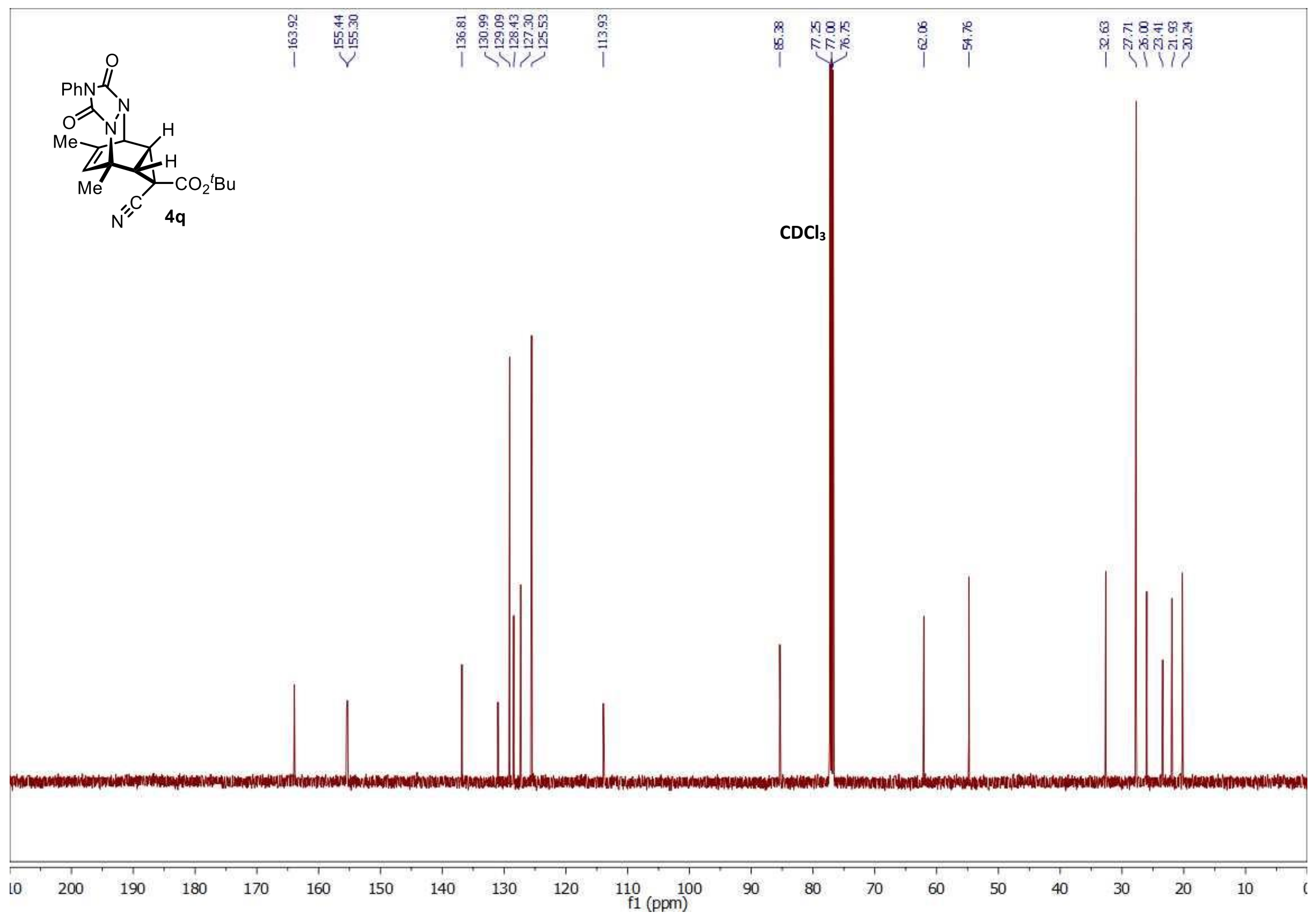


Compound $3 r\left({ }^{1} \mathrm{H}, 600 \mathrm{MHz}, \mathrm{CDCl}_{3}\right)$

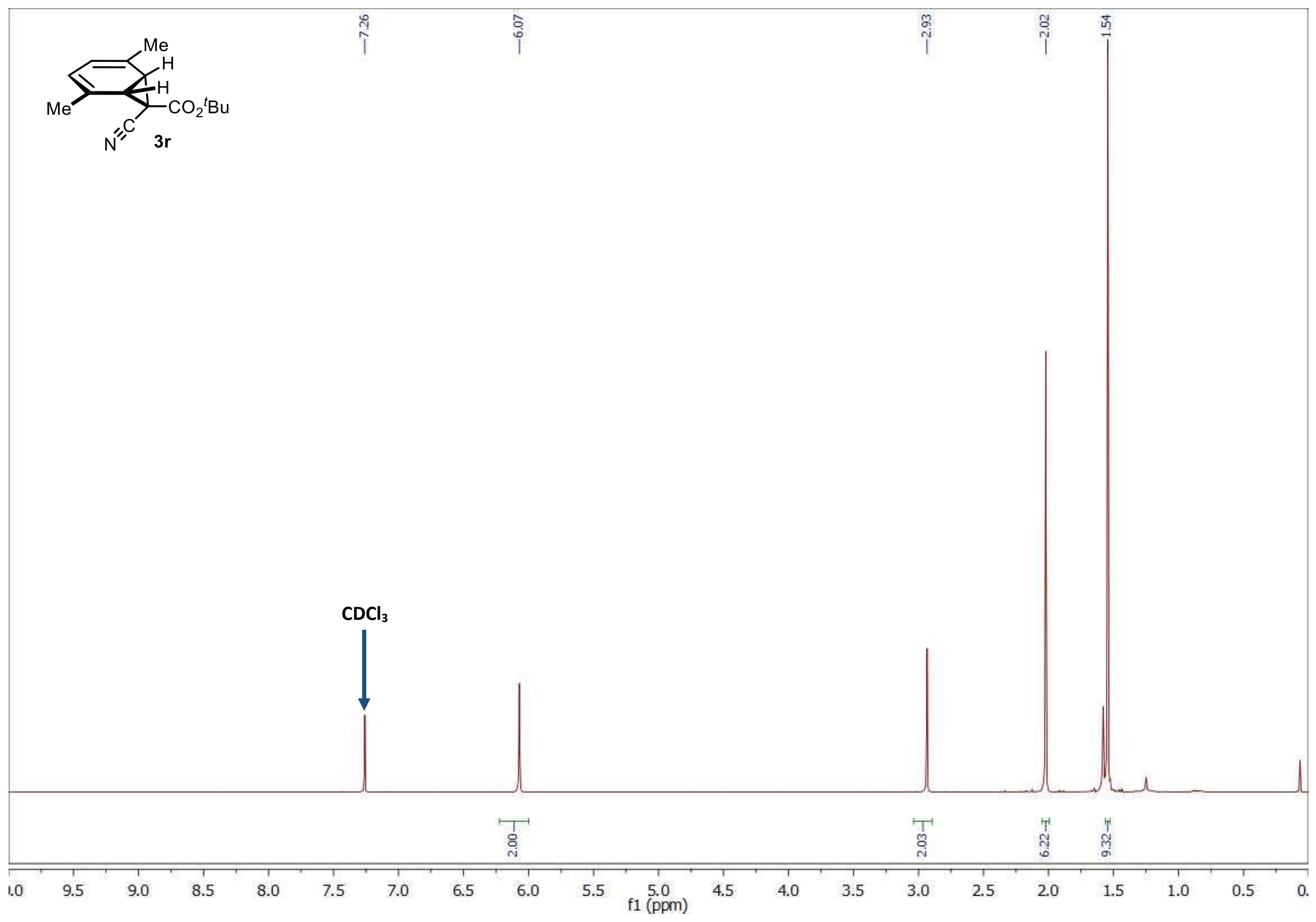


Compound $3 r\left({ }^{13} \mathrm{C}, 151 \mathrm{MHz}, \mathrm{CDCl}_{3}\right)$

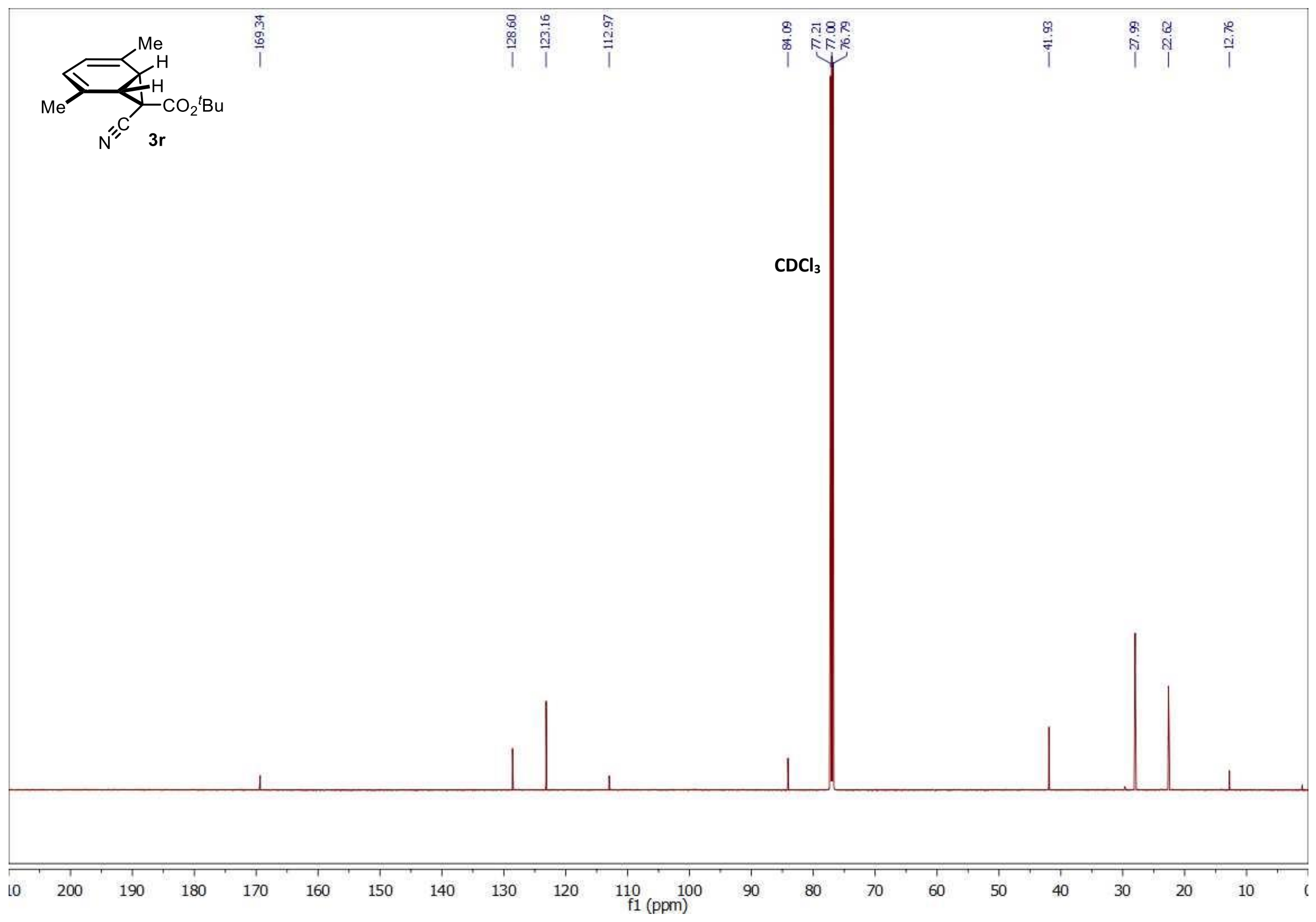


Compounds $3 s+3 s^{\prime}\left({ }^{1} \mathrm{H}, 500 \mathrm{MHz}, \mathrm{CDCl}_{3}\right)$

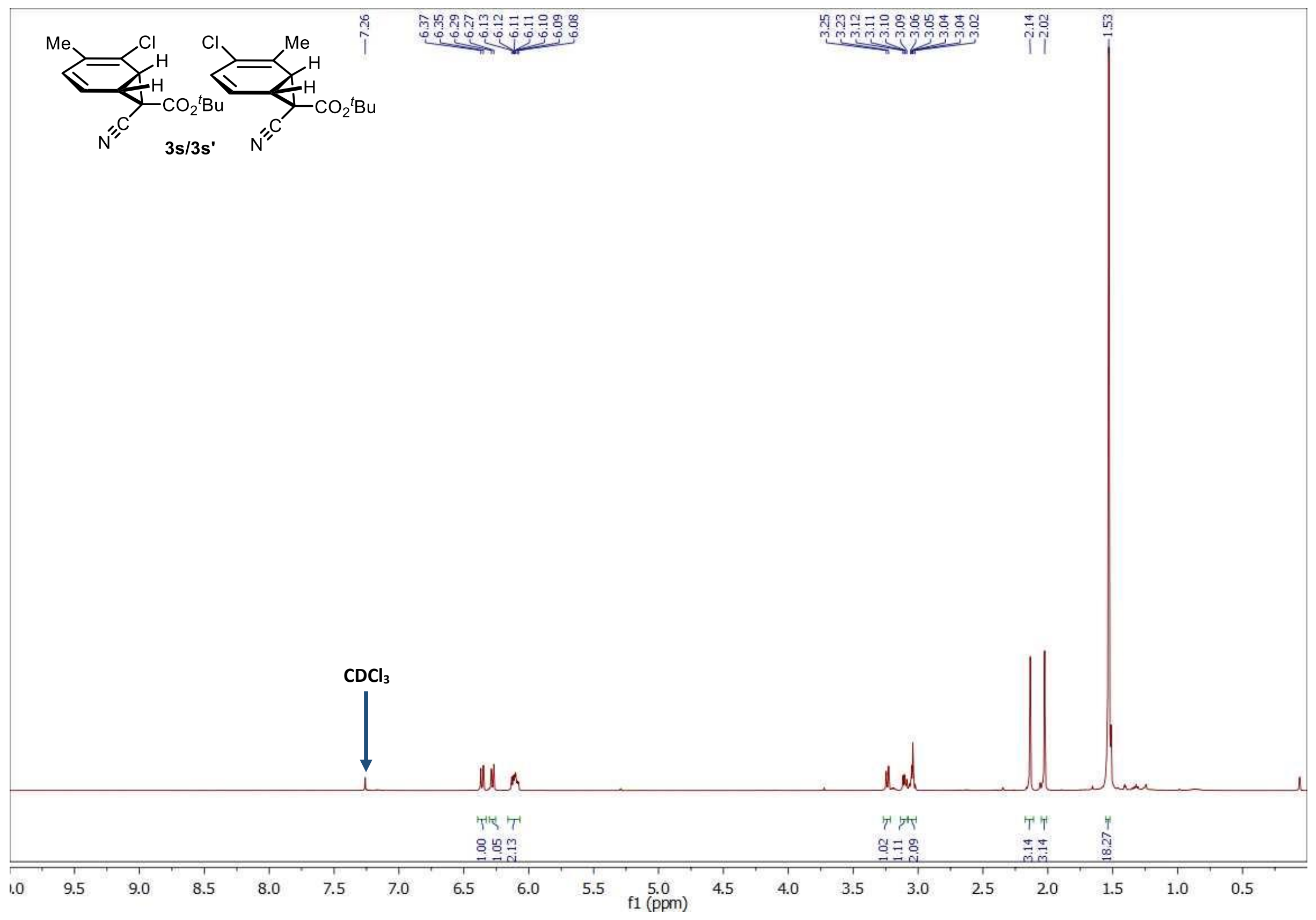


Compounds $3 s+3 s^{\prime}\left({ }^{13} \mathrm{C}, 126 \mathrm{MHz}, \mathrm{CDCl}_{3}\right)$

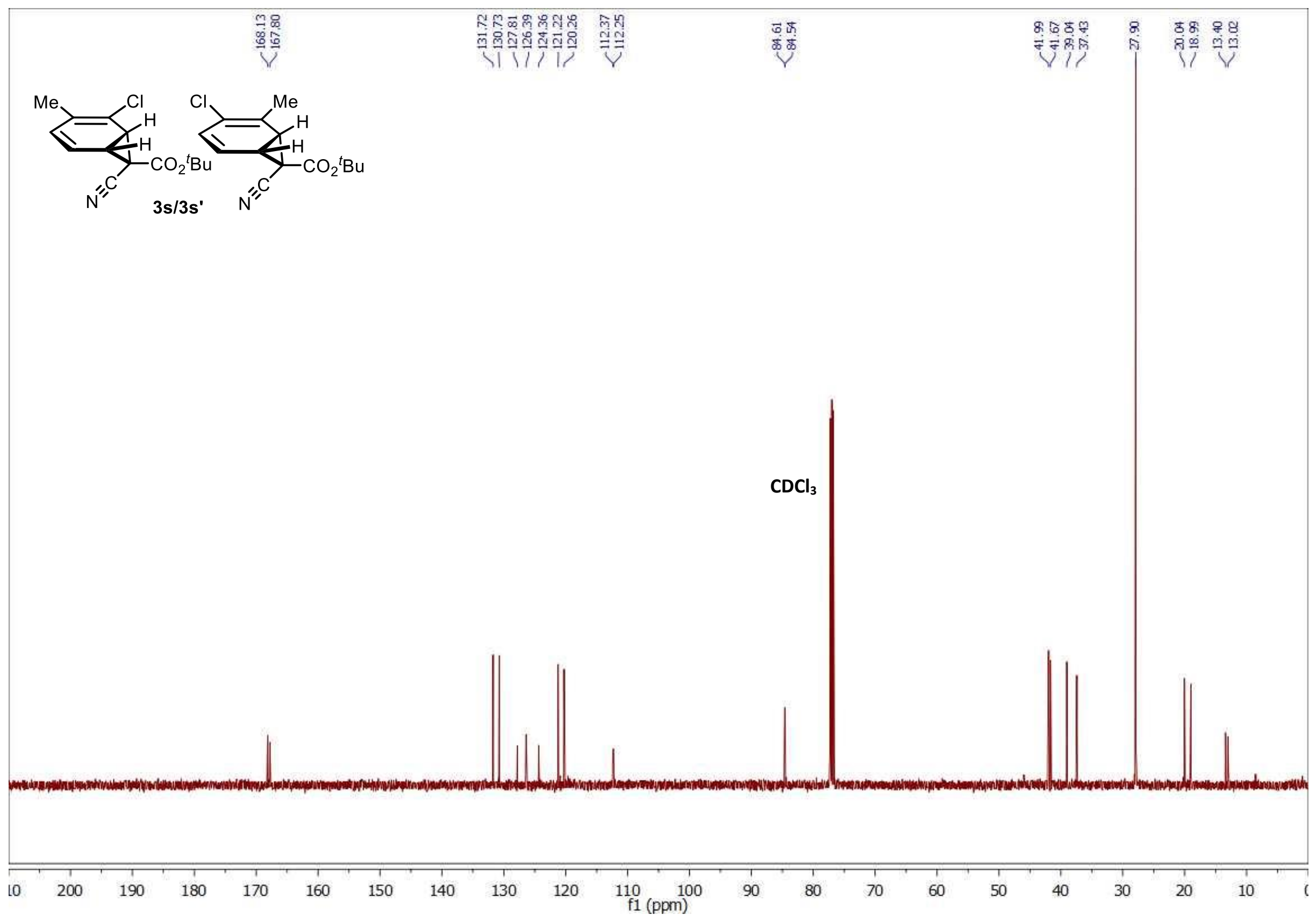


Compound $5\left({ }^{1} \mathrm{H}, 500 \mathrm{MHz}, \mathrm{CDCl}_{3}\right)$

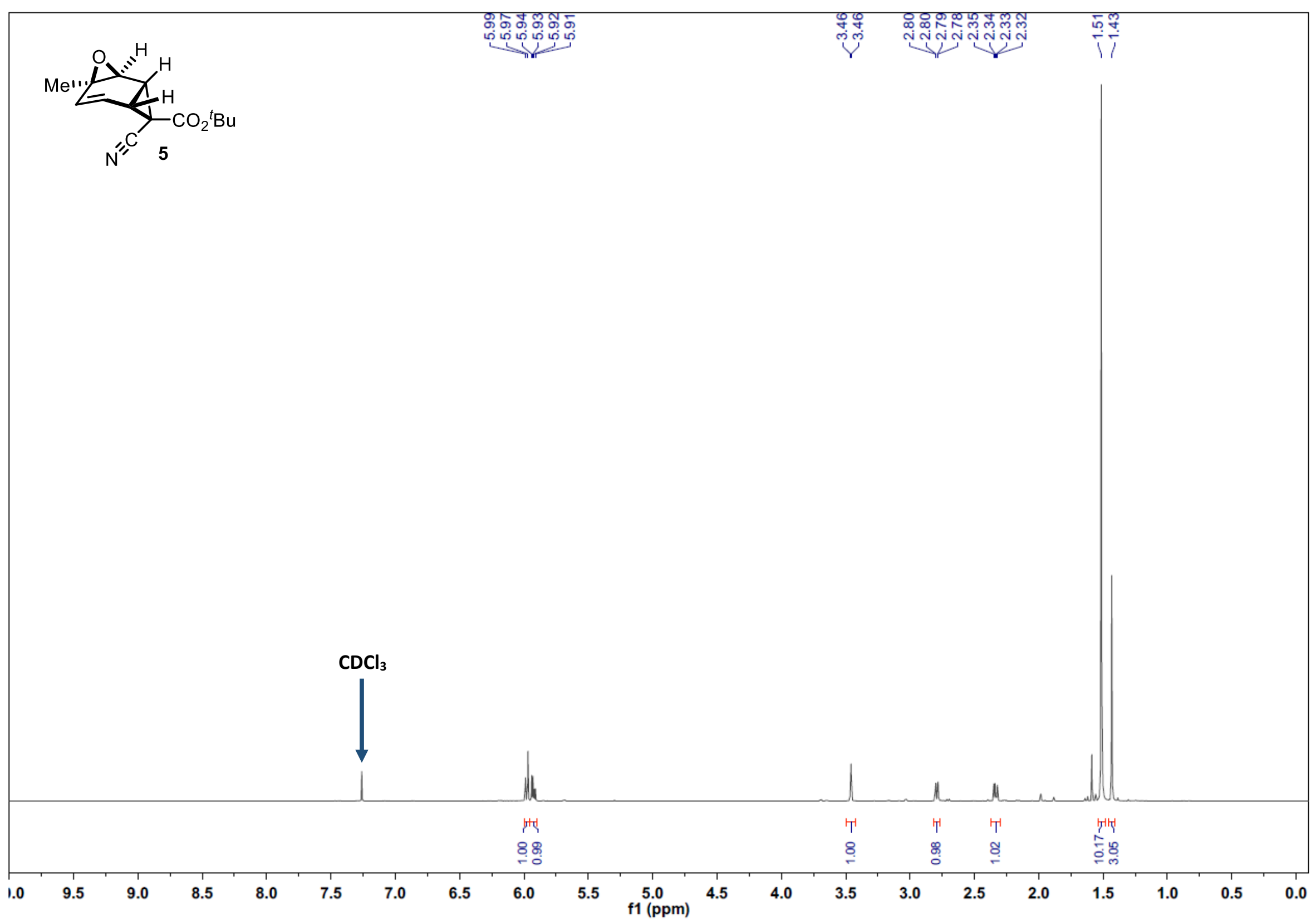


Compound $5\left({ }^{13} \mathrm{C}, 151 \mathrm{MHz}, \mathrm{CDCl}_{3}\right)$

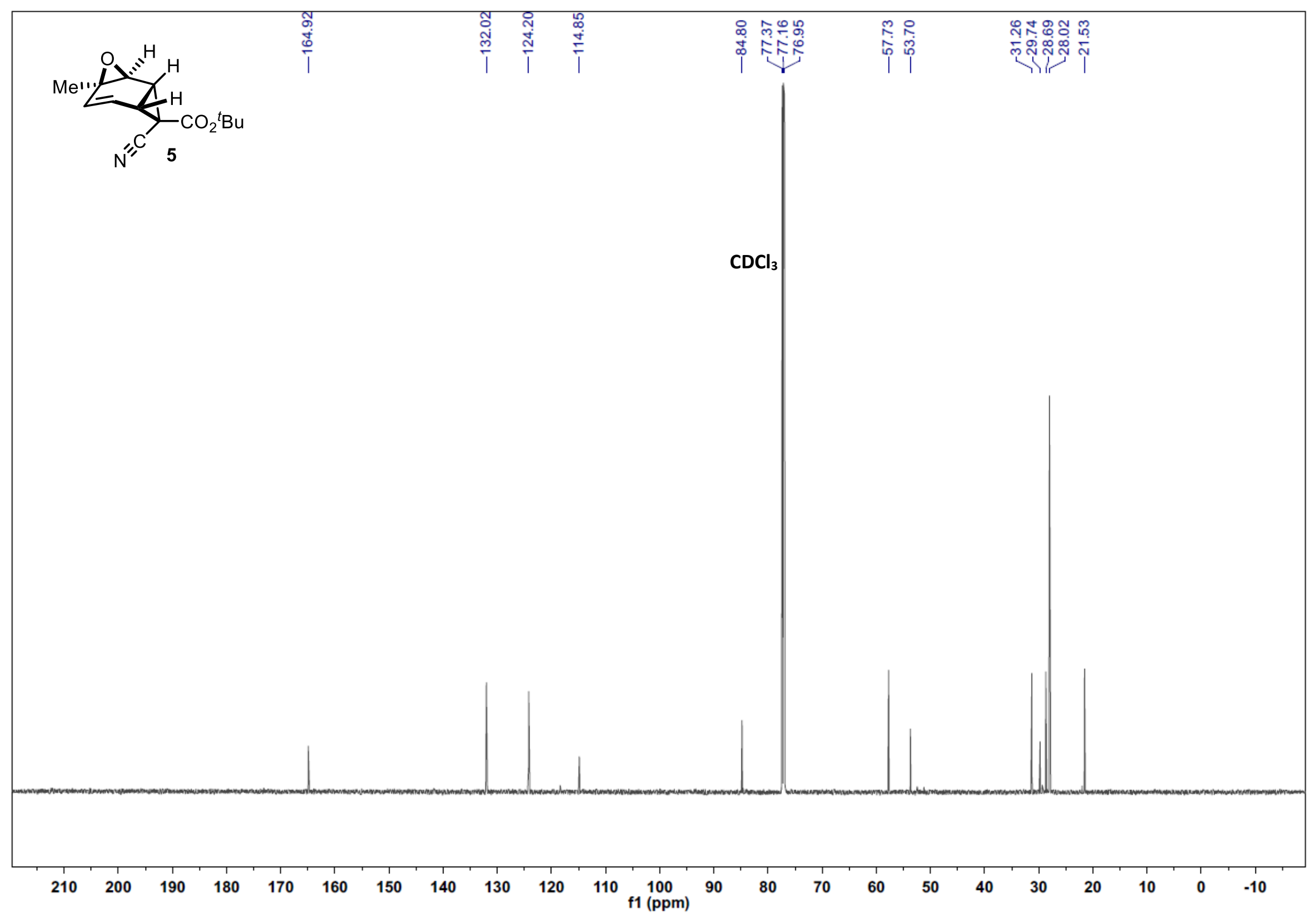


Compound $6\left({ }^{1} \mathrm{H}, 600 \mathrm{MHz}, \mathrm{CDCl}_{3}\right)$

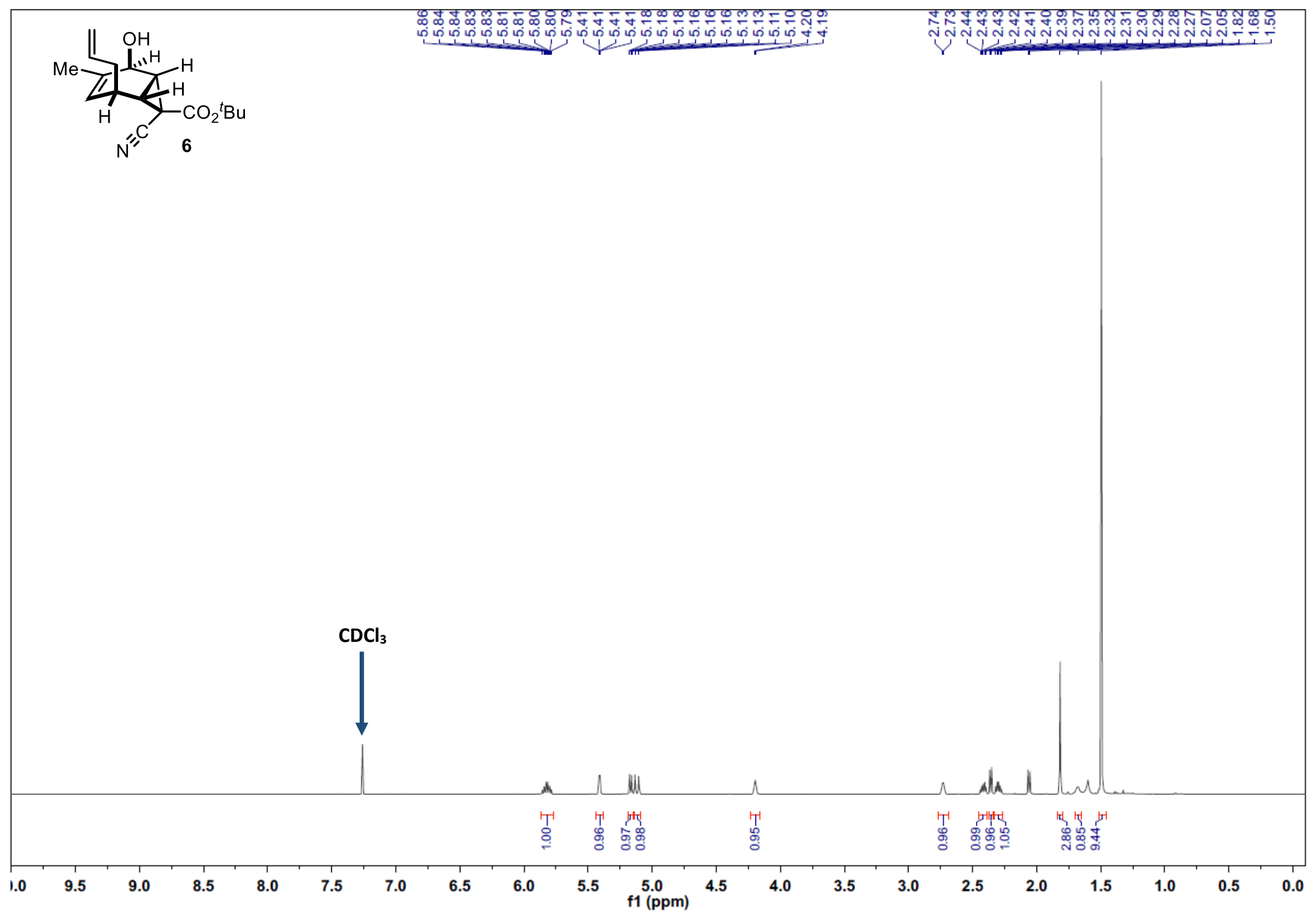


Compound $6\left({ }^{13} \mathrm{C}, 151 \mathrm{MHz}, \mathrm{CDCl}_{3}\right)$

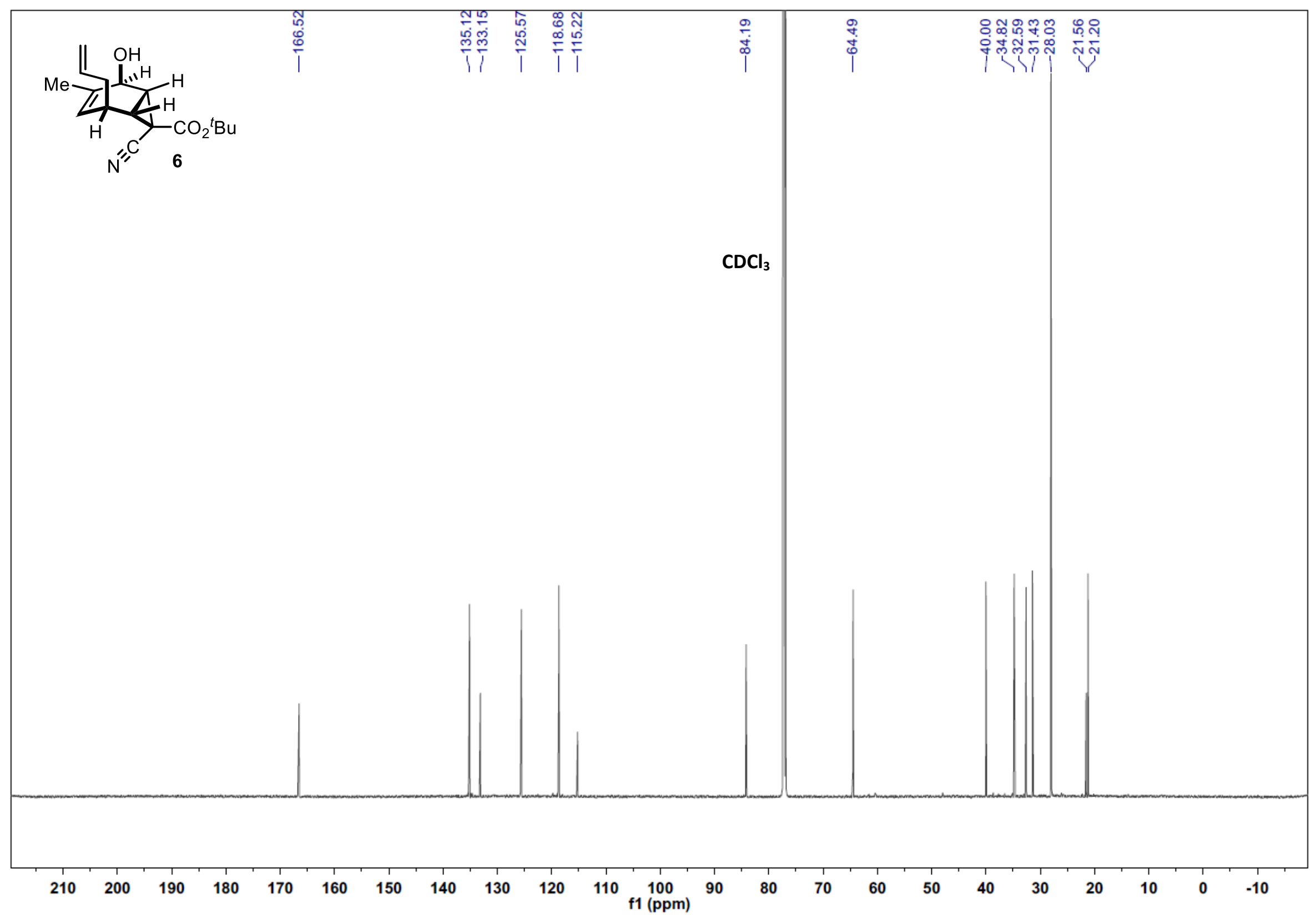


Compound 6' ( $\left.{ }^{1} \mathrm{H}, 600 \mathrm{MHz}, \mathrm{CDCl}_{3}\right)$

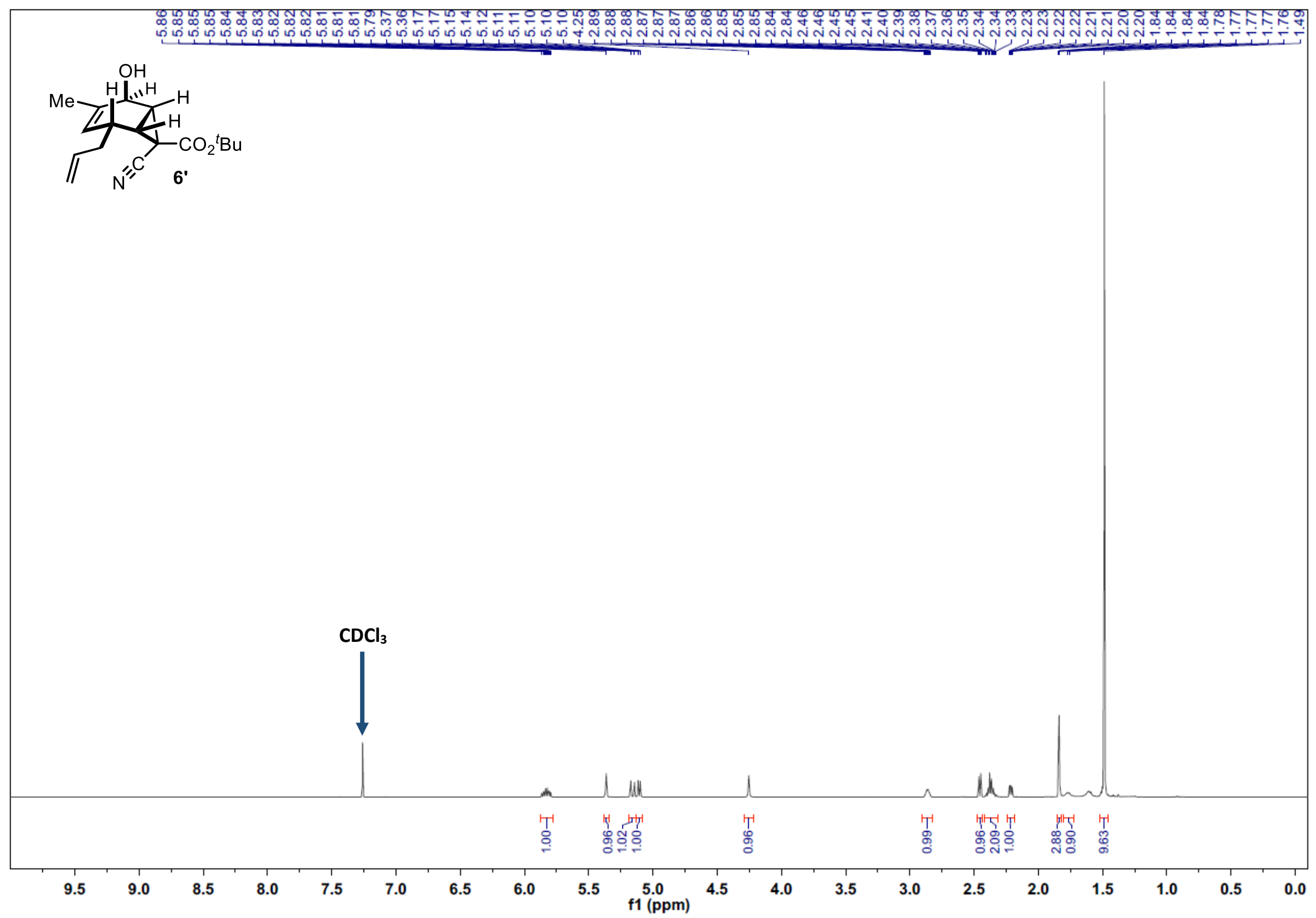


Compound 6' $\left({ }^{13} \mathrm{C}, 151 \mathrm{MHz}, \mathrm{CDCl}_{3}\right)$

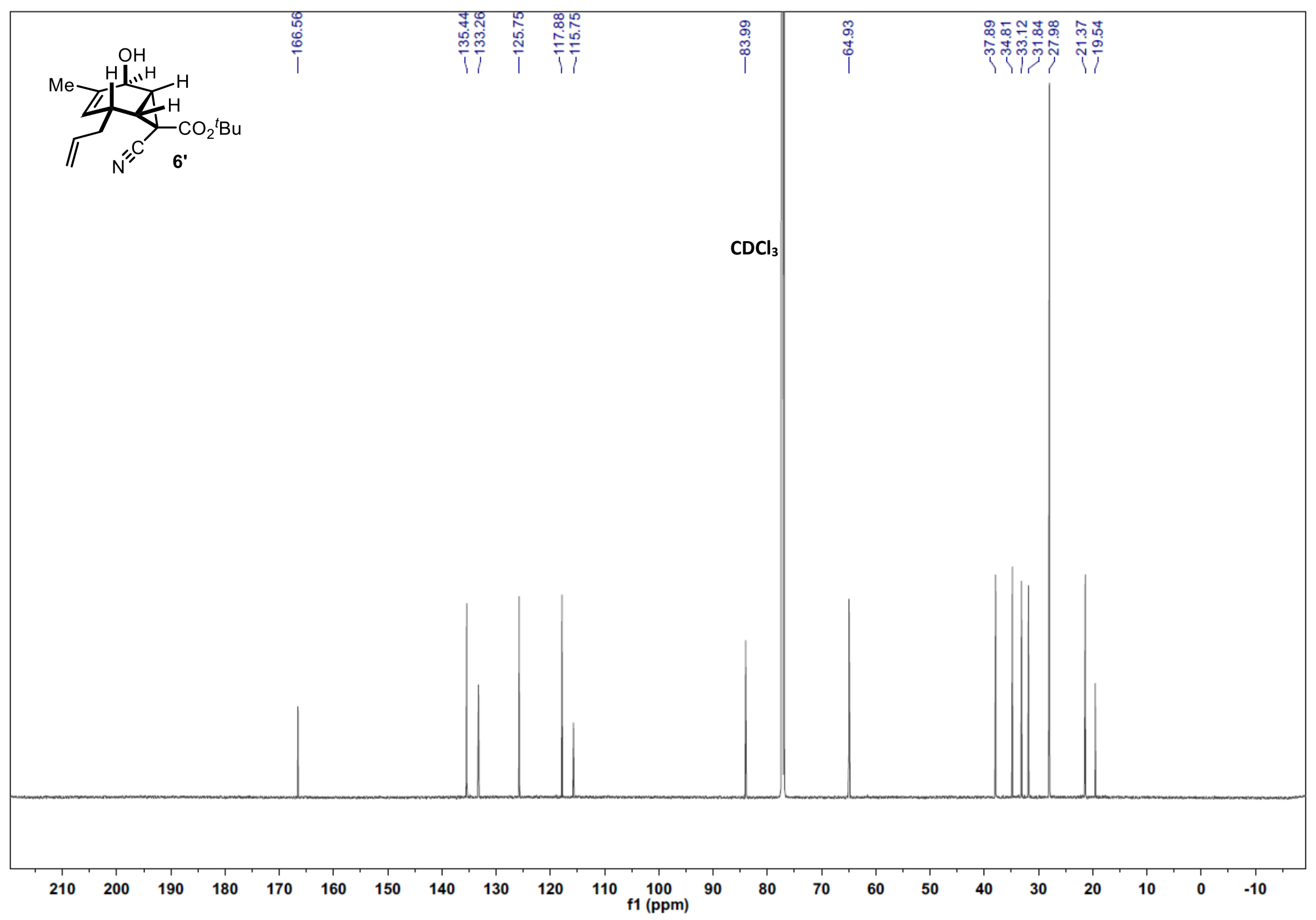


Compound 7 and 7' ( $\left.{ }^{1} \mathrm{H}, 600 \mathrm{MHz}, \mathrm{CDCl}_{3}\right)$

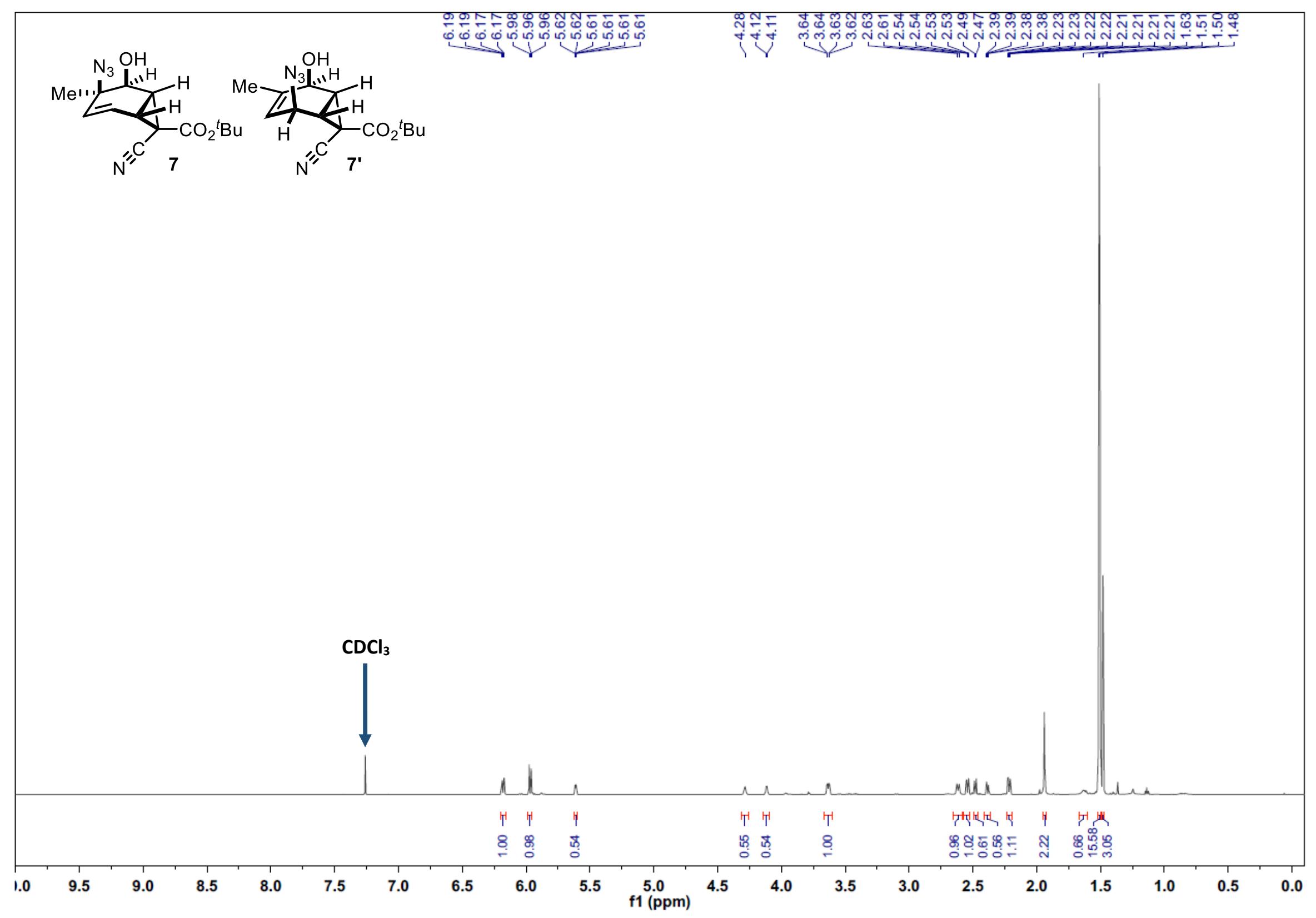


Compound 7 and 7' ( $\left.{ }^{13} \mathrm{C}, 151 \mathrm{MHz}, \mathrm{CDCl}_{3}\right)$

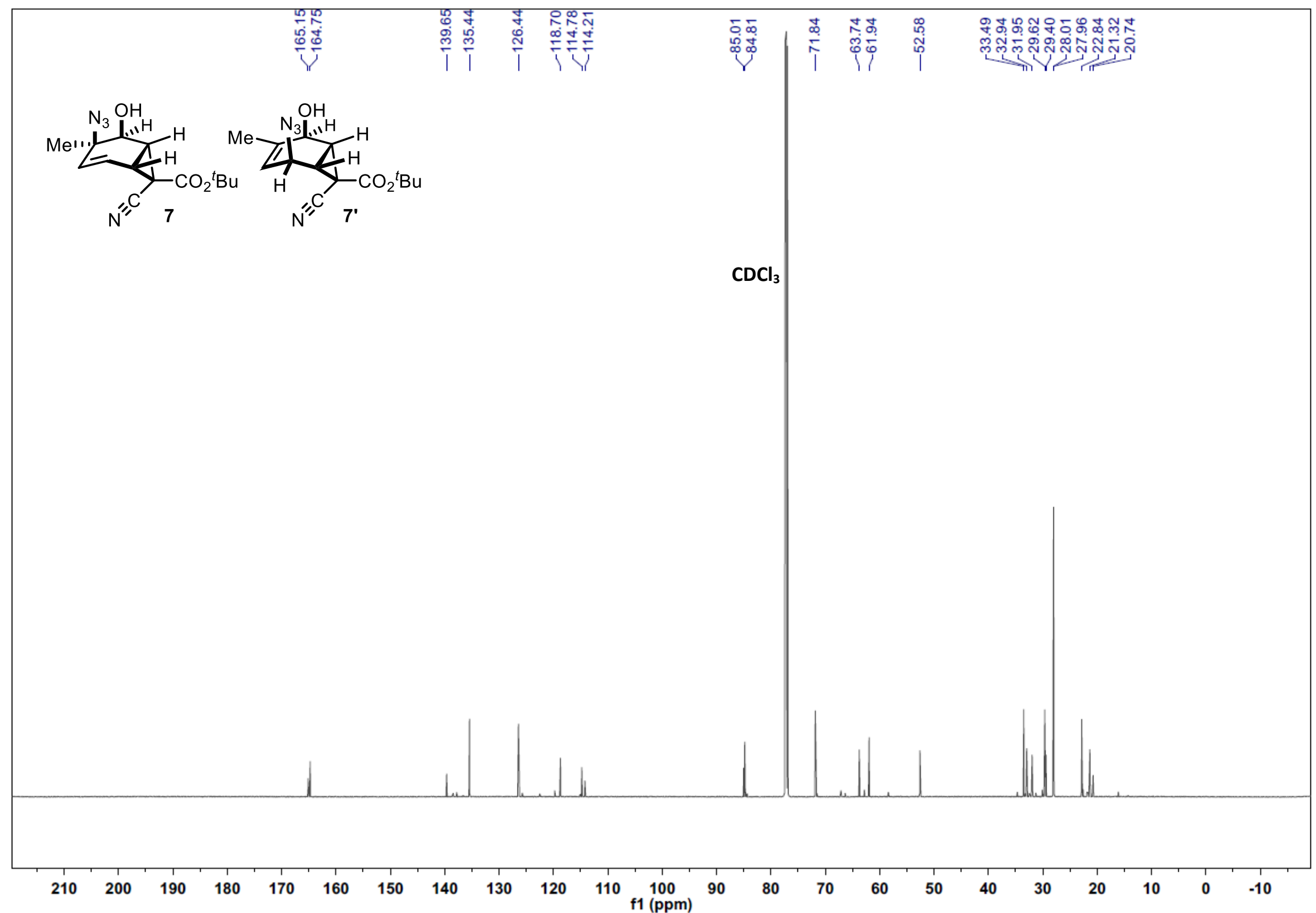


Compound 7 and 7' (Selective 1D NOESY)

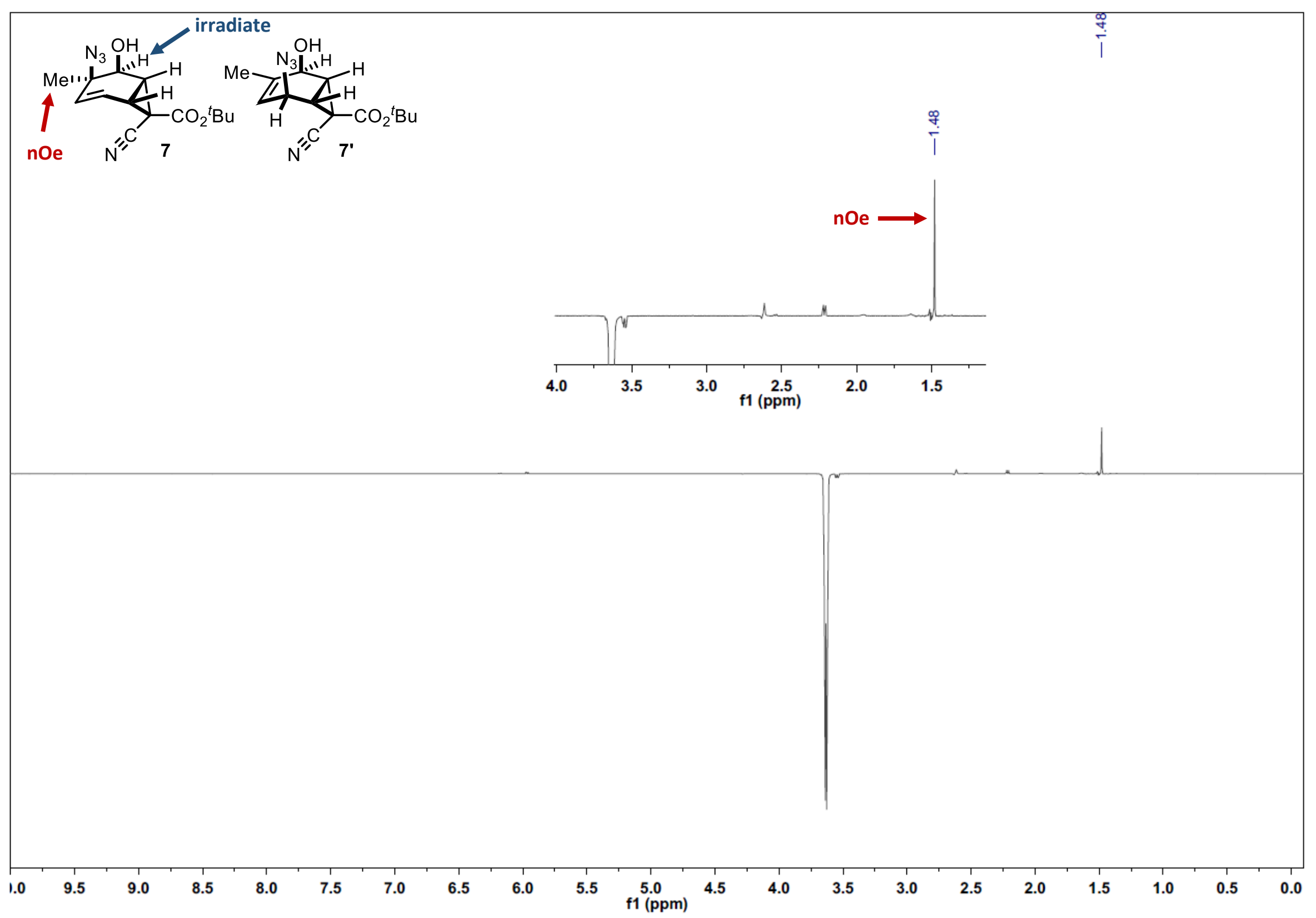


Compound $8\left({ }^{1} \mathrm{H}, 600 \mathrm{MHz}, \mathrm{CDCl}_{3}\right)$

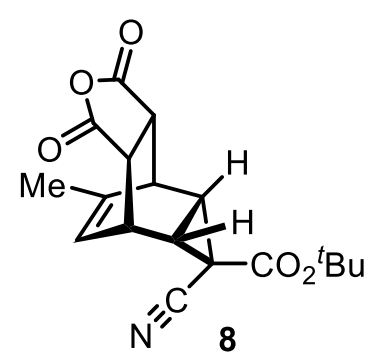

$N^{\prime \prime} 8$

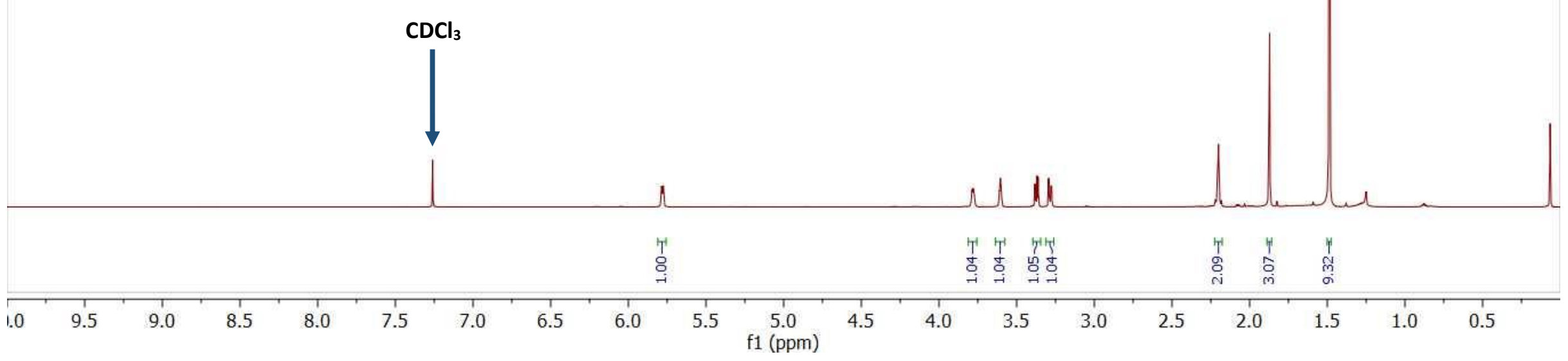


Compound $8\left({ }^{13} \mathrm{C}, 151 \mathrm{MHz}, \mathrm{CD}_{2} \mathrm{Cl}_{2}\right)$
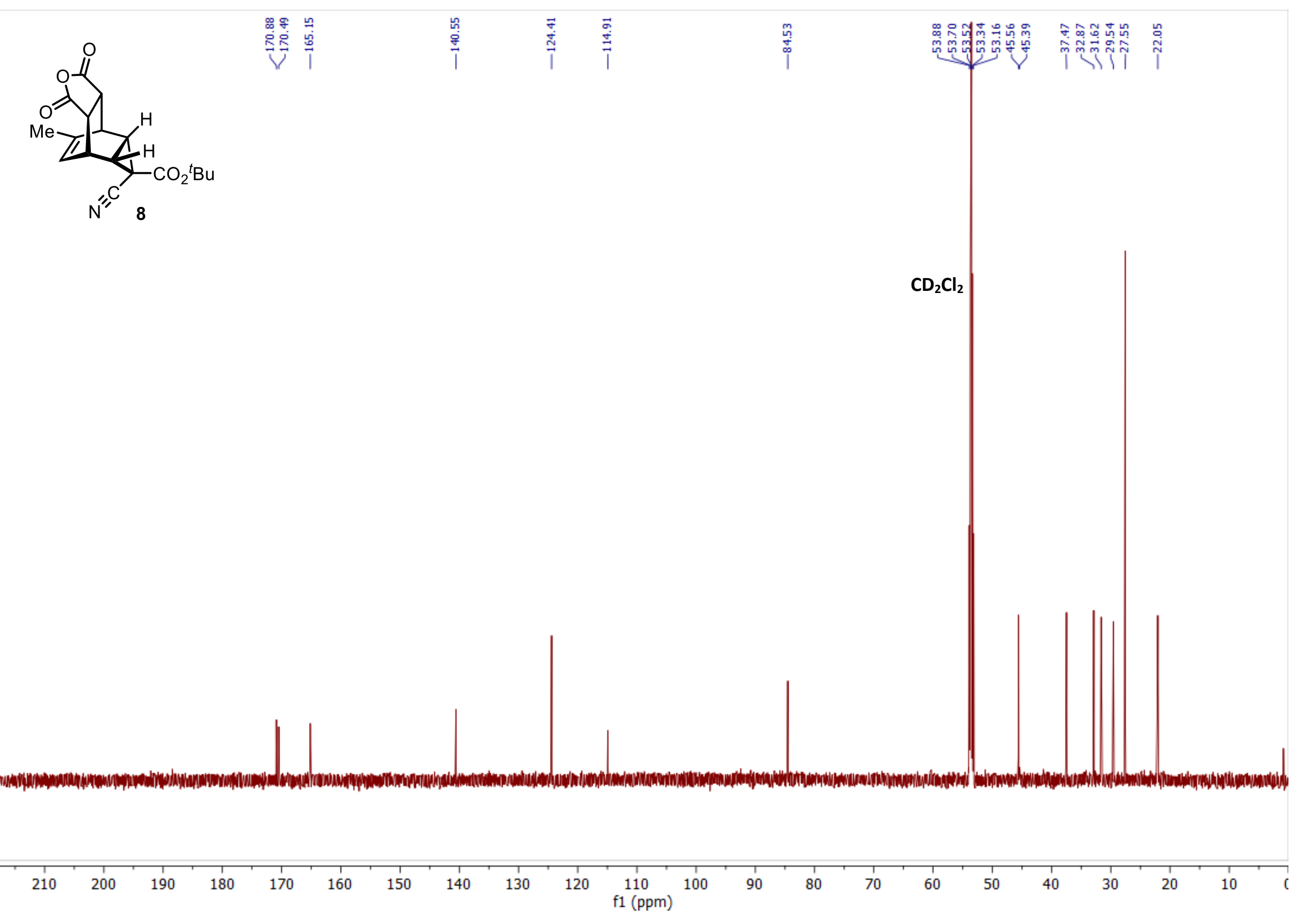
Compound $9\left({ }^{1} \mathrm{H}, 500 \mathrm{MHz}, \mathrm{CDCl}_{3}\right)$

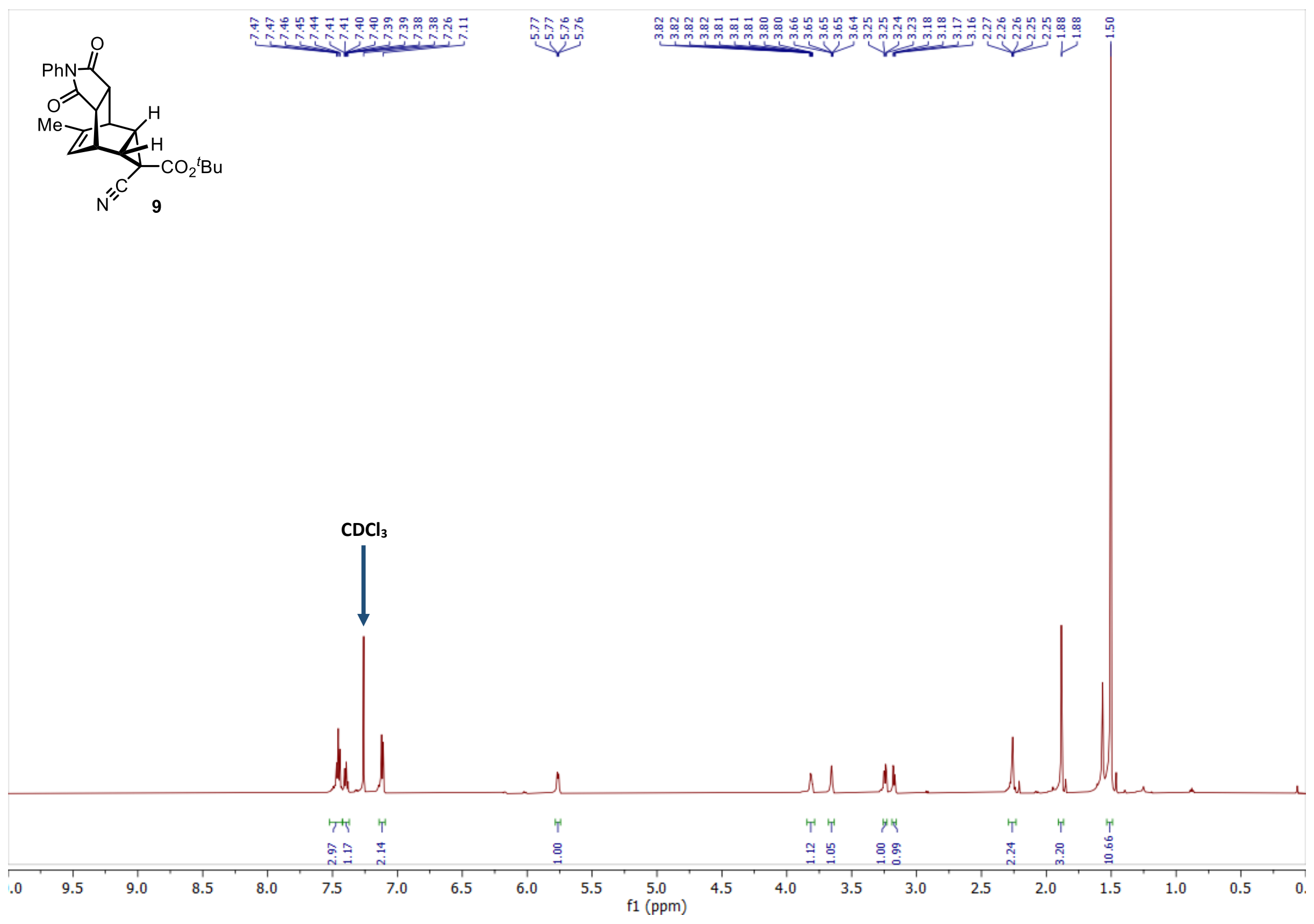


Compound $9\left({ }^{13} \mathrm{C}, 126 \mathrm{MHz}, \mathrm{CDCl}_{3}\right)$
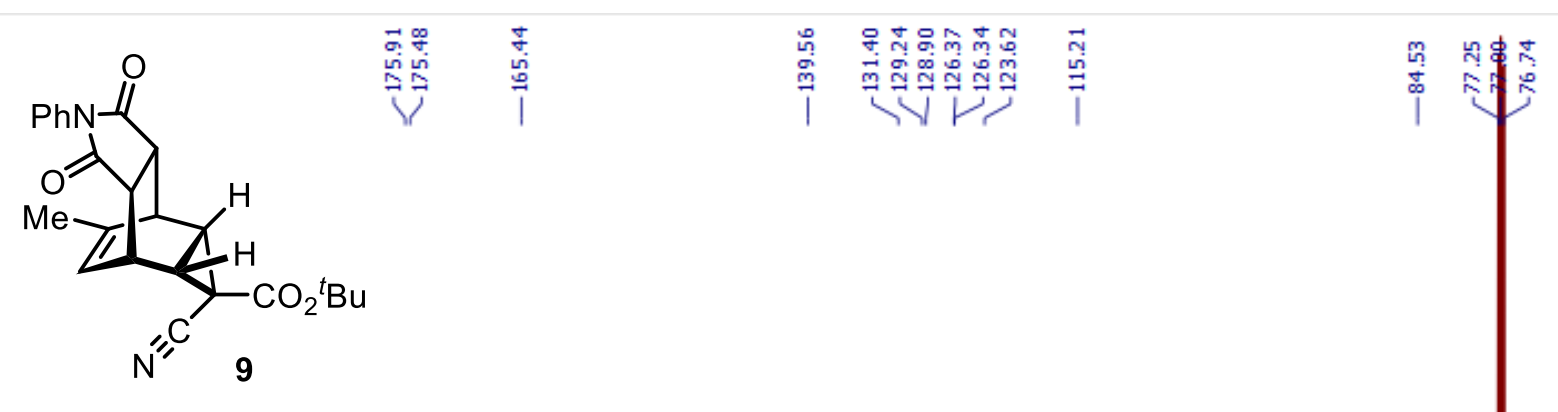

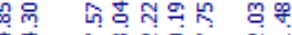

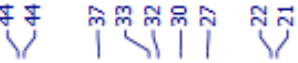
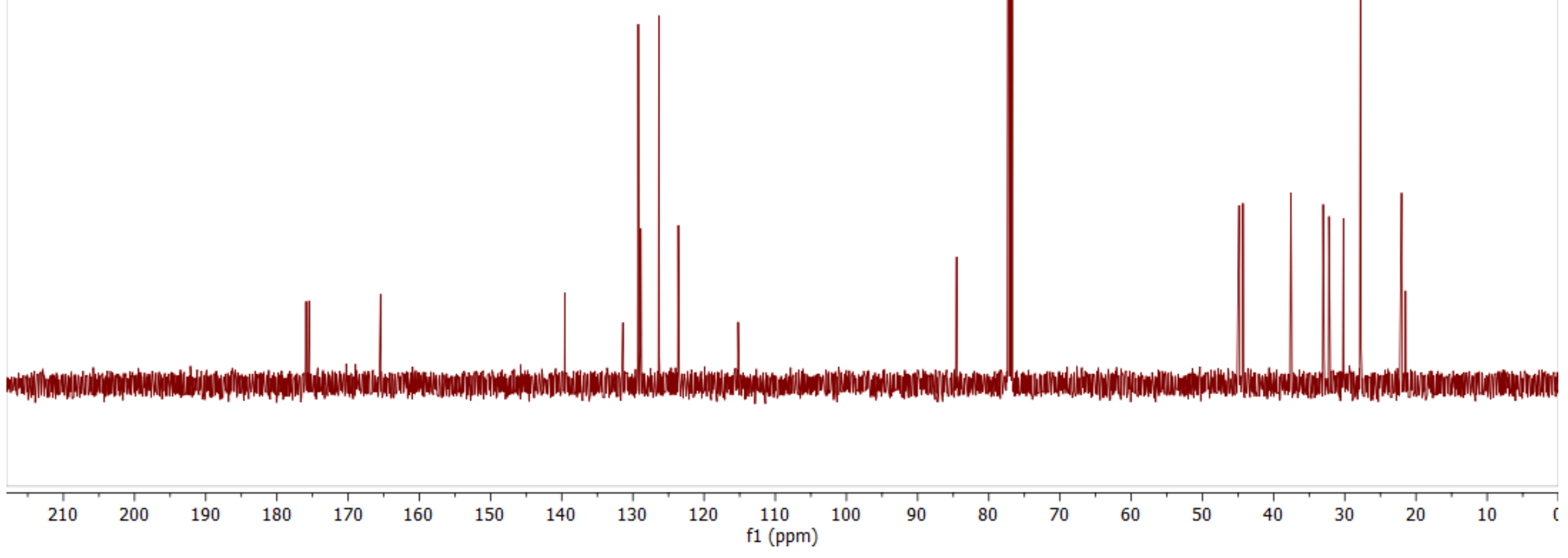
Compound $4 \mathrm{c}\left({ }^{1} \mathrm{H}, 600 \mathrm{MHz}, \mathrm{CDCl}_{3}\right)$

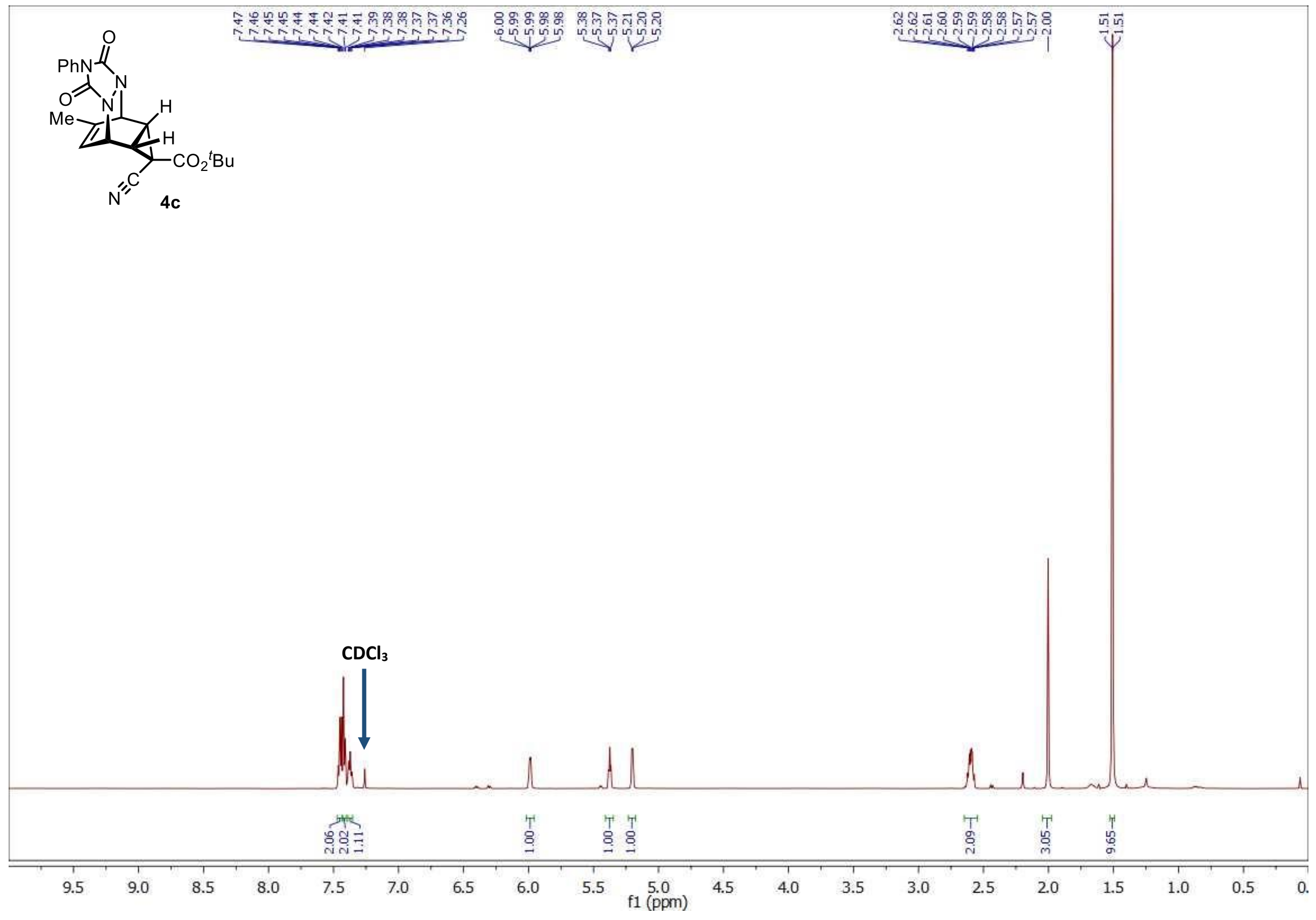


Compound $4 \mathrm{C}\left({ }^{13} \mathrm{C}, 126 \mathrm{MHz}, \mathrm{CDCl}_{3}\right)$

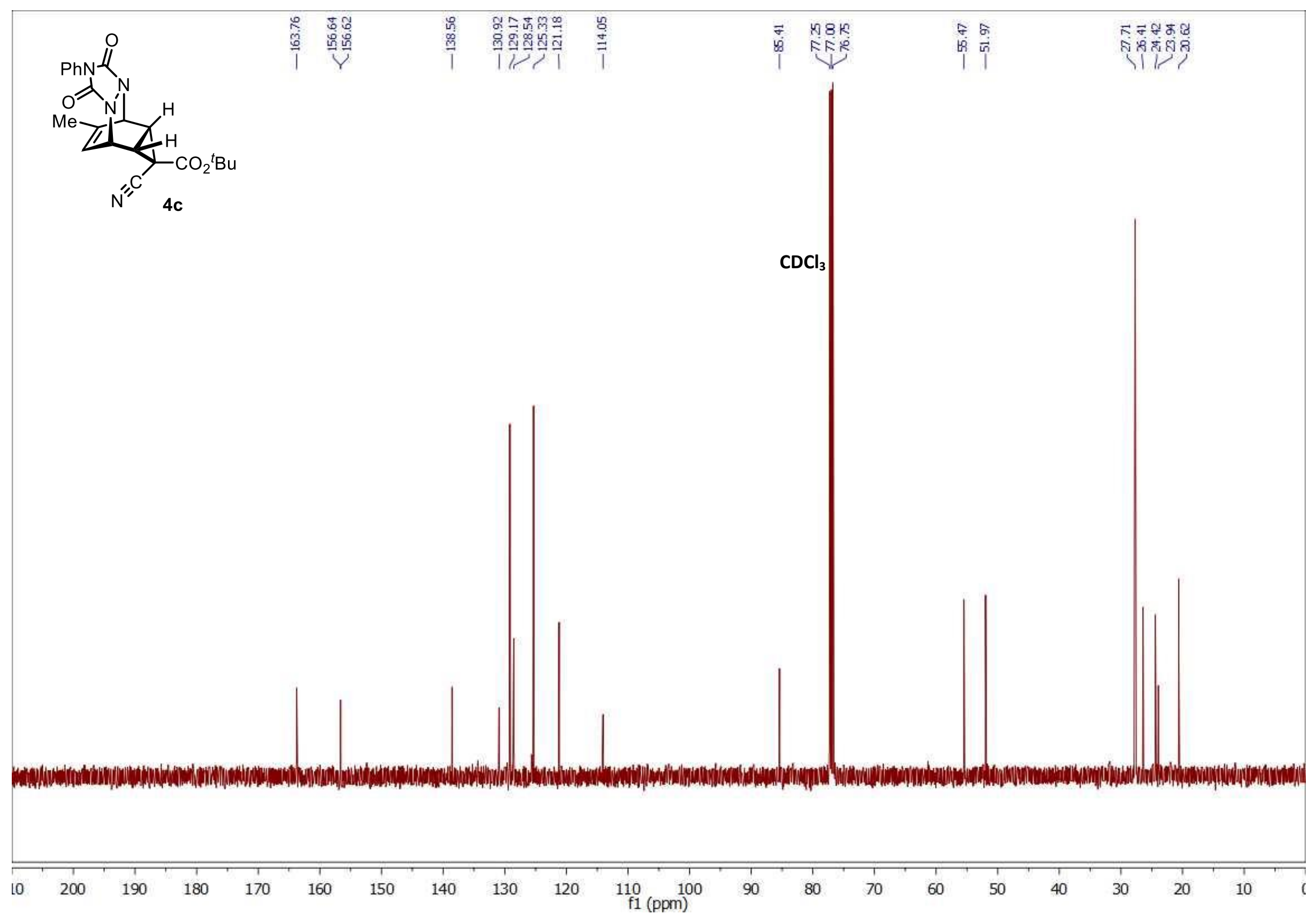


Compound $10\left({ }^{1} \mathrm{H}, 500 \mathrm{MHz}, \mathrm{CDCl}_{3}\right)$

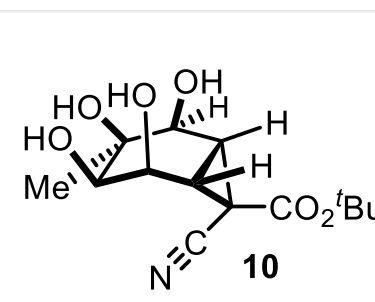

(1)

$N=$

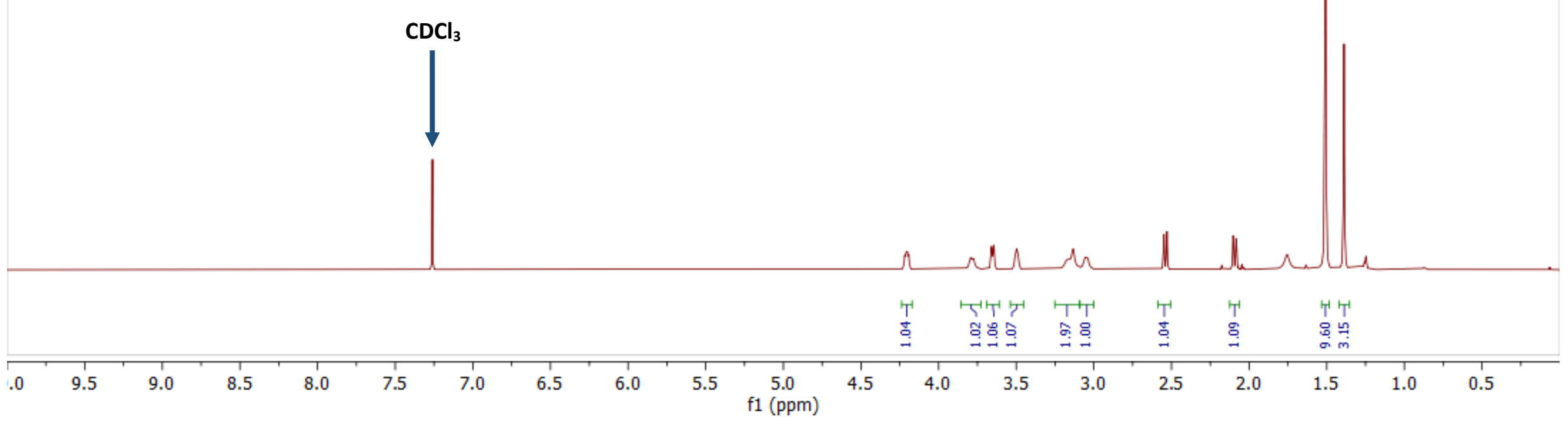


Compound $10\left({ }^{13} \mathrm{C}, 126 \mathrm{MHz}, \mathrm{CDCl}_{3}\right)$
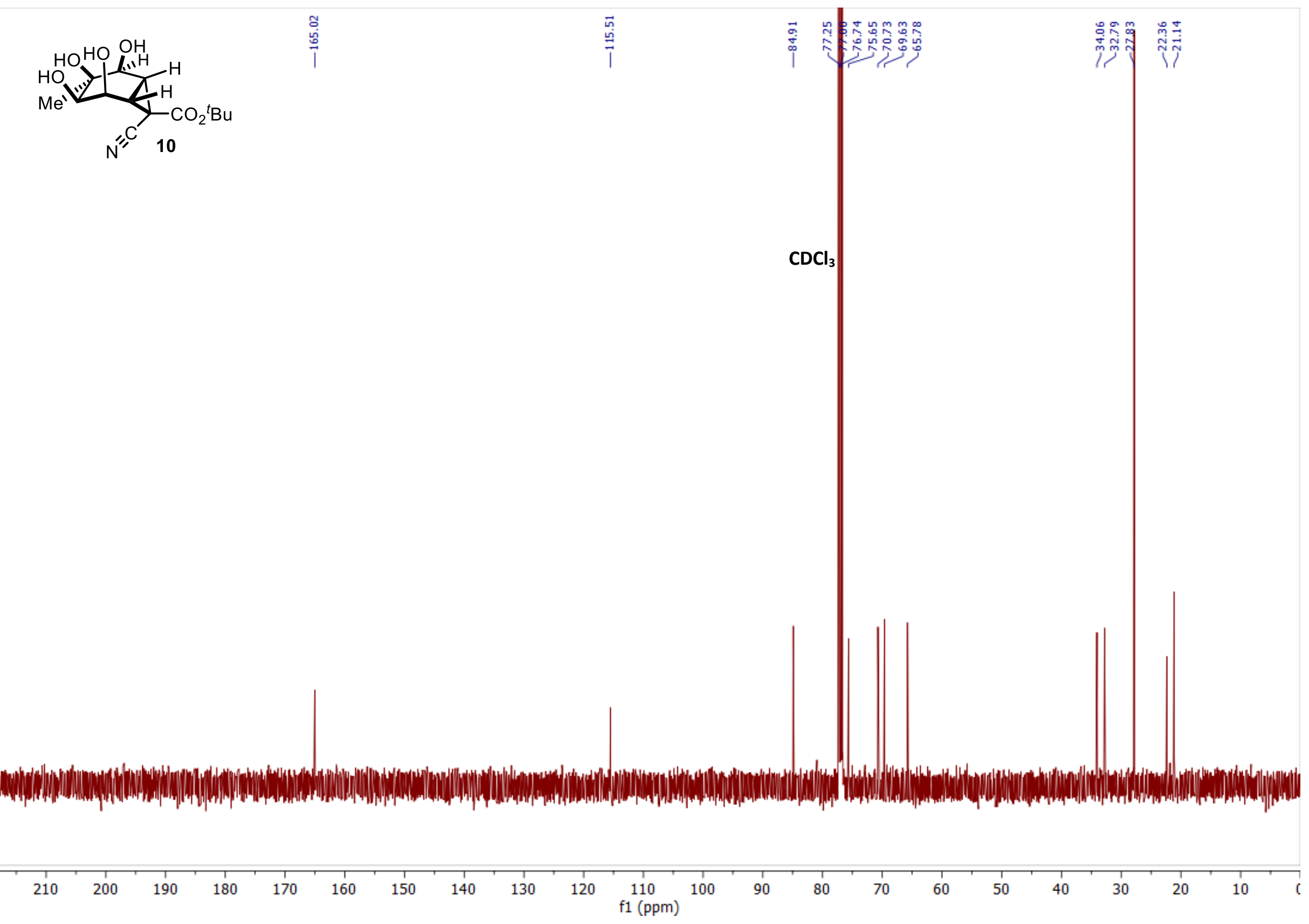
Compound $11\left({ }^{1} \mathrm{H}, 600 \mathrm{MHz}, \mathrm{CDCl}_{3}\right)$

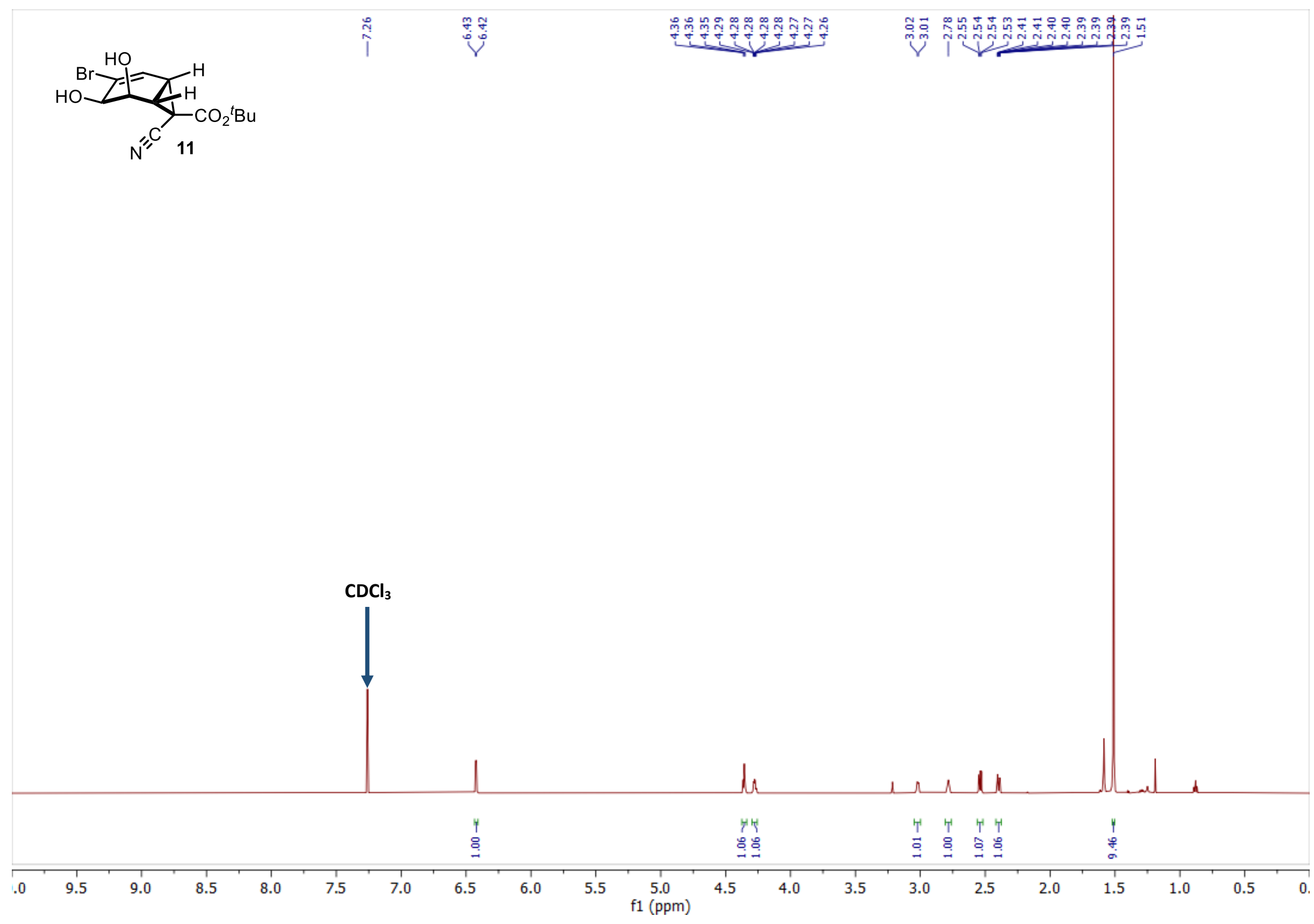


Compound $11\left({ }^{13} \mathrm{C}, 151 \mathrm{MHz}, \mathrm{CDCl}_{3}\right)$
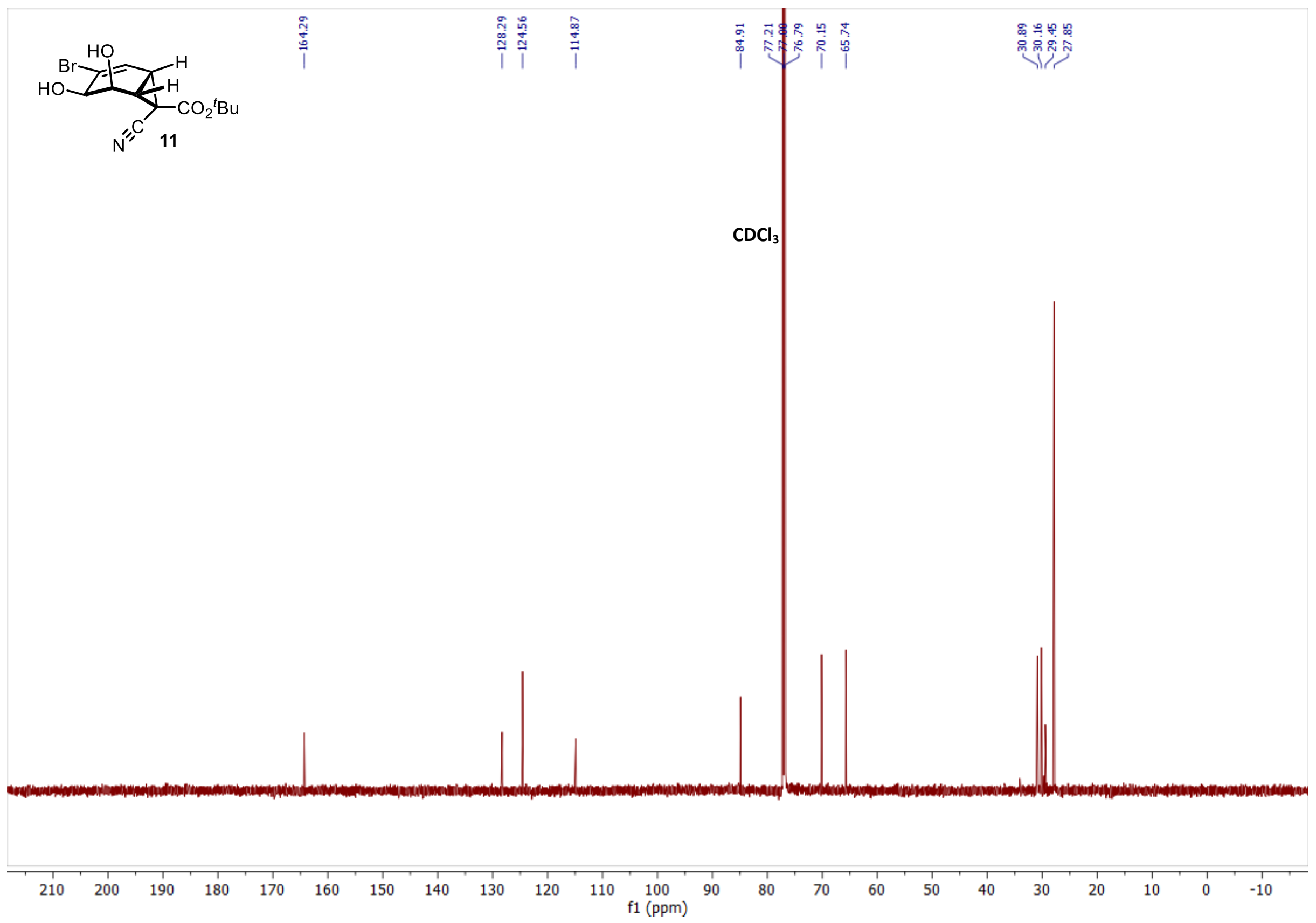
Compound $3 \mathrm{u}\left({ }^{1} \mathrm{H}, 500 \mathrm{MHz}, \mathrm{CDCl}_{3}\right)$

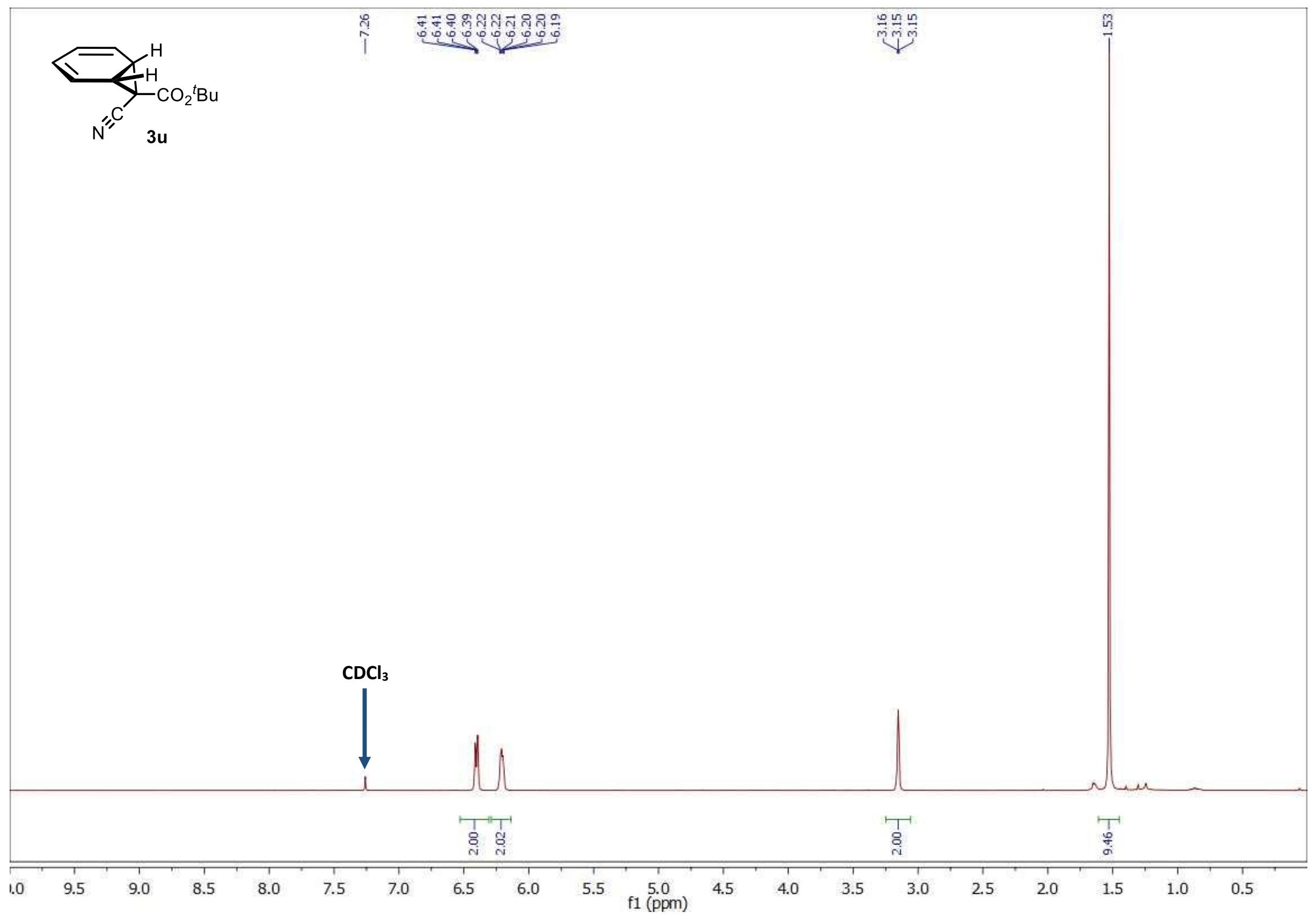


Compound $3 \mathrm{u}\left({ }^{13} \mathrm{C}, 101 \mathrm{MHz}, \mathrm{CDCl}_{3}\right)$

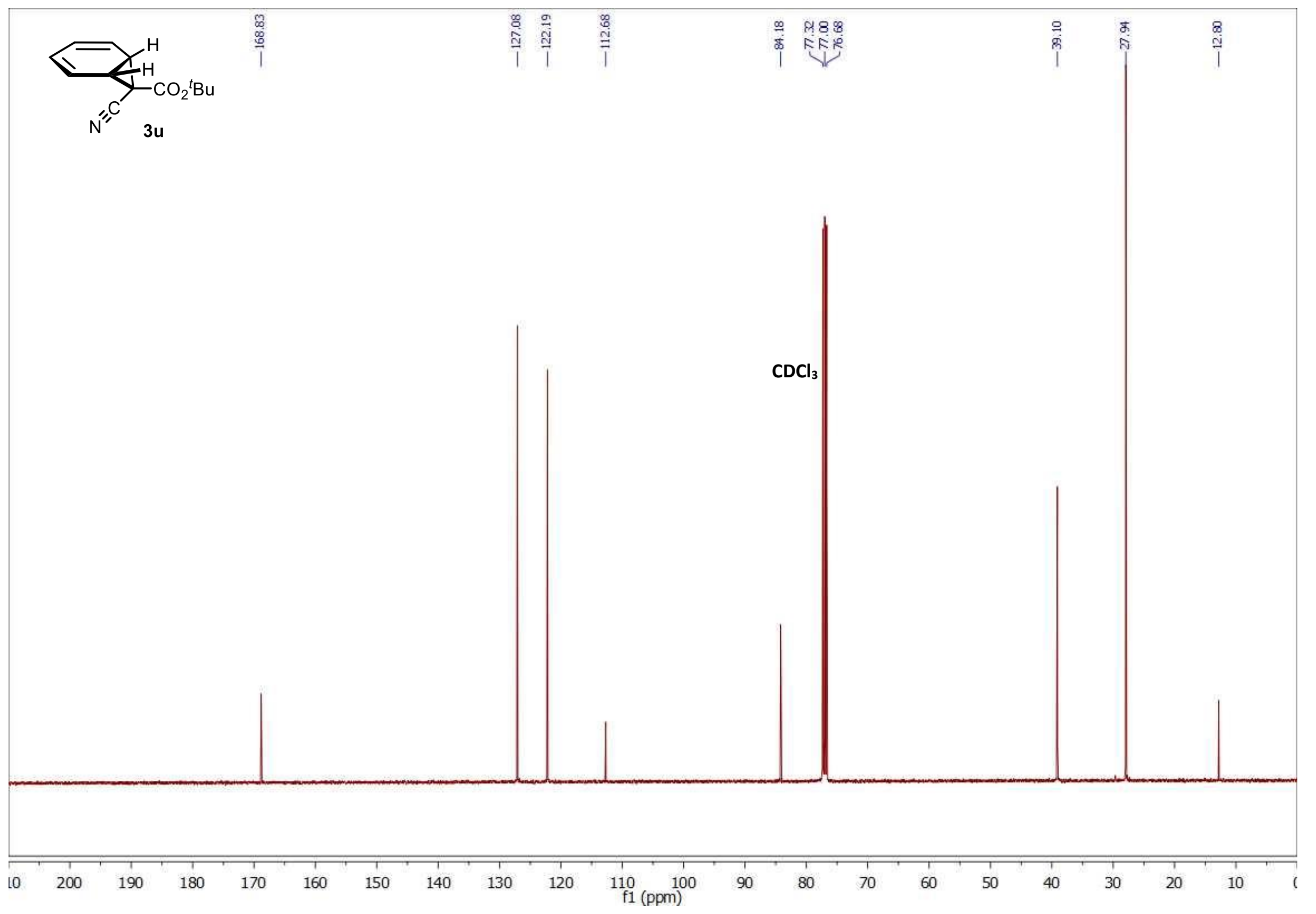


Compound $12\left({ }^{1} \mathrm{H}, 500 \mathrm{MHz}, \mathrm{CDCl}_{3}\right)$

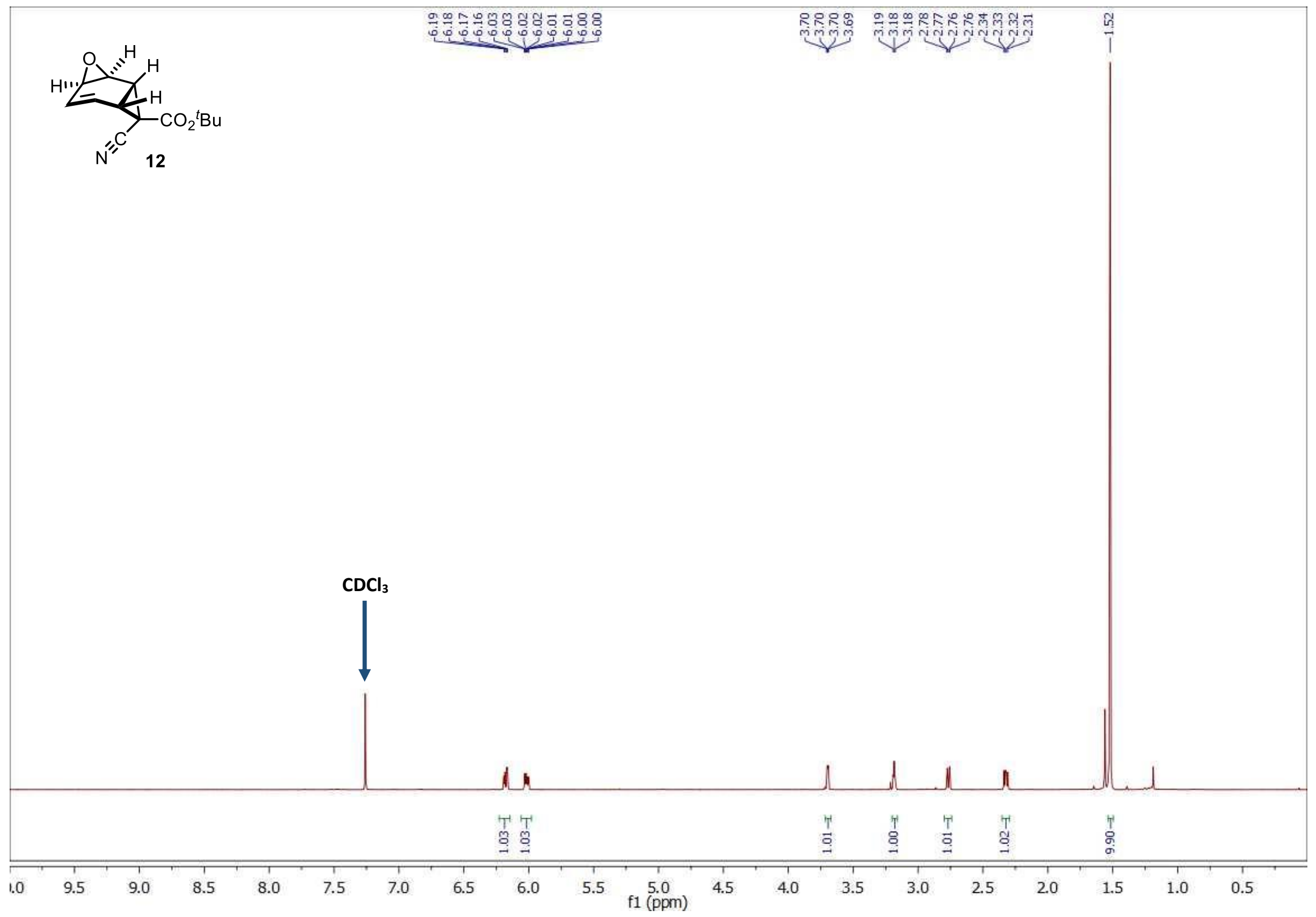


Compound $12\left({ }^{13} \mathrm{C}, 151 \mathrm{MHz}, \mathrm{CDCl}_{3}\right)$

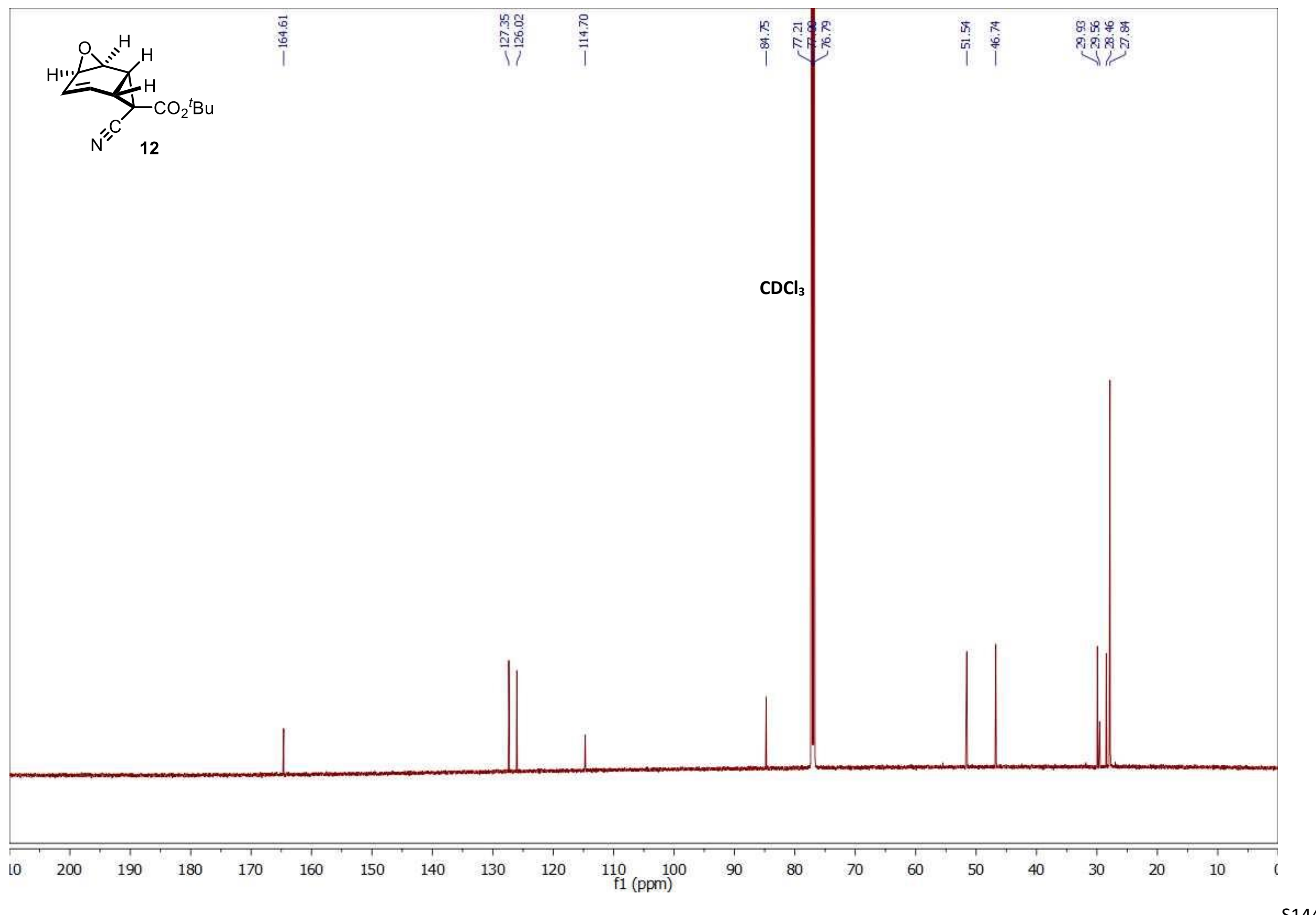


Compound $13\left({ }^{1} \mathrm{H}, 500 \mathrm{MHz}, \mathrm{CDCl}_{3}\right)$

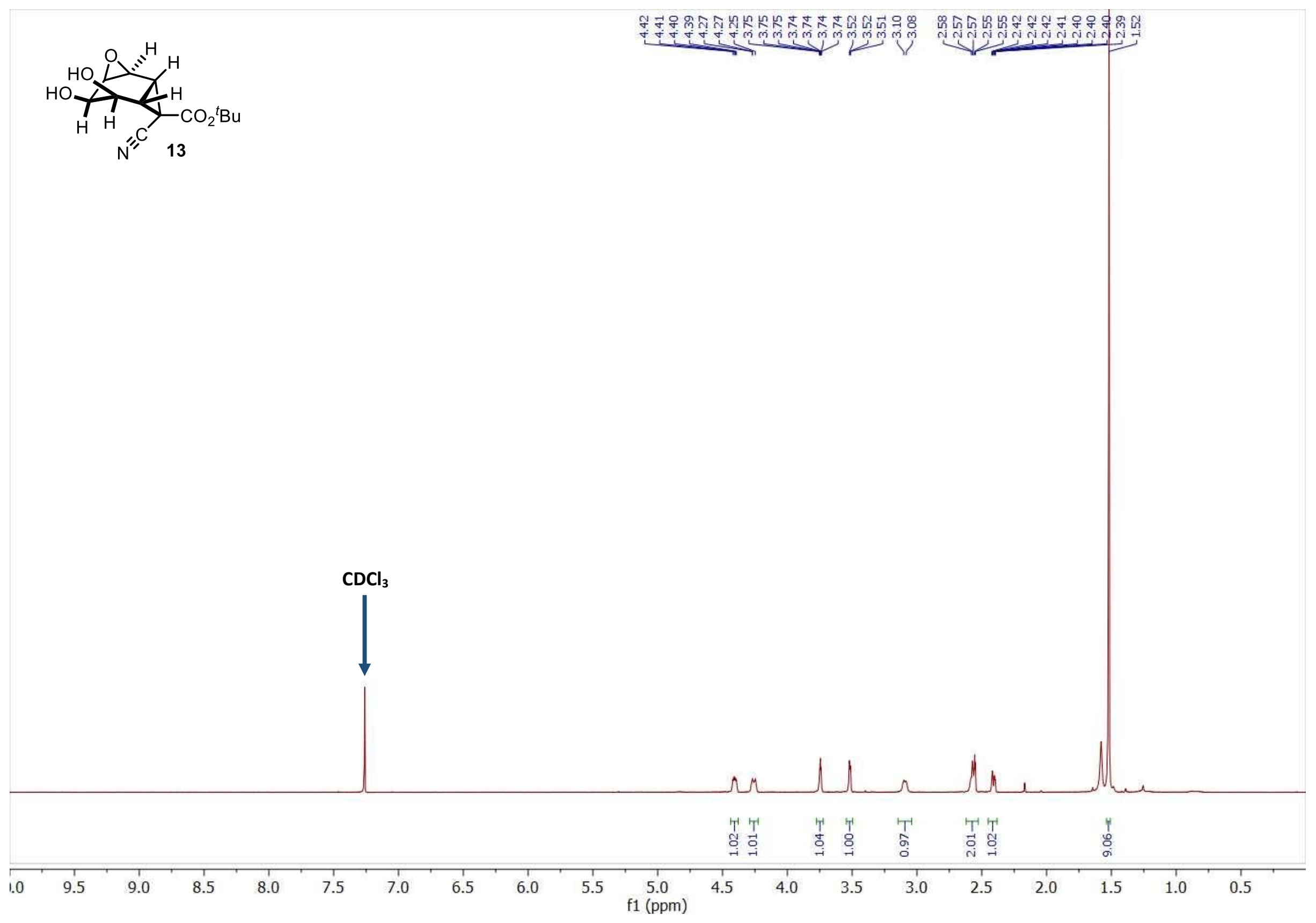


Compound $13\left({ }^{13} \mathrm{C}, 126 \mathrm{MHz}, \mathrm{CDCl}_{3}\right)$
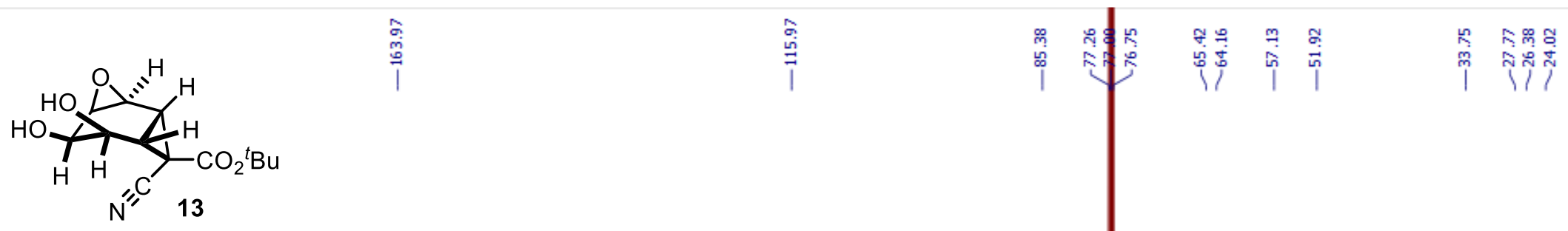

$\mathrm{CDCl}_{3}$

(I)

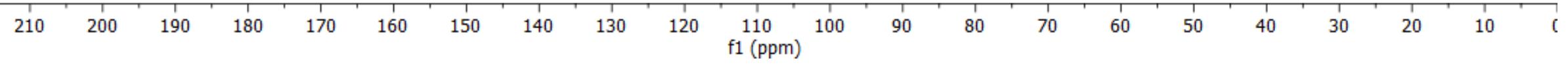


Compound $14\left({ }^{1} \mathrm{H}, 400 \mathrm{MHz}, \mathrm{CDCl}_{3}\right)$
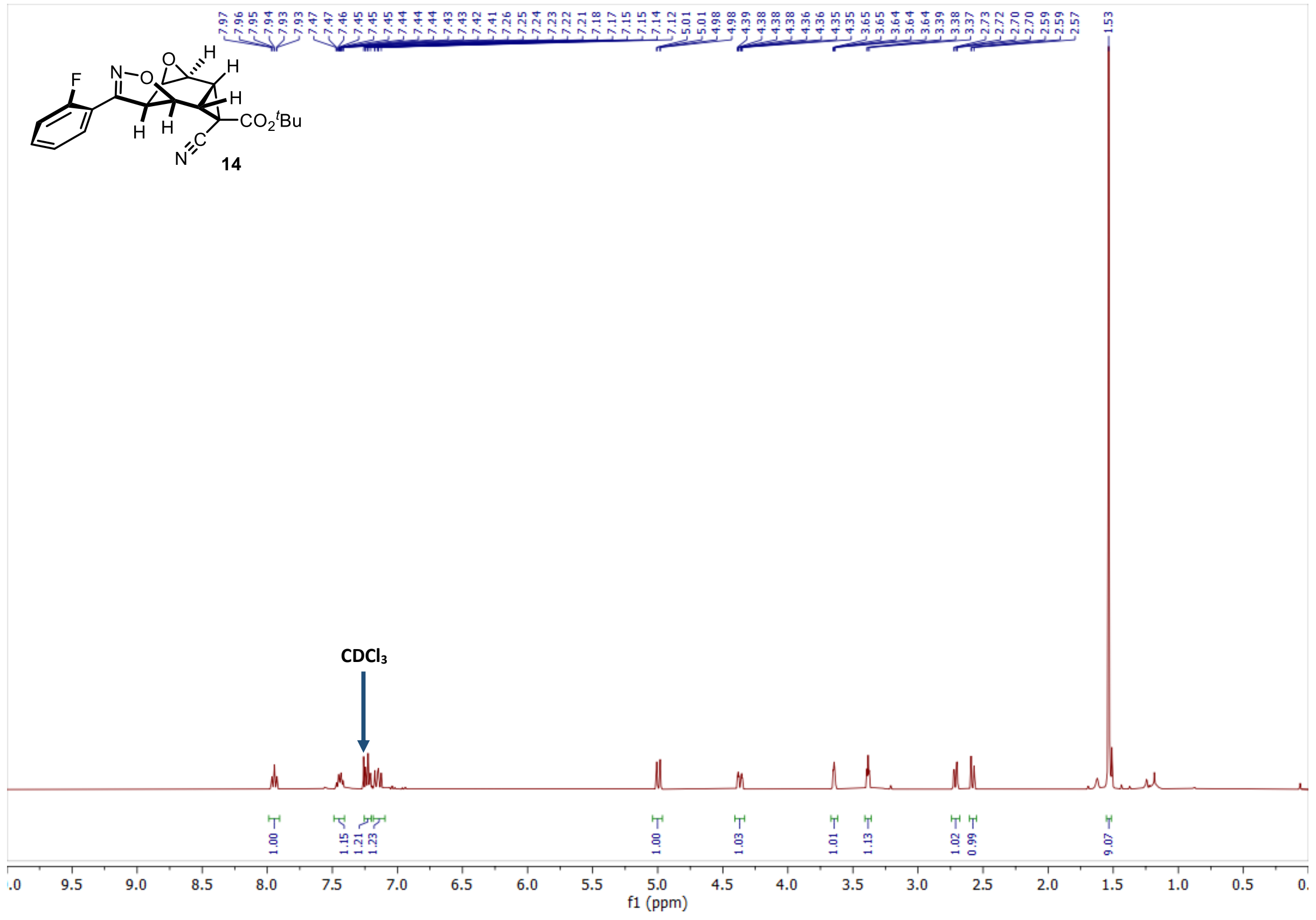


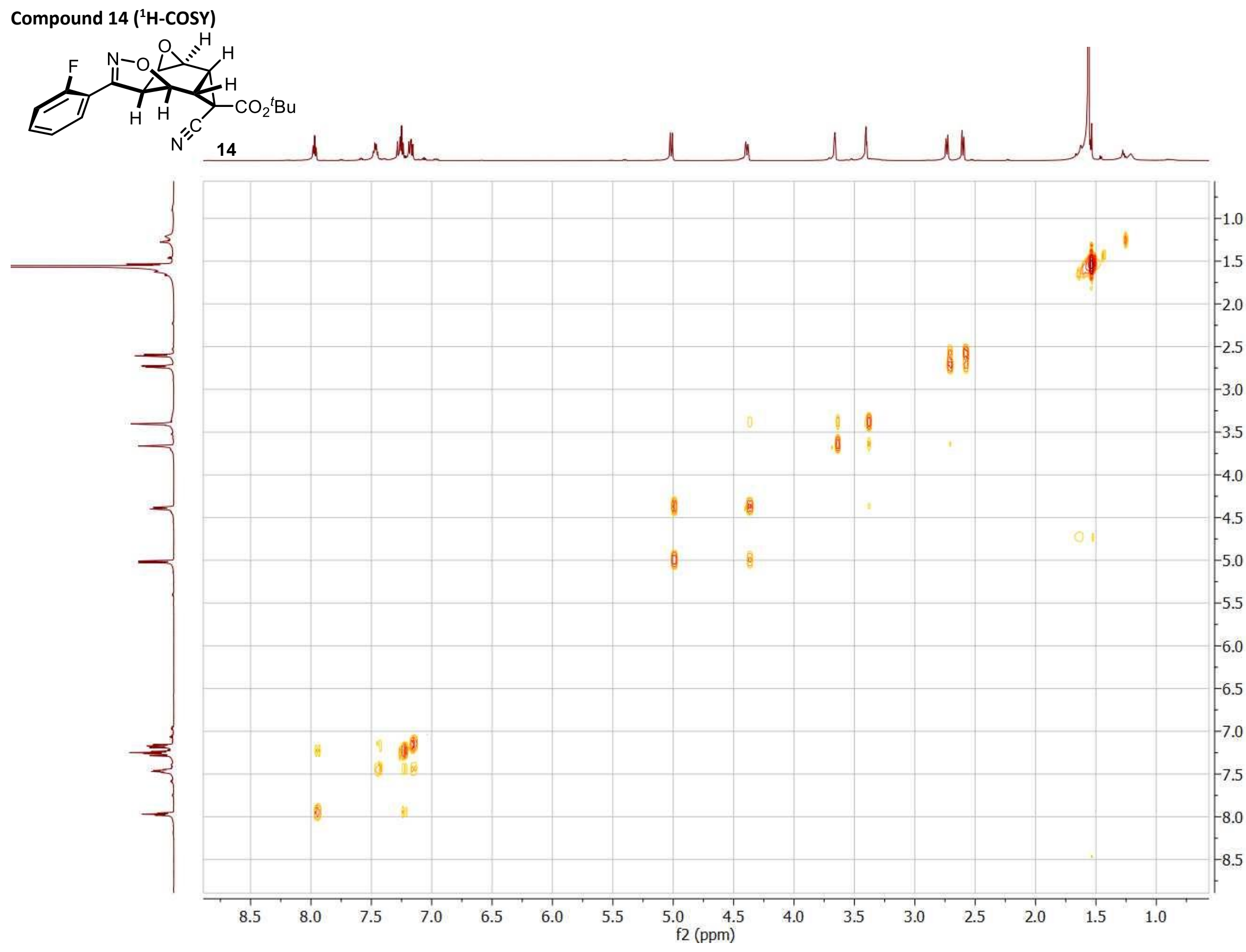


Compound 14 (Selective 1D COSY; irradiation at $\delta=5.03$ ppm)

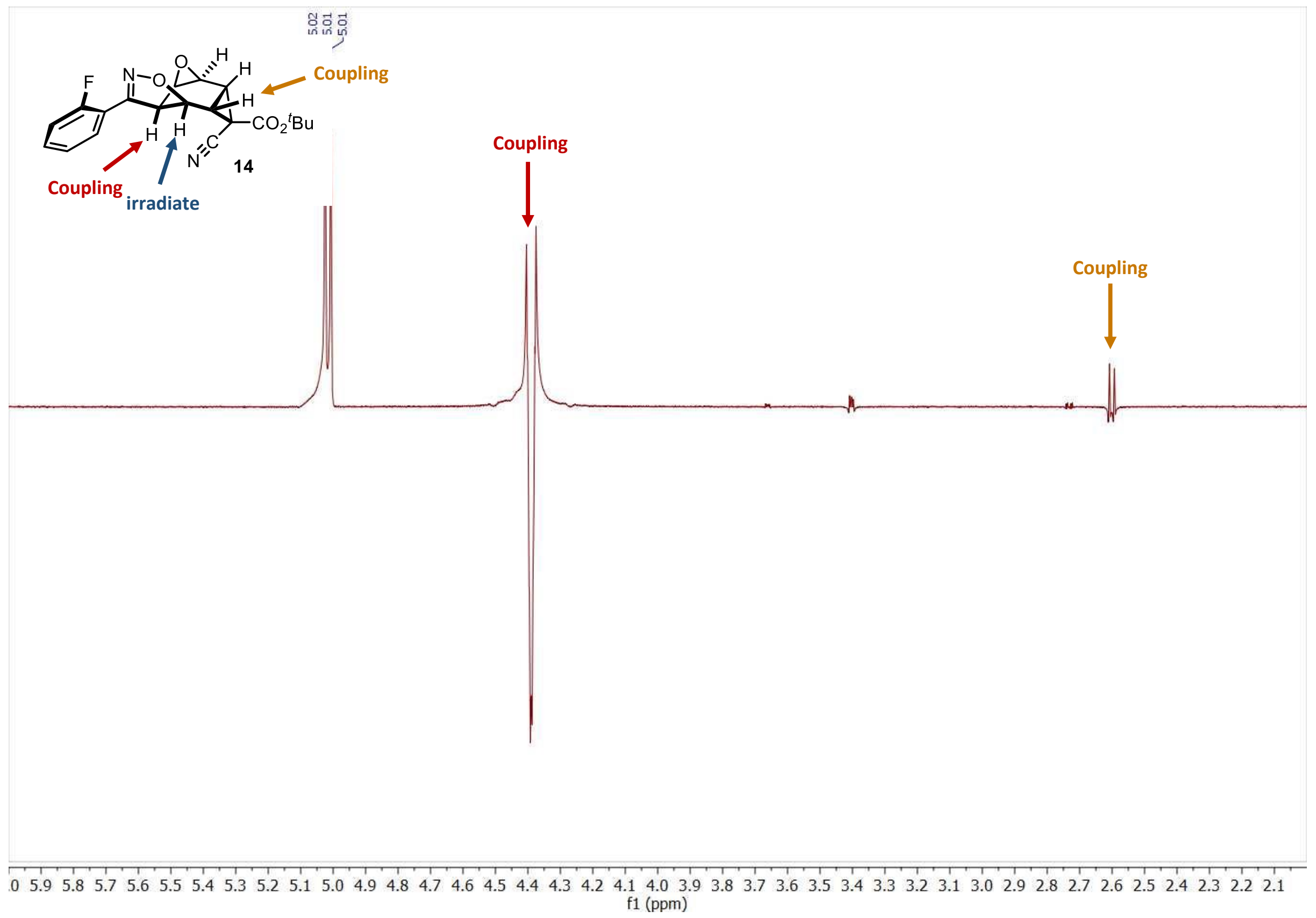


Compound 14 (Selective 1D NOESY; irradiation at $\delta=4.38 \mathrm{ppm}$ )

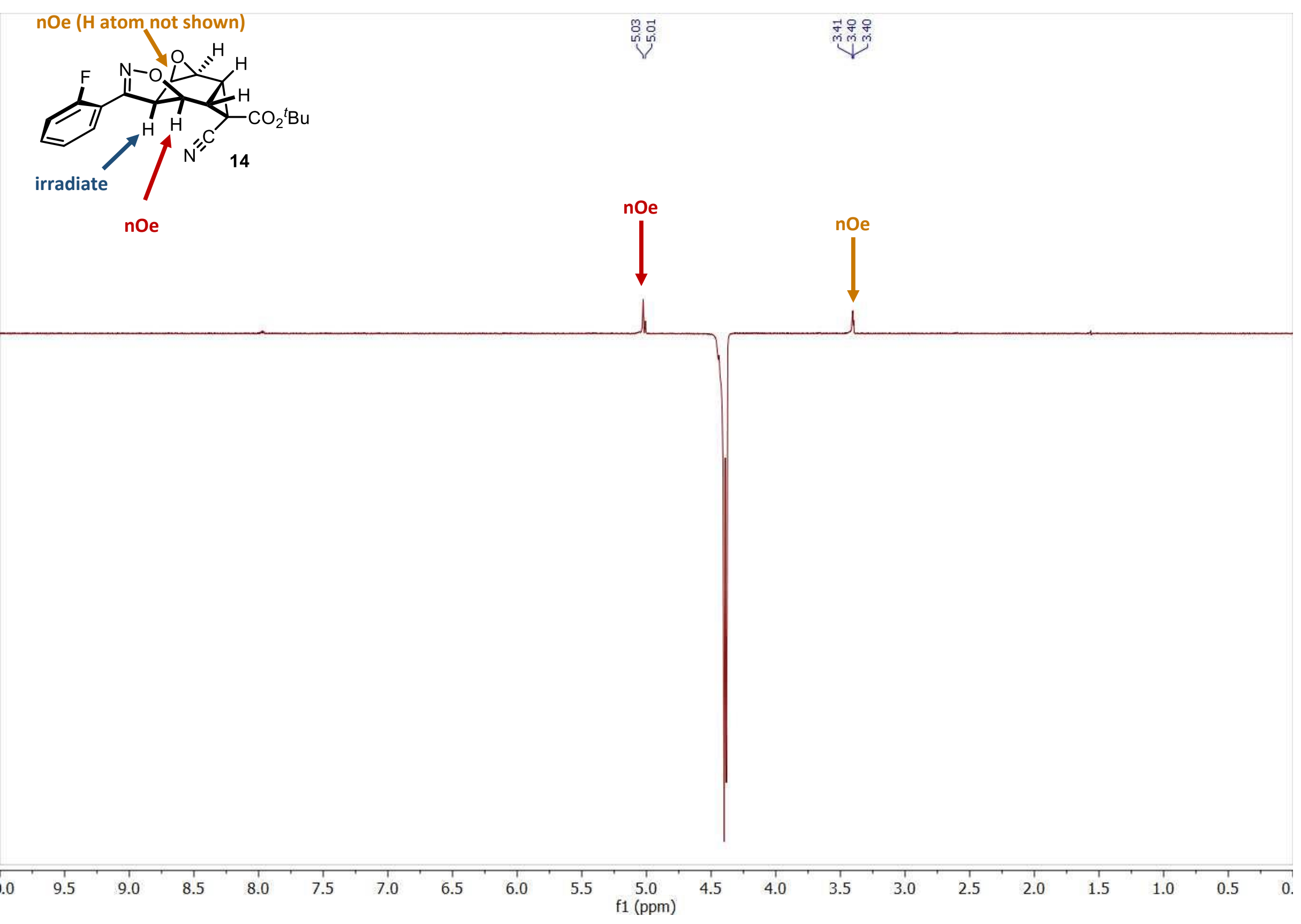


Compound 14 (Selective 1D NOESY; irradiation at $\delta=5.03 \mathrm{ppm}$ )
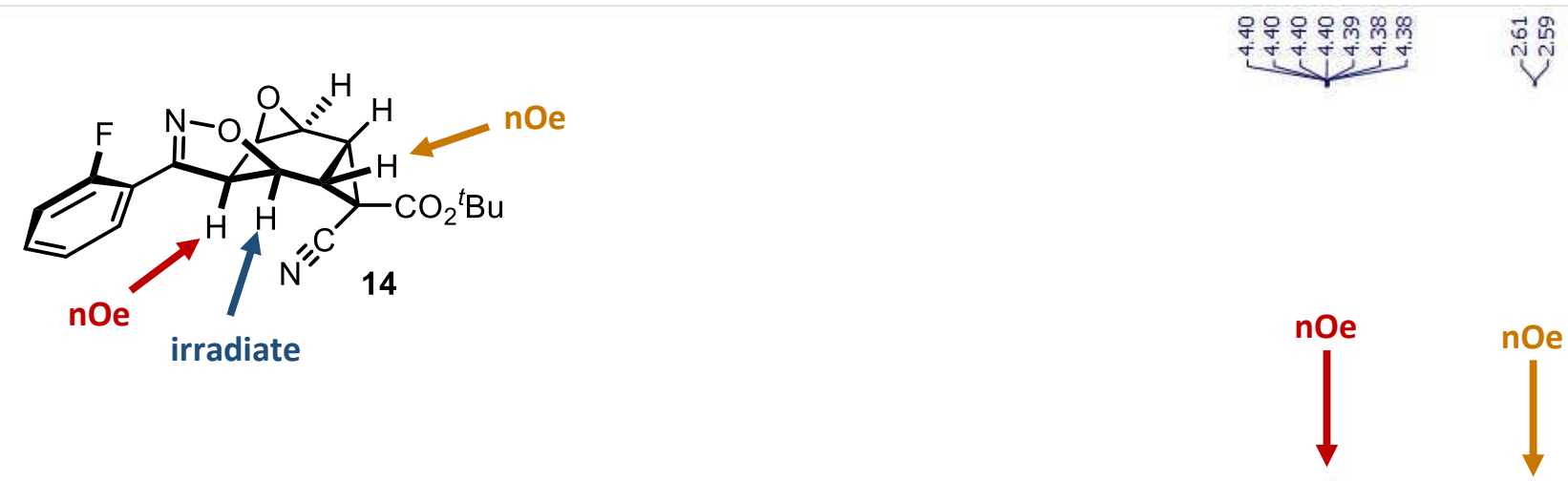
Compound $14\left({ }^{13} \mathrm{C}, 151 \mathrm{MHz}, \mathrm{CDCl}_{3}\right)$
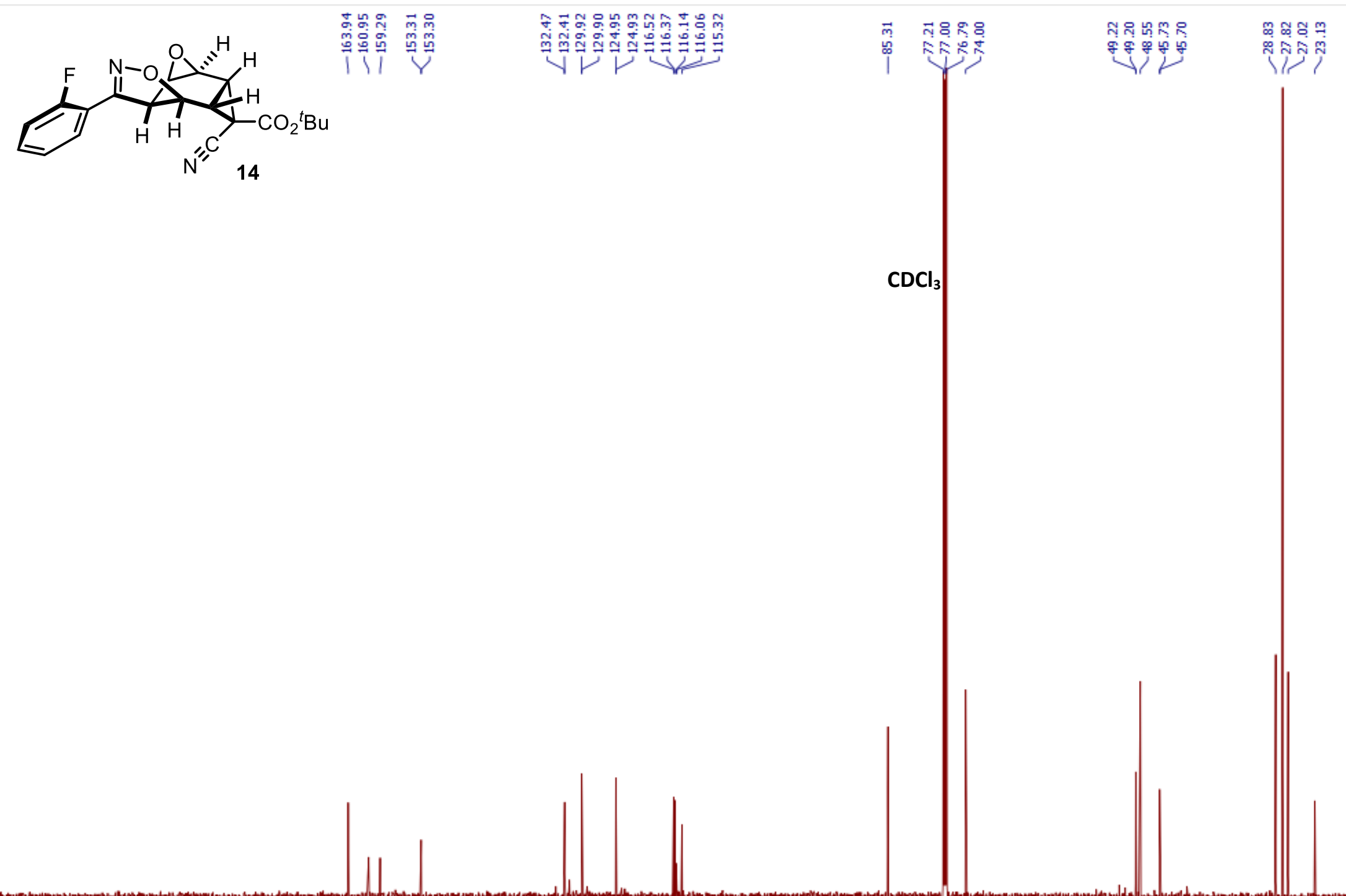
Compound $14\left({ }^{19} \mathrm{~F}, 564 \mathrm{MHz}, \mathrm{CDCl}_{3}\right)$
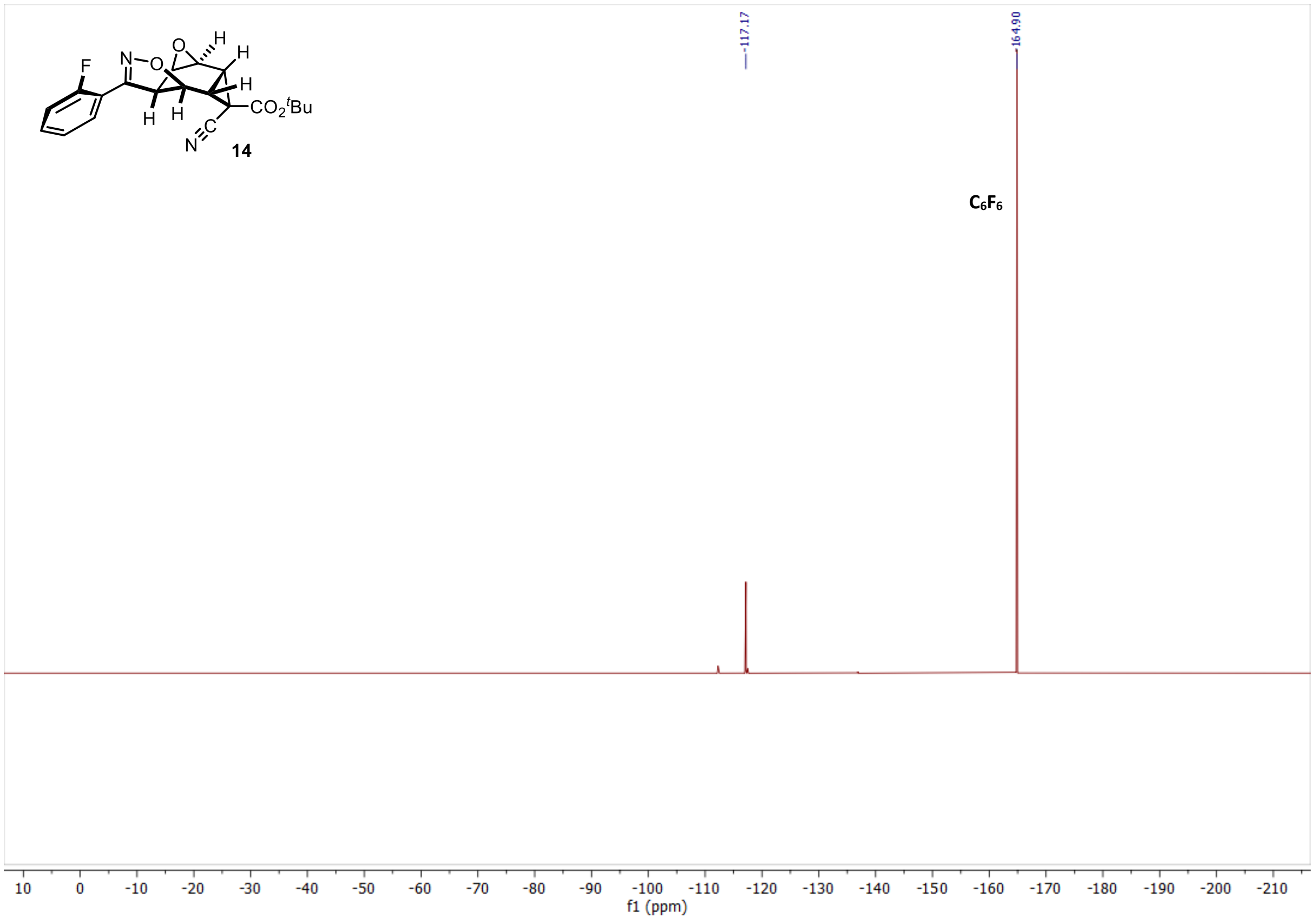
Compound $15\left({ }^{1} \mathrm{H}, 600 \mathrm{MHz}, \mathrm{CDCl}_{3}\right)$

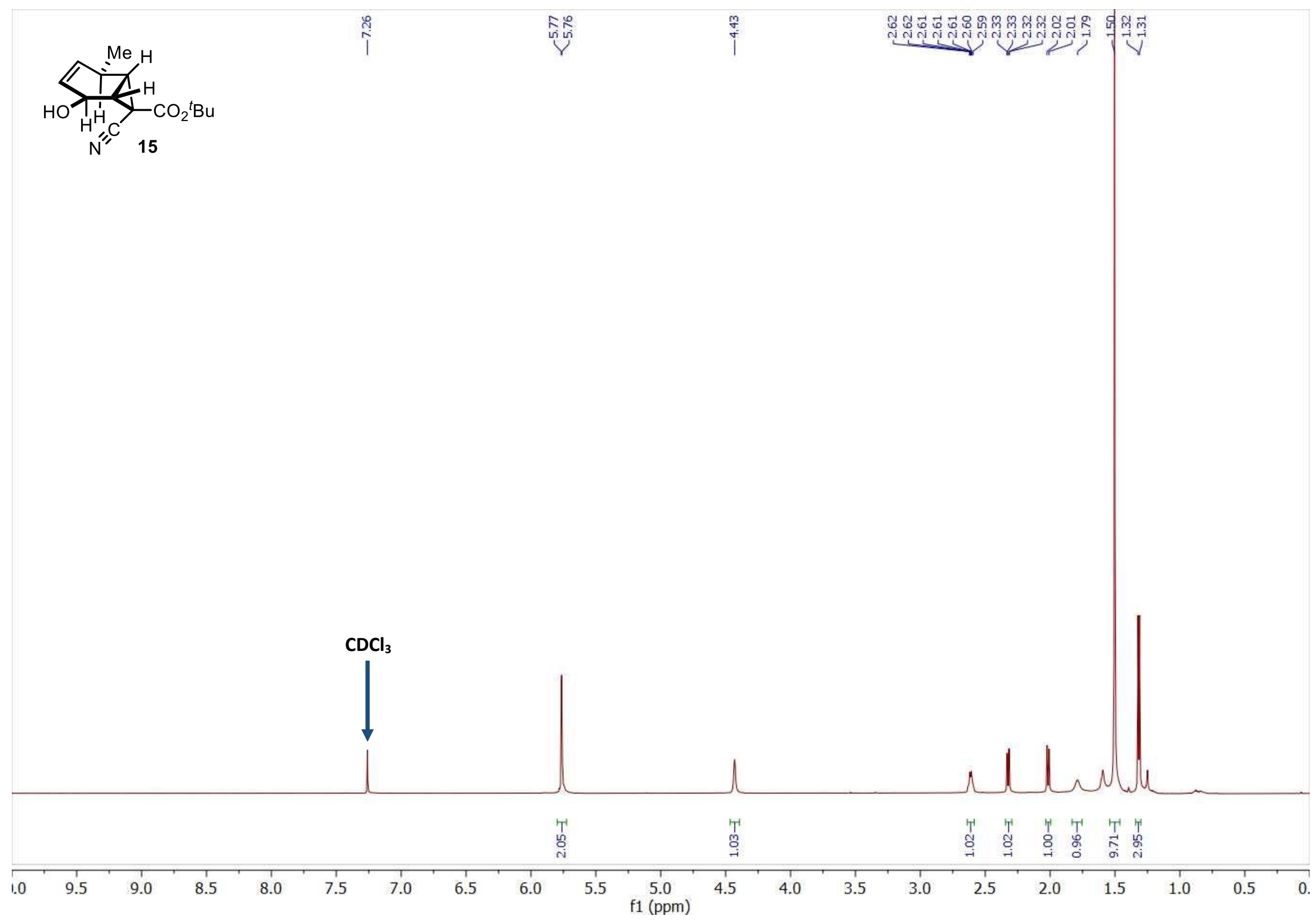


Compound $15\left({ }^{1} \mathrm{H}-\mathrm{COSY}, 500 \mathrm{MHz}, \mathrm{CDCl}_{3}\right)$

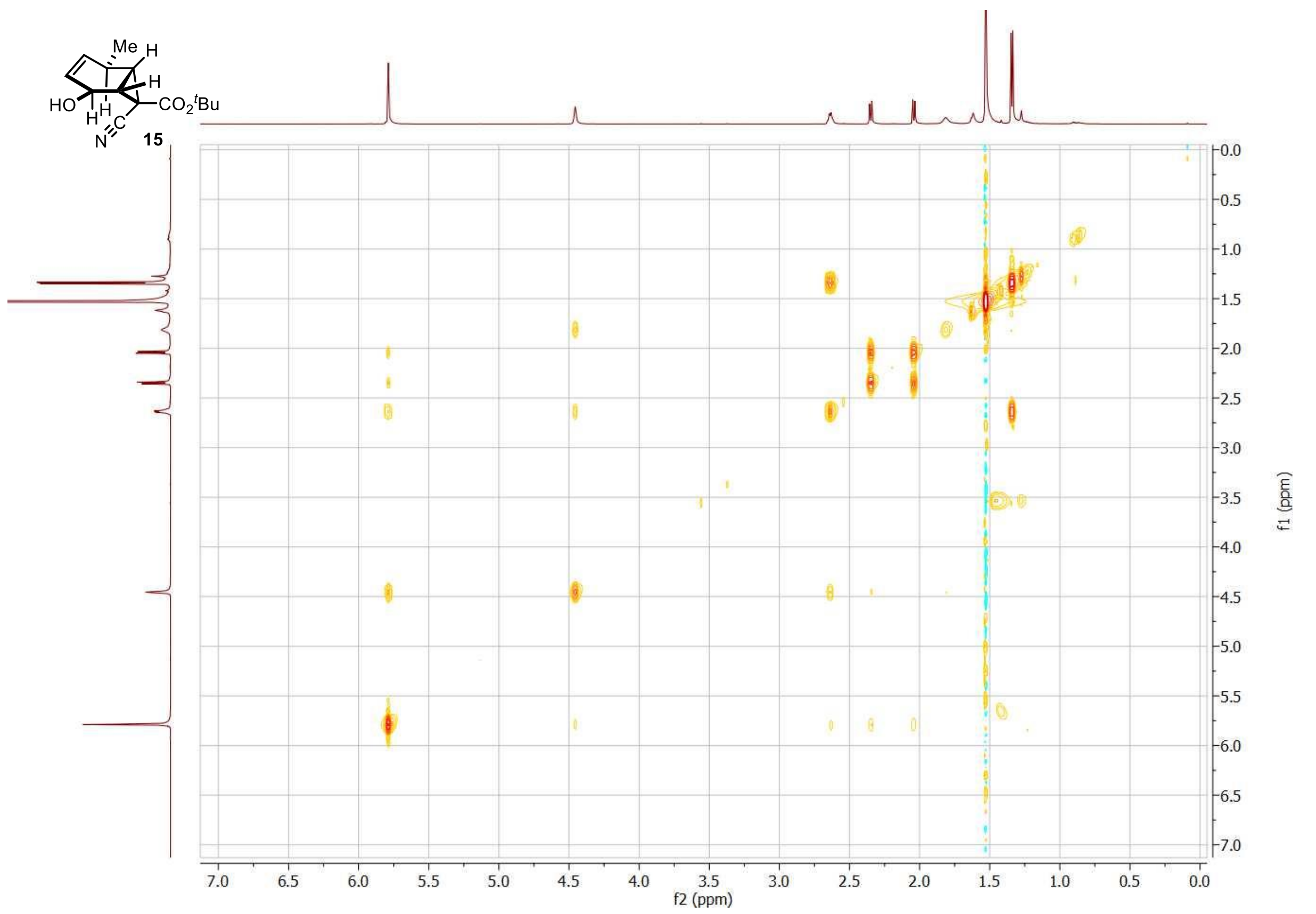


Compound $15\left({ }^{13} \mathrm{C}, 151 \mathrm{MHz}, \mathrm{CDCl}_{3}\right)$

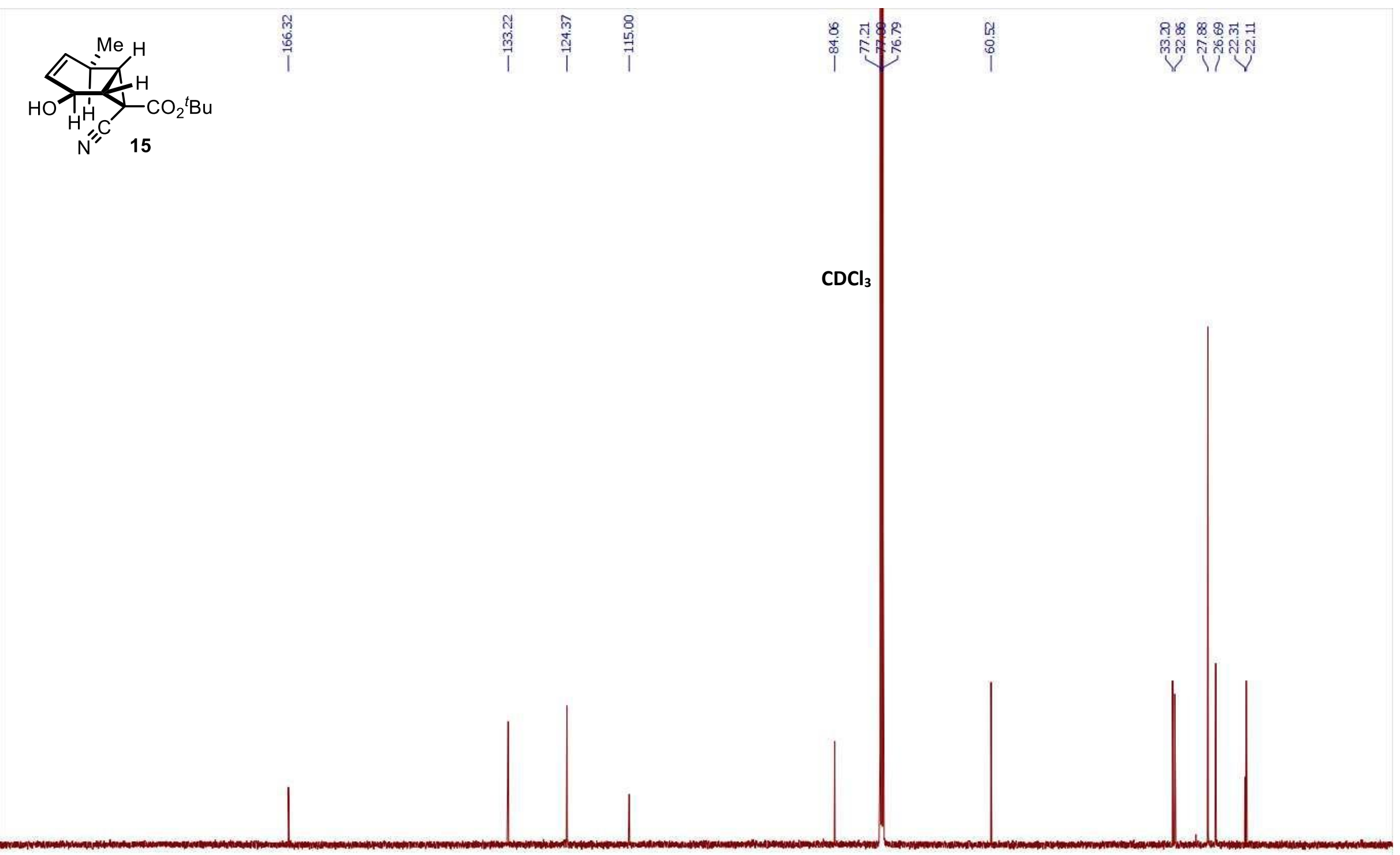

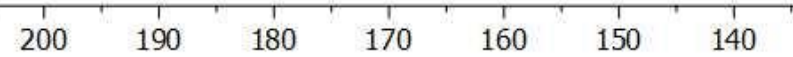

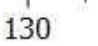


Compound $15\left({ }^{1} \mathrm{H},{ }^{13} \mathrm{C}-\mathrm{HSQC}, \mathrm{CDCl}_{3}\right)$

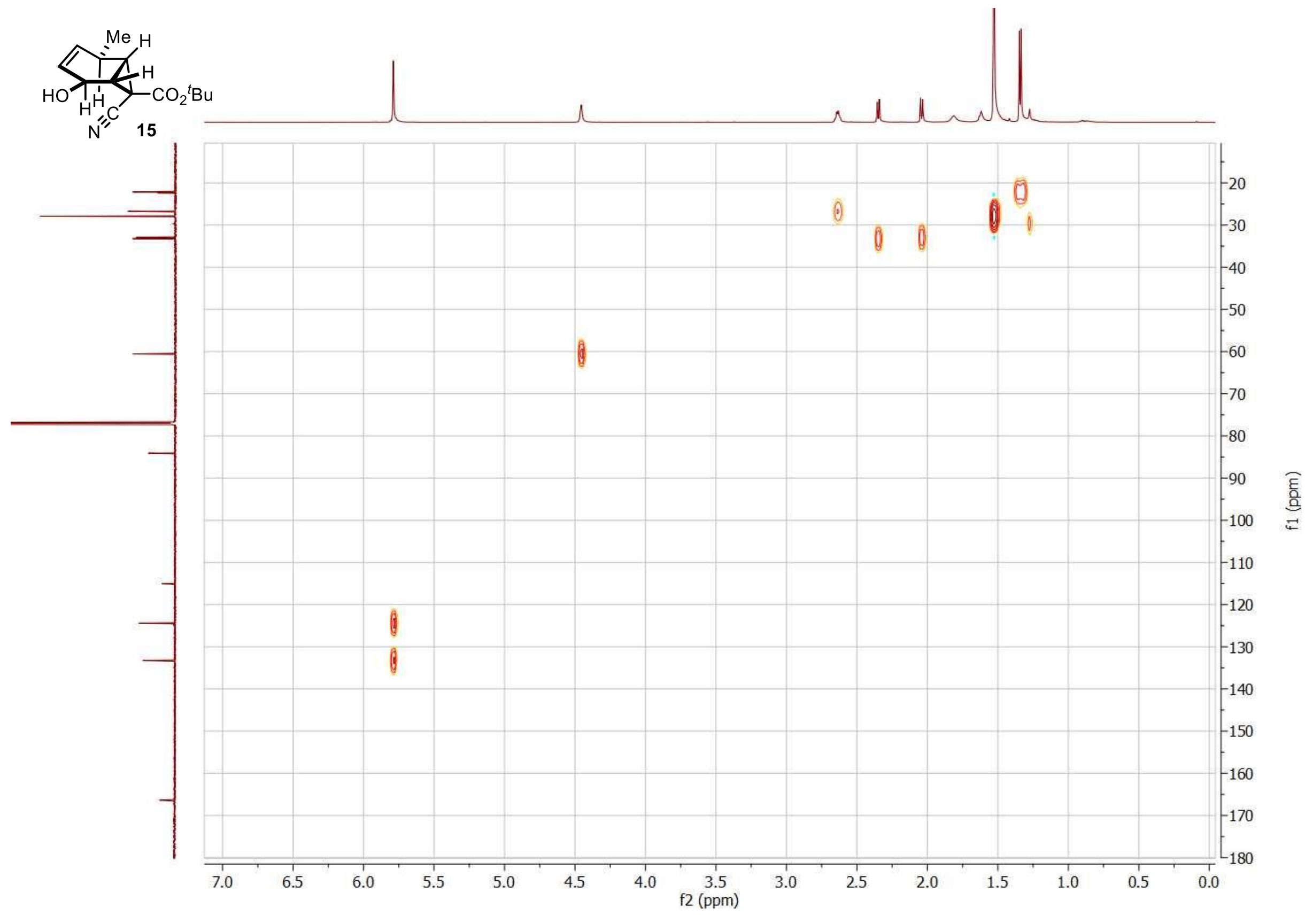


Compound $15 \bullet \mathrm{OsO}_{4}(\mathrm{TMEDA})\left({ }^{1} \mathrm{H}, 500 \mathrm{MHz}, \mathrm{CDCl}_{3}\right)$

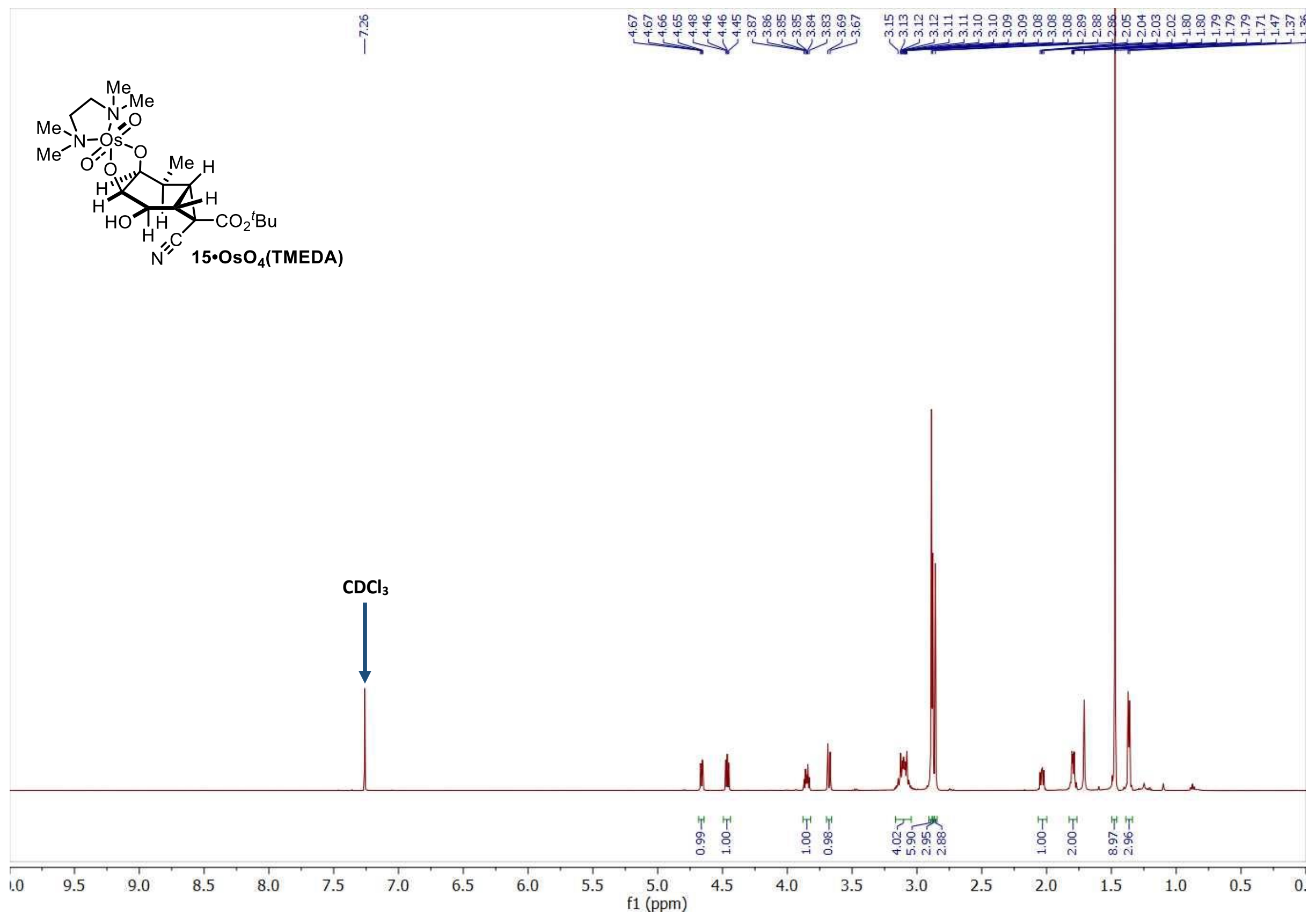


Compound $15 \bullet \mathrm{OsO}_{4}(\mathrm{TMEDA})\left({ }^{13} \mathrm{C}, 151 \mathrm{MHz}, \mathrm{CDCl}_{3}\right)$

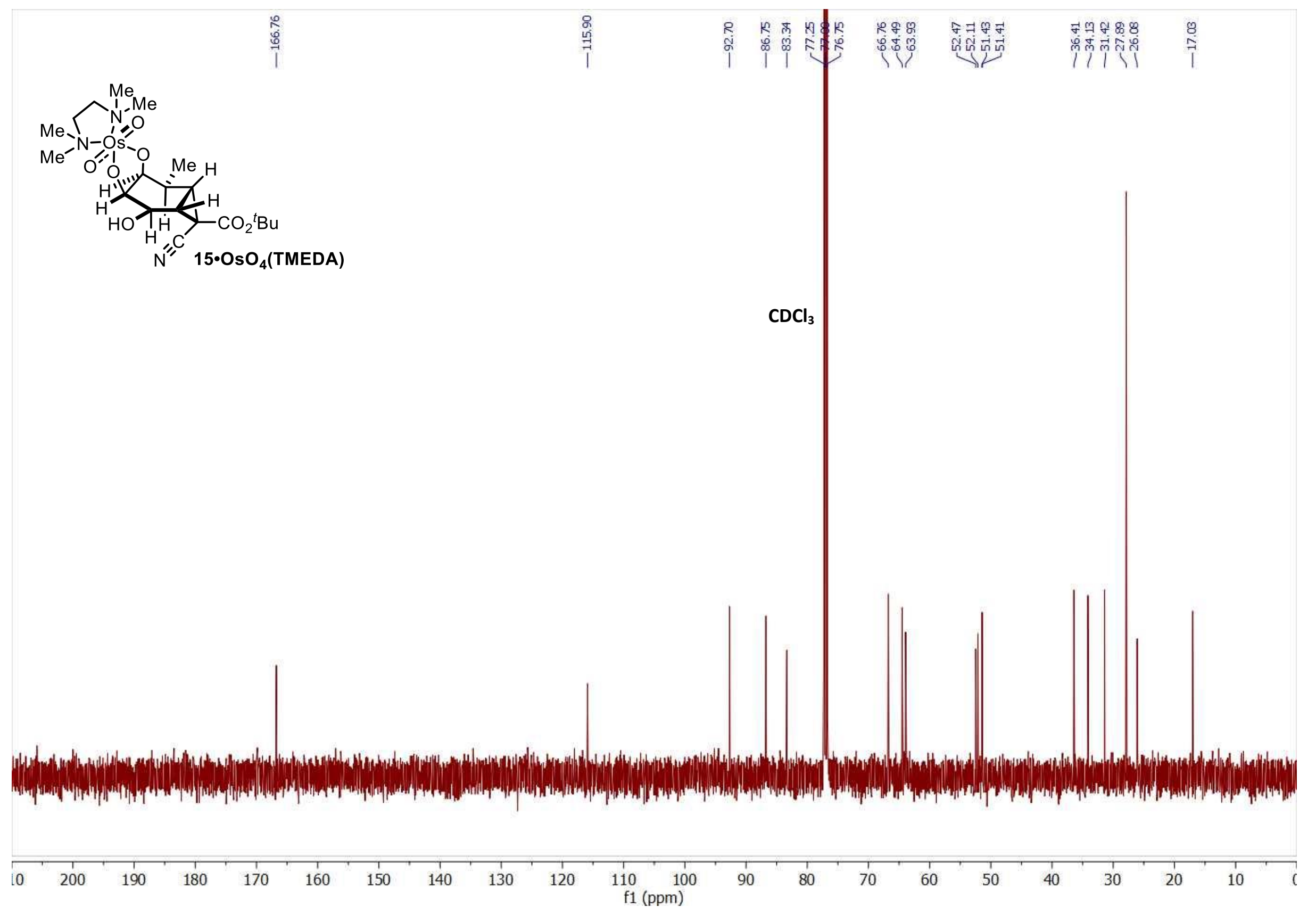


Compound $16\left({ }^{1} \mathrm{H}, 400 \mathrm{MHz}, \mathrm{d}^{7}\right.$-DMF)

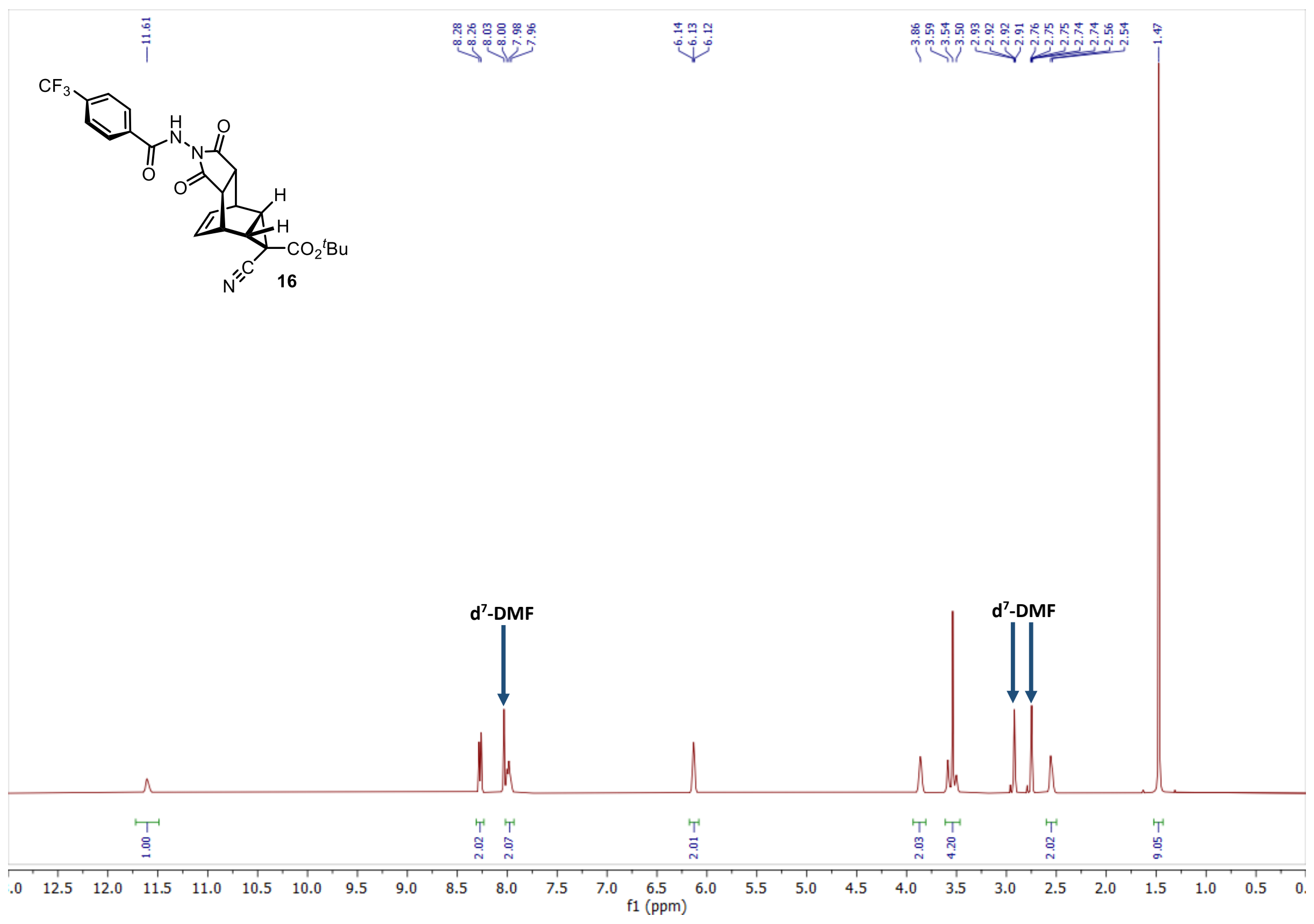


Compound $16\left({ }^{13} \mathrm{C}, 151 \mathrm{MHz}, \mathrm{d}^{7}-\mathrm{DMF}\right)$

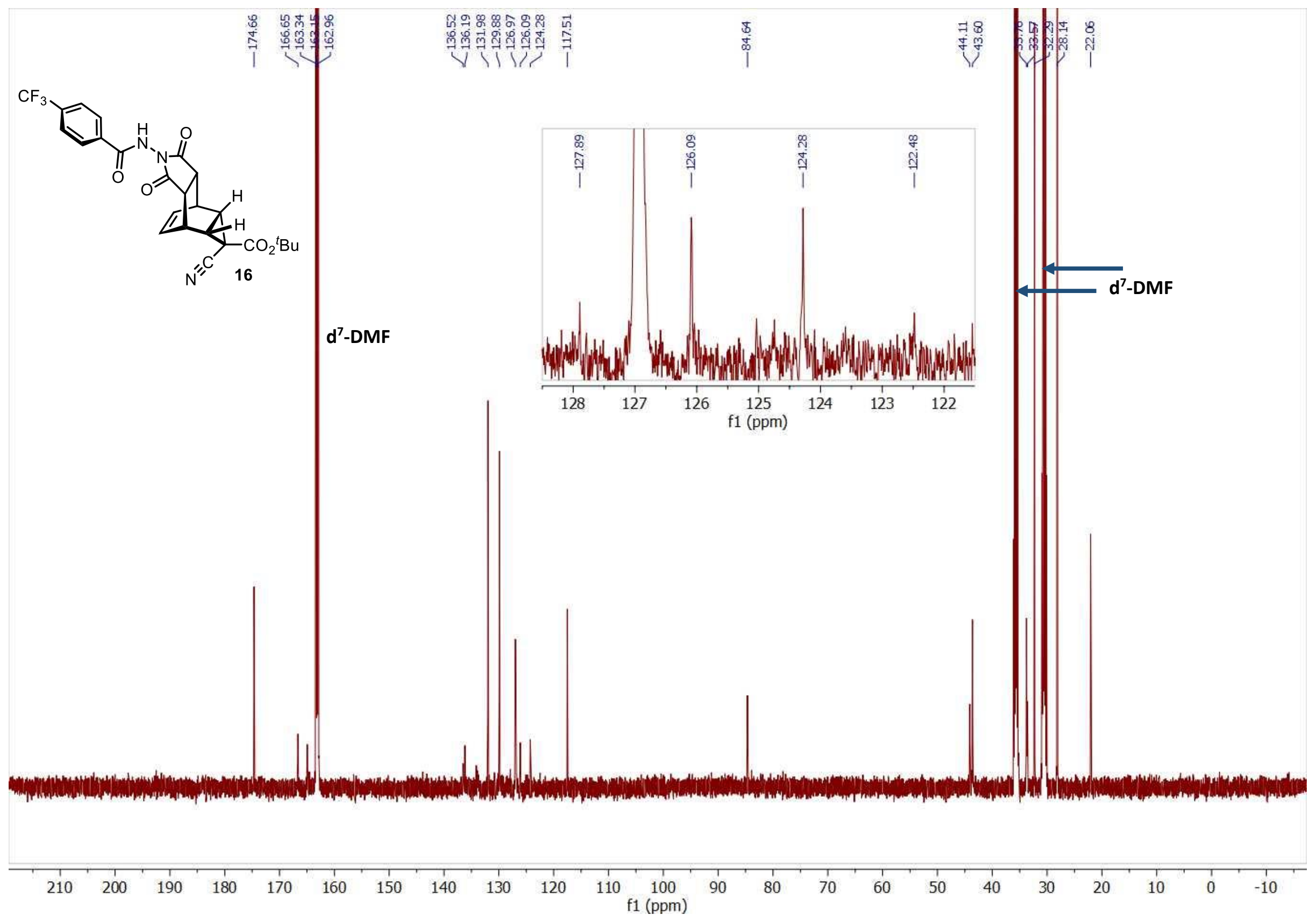


Compound $16\left({ }^{19} \mathrm{~F}, 564 \mathrm{MHz}, \mathrm{d}^{7}\right.$-DMF)

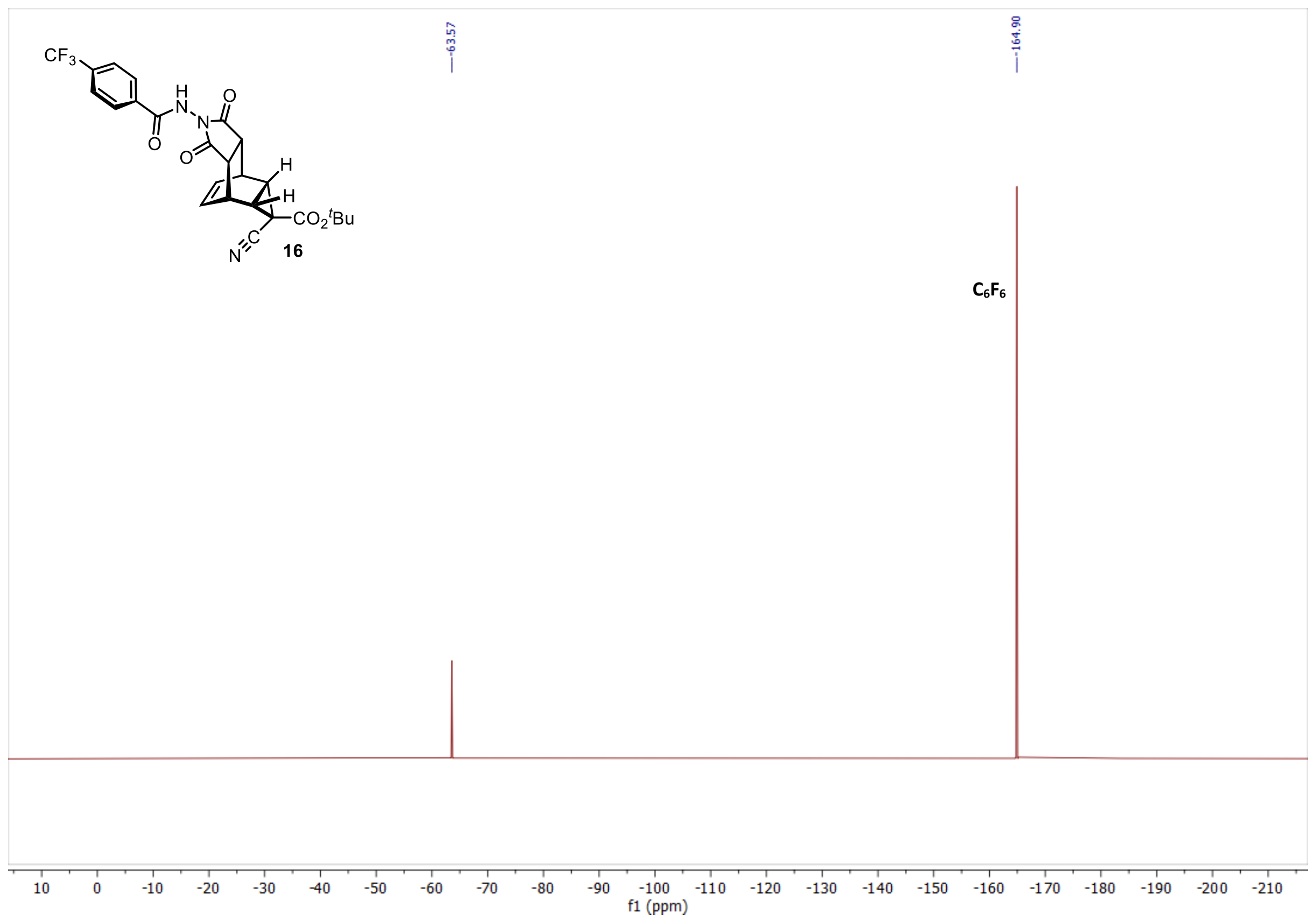




\section{HPLC Traces}

Preparation of authentic racemic standards: Racemic samples of norcaradienes $\mathbf{3 a}-\mathbf{3 l}$, $\mathbf{3 n} \mathbf{n} \mathbf{3 p}$, and $\mathbf{3 s} / \mathbf{3} \mathbf{s}^{\prime}$ were prepared according to their respective general procedures using $\mathrm{Rh}_{2}(\mathrm{esp})_{2}$ as catalyst. Racemic samples of derivatives $\mathbf{4 b}, \mathbf{4 q}, \mathbf{5}$, $6 / \mathbf{6}^{\prime}, 7 / \mathbf{7}^{\prime}, \mathbf{8}$, and $\mathbf{9}$ were prepared from the appropriate racemic norcaradiene using the procedures described above. Racemic epoxide 12 was prepared from norcaradiene $\mathbf{3 u}$ by following the $m$-CPBA/KF procedure for the preparation of compound 5.

Sample preparation: Analyte solutions were prepared using HPLC grade solvents at concentrations ranging from 0.5 $\mathrm{mg} / \mathrm{mL}$ to $1.5 \mathrm{mg} / \mathrm{mL}$. The solutions were filtered through a $13 \mathrm{~mm}$ diameter syringe filter ( $0.45 \mu \mathrm{m}$ PTFE membrane) prior to injection.

Analysis: All analyses were performed at $1 \mathrm{~mL} / \mathrm{min}$ solvent flow rate and at a column temperature of $25^{\circ} \mathrm{C}$. Injection volumes ranged from $7-20 \mu \mathrm{L}$.

\section{Compound 3a [Daicel CHIRALPAK IC; 95:5 hexanes:'PrOH]}

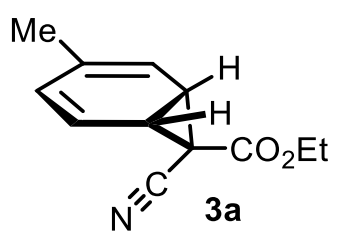

95:5 Hexanes:IPA (A:B) : 230:5:500:5: 1

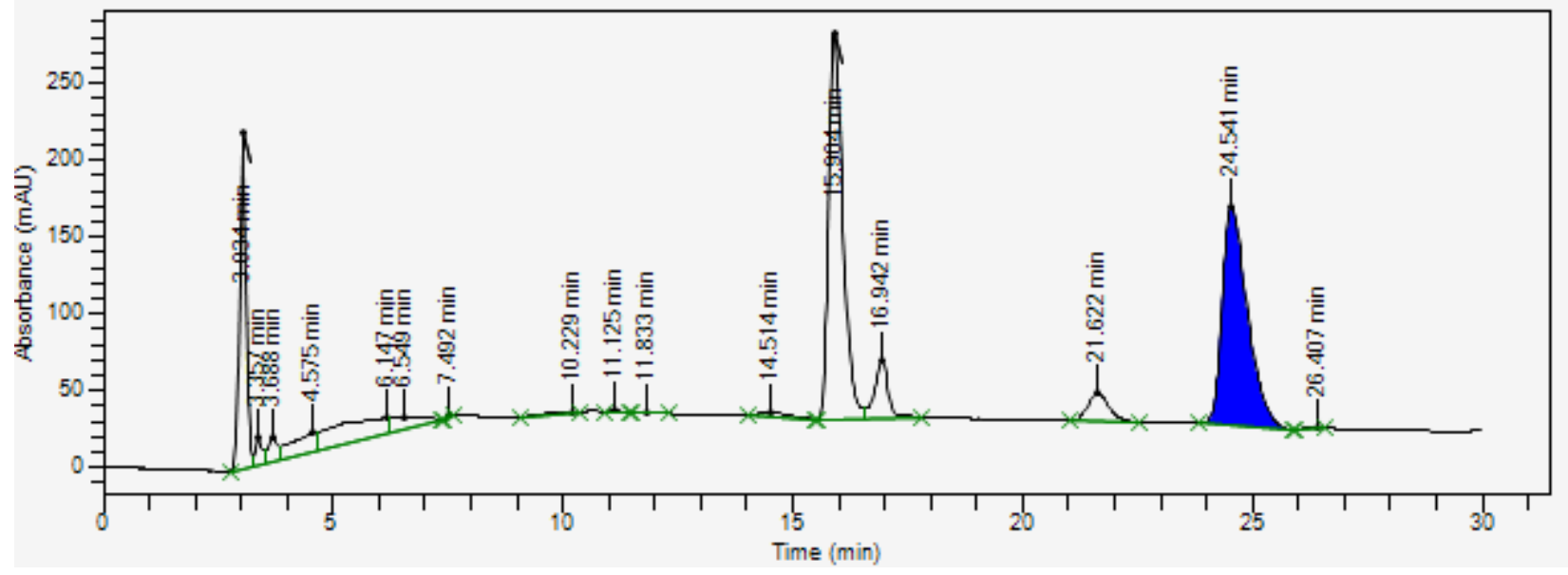

\begin{tabular}{lll}
\hline \hline $\begin{array}{l}\text { Retention Time } \\
(\mathrm{min})\end{array}$ & $\begin{array}{l}\text { Area } \\
(\mathrm{mAU} \bullet \min )\end{array}$ & Area \% \\
\hline \hline 15.904 & 5417384.614 & 49.7 \\
24.541 & 5472392.368 & 50.3
\end{tabular}


95:5 Hexanes:IPA (A:B) : 230:5:500:5: 1

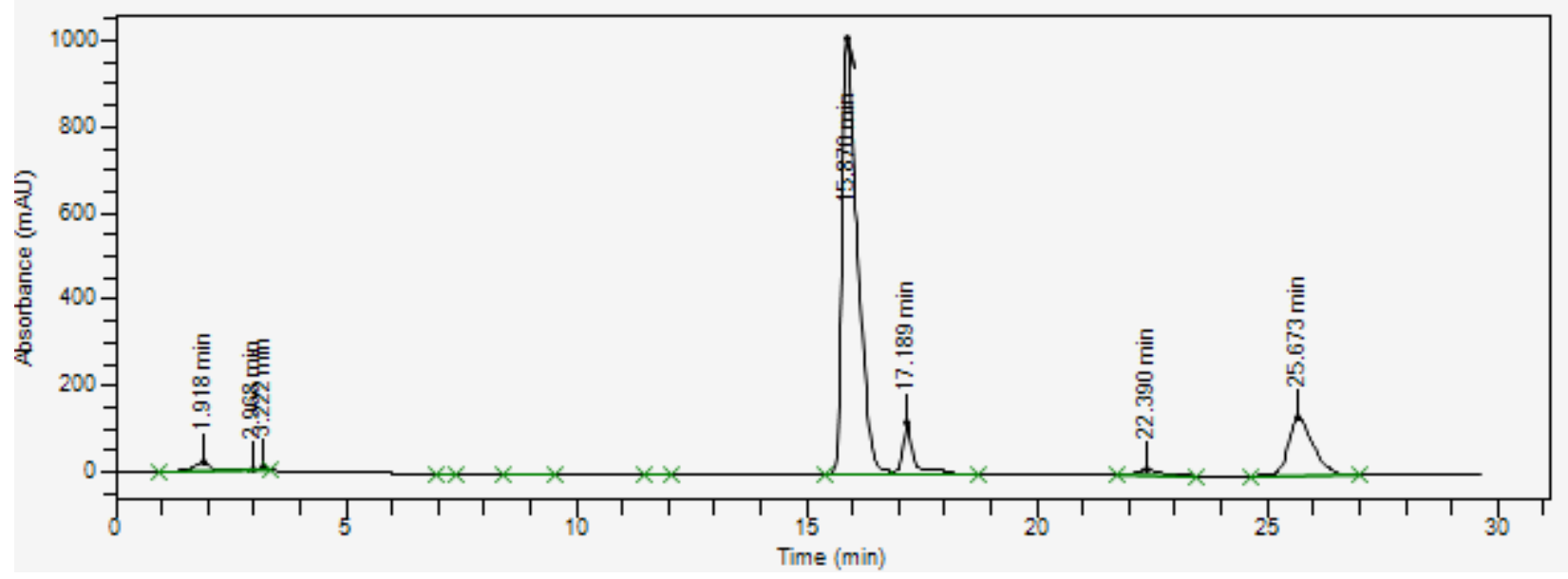

\begin{tabular}{lll}
\hline \hline $\begin{array}{l}\text { Retention Time } \\
(\mathrm{min})\end{array}$ & $\begin{array}{l}\text { Area } \\
(\mathrm{mAU} \bullet \mathrm{min})\end{array}$ & Area \% \\
\hline \hline 15.870 & 23856181.12 & 82.6 \\
25.673 & 5025219.046 & 17.4
\end{tabular}




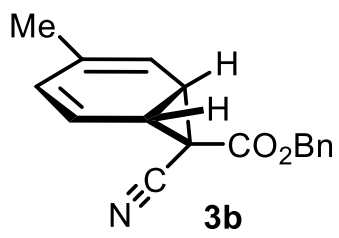

95:5 Hexanes:IPA (A:B) : 210:5:395:5: 1

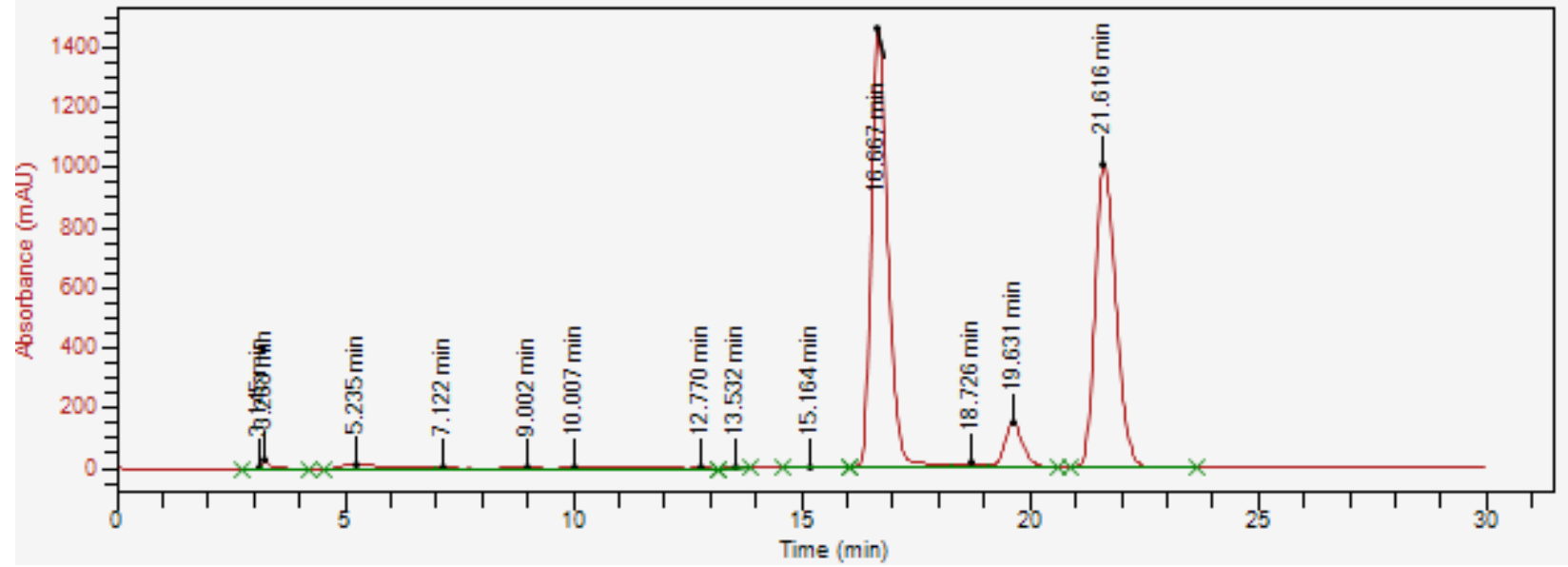

\begin{tabular}{lll}
\hline \hline $\begin{array}{l}\text { Retention Time } \\
(\mathrm{min})\end{array}$ & $\begin{array}{l}\text { Area } \\
(\mathrm{mAU} \bullet \mathrm{min})\end{array}$ & Area \% \\
\hline \hline 16.672 & 8256263.05 & 53.9 \\
21.615 & 7043936.894 & 46.1
\end{tabular}

95:5 Hexanes:IPA (A:B) : 230:5:500:5: 1

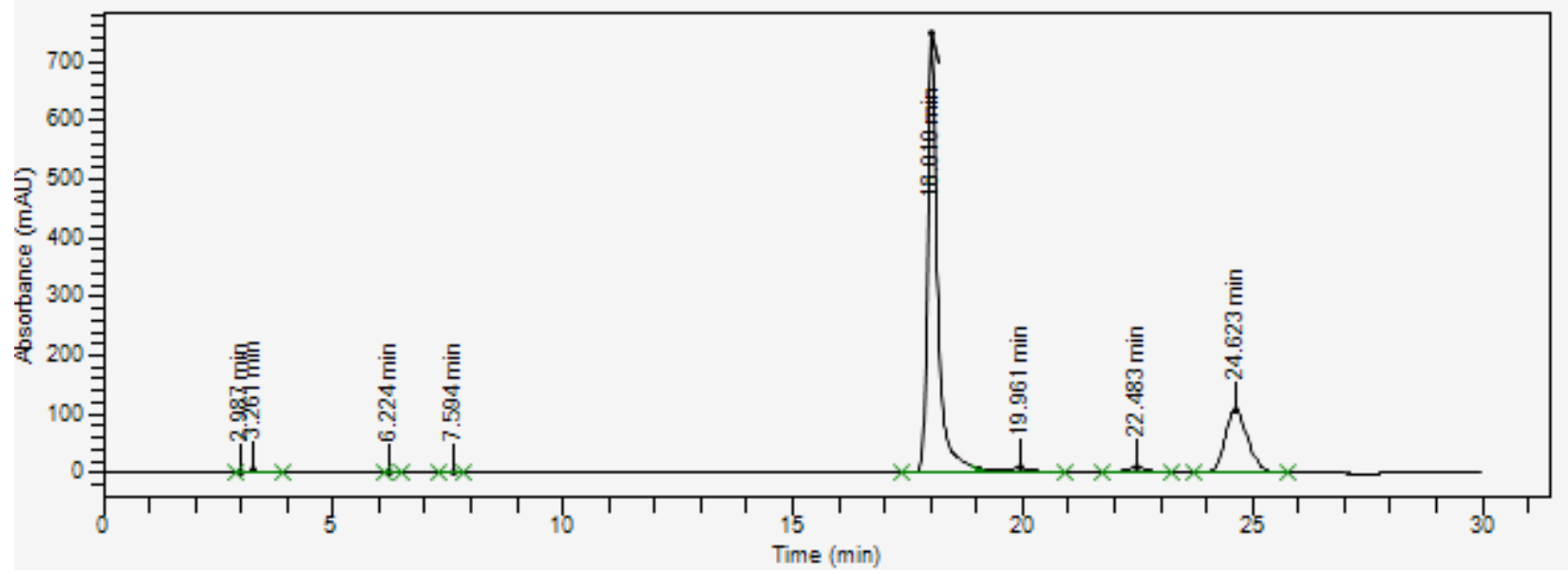

\begin{tabular}{lll}
\hline \hline $\begin{array}{l}\text { Retention Time } \\
(\mathrm{min})\end{array}$ & $\begin{array}{l}\text { Area } \\
(\mathrm{mAU} \bullet \mathrm{min})\end{array}$ & Area \% \\
\hline \hline 18.010 & 11687768.4 & 24.3 \\
24.623 & 3742685.82 & 75.7
\end{tabular}




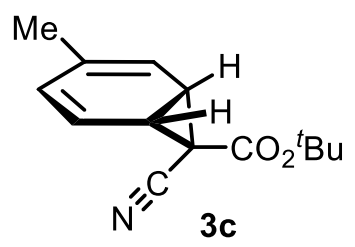

95:5 Hexanes:IPA (A:B) : 230:5:500:5 : 1

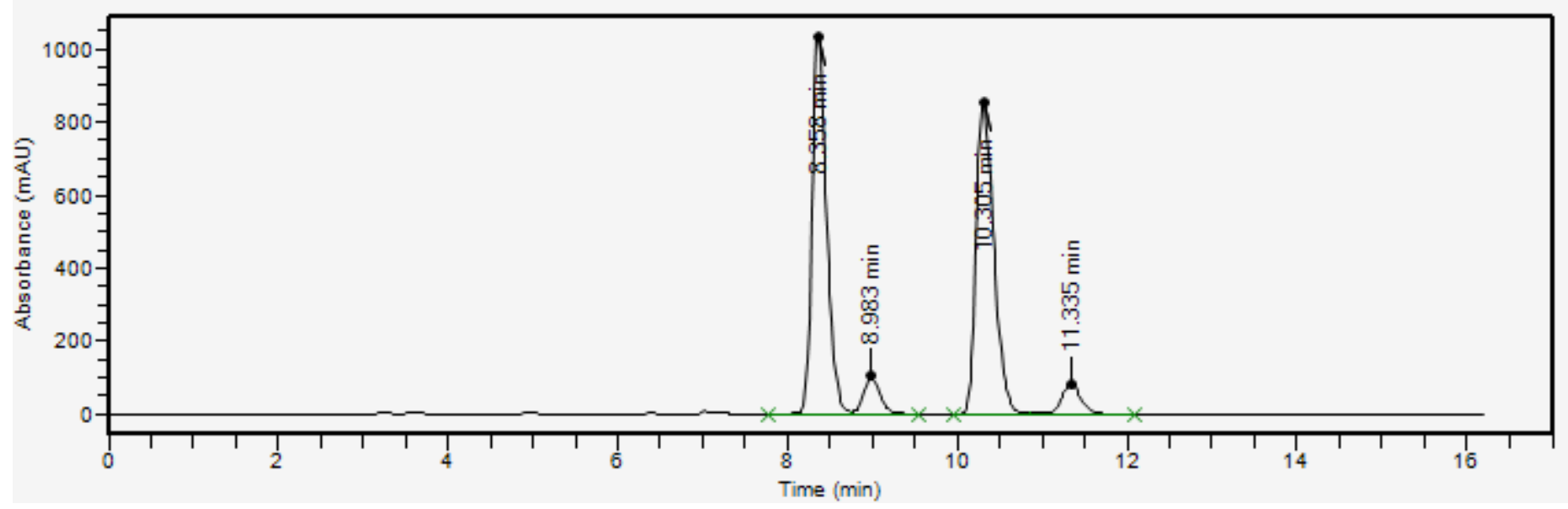

\begin{tabular}{lll}
\hline \hline $\begin{array}{l}\text { Retention Time } \\
(\mathrm{min})\end{array}$ & $\begin{array}{l}\text { Area } \\
(\mathrm{mAU} \bullet \mathrm{min})\end{array}$ & Area \% \\
\hline \hline 8.358 & 12515801.42 & 50.0 \\
10.305 & 12478880.6 & $50.0 \%$
\end{tabular}

TRIAL4 : 230:5:500:5 : 1

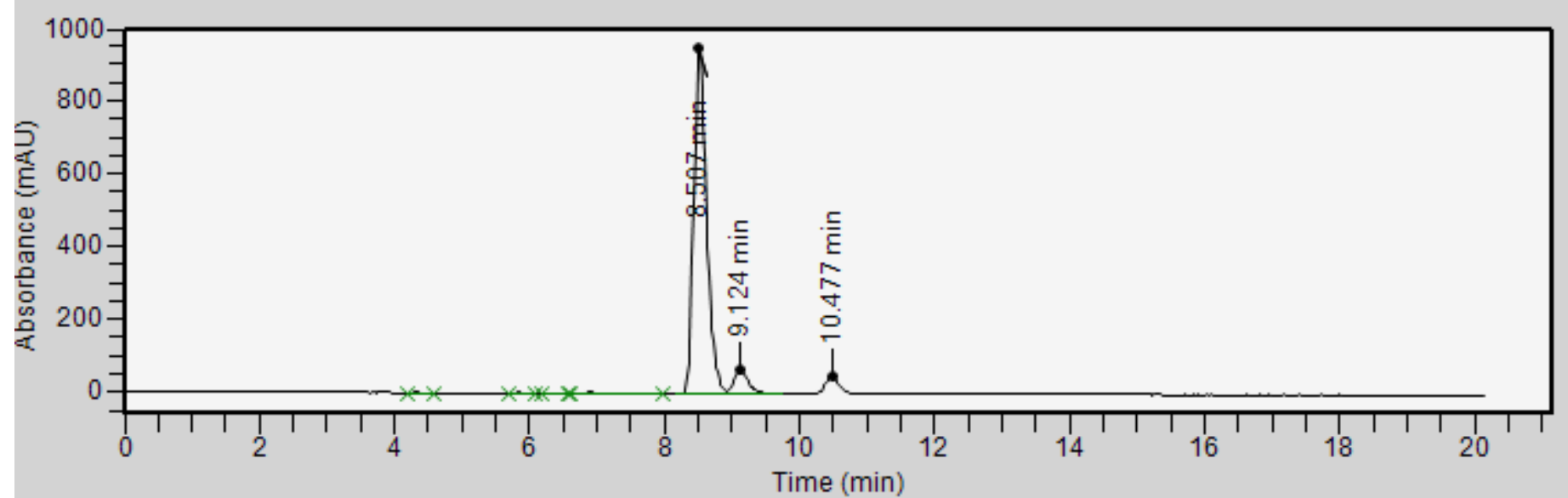

\begin{tabular}{lll}
\hline \hline $\begin{array}{l}\text { Retention Time } \\
(\mathrm{min})\end{array}$ & $\begin{array}{l}\text { Area } \\
(\mathrm{mAU} \bullet \min )\end{array}$ & Area \% \\
\hline \hline 8.507 & 12014102.21 & 94.3 \\
10.477 & 722012.9169 & 5.7
\end{tabular}




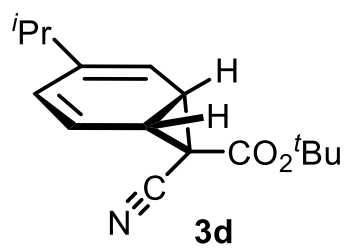

95:5 Hexanes:IPA (A:B) : 210:5:395:5 : 1

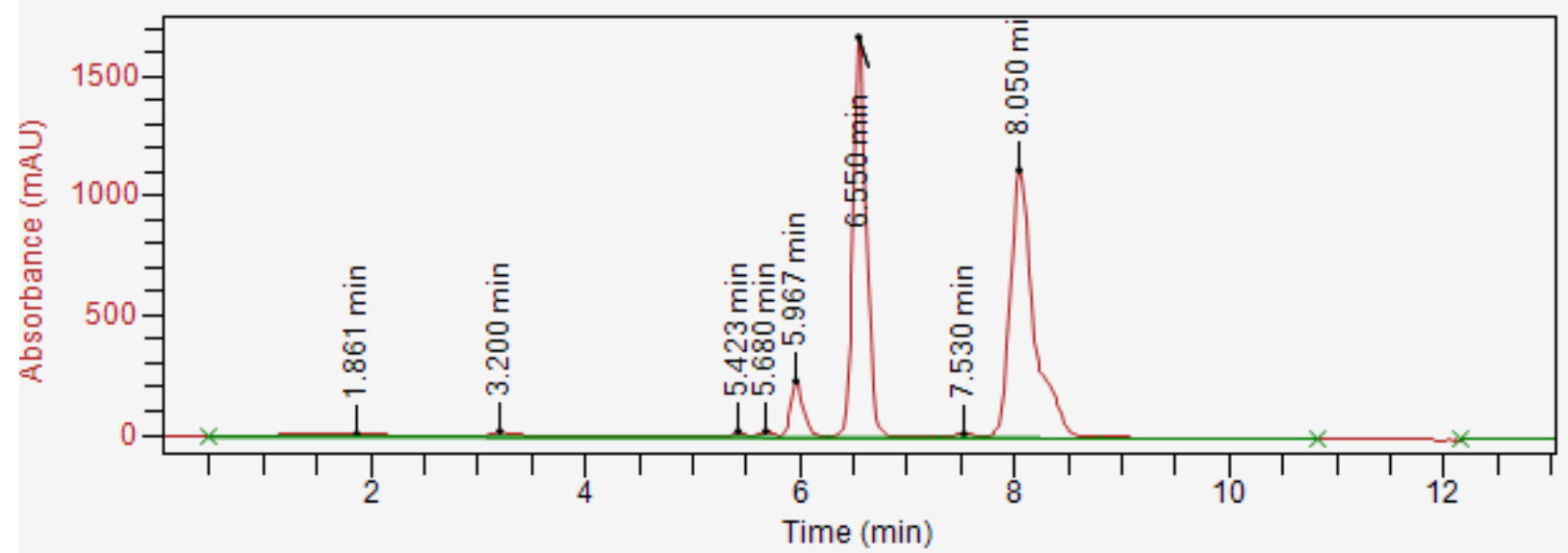

\begin{tabular}{lll}
\hline \hline $\begin{array}{l}\text { Retention Time } \\
(\mathrm{min})\end{array}$ & $\begin{array}{l}\text { Area } \\
(\mathrm{mAU} \bullet \min )\end{array}$ & Area \% \\
\hline \hline 6.551 & 3815773.927 & 55.6 \\
8.045 & 4792691.057 & 44.4
\end{tabular}

95:5 Hexanes:IPA (A:B) : 230:5:500:5: 1

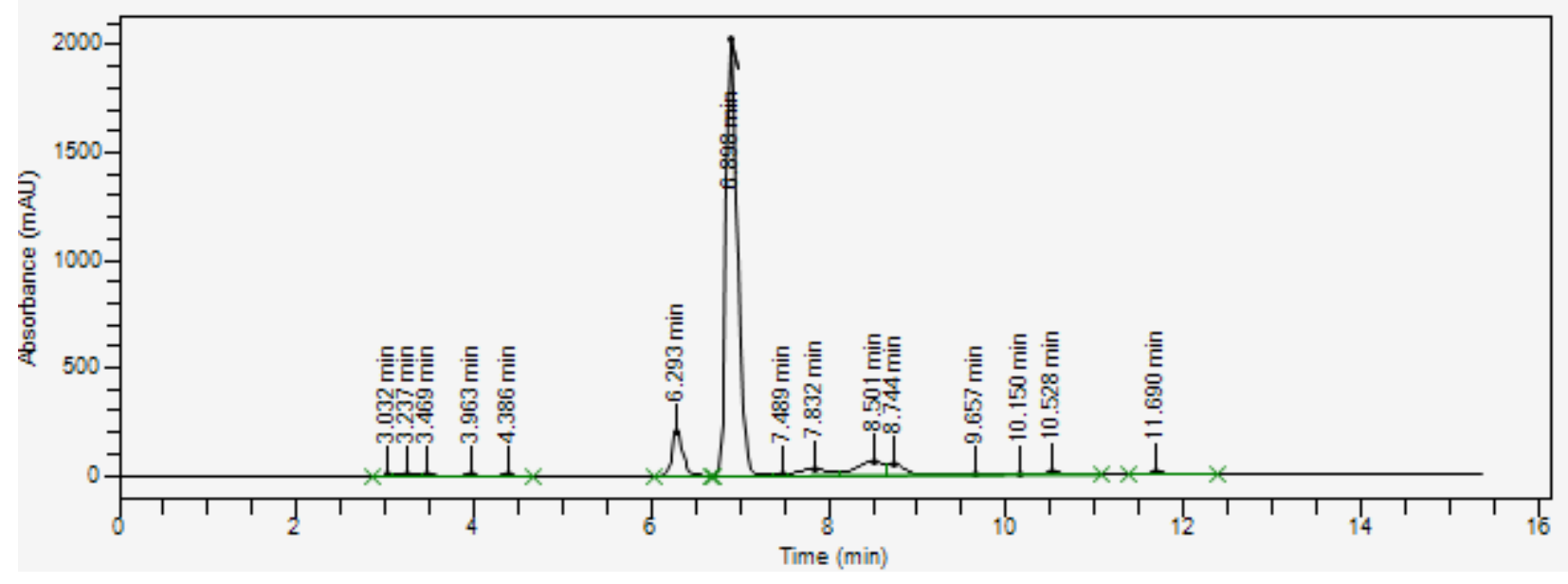

\begin{tabular}{lll}
\hline \hline $\begin{array}{l}\text { Retention Time } \\
(\mathrm{min})\end{array}$ & $\begin{array}{l}\text { Area } \\
(\mathrm{mAU} \bullet \min )\end{array}$ & Area \% \\
\hline \hline 6.898 & 19182919.78 & 89.9 \\
8.501 & 2143831.3 & 10.1
\end{tabular}




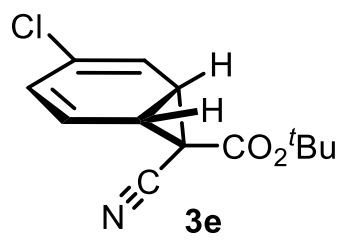

\section{Batch: TDCA_CLBENZ_RAC_2}

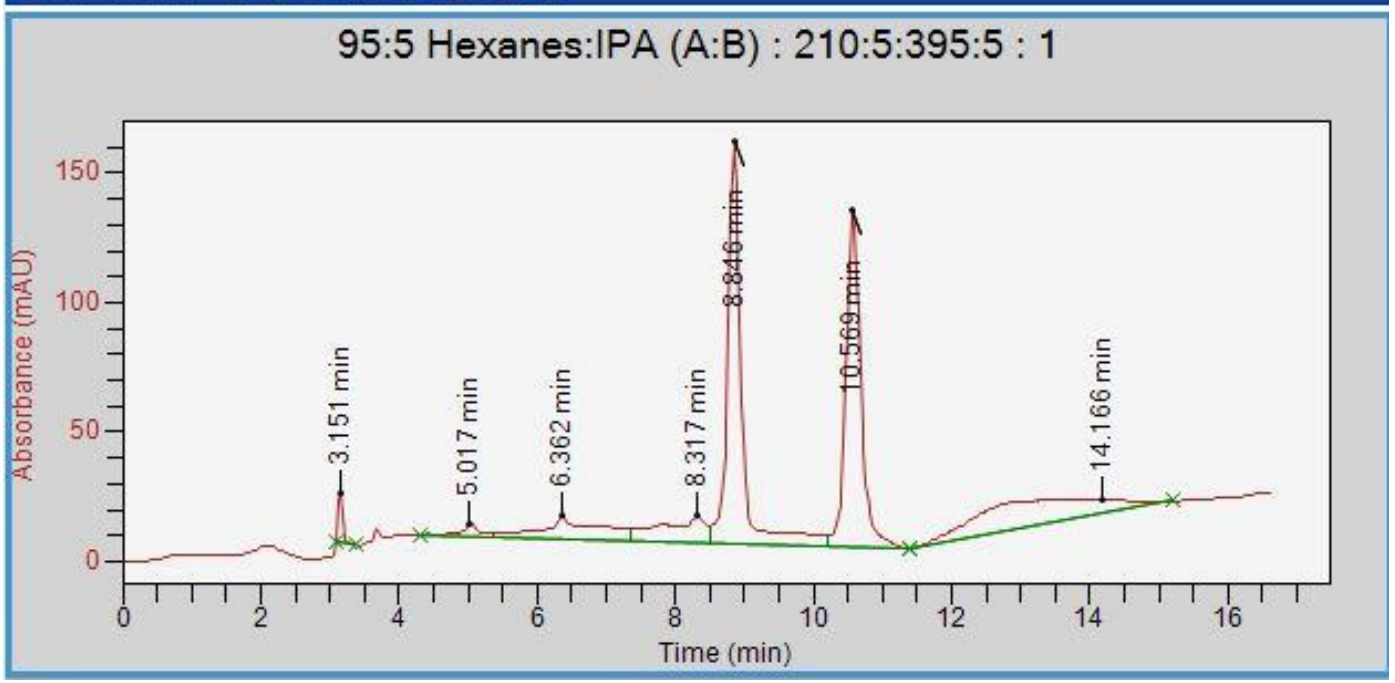

\begin{tabular}{lll}
\hline \hline $\begin{array}{l}\text { Retention Time } \\
(\mathrm{min})\end{array}$ & $\begin{array}{l}\text { Area } \\
(\mathrm{mAU} \bullet \min )\end{array}$ & Area \% \\
\hline \hline 8.846 & 2226919.31 & 52.6 \\
10.569 & 2001598.82 & 47.4
\end{tabular}

\section{Batch: CLP-BUC2-Chloro asym 2'-Diluted FURTHER}

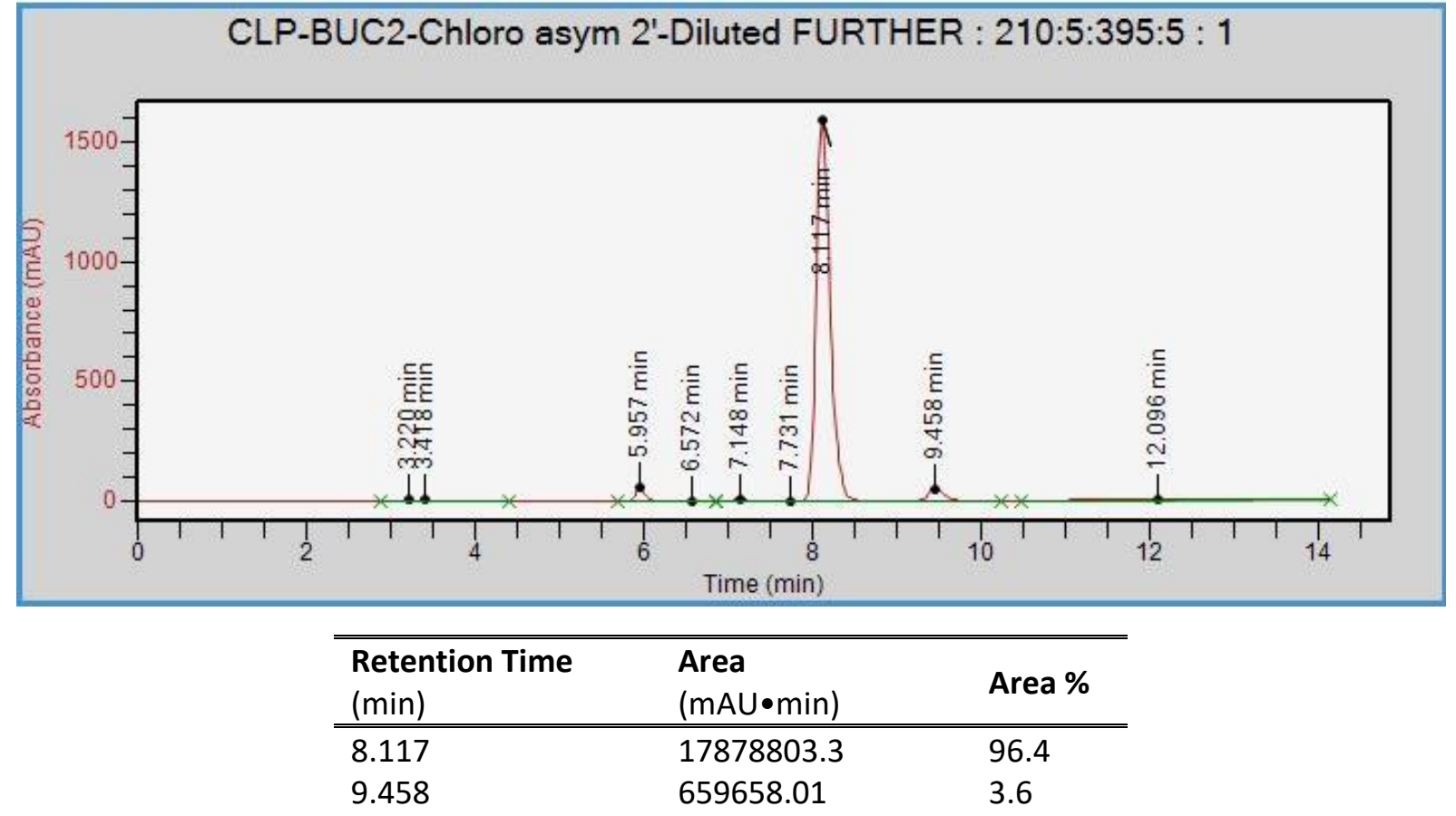




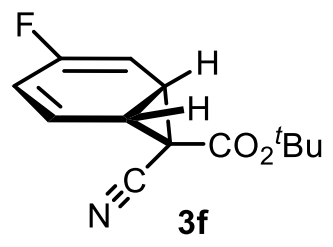

\section{Batch: CLP-BUC2-Fluoro RAC}

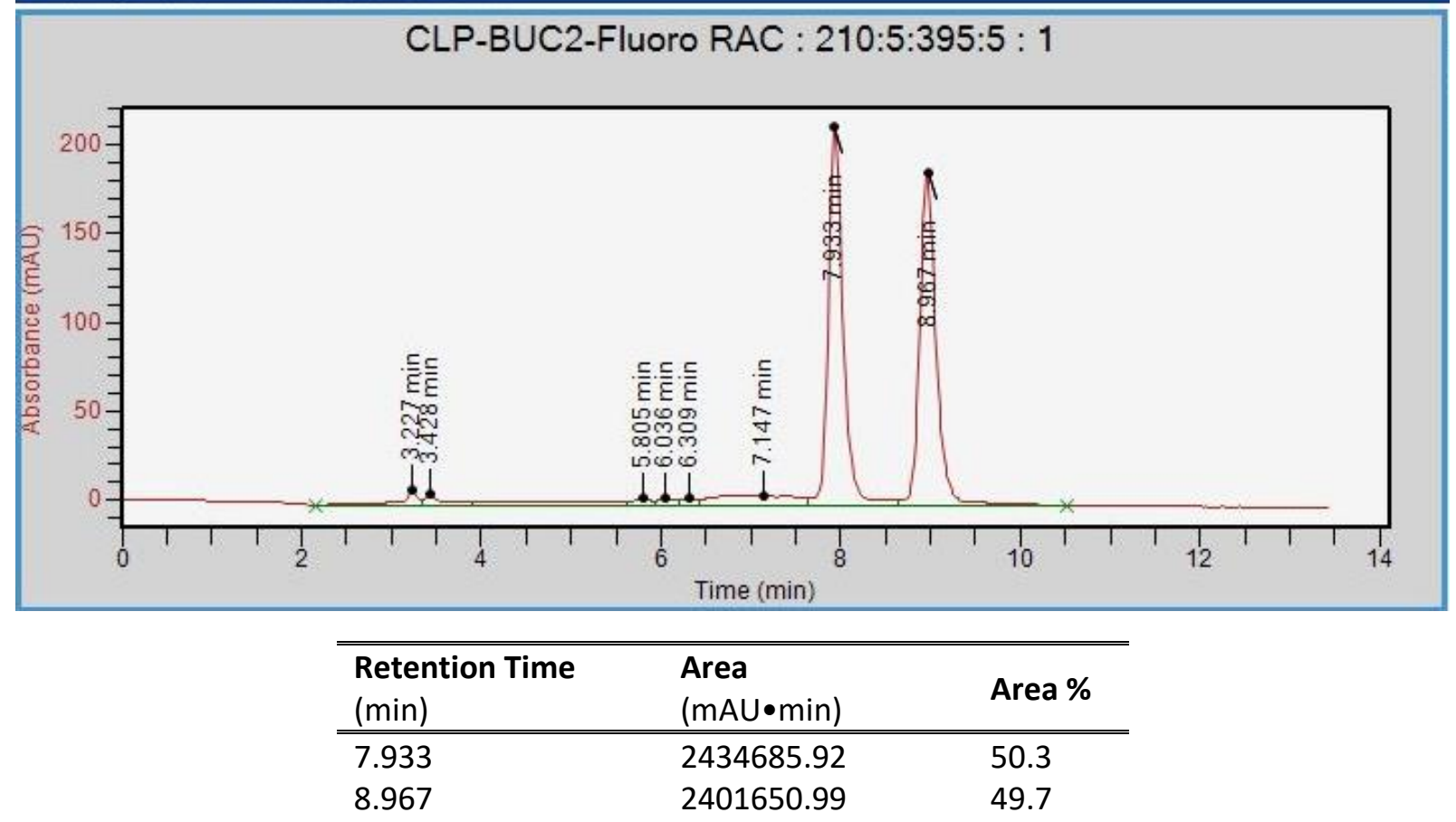

\section{Batch: CLP-BUC2-Fluoro Asym 1}

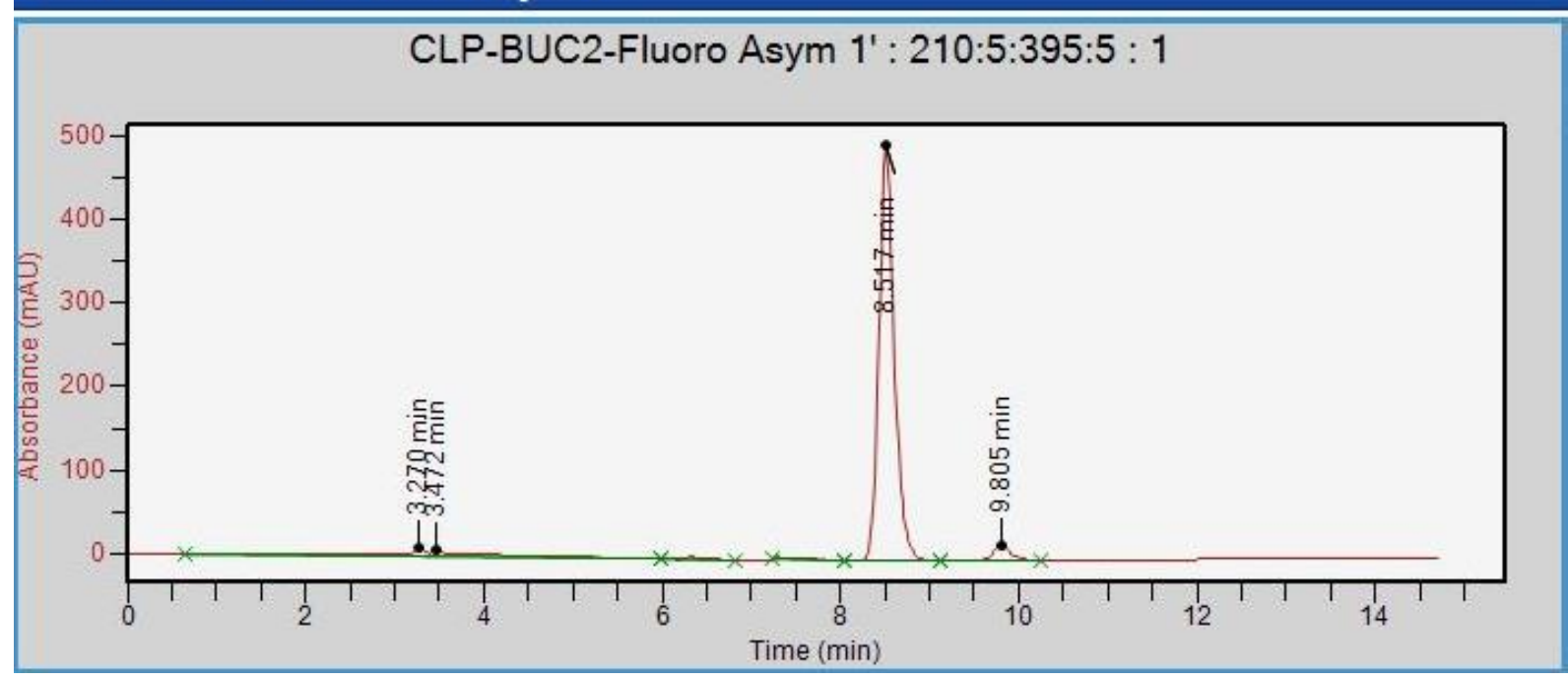

\begin{tabular}{lll}
\hline \hline $\begin{array}{l}\text { Retention Time } \\
(\mathrm{min})\end{array}$ & $\begin{array}{l}\text { Area } \\
(\mathrm{mAU} \bullet \min )\end{array}$ & Area \% \\
\hline 8.517 & 5991463.59 & 96.4 \\
9.805 & 225302.69 & 3.6
\end{tabular}




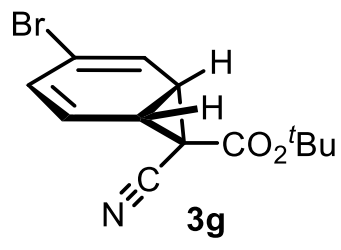

\section{Batch: CLP-BUC2-Bromo RAC}

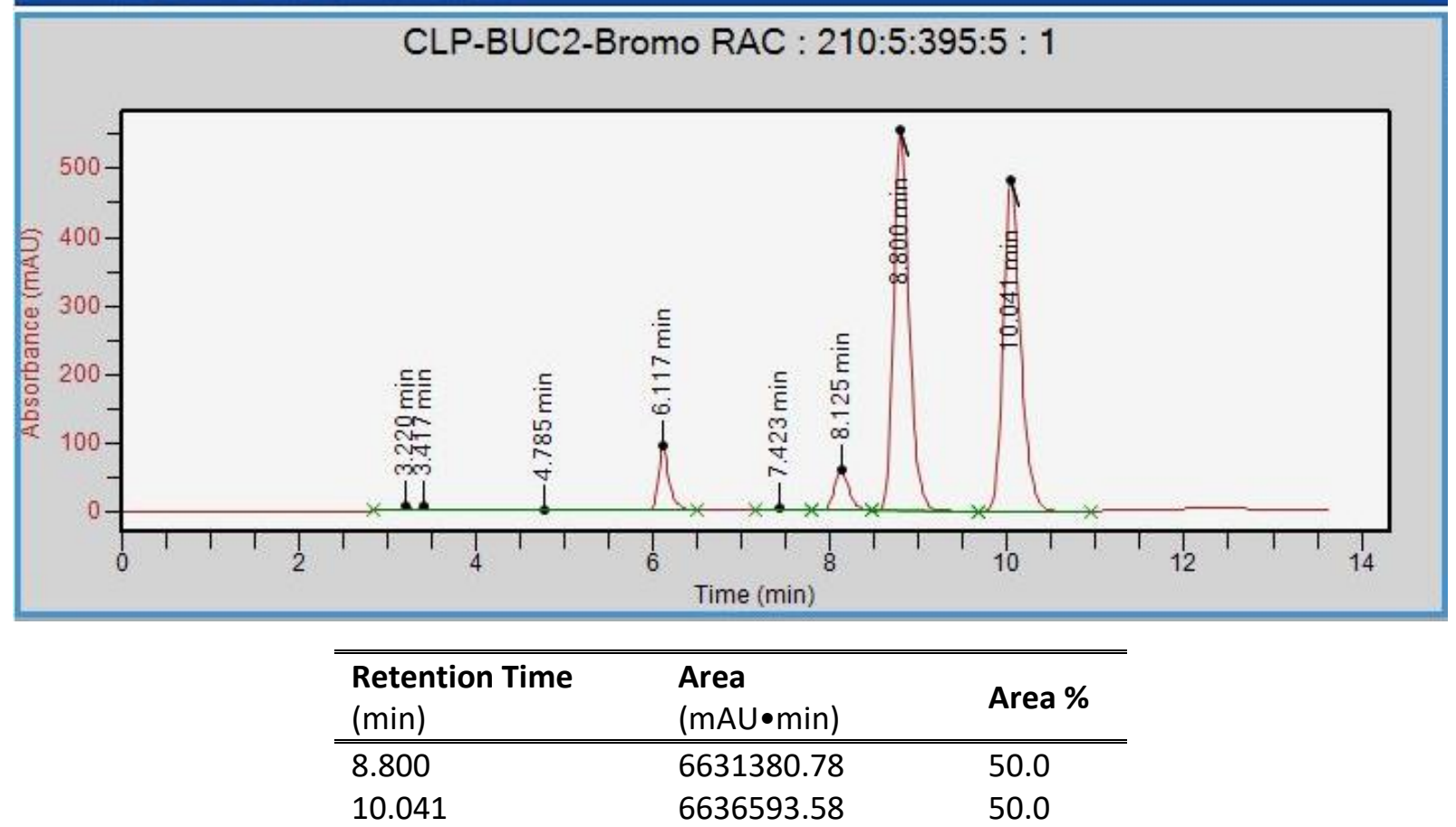

\section{Batch: CLP-BUC2-Bromo Asym 1}

CLP-BUC2-Bromo Asym $1: 210: 5: 395: 5: 1$

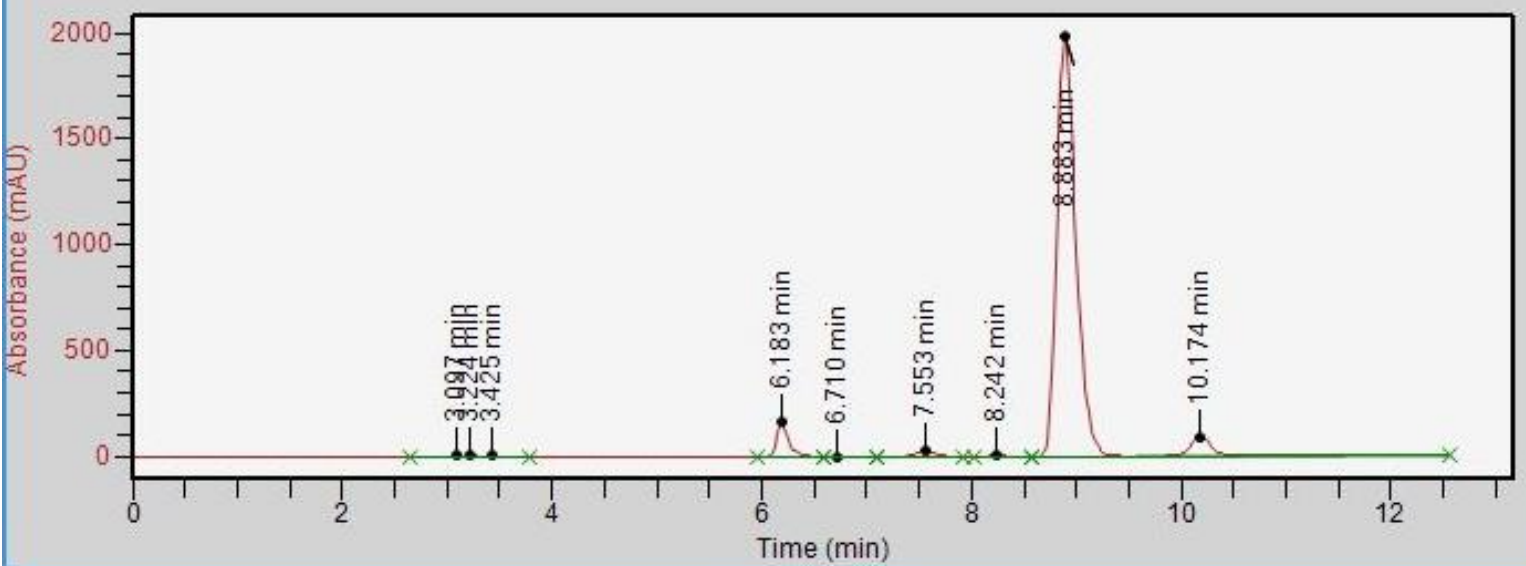

\begin{tabular}{lll}
\hline $\begin{array}{l}\text { Retention Time } \\
(\mathrm{min})\end{array}$ & $\begin{array}{l}\text { Area } \\
(\mathrm{mAU} \bullet \min )\end{array}$ & Area \% \\
\hline \hline 8.883 & 25293391.39 & 94.5 \\
10.174 & 1462677.80 & 5.5
\end{tabular}




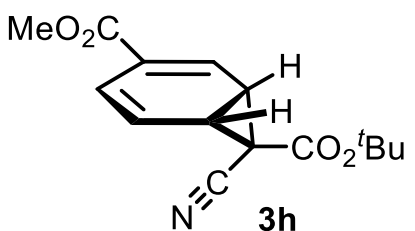

\section{Batch: CLP-BUC2-090B-60 min}

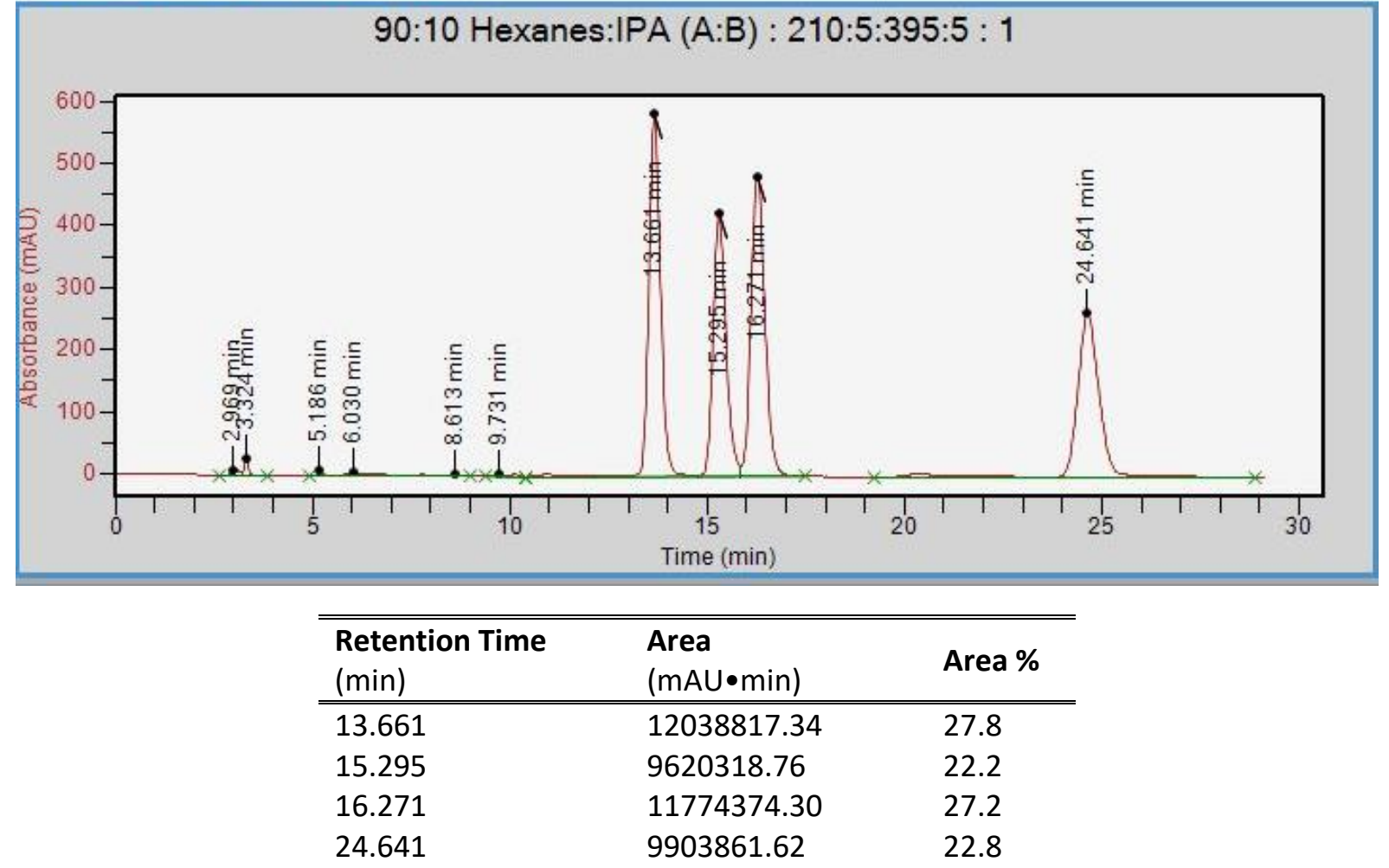

\section{Batch: CLP-BUC2-212X}

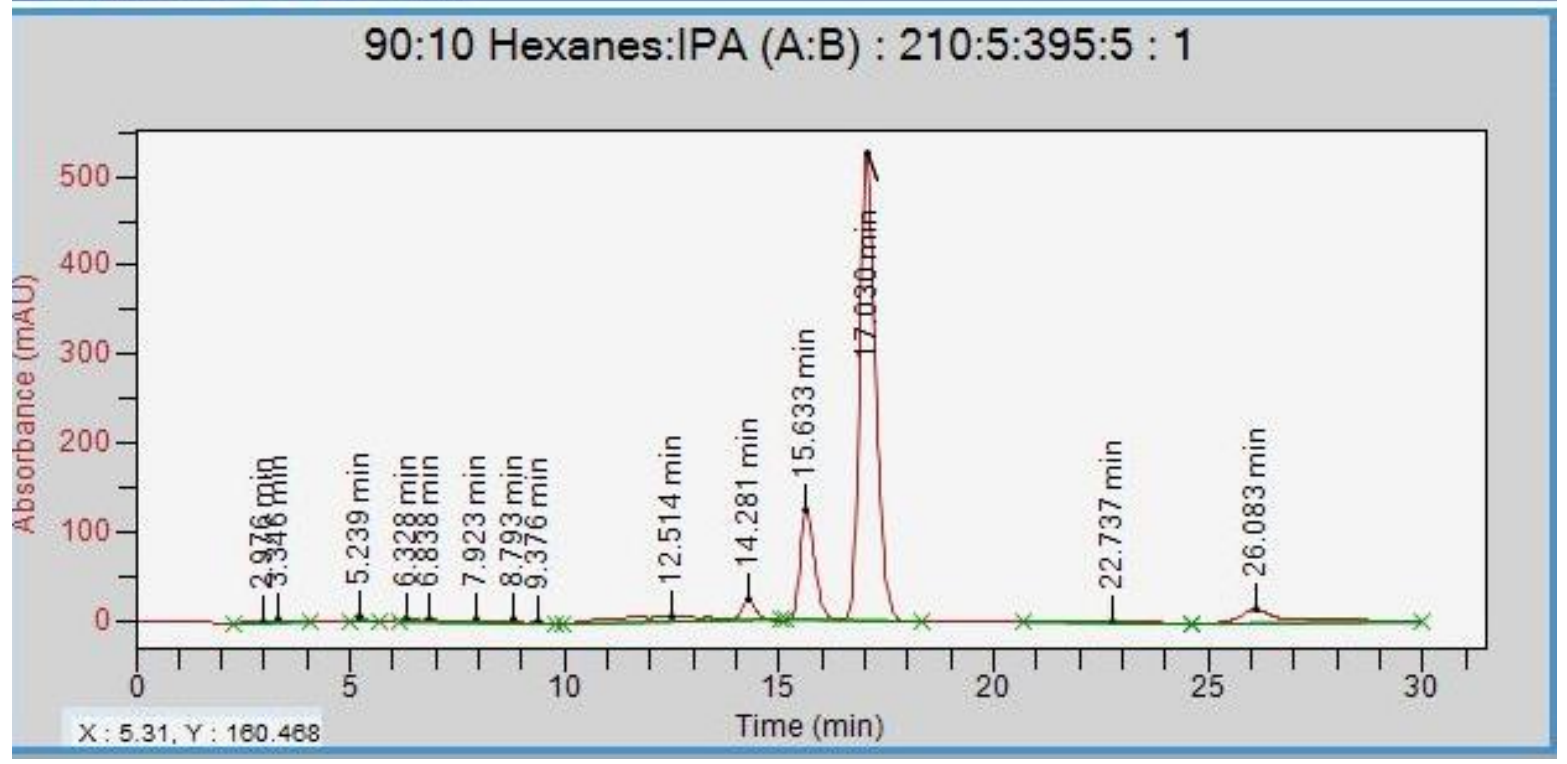




\begin{tabular}{lll}
\hline \hline $\begin{array}{l}\text { Retention Time } \\
(\mathrm{min})\end{array}$ & $\begin{array}{l}\text { Area } \\
(\mathrm{mAU} \bullet \min )\end{array}$ & Area \% \\
\hline \hline 14.281 & 528728.63 & 3.0 \\
15.633 & 2955781.49 & 16.2 \\
17.030 & 13637831.06 & 74.8 \\
26.083 & 1106103.64 & 6.0
\end{tabular}




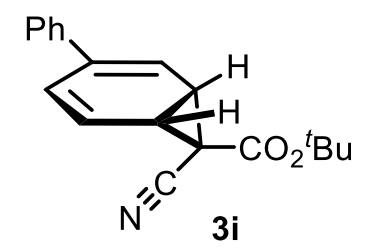

BUCH_SHORTRUN_COL3_95_5 : 230:5:500:5 : 1

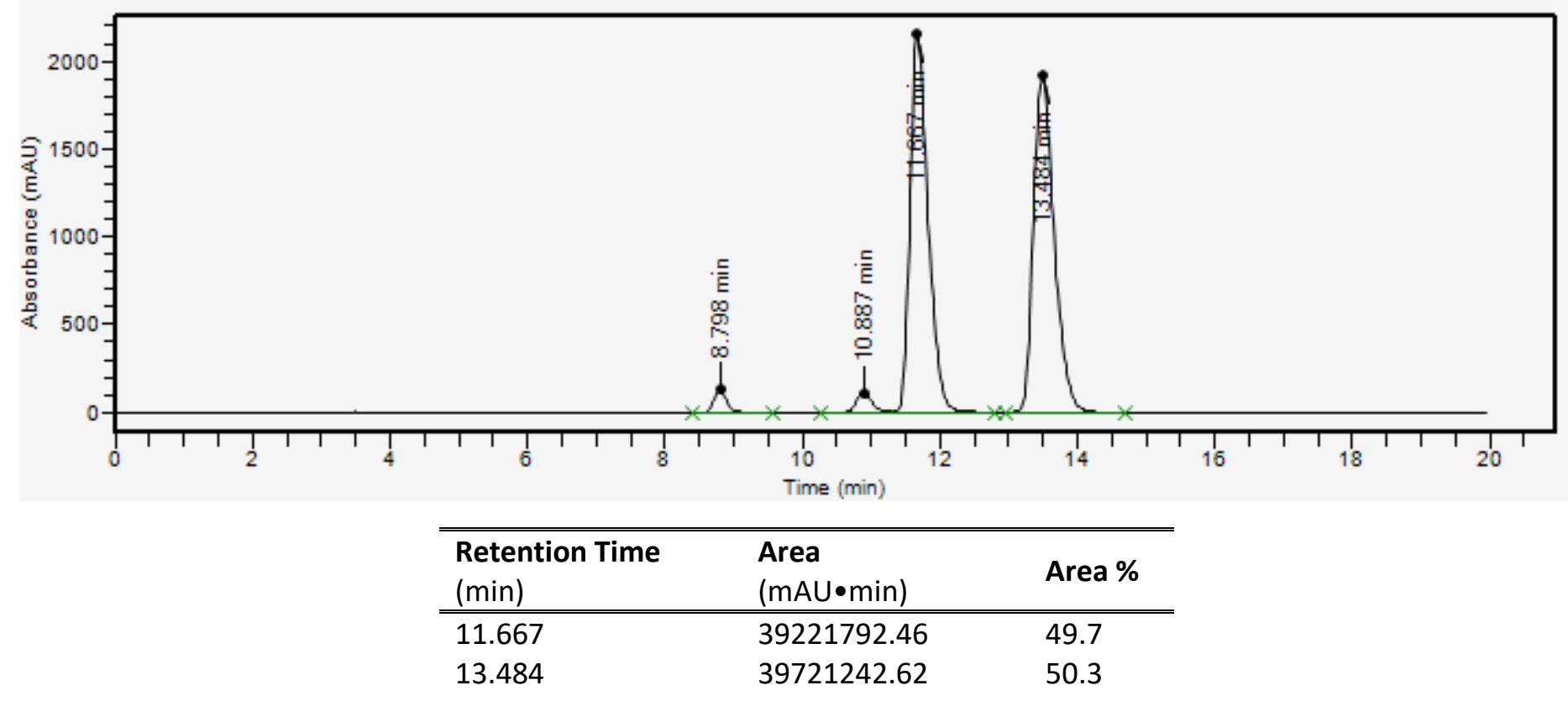

TRIAL $1: 230: 5: 500: 5: 1$

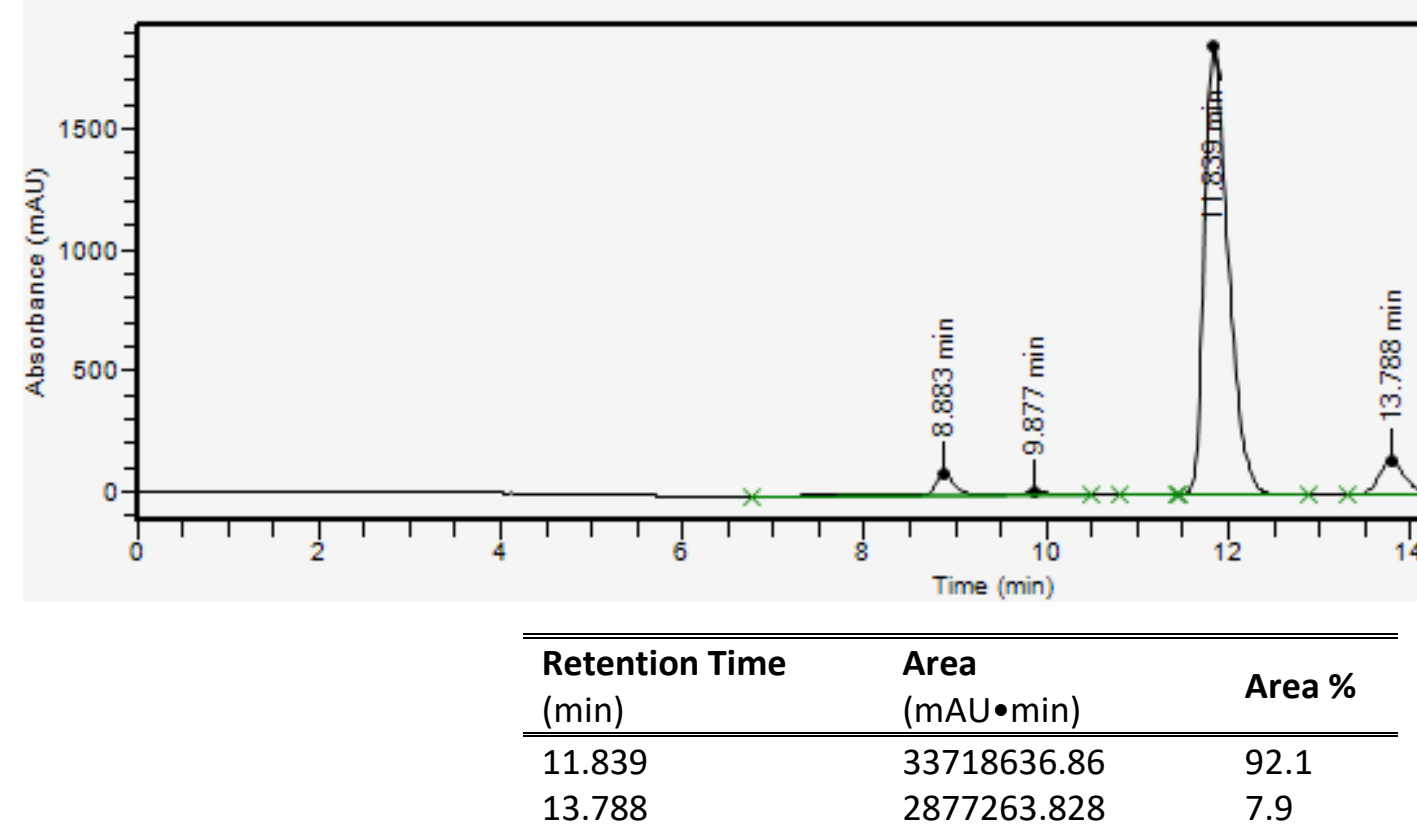




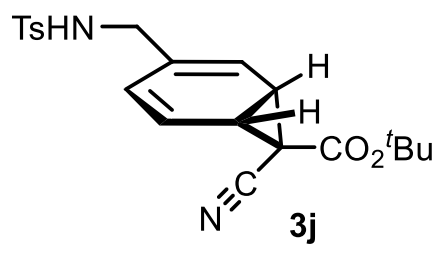

80:20 Hexanes:IPA (A:B) : 230:5:500:5 : 1
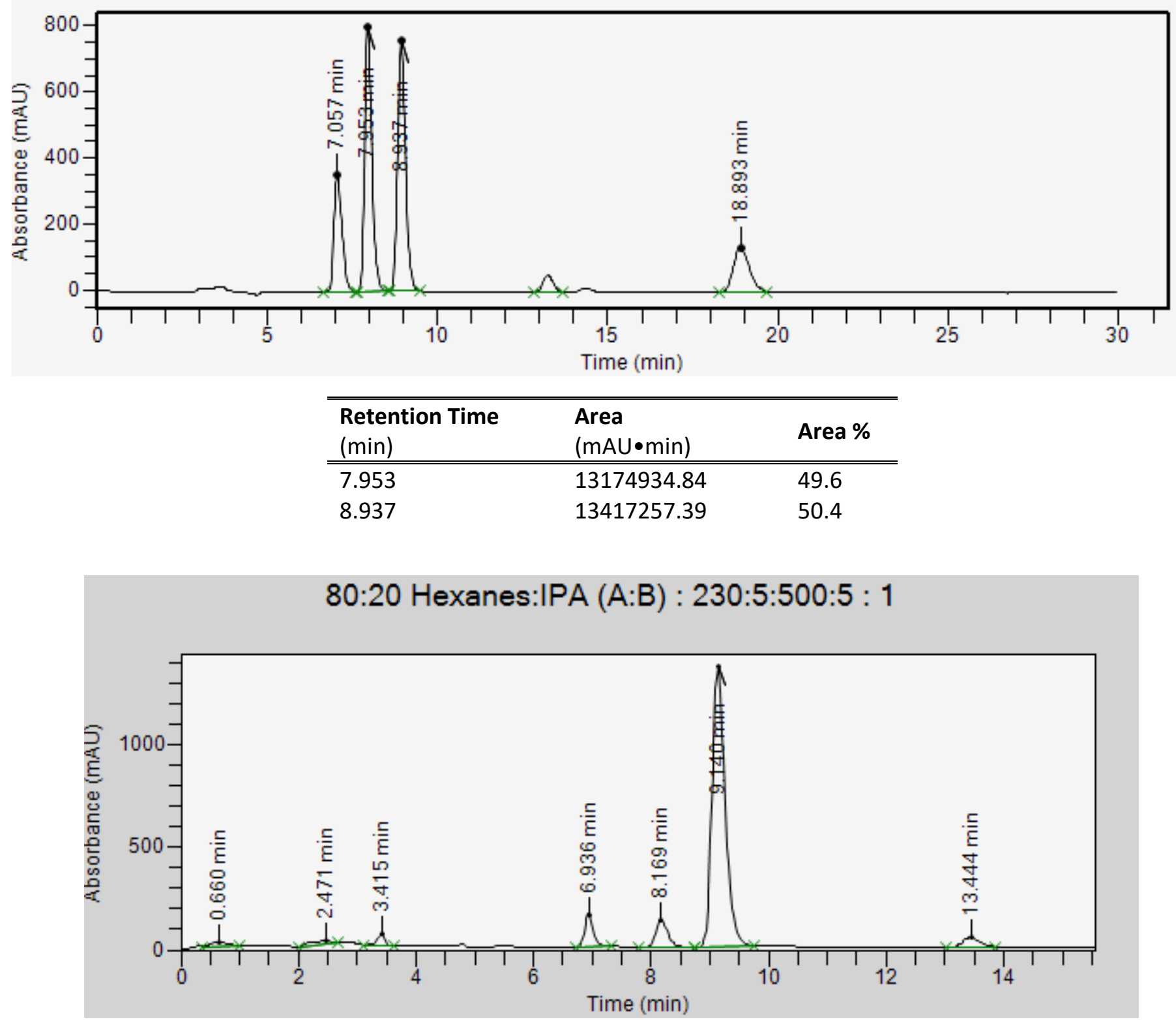

\begin{tabular}{lll}
\hline \hline $\begin{array}{l}\text { Retention Time } \\
(\mathrm{min})\end{array}$ & $\begin{array}{l}\text { Area } \\
(\mathrm{mAU} \cdot \mathrm{min})\end{array}$ & Area \% \\
\hline \hline 8.169 & 1944032.683 & 8.5 \\
9.140 & 21113529.04 & 91.5
\end{tabular}




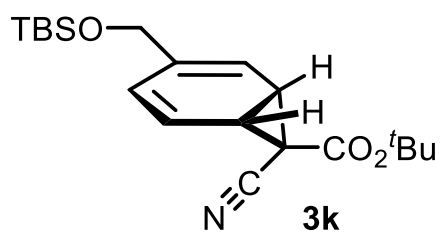

takke2 : 230:5:500:5 : 1

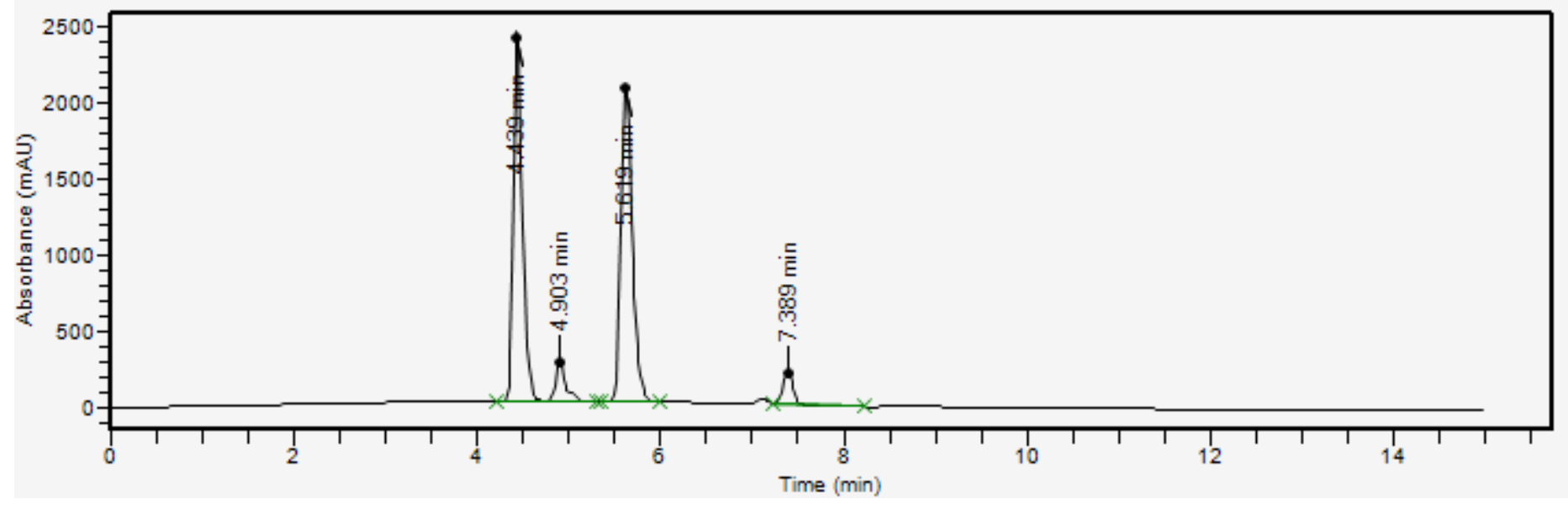

\begin{tabular}{lll}
\hline \hline $\begin{array}{l}\text { Retention Time } \\
(\mathrm{min})\end{array}$ & $\begin{array}{l}\text { Area } \\
(\mathrm{mAU} \bullet \min )\end{array}$ & Area \% \\
\hline \hline 4.439 & 16668798.58 & 48.6 \\
5.619 & 17649306.01 & 51.4
\end{tabular}

95:5 Hexanes:IPA (A:B) : 230:5:500:5 : 1

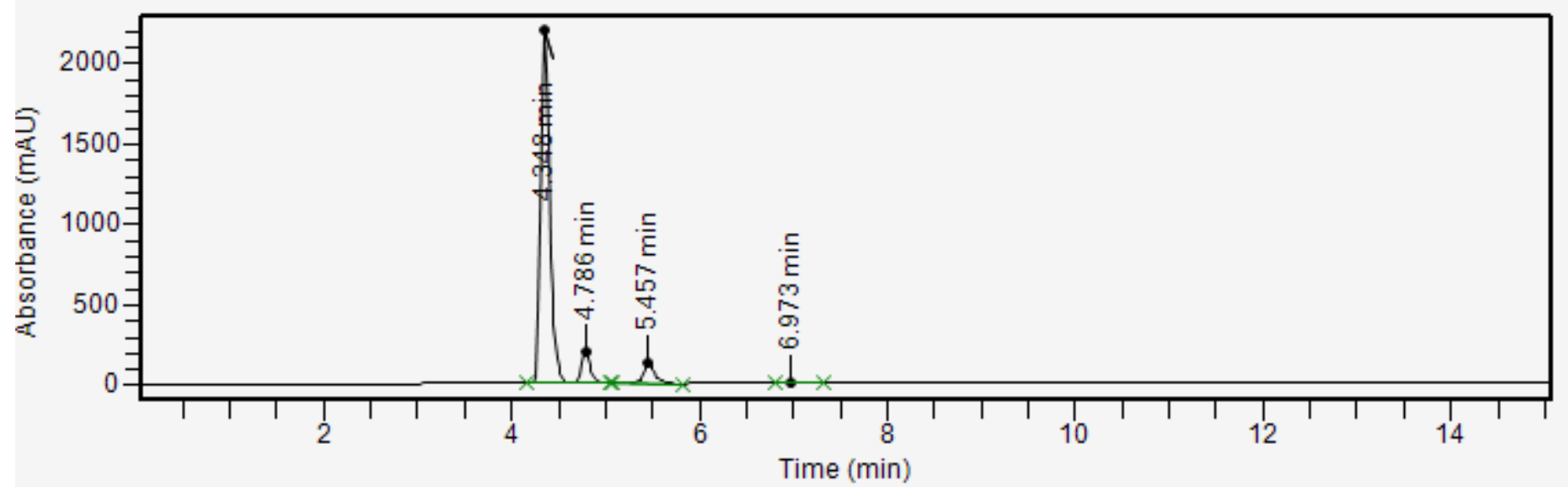

\begin{tabular}{lll}
\hline $\begin{array}{l}\text { Retention Time } \\
(\min )\end{array}$ & $\begin{array}{l}\text { Area } \\
(\mathrm{mAU} \bullet \min )\end{array}$ & Area \% \\
\hline \hline 4.348 & 14483469.23 & 92.5 \\
5.457 & 1165713.079 & 7.5
\end{tabular}




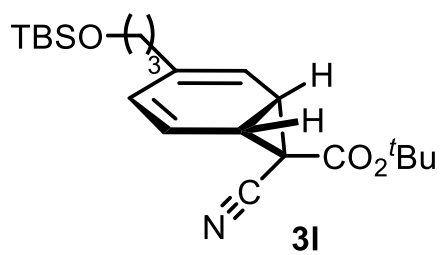

98:2 Hexanes:IPA (A:B) : 230:5:500:5 : 1

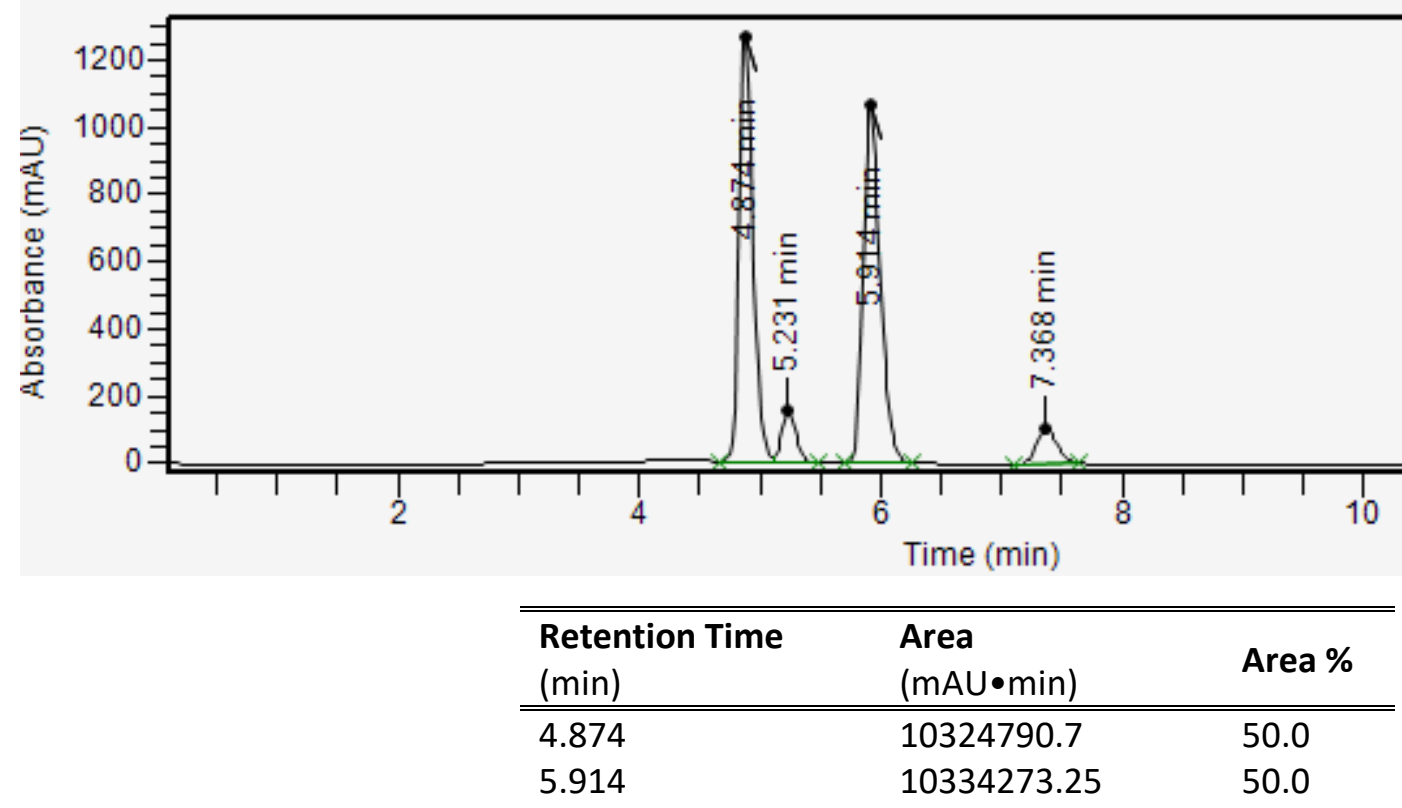

HYDROCIN_T3_BUC : 230:5:500:5 : 1

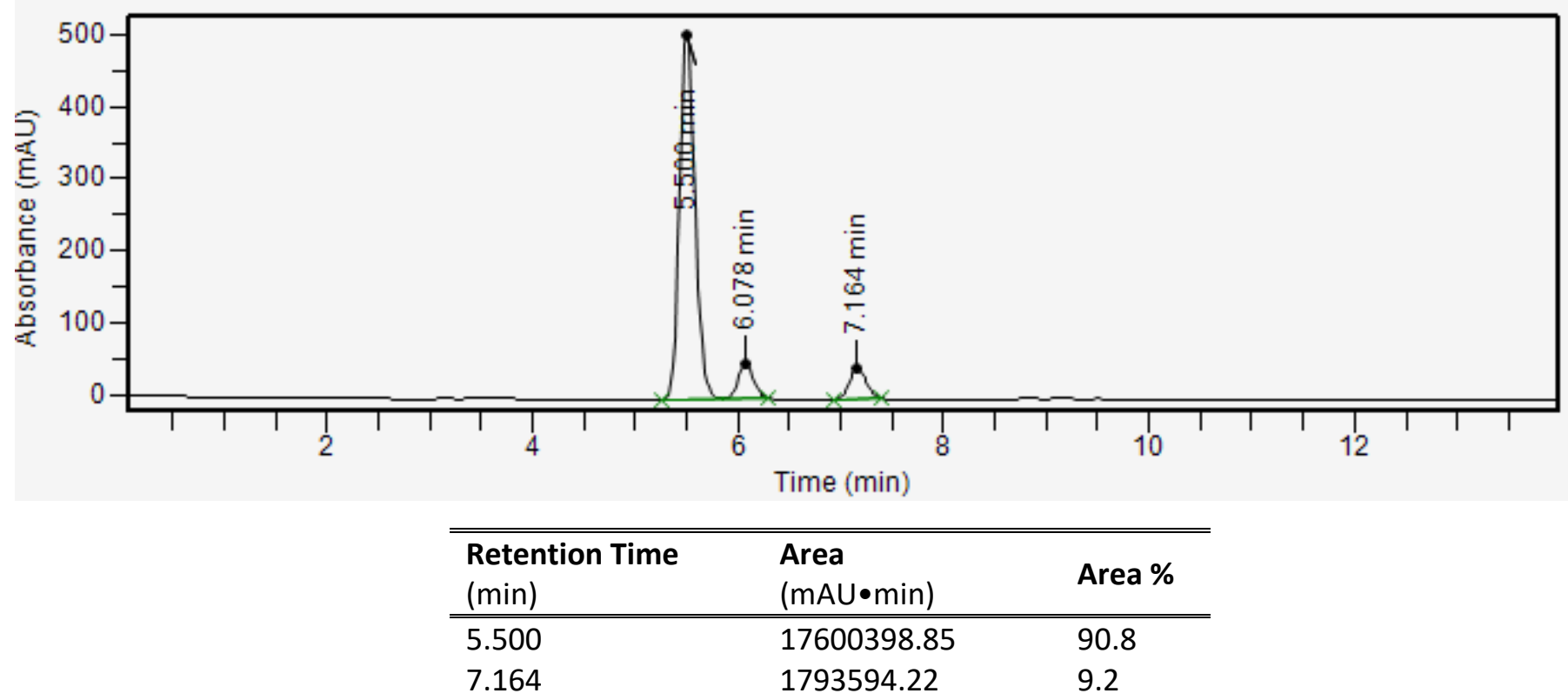




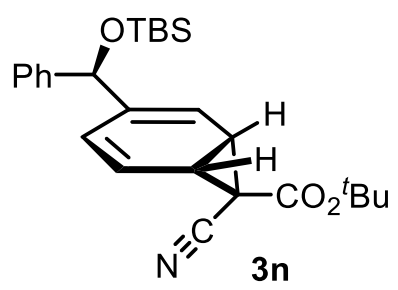

99:1 Hexanes:IPA (A:B) : 218:5:500:5 : 1

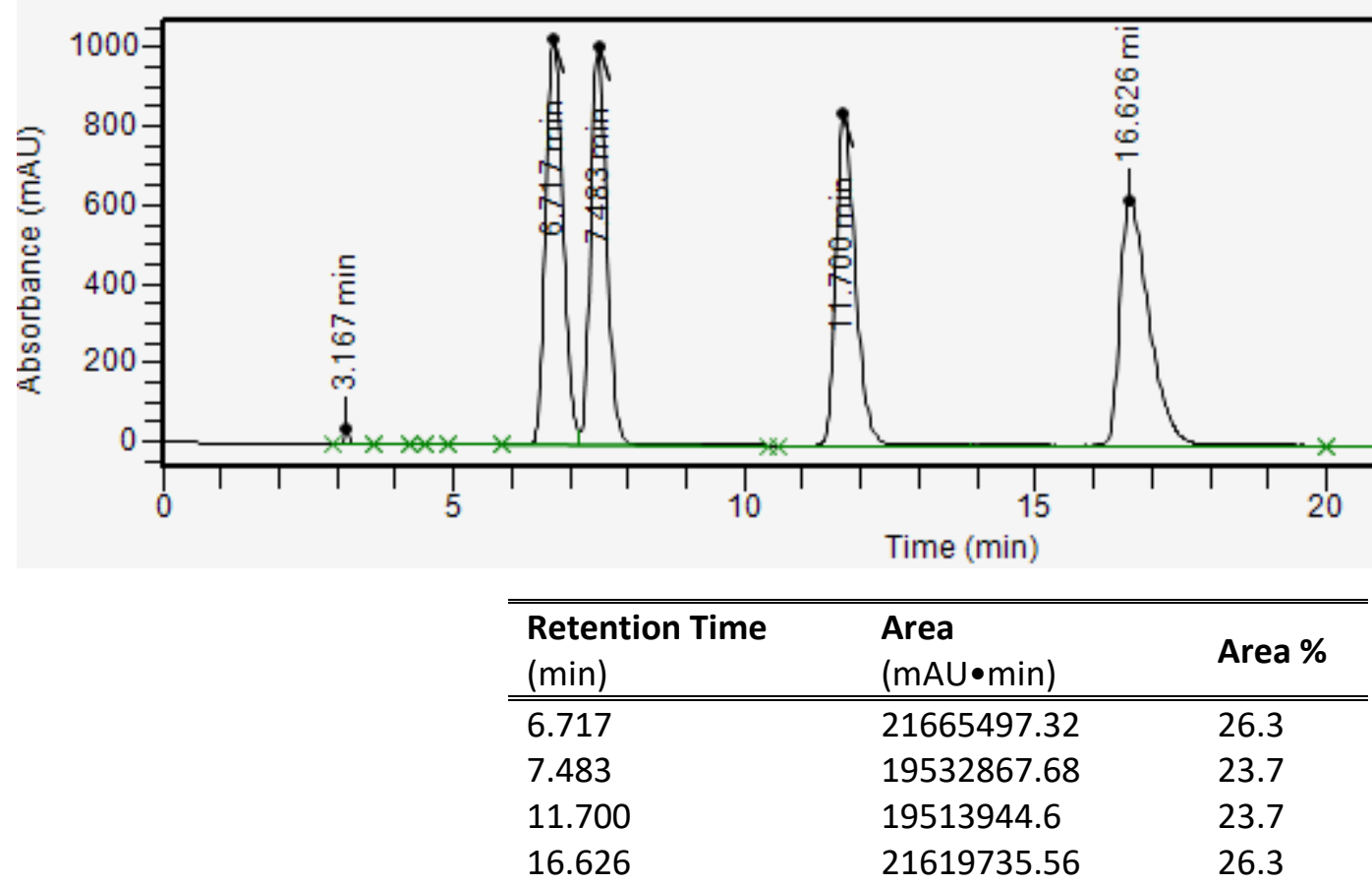

99:1 Hexanes:IPA (A:B) : 218:5:500:5: 1

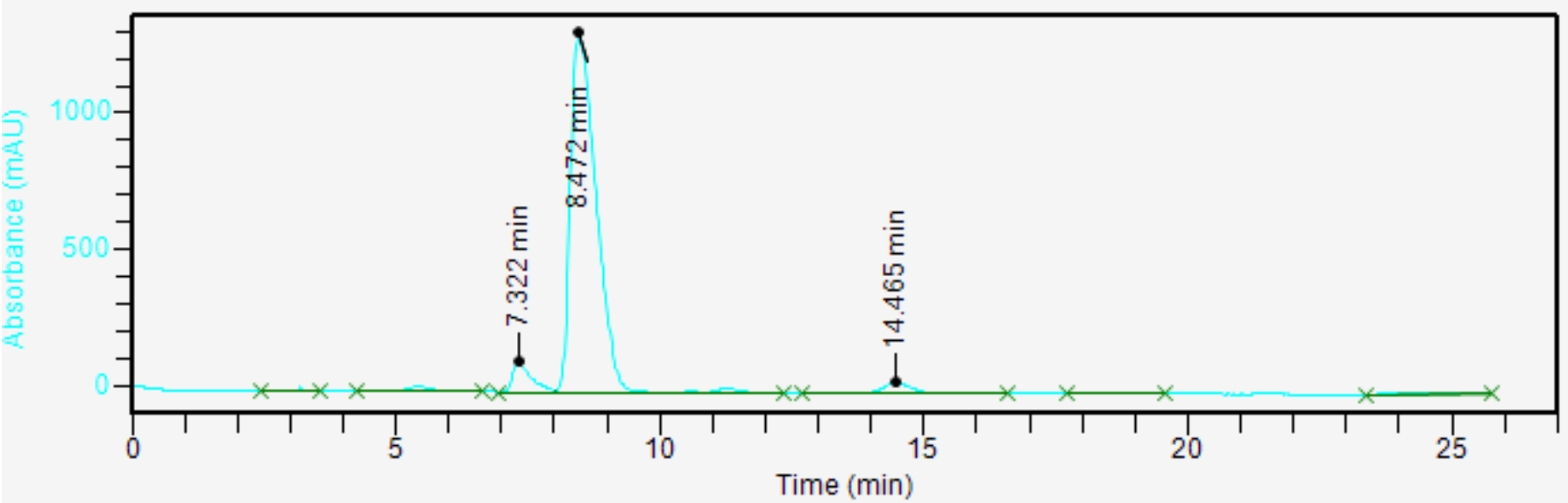




\begin{tabular}{lll}
\hline \hline $\begin{array}{l}\text { Retention Time } \\
(\mathrm{min})\end{array}$ & $\begin{array}{l}\text { Area } \\
(\mathrm{mAU} \bullet \min )\end{array}$ & Area \% \\
\hline \hline 8.472 & 44216758.05 & 96.9 \\
14.465 & 1400287.933 & 3.1
\end{tabular}




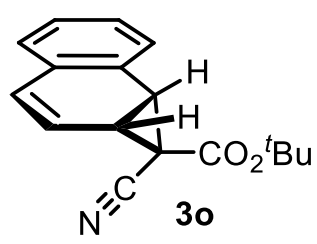

90:10 Hexanes:IPA (A:B) : 230:5:500:5: 1

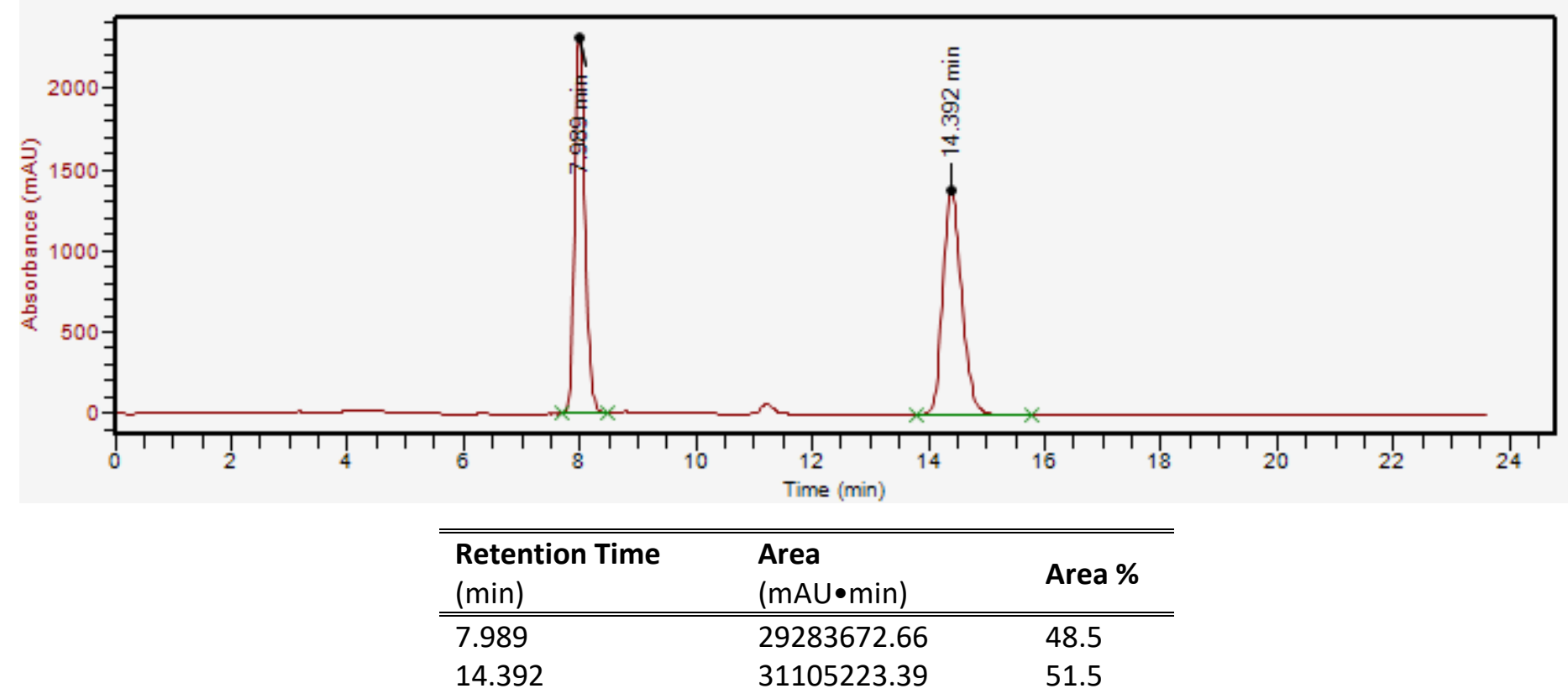

90:10 Hexanes:IPA (A:B) : 230:5:500:5 : 1

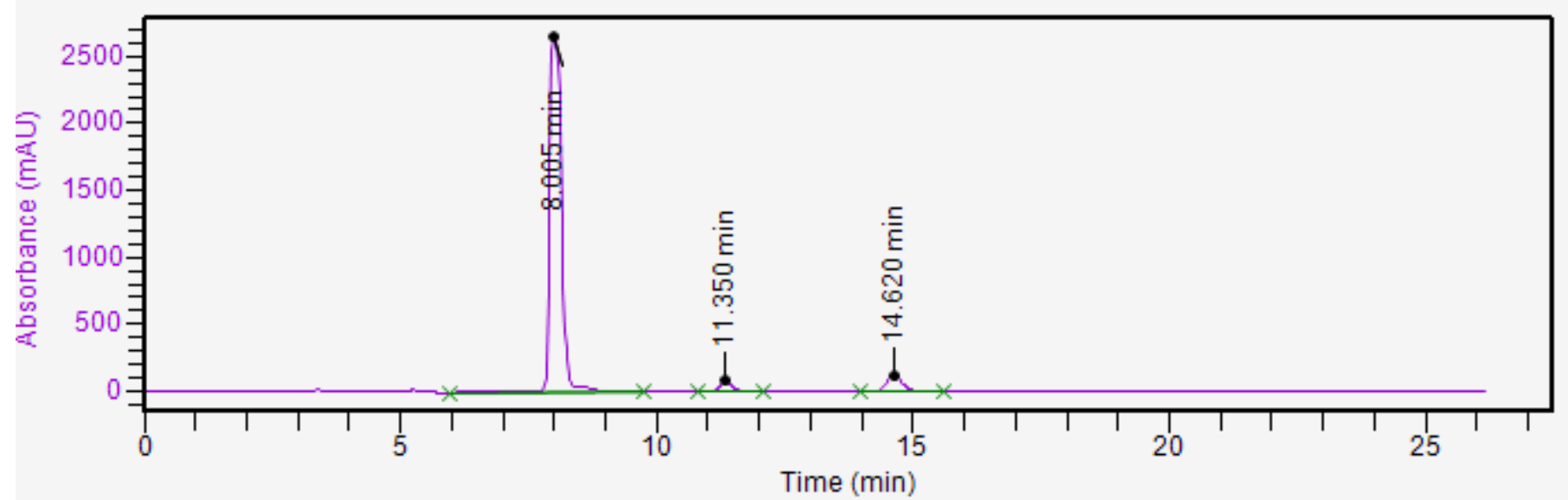

\begin{tabular}{lll}
\hline \hline $\begin{array}{l}\text { Retention Time } \\
(\mathrm{min})\end{array}$ & $\begin{array}{l}\text { Area } \\
(\mathrm{mAU} \bullet \mathrm{min})\end{array}$ & Area \% \\
\hline \hline 8.005 & 42715062.61 & 94.1 \\
14.620 & 2695400.843 & 5.9
\end{tabular}




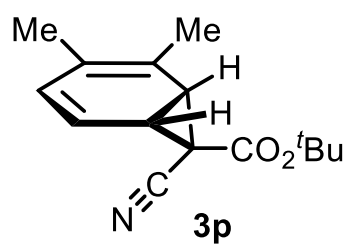

RAC_ISOMER : 230:5:500:5 : 1

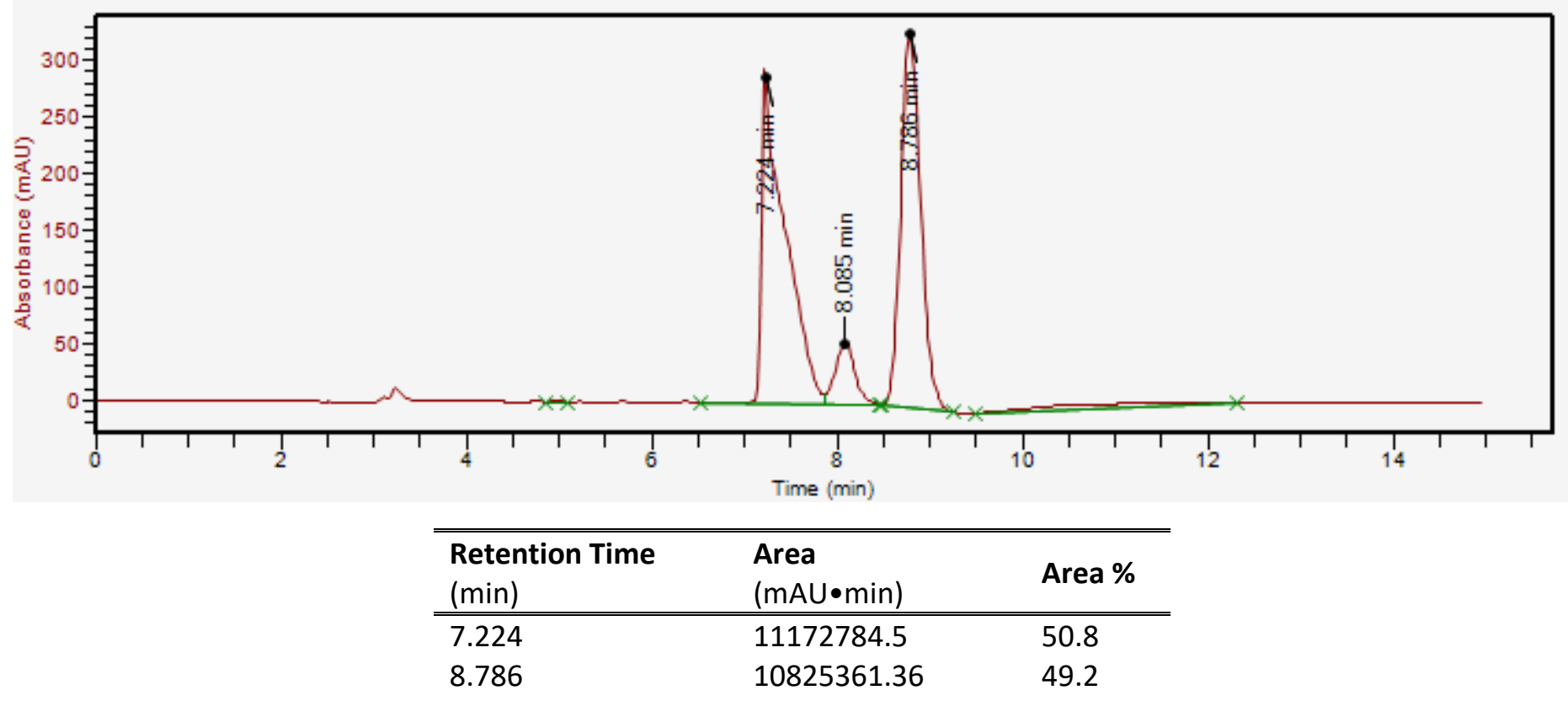

OXYL_4 : 230:5:500:5: 1

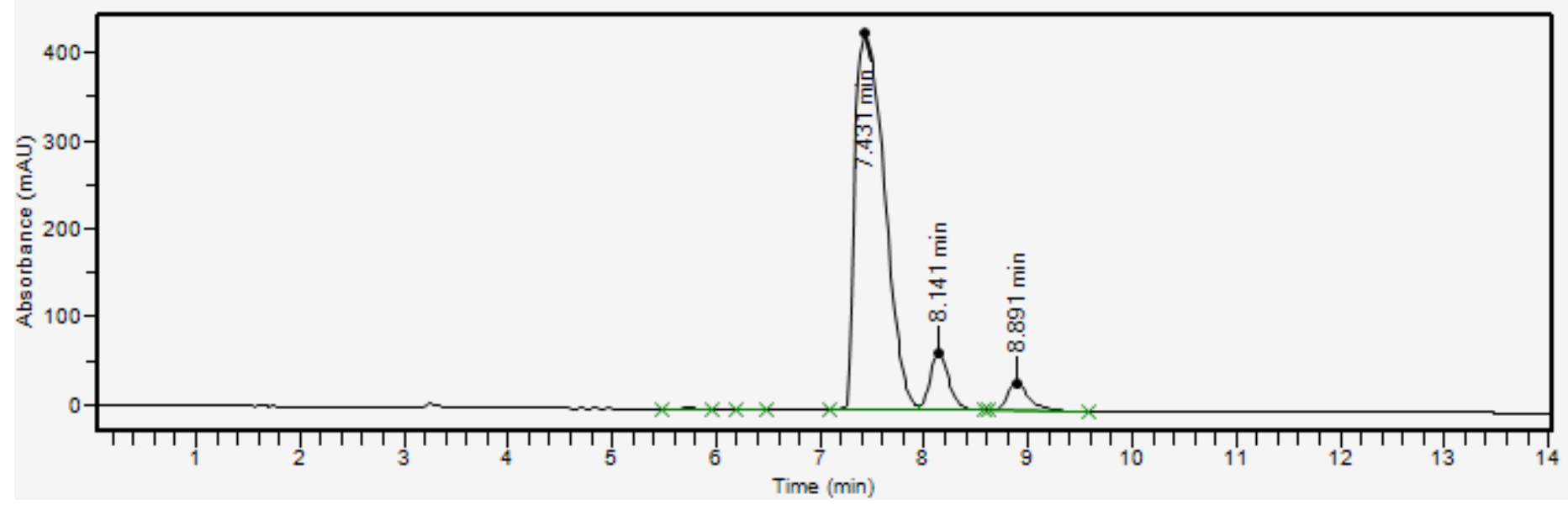

\begin{tabular}{lll}
\hline \hline $\begin{array}{l}\text { Retention Time } \\
(\mathrm{min})\end{array}$ & $\begin{array}{l}\text { Area } \\
(\mathrm{mAU} \bullet \min )\end{array}$ & Area \% \\
\hline \hline 7.431 & 8415049.743 & 94.8 \\
8.891 & 462102.342 & 5.2
\end{tabular}



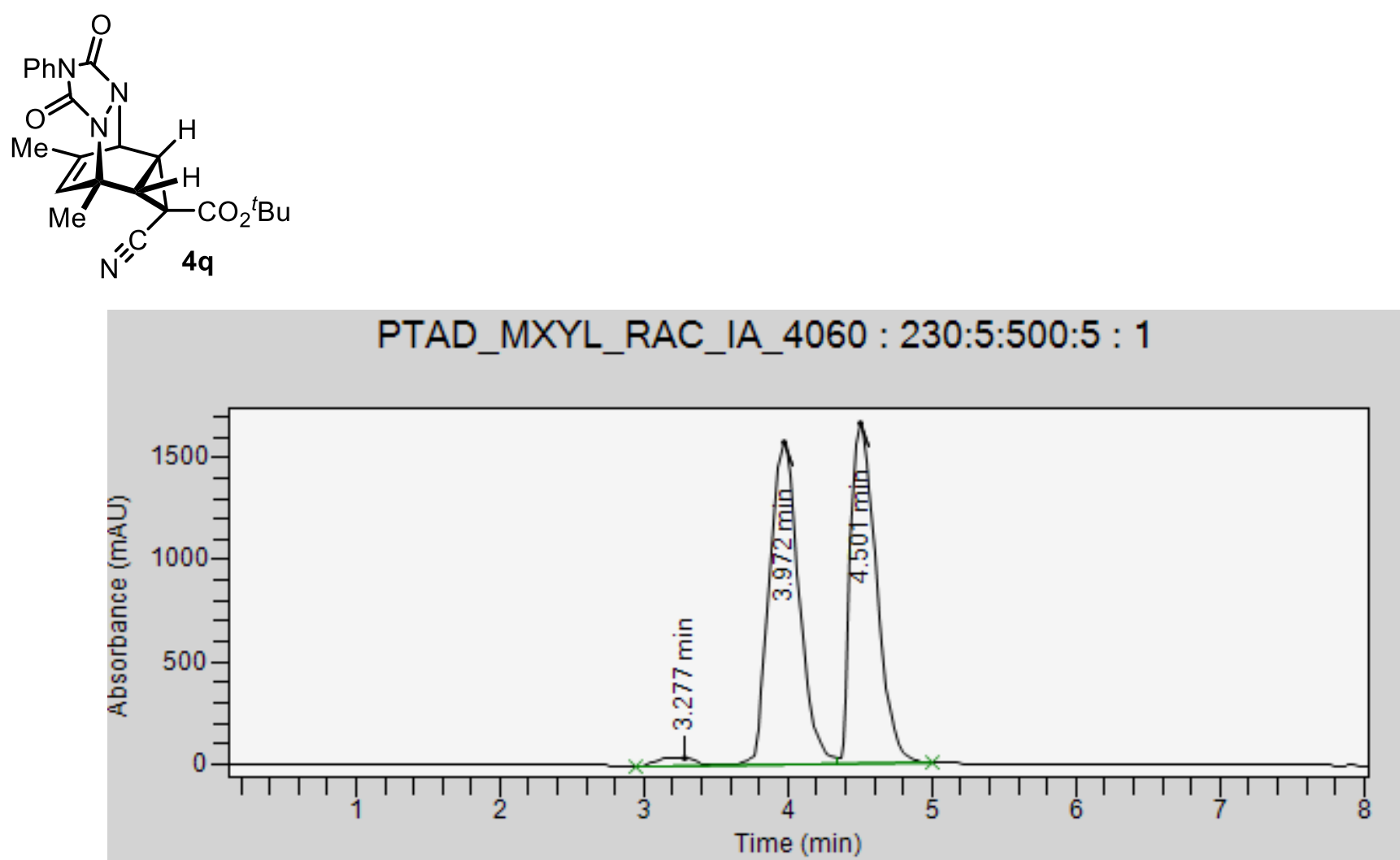

\begin{tabular}{lll}
\hline $\begin{array}{l}\text { Retention Time } \\
(\mathrm{min})\end{array}$ & $\begin{array}{l}\text { Area } \\
(\mathrm{mAU} \bullet \min )\end{array}$ & Area \% \\
\hline \hline 3.972 & 22553789.78 & 51.9 \\
4.501 & 20860580.78 & 48.1
\end{tabular}

\section{0:60 Hexanes:IPA (A:B) : 230:5:500:5 : 1}

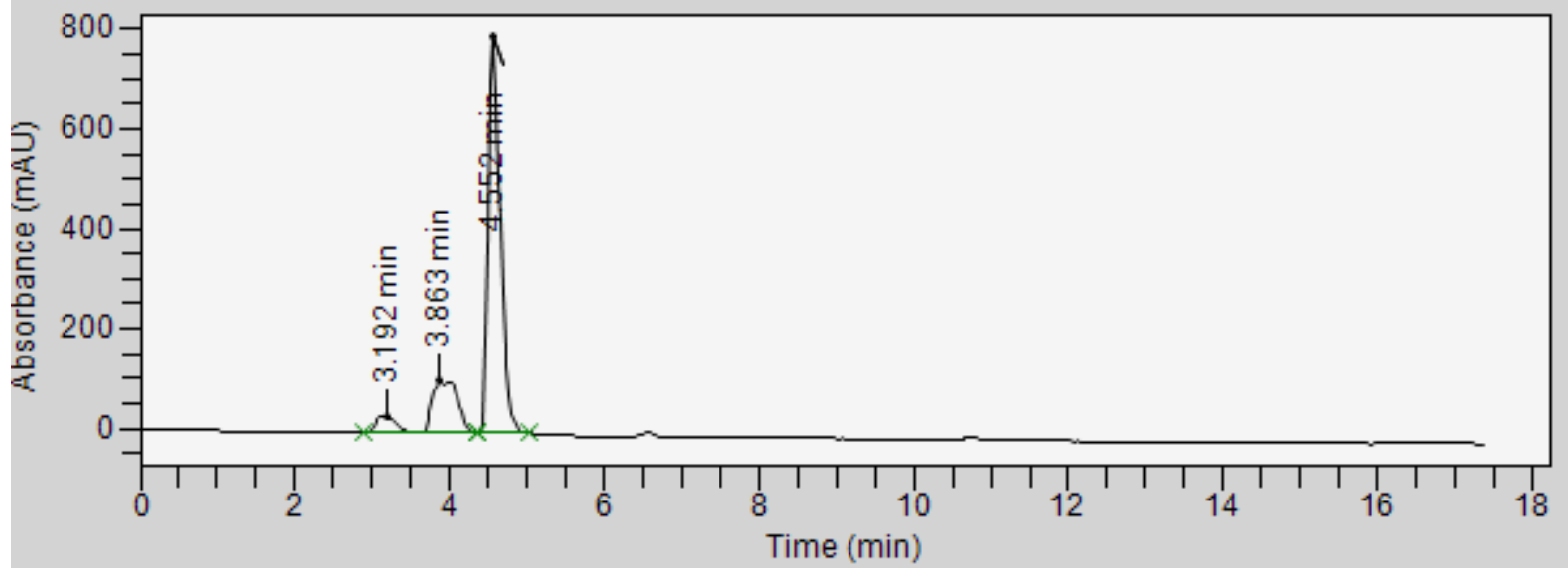

\begin{tabular}{lll}
\hline \hline $\begin{array}{l}\text { Retention Time } \\
(\mathrm{min})\end{array}$ & $\begin{array}{l}\text { Area } \\
(\mathrm{mAU} \bullet \min )\end{array}$ & Area \% \\
\hline \hline 3.863 & 2383719.54 & 21.5 \\
4.552 & 8720972.884 & 78.5
\end{tabular}



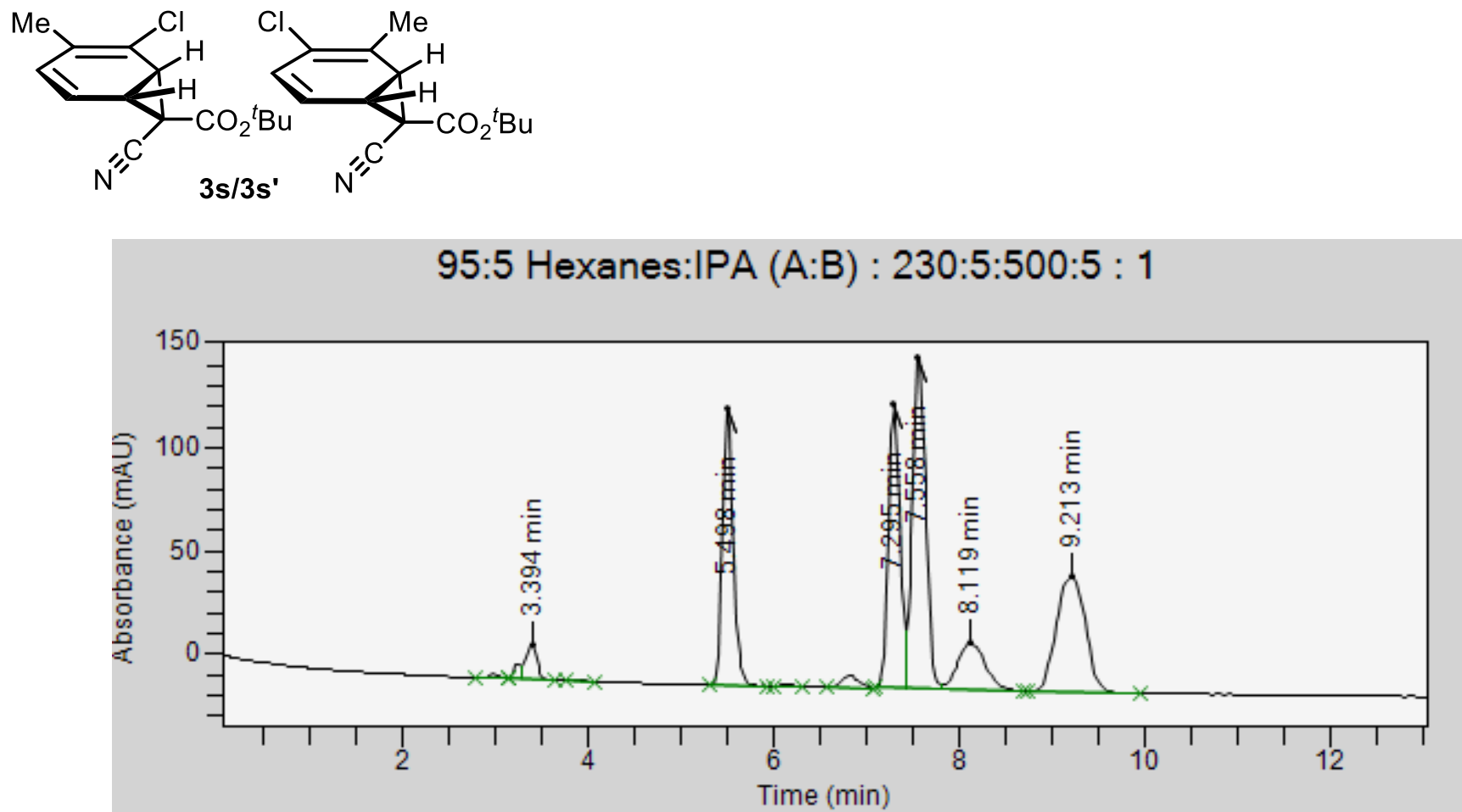

\begin{tabular}{lll}
\hline $\begin{array}{l}\text { Retention Time } \\
(\mathrm{min})\end{array}$ & $\begin{array}{l}\text { Area } \\
(\mathrm{mAU} \bullet \mathrm{min})\end{array}$ & Area \% \\
\hline \hline 5.498 & 1075086.079 & 47.5 \\
7.295 & 1187504.355 & 52.5 \\
7.558 & 1628277.208 & 57.2 \\
9.213 & 1215835.15 & 42.8
\end{tabular}

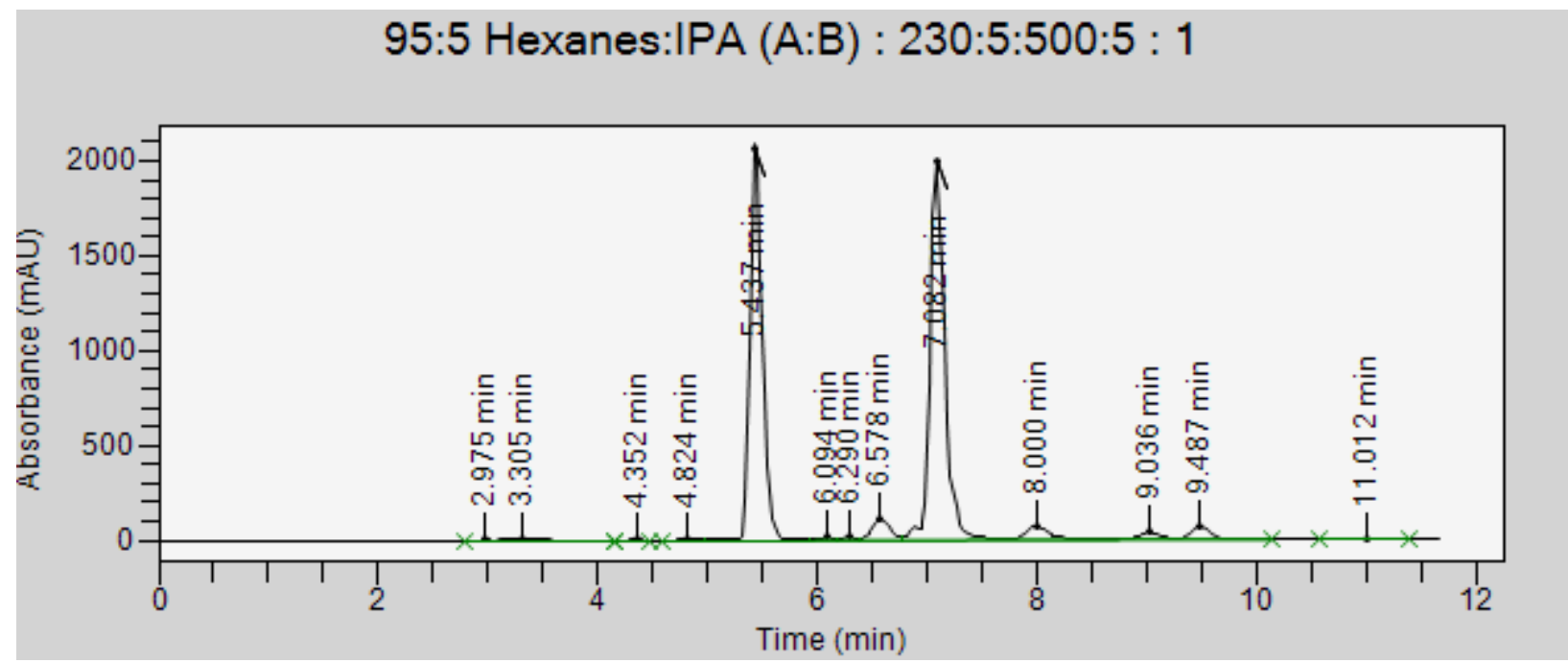




\begin{tabular}{lll}
\hline \hline $\begin{array}{l}\text { Retention Time } \\
(\mathrm{min})\end{array}$ & $\begin{array}{l}\text { Area } \\
(\mathrm{mAU} \bullet \min )\end{array}$ & Area \% \\
\hline \hline 5.437 & 16112480.11 & 92.3 \\
6.578 & 1337723.2 & 7.7 \\
7.082 & 18747400.96 & 95.3 \\
9.036 & 594809.08 & 4.7
\end{tabular}


<smiles>CCOC(=O)C1C2C=C[C@H](O2)[C@H](C)C1C#N</smiles>

\section{Batch: CLP-BUC2-055 Epoxide Rac'}

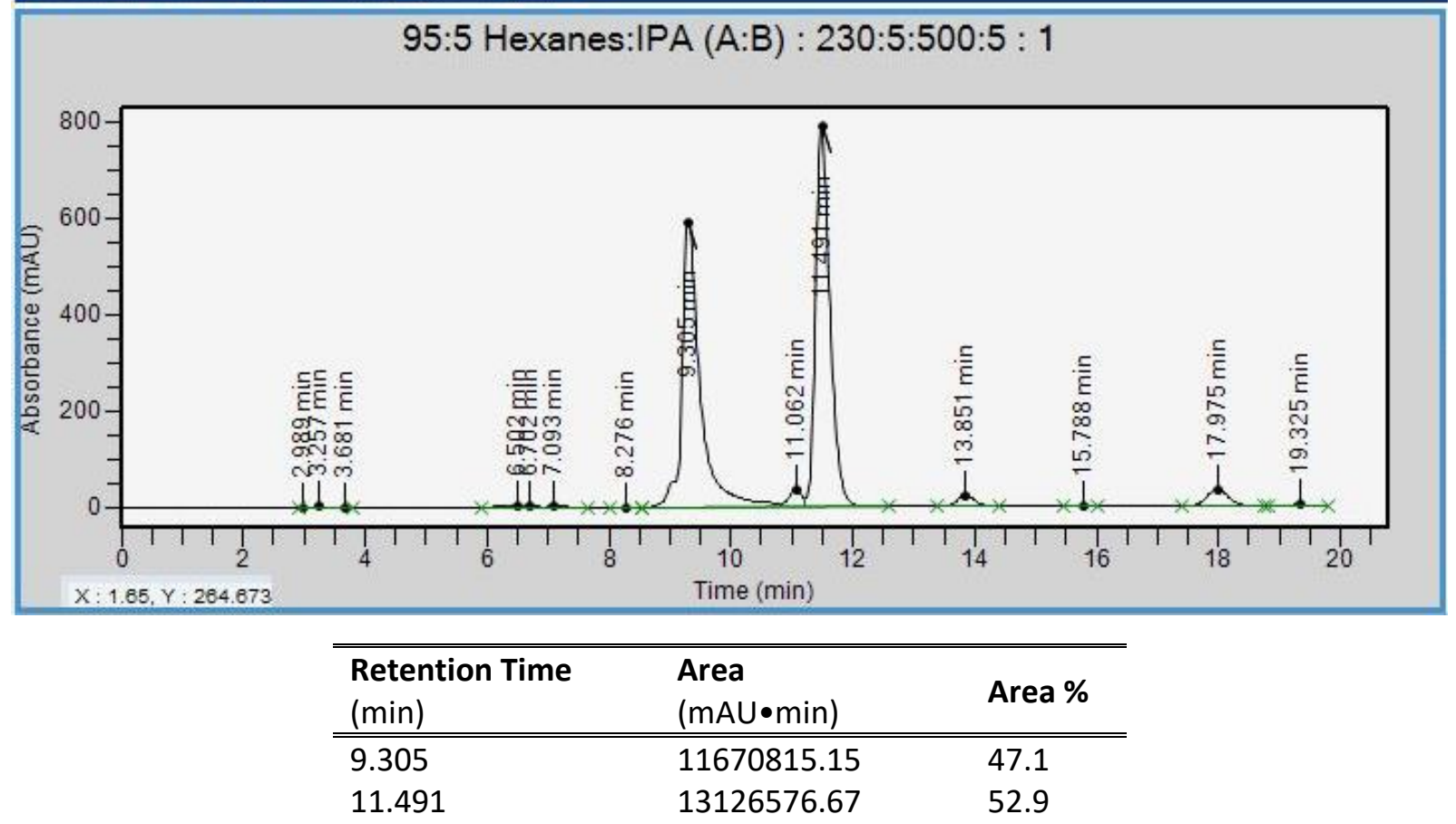

\section{Batch: CLP-BUC2-058' Epox Asym 2}

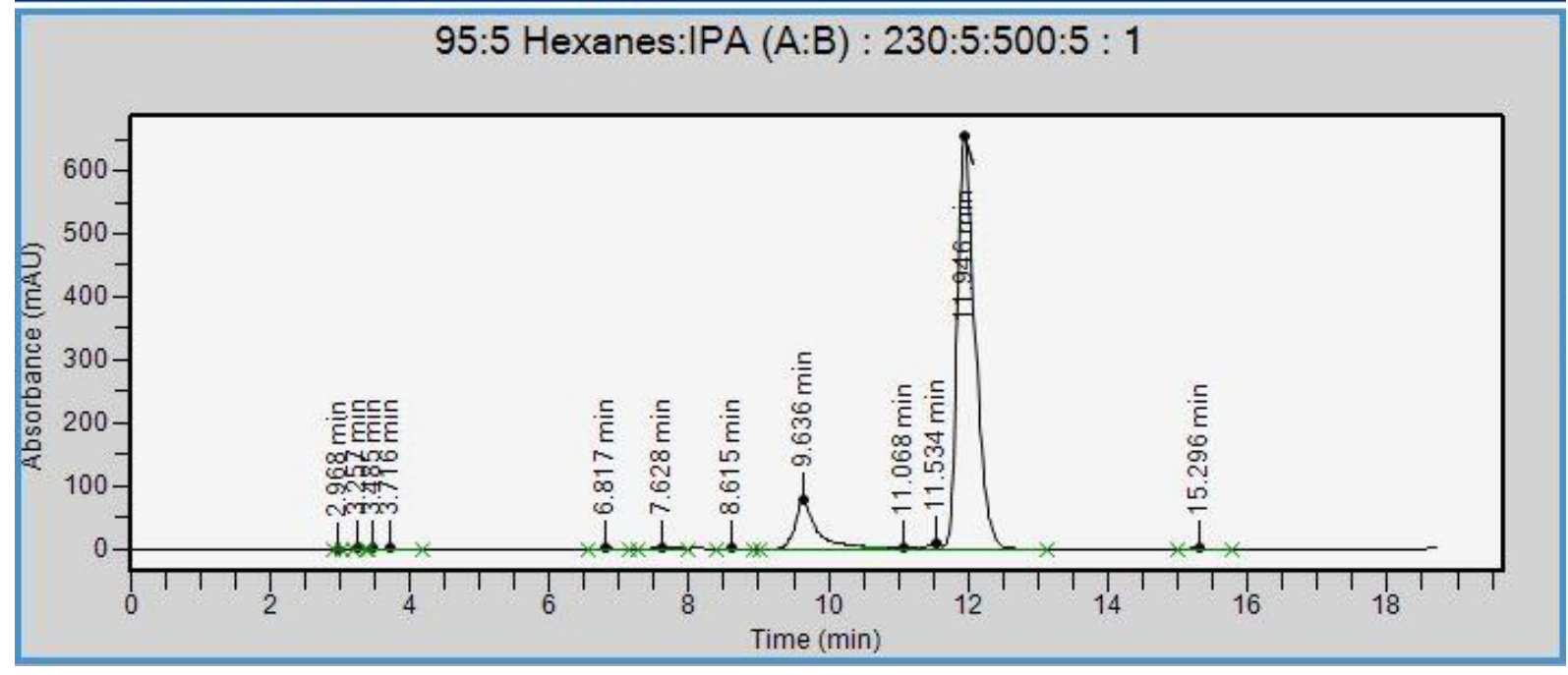

\begin{tabular}{lll}
\hline $\begin{array}{l}\text { Retention Time } \\
(\mathrm{min})\end{array}$ & $\begin{array}{l}\text { Area } \\
(\mathrm{mAU} \bullet \mathrm{min})\end{array}$ & Area \% \\
\hline \hline 9.636 & 1780344.30 & 13.3 \\
11.946 & 11599005.13 & 86.7
\end{tabular}




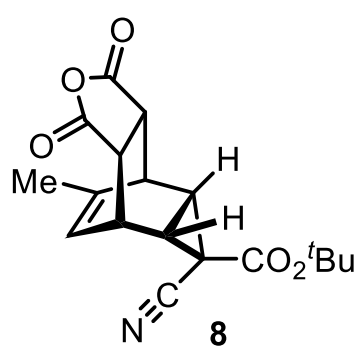

55:45 Hexanes:IPA (A:B) : 230:5:500:5 : 1

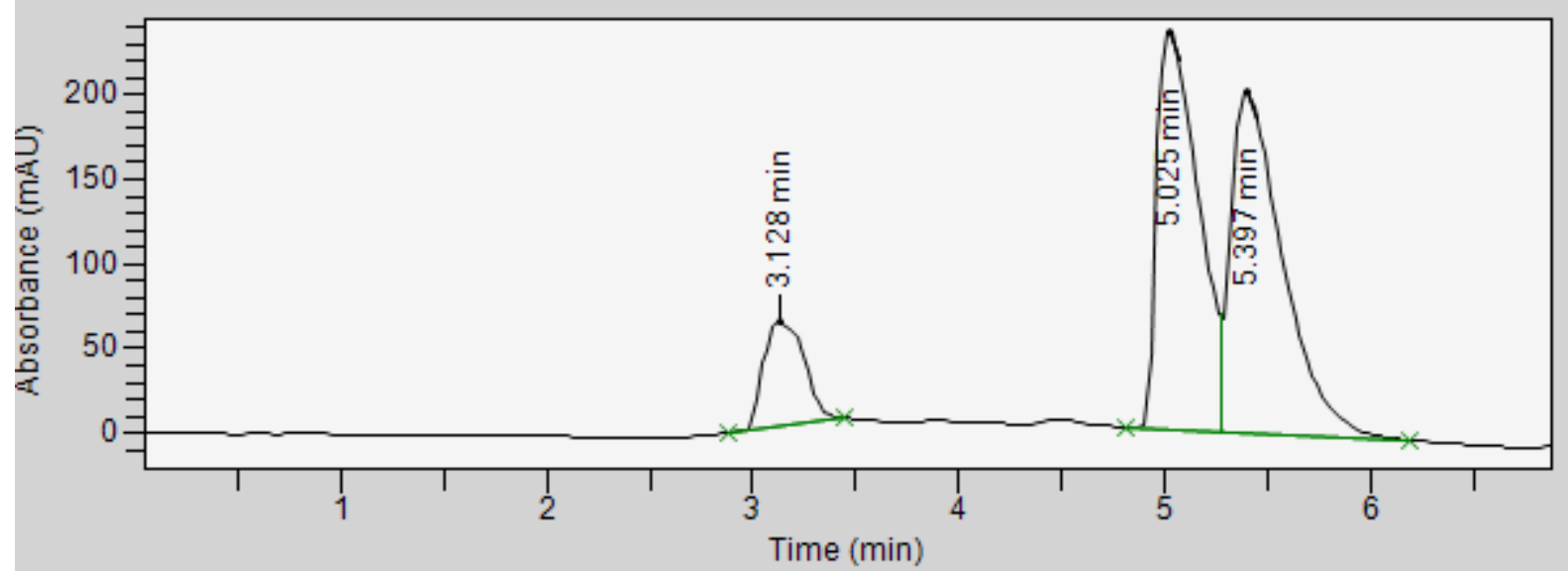

\begin{tabular}{lll}
\hline \hline $\begin{array}{l}\text { Retention Time } \\
(\mathrm{min})\end{array}$ & $\begin{array}{l}\text { Area } \\
(\mathrm{mAU} \bullet \min )\end{array}$ & Area \% \\
\hline \hline 5.025 & 3353784.112 & 48.0 \\
5.397 & 3638029.974 & 52.0
\end{tabular}

55:45 Hexanes:IPA (A:B) : 230:5:500:5 : 1

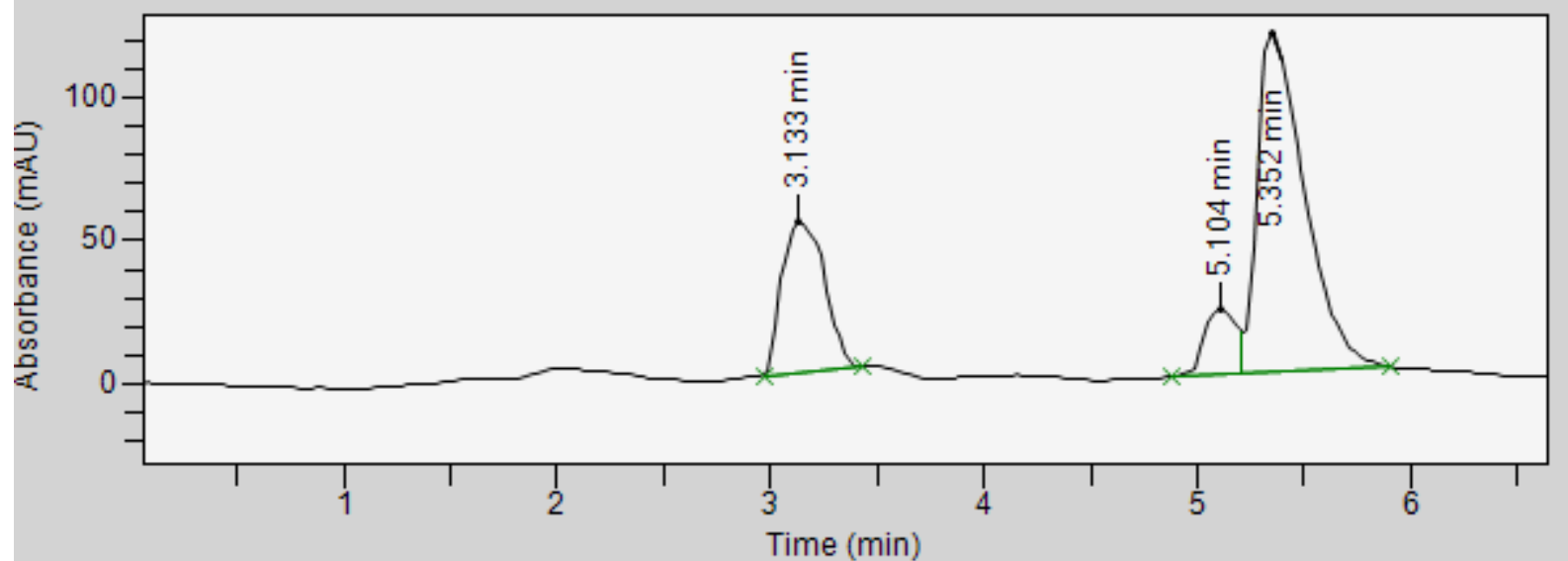

\begin{tabular}{lll}
\hline \hline $\begin{array}{l}\text { Retention Time } \\
(\mathrm{min})\end{array}$ & $\begin{array}{l}\text { Area } \\
(\mathrm{mAU} \bullet \min )\end{array}$ & Area \% \\
\hline \hline 5.104 & 241916.4731 & 11.7 \\
5.352 & 1820470.776 & 88.3
\end{tabular}




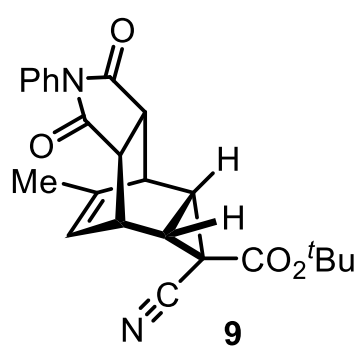

NPH_RAC_IC_2575: 230:5:500:5 : 1

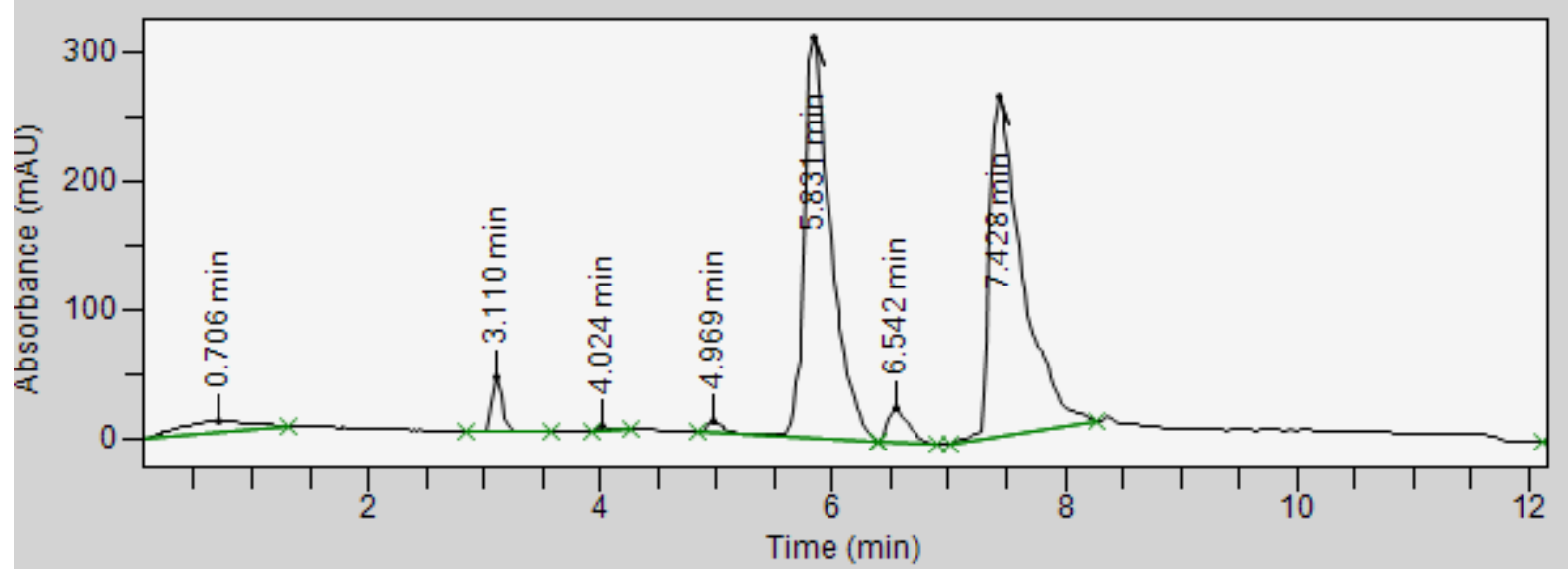

\begin{tabular}{lll}
\hline \hline $\begin{array}{l}\text { Retention Time } \\
(\mathrm{min})\end{array}$ & $\begin{array}{l}\text { Area } \\
(\mathrm{mAU} \bullet \mathrm{min})\end{array}$ & Area \% \\
\hline \hline 5.831 & 4944493.841 & 48.4 \\
7.428 & 5279660.525 & 51.6
\end{tabular}

25:75 Hexanes:IPA (A:B) : 230:5:500:5 : 1

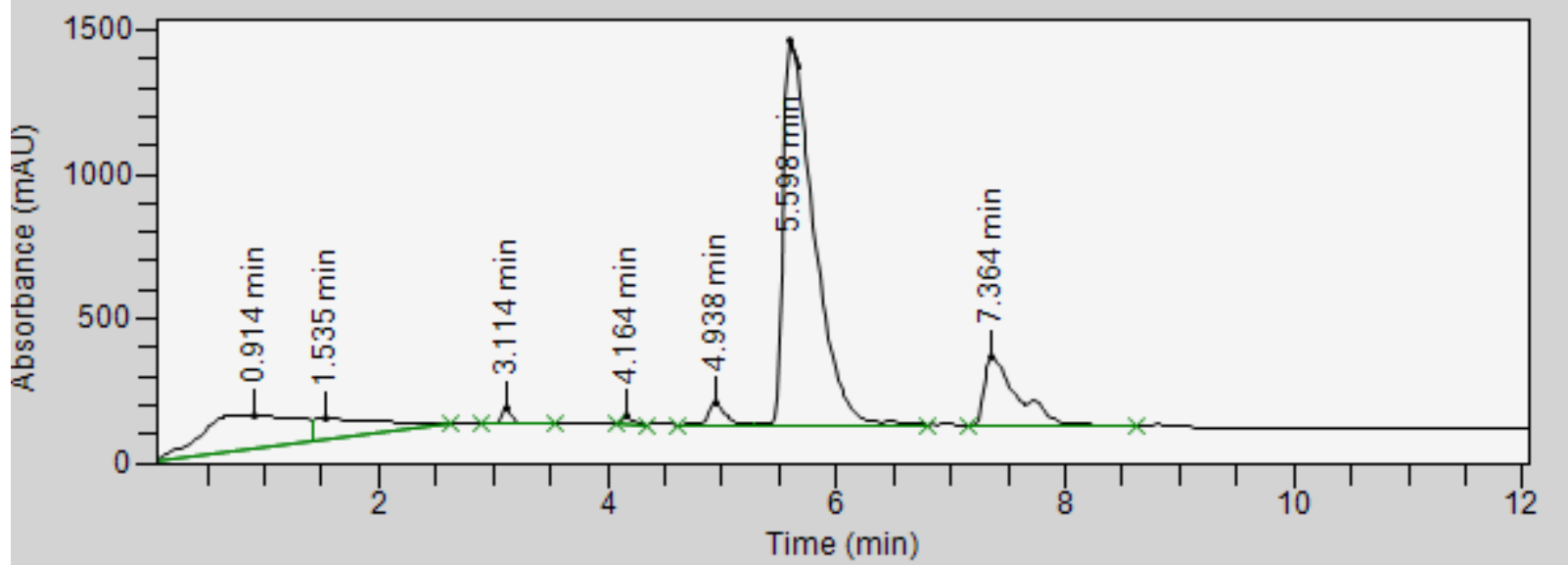

\begin{tabular}{lll}
\hline $\begin{array}{l}\text { Retention Time } \\
(\min )\end{array}$ & $\begin{array}{l}\text { Area } \\
(\mathrm{mAU} \bullet \min )\end{array}$ & Area \% \\
\hline 5.598 & 24787892.95 & 83.3 \\
7.364 & 4950196.397 & 16.7
\end{tabular}



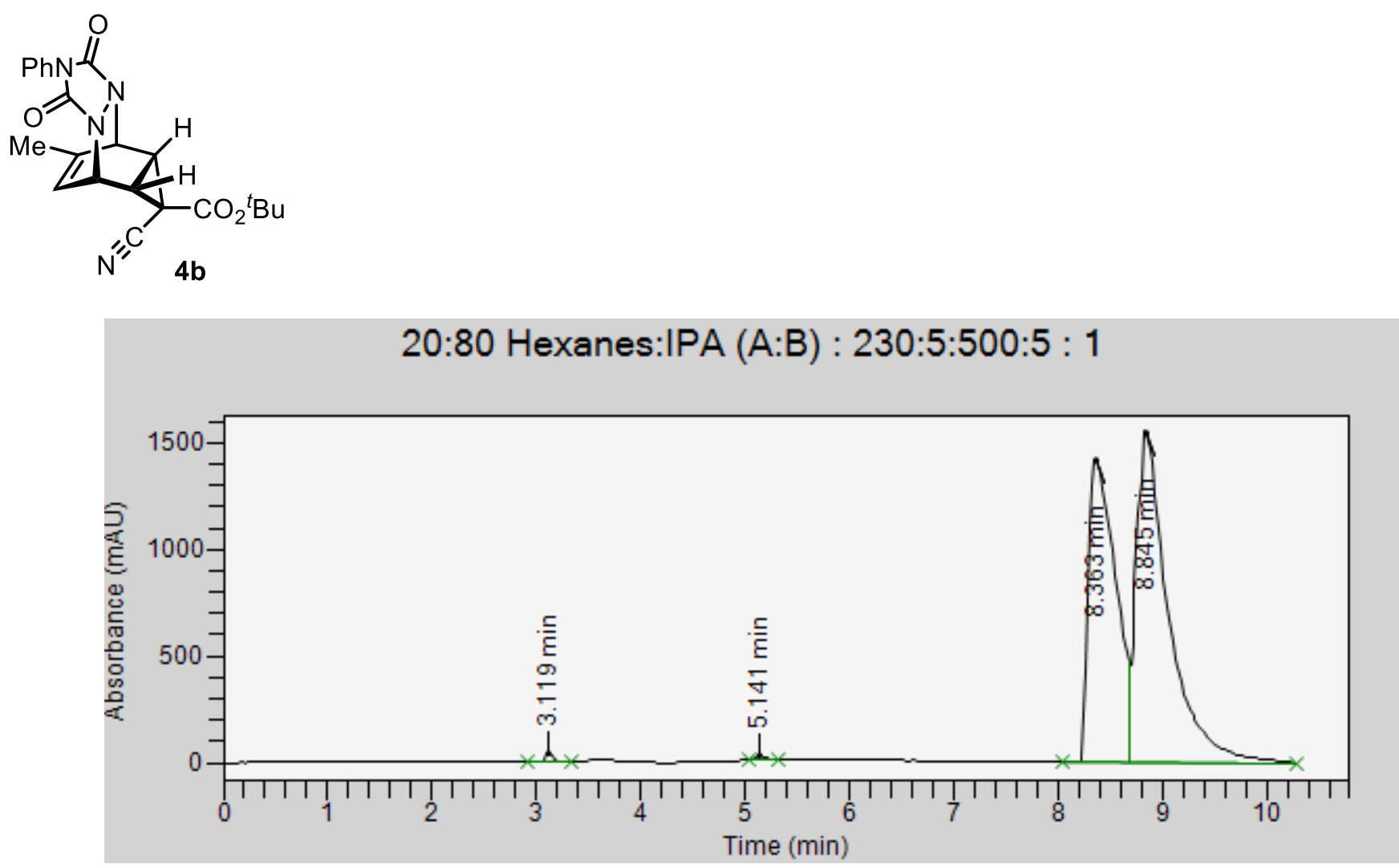

\begin{tabular}{lll}
\hline \hline $\begin{array}{l}\text { Retention Time } \\
(\mathrm{min})\end{array}$ & $\begin{array}{l}\text { Area } \\
(\mathrm{mAU} \cdot \min )\end{array}$ & Area \% \\
\hline \hline 8.363 & 25554754.26 & 43.1 \\
8.845 & 33803232.69 & 56.9
\end{tabular}

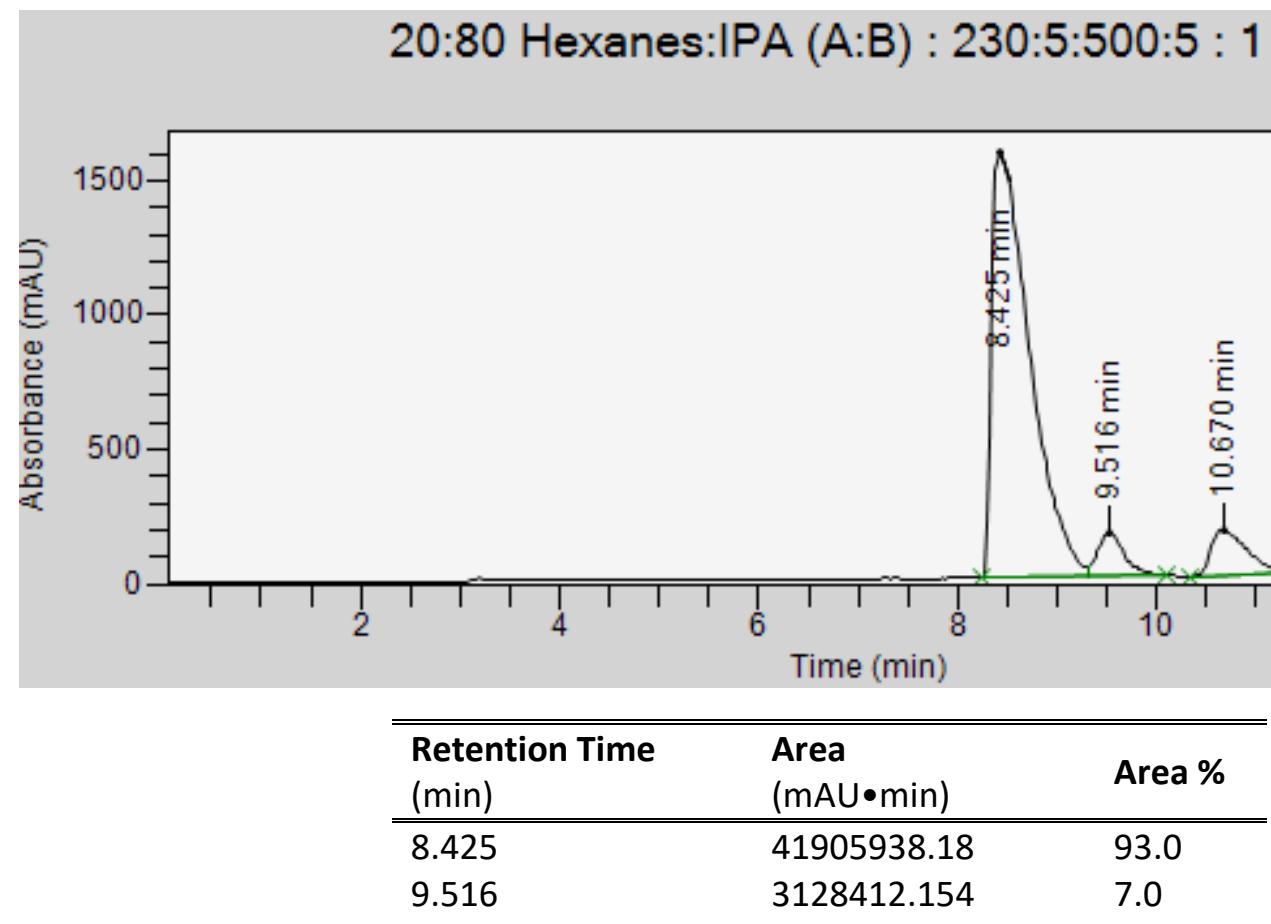



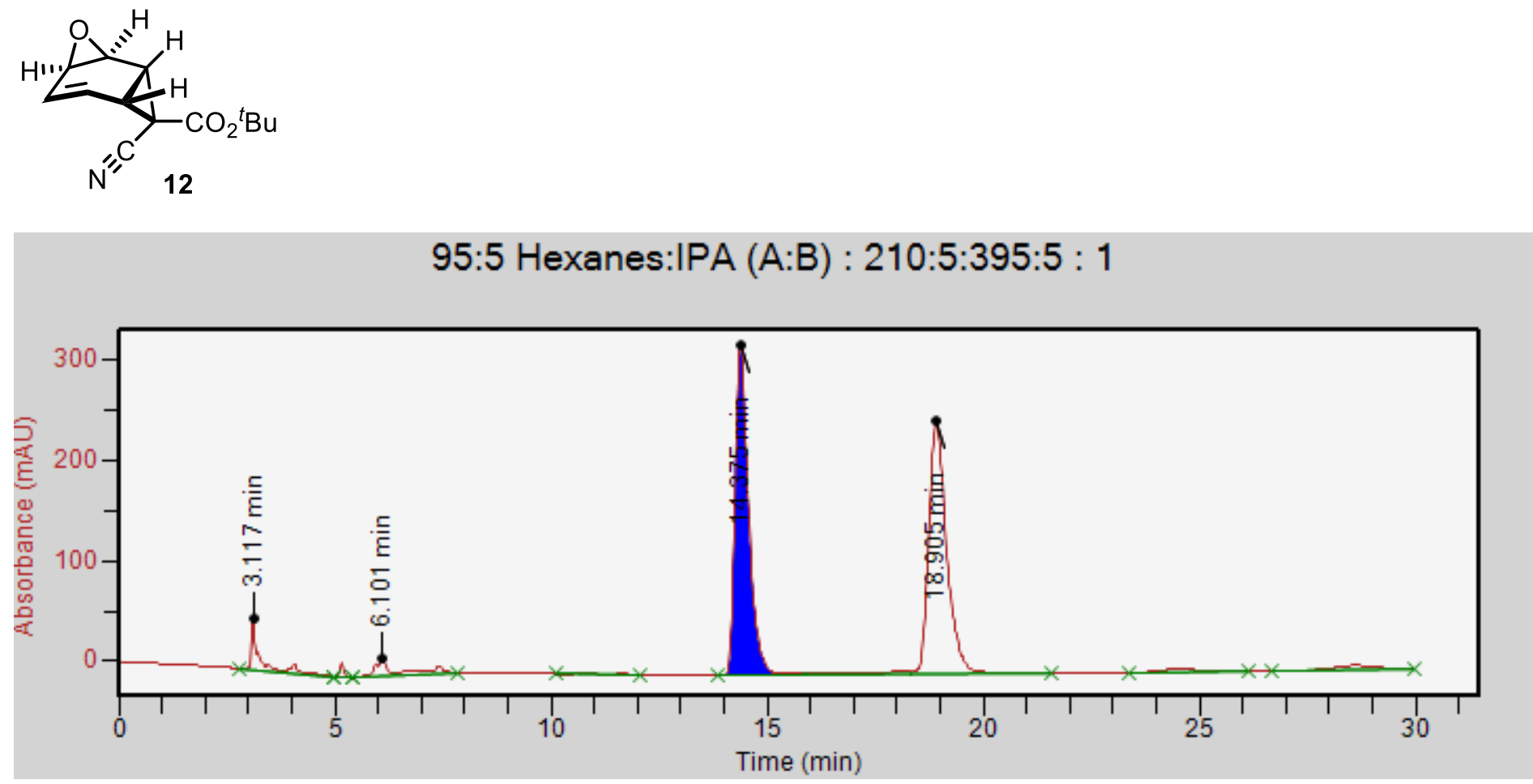

\begin{tabular}{lll}
\hline \hline $\begin{array}{l}\text { Retention Time } \\
(\mathrm{min})\end{array}$ & $\begin{array}{l}\text { Area } \\
(\mathrm{mAU} \bullet \min )\end{array}$ & Area \% \\
\hline \hline 14.375 & 8637223.518 & 50.2 \\
18.905 & 8548177.799 & 49.8
\end{tabular}

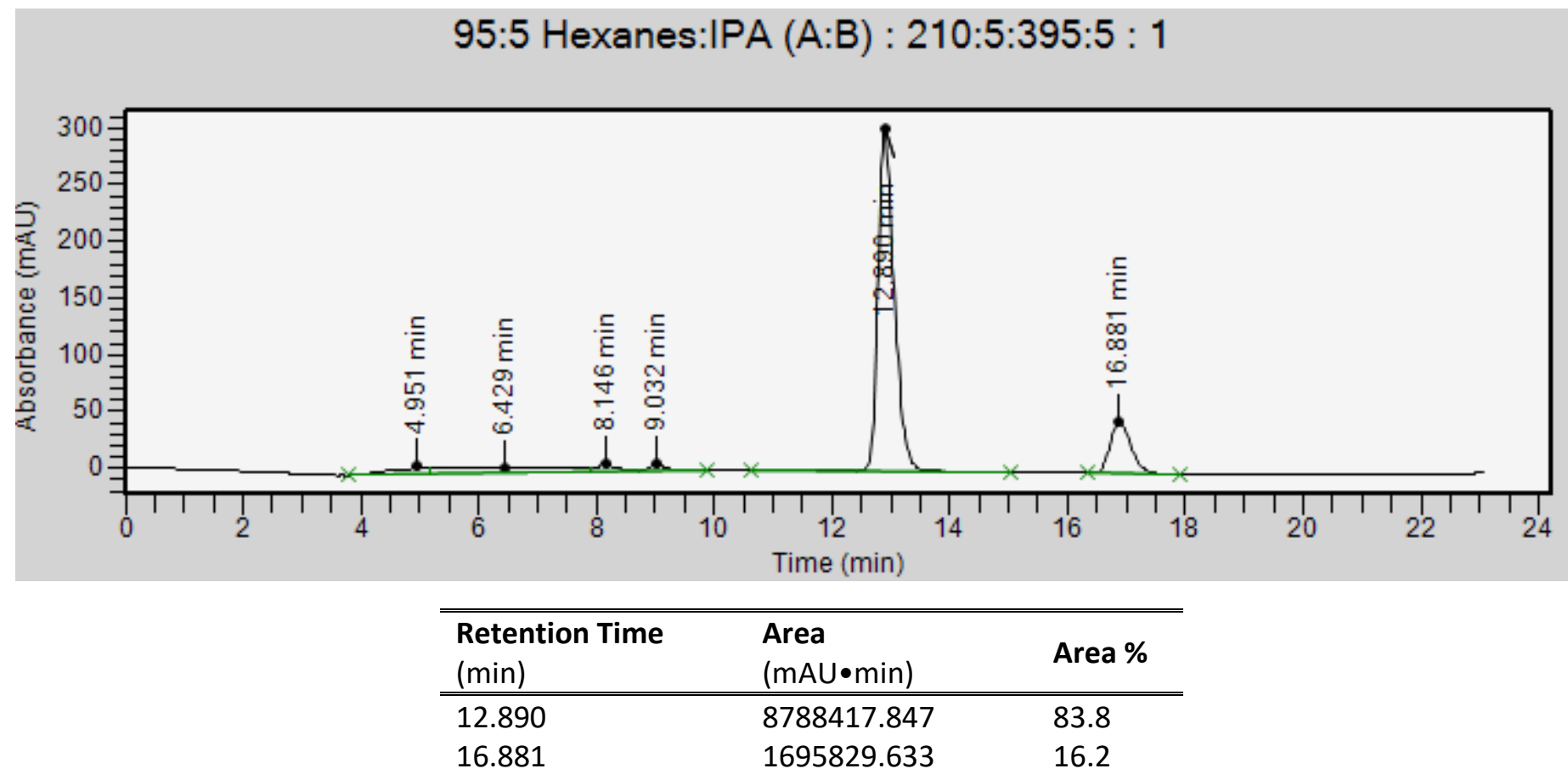


A colorless crystal (approximate dimensions $0.100 \times 0.100 \times 0.100 \mathrm{~mm}^{3}$ ) was placed onto the tip of MiTeGen and mounted on a Bruker SMART Apex II diffractometer and measured at $150 \mathrm{~K}$.

Data collection

A preliminary set of cell constants was calculated from reflections harvested from three sets of 12 frames. These initial sets of frames were oriented such that orthogonal wedges of reciprocal space were surveyed. This produced initial orientation matrices determined from 97 reflections. The data collection was carried out using $\mathrm{Cu} \mathrm{K} \alpha$ radiation (graphite monochromator) with a frame time of 10 seconds and a detector distance of $4.0 \mathrm{~cm}$. A randomly oriented region of reciprocal space was surveyed to achieve complete data with a redundancy of 4 . Sections of frames were collected with $0.50^{\circ}$ steps in $\omega$ and $\phi$ scans. Data to a resolution of $0.84 \AA$ were considered in the reduction. Final cell constants were calculated from the xyz centroids of 6009 strong reflections from the actual data collection after integration (SAINT). ${ }^{1}$ The intensity data were corrected for absorption (SADABS). ${ }^{2}$ Please refer to Table 1 for additional crystal and refinement information.

Structure solution and refinement

The space group P21/c was determined based on intensity statistics and systematic absences. The structure was solved using Superflip ${ }^{3}$ and refined (full-matrix-least squares) using the Oxford University Crystals for Windows system. ${ }^{4}$ The charge-flipping solution provided most non-hydrogen atoms from the E-map. Fullmatrix least squares / difference Fourier cycles were performed, which located the remaining non-hydrogen atoms.

Two isomers were proposed in the submission of structure 19005 with ethylene oxide on the different carbons of the cyclohexene. Structure solution showed that the 2-part disorder, located at $\mathrm{C}(2)-\mathrm{C}(3)$ and $\mathrm{C}(41)-\mathrm{C}(51)$, respectively, indicates co-crystallization of the two proposed structures took place in 84:16 ratio. All nonhydrogen atoms were refined with anisotropic displacement parameters. The hydrogen atoms were placed in ideal positions and refined as riding atoms. The final full matrix least squares refinement converged to $\mathrm{R} 1=$ 0.0425 and $\mathrm{wR} 2=0.1063\left(\mathrm{~F}^{2}\right.$, all data $)$.

Structure description

Two proposed structures were co-crystallized in 84:16 ratio.

${ }^{1}$ SAINT, Bruker Analytical X-Ray Systems, Madison, WI, current version.

${ }^{2}$ An empirical correction for absorption anisotropy, R. Blessing, Acta Cryst. A51, 33 - 38 (1995).

${ }^{3}$ Palatinus L., Chapuis G. (2007): Superflip - a computer program for the solution of crystal structures by charge flipping in arbitrary dimensions. J. Appl. Cryst. 40, 786-790.

${ }^{4}$ Betteridge, P. W.; Carruthers, J. R.; Cooper, R. I.; Prout, K.; Watkin, D. J. J. Appl. Cryst. 2003, $36,1487$. 


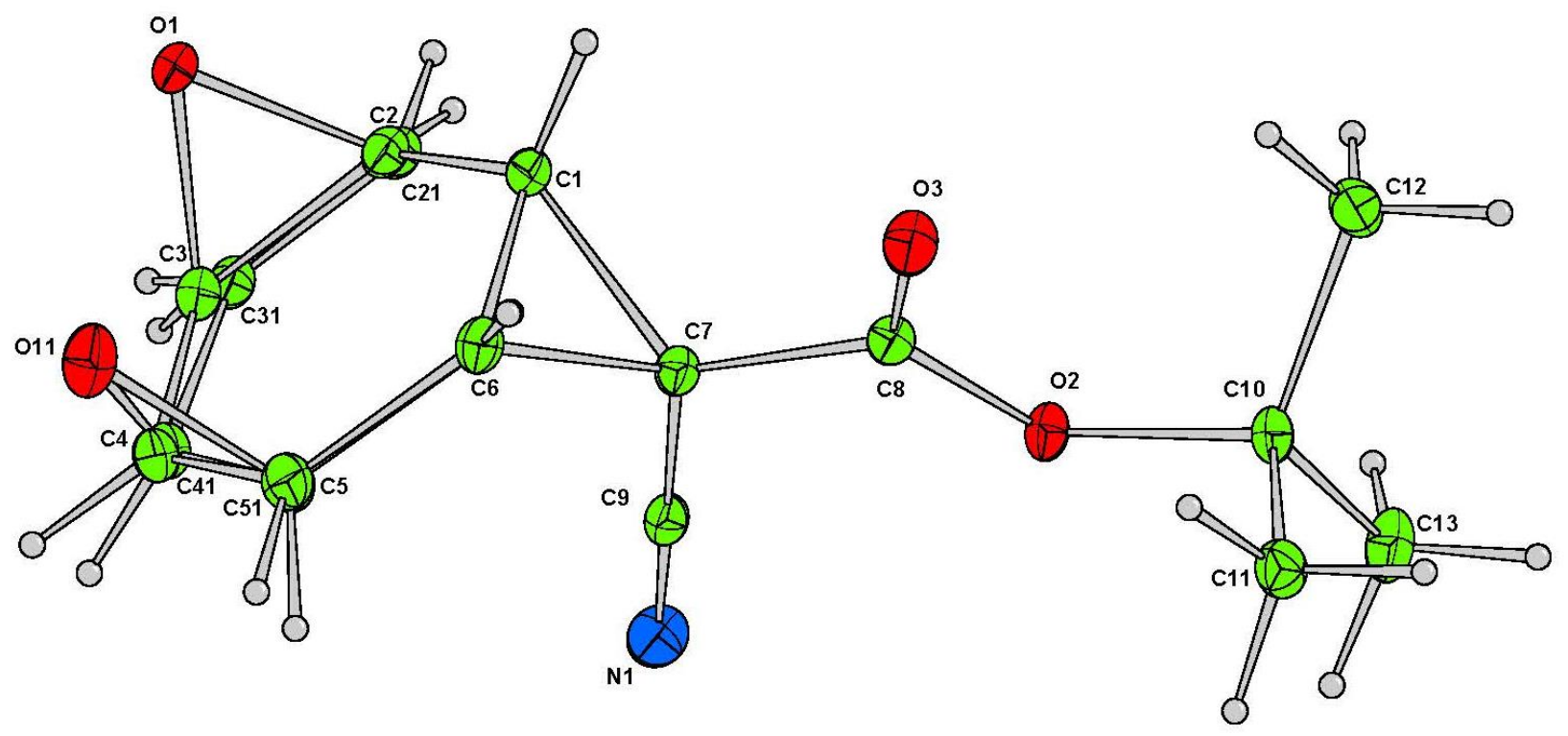

Molecular structure with labels on the asymmetric unit

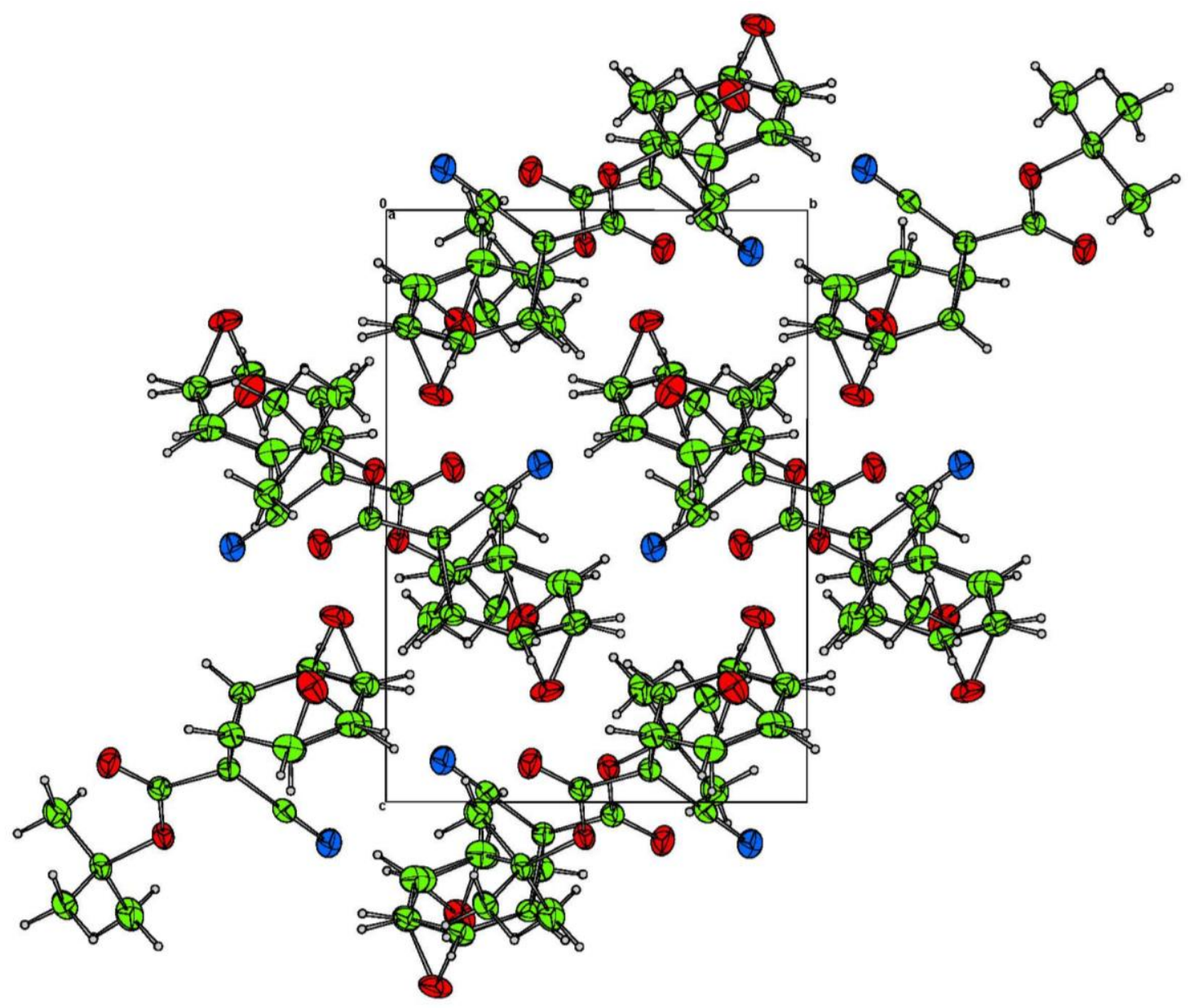

Cell plot, viewed along a- axis 


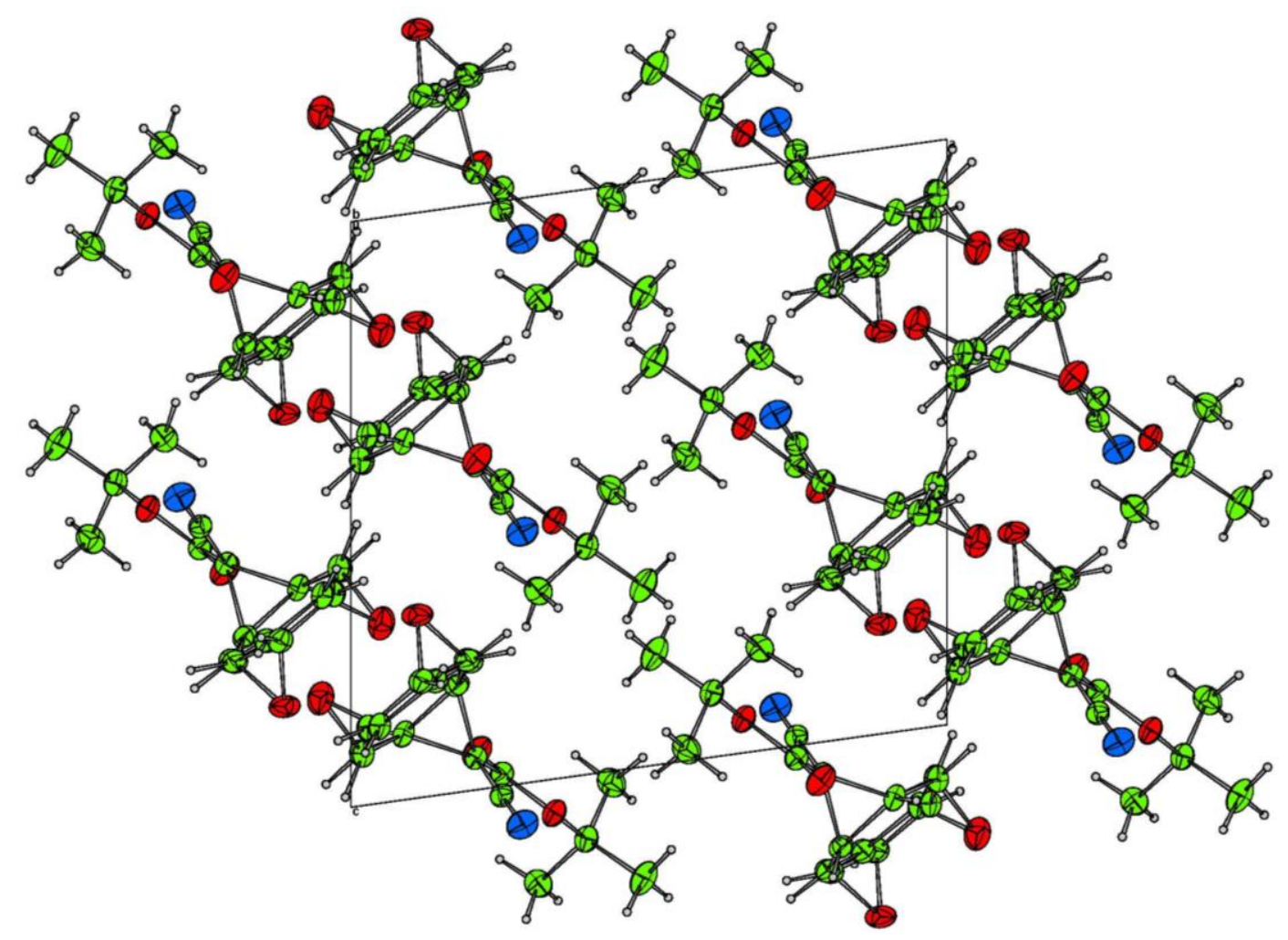

Cell plot, viewed along $b$ - axis

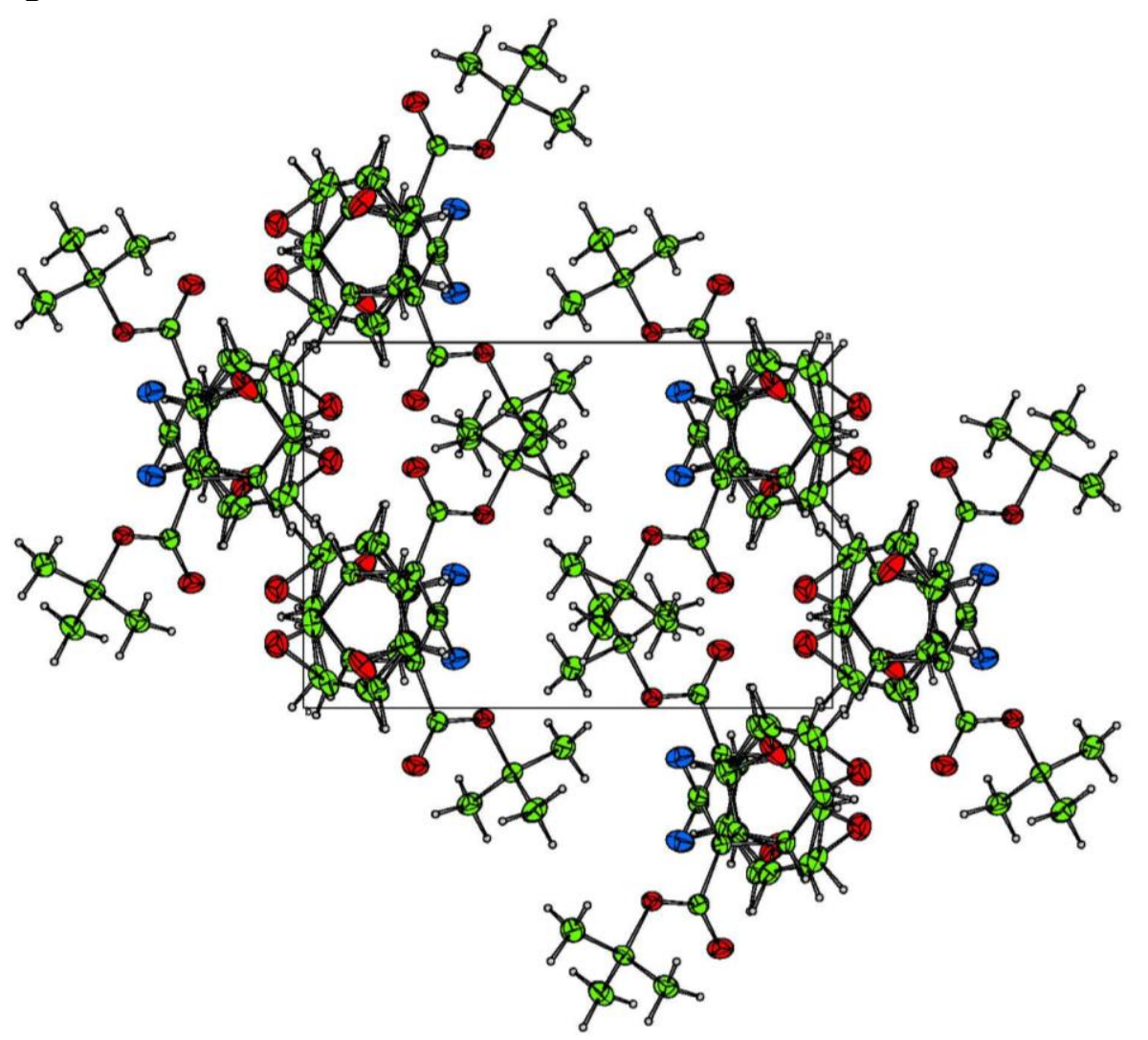

Cell plot, viewed along c- axis

Table 1. Crystal data and structure refinement for 19005.

Empirical formula

C13 H15 N1 O3.00

Formula weight 
Crystal color, shape, size

Temperature

Wavelength

Crystal system, space group

Unit cell dimensions

Volume

Z

Density (calculated)

Absorption coefficient

$\mathrm{F}(000)$

Data collection

Diffractometer

Theta range for data collection

Index ranges

Reflections collected

Independent reflections

Observed Reflections

Completeness to theta $=72.398^{\circ}$

Solution and Refinement

Absorption correction

Max. and min. transmission

Solution

Refinement method

Weighting scheme

Data / restraints / parameters

Goodness-of-fit on $\mathrm{F}^{2}$

Final $\mathrm{R}$ indices [I $>2 \operatorname{sigma}(\mathrm{I})]$

$\mathrm{R}$ indices (all data)

Largest diff. peak and hole colorless block fragment, $0.100 \times 0.100 \times 0.100 \mathrm{~mm}^{3}$

$150 \mathrm{~K}$

$1.54178 \AA$

Monoclinic, $\mathrm{P} 21 / \mathrm{c}$

$\mathrm{a}=12.1971(3) \AA \quad \alpha=90^{\circ}$.

$\mathrm{b}=8.3395(2) \AA$

$\beta=97.8644(14)^{\circ}$.

$\mathrm{c}=11.8517(3) \AA$

$\gamma=90^{\circ}$.

$1194.19(5) \AA^{3}$

4

$1.297 \mathrm{Mg} / \mathrm{m}^{3}$

$0.758 \mathrm{~mm}^{-1}$

496

Bruker Apex Kappa Duo, Bruker

3.658 to $72.398^{\circ}$.

$-14<=\mathrm{h}<=15,-10<=\mathrm{k}<=10,-14<=\mathrm{l}<=14$

17451

$2369[\mathrm{R}($ int $)=0.027]$

2196

$100.0 \%$

Semi-empirical from equivalents

0.93 and 0.93

Direct methods

Full-matrix least-squares on $\mathrm{F}^{2}$

$\mathrm{w}=\left[\sigma^{2} \mathrm{Fo}^{2}+\mathrm{AP}^{2}+\mathrm{BP}\right]^{-1}$, with

$\mathrm{P}=\left(\mathrm{Fo}^{2}+2 \mathrm{Fc}^{2}\right) / 3, \mathrm{~A}=0.043, \mathrm{~B}=0.853$

$2360 / 85 / 200$

1.0339

$\mathrm{R} 1=0.0425, \mathrm{wR} 2=0.1047$

$\mathrm{R} 1=0.0451, \mathrm{wR} 2=0.1063$

0.26 and -0.21 e. $\AA^{-3}$ 
Table 2. Atomic coordinates ( $\left.\times 10^{4}\right)$ and equivalent isotropic displacement parameters $\left(\AA^{2} \times 10^{3}\right)$ for 19005 . $\mathrm{U}(\mathrm{eq})$ is defined as one third of the trace of the orthogonalized $\mathrm{U}^{\mathrm{ij}}$ tensor.

\begin{tabular}{|c|c|c|c|c|}
\hline & $\mathrm{x}$ & y & $\mathrm{z}$ & $\mathrm{U}(\mathrm{eq})$ \\
\hline $\mathrm{O} 1$ & $1114(1)$ & $6177(2)$ & 1878(1) & 36 \\
\hline $\mathrm{O} 2$ & $3410(1)$ & $10287(1)$ & $5580(1)$ & 24 \\
\hline $\mathrm{O} 3$ & $2118(1)$ & $11578(1)$ & 4349(1) & 33 \\
\hline O11 & $-508(6)$ & $6754(10)$ & $3069(7)$ & 39 \\
\hline N1 & $2877(1)$ & $6351(2)$ & $5700(1)$ & 34 \\
\hline $\mathrm{C} 1$ & $1780(1)$ & $8415(2)$ & $3165(1)$ & 25 \\
\hline $\mathrm{C} 2$ & 1945(7) & $6749(3)$ & $2758(10)$ & 28 \\
\hline C3 & $1187(2)$ & $5482(2)$ & $3016(3)$ & 28 \\
\hline $\mathrm{C} 4$ & $280(2)$ & $5859(2)$ & $3683(3)$ & 28 \\
\hline $\mathrm{C} 5$ & 157(7) & $7320(4)$ & 4096(9) & 30 \\
\hline C6 & $882(1)$ & $8677(2)$ & $3875(1)$ & 26 \\
\hline $\mathrm{C} 7$ & 2097(1) & $8736(2)$ & $4452(1)$ & 22 \\
\hline $\mathrm{C} 8$ & 2531(1) & $10379(2)$ & 4782(1) & 23 \\
\hline C9 & $2529(1)$ & $7408(2)$ & 5153(1) & 23 \\
\hline $\mathrm{C} 10$ & $3949(1)$ & $11768(2)$ & $6100(1)$ & 24 \\
\hline $\mathrm{C} 11$ & $3140(1)$ & $12627(2)$ & $6748(1)$ & 31 \\
\hline $\mathrm{C} 12$ & $4369(1)$ & 12803(2) & $5196(2)$ & 34 \\
\hline $\mathrm{C} 13$ & 4910(1) & $11081(2)$ & $6905(2)$ & 37 \\
\hline $\mathrm{C} 21$ & 2010(40) & $6778(14)$ & $2790(50)$ & 28 \\
\hline C31 & $1415(12)$ & $5515(10)$ & $3039(17)$ & 27 \\
\hline C41 & $478(12)$ & $5685(11)$ & $3688(18)$ & 29 \\
\hline C51 & $210(40)$ & 7261(19) & $4120(50)$ & 30 \\
\hline
\end{tabular}


Table 3. Bond lengths $[\AA ̊]$ and angles $\left[{ }^{\circ}\right]$ for 19005.

\begin{tabular}{|c|c|c|c|c|}
\hline $\mathrm{O} 1-\mathrm{C} 2$ & $1.433(12)$ & $\mathrm{O} 1-\mathrm{C} 3$ & $1.461(4)$ & $\mathrm{O} 2-\mathrm{C} 8$ \\
\hline $1.3309(17)$ & $\mathrm{O} 2-\mathrm{C} 10$ & $1.4912(17)$ & \multicolumn{2}{|c|}{$1.2027(18)$} \\
\hline O11-C41 & $1.59(2)$ & O11-C51 & 1.48(6) N1-C9 & $1.142(2)$ \\
\hline $\mathrm{C} 1-\mathrm{C} 2$ & 1.494(3) & C1-C6 & $1.4862(18)$ & $\mathrm{C} 1-\mathrm{C} 7$ \\
\hline $1.5455(19)$ & C1-H11 & 0.950 & \multicolumn{2}{|c|}{$1.464(3)$} \\
\hline $\mathrm{C} 2-\mathrm{H} 21$ & 0.950 & $\mathrm{C} 3-\mathrm{C} 4$ & $1.478(3)$ & C3-H31 \\
\hline 0.950 & C4-C5 & $1.329(3)$ & $\mathrm{C} 4-\mathrm{H} 41 \quad 0.950$ & C5-C6 \\
\hline $1.481(3)$ & C5-H51 & 0.950 & C6-C7 1.5459 & $1.5459(19)$ \\
\hline C6-H61 & 0.950 & $\mathrm{C} 7-\mathrm{C} 8$ & $1.502(2)$ & C7-C9 \\
\hline $1.439(2)$ & $\mathrm{C} 10-\mathrm{C} 11$ & $1.511(2)$ & $\mathrm{C} 10-\mathrm{C} 12 \quad 1.518(2$ & $1.518(2)$ \\
\hline $\mathrm{C} 10-\mathrm{C} 13$ & $1.519(2)$ & C11-H111 & $0.950 \quad \mathrm{C} 11-\mathrm{H} 1$ & C11-H112 \\
\hline 0.950 & C11-H113 & 0.950 & C12-H121 0.950 & C12- \\
\hline H122 & 0.950 & $\mathrm{C} 12-\mathrm{H} 123$ & $0.950 \quad \mathrm{C} 13-\mathrm{H} 1$ & C13-H131 \\
\hline 0.950 & C13-H132 & 0.950 & C13-H134 0.950 & $\mathrm{C} 21-$ \\
\hline C31 & $1.333(8)$ & $\mathrm{C} 21-\mathrm{H} 211$ & $0.950 \quad \mathrm{C} 31-\mathrm{C} 4$ & C31-C41 \\
\hline $1.469(7)$ & C31-H311 & 0.950 & C41-C51 1.464(8 & $1.464(8)$ \\
\hline C41-H411 & 0.950 & C51-H511 & 0.950 & \\
\hline $\mathrm{C} 2-\mathrm{O} 1-\mathrm{C} 3$ & $60.8(3)$ & $\mathrm{C} 8-\mathrm{O} 2-\mathrm{C} 10$ & $120.84(11)$ & C41- \\
\hline O11-C51 & $56.8(13)$ & C2-C1-C6 & \multicolumn{2}{|c|}{ 117.55(7) C2-C1-C7 } \\
\hline $117.0(5)$ & $\mathrm{C} 6-\mathrm{C} 1-\mathrm{C} 7$ & $61.28(9)$ & C2-C1-H11 & 116.8 \\
\hline C6-C1-H11 & 116.3 & C7-C1-H11 & 116.3 C1-C2- & $\mathrm{C} 1-\mathrm{C} 2-\mathrm{O} 1$ \\
\hline $115.6(7)$ & $\mathrm{C} 1-\mathrm{C} 2-\mathrm{C} 3$ & $119.13(8)$ & $\mathrm{O} 1-\mathrm{C} 2-\mathrm{C} 3$ & $60.5(3)$ \\
\hline $\mathrm{C} 1-\mathrm{C} 2-\mathrm{H} 21$ & 116.2 & $\mathrm{O} 1-\mathrm{C} 2-\mathrm{H} 21$ & 117.2 C3-C2- & $\mathrm{C} 3-\mathrm{C} 2-\mathrm{H} 21$ \\
\hline 116.7 & $\mathrm{C} 2-\mathrm{C} 3-\mathrm{O} 1$ & $58.7(5)$ & \multicolumn{2}{|c|}{$\mathrm{C} 2-\mathrm{C} 3-\mathrm{C} 4$} \\
\hline $119.89(8)$ & $\mathrm{O} 1-\mathrm{C} 3-\mathrm{C} 4$ & $117.0(2)$ & C2-C3-H31 & 114.9 \\
\hline O1-C3-H31 & 116.5 & $\mathrm{C} 4-\mathrm{C} 3-\mathrm{H} 31$ & 117.1 C3-C4- & C3-C4-C5 \\
\hline $121.51(8)$ & $\mathrm{C} 3-\mathrm{C} 4-\mathrm{H} 41$ & 118.9 & C5-C4-H41 & 119.6 \\
\hline C4-C5-C6 & $122.34(8)$ & C4-C5-H51 & 118.6 C6-C5- & C6-C5-H51 \\
\hline 119.1 & C1-C6-C5 & $119.44(7)$ & C1-C6-C7 & $61.25(9)$ \\
\hline C5-C6-C7 & $120.3(5)$ & C1-C6-H61 & C5-C6- & C5-C6-H61 \\
\hline 114.6 & C7-C6-H61 & 115.5 & C1-C7-C6 & $57.47(8)$ \\
\hline $\mathrm{C} 1-\mathrm{C} 7-\mathrm{C} 8$ & $116.54(12)$ & C6-C7-C8 & $115.26(11)$ & C1-C7- \\
\hline $\mathrm{C} 9$ & $117.29(12)$ & C6-C7-C9 & $118.96(12)$ & C8-C7- \\
\hline C9 & $117.61(12)$ & $\mathrm{C} 7-\mathrm{C} 8-\mathrm{O} 2$ & $110.72(12)$ & C7-C8- \\
\hline $\mathrm{O} 3$ & $122.35(13)$ & $\mathrm{O} 2-\mathrm{C} 8-\mathrm{O} 3$ & $126.92(14)$ & C7-C9- \\
\hline N1 & $179.34(16)$ & $\mathrm{O} 2-\mathrm{C} 10-\mathrm{C} 11$ & $108.74(11)$ & $\mathrm{O} 2-\mathrm{C} 10-$ \\
\hline $\mathrm{C} 12$ & $110.62(12)$ & C11-C10-C12 & $113.30(13)$ & $\mathrm{O} 2-\mathrm{C} 10-$ \\
\hline C13 & 101.92(12) & C11-C10-C13 & $111.14(13)$ & $\mathrm{C} 12-$ \\
\hline $\mathrm{C} 10-\mathrm{C} 13$ & $110.53(14)$ & C10-C11-H111 & 109.5 C10-C1 & C10-C11-H112 \\
\hline 109.5 & H111-C11-H112 & 109.5 & C10-C11-H113 & 109.5 \\
\hline H111-C11-H113 & 109.5 & H112-C11-H113 & 109.5 C10-C1 & C10-C12-H121 \\
\hline
\end{tabular}




$\begin{array}{lcl}109.5 & \mathrm{C} 10-\mathrm{C} 12-\mathrm{H} 122 & 109.5 \\ \mathrm{C} 10-\mathrm{C} 12-\mathrm{H} 123 & 109.5 & \mathrm{H} 121-\mathrm{C} 12-\mathrm{H} 123 \\ 109.5 & \mathrm{C} 10-\mathrm{C} 13-\mathrm{H} 131 & 109.5 \\ \mathrm{H} 131-\mathrm{C} 13-\mathrm{H} 132 & 109.5 & \mathrm{C} 10-\mathrm{C} 13-\mathrm{H} 134 \\ 109.5 & \mathrm{H} 132-\mathrm{C} 13-\mathrm{H} 134 & 109.5 \\ 122.37(9) & \mathrm{C} 1-\mathrm{C} 21-\mathrm{H} 211 & 121.6 \\ \mathrm{C} 21-\mathrm{C} 31-\mathrm{C} 41 & 121.54(9) & \mathrm{C} 21-\mathrm{C} 31-\mathrm{H} 311 \\ 113.0 & \mathrm{O} 11-\mathrm{C} 41-\mathrm{C} 31 & 113.9(14) \\ \text { C31-C41-C51 } & 119.92(9) & \mathrm{O} 11-\mathrm{C} 41-\mathrm{H} 411 \\ 120.7 & \mathrm{C} 51-\mathrm{C} 41-\mathrm{H} 411 & 114.4 \\ \text { C6-C51-C41 } & 119.11(9) & \mathrm{O} 11-\mathrm{C} 51-\mathrm{C} 41 \\ 117.2 & \text { O11-C51-H511 } & 118.8 \\ \end{array}$

Symmetry transformations used to generate equivalent atoms: 
Table 4. Anisotropic displacement parameters $\left(\AA^{2} \times 10^{3}\right)$ for 19005. The anisotropic displacement factor exponent takes the form: $-2 \pi^{2}\left[h^{2} a^{* 2} U^{11}+\ldots+2 h k a^{*} b^{*} U^{12}\right]$

\begin{tabular}{lllllll}
\hline & $\mathrm{U}^{11}$ & $\mathrm{U}^{22}$ & $\mathrm{U}^{33}$ & $\mathrm{U}^{23}$ & $\mathrm{U}^{13}$ & $\mathrm{U}^{12}$ \\
\hline $\mathrm{O} 1$ & $41(1)$ & $46(1)$ & $21(1)$ & $-7(1)$ & $3(1)$ & $-20(1)$ \\
$\mathrm{O} 2$ & $24(1)$ & $19(1)$ & $29(1)$ & $-2(1)$ & $-3(1)$ & $0(1)$ \\
$\mathrm{O} 3$ & $37(1)$ & $22(1)$ & $37(1)$ & $4(1)$ & $-7(1)$ & $2(1)$ \\
$\mathrm{O} 11$ & $30(4)$ & $40(4)$ & $46(4)$ & $-10(3)$ & $-1(3)$ & $-1(3)$ \\
$\mathrm{N} 1$ & $43(1)$ & $25(1)$ & $34(1)$ & $2(1)$ & $-1(1)$ & $4(1)$ \\
$\mathrm{C} 1$ & $25(1)$ & $28(1)$ & $21(1)$ & $2(1)$ & $-1(1)$ & $-5(1)$ \\
$\mathrm{C} 2$ & $27(2)$ & $34(1)$ & $22(1)$ & $-6(1)$ & $3(1)$ & $-6(1)$ \\
$\mathrm{C} 3$ & $28(1)$ & $30(1)$ & $25(1)$ & $-4(1)$ & $1(1)$ & $-7(1)$ \\
$\mathrm{C} 4$ & $21(1)$ & $35(1)$ & $28(1)$ & $0(1)$ & $2(1)$ & $-7(1)$ \\
$\mathrm{C} 5$ & $20(1)$ & $40(1)$ & $31(1)$ & $-2(1)$ & $3(1)$ & $-3(1)$ \\
$\mathrm{C} 6$ & $20(1)$ & $29(1)$ & $28(1)$ & $-1(1)$ & $-2(1)$ & $1(1)$ \\
$\mathrm{C} 7$ & $21(1)$ & $21(1)$ & $22(1)$ & $-1(1)$ & $0(1)$ & $0(1)$ \\
$\mathrm{C} 8$ & $24(1)$ & $23(1)$ & $23(1)$ & $-1(1)$ & $2(1)$ & $0(1)$ \\
$\mathrm{C} 9$ & $23(1)$ & $22(1)$ & $23(1)$ & $-4(1)$ & $2(1)$ & $-1(1)$ \\
$\mathrm{C} 10$ & $24(1)$ & $20(1)$ & $29(1)$ & $-4(1)$ & $0(1)$ & $-4(1)$ \\
$\mathrm{C} 11$ & $33(1)$ & $26(1)$ & $34(1)$ & $-6(1)$ & $7(1)$ & $-4(1)$ \\
$\mathrm{C} 12$ & $34(1)$ & $32(1)$ & $37(1)$ & $-4(1)$ & $10(1)$ & $-8(1)$ \\
$\mathrm{C} 13$ & $32(1)$ & $31(1)$ & $44(1)$ & $-5(1)$ & $-10(1)$ & $-2(1)$ \\
$\mathrm{C} 21$ & $26(2)$ & $33(2)$ & $23(2)$ & $-6(2)$ & $3(2)$ & $-6(2)$ \\
$\mathrm{C} 31$ & $26(2)$ & $32(2)$ & $24(2)$ & $-5(2)$ & $3(2)$ & $-5(2)$ \\
$\mathrm{C} 41$ & $21(2)$ & $36(2)$ & $30(2)$ & $-1(2)$ & $1(2)$ & $-6(2)$ \\
$\mathrm{C} 51$ & $20(2)$ & $38(2)$ & $30(2)$ & $-1(2)$ & $2(2)$ & $-4(2)$ \\
& & & & & & \\
\hline
\end{tabular}


Table 5. Hydrogen coordinates ( x 104) and isotropic displacement parameters $\left(\AA^{2} \times 10^{3}\right)$ for 19005 .

\begin{tabular}{|c|c|c|c|c|}
\hline & $\mathrm{x}$ & $\mathrm{y}$ & $\mathrm{z}$ & $\mathrm{U}(\mathrm{eq})$ \\
\hline H11 & 1912 & 9265 & 2667 & 30 \\
\hline $\mathrm{H} 21$ & 2688 & 6439 & 2716 & 33 \\
\hline H31 & 1507 & 4444 & 3114 & 37 \\
\hline $\mathrm{H} 41$ & -211 & 5027 & 3835 & 35 \\
\hline H51 & -416 & 7494 & 4551 & 37 \\
\hline H61 & 516 & 9684 & 3778 & 31 \\
\hline H111 & 3476 & 13573 & 7083 & 37 \\
\hline H112 & 2941 & 11945 & 7328 & 37 \\
\hline H113 & 2497 & 12905 & 6240 & 37 \\
\hline H121 & 4710 & 13739 & 5542 & 41 \\
\hline H122 & 3767 & 13102 & 4642 & 41 \\
\hline H123 & 4895 & 12215 & 4841 & 41 \\
\hline H131 & 5322 & 11932 & 7291 & 45 \\
\hline H132 & 4634 & 10402 & 7444 & 45 \\
\hline H134 & 5376 & 10481 & 6482 & 45 \\
\hline H211 & 2619 & 6553 & 2397 & 23 \\
\hline H311 & 1553 & 4433 & 2849 & 28 \\
\hline H411 & 242 & 4806 & 4105 & 33 \\
\hline H511 & -94 & 7261 & 4816 & 34 \\
\hline H12 & 1913 & 9262 & 2665 & 30 \\
\hline H62 & 503 & 9675 & 3780 & 31 \\
\hline
\end{tabular}


Table 6. Torsion angles $\left[{ }^{\circ}\right]$ for 19005.

\begin{tabular}{lcl}
\hline $\mathrm{C} 3-\mathrm{O} 1-\mathrm{C} 2-\mathrm{C} 1$ & $-110-47(1)$ & $\mathrm{C} 2-\mathrm{O} 1-\mathrm{C} 3-\mathrm{C} 4$ \\
$4.48(1)$ & $\mathrm{C} 10-\mathrm{O} 2-\mathrm{C} 8-\mathrm{C} 7$ & $-176.23(1)$ \\
$\mathrm{C} 8-\mathrm{O} 2-\mathrm{C} 10-\mathrm{C} 12$ & $-60.37(1)$ & $\mathrm{C} 8-\mathrm{O} 2-\mathrm{C} 10-\mathrm{C} 13$ \\
$72.39(1)$ & $\mathrm{C} 6-\mathrm{C} 1-\mathrm{C} 2-\mathrm{C} 3$ & $3.37(1)$ \\
$142.37(1)$ & $\mathrm{C} 7-\mathrm{C} 1-\mathrm{C} 2-\mathrm{C} 3$ & $73.35(1)$ \\
$\mathrm{C} 2-\mathrm{C} 1-\mathrm{C} 6-\mathrm{C} 7$ & $107.33(1)$ & $\mathrm{C} 7-\mathrm{C} 1-\mathrm{C} 6-\mathrm{C} 5$ \\
$-108.20(1)$ & $\mathrm{C} 2-\mathrm{C} 1-\mathrm{C} 7-\mathrm{C} 8$ & $147.47(1)$ \\
$\mathrm{C} 6-\mathrm{C} 1-\mathrm{C} 7-\mathrm{C} 8$ & $-104.33(1)$ & $\mathrm{C} 6-\mathrm{C} 1-\mathrm{C} 7-\mathrm{C} 9$ \\
$-105.19(1)$ & $\mathrm{C} 1-\mathrm{C} 2-\mathrm{C} 3-\mathrm{O} 1$ & $104.60(1)$ \\
$\mathrm{O} 1-\mathrm{C} 3-\mathrm{C} 4-\mathrm{C} 5$ & $-70.34(1)$ & $\mathrm{C} 2-\mathrm{C} 3-\mathrm{C} 4-\mathrm{C} 5$ \\
$2.88(1)$ & $\mathrm{C} 4-\mathrm{C} 5-\mathrm{C} 6-\mathrm{C} 1$ & $0.13(1)$ \\
$71.80(1)$ & $\mathrm{C} 1-\mathrm{C} 6-\mathrm{C} 7-\mathrm{C} 8$ & $106.52(1)$ \\
$105.56(1)$ & $\mathrm{C} 5-\mathrm{C} 6-\mathrm{C} 7-\mathrm{C} 1$ & $109.19(1)$ \\
$144.30(1)$ & $\mathrm{C} 5-\mathrm{C} 6-\mathrm{C} 7-\mathrm{C} 9$ & $3.63(1)$ \\
$136.00(1)$ & $\mathrm{C} 1-\mathrm{C} 7-\mathrm{C} 8-\mathrm{O} 3$ & $43.33(1)$ \\
$159.42(1)$ & $\mathrm{C} 6-\mathrm{C} 7-\mathrm{C} 8-\mathrm{O} 3$ & $-21.25(1)$ \\
$\mathrm{C} 9-\mathrm{C} 7-\mathrm{C} 8-\mathrm{O} 3$ & $-169.60(1)$ & \\
& & \\
\hline
\end{tabular}

110.23(1) C10-O2-C8-O3

C8-O2-C10-C11 64.66(1)

-177.99 (1) C6-C1-C2-O1

$\mathrm{C} 7-\mathrm{C} 1-\mathrm{C} 2-\mathrm{O} 1$

C2-C1-C6-C5 -3.24(1)

$-110.57(1) \mathrm{C} 2-\mathrm{C} 1-\mathrm{C} 7-\mathrm{C} 6$

C2-C1-C7-C9 0.27(1)

108.47(1) O1-C2-C3-C4

C1-C2-C3-C4 $-0.59(1)$

-2.66 (1) C3-C4-C5-C6

C4-C5-C6-C7 -

$\mathrm{C} 1-\mathrm{C} 6-\mathrm{C} 7-\mathrm{C} 9$ -

$\mathrm{C} 5-\mathrm{C} 6-\mathrm{C} 7-\mathrm{C} 8$ -

$\mathrm{C} 1-\mathrm{C} 7-\mathrm{C} 8-\mathrm{O} 2$

$\mathrm{C} 6-\mathrm{C} 7-\mathrm{C} 8-\mathrm{O} 2$

C9-C7-C8-O2 11.07(1)

Symmetry transformations used to generate equivalent atoms: 
A green crystal (approximate dimensions $0.200 \times 0.100 \times 0.100 \mathrm{~mm}^{3}$ ) was placed onto the tip of MiTeGen and mounted on an Apex Kappa Duo diffractometer and measured at $150 \mathrm{~K}$.

\section{Data collection}

A preliminary set of cell constants was calculated from reflections harvested from three sets of 12 frames. These initial sets of frames were oriented such that orthogonal wedges of reciprocal space were surveyed. This produced initial orientation matrices determined from 144 reflections. The data collection was carried out using $\mathrm{Mo} \mathrm{K} \alpha$ radiation (graphite monochromator) with a frame time of 9 seconds and a detector distance of $5.0 \mathrm{~cm}$. A randomly oriented region of reciprocal space was surveyed to achieve complete data with a redundancy of 4 . Sections of frames were collected with $0.50^{\circ}$ steps in $\omega$ and $\phi$ scans. Data to a resolution of $0.82 \AA$ were considered in the reduction. Final cell constants were calculated from the xyz centroids of 9890 strong reflections from the actual data collection after integration (SAINT). ${ }^{1}$ The intensity data were corrected for absorption (SADABS). ${ }^{2}$ Please refer to Table 1 for additional crystal and refinement information.

\section{Structure solution and refinement}

The space group $P 21$ was determined based on intensity statistics and systematic absences. The structure was solved using Superflip ${ }^{3}$ and refined (full-matrix-least squares) using the Oxford University Crystals for Windows system. ${ }^{4}$ The charge-flipping solution provided most non-hydrogen atoms from the E-map. Full-matrix least squares / difference Fourier cycles were performed, which located the remaining non-hydrogen atoms. All nonhydrogen atoms were refined with anisotropic displacement parameters. Hydrogen atoms involved in hydrogen bonding were generated geometrically and were refined their position, and the rest of the hydrogen atoms were placed in ideal positions and refined as riding atoms. The final full matrix least squares refinement converged to $\mathrm{R} 1=0.0313$ and $\mathrm{wR} 2=0.0686\left(\mathrm{~F}^{2}\right.$, all data $)$.

\section{Structure description}

The structure was found as proposed.

${ }^{1}$ SAINT, Bruker Analytical X-Ray Systems, Madison, WI, current version.

2 An empirical correction for absorption anisotropy, R. Blessing, Acta Cryst. A51, 33 - 38 (1995).

${ }^{3}$ Palatinus L., Chapuis G. (2007): Superflip - a computer program for the solution of crystal structures by charge flipping in arbitrary dimensions. J. Appl. Cryst. 40, 786-790.

${ }^{4}$ Betteridge, P. W.; Carruthers, J. R.; Cooper, R. I.; Prout, K.; Watkin, D. J. J. Appl. Cryst. 2003, $36,1487$. 


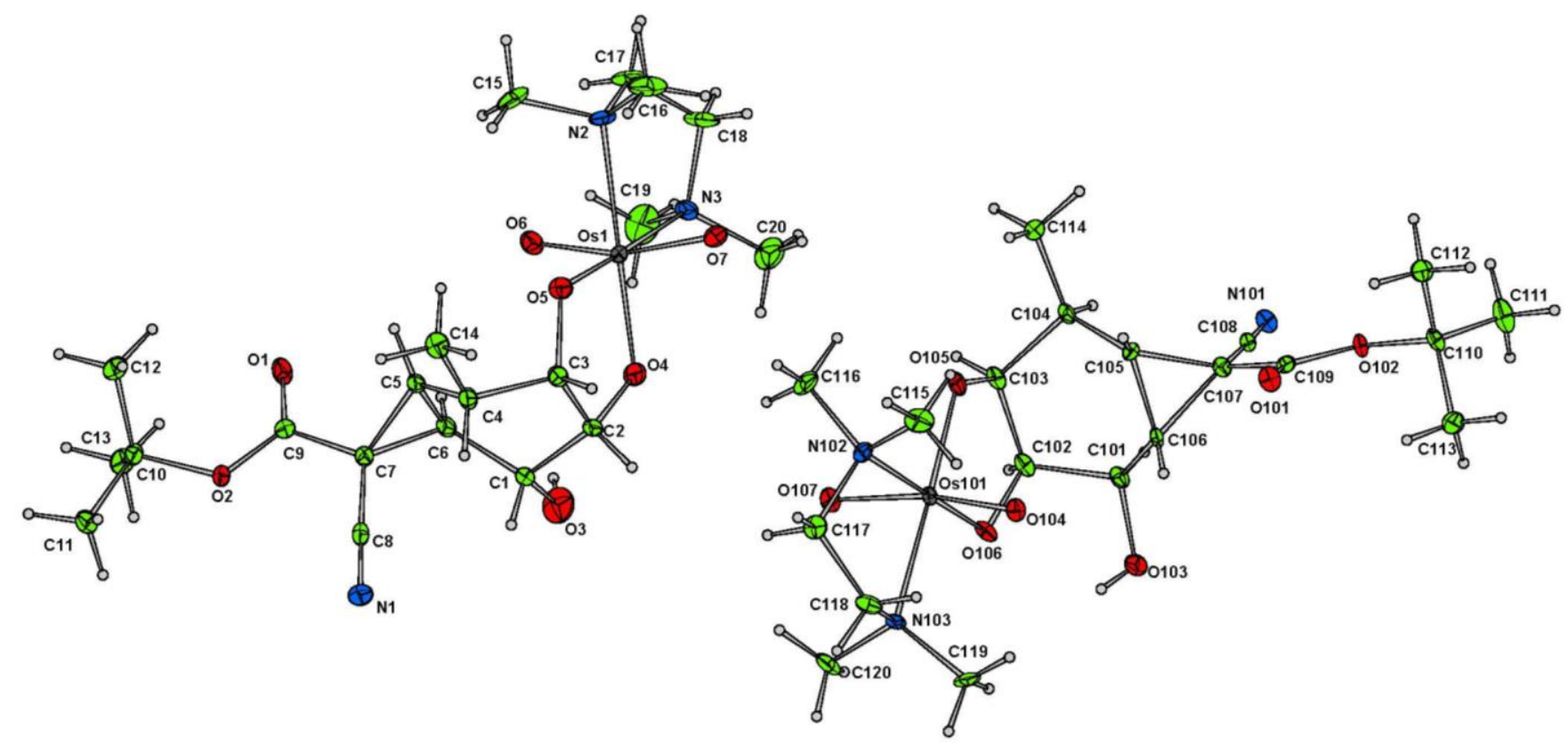

Molecular structure with labels on the asymmetric unit

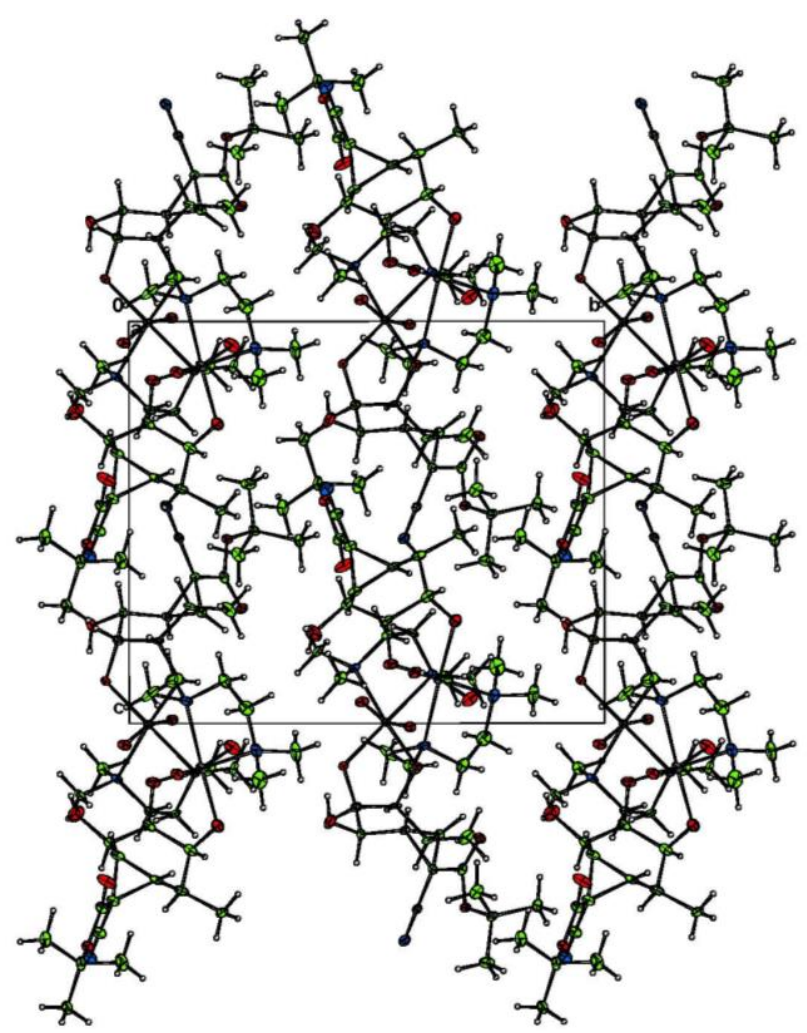

Cell plot, viewed along a- axis 

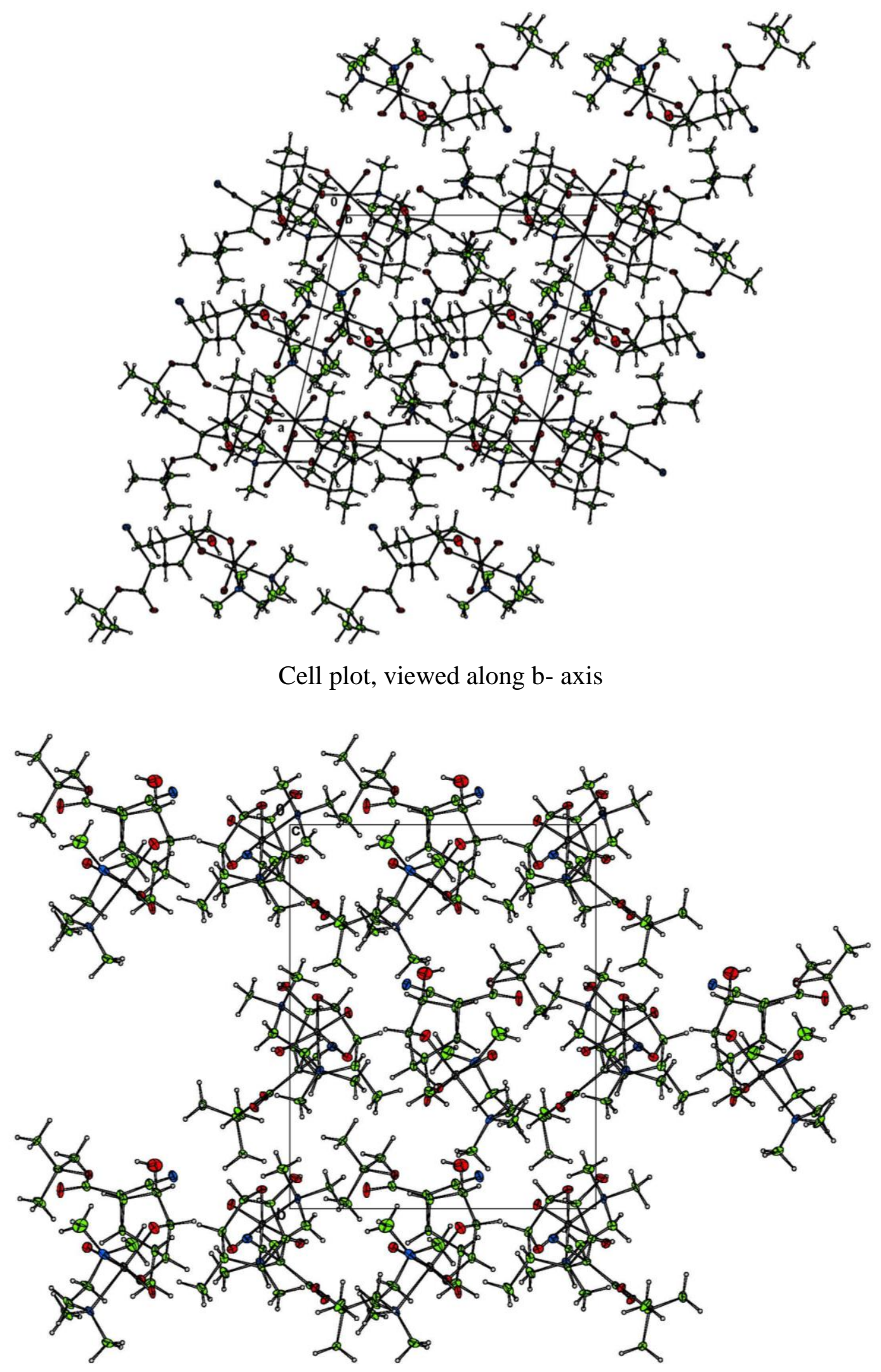

Cell plot, viewed along c- axis 
Table 1. Crystal data and structure refinement for 20020.

Empirical formula

Formula weight

Crystal color, shape, size

Temperature

Wavelength

Crystal system, space group

Unit cell dimensions

Volume

$\mathrm{Z}$

Density (calculated)

Absorption coefficient

$\mathrm{F}(000)$

Data collection

Diffractometer

Theta range for data collection

Index ranges

Reflections collected

Independent reflections

Observed Reflections

Completeness to theta $=70.165^{\circ}$

Solution and Refinement

Absorption correction

Max. and min. transmission

Solution

Refinement method

Weighting scheme

Data / restraints / parameters

Goodness-of-fit on $\mathrm{F}^{2}$

Final $\mathrm{R}$ indices [I $>2 \operatorname{sigma}(\mathrm{I})$ ]

$\mathrm{R}$ indices (all data)

Absolute structure parameter

Largest diff. peak and hole
C20 H35 N3 O7 Os1

619.71

green block fragment, $0.200 \times 0.100 \times 0.100 \mathrm{~mm}^{3}$

$150 \mathrm{~K}$

$1.54178 \AA$

Monoclinic, P21

$\mathrm{a}=12.3859(2) \AA$

$\alpha=90^{\circ}$.

$\mathrm{b}=15.1577(3) \AA$

$\beta=103.2123(9)^{\circ}$.

$\mathrm{c}=13.1632(2) \AA$

$\gamma=90^{\circ}$.
4

$1.711 \mathrm{Mg} / \mathrm{m}^{3}$

$10.386 \mathrm{~mm}^{-1}$

1232

Bruker Apex Kappa Duo, Bruker

3.449 to $70.165^{\circ}$.

$-15<=\mathrm{h}<=15,-18<=\mathrm{k}<=16,-15<=\mathrm{l}<=16$

50943

8993 [R(int) $=0.062]$

8620

$99.6 \%$

Semi-empirical from equivalents

0.35 and 0.35

Direct methods

Full-matrix least-squares on $\mathrm{F}^{2}$

$\mathrm{w}=\left[\sigma^{2} \mathrm{Fo}^{2}+\mathrm{AP}^{2}+\mathrm{BP}\right]^{-1}$, with

$\mathrm{P}=\left(\mathrm{Fo}^{2}+2 \mathrm{Fc}^{2}\right) / 3, \mathrm{~A}=0.000, \mathrm{~B}=10.650$

8958 / 45 / 568

1.0260

$\mathrm{R} 1=0.0313, \mathrm{wR} 2=0.0678$

$\mathrm{R} 1=0.0329, \mathrm{wR} 2=0.0686$

$-0.018(9)$

0.85 and -1.02 e. $\AA^{-3}$ 
Table 2. Atomic coordinates $\left(\times 10^{4}\right)$ and equivalent isotropic displacement parameters $\left(\AA^{2} \times 10^{3}\right)$ for 20020. $\mathrm{U}(\mathrm{eq})$ is defined as one third of the trace of the orthogonalized $\mathrm{U}^{\mathrm{ij}}$ tensor.

\begin{tabular}{|c|c|c|c|c|}
\hline & $\mathrm{x}$ & $\mathrm{y}$ & $\mathrm{z}$ & $\mathrm{U}(\mathrm{eq})$ \\
\hline Os1 & $5413(1)$ & $6524(1)$ & $8890(1)$ & 24 \\
\hline Os101 & $900(1)$ & $5399(1)$ & $9973(1)$ & 18 \\
\hline $\mathrm{O} 1$ & $7489(4)$ & $4520(5)$ & $6076(5)$ & 50 \\
\hline $\mathrm{O} 2$ & $6566(4)$ & $4116(3)$ & $4456(4)$ & 27 \\
\hline $\mathrm{O} 3$ & $4424(7)$ & $3870(5)$ & $7758(6)$ & 70 \\
\hline $\mathrm{O} 4$ & $4431(4)$ & $5499(4)$ & $8532(4)$ & 39 \\
\hline O5 & $4865(4)$ & $6856(3)$ & $7452(4)$ & 35 \\
\hline O6 & $6617(5)$ & $6007(4)$ & $8737(4)$ & 35 \\
\hline $\mathrm{O} 7$ & $4500(4)$ & $7166(4)$ & $9399(5)$ & 44 \\
\hline O101 & $-1159(4)$ & $7367(3)$ & $12859(4)$ & 29 \\
\hline O102 & $-838(4)$ & $7063(3)$ & $14586(3)$ & 24 \\
\hline O103 & $-187(5)$ & $4212(4)$ & $12447(5)$ & 42 \\
\hline O104 & 913(4) & $4502(3)$ & $11058(3)$ & 27 \\
\hline O105 & $1879(4)$ & $6053(3)$ & 11071(4) & 27 \\
\hline O106 & $-329(4)$ & $5901(3)$ & $10089(4)$ & 28 \\
\hline O107 & 1914(4) & 4893(4) & $9467(4)$ & 31 \\
\hline N1 & $3813(5)$ & $4161(5)$ & $4176(6)$ & 40 \\
\hline $\mathrm{N} 2$ & $6535(5)$ & $7667(4)$ & $9324(5)$ & 34 \\
\hline N3 & $6068(6)$ & 6191(4) & $10561(5)$ & 35 \\
\hline N101 & $1388(5)$ & $5781(4)$ & $15401(5)$ & 31 \\
\hline N102 & $974(4)$ & $6391(4)$ & $8781(4)$ & 24 \\
\hline N103 & $-256(4)$ & $4737(4)$ & $8624(4)$ & 23 \\
\hline $\mathrm{C} 1$ & $4347(7)$ & $4582(5)$ & $7023(6)$ & 30 \\
\hline $\mathrm{C} 2$ & $3901(5)$ & $5413(6)$ & $7459(5)$ & 31 \\
\hline $\mathrm{C} 3$ & $4048(6)$ & $6280(5)$ & $6849(6)$ & 31 \\
\hline $\mathrm{C} 4$ & $4401(6)$ & $6090(5)$ & $5835(6)$ & 32 \\
\hline $\mathrm{C} 5$ & $5472(5)$ & $5563(5)$ & $6106(5)$ & 27 \\
\hline C6 & $5430(6)$ & $4747(5)$ & $6723(6)$ & 31 \\
\hline $\mathrm{C} 7$ & $5525(6)$ & $4649(5)$ & $5590(6)$ & 28 \\
\hline $\mathrm{C} 8$ & $4587(6)$ & $4364(5)$ & $4795(6)$ & 32 \\
\hline C9 & $6653(6)$ & $4415(5)$ & $5419(6)$ & 30 \\
\hline $\mathrm{C} 10$ & $7562(6)$ & $3972(5)$ & $4028(6)$ & 31 \\
\hline $\mathrm{C} 11$ & $7039(7)$ & $3683(5)$ & 2931(6) & 37 \\
\hline C12 & $8177(8)$ & $4832(6)$ & 4063(8) & 52 \\
\hline C13 & $8259(7)$ & $3231(5)$ & $4636(7)$ & 39 \\
\hline C14 & $4563(7)$ & $6946(5)$ & $5300(6)$ & 34 \\
\hline C15 & $7288(8)$ & $7738(7)$ & $8598(8)$ & 59 \\
\hline $\mathrm{C} 16$ & $5944(8)$ & $8501(6)$ & 9288(9) & 62 \\
\hline $\mathrm{C} 17$ & $7225(8)$ & $7461(6)$ & $10379(7)$ & 53 \\
\hline C18 & $6609(9)$ & $7011(6)$ & $11056(8)$ & 54 \\
\hline C19 & $6843(9)$ & $5447(9)$ & $10740(8)$ & 71 \\
\hline
\end{tabular}




\begin{tabular}{lrrrr} 
C20 & $5146(10)$ & $5944(7)$ & $11078(9)$ & 64 \\
$\mathrm{C} 101$ & $643(6)$ & $4870(4)$ & $12758(5)$ & 26 \\
$\mathrm{C} 102$ & $1493(6)$ & $4764(5)$ & $12082(5)$ & 27 \\
$\mathrm{C} 103$ & $2206(6)$ & $5600(5)$ & $12056(5)$ & 23 \\
$\mathrm{C} 104$ & $2144(6)$ & $6282(5)$ & $12908(5)$ & 27 \\
$\mathrm{C} 105$ & $928(5)$ & $6522(5)$ & $12763(5)$ & 21 \\
$\mathrm{C} 106$ & $138(6)$ & $5792(4)$ & $12658(5)$ & 22 \\
$\mathrm{C} 107$ & $300(5)$ & $6381(4)$ & $13641(5)$ & 21 \\
$\mathrm{C} 108$ & $888(5)$ & $6045(4)$ & $14621(5)$ & 21 \\
$\mathrm{C} 109$ & $-648(6)$ & $6999(4)$ & $13638(6)$ & 24 \\
$\mathrm{C} 110$ & $-1746(6)$ & $7628(5)$ & $14800(6)$ & 26 \\
$\mathrm{C} 111$ & $-1633(8)$ & $7513(6)$ & $15955(6)$ & 45 \\
$\mathrm{C} 112$ & $-1528(6)$ & $8581(5)$ & $14546(6)$ & 31 \\
$\mathrm{C} 113$ & $-2845(6)$ & $7298(5)$ & $14196(7)$ & 38 \\
$\mathrm{C} 114$ & $2858(7)$ & $7088(6)$ & $12832(7)$ & 46 \\
$\mathrm{C} 115$ & $344(7)$ & $7200(5)$ & $8889(7)$ & 40 \\
$\mathrm{C} 116$ & $2130(6)$ & $6668(6)$ & $8848(6)$ & 37 \\
$\mathrm{C} 117$ & $491(7)$ & $5950(5)$ & $7752(5)$ & 31 \\
$\mathrm{C} 118$ & $-536(6)$ & $5438(7)$ & $7803(5)$ & 33 \\
$\mathrm{C} 119$ & $-1306(6)$ & $4449(5)$ & $8869(6)$ & 35 \\
$\mathrm{C} 120$ & $230(7)$ & $3968(5)$ & $8210(6)$ & 38 \\
& & & & \\
\hline
\end{tabular}


Table 3. Bond lengths $[\AA]$ and angles $\left[{ }^{\circ}\right]$ for 20020.

\begin{tabular}{|c|c|c|c|c|}
\hline Os1-O4 & $1.963(6)$ & Os1-O5 & $1.927(6)$ & Os1-O6 \\
\hline $1.736(6)$ & Os1-O7 & $1.739(6)$ & \multicolumn{2}{|c|}{ Os1-N2 $2.213(6)$} \\
\hline Os1-N3 & $2.221(6)$ & Os101-O104 & $1.970(5)$ & Os101- \\
\hline O105 & $1.934(5)$ & Os101-O106 & $1.740(5)$ & Os101- \\
\hline $\mathrm{O} 107$ & $1.731(5)$ & Os101-N102 & $2.189(5)$ & Os101- \\
\hline N103 & $2.247(5)$ & $\mathrm{O} 1-\mathrm{C} 9$ & 1.199(9) & $\mathrm{O} 2-\mathrm{C} 9$ \\
\hline $1.327(8)$ & $\mathrm{O} 2-\mathrm{C} 10$ & $1.485(8)$ & \multicolumn{2}{|c|}{$\mathrm{O} 3-\mathrm{C} 1 \quad 1.437(10)$} \\
\hline O3-H1 & $0.83(2)$ & $\mathrm{O} 4-\mathrm{C} 2$ & $1.421(8)$ & O5-C3 \\
\hline $1.432(9)$ & O101-C109 & $1.211(9)$ & \multicolumn{2}{|c|}{ O102-C109 1.326(8) } \\
\hline $\mathrm{O} 102-\mathrm{C} 110$ & 1.491(8) & O103-C101 & $1.424(9)$ & O103- \\
\hline H101 & $0.82(2)$ & O104-C102 & $1.431(8)$ & O105- \\
\hline $\mathrm{C} 103$ & $1.441(8)$ & N1-C8 & $1.149(10)$ & $\mathrm{N} 2-\mathrm{C} 15$ \\
\hline $1.484(11)$ & N2-C16 & $1.456(11)$ & \multicolumn{2}{|c|}{$\mathrm{N} 2-\mathrm{C} 17 \quad 1.488(11)$} \\
\hline N3-C18 & $1.489(9)$ & N3-C19 & $1.465(12)$ & N3-C20 \\
\hline $1.505(12)$ & N101-C108 & $1.142(9)$ & \multicolumn{2}{|c|}{ N102-C115 1.478(9) } \\
\hline N102-C116 & $1.475(8)$ & N102-C117 & $1.507(9)$ & N103- \\
\hline $\mathrm{C} 118$ & $1.499(10)$ & N103-C119 & $1.476(9)$ & N103- \\
\hline $\mathrm{C} 120$ & $1.472(9)$ & $\mathrm{C} 1-\mathrm{C} 2$ & $1.538(11)$ & $\mathrm{C} 1-\mathrm{C} 6$ \\
\hline $1.503(10)$ & $\mathrm{C} 1-\mathrm{H} 11$ & 0.950 & \multicolumn{2}{|c|}{$\mathrm{C} 2-\mathrm{C} 3 \quad 1.573(12)$} \\
\hline $\mathrm{C} 2-\mathrm{H} 21$ & 0.950 & $\mathrm{C} 3-\mathrm{C} 4$ & $1.523(10)$ & C3-H31 \\
\hline 0.950 & C4-C5 & $1.519(10)$ & \multicolumn{2}{|c|}{ C4-C14 $1.512(10)$} \\
\hline C4-H41 & 0.950 & C5-C6 & $1.486(11)$ & $\mathrm{C} 5-\mathrm{C} 7$ \\
\hline $1.551(10)$ & $\mathrm{C} 5-\mathrm{H} 51$ & 0.950 & \multicolumn{2}{|c|}{ C6-C7 $1.530(10)$} \\
\hline C6-H61 & 0.950 & $\mathrm{C} 7-\mathrm{C} 8$ & $1.441(10)$ & $\mathrm{C} 7-\mathrm{C} 9$ \\
\hline $1.507(10)$ & $\mathrm{C} 10-\mathrm{C} 11$ & $1.506(11)$ & \multicolumn{2}{|c|}{ C10-C12 1.504(10) } \\
\hline $\mathrm{C} 10-\mathrm{C} 13$ & $1.527(11)$ & C11-H111 & \multicolumn{2}{|c|}{$0.950 \quad \mathrm{C} 11-\mathrm{H} 112$} \\
\hline 0.950 & C11-H113 & 0.950 & C12-H121 0.950 & $\mathrm{C} 12-$ \\
\hline H122 & 0.950 & $\mathrm{C} 12-\mathrm{H} 123$ & \multicolumn{2}{|c|}{$0.950 \quad \mathrm{C} 13-\mathrm{H} 131$} \\
\hline 0.950 & $\mathrm{C} 13-\mathrm{H} 132$ & 0.950 & C13-H133 0.950 & C14- \\
\hline H141 & 0.950 & C14-H142 & \multicolumn{2}{|c|}{$0.950 \quad \mathrm{C} 14-\mathrm{H} 143$} \\
\hline 0.950 & $\mathrm{C} 15-\mathrm{H} 151$ & 0.950 & C15-H152 0.950 & C15- \\
\hline H153 & 0.950 & C16-H161 & \multicolumn{2}{|c|}{$0.950 \quad \mathrm{C} 16-\mathrm{H} 162$} \\
\hline 0.950 & C16-H163 & 0.950 & \multicolumn{2}{|c|}{ C17-C18 1.466(13) } \\
\hline C17-H171 & 0.950 & $\mathrm{C} 17-\mathrm{H} 172$ & \multicolumn{2}{|c|}{$0.950 \quad \mathrm{C} 18-\mathrm{H} 181$} \\
\hline 0.950 & C18-H182 & 0.950 & C19-H191 0.950 & C19- \\
\hline H192 & 0.950 & C19-H193 & \multicolumn{2}{|c|}{$0.950 \quad \mathrm{C} 20-\mathrm{H} 201$} \\
\hline 0.950 & $\mathrm{C} 20-\mathrm{H} 202$ & 0.950 & $\mathrm{C} 20-\mathrm{H} 2030.950$ & C101- \\
\hline C102 & $1.534(10)$ & C101-C106 & $1.525(9)$ & C101- \\
\hline H1011 & 0.950 & C102-C103 & $1.549(10)$ & C102- \\
\hline H1021 & 0.950 & C103-C104 & $1.540(9)$ & C103- \\
\hline H1031 & 0.950 & C104-C105 & $1.518(9)$ & C104- \\
\hline C114 & $1.525(10)$ & C104-H1041 & \multicolumn{2}{|c|}{$0.950 \quad \mathrm{C} 105-\mathrm{C} 106$} \\
\hline $1.462(9)$ & C105-C107 & $1.548(8)$ & C105-H1051 & 0.950 \\
\hline C106-C107 & $1.547(8)$ & C106-H1061 & \multicolumn{2}{|c|}{$0.950 \quad \mathrm{C} 107-\mathrm{C} 108$} \\
\hline
\end{tabular}




$\begin{array}{lcl}1.423(9) & \mathrm{C} 107-\mathrm{C} 109 & 1.502(9) \\ \mathrm{C} 110-\mathrm{C} 112 & 1.520(10) & \mathrm{C} 110-\mathrm{C} 113 \\ \mathrm{H} 1111 & 0.950 & \mathrm{C} 111-\mathrm{H} 1112 \\ 0.950 & \mathrm{C} 112-\mathrm{H} 1121 & 0.950 \\ \mathrm{C} 112-\mathrm{H} 1123 & 0.950 & \mathrm{C} 113-\mathrm{H} 1131 \\ 0.950 & \mathrm{C} 113-\mathrm{H} 1133 & 0.950 \\ \mathrm{C} 114-\mathrm{H} 1142 & 0.950 & \mathrm{C} 114-\mathrm{H} 1143 \\ 0.950 & \mathrm{C} 115-\mathrm{H} 1152 & 0.950 \\ \mathrm{C} 116-\mathrm{H} 1161 & 0.950 & \mathrm{C} 116-\mathrm{H} 1162 \\ 0.950 & \mathrm{C} 117-\mathrm{C} 118 & 1.505(11) \\ \mathrm{C} 117-\mathrm{H} 1172 & 0.950 & \mathrm{C} 118-\mathrm{H} 1181 \\ 0.950 & \mathrm{C} 119-\mathrm{H} 1191 & 0.950 \\ \mathrm{C} 119-\mathrm{H} 1193 & 0.950 & \mathrm{C} 120-\mathrm{H} 1201 \\ 0.950 & \mathrm{C} 120-\mathrm{H} 1203 & 0.950\end{array}$

O4-Os1-O5

97.1(2)

O6-Os1-O7

96.2(2)

O4-Os1-N3

83.3(3)

O104-Os101-O105

O106

$\mathrm{O} 107$

N102

N102

N103

N103

N103

109.5(10)

C109-O102-C110

C102

109.9(5)

Os1-N2-C17

112.9(8)

C18-N3-C19

108.8(7)

Os101-N102-C116

C117

$\mathrm{C} 117$

C119

C120

C120

112.1(7)
84.9(2)

O4-Os1-O7

161.7(3)

O6-Os1-N2

97.1(2)

O7-Os1-N3

84.96(19)

$97.0(2)$

97.4(2)

177.2(2)

$86.8(2)$

99.3(2)

$81.5(2)$

$82.2(2)$

Os1-O4-C2

121.6(5)

114.2(4)

Os1-N2-C16

105.6(5)

Os1-N3-C18

111.1(8)

C19-N3-C20

110.6(4)

105.5(4)

111.1(6)

113.2(4)

$113.9(4)$

107.6(6)

C2-C1-C6
O4-Os1-O6

96.5(2)

O4-Os1-N2

83.0(2)

O5-Os1-N3

82.4(3)

O104-Os101-O106

O104-Os101-O107

O106-Os101-O107

O105-Os101-N102

O107-Os101-N102

O105-Os101-N103

O107-Os101-N103

C9-O2-C10

115.6(5)

C101-O103-H101

Os101-O105-C103

113.0(5)

C15-N2-C17

105.6(5)

Os1-N3-C20

105.8(7)

C115-N102-C116

C115-N102-C117

Os101-N103-C118

C118-N103-C119

C118-N103-C120

O3-C1-C2

112.3(6)
C110-C111 1.504(10)

1.497(10) C111-

$0.950 \quad \mathrm{C} 111-\mathrm{H} 1113$

C112-H1122 $\quad 0.950$

$0.950 \quad \mathrm{C} 113-\mathrm{H} 1132$

C114-H1141 0.950

$0.950 \quad \mathrm{C} 115-\mathrm{H} 1151$

C115-H1153 $\quad 0.950$

$0.950 \quad \mathrm{C} 116-\mathrm{H} 1163$

C117-H1171 $\quad 0.950$

$0.950 \quad \mathrm{C} 118-\mathrm{H} 1182$

C119-H1192 $\quad 0.950$

$0.950 \quad \mathrm{C} 120-\mathrm{H} 1202$
96.7(3) O5-Os1-O6

O5-Os1-O7 96.8(3)

178.9(2) O5-Os1-N2

O7-Os1-N2 83.6(3)

177.9(2) O6-Os1-N3

N2-Os1-N3 81.8(2)

95.8(2) O105-Os101-

95.0(2) O105-Os101-

162.7(2) O104-Os101-

93.5(2) O106-Os101-

82.8(2) O104-Os101-

175.6(2) O106-Os101-

83.4(2) N102-Os101-

121.3(6) C1-O3-H1

Os1-O5-C3 $115.5(5)$

110(8) Os101-O104-

115.3(4) Os1-N2-C15

C15-N2-C16 107.5(8)

107.8(7) C16-N2-C17

Os1-N3-C19 114.3(5)

111.2(6) C18-N3-C20

Os101-N102-C115 113.0(4)

106.5(6) Os101-N102-

110.1(6) C116-N102-

104.7(4) Os101-N103-

107.3(6) Os101-N103-

109.9(6) C119-N103-

109.7(6) O3-C1-C6

O3-C1-H11 107.3 
C2-C1-H11

108.8(7)

C1-C2-H21

108.1

O5-C3-C4

108.5

C3-C4-C14

109.9

C4-C5-C6

60.4(5)

C7-C5-H51

120.8(6)

C5-C6-H61

57.7(5)

C6-C7-C9

116.2(6)

C7-C9-O1

101.1(6)

O2-C10-C13

113.6(8)

H111-C11-H1 12

109.5

C10-C12-H122

110.8

C10-C13-H131

109.5

H132-C13-H133

108.7

H141-C14-H143

109.5

N2-C15-H153

109.5

H161-C16-H162

109.5

N2-C17-H171

107.0

N3-C18-C17

110.1

H181-C18-H182

108.2

H191-C19-H193

111.0

N3-C20-H203

109.5

C102-C101-C106

H1011
107.9

\section{C1-C2-C3}

107.6

C2-C3-O5

107.0(6)

C4-C3-H31

110.0(6)

C5-C4-H41

115.4(6)

C4-C5-H51

116.5

C5-C6-C7

116.7

C6-C7-C8

116.7(6)

C7-C8-N1

122.6(7)

O2-C10-C12

109.2(6)

C10-C11-H111

109.5

H112-C11-H113

108.6

H121-C12-H123

108.6

C10-C13-H133

109.5

H141-C14-H142

109.5

N2-C15-H152

109.8

N2-C16-H161

109.5

H162-C16-H163

109.8

C18-C17-H172

111.5(8)

N3-C18-H182

109.5

H191-C19-H192

109.5

N3-C20-H202

109.5

O103-C101-C102

111.6(6)

108.7
C6-C1-H1 1

113.6(5)

O4-C2-H2 1

112.1(6)

C2-C3-H31

108.3

C5-C4-C14

109.3

C4-C5-C7

116.5

C1-C6-C5

61.9(5)

C7-C6-H61

120.5(6)

C5-C7-C9

177.3(8)

O2-C9-O1

108.6(6)

C11-C10-C13

108.6

C10-C11-H113

109.5

H121-C12-H122

109.5

C10-C13-H132

110.3

C4-C14-H141

109.5

H142-C14-H143

109.1

H151-C15-H153

108.2

N2-C16-H163

109.5

C18-C17-H171

106.6

N3-C18-H181

108.2

N3-C19-H191

109.5

H192-C19-H193

107.9

H201-C20-H203

107.9(5)

O103-C101-H1011

C106-C101-H1011
107.3 C1-C2-O4

O4-C2-C3 110.5(6)

$108.0 \quad \mathrm{C} 3-\mathrm{C} 2-\mathrm{H} 21$

C2-C3-C4 112.3(6)

108.5 O5-C3-H31

C3-C4-C5 107.7(6)

111.1(6) C3-C4-H41

C14-C4-H41 108.9

119.3(6) C6-C5-C7

C6-C5-H51 116.9

115.3(7) C1-C6-C7

C1-C6-H61 115.5

$116.0 \quad$ C6-C7-C5

C5-C7-C8 118.6(6)

114.2(6) C8-C7-C9

C7-C9-O2 110.3(6)

127.0(7) O2-C10-C11

C11-C10-C12 112.7(7)

110.9(6) C12-C10-C13

C10-C11-H112 110.2

109.5 H111-C11-H113

C10-C12-H121 108.9

109.5 C10-C12-H123

H122-C12-H123 109.5

109.5 H131-C13-H132

H131-C13-H133 109.5

$109.8 \quad$ C4-C14-H142

C4-C14-H143 109.9

$109.5 \quad$ N2-C15-H151

H151-C15-H152 109.5

109.5 H152-C15-H153

N2-C16-H162 110.3

109.9 H161-C16-H163

N2-C17-C18 113.4(7)

$110.4 \quad \mathrm{~N} 2-\mathrm{C} 17-\mathrm{H} 172$

H171-C17-H172 109.5

110.4 C17-C18-H181

C17-C18-H182 107.0

$110.2 \quad$ N3-C19-H192

N3-C19-H193 110.0

$109.5 \quad \mathrm{~N} 3-\mathrm{C} 20-\mathrm{H} 201$

H201-C20-H202 109.5

$109.5 \quad \mathrm{H} 202-\mathrm{C} 20-\mathrm{H} 203$

O103-C101-C106 111.2(6)

108.9 C102-C101-

108.5 C101-C102- 


\begin{tabular}{|c|c|c|c|c|}
\hline O104 & $108.1(6)$ & C101-C102-C103 & $113.4(6)$ & O104-C102- \\
\hline C103 & $111.9(6)$ & C101-C102-H1021 & 107.5 & O104-C102- \\
\hline H1021 & 107.8 & C103-C102-H1021 & 107.9 & C102-C103- \\
\hline O105 & $111.4(5)$ & C102-C103-C104 & $114.2(6)$ & O105-C103- \\
\hline $\mathrm{C} 104$ & $106.6(5)$ & C102-C103-H1031 & 108.2 & O105-C103- \\
\hline H1031 & 108.1 & C104-C103-H1031 & 108.2 & C103-C104-C105 \\
\hline $106.4(5)$ & C103-C104-C114 & $111.3(6)$ & \multicolumn{2}{|c|}{ C105-C104-C114 111.9(7) } \\
\hline C103-C104-H1041 & 109.2 & C105-C104-H1041 & 109.0 & C114-C104- \\
\hline H1041 & 109.0 & C104-C105-C106 & $116.9(6)$ & C104-C105-C107 \\
\hline $121.7(6)$ & C106-C105-C107 & $61.8(4)$ & \multicolumn{2}{|c|}{ C104-C105-H1051 115.2} \\
\hline C106-C105-H1051 & 115.3 & C107-C105-H1051 & 115.3 & C101-C106-C105 \\
\hline $115.7(6)$ & C101-C106-C107 & $119.0(6)$ & \multicolumn{2}{|c|}{ C105-C106-C107 61.9(4) } \\
\hline C101-C106-H1061 & 115.9 & C105-C106-H1061 & 116.9 & C107-C106- \\
\hline H1061 & 116.6 & C106-C107-C105 & $56.4(4)$ & C106-C107-C108 \\
\hline $119.6(6)$ & C105-C107-C108 & $119.1(6)$ & \multicolumn{2}{|c|}{ C106-C107-C109 114.0(5) } \\
\hline C105-C107-C109 & $116.0(6)$ & C108-C107-C109 & $117.6(6)$ & C107-C108- \\
\hline N101 & $178.0(7)$ & C107-C109-O102 & $110.5(6)$ & C107-C109- \\
\hline O101 & $123.2(6)$ & O102-C109-O101 & $126.3(6)$ & O102-C110- \\
\hline $\mathrm{C} 111$ & $102.9(6)$ & O102-C110-C112 & $108.9(6)$ & C111-C110-C112 \\
\hline $110.7(7)$ & O102-C110-C113 & $110.0(6)$ & \multicolumn{2}{|c|}{$\mathrm{C} 111-\mathrm{C} 110-\mathrm{C} 113 \quad 111.2(7)$} \\
\hline C112-C110-C113 & $112.7(6)$ & C110-C111-H1111 & 108.4 & C110-C111- \\
\hline H1112 & 109.6 & H1111-C111-H1112 & 109.5 & C110-C111- \\
\hline H1113 & 110.3 & H1111-C111-H1113 & 109.5 & H1112-C111- \\
\hline H1113 & 109.5 & C110-C112-H1121 & 108.8 & C110-C112- \\
\hline H1122 & 109.7 & H1121-C112-H1122 & 109.5 & C110-C112- \\
\hline H1123 & 109.9 & H1121-C112-H1123 & 109.5 & H1122-C112- \\
\hline H1123 & 109.5 & C110-C113-H1131 & 108.8 & C110-C113- \\
\hline H1132 & 109.5 & H1131-C113-H1132 & 109.5 & C110-C113- \\
\hline H1133 & 110.0 & H1131-C113-H1133 & 109.5 & H1132-C113- \\
\hline H1133 & 109.5 & C104-C114-H1141 & 109.6 & C104-C114- \\
\hline H1142 & 109.6 & H1141-C114-H1142 & 109.5 & C104-C114- \\
\hline H1143 & 109.2 & H1141-C114-H1143 & 109.5 & H1142-C114- \\
\hline H1143 & 109.5 & N102-C115-H1151 & 109.7 & N102-C115- \\
\hline H1152 & 109.4 & H1151-C115-H1152 & 109.5 & N102-C115- \\
\hline H1153 & 109.2 & H1151-C115-H1153 & 109.5 & H1152-C115- \\
\hline H1153 & 109.5 & N102-C116-H1161 & 109.8 & N102-C116- \\
\hline H1162 & 109.4 & H1161-C116-H1162 & 109.5 & N102-C116- \\
\hline H1163 & 109.2 & H1161-C116-H1163 & 109.5 & H1162-C116- \\
\hline H1163 & 109.5 & N102-C117-C118 & $110.8(6)$ & N102-C117- \\
\hline H1171 & 109.5 & C118-C117-H1171 & 109.1 & N102-C117- \\
\hline H1172 & 108.5 & C118-C117-H1172 & 109.5 & H1171-C117- \\
\hline H1172 & 109.5 & C117-C118-N103 & $109.8(6)$ & C117-C118- \\
\hline H1181 & 109.6 & N103-C118-H1181 & 110.5 & C117-C118- \\
\hline H1182 & 109.0 & N103-C118-H1182 & 108.4 & H1181-C118- \\
\hline H1182 & 109.5 & N103-C119-H1191 & 108.9 & N103-C119- \\
\hline H1192 & 109.8 & H1191-C119-H1192 & 109.5 & N103-C119- \\
\hline
\end{tabular}


H1193

H1193

H1202

H1203

H1203
109.8

109.5

109.7

108.9

109.5
H1191-C119-H1193

N103-C120-H1201

H1201-C120-H1202

H1201-C120-H1203
109.5 H1192-C119-

109.9 N103-C120-

109.5 N103-C120-

109.5 H1202-C120-

Symmetry transformations used to generate equivalent atoms: 
Table 4. Anisotropic displacement parameters $\left(\AA^{2} \times 10^{3}\right)$ for 20020. The anisotropic displacement factor exponent takes the form: $-2 \pi^{2}\left[h^{2} a^{* 2} U^{11}+\ldots+2 h \mathrm{k} \mathrm{a}^{*} b^{*} U^{12}\right]$

\begin{tabular}{|c|c|c|c|c|c|c|}
\hline & $\mathrm{U}^{11}$ & $\mathrm{U}^{22}$ & $\mathrm{U}^{33}$ & $\mathrm{U}^{23}$ & $\mathrm{U}^{13}$ & $\mathrm{U}^{12}$ \\
\hline Os1 & $20(1)$ & $30(1)$ & $25(1)$ & $-8(1)$ & $9(1)$ & $-7(1)$ \\
\hline Os101 & $17(1)$ & $20(1)$ & $16(1)$ & $-1(1)$ & $5(1)$ & $3(1)$ \\
\hline $\mathrm{O} 1$ & $18(3)$ & $86(5)$ & $46(4)$ & $-34(3)$ & $7(3)$ & $1(3)$ \\
\hline $\mathrm{O} 2$ & $23(3)$ & $32(3)$ & $29(3)$ & $-5(2)$ & $11(2)$ & $0(2)$ \\
\hline $\mathrm{O} 3$ & $97(6)$ & $61(5)$ & $60(5)$ & $14(4)$ & $38(5)$ & $-2(4)$ \\
\hline $\mathrm{O} 4$ & $41(3)$ & $52(4)$ & $25(2)$ & $-4(3)$ & $11(2)$ & $-16(3)$ \\
\hline O5 & $32(3)$ & $36(3)$ & $38(3)$ & $-5(2)$ & $8(2)$ & $-3(2)$ \\
\hline O6 & $35(3)$ & $38(3)$ & $30(3)$ & $-6(2)$ & $5(2)$ & $2(2)$ \\
\hline $\mathrm{O} 7$ & $17(3)$ & $62(4)$ & $52(4)$ & $-21(3)$ & $8(3)$ & $-9(2)$ \\
\hline O101 & $30(3)$ & $31(3)$ & $24(3)$ & $6(2)$ & $2(2)$ & $11(2)$ \\
\hline O102 & $26(3)$ & $28(3)$ & $19(2)$ & $-2(2)$ & $10(2)$ & $7(2)$ \\
\hline O103 & $56(3)$ & $29(3)$ & $47(3)$ & $-14(3)$ & $26(3)$ & $-14(2)$ \\
\hline O104 & $40(3)$ & 21(3) & $17(2)$ & $-3(2)$ & $3(2)$ & $2(2)$ \\
\hline O105 & $40(3)$ & $28(3)$ & $16(2)$ & $2(2)$ & $10(2)$ & $4(2)$ \\
\hline O106 & $30(3)$ & $32(3)$ & $24(3)$ & $0(2)$ & $8(2)$ & $2(2)$ \\
\hline O107 & $23(3)$ & $44(3)$ & $24(3)$ & $-5(2)$ & $1(2)$ & $9(2)$ \\
\hline N1 & $29(4)$ & $47(4)$ & $44(4)$ & $-12(3)$ & $7(3)$ & $-9(3)$ \\
\hline $\mathrm{N} 2$ & $25(3)$ & $30(3)$ & $45(3)$ & $-7(3)$ & 1(3) & $-14(2)$ \\
\hline N3 & $46(4)$ & $40(4)$ & 19(3) & $-6(3)$ & $7(3)$ & $-16(3)$ \\
\hline N101 & $36(4)$ & $31(3)$ & $28(4)$ & $-6(2)$ & $9(3)$ & $2(2)$ \\
\hline N102 & $25(3)$ & $25(3)$ & $22(3)$ & $7(2)$ & $8(2)$ & $-3(2)$ \\
\hline N103 & $12(3)$ & $32(3)$ & 21(3) & $-11(2)$ & $-5(2)$ & $-1(2)$ \\
\hline $\mathrm{C} 1$ & $32(4)$ & $31(4)$ & $30(4)$ & $-11(3)$ & $14(3)$ & $-10(3)$ \\
\hline $\mathrm{C} 2$ & $23(3)$ & $39(4)$ & $33(4)$ & $-18(4)$ & $7(3)$ & $-9(4)$ \\
\hline $\mathrm{C} 3$ & $18(4)$ & $41(6)$ & $33(4)$ & $-12(3)$ & $3(3)$ & $2(3)$ \\
\hline $\mathrm{C} 4$ & 20(4) & $50(5)$ & $24(4)$ & $-12(3)$ & $4(3)$ & $-1(3)$ \\
\hline $\mathrm{C} 5$ & $17(3)$ & $42(5)$ & 21(3) & $-12(3)$ & $1(3)$ & $-3(3)$ \\
\hline C6 & $24(4)$ & $45(5)$ & 21(4) & $-11(3)$ & $2(3)$ & $-4(3)$ \\
\hline $\mathrm{C} 7$ & $23(4)$ & $37(4)$ & $26(4)$ & $-8(3)$ & $7(3)$ & $-5(3)$ \\
\hline $\mathrm{C} 8$ & $27(4)$ & $42(5)$ & $31(4)$ & $-8(3)$ & $15(3)$ & $-1(3)$ \\
\hline C9 & $25(4)$ & $35(4)$ & $32(4)$ & $-7(3)$ & $8(3)$ & $-7(3)$ \\
\hline $\mathrm{C} 10$ & $36(4)$ & $19(4)$ & $47(5)$ & $-3(3)$ & $25(4)$ & $-1(3)$ \\
\hline $\mathrm{C} 11$ & $43(5)$ & $29(4)$ & $42(5)$ & $-8(3)$ & $18(4)$ & $-2(3)$ \\
\hline $\mathrm{C} 12$ & $59(6)$ & $39(5)$ & $68(7)$ & $-13(4)$ & $38(5)$ & $-22(4)$ \\
\hline $\mathrm{C} 13$ & $26(4)$ & $31(5)$ & $60(6)$ & $-1(4)$ & $13(4)$ & $11(3)$ \\
\hline $\mathrm{C} 14$ & $41(5)$ & $35(4)$ & $24(4)$ & $9(3)$ & $6(3)$ & $4(3)$ \\
\hline $\mathrm{C} 15$ & $48(5)$ & $56(5)$ & $79(6)$ & 1(4) & $25(4)$ & $-34(4)$ \\
\hline $\mathrm{C} 16$ & $52(5)$ & $29(4)$ & $97(7)$ & $-13(4)$ & $-3(5)$ & $-11(4)$ \\
\hline $\mathrm{C} 17$ & $41(5)$ & $53(5)$ & $53(5)$ & $-7(4)$ & $-15(4)$ & $-27(4)$ \\
\hline $\mathrm{C} 18$ & $66(7)$ & $39(5)$ & $50(6)$ & $-13(4)$ & $-6(5)$ & $-29(5)$ \\
\hline C19 & $86(5)$ & $71(5)$ & $55(6)$ & $43(6)$ & $16(5)$ & $14(6)$ \\
\hline
\end{tabular}




\begin{tabular}{llllccc}
$\mathrm{C} 20$ & $68(7)$ & $74(5)$ & $53(5)$ & $15(5)$ & $23(5)$ & $-16(5)$ \\
$\mathrm{C} 101$ & $40(4)$ & $16(3)$ & $23(3)$ & $1(2)$ & $11(3)$ & $3(3)$ \\
$\mathrm{C} 102$ & $32(4)$ & $27(4)$ & $21(4)$ & $-3(3)$ & $4(3)$ & $9(3)$ \\
$\mathrm{C} 103$ & $24(4)$ & $34(5)$ & $8(3)$ & $-1(3)$ & $-4(3)$ & $9(3)$ \\
$\mathrm{C} 104$ & $27(4)$ & $40(5)$ & $13(3)$ & $-9(3)$ & $4(3)$ & $-3(3)$ \\
$\mathrm{C} 105$ & $19(3)$ & $24(3)$ & $22(3)$ & $0(3)$ & $8(2)$ & $-4(3)$ \\
$\mathrm{C} 106$ & $27(3)$ & $25(3)$ & $17(3)$ & $-5(2)$ & $12(2)$ & $0(2)$ \\
$\mathrm{C} 107$ & $27(3)$ & $19(3)$ & $18(3)$ & $2(2)$ & $5(2)$ & $2(2)$ \\
$\mathrm{C} 108$ & $23(3)$ & $21(3)$ & $20(3)$ & $-4(3)$ & $9(3)$ & $-1(2)$ \\
$\mathrm{C} 109$ & $21(4)$ & $20(4)$ & $34(4)$ & $-5(3)$ & $11(3)$ & $-4(3)$ \\
$\mathrm{C} 110$ & $30(4)$ & $26(4)$ & $23(4)$ & $-6(3)$ & $8(3)$ & $9(3)$ \\
$\mathrm{C} 111$ & $49(5)$ & $57(6)$ & $28(4)$ & $1(4)$ & $10(4)$ & $26(4)$ \\
$\mathrm{C} 112$ & $26(4)$ & $26(4)$ & $40(4)$ & $-2(3)$ & $7(3)$ & $4(3)$ \\
$\mathrm{C} 113$ & $24(4)$ & $43(5)$ & $49(5)$ & $-12(4)$ & $11(4)$ & $-2(3)$ \\
$\mathrm{C} 114$ & $39(5)$ & $53(6)$ & $53(6)$ & $-25(4)$ & $26(4)$ & $-21(4)$ \\
$\mathrm{C} 115$ & $56(5)$ & $16(4)$ & $46(5)$ & $10(3)$ & $10(4)$ & $0(3)$ \\
$\mathrm{C} 116$ & $32(4)$ & $45(5)$ & $35(4)$ & $11(4)$ & $11(3)$ & $-14(3)$ \\
$\mathrm{C} 117$ & $41(5)$ & $35(4)$ & $17(4)$ & $11(3)$ & $5(3)$ & $-6(3)$ \\
$\mathrm{C} 118$ & $36(4)$ & $35(4)$ & $23(3)$ & $-7(4)$ & $-6(3)$ & $-5(4)$ \\
$\mathrm{C} 119$ & $23(4)$ & $38(5)$ & $40(5)$ & $-5(3)$ & $-1(3)$ & $-18(3)$ \\
$\mathrm{C} 120$ & $48(5)$ & $31(4)$ & $35(4)$ & $-19(3)$ & $7(4)$ & $1(3)$ \\
& & & & & & \\
\hline
\end{tabular}


Table 5. Hydrogen coordinates ( x 104) and isotropic displacement parameters $\left(\AA^{2} \times 10^{3}\right)$ for 20020.

\begin{tabular}{|c|c|c|c|c|}
\hline & $\mathrm{X}$ & $\mathrm{y}$ & $\mathrm{z}$ & $\mathrm{U}(\mathrm{eq})$ \\
\hline $\mathrm{H} 1$ & $4390(110)$ & $4070(14)$ & $8340(30)$ & $106(2)$ \\
\hline H11 & 3824 & 4412 & 6408 & 38 \\
\hline $\mathrm{H} 21$ & 3131 & 5326 & 7410 & 40 \\
\hline H31 & 3358 & 6582 & 6684 & 39 \\
\hline H41 & 3847 & 5753 & 5382 & 41 \\
\hline H51 & 6142 & 5892 & 6269 & 36 \\
\hline H61 & 6077 & 4607 & 7241 & 39 \\
\hline H101 & $-350(90)$ & $4170(80)$ & $11810(18)$ & $70(2)$ \\
\hline H111 & 7611 & 3572 & 2574 & 48 \\
\hline H112 & 6562 & 4131 & 2577 & 48 \\
\hline H113 & 6625 & 3158 & 2951 & 48 \\
\hline H121 & 8813 & 4744 & 3786 & 64 \\
\hline H122 & 8402 & 5017 & 4769 & 64 \\
\hline H123 & 7718 & 5271 & 3668 & 64 \\
\hline H131 & 8894 & 3143 & 4358 & 50 \\
\hline H132 & 8487 & 3393 & 5351 & 50 \\
\hline H133 & 7841 & 2701 & 4577 & 50 \\
\hline H141 & 4786 & 6826 & 4670 & 44 \\
\hline H142 & 5123 & 7280 & 5753 & 44 \\
\hline H143 & 3891 & 7273 & 5150 & 44 \\
\hline H151 & 7766 & 8231 & 8786 & 83 \\
\hline H152 & 7719 & 7215 & 8642 & 83 \\
\hline H153 & 6866 & 7810 & 7904 & 83 \\
\hline H161 & 6476 & 8958 & 9481 & 97 \\
\hline H162 & 5467 & 8491 & 9760 & 97 \\
\hline H163 & 5519 & 8606 & 8601 & 97 \\
\hline H171 & 7555 & 7986 & 10703 & 65 \\
\hline H172 & 7788 & 7065 & 10285 & 65 \\
\hline H181 & 7090 & 6880 & 11711 & 58 \\
\hline H182 & 6045 & 7404 & 11155 & 58 \\
\hline H191 & 7094 & 5339 & 11467 & 81 \\
\hline H192 & 7457 & 5592 & 10453 & 81 \\
\hline H193 & 6489 & 4932 & 10408 & 81 \\
\hline H201 & 5428 & 5799 & 11792 & 99 \\
\hline $\mathrm{H} 202$ & 4660 & 6435 & 11028 & 99 \\
\hline H203 & 4752 & 5453 & 10727 & 99 \\
\hline H1011 & 1006 & 4774 & 13467 & 33 \\
\hline H1021 & 1978 & 4296 & 12371 & 34 \\
\hline H1031 & 2957 & 5422 & 12144 & 31 \\
\hline H1041 & 2397 & 6017 & 13575 & 33 \\
\hline
\end{tabular}




\begin{tabular}{|c|c|c|c|c|}
\hline H1051 & 689 & 7013 & 12321 & 28 \\
\hline H1061 & -541 & 5858 & 12154 & 28 \\
\hline H1111 & -2185 & 7860 & 16160 & 56 \\
\hline H1112 & -919 & 7705 & 16319 & 56 \\
\hline H1113 & -1731 & 6911 & 16114 & 56 \\
\hline H1121 & -2107 & 8940 & 14684 & 40 \\
\hline H1122 & -838 & 8769 & 14968 & 40 \\
\hline H1123 & -1510 & 8632 & 13831 & 40 \\
\hline H1131 & -3413 & 7667 & 14338 & 51 \\
\hline H1132 & -2956 & 6711 & 14403 & 51 \\
\hline H1133 & -2868 & 7311 & 13470 & 51 \\
\hline H1141 & 2804 & 7497 & 13365 & 59 \\
\hline H1142 & 3609 & 6912 & 12913 & 59 \\
\hline H1143 & 2604 & 7357 & 12169 & 59 \\
\hline H1151 & 401 & 7606 & 8354 & 50 \\
\hline H1152 & 637 & 7460 & 9551 & 50 \\
\hline H1153 & -413 & 7052 & 8832 & 50 \\
\hline H1161 & 2151 & 7097 & 8327 & 45 \\
\hline H1162 & 2428 & 6914 & 9518 & 45 \\
\hline H1163 & 2557 & 6169 & 8745 & 45 \\
\hline H1171 & 307 & 6384 & 7220 & 41 \\
\hline H1172 & 1031 & 5560 & 7594 & 41 \\
\hline H1181 & -1080 & 5828 & 7951 & 43 \\
\hline H1182 & -816 & 5160 & 7149 & 43 \\
\hline H1191 & -1755 & 4177 & 8269 & 43 \\
\hline H1192 & -1685 & 4944 & 9062 & 43 \\
\hline H1193 & -1156 & 4037 & 9428 & 43 \\
\hline H1201 & -297 & 3719 & 7644 & 50 \\
\hline H1202 & 444 & 3539 & 8744 & 50 \\
\hline H1203 & 863 & 4154 & 7975 & 50 \\
\hline
\end{tabular}


Table 6. Torsion angles $\left[{ }^{\circ}\right]$ for 20020 .

\begin{tabular}{|c|c|c|c|}
\hline O5-Os1-O4-C2 & $6.1(5)$ & O6-Os1-O4-C2 & $-90.4(5) \quad$ O7-Os1-O4-C2 \\
\hline $102.4(5)$ & $\mathrm{N} 3-\mathrm{Os} 1-\mathrm{O} 4-\mathrm{C} 2$ & $-174.5(5)$ & O4-Os1-O5-C3 1.9(5) \\
\hline O6-Os1-O5-C3 & $98.0(5)$ & O7-Os1-O5-C3 & $-94.1(5) \quad \mathrm{N} 2-\mathrm{Os} 1-\mathrm{O} 5-\mathrm{C} 3$ \\
\hline$-178.3(5)$ & O5-Os1-N2-C15 & $-53.5(6)$ & O5-Os1-N2-C16 66.6(6) \\
\hline O5-Os1-N2-C17 & $-169.4(5)$ & O6-Os1-N2-C15 & 42.9(6) O6-Os1-N2-C16 \\
\hline $163.0(6)$ & O6-Os1-N2-C17 & $-73.1(5)$ & O7-Os1-N2-C15 - \\
\hline $149.6(6)$ & O7-Os1-N2-C16 & $-29.5(6)$ & O7-Os1-N2-C17 94.4(5) \\
\hline N3-Os1-N2-C15 & $127.2(6)$ & N3-Os1-N2-C16 & $-112.7(6) \quad \mathrm{N} 3-\mathrm{Os} 1-\mathrm{N} 2-\mathrm{C} 17$ \\
\hline $11.2(5)$ & O4-Os1-N3-C18 & $-165.3(6)$ & O4-Os1-N3-C19 72.3(7) \\
\hline O4-Os1-N3-C20 & $-47.4(6)$ & O6-Os1-N3-C18 & 98.8(6) O6-Os1-N3-C19 \\
\hline$-23.6(7)$ & O6-Os1-N3-C20 & $-143.4(6)$ & O7-Os1-N3-C18 -69.6(6) \\
\hline O7-Os1-N3-C19 & $168.0(7)$ & O7-Os1-N3-C20 & 48.3(6) N2-Os1-N3-C18 \\
\hline $14.9(6)$ & N2-Os1-N3-C19 & $-107.5(7)$ & N2-Os1-N3-C20 132.8(6) \\
\hline O105-Os101-N102-C115 & $-73.1(5)$ & O105-Os101-N102-C116 & 46.2(5) O105-Os101- \\
\hline N102-C117 & $166.5(4)$ & O106-Os101-N102-C115 & 23.7(5) O106-Os101- \\
\hline N102-C116 & $143.1(5)$ & O106-Os101-N102-C117 & $-96.7(5) \quad$ O107-Os101- \\
\hline N102-C115 & $-170.1(5)$ & O107-Os101-N102-C116 & $-50.8(5) \quad$ O107-Os101- \\
\hline N102-C117 & $69.5(5)$ & N103-Os101-N102-C115 & 105.6(5) N103-Os101- \\
\hline N102-C116 & $-135.1(5)$ & N103-Os101-N102-C117 & -14.8(4) O104-Os101- \\
\hline N103-C118 & $168.0(4)$ & O104-Os101-N103-C119 & 51.5(5) O104-Os101- \\
\hline N103-C120 & $-71.9(5)$ & O106-Os101-N103-C118 & 73.5(4) O106-Os101- \\
\hline N103-C119 & $-43.0(5)$ & O106-Os101-N103-C120 & -166.4(5) O107-Os101- \\
\hline N103-C118 & $-98.1(4)$ & O107-Os101-N103-C119 & 145.4(5) O107-Os101- \\
\hline N103-C120 & $22.1(5)$ & N102-Os101-N103-C118 & $-14.4(4) \quad$ N102-Os101- \\
\hline N103-C119 & $-130.9(5)$ & N102-Os101-N103-C120 & 105.7(5) O105-Os101- \\
\hline O104-C102 & $5.6(5)$ & O106-Os101-O104-C102 & -91.0(5) O107-Os101- \\
\hline O104-C102 & $102.6(5)$ & N103-Os101-O104-C102 & -173.3(4) O104-Os101- \\
\hline $\mathrm{O} 105-\mathrm{C} 103$ & $4.3(5)$ & O106-Os101-O105-C103 & 99.5(5) O107-Os101- \\
\hline $\mathrm{O} 105-\mathrm{C} 103$ & $-90.0(5)$ & N102-Os101-O105-C103 & $-173.3(5) \quad \mathrm{C} 10-\mathrm{O} 2-\mathrm{C} 9-\mathrm{O} 1$ \\
\hline$-7.8(12)$ & $\mathrm{C} 10-\mathrm{O} 2-\mathrm{C} 9-\mathrm{C} 7$ & $170.2(6)$ & C9-O2-C10-C11 - \\
\hline $177.4(6)$ & $\mathrm{C} 9-\mathrm{O} 2-\mathrm{C} 10-\mathrm{C} 12$ & $-58.7(9)$ & C9-O2-C10-C13 65.6(8) \\
\hline Os1-O4-C2-C1 & $113.7(6)$ & $\mathrm{Os} 1-\mathrm{O} 4-\mathrm{C} 2-\mathrm{C} 3$ & $-11.7(7) \quad$ Os1-O5-C3-C2 \\
\hline$-8.5(7)$ & Os1-O5-C3-C4 & $-132.0(5)$ & Os1-N2-C17-C18 -37.9(8) \\
\hline C15-N2-C17-C18 & $-155.4(8)$ & C16-N2-C17-C18 & 86.0(9) Os1-N3-C18-C17 \\
\hline$-40.3(9)$ & C19-N3-C18-C17 & $84.1(10)$ & C20-N3-C18-C17 - \\
\hline $159.8(8)$ & $\mathrm{O} 3-\mathrm{C} 1-\mathrm{C} 2-\mathrm{O} 4$ & $42.8(9)$ & $\mathrm{O} 3-\mathrm{C} 1-\mathrm{C} 2-\mathrm{C} 3$ \\
\hline $\mathrm{C} 6-\mathrm{C} 1-\mathrm{C} 2-\mathrm{O} 4$ & $-82.5(7)$ & $\mathrm{C} 6-\mathrm{C} 1-\mathrm{C} 2-\mathrm{C} 3$ & 41.0(8) O3-C1-C6-C5 \\
\hline$-170.3(6)$ & $\mathrm{O} 3-\mathrm{C} 1-\mathrm{C} 6-\mathrm{C} 7$ & $118.7(8)$ & C2-C1-C6-C5 $\quad-46.2(9)$ \\
\hline C2-C1-C6-C7 & $-117.2(7)$ & $\mathrm{O} 4-\mathrm{C} 2-\mathrm{C} 3-\mathrm{C} 4$ & 133.4(6) C1-C2-C3-O5 \\
\hline$-109.8(7)$ & $\mathrm{C} 1-\mathrm{C} 2-\mathrm{C} 3-\mathrm{C} 4$ & $10.8(9)$ & $\mathrm{O} 4-\mathrm{C} 2-\mathrm{C} 3-\mathrm{O} 5 \quad 12.8(8)$ \\
\hline $\mathrm{O} 5-\mathrm{C} 3-\mathrm{C} 4-\mathrm{C} 14$ & $-54.9(8)$ & $\mathrm{C} 2-\mathrm{C} 3-\mathrm{C} 4-\mathrm{C} 5$ & $-57.2(8) \quad \mathrm{O} 5-\mathrm{C} 3-\mathrm{C} 4-\mathrm{C} 5$ \\
\hline $66.2(7)$ & $\mathrm{C} 2-\mathrm{C} 3-\mathrm{C} 4-\mathrm{C} 14$ & $-178.3(6)$ & C3-C4-C5-C6 $\quad 54.2(8)$ \\
\hline $\mathrm{C} 3-\mathrm{C} 4-\mathrm{C} 5-\mathrm{C} 7$ & $123.1(7)$ & $\mathrm{C} 14-\mathrm{C} 4-\mathrm{C} 5-\mathrm{C} 7$ & $-116.6(7) \quad$ C14-C4-C5-C6 \\
\hline $174.6(6)$ & C4-C5-C6-C1 & $-2.3(9)$ & C4-C5-C6-C7 110.7(7) \\
\hline
\end{tabular}




\begin{tabular}{|c|c|c|c|}
\hline C4-C5-C7-C6 & $-104.2(7)$ & $\mathrm{C} 4-\mathrm{C} 5-\mathrm{C} 7-\mathrm{C} 8$ & 5.7(10) C7-C5-C6-C1 \\
\hline$-112.9(7)$ & C6-C5-C7-C8 & $109.9(8)$ & C6-C5-C7-C9 - \\
\hline $107.4(7)$ & $\mathrm{C} 4-\mathrm{C} 5-\mathrm{C} 7-\mathrm{C} 9$ & $148.4(7)$ & C1-C6-C7-C5 104.1(8) \\
\hline C1-C6-C7-C8 & $-2.4(11)$ & C5-C6-C7-C8 & $-106.5(8) \quad$ C5-C6-C7-C9 \\
\hline $103.0(7)$ & C1-C6-C7-C9 & $-152.9(7)$ & $\mathrm{C} 5-\mathrm{C} 7-\mathrm{C} 9-\mathrm{O} 2$ \\
\hline $132.6(6)$ & C6-C7-C9-O1 & $-19.0(11)$ & $\mathrm{C} 6-\mathrm{C} 7-\mathrm{C} 9-\mathrm{O} 2$ \\
\hline C8-C7-C9-O1 & $-170.9(8)$ & $\mathrm{C} 8-\mathrm{C} 7-\mathrm{C} 9-\mathrm{O} 2$ & 11.0(9) C5-C7-C9-O1 \\
\hline $45.5(11)$ & N2-C17-C18-N3 & $55.5(10)$ & C110-O102-C109-O101 \\
\hline$-0.3(10)$ & C110-O102-C109-C107 & $-179.3(5)$ & C109-O102-C110-C111 \\
\hline$-178.8(6)$ & C109-O102-C110-C112 & $-61.4(8)$ & C109-O102-C110-C113 \\
\hline $62.7(8)$ & Os101-O104-C102-C101 & $112.2(5)$ & Os101-O104-C102-C103 \\
\hline$-13.4(7)$ & Os101-O105-C103-C102 & $-12.4(7)$ & Os101-O105-C103-C104 \\
\hline$-137.5(5)$ & Os101-N102-C117-C118 & $43.4(7)$ & C115-N102-C117-C118 \\
\hline$-78.9(8)$ & C116-N102-C117-C118 & $163.3(7)$ & Os101-N103-C118-C117 \\
\hline $42.2(6)$ & C119-N103-C118-C117 & $162.8(6)$ & C120-N103-C118-C117 \\
\hline$-80.6(8)$ & O103-C101-C102-O104 & $35.7(7)$ & O103-C101-C102-C103 \\
\hline $160.4(6)$ & C106-C101-C102-O104 & $-86.8(7)$ & C106-C101-C102-C103 \\
\hline $37.9(8)$ & O103-C101-C106-C105 & $-168.7(6)$ & O103-C101-C106-C107 \\
\hline $120.7(7)$ & C102-C101-C106-C105 & $-48.2(8)$ & C102-C101-C106-C107 \\
\hline$-118.8(7)$ & O104-C102-C103-O105 & $16.5(8)$ & O104-C102-C103-C104 \\
\hline $137.3(6)$ & C101-C102-C103-O105 & $-106.2(6)$ & C101-C102-C103-C104 \\
\hline $14.6(8)$ & O105-C103-C104-C105 & $66.0(7)$ & O105-C103-C104-C114 \\
\hline$-56.2(8)$ & C102-C103-C104-C105 & $-57.5(7)$ & C102-C103-C104-C114 \\
\hline$-179.6(6)$ & C103-C104-C105-C106 & $49.0(7)$ & C103-C104-C105-C107 \\
\hline $121.0(7)$ & C114-C104-C105-C106 & $170.8(6)$ & C114-C104-C105-C107 \\
\hline$-117.2(7)$ & C104-C105-C106-C101 & $2.7(8)$ & C104-C105-C106-C107 \\
\hline $113.4(6)$ & C107-C105-C106-C101 & $-110.7(6)$ & C104-C105-C107-C106 \\
\hline$-105.9(8)$ & C104-C105-C107-C108 & $2.1(10)$ & C104-C105-C107-C109 \\
\hline $151.5(6)$ & C106-C105-C107-C108 & $108.0(6)$ & C106-C105-C107-C109 \\
\hline$-102.6(6)$ & C101-C106-C107-C105 & $105.4(7)$ & C101-C106-C107-C108 \\
\hline$-1.7(9)$ & C101-C106-C107-C109 & $-148.4(6)$ & C105-C106-C107-C108 \\
\hline$-107.1(7)$ & C105-C106-C107-C109 & $106.3(6)$ & C105-C107-C109-O101 \\
\hline $25.3(9)$ & C105-C107-C109-O102 & $-155.6(6)$ & C106-C107-C109-O101 \\
\hline$-37.5(9)$ & C106-C107-C109-O102 & $141.6(6)$ & C108-C107-C109-O101 \\
\hline $175.2(6)$ & C108-C107-C109-O102 & $-5.8(8)$ & N102-C117-C118-N103 \\
\hline
\end{tabular}

Symmetry transformations used to generate equivalent atoms: 
